INSTITUTO DE PESQUISAS ENERGÉTICAS E NUCLEARES

Autarquia associada à Universidade de São Paulo

\title{
CONTRIBUIÇÃO AO ESTUDO DO IMPACTO AMBIENTAL DAS PILHAS A COMBUSTÍVEL DE BAIXA E MÉDIA TEMPERATURA ATRAVÉS DA METODOLOGIA DELPHI
}

\author{
Maria Alice Morato Ribeiro
}

Tese apresentada como parte dos requisitos para obtenção do Grau de Doutor em Ciências na Área de

Tecnologia Nuclear - Aplicações

Orientadora: Dra. Margarida Mizue Hamada

São Paulo

2009 
Para Olavo e Carolina. 


\section{AGRADECIMENTOS}

Agradeço ao Dr. Wagner dos Santos Oliveira e à Dra. Margarida Mizue Hamada pela dedicação ao trabalho.

Agradeço também ao Msc. Arivaldo Vicente Gomes pelo apoio e colaboração, e a todos os colegas da minha área no CEN-IPEN, que sempre colaboraram muito com este trabalho. 


\section{SUMÁRIO}

Página.

LISTA DE TABELAS

LISTA DE FIGURAS

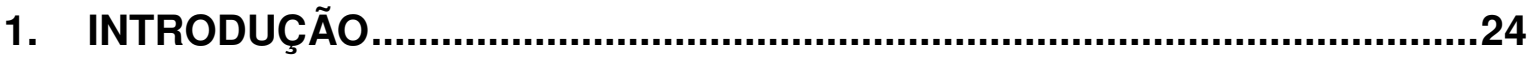

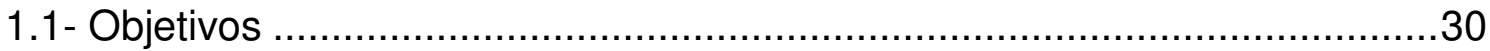

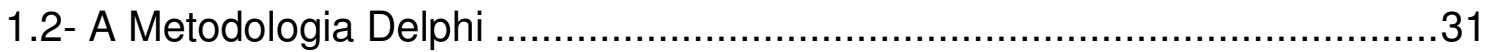

1.3 -Impacto ambiental em razão do ciclo de vida das pilhas............................32

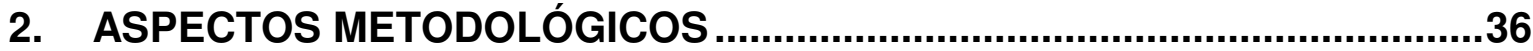

2.1-Métodos de previsão para tecnologias futuras ......................................... 41

2.1.1-Métodos de previsão baseados notadamente na opinião de peritos ....43

2.1.1.1 - Métodos de previsão de "gênios" ...............................................4

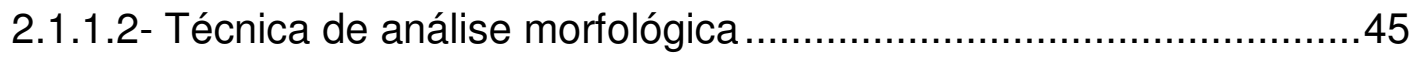

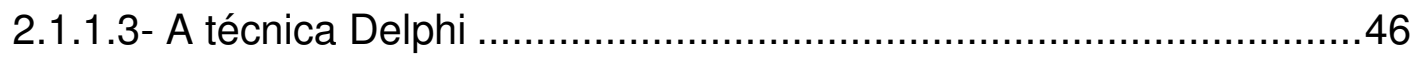

2.1.2-Métodos de previsão baseados notadamente em análise matemática ou

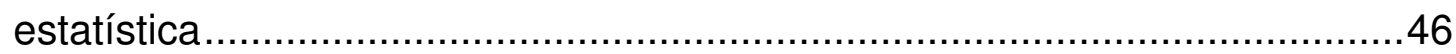

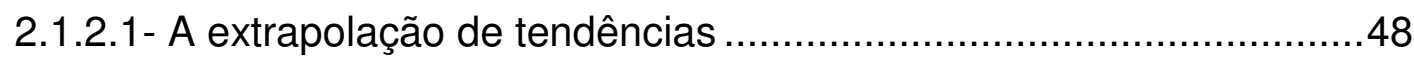

2.1.2.2- A modelagem por simulação .................................................... 50

2.1.2.3- Técnica de árvores de relevância...............................................52

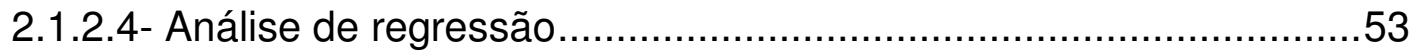

2.2-Problemas metodológicos na prospecção de tecnologias futuras................53 
2.3- Critérios de escolha para o método .............................................. 55

2.3.1-Problemas metodológicos no uso de ACV ou LCA ............................56

3. TIPOS DE PILHAS E COMBUSTÍVEIS UTILIZADOS..................................61

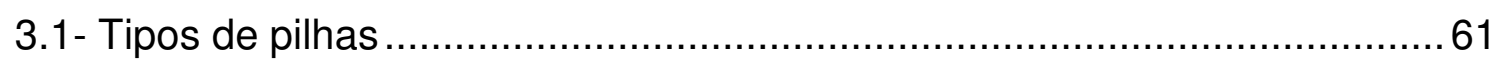

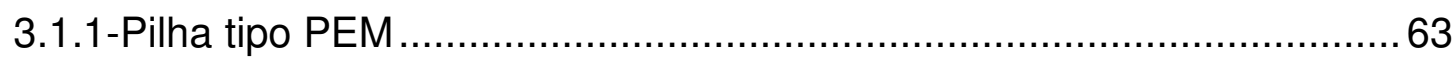

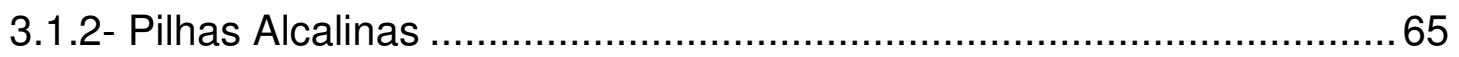

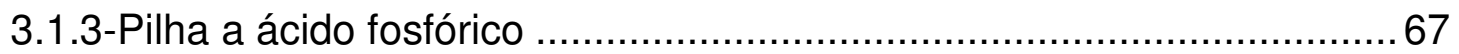

3.1.4-Pilhas de Carbonato Fundido (MCFC) ..................................... 71

3.2- Combustíveis utilizados nas pilhas ................................................... 74

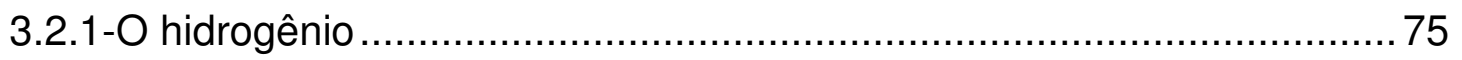

3.2.1.1 - Produção de hidrogênio a partir de combustíveis fósseis ............76 76

3.2.1.1.1-A gaseificação do carvão. ................................................ 78

3.2.1.1.2- Reforma a vapor do gás natural......................................78

3.2.1.1.3-Autorreforma do gás natural e óleo ..................................... 79

3.2.1.1.4-Dissociação Térmica ......................................................... 81

3.2.1.1.5-Processo Kvaerner .................................................. 81

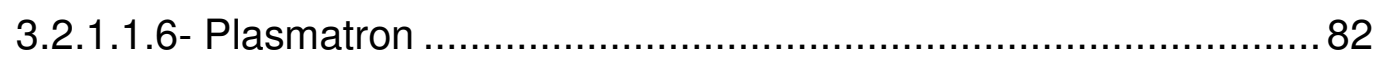

3.2.1.1.7- A energia nuclear ..................................................... 83

3.2.1.2- Produção de hidrogênio a partir de combustíveis renováveis.......86 86

3.2.1.2.1- Eletrólise da água............................................................ 86

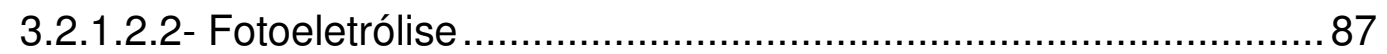

3.2.1.2.3- Decomposição térmica da água ....................................... 88

3.2.1.2.4- Gaseificação de biomassa. ........................................... 89

3.2.1.2.5- Produção biológica de hidrogênio .....................................90

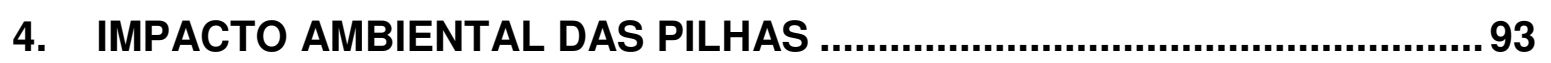

4.1-Impacto ambiental das pilhas PEM ................................................ 93

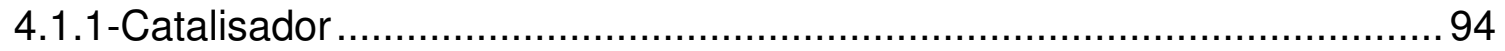

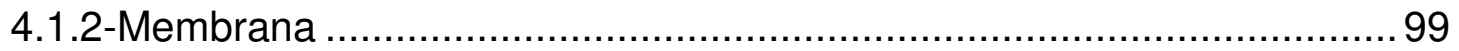

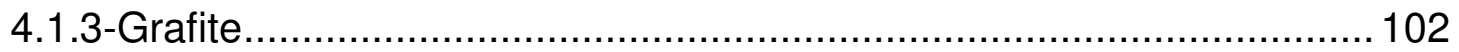

4.1.4 Outros materiais na etapa de fabricação ...................................... 104

4.1.5 Ciclo da vida de uma pilha PEM............................................... 104

4.1.5.1-Potencial de melhorias na pilha PEM ................................... 109

4.1.5.1.1- Platina e metais do grupo PGM....................................... 109

4.1.5.1.2- Fontes de eletricidade para a produção ............................ 112 
4.1.5.1.3- Potenciais de melhoria a longo prazo 112

4.1.5.2- Comparação entre o impacto de produção e o uso das pilhas combustíveis móveis em carros 113

4.1.5.3- Comparação entre o impacto de produção e o uso das pilhas combustíveis estacionárias

4.2 - Materiais utilizados nas pilhas a ácido fosfórico e seu impacto ...............120

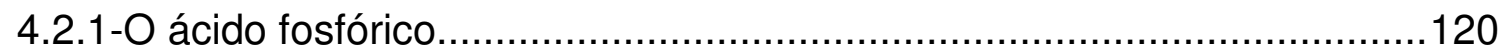

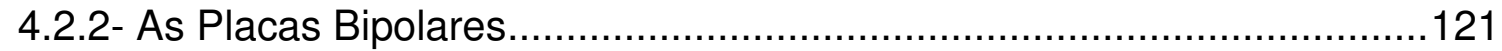

4.2.3- Estudo de um caso de ciclo da vida para PAFC.................................123

4.2.4-Impacto ambiental por causa do término da vida útil.............................128

4.3 - Impacto ambiental por causa do uso da Pilha de Carbonato Fundido ...129

4.4-Impacto ambiental do hidrogênio .....................................................137

4.4.1 - Mecanismos de Impacto Ambiental do hidrogênio...........................139

4.4.1.2- Produção de Ozônio ao nível do solo........................................139

4.4.1.3 - Produção de Ozônio na troposfera...........................................140

4.4.1.4 - Alterações Climáticas .............................................................140

4.4.1.5- Química do Ozônio na Estratosfera .......................................... 141

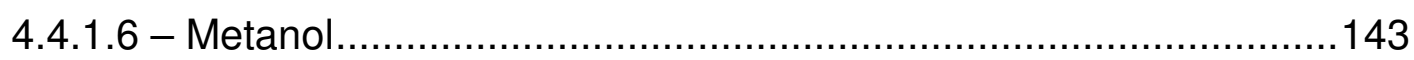

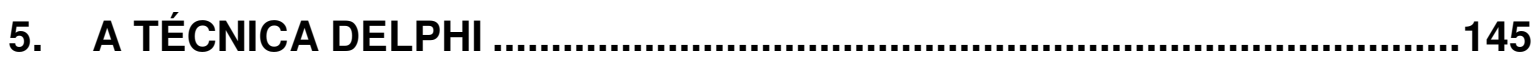

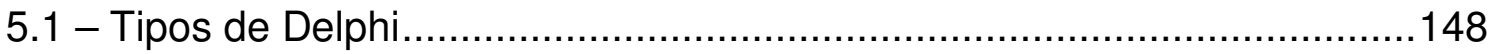

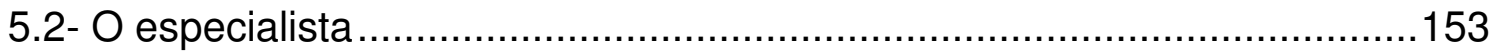

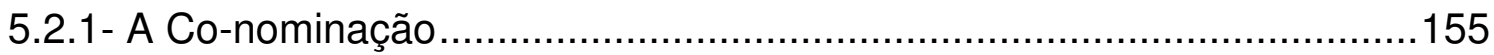

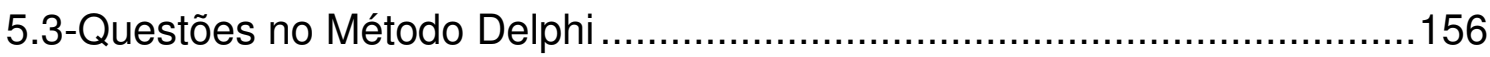

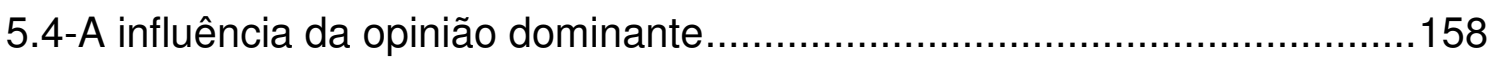

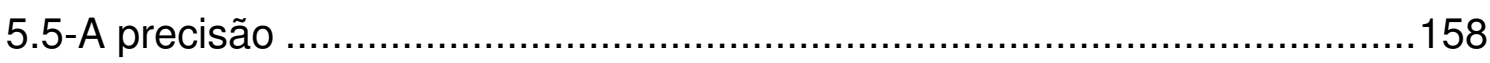

6. DESCRIÇÃO DA PESQUISA DELPHI REALIZADA COM ESPECIALIS-TAS E APRESENTAÇÃO DOS RESULTADOS …...............................................160

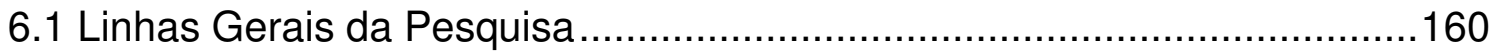

6.2 Condução da Pesquisa e População.....................................................162

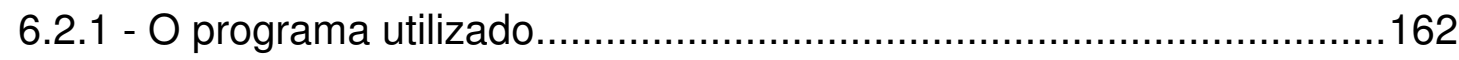

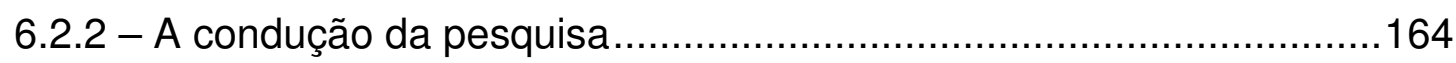

6.3 - Análise de variância da primeira rodada na pesquisa Delphi ..................170

6.4 - Medição do consenso e mudança de opinião na pesquisa Delphi ...........172

6.5 - Análise de convergência das respostas na pesquisa Delphi...................174 
6.6 - Apresentação dos resultados da primeira rodada da consulta Delphi ....174

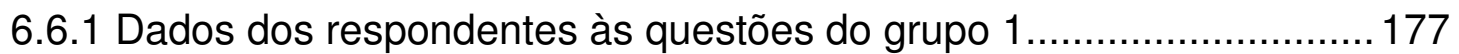

6.6.1.1 Grupo 1 - Questão 3 ....................................................... 177

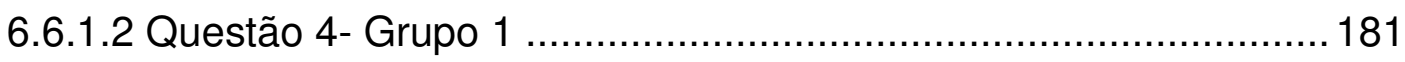

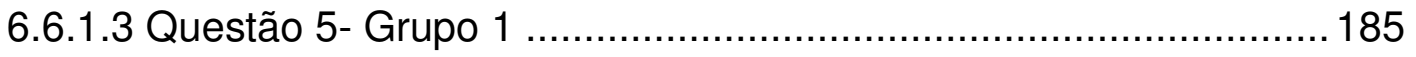

6.6.1.4- Questão 6- Grupo 1 .................................................... 189

6.6.1.5 Dados do Grupo 2 ......................................................... 191

6.6.1.6 Questão 8- Grupo 2 ........................................................... 191

6.6.1.7 Questão 9- Grupo 2 ....................................................... 196

6.6.1.8 Questão 10- Grupo 2 .................................................... 199

6.6.1.9 Questão 11 - Grupo 2.................................................... 202

6.6.1.10 Questão 12- Grupo 2................................................... 205

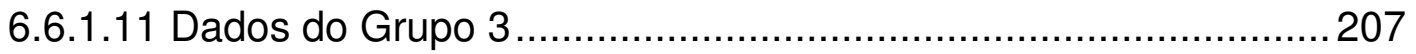

6.6.1.12 Questão 14- Grupo 3......................................................207

6.6.1.13 Questão 15- Grupo 3......................................................2 211

6.6.1.14 Questão 16- Grupo 2................................................. 213

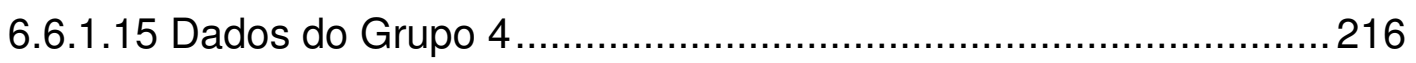

6.6.1.16 Questão 18- Grupo 4....................................................216

6.6.1.17 Questão 19- Grupo 4..................................................2 219

6.6.1.18 Questão 20- Grupo 4......................................................221

6.6.1.19 Questão 21- Grupo 4...................................................... 224

6.7 - Apresentação dos resultados da segunda rodada da consulta Delphi sobre impacto ambiental das pilhas a combustível ..............................................227

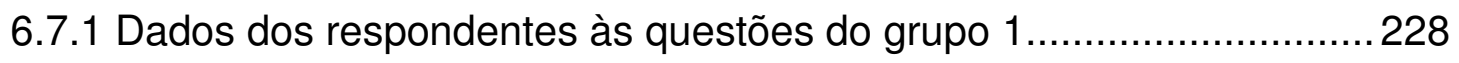

6.7.1.1- Grupo 1 - Questão 3 ..................................................... 228

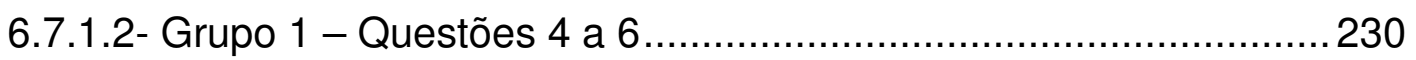

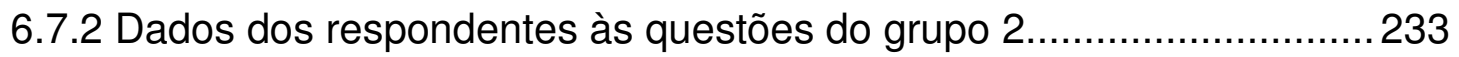

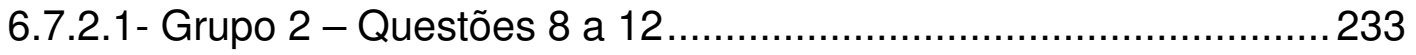

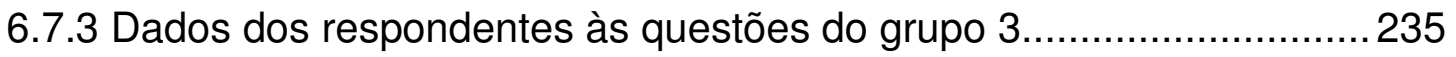

6.7.3.1 Grupo 3 - Questões 14 a 16............................................... 235

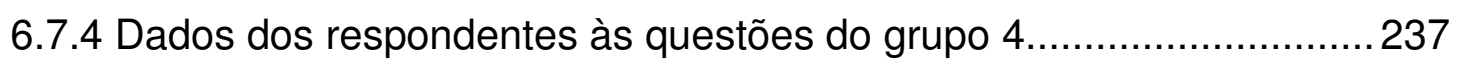

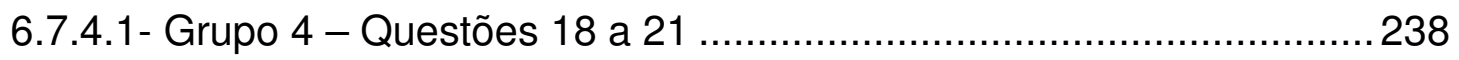

6.7.4.2- Grupo 4 - Questão 22 ...................................................... 240

6.8 Resultados do cálculo do fator de Cronbach para o questionário ..............242 
6.9 Comentários sobre os resultados 242

6.10 Discussão dos resultados da pesquisa Delphi efetuada..........................245

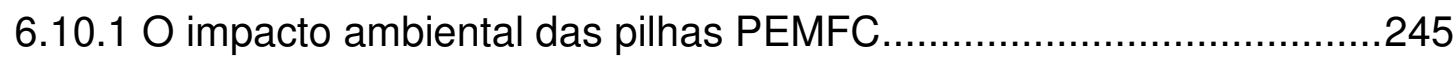

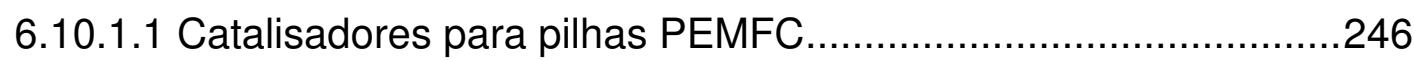

6.10.2 O impacto ambiental das pilhas PAFC.........................................248

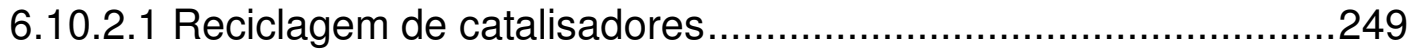

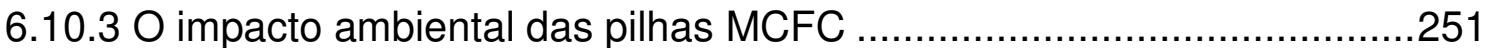

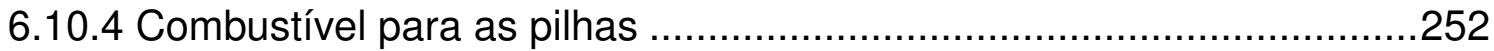

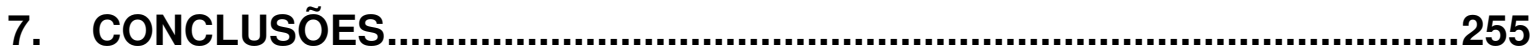

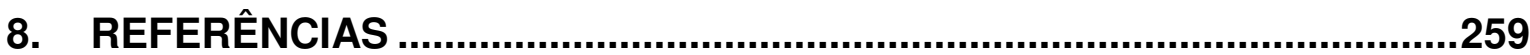

APÊNDICE A- Lista dos Tópicos a serem discutidos ...................................270

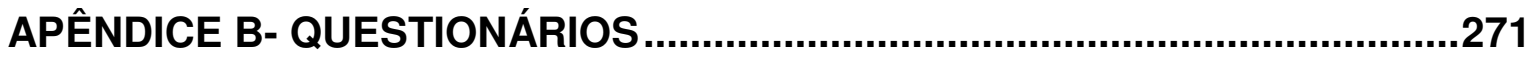

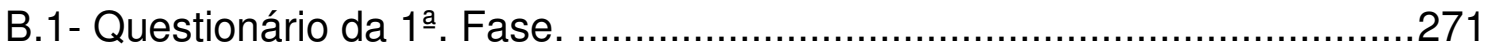

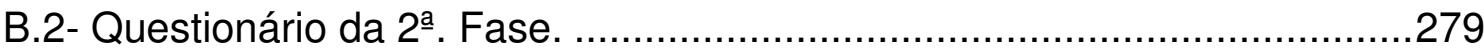

A. ANEXO A - ANÁLISE ESTATÍSTICA DOS DADOS.................................294

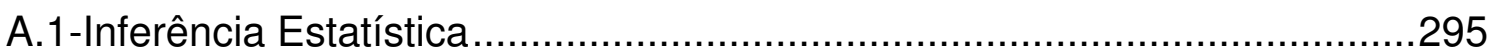

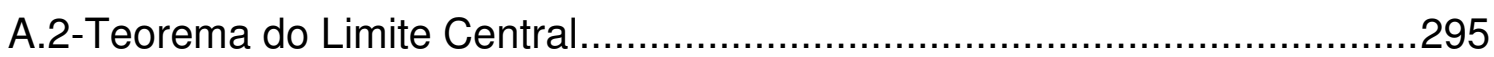

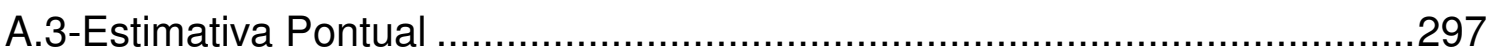

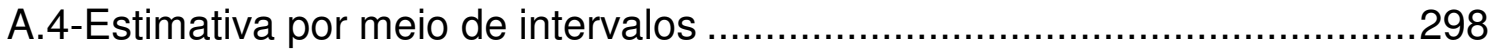

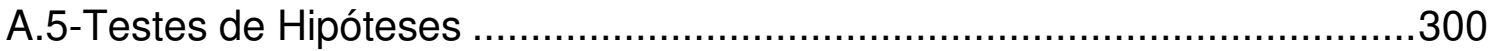

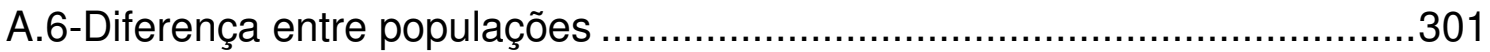

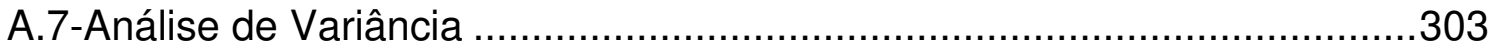

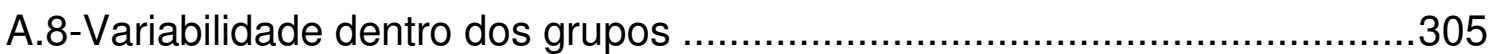

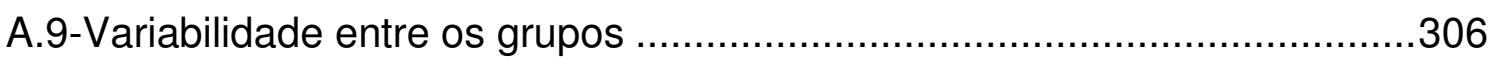

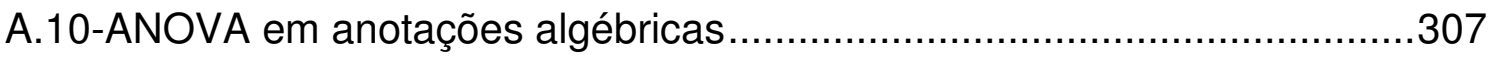

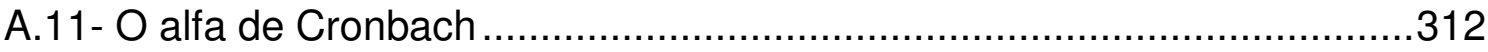




\section{LISTA DE TABELAS}

\section{Página}

Tabela 2-1 - Enfoque filosófico da geração do conhecimento ..............................42

Tabela 2-2 Critério para seleção do método de prospecção. ...............................55

Tabela 2-3 - Classificação da falta de dados na produção dos processos

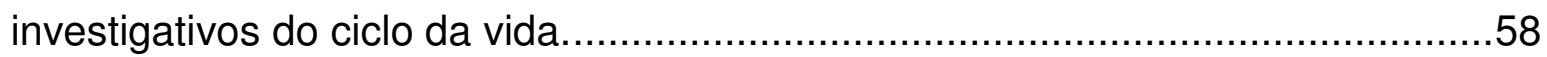

Tabela 3-1 - Características dos principais tipos de pilhas.................................62

Tabela 4-1 - Pilha de referência e análise de sensibilidade utilizada por ............106

Tabela 4-2 - Resultados de avaliação de impacto e inventário para uma pilha a

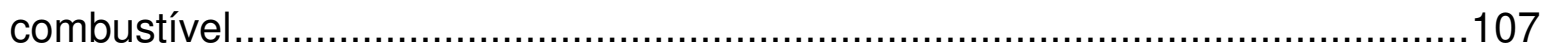

Tabela 4-3 - Resultado comparativo entre o carro movido a pilha a combustível utilizando hidrogênio obtido a partir de: (a) reforma do gás natural e (b) metanol, em um ciclo de direção misto, conforme Figura 4-10 sem considerar a produção do veículo.

Tabela 4-4 - Impacto ambiental (LCA) de pilha a combustível em carro movido a pilha a combustível e motores a combustão. 114

Tabela 4-5 - Emissões ocorridas durante a etapa de fabricação da pilha para aplicações estacionárias.................................................................................118

Tabela 4-6 - Composição da célula PAFC ....................................................124

Tabela 4-7 - Peso dos componentes do sistema PAFC. ..................................124

Tabela 4-8 - Peso dos materiais utilizados no sistema PAFC . ..........................124

Tabela 4-9 - Comparação entre os vários cenários ..........................................131

Tabela 4-10 - Características e desempenho da pilha MCFC utilizada por Raugei

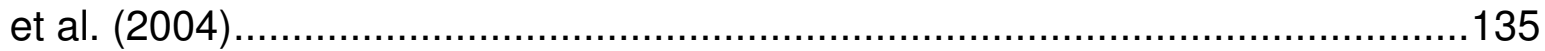

Tabela 4-11 - Principais emissões sólidas, líquidas e gasosas associadas com a produção de energia elétrica via pilha MCFC de 500MW ................................136

Tabela 6-1 - Descrição dos Grupos e os respectivos itens pesquisados..............166

Tabela 6-2 - Exemplo do quadro final de ANOVA ............................................171 
Tabela 6-3 - Visão geral da população de respondentes na primeira rodada ..... 175

Tabela 6-4 - Opções de resposta para os itens da questão 3 (\%).................... 178

Tabela 6-5 - Correlação entre respostas e características do respondente........178

Tabela 6-6 - Resposta para os itens da questão 4 (\%) ................................ 181

Tabela 6-7 - Correlação entre respostas e características do respondente para questão 4.

Tabela 6-8 - Opções escolhidas pelos respondentes para os itens da questão 5 185

Tabela 6-9 - Correlação entre respostas e características do respondente, para questão 5 . 186

Tabela 6-10 - Opções escolhidas pelos respondentes para os itens da questão 6. 189

Tabela 6-11 Respostas para os itens da questão 8 192

Tabela 6-12 - Correlação entre respostas e características do respondente...... 192

- Tabela 6-13 - Respostas obtidas para os itens da questão 9 (\%)..................... 196

Tabela 6-14 - Correlação entre respostas e características do respondente, para a

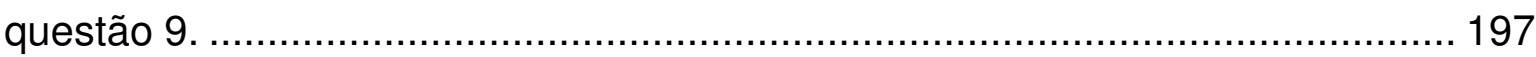

Tabela 6-15 - Respostas para os itens da questão 10 (\%). ............................. 199

Tabela 6-16 - Correlação entre respostas e características do respondente, para a

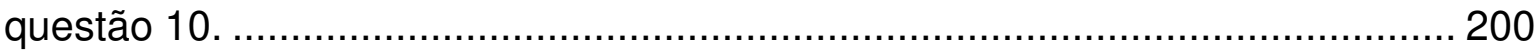

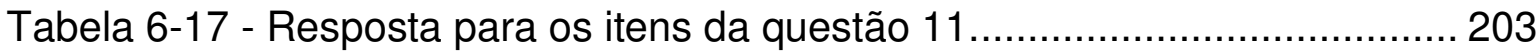

Tabela 6-18 - Respostas para os itens da questão 12 (\%). .............................. 205

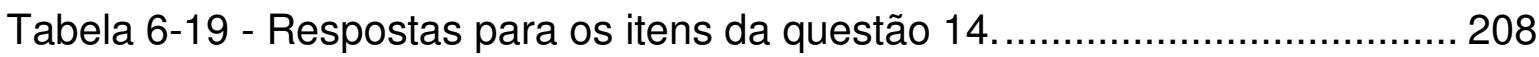

Tabela 6-20 - Correlação entre respostas e características do respondente para

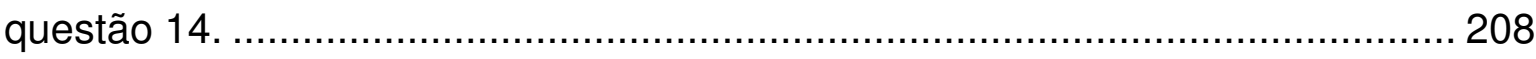

Tabela 6-21 - Opções de resposta para os itens da questão $15 \ldots \ldots \ldots \ldots \ldots \ldots \ldots . \ldots . \ldots . \ldots 11$

Tabela 6-22 - Opções de resposta para os itens da questão 16 (\%) ................. 213

Tabela 6-23 Correlação entre respostas e características do respondente.......213

Tabela 6-24 - Opções de resposta para os itens da questão 16 (\%) ...................216

Tabela 6-25 - Correlação entre respostas e características do respondente...... 217

Tabela 6-26 - Opções de resposta para os itens da questão 19 (\%) ................. 219

Tabela 6-27 - Correlação entre respostas e características do respondente...... 219

Tabela 6-28 - Opções de resposta para os itens da questão 20 (\%). .................. 222 
Tabela 6-29 - Correlação entre respostas e características do respondente. ....222 Tabela 6-30 - Opções de resposta para os itens da questão 21 (\%) ..................225 Tabela 6-31 - Correlação entre respostas e características do respondente. .....225 Tabela 6-32 - Visão geral da população de respondentes na primeira e segunda rodadas. 227

Tabela 6-33 - Valores de média e desvio padrão para os itens da questão 3. ...229 Tabela 6-34 - Dados de média e desvio padrão por grupos de respondentes mais e menos qualificados (questão 3). .230 Tabela 6-35 - Valores de média e desvio padrão para os itens das questões 4, 5 e 6.

Tabela 6-36 - Percentagem dos itens em que ocorreu convergência da média da segunda rodada para outra média da primeira rodada. 231 Tabela 6-37 - Valores de média e desvio padrão para os itens das questões 8 a12. .234

Tabela 6-38 - Percentagem dos itens em que ocorreu convergência da média da segunda rodada para outra média da primeira rodada. .234 Tabela 6-39 - Valores de média e desvio padrão para os itens das questões 14,15 e 16. 236

Tabela 6-40 - Percentagem dos itens em que ocorreu convergência da média da segunda rodada para outra média da primeira rodada. 237 Tabela 6-41 - Valores de média e desvio padrão para os itens das questões $18,19,20$ e 21 . 239

Tabela 6-42 - Percentagem dos itens em que ocorreu convergência da média da segunda rodada para outra média da primeira rodada. 239 Tabela A-1 - Dados de desempenho das duas amostras de estudantes que fizeram o curso .302

Tabela A-2 - Situação hipotética para uma ANOVA. .305

Tabela A-3 - Soma dos desvios quadrados dentro dos grupos. 306

Tabela A-4 - Notações utilizadas para a ANOVA ..........................................308

Tabela A-5 -Soma dos quadrados totais...............................................309

Tabela A-6 -Tabela de Análise de Variância...................................................309

Tabela A-7 Exemplo hipotético com diferentes tamanhos de amostras 310 


\section{LISTA DE FIGURAS}

Página

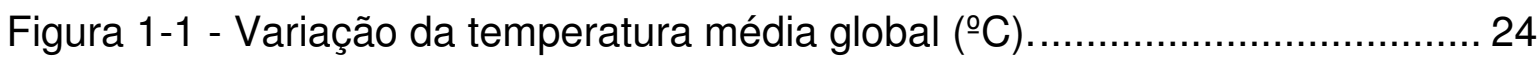

Figura 1-2 - Anomalia da temperatura média superficial global. Desvio da temperatura global superficial anual relativa à média 1951-1980, em ${ }^{\circ} \mathrm{C}$............. 25 Figura 1-3 - Anomalias da temperatura em 2007 em relação ao período 1951-

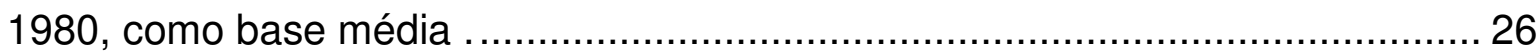

Figura 1-4 - Temperatura isotópica da terra (b) e Concentração de $\mathrm{CO}_{2}(\mathrm{a})$......... 27 Figura 1-5 - O mecanismo de aquecimento através da emissão de gases do efeito

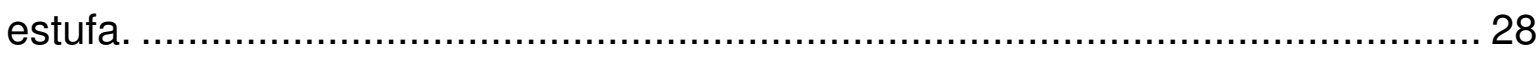

Figura 1-6 - Probabilidade de variação da temperatura média global $\left({ }^{\circ} \mathrm{C}\right)$............ 29

Figura 1-7 - O ciclo de vida da pilha a combustível............................................ 35

Figura 1-8 - Fontes de emissão de gases poluentes. ...................................... 35

Figura 2-1 - Evolução de uma variável ao longo do tempo representada pela curva S

Figura 2-2 - llustração do esquema dos processos combinados que resultam na

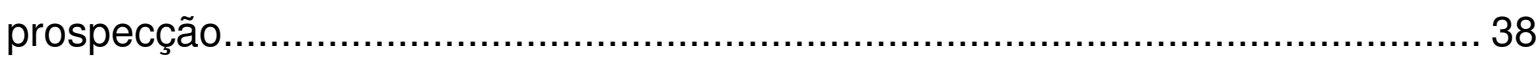

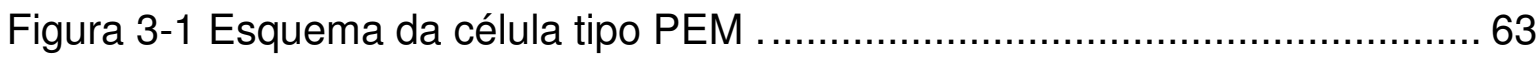

Figura 3-2 - Esquema do projeto de uma célula combustível PEM .................... 64

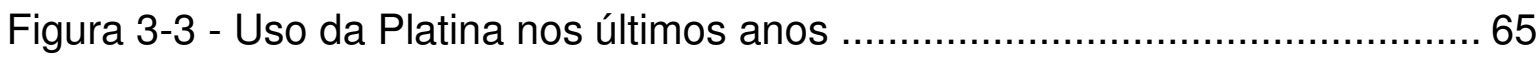

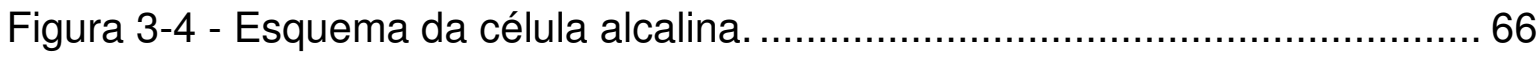

Figura 3-5 - Pilha Alcalina utilizada em ônibus espacial ................................... 67

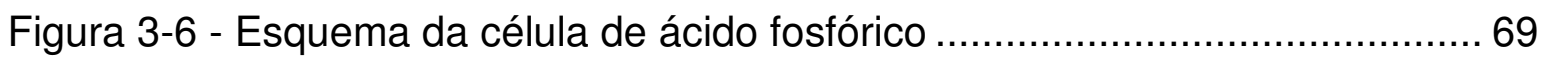

Figura 3-7 - Esquema do projeto de uma célula combustível PAFC .................. 70

Figura 3-8 - Pilhas de ácido fosfórico instaladas no Alaska. O sistema gera 1 MW70 Figura 3-9 - Pilha de ácido fosfórico da UTC Power (200kW), Stockton College, N.

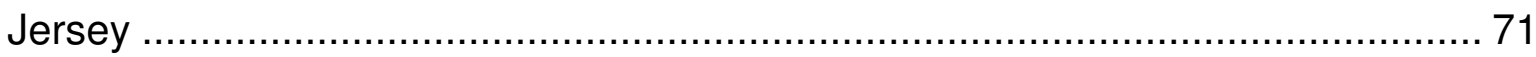

Figura 3-10 - Esquema da célula Carbonato fundido .......................................... 73

Figura 3-11 - Pilha MCFC - Expo AICHI 2005............................................... 73

Figura 3-12 - Visão em corte de uma pilha MCFC …….................................... 74 
Figura 3-13 - Unidade de produção de energia utilizando MCFC de 1MW , South Treatment Plant

Figura 3-14 - Processos de Produção de hidrogênio a partir de diferentes fontes de energia.

Figura 3-15 - Conversor de combustível Plasmatron, ultracompacto, desenvolvido pelo MIT. .83

Figura 3-16 - Ciclo S-I (Enxofre - lodo) termoquímico de decomposição da água85

Figura 3-17 - Visão geral do sistema de produção nuclear do hidrogênio. .85

Figura 3-18 - Impacto ambiental dos diferentes processos de produção do $\mathrm{H}_{2} \ldots .86$

Figura 3-19 - Produção solar de $\mathrm{H}_{2}$ via fotoeletrólise. .88

Figura 3-20 - Visão das várias fontes de produção de $\mathrm{H}_{2}$ e as possíveis

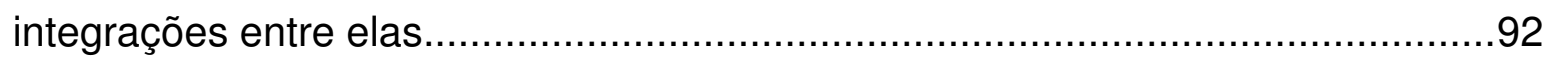

Figura 4-1 - Esquema do processo de produção da Platina.................................95

Figura 4-2 - Esquema de produção do colóide de Platina.....................................96

Figura 4-3 - Processo de produção do PTFE. ..............................................100

Figura 4-4 - Processo de produção da membrana ..........................................101

Figura 4-5 - Processos de produção da grafite...............................................102

Figura 4-6 - Processo de fabricação das placas de grafite..................................103

Figura 4-7 - Esquema do processo de produção de uma pilha tipo PEM na empresa Ballard. 105

Figura 4-8 - Contribuição dos componentes da pilha nos impactos ambientais considerados (para pilha móvel no caso 1) ..................................................108

Figura 4-9 - Consumo de hidrogênio como função da carga de PGM ...............110

Figura 4-10 - Ciclo de direção adotado para calcular o consumo de combustível.115

Figura 4-11 - Processo de produção do ácido fosfórico. ..................................121

Figura 4-12 - Produção da Matriz de eletrólito para pilha PAFC ..........................122

Figura 4-13 - Esquema do ciclo da vida de uma pilha PAFC ............................123

Figura 4-14 - Emissões para PAFC, separadas por etapa durante a vida ..........125

Figura 4-15 - Variação da eficiência do sistema da PAFC e turbina a gás (ciclo simples) em função da carga.

Figura 4-16 - Emissões de $\mathrm{SO}_{2}$ e $\mathrm{NOx}$ de vários sistemas durante os respectivos ciclos de vida. 126

Figura 4-17 - Emissões de $\mathrm{CO}_{2}$ de vários sistemas durante os respectivos ciclos 
de vida.

Figura 4-18 - Crédito de emissões referente ao uso da energia térmica oriunda da PAFC, em relação ao caso em que esta energia não é utilizada 127

Figura 4-19 - Sistema de uma pilha de carbonato fundido 129

Figura 4-20 - Resultados para o cenário $1 \mathrm{com}$ a pilha MCFC 130

Figura 4-21 - Resultados para o cenário 2 com a pilha MCFC 130

Figura 4-22 - Comparação da quantidade de SO2-eq emitida pelos sistemas ... 131 Figura 4-23 - Comparação da emissão de gases CO2-eq para vários cenários. 132 Figura 4-24 - Esquema de uma pilha MCFC operando com gases de aterro.... 133 Figura 4-25 - Comparação do aquecimento global para MCFC operada com gás natural (NG) e com gases obtidos valendo-se de aterros (LFG). 133

Figura 4-26 - Acidificação com comparação entre pilha de Carbonato fundido operada com gás natural (NG) e com gases obtidos valendo-se de aterros (LFG)

Figura 4-27 - Comparação do potencial de aquecimento global e acidificação para diferentes cenários de transporte de hidrogênio gerado a partir de fontes de energia renováveis 138

Figura 4-28 - Contribuição dos componentes para a energia primária, aquecimento global e acidificação. Produção de veículo baseado em pilha a combustível a metanol. 144

Figura 5-1 - Diagrama explicativo das etapas do Delphi clássico 151

Figura 5-2 - Diagrama explicativo das etapas do "Policy Delphi". 152

Figura 5-3 - Relação entre o número de palavras usadas numa descrição de evento e a quantidade de informação obtida sobre o tempo provável de ocorrência desses eventos.

Figura 6-1 - Principais fases da pesquisa. 161

Figura 6-2 - Tela do questionário, tal qual visualizada pelo respondente 163

Figura 6-3 - Exemplo de email de envio da pesquisa para o respondente. 168

Figura 6-4 - Apresentação da questão 4 na segunda rodada. 169

Figura 6-5 - Exemplo de como as médias e os desvios padrão podem variar de forma diferente

Figura 6-6 - Respondentes por continente na primeira rodada. 176

Figura 6-7 - Respondentes por país, na primeira rodada 176 
Figura 6-8 - Nível de especialização e área de atuação dos respondentes na primeira rodada, para o grupo 1 .

Figura 6-9 - Expectativa de redução do impacto ambiental das pilhas tipo PEM, por causa do catalisador, a longo prazo, por especialização do respondente.....179 Figura 6-10 - Expectativa do impacto ambiental por causa do desenvolvimento na área de placas bipolares, a longo prazo, por especialização do respondente.....179 Figura 6-11 - Comparação das respostas para os quatro itens considerados na questão 3: Catalisador, Membrana, Placas Bipolares e Outros Materiais. 180 Figura 6-12 - Comparação entre médias e desvio padrão das respostas para os itens da pilha: Catalisador, Membrana, Placas Bipolares e Outros Materiais......181 Figura 6-13 - Expectativa de diminuição do impacto ambiental devido à substituição da membrana, para as pilhas tipo PEM, a longo prazo, considerando a especialização do respondente. 182 Figura 6-14 - Expectativa da diminuição do impacto ambiental devido à substituição das placas bipolares, para as pilhas tipo PEM, a longo prazo, considerando a especialização do respondente.

Figura 6-15 - Expectativa de diminuição do impacto ambiental devido à substituição dos materiais de vários itens das pilhas PEM, a longo prazo. 184 Figura 6-16 - Valores de médias e desvios padrão para os itens que compõem a pilha PEM, para a questão 4 .

Figura 6-17 - Expectativa da diminuição do impacto ambiental devido à evolução/alterações no projeto que possam vir a abolir ou substituir o catalisador, para as pilhas tipo PEM, I a longo prazo, por especialização do respondente. ...186 Figura 6-18 - Expectativa da redução do impacto ambiental por causa dos novos projetos que venham a abolir ou substituir a membrana, para as pilhas PEM, a longo prazo, considerando a qualificação do respondente. .

Figura 6-19 - Expectativa da probabilidade de redução do impacto ambiental em razão dos novos projetos que possam vir a abolir ou substituir a membrana, a longo prazo, por continente onde o respondente reside.

Figura 6-20 - Comparação das respostas para os quatro itens considerados na questão 5: Catalisador, Membrana, Placas Bipolares e Outros Materiais. 188

Figura 6-21 - Valores médios e desvios padrão das respostas à questão 5 para os itens que compõem as pilhas tipo PEM. 
Figura 6-22 - Avaliação da substituição do uso de catalisadores do grupo PGM, a longo prazo, para pilhas tipo PEM. 190

Figura 6-23 - Gráfico mostrando as respostas por continente, para a questão 5.

Figura 6-24 - Qualificação e ramo de atividade do grupo de respondentes das questões pertencentes ao grupo 2 .

Figura 6-25 - Expectativa do impacto ambiental por causa do catalisador, na pilha PAFC, a longo prazo, com as respostas separadas por qualificação dos respondentes. 193

Figura 6-26 - Respostas para a questão 8 por local de residência do respondente. 194

Figura 6-27 - Avaliação do impacto ambiental por causa dos vários itens que compõem as pilhas PAFC, considerando os avanços tecnológicos a longo prazo. 195

Figura 6-28 - Valores médios e desvios padrão para redução de impacto, a longo prazo, para os diversos itens que compões as pilhas PAFC, a longo prazo....... 195 Figura 6-29 - Expectativa de substituição/abolição do uso de materiais do grupo PGM como catalisador para pilhas PAFC, considerando os avanços tecnológicos a longo prazo.

Figura 6-30 - Respostas obtidas para a questão 9, separadas por continente do respondente. 198

Figura 6-31 - Respostas obtidas para a questão 9, separadas por grau de especialização do respondente. 198

Figura 6-32 - Expectativa de substituição/abolição dos materiais utilizados como catalisador para pilhas PAFC, a longo prazo, com as respostas separadas por sexo do respondente. 199

Figura 6-33 - Avaliação da probabilidade de redução do impacto ambiental das pilhas PAFC, considerando a evolução do projeto, a longo prazo. 200 Figura 6-34 - Respostas para a questão 10, separadas por continente do respondente. 201

Figura 6-35 - Média e desvio padrão da expectativa de redução do impacto ambiental em razão de alterações em projetos das pilhas PAFC. 202

Figura 6-36 - Expectativa do desempenho dos catalisadores pertencentes ao 
grupo PGM, a longo prazo, para pilhas PAFC e PEM. 203

Figura 6-37 - Respostas à questão 11, separadas por continente do respondente.

Figura 6-38 - Expectativa do desempenho dos catalisadores pertencentes ao grupo PGM, a longo prazo para pilhas PAFC e PEM, separados por atividade do respondente. 204

Figura 6-39 - Expectativa da reciclagem dos catalisadores pertencentes ao grupo PGM, a longo prazo para grupos "mais" e "menos qualificados". 205 Figura 6-40 - Respostas à questão 12 separadas por continente do respondente. 206

Figura 6-41 -Expectativa de reciclagem do catalisador do grupo da Platina por ramo de atividade do respondente. 206

Figura 6-42- Qualificação e ramo de atividade dos respondentes das questões pertencentes ao grupo 3 . 207 Figura 6-43 - Expectativa da redução do impacto ambiental, em razão dos catalisadores, para as pilhas MCFC, por continente onde o respondente reside.209 Figura 6-44 - Avaliação da diminuição do impacto ambiental em razão dos "outros materiais", a longo prazo para pilhas MCFC, por sexo do respondente. 209 Figura 6-45 - Comparação das respostas para os quatro itens considerados na questão 14: Catalisador, Membrana, Placas Bipolares e Outros Materiais. 210 Figura 6-46 - Média e desvio padrão das respostas obtidas para os vários itens das pilhas MCFC, na questão 14 . 210 Figura 6-47 - Expectativa de substituição/abolição do uso de materiais do grupo PGM como catalisador para MCFC, para grupos mais e menos qualificados. ....212 Figura 6-48 - Respostas à questão 15 separadas por continente do respondente. 212

Figura 6-49 - Expectativa de redução do impacto ambiental frente à evolução para outro tipo de projeto, no qual os vários itens que compõem a pilha tipo MCFC, possam ser substituídas ou abolidas, para um horizonte de longo prazo.............214 Figura 6-50 - Respostas à questão 16, separadas por continente do respondente.

Figura 6-51 - Médias e Desvios Padrão para expectativa de redução do impacto ambiental considerando outro tipo de projeto, para os diversos itens das pilhas 
MCFC, a longo prazo.

Figura 6-52 - Qualificação e ramo de atividade dos respondentes das questões pertencentes ao grupo 4

Figura 6-53 - Expectativa de redução do impacto ambiental em razão do processo de produção de hidrogênio ser efetuado: 1-em local distante do consumo e 2- em local próximo ao consumo ou "onboard", a longo prazo. 217 Figura 6-54 - Respostas à questão 19 separadas por continente do respondente. 218

Figura 6-55 - Médias e Desvio padrão das respostas para expectativa de redução do impacto ambiental em razão do processo estar próximo ou longe do consumidor. 218

Figura 6-56 - Expectativa de redução do impacto ambiental devido à: 1- novos processos de produção de H2, 2-novas matérias primas utilizadas no processo de produção de $\mathrm{H} 2$, a longo prazo. 220

Figura 6-57 - Expectativa de redução do impacto ambiental devido à produção de hidrogênio por meio de novos processos a longo prazo, com as respostas separadas por qualificação dos respondentes.

Figura 6-58 - Expectativa de redução do impacto ambiental em razão do uso de novos processos e novas matérias primas na produção de hidrogênio, a longo prazo, com as respostas separadas por atividade do respondente. 221 Figura 6-59 - Respostas à questão 19 separadas por continente do respondente.

Figura 6-60 - Expectativa de uso dos processos mais comumente utilizados para produção de hidrogênio, a longo prazo. 223

Figura 6-61- Expectativa de continuidade do uso do processo Eletrolítico para produção de hidrogênio, a longo prazo, com as respostas separadas por atividade do respondente. 224

Figura 6-62 - Expectativa de continuidade do uso dos processos: gaseificação do carvão e reforma do gás natural, para produção de hidrogênio, a longo prazo, com as respostas separadas por continente do respondente. 224 Figura 6-63 - Expectativa do uso da energia do gás natural como insumo no processo de produção de hidrogênio, a longo prazo, com as respostas separadas por atividade do respondente. 226 
Figura 6-64 - Expectativa do uso da energia de várias fontes como insumo no processo de produção de hidrogênio, a longo prazo.

Figura 6-65 -Dados de sexo e continente onde residem todos os respondentes na segunda rodada.

Figura 6-66 -Nível de especialização e Área de atuação dos respondentes na primeira rodada, para o grupo 1 .

Figura 6-67 - Redução de impacto em razão do desenvolvimento e novas descobertas na área de catalisadores (1a e 2a rodadas)

Figura 6-68 - Variação(*) do Desvio Padrão da segunda rodada em relação à primeira rodada para os itens de todas as questões do Grupo 1. 232 Figura 6-69 - Nível de especialização e Área de atuação dos respondentes na primeira rodada, para o grupo 2 . 233 Figura 6-70 - Variação do Desvio Padrão da segunda rodada em relação à primeira rodada para os itens de todas as questões do Grupo 2. 235 Figura 6-71 - Nível de especialização e Área de atuação dos respondentes na primeira rodada, para o grupo 3 . 235 Figura 6-72 - Variação do Desvio Padrão da segunda rodada em relação à primeira rodada para os itens de todas as questões do Grupo 3. 237 Figura 6-73 - Nível de especialização e Área de atuação dos respondentes na primeira rodada, para o grupo 4.

Figura 6-74 - Variação do Desvio Padrão da segunda rodada em relação à primeira rodada para os itens de todas as questões do Grupo 4. 240 Figura 6-75 - Expectativa do impacto ambiental da tecnologia de produção de hidrogênio através da energia nuclear 241 Figura 6-76 - Expectativa do impacto ambiental devido à produção de hidrogênio através da energia nuclear, com respostas separadas por continente dos respondentes. 241

Figura 6-77- Valores do fator de Cronbach calculado para o questionário, separado por partes. .242

Figura 6-78 - Percentagem das respostas em que ocorreu aumento de consenso. .243

Figura 6-79 - Variação das médias dos grupos de menos e mais qualificados ...244 Figura 6-80 - Grau de redução do impacto ambiental para as questões 3 a 5 
sobre impacto ambiental das pilhas PEMFC.

245

Figura 6-81 - Redução nas emissões relativas à etapa de produção da Platina, para o caso em que se use $10 \mathrm{~g}$ e $5 \mathrm{~g}$ de Pt por pilha, por carro

Figura 6-82 - Emissões de emissões de gases do efeito estufa para vários tipos de geração em ciclo combinado. Emissões expressas como ton. $\mathrm{CO}_{2 \text {-eq }}$ por $1 \mathrm{GWh}$ de exergia produzida. 250

Figura 6-83 - Expectativa dos respondentes para Pilhas PEMFC e PAFC e metais do grupo da Platina.

Figura 6-84 - Eficiência dos vários tipos de ciclos com pilhas PAFC, PEFC e MCFC 252

Figura 6-85 - Expectativa de continuidade no uso dos processos de produção de $\mathrm{H} 2$ (na $1^{\mathrm{a}}$ rodada (superior) e $2^{\mathrm{a}}$ rodada (inferior) da pesquisa Delphi). 253

Figura 6-86 - Expectativa de uso dos vários tipos de energia no processo de produção de $\mathrm{H} 2$ (na $1^{\mathrm{a}}$ rodada (superior) e $2^{\mathrm{a}}$ rodada (inferior) da pesquisa Delphi)..... 254

Figura A-1 Gráfico mostrando que a distribuição de médias aproxima-se da normal quando aumenta o tamanho de amostras. 296

Figura A-2 Distribuição amostral de $\bar{x}$ 299

Figura A-3 Distribuições de probabilidades de $z$, t1 e t2. 300

Figura A-4 Distribuição amostral da média com $\mu=3300 \mathrm{~g}$ e $\sigma=516 \mathrm{~g}$. 301

Figura A-5 Variância não suficiente 304

Figura A-6 Variância suficiente 304

Figura A-7 Gráfico de três distribuições hipotéticas 311

Figura A-8 Aumento da razão- $F$ em razão do aumento da diferença entre as médias, mantendo-se as dispersões constantes.

Figura A-9 Aumento da razão-F em razão da diminuição da dispersão das amostras, mantendo-se as médias constantes. 


\section{LISTA DE ABREVIATURAS}

ACV- Avaliação do ciclo da vida

AFC - Pilha com eletrólito alcalino

AGT- "Axial Gas Turbine" - Turbina a gás axial

AP- Potencial de acidificação

CCGT - ("Combined Cycle Gas Turbine" - Ciclo combinado

CTPETRO Fundo Setorial de Petróleo e Gás Natural

DMFC - "Direct Methanol Fuel Cell" - Pilha utilizando combustível metanol diretamente

DOE - "U. S. Department of Energy"- Departamento de Energia dos EUA

ECE- "Economic Commission for Europe"

ECE R49- Norma antiga da Comissão Econômica Européia (anterior a 2000) para emissões veiculares ("Economic Commission for Europe")

EEV- "Enhanced environmentally friendly vehicle" - Veículos ecológicos,

EUDC- "Extra-Urban driving cycle" - Ciclo de direção fora do centro urbano

EUROFOU "European Foundation for the Improvement of Living and Working

ND- Conditions"

ENEA- Agência Nacional Energia e Meio-Ambiente. (Itália)

GDE- Eletrodo de Difusão Gasosa

GE - "General Electric"

GISS- "Goddard Institute for Space Studies" - Instituto Goddard para Estudos Espaciais

GHG- "Greenhouse Gases"- Gases responsáveis pelo efeito estufa

Gg- $\quad$ Gigagrama $=1 \times 10^{6} \mathrm{~kg}$

HTFC - "High Temperature Fuel Cell" - Pilha a combustível de alta temperatura

ICE- "Internal Combustion Engine" - Motor de combustão interna. 
ICEV- "Internal Combustion Engine Vehicle" - Veículo com motor de combustão interna

IPCC- "Intergovernmental Panel on Climate Change" - Painel intergovernamental sobre mudanças climáticas

kWhe - Kilo Watt hora equivalente

LCA - " "Life Cycle Assessment"

LHV - $\quad$ "Low Heat Value" - Capacidade calorífica inferior

MCFC- "Molten Carbonate Fuel Cell" - Pilha com eletrólito de carbonato fundido

MEA- "Membrane Electrode Assembly" - Conjunto do eletrodo de membrana.

MIT- "Massachusetts Institute of Technology".

NASA - "National Airspace Agency"

NREL - " National Renewable Energy Laboratory"

NMVOC- "Non-Methane Volatile Organic Compounds" - Compostos orgânicos voláteis exceto Metano

NYSERDA-“New York State Energy Research and Development Authority”

PAFC- "Phosphoric Acid Fuel Cell” - Pilha com eletrólito de ácido fosfórico

PEM- "Proton Exchange Membrane" - Pilha com eletrólito de membrana polimérica

PEMFC "Proton Exchange Membrane Fuel Cell" - Pilha com eletrólito de membrana polimérica

PEN- "Positive-electrolyte-negative" - Eletrólito positivo-negativo

PGM- "Platinum Metal Group" - Metais do grupo da Platina

Ppbv "Parts Per Billion in Volume"

PWR "Power Water Reactor"

RAND "Research ANd Development" - RAND Corporation

RGT - "Radial Gas Turbine" - Turbina a gás radial

SPFC- "Solid Polymer Fuel Cell" - Pilha de polímero sólido

SOFC- "Solid Oxide Fuel Cell" - Pilha com eletrólito sólido

UK- “United Kingdom” - Reino Unido 


\section{CONTRIBUIÇÃO AO ESTUDO DO IMPACTO AMBIENTAL DAS PILHAS A COMBUSTÍVEL DE BAIXA E MÉDIA TEMPERATURA ATRAVÉS DA METODOLOGIA DELPHI}

\section{Maria Alice Morato Ribeiro}

\section{RESUMO}

A avaliação dos sistemas de fornecimento de energia para o futuro é da maior importância para se obter informações sobre o potencial de impacto ambiental dos vários estágios do ciclo de vida das tecnologias inovadoras, determinando as vantagens competitivas sobre as tecnologias convencionais e para o desenvolvimento de cenários futuros.

Este trabalho apresenta e caracteriza os tipos de pilhas combustíveis de média e baixa temperatura mais pesquisadas e comercializadas nos últimos anos. Realiza-se também a apresentação da avaliação do impacto ambiental dos principais materiais utilizados nas pilhas a combustível, considerando as fases de fabricação, operação e disposição final após o término da vida útil. São apresentados vários dados de LCA ("Life Cycle Assessment") efetuados para alguns tipos de pilhas.

O trabalho efetuou uma contribuição ao estudo da avaliação de impacto ambiental das pilhas a combustível de média e baixa temperatura utilizando a metodologia Delphi. Foi construído um questionário e um banco de dados para formação do conjunto de respondentes que participaram da pesquisa. Eles receberam o questionário na primeira rodada e o responderam. Depois receberam novamente o questionário em conjunto com as respostas obtidas na primeira etapa, para nova rodada de respostas. Ao final o estudo verifica se ocorreu aumento de consenso e a influência dos respondentes mais qualificados sobre os menos qualificados.

Os resultados mostraram que os respondentes acreditam numa redução do impacto ambiental das pilhas. O mais surpreendente é que os respondentes acreditam que os catalisadores do grupo PGM Podem ser substituídos. 


\title{
CONTRIBUTION TO ENVIRONMENTAL IMPACT STUDY OF FUEL CELLS OF LOW AND MEDIUM TEMPERATURE USING THE DELPHI METHODOLOGY.
}

\section{Maria Alice Morato Ribeiro}

\begin{abstract}
Assessing future energy systems is of major importance for providing information on potential environmental awareness of the some life cycle stage of innovative technologies, for determining competitive advantages compared to conventional technologies and for developing scenarios of future.

The main objective of this work is to provide a contribution for the evaluation of the environmental impact of fuel cells of low and media temperature, including all life cycles, and hydrogen production step, using the Delphi methodology. This work introduces and characterizes several types of fuel cells, which are more researched in the last years and presents several life cycles analysis for the fuel cells, their manufacture, operation and waste after the lifetime.

The Delphi research is presented, with the first and second round results, the questionnaire and the methods descriptions adopted in this study. The Delphi Methodology is detailed in this work detailing the entrance data, the philosophy to be used in this study of the future scenes, as well as, the statistical treatment to be used for evaluation of the final results.

A questionnaire was constructed and a respondent's team participated in the research. Initially they received the questionnaire in the first round. In the next round they received again the questionnaire together with the responses obtained in the first stage. At the end, the study it was verified it there was an increase of consensus and an influence of the most qualified respondents on the other respondents.

The results showed that the respondents believe in reducing the environmental impact of fuel cells. The most surprising in the research is that the respondents believe that the group's PGM catalysts can be replaced.
\end{abstract}




\section{INTRODUÇÃO}

A ocorrência do aquecimento global, devido à emissão de gases, sobretudo o dióxido de Carbono $\left(\mathrm{CO}_{2}\right)$, já é fato bem estabelecido. Isto pode ser comprovado através da reconstrução do histórico das temperaturas globais ao longo do último milênio, que evidencia uma subida acentuada da temperatura média da Terra. Em um exercício de grande escala, Mann et al. $(1998,1999)$ utilizou dados históricos baseando-se em anéis de árvores, núcleos de gelo, e outros artifícios para reconstruir a temperatura média do hemisfério norte, ao longo dos últimos 1.000 anos. Deste trabalho resultou o gráfico apresentado na Figura 1-1 e que se tornou muito conhecido após sua apresentação no relatório de 2001 do IPCC (Intergovernmental Panel on Climate Change), inclusive porque gerou várias polêmicas.

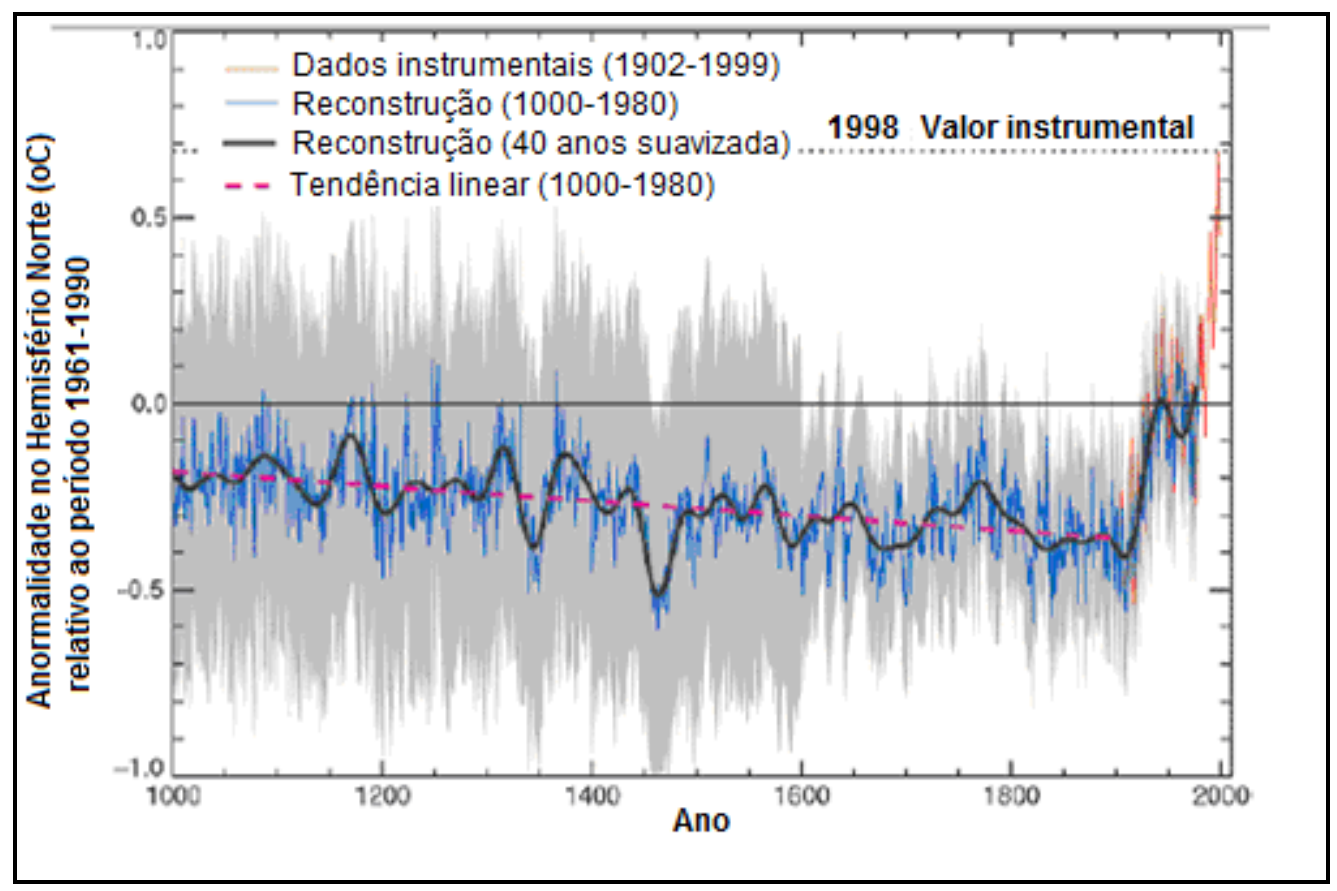

Figura 1-1 - Variação da temperatura média global $\left({ }^{\circ} \mathrm{C}\right)$.

De acordo com o IPCC (2001), durante o século XX, o aquecimento global na temperatura superficial da terra aumentou aproximadamente 
$0,6^{\circ} \mathrm{C} /$ século. $\mathrm{O}$ ano de 2005 foi o ano mais quente em alguns milhares de anos. Ademais Shaw (2006), relatou que, nos últimos dez anos (1996-2006), nove foram os mais quentes desde que se iniciou o registro de temperatura, por volta do final do século IXX.

Outro exercício, realizado pela NASA (2005) e que abrangeu os últimos 125 anos, usando medidas indiretas, e especialmente instrumentais, também indica o aquecimento global. Inicialmente, os resultados foram inconclusivos: por que os balões mostravam que a temperaturas diurnas diminuíam ao longo do tempo, ao passo que as temperaturas noturnas aumentavam ao longo do tempo. Entretanto, no início os sensores foram isolados de modo inadequado contra a luz solar e, portanto a temperatura ao longo do dia estava com leitura errada. Além disso, ocorreram erros nos cálculos das órbitas dos satélites que causaram erros nas observações iniciais. Corrigidos estes erros os dados mostram uma consistente história de aquecimento ao longo do período, em quatro fases, conforme mostrado na Figura 1-2. Nesta figura é mostrado o desvio da temperatura média superficial anual global relativa à média 1951-80 e os valores foram baseados na medida da temperatura do ar na superfície em estações meteorológicas e na temperatura e medidas da temperatura superficial do mar por satélites e navios.

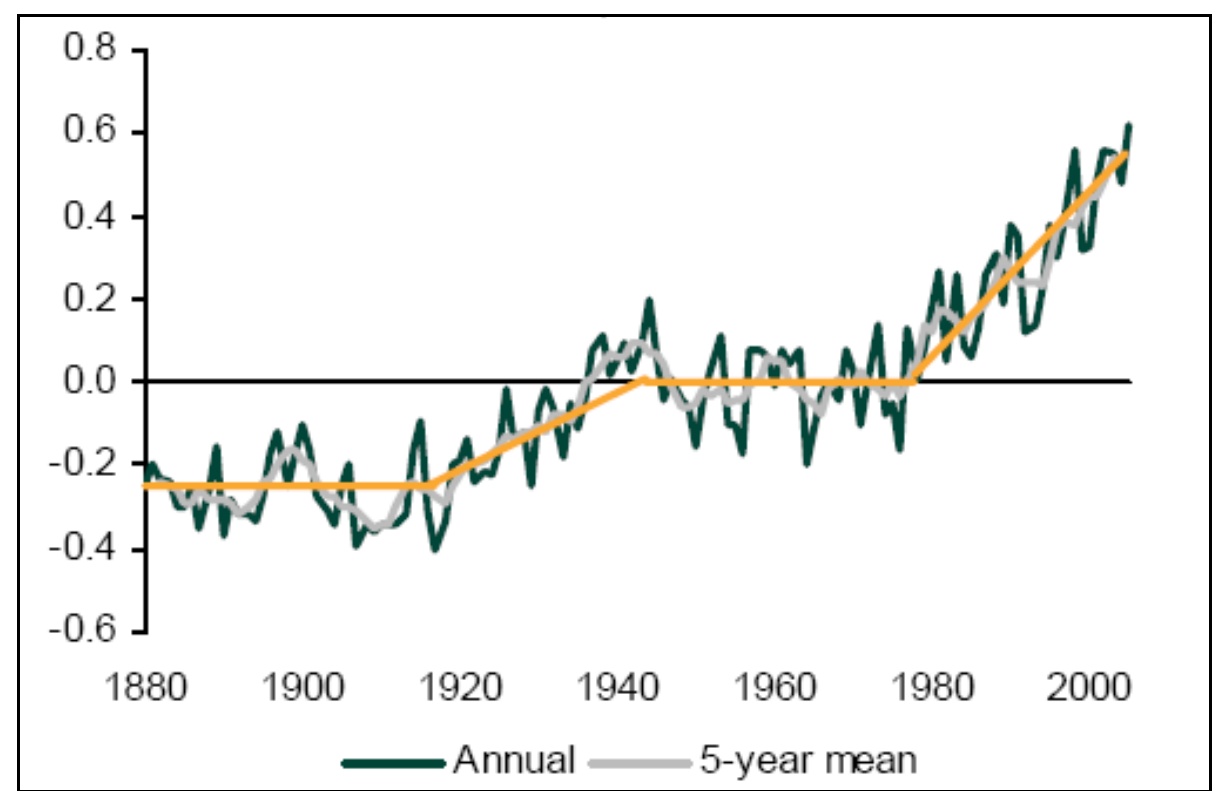

Figura 1-2 - Anomalia da temperatura média superficial global. Desvio da temperatura global superficial anual relativa à média 1951-1980, em ${ }^{\circ} \mathrm{C}$. (NASA-

Goddard Institute for Space Studies http://data.giss.nasa.gov/gistemp/2005/) 
O segundo ano mais quente, atrás apenas do recorde de calor de 2005, foi o ano de 2007, na análise do Instituto Goddard para Estudos Espaciais (GISS). O calor incomum em 2007 foi notável porque ocorreu num momento em que a irradiação solar mínima e o Oceano Pacífico equatorial estavam em fase de resfriamento no ciclo El Niño-La Niña. A Figura 1-3 mostra as anomalias da temperatura em 2007 em relação ao valor médio do período 1951-1980. Estes valores também estão baseados nas medições do ar na superfície de estações meteorológicas e navios, e nas medições de temperatura superficial do mar por meio de satélites. A temperatura média global anômala (aproximadamente $0,57^{\circ} \mathrm{C}$ mais quente que a média de 1951-1980) confirma a tendência de aquecimento global dos últimos trinta anos, que tem sido atribuída como efeito do aumento dos gases do efeito de estufa (GHG - "Greenhouse Gases"). Os oito anos mais quentes, registrados pelo GISS, ocorreram desde 1998, e os 14 anos mais quentes nos registros do GISS ocorreram todos a partir de 1990.

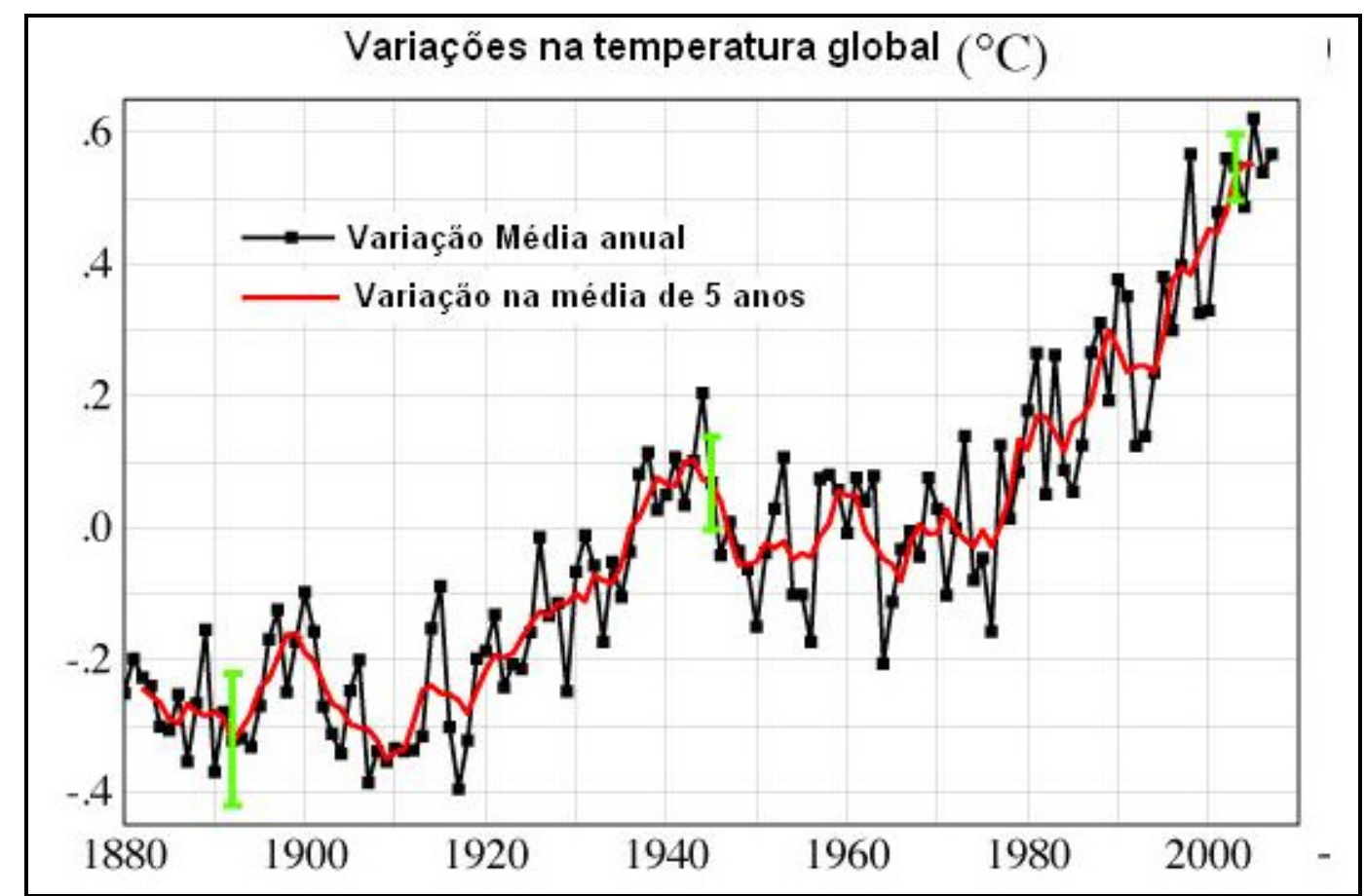

Figura 1-3 - Anomalias da temperatura em 2007 em relação ao período 19511980, como base média (NASA Goddard Institute for Space Studies http://www.giss.nasa.gov/research/news/20080116/).

Muitas das flutuações da temperatura da Terra são conseqüências da concentração de gases de efeito estufa na atmosfera: a correlação (mais de 400.000 anos) entre a concentração dos gases responsáveis pelo efeito estufa e 
a temperatura da Terra pode ser notada conforme mostrado na Figura 1-4.

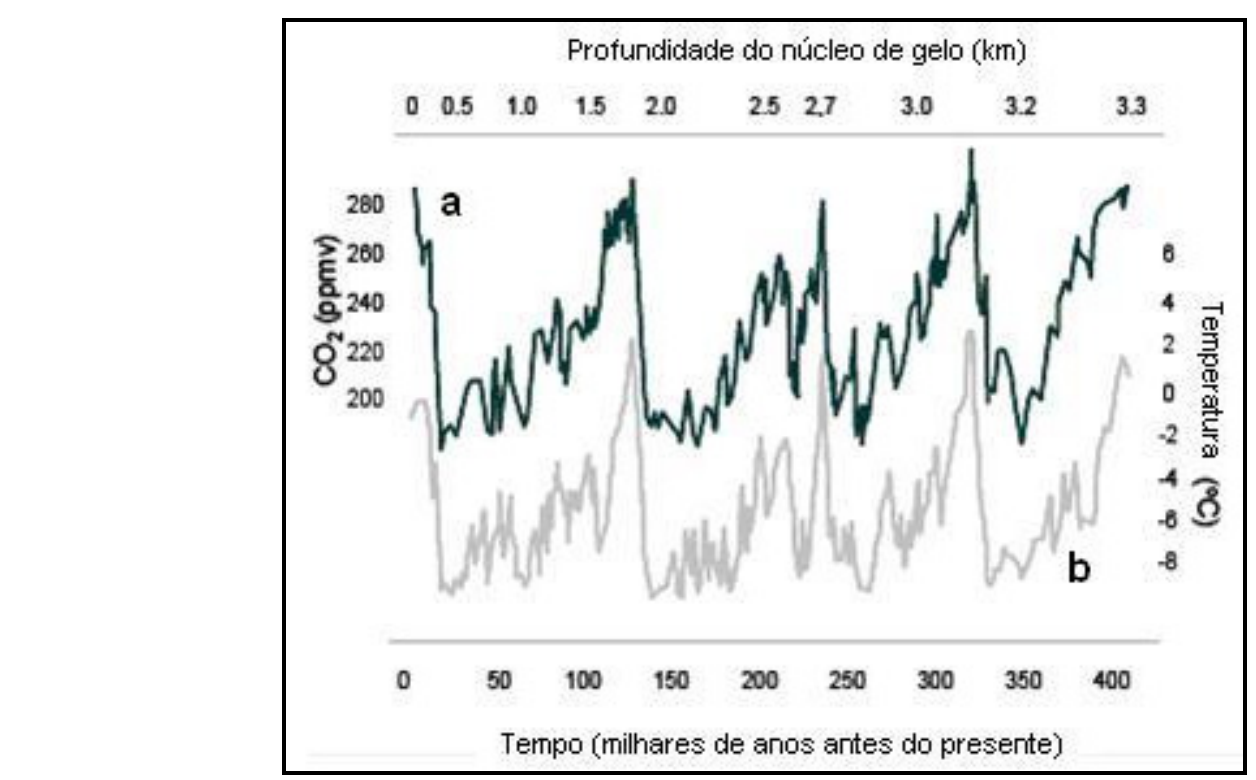

Figura 1-4 - Temperatura isotópica da terra (b) e Concentração de $\mathrm{CO}_{2}(\mathrm{a})$, Petit (1999).

Os processos em que gases responsáveis pelo efeito de estufa, notadamente dióxido de carbono $\left(\mathrm{CO}_{2}\right)$, metano $\left(\mathrm{CH}_{4}\right)$ e o ozônio $\left(\mathrm{O}_{3}\right)$, causam o aumento de temperatura da Terra são complexos, mas eles podem ser esquematizados de forma simples como na Figura 1-5. A principal fonte de aquecimento da Terra é a energia recebida do sol, cujo valor é de aproximadamente $340 \mathrm{~W} / \mathrm{m}^{2}$. A atmosfera terrestre é relativamente transparente ao comprimento de onda curto da radiação solar $(0,2$ to $4,0 \mu)$. Assim, embora cerca de $100 \mathrm{~W} / \mathrm{m}^{2}$ da energia irradiada a partir do sol seja refletida de volta para a parte superior da atmosfera acima das nuvens, a maior parte da energia do sol, em torno de $240 \mathrm{~W} / \mathrm{m}^{2}$, chega até a superfície da Terra.

A superfície da Terra é aquecida assim, e ainda re-irradia alguma dessa energia. E como a Terra é acentuadamente menos quente do que o sol, o comprimento de onda da energia que irradia é mais longo (4 a $100 \mu$ ). Os gases responsáveis pelo efeito de estufa são relativamente opacos a esses comprimentos de onda e uma grande parte dessa energia, por sua vez se reirradia, em torno de $180 \mathrm{~W} / \mathrm{m}^{2}$, de volta para a Terra.

A temperatura do sistema Terra / atmosfera estaria em equilíbrio quando o sistema estiver irradiando de volta para o espaço a mesma quantidade de energia, isto é, $340 \mathrm{~W} / \mathrm{m}^{2}$. 


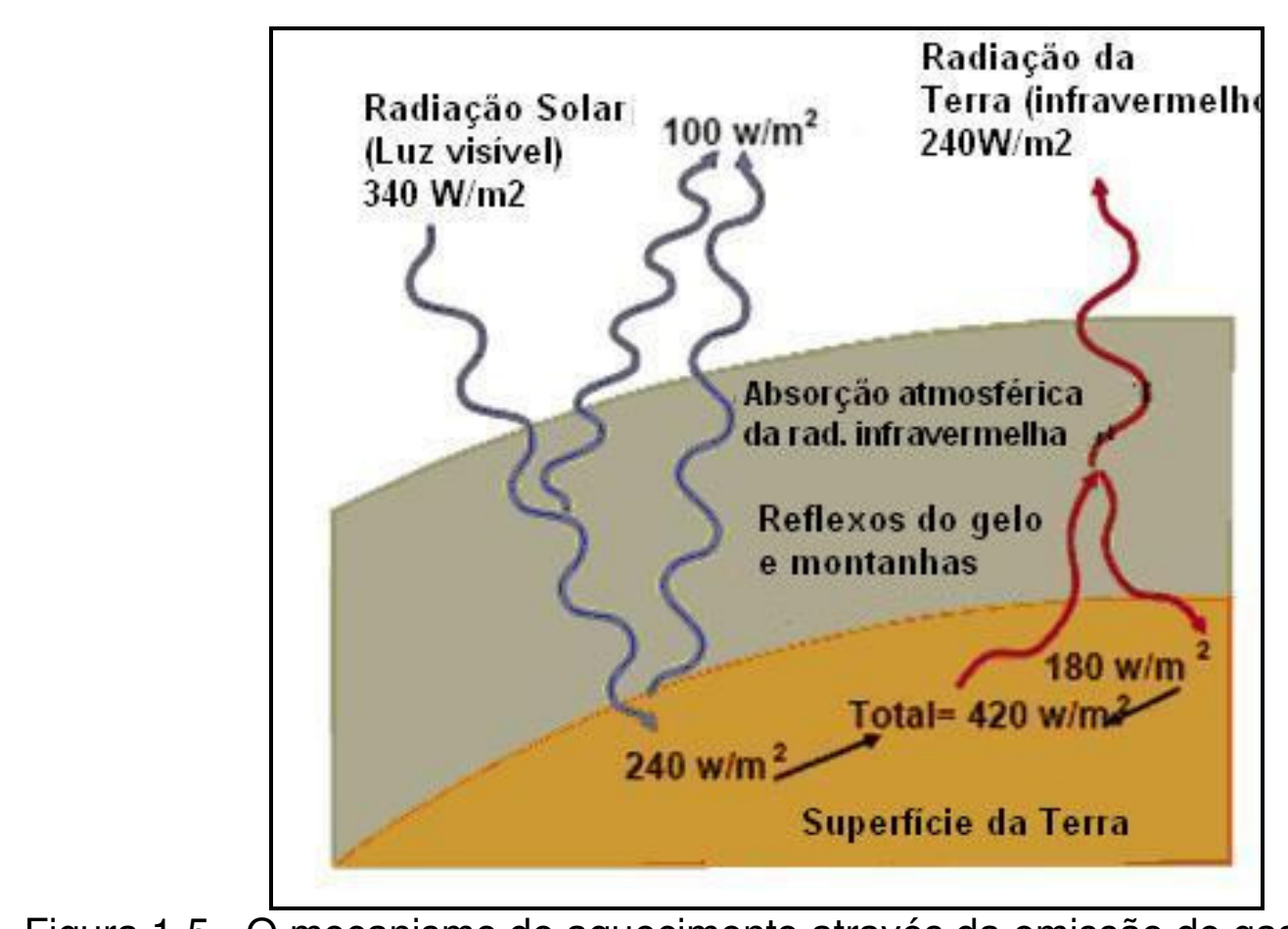

Figura 1-5 - O mecanismo de aquecimento através da emissão de gases do efeito estufa (CLINE,1992).

Dado que $100 \mathrm{~W} / \mathrm{m}^{2}$ estão sendo refletido de volta para o espaço pela parte superior da atmosfera acima das nuvens, isto significa que, quando alcançasse o equilíbrio, o sistema Terra / atmosfera deveria irradiar para o espaço também $240 \mathrm{~W} / \mathrm{m}^{2}$. Assim, a temperatura da Terra deveria ser de tal ordem que ela emita cerca de $(240+180)=420 \mathrm{~W} / \mathrm{m}^{2}$ (Figura 1-5). A temperatura na qual a Terra irradia cerca de $420 \mathrm{~W} / \mathrm{m}^{2}$ é de $15^{\circ} \mathrm{C}$.

A sensibilidade do sistema à concentração dos gases causadores do efeito estufa pode ser entendida da seguinte forma: quando aumenta a concentração atmosférica de gases do efeito de estufa, aumenta a proporção da energia irradiada (onda longa) a partir da Terra que é re-irradiada de volta para a Terra. Correspondentemente, a quantidade de energia irradiada da Terra que escapa para o espaço através da atmosfera cai para valor abaixo do valor de equilíbrio (em torno $240 \mathrm{~W} / \mathrm{m}^{2}$ ). O equilíbrio é restaurado somente quando a quantidade de energia líquida irradiada pelo sistema Terra/atmosfera diminui para o valor anterior $340 \mathrm{~W} / \mathrm{m}^{2}$, resultante da soma de $100 \mathrm{~W} / \mathrm{m}^{2}+240 \mathrm{~W} / \mathrm{m}^{2}$. Esta condição só pode ser conseguida através do aquecimento da Terra, emitindo radiações mais rapidamente, até o ponto em que o sistema Terra/atmosfera entre novamente em estado de equilíbrio.

Uma duplicação na concentração de gases do efeito estufa na 
atmosfera aumenta a quantidade de energia refletida de volta para a Terra na ordem de $4 \mathrm{~W} / \mathrm{m}^{2}$. Assim, a duplicação implica num aumento da temperatura de equilíbrio da terra até que a irradiação alcance $424 \mathrm{~W} / \mathrm{m}^{2}$. A temperatura na qual a Terra irradia $424 \mathrm{~W} / \mathrm{m}^{2}$ é de aproximadamente $18{ }^{\circ} \mathrm{C}$. Assim, a duplicação da concentração dos gases que causam o efeito estufa aumenta a temperatura da Terra em aproximadamente $3^{\circ} \mathrm{C}$.

De acordo com o Departamento de Energia Americano (DOE) esperase que em 2015 as emissões globais de carbono aumentem 54\% acima dos níveis de 1990 , causando um aumento de 1,7 a $4,9^{\circ} \mathrm{C}$ acima do previsto no período 1990-2100, tal qual mostrado na Figura 1-6.

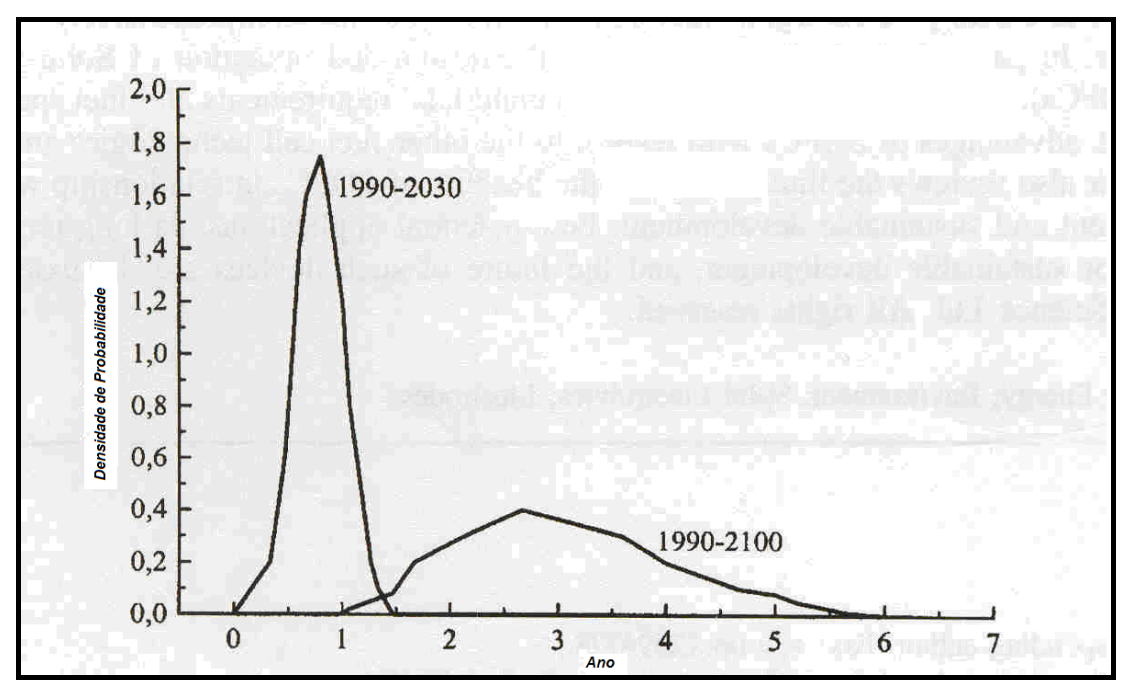

Figura 1-6 - Probabilidade de variação da temperatura média global $\left({ }^{\circ} \mathrm{C}\right)$

Por outro lado é esperado um aumento no crescimento populacional a uma taxa de 1,2 a 2\% ao ano, alcançando a casa de 12 bilhões em 2050 . Portanto o desenvolvimento econômico continuará e espera-se que a demanda global de energia aumente na ordem de uma magnitude ao passo que a demanda por energia primária crescerá 1,5 a 3 vezes.

Em resposta a necessidade da sociedade por tecnologia de energia limpa, algumas soluções potenciais têm sido desenvolvidas, incluindo conservação de energia através do aumento da eficiência e da redução no consumo de combustíveis.

As pilhas a combustível são o sistema de fornecimento de energia do futuro produzindo energia limpa e podendo ser utilizadas em aplicações 
estacionárias ou móveis. Dependendo do tipo de pilha as aplicações estacionárias podem incluir: pequenas residências e cogeração de médio porte entre outros. No setor móvel a maior aplicação está na indústria automobilística para carros ou utilitários, trens e até mesmo barcos.

Num cenário futurista a emissão da pilha será realmente zero, caso seja utilizada a pilha a combustível alimentada a gás com alto teor de hidrogênio, proveniente de processos limpos, tais como a produção de hidrogênio via eletrólise, e com a energia elétrica oriunda da conversão fotovoltaica da luz solar. Mas atualmente este processo ainda é economicamente inviável.

Nos processos mais utilizados atualmente, durante a produção do hidrogênio ocorre a emissão de gases poluentes que causam o aumento do aquecimento global, pois a matéria prima mais comum para obtenção do hidrogênio são os combustíveis fósseis.

Caso se utilize combustíveis obtidos a partir de fontes renováveis de energia, por exemplo, a hidroeletricidade ou a biomassa, para as pilhas, as quais possuem alta eficiência, isto pode significar uma grande redução na emissão de gases que causam poluição e na diminuição do consumo de combustíveis fósseis. Devido às reações que ocorrem nas pilhas serem de natureza eletroquímica e de baixas temperaturas, existe necessidade dos gases combustíveis estarem isentos dos compostos a base de enxofre e, conseqüentemente, diminuem as emissões de poluentes. Também ocorre diminuição na poluição sonora, visto que as pilhas não possuem engrenagens nem partes móveis.

\section{1- Objetivos}

O principal objetivo da pesquisa é apresentar uma contribuição para a previsão do impacto ambiental das pilhas combustíveis de média e baixa temperatura, a longo prazo.

Neste estudo será observado o impacto ambiental da pilha, não considerando somente o impacto da operação da pilha, mas também o impacto de toda a etapa da produção e a deposição dos materiais da célula no meio ambiente após o seu tempo de vida útil. Para tanto o estudo procurará avaliar o impacto ambiental causado pelos vários materiais e processos utilizados nos diversos tipos de pilhas aqui estudados. Os tipos de pilhas a combustível estudadas foram tipo PEMFC ("Proton Exchange Membrane Fuel Cell'), PAFC 
("Phosphoric Acid Fuel Cell') e MCFC. ("Molten Carbonate Fuel Cell').

Nesta pesquisa será utilizada a metodologia Delphi realizada com a colaboração de especialistas da academia, da indústria e do governo, para um prazo de 20-30 anos. Este prazo foi escolhido em vista da probabilidade de que as pilhas venham a ser utilizadas em maior escala num prazo desta ordem. A metodologia Delphi é preferida a outras técnicas de previsão quando o estudo não possui dados históricos, ou quando o setor de atividade está passando por uma fase de transição com perspectivas de mudanças estruturais ou ainda quando a abordagem pretendida para o estudo é interdisciplinar.

A inovação do estudo reside na utilização da metodologia Delphi aplicada ao estudo de previsão do impacto ambiental das pilhas a combustível.

\section{2- A Metodologia Delphi}

No presente trabalho a Metodologia Delphi foi escolhida para avaliar o impacto ambiental das pilhas em longo prazo para horizonte de 20 a 30 anos. Existem vários aspectos que são considerados na avaliação de tecnologias futuras e estes aspectos são abordados com maior profundidade no capítulo 2.

Todas as pessoas estão acostumadas a antever o futuro, senão não seria possível nem mesmo atravessar a rua porque não saberíamos se um carro poderia nos atingir (HEIJDEN (2000) apud SANT'ANA (2005)). Portanto as pessoas prevêem e ajustam suas ações conforme uma dedução lógica desenvolvida durante a vida. Quando algum evento ocorre, tentamos sempre explicá-lo por meio de uma relação causa-efeito, e tentamos usar o nosso conhecimento para manipular o mundo ao redor. $\mathrm{Na}$ verdade, temos uma tendência em confiar mais em nossa habilidade de manipular os eventos como uma fonte de conhecimento, do que na mera correspondência espaço-tempo.

A técnica Delphi foi projetada para aproveitar os benefícios de um grupo e a troca de opinião entre os respondentes, os quais podem aprender com as visões dos outros participantes. Isto ocorre sem a influência do face a face convencional no qual algumas pessoas tipicamente dominam, pois se expressam muito bem e possuem prestígio. Assim, cada indivíduo completa o questionário e então está apto a receber um retorno do conjunto de todas as respostas e preencher o questionário novamente, após ter recebido as informações. Essencialmente, o mesmo questionário será completado mais de uma vez pelo 
conjunto de especialistas. Também pode ser pedido, aos que possuem visões divergentes do consenso, que expliquem suas razões para estas visões e serve como inteligência comum. A idéia é que as visões dissonantes estejam baseadas em informações raras ou privilegiadas, que podem pesar para a maioria.

A estrutura da técnica visa utilizar os elementos positivos dos grupos de especialistas e minimizar os seus inconvenientes, como os conflitos políticosociais. O método é geralmente recomendado para realizar previsões quando modelos puramente matemáticos não podem ser utilizados e também quando o julgamento pessoal é pertinente.

A técnica Delphi tem por objetivo evidenciar as convergências de opiniões e destacar certos consensos sobre assuntos muito concretos, graças à interrogação de especialistas por meio de questionários interativos sucessivos que preservem $O$ anonimato nas respostas. $O$ objetivo mais comum nas pesquisas que utilizam a Delphi é fazer incidir os esclarecimentos dos especialistas sobre zonas de incertezas com o objetivo de auxiliar na tomada de decisões futuras (EPUSP, 2002).

Como a metodologia Delphi foi a escolhida para utilização no presente trabalho para efetuar uma avaliação a longo prazo, é apresentada de modo mais detalhado no capítulo 5 .

\section{3 -Impacto ambiental em razão do ciclo de vida das pilhas}

É comum que diversos estudos apresentem a previsão de diminuição do impacto ambiental das pilhas a combustível por causa da sua operação, pois elas utilizam os combustíveis mais eficientemente e com menor impacto ambiental. Mas existe também a outra face do problema que é o impacto ambiental devido à etapa de produção da pilha, a utilização de matérias prima que causam alto impacto ambiental, além do impacto da deposição final da pilha após sua vida útil

Várias tecnologias emergentes de geração de energia possuem a intenção de produzir energia "limpa". A definição de energia "limpa" inclui freqüentemente emissões insignificantes ou muito baixas durante a operação, além de considerar a reciclagem de materiais e o seqüestro de carbono em biosistemas. Num modo mais abrangente energia "limpa" considera o impacto ambiental da tecnologia durante seu ciclo de vida completo. 
O "ciclo de vida" inclui a aquisição dos materiais e dos combustíveis (por exemplo, mineração e atividades agrícolas); processamento dos materiais e dos combustíveis; e fabricação da tecnologia, uso, manutenção, remanufatura, e aposentadoria/reciclagem, que inclui a gerência final dos materiais, por exemplo, reciclagem, descarga, e incineração (COOPER et al., 2008). A Avaliação do Ciclo da Vida (ACV ou LCA em inglês: "Life cycle Assessment") inclui, por exemplo, o uso de recursos, ou seja, o uso de combustíveis ou da terra, a contribuição para a mudança de clima, a acidificação, ou a formação de poluição atmosférica.

A produção e utilização das pilhas combustíveis ainda estão em estágio emergente e assim os efeitos ambientais na produção e operação em massa de pilhas só podem ser avaliados por meio dos resultados das unidades piloto. Os competidores neste mercado utilizam diferentes cenários tanto de mercado como de diferentes cenários para seleção e materiais e combustíveis.

O ACV (Avaliação do Ciclo da Vida ou LCA-“Life Cycle Assessment") é uma ferramenta para avaliação do impacto ambiental potencial dos produtos $\mathrm{e}$ serviços ao longo de todo ciclo de vida, desde a exploração das matérias primas e combustíveis até a produção dos objetos investigados e a deposição/reciclagem dos referidos objetos. Atualmente é comum efetuar a avaliação do impacto de um determinado processo através do ACV que deve estar baseado na norma International Organization for Standardization. ISO 14040: Life Cycle Assessment - Principles and Framework.

Assim o ACV é utilizado como um protocolo de avaliação do impacto ambiental, social e econômico de um sistema industrial. Este protocolo deve incluir as seguintes análises:

- Metas e definição do escopo: determinação das tecnologias que compreendem o ciclo da vida do sistema. Descrevem as razões para a realização do estudo, o alcance do estudo (os processos que serão incluídos), planos para coleta de dados e avaliação dos mesmos, e os planos para a análise crítica.

- Análise do Inventário: quantificação do material, do uso da energia, recuperação e geração de lixo para cada processo do ciclo de vida da tecnologia analisada (por exemplo, quanta energia é consumida e quanto dióxido de carbono é emitido pelos processos durante todo o ciclo de vida).

- Análise do impacto: exame da contribuição ao impacto ambiental, econômico e social do uso de materiais e energia, recuperação e geração do lixo 
no processo analisado. Os impactos ambientais são estimados a partir dos resultados de inventário (por exemplo, o quanto as emissões atmosféricas do ciclo de vida contribuem à mudança de clima global), como também podem ser obtidos através dos resultados de impacto de algum sistema de interesse (por exemplo, impacto per capita).

- Interpretação: técnica para identificar, quantificar e avaliar os resultados da avaliação do impacto e inventário, incluindo a identificação de parâmetros sensíveis e a quantificação das incertezas

O impacto ambiental das plantas de geração térmicas ou de potência é normalmente dominado pela produção do combustível e pela combustão. A construção da planta e da infra-estrutura requerida geralmente possui um fator 10 vezes menos relevante ambientalmente que a conversão de energia, pois existe um alto consumo de combustíveis e um longo tempo de vida do sistema. Muitas fontes de energia renováveis, tais como células solares, por outro lado mostram valores de emissão próximos de zero durante a conversão de energia e, portanto a construção da planta torna-se um valor dominante. É usual investigar os sistemas de energia do futuro, tal qual para pilhas a combustível, em função dos estágios atuais de desenvolvimento de mercado, acoplado ao problema metodológico de antecipação tecnológica (p.ex. consumo de energia futura para certas fases do processo) e desenvolvimentos da sociedade (p.ex. escolha dos transportadores de energia para a rede elétrica). Os métodos utilizados para prospecção do desenvolvimento tecnológico e a conseqüente influência nos ACVs são apresentados no capítulo 2.

Na Fig. 1-7 podemos observar a interação entre as diversas fases da vida da pilha e o meio ambiente.

Na Fig. 1-8 observamos as emissões de gases que causam o efeito estufa, em percentuais durante as várias fases da produção de energia por meio das pilhas.

Neste trabalho são prospectados, através do uso da Metodologia Delphi, os aspectos qualitativos abrangidos por vários LCA que já foram efetuados anteriormente na área de pilhas a combustível de média e baixa temperatura. 


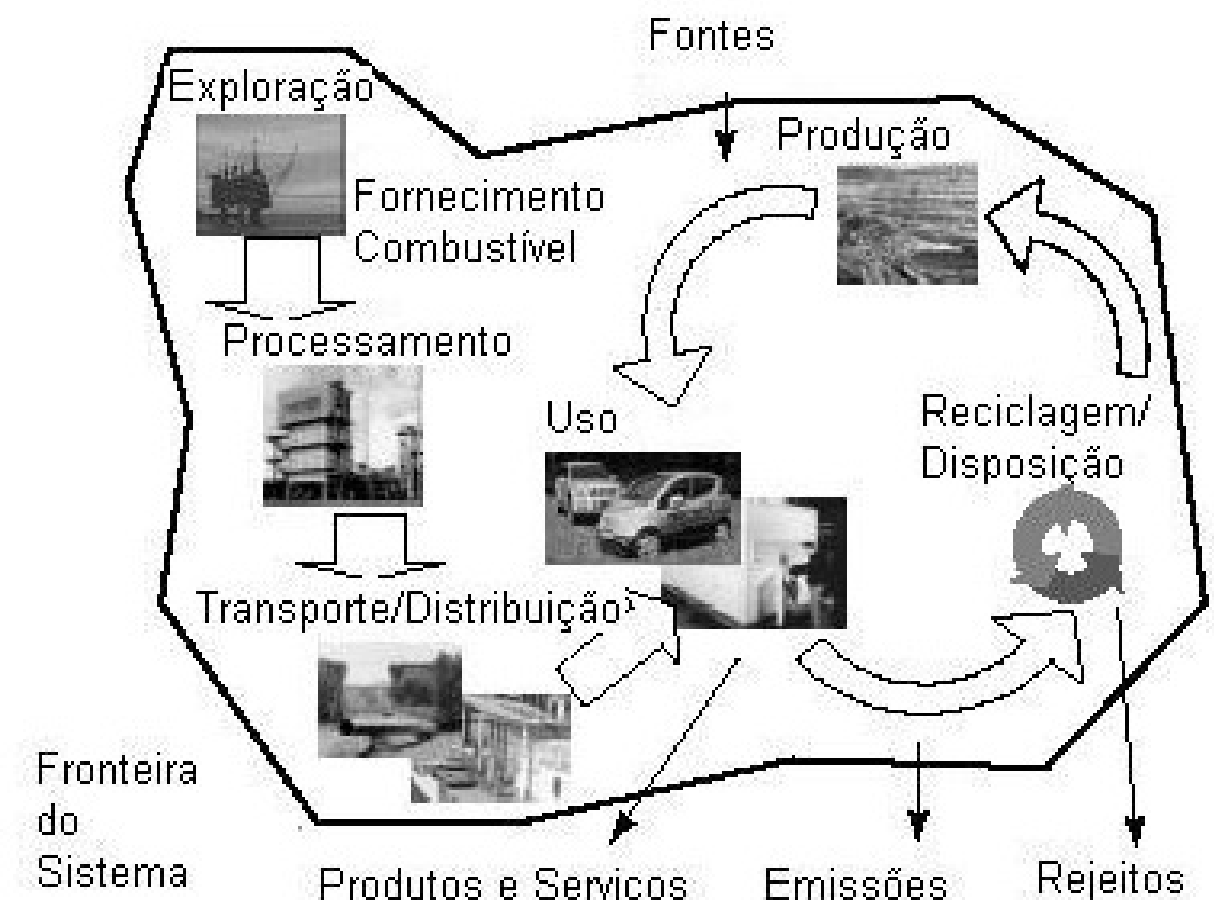

Figura 1-7 - O ciclo de vida da pilha a combustível (PEHNT, 2003).

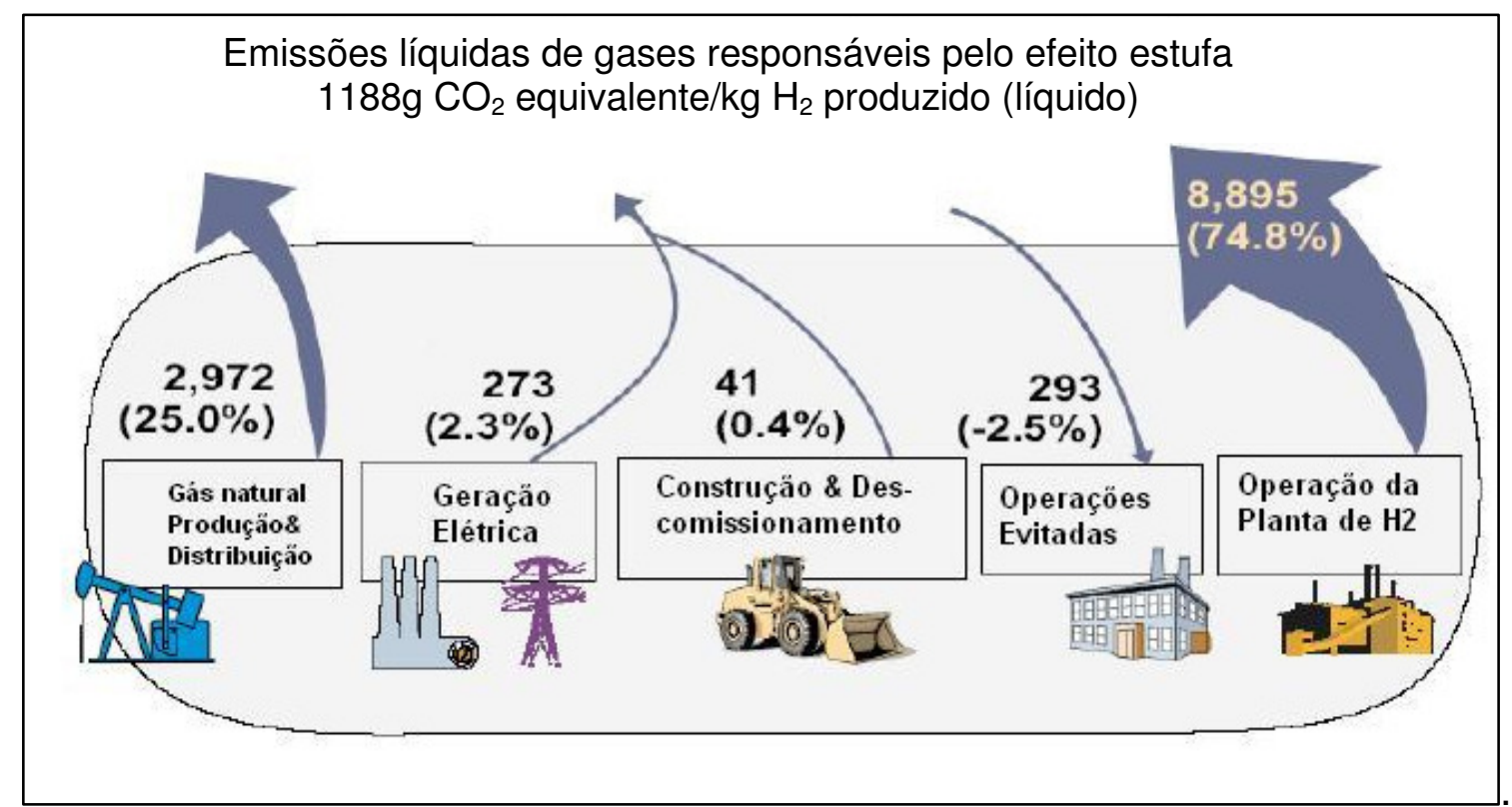

Figura 1-8 - Fontes de emissão de gases poluentes (UPADHYAYA et al., 2004). Nota: O item "Operações evitadas" refere-se à produção de vapor a partir da recuperação de calor e os valores são baseados em caldeiras que queimam gás natural. $O$ item "produção e distribuição" requerida nas etapas de produção do gás natural. 


\section{ASPECTOS METODOLÓGICOS}

A prospecção tecnológica é uma sistemática, um processo participativo que envolve a coleta de informações e a construção de visões para o futuro a médio e longo prazo destinando-se a impactar as decisões atuais e mobilizar ações conjuntas.

A prospecção tecnológica é dificultada pela interconexão entre os diversos ramos técnicos do conhecimento; assim sendo avanços numa área podem atravessar para outra área e então acelerar o desenvolvimento de outro ramo científico. Um exemplo disso é que os principais avanços na área de processamento de informações também afetaram outras áreas como, por exemplo, o Projeto Genoma. Avanços nas áreas de ciências dos materiais podem colaborar com o avanço da célula combustível.

Também se deve observar que a ciência não progride em linha reta e alterações ocorrem freqüentemente de modo acidental ou fortuito. No entanto, tais alterações podem incentivar uma espiral de polinização cruzada que promete aumentar o ritmo de inovação tão fortemente que as sociedades modernas podem vir a ser transformadas. Ao mesmo tempo em que cresce o progresso técnico, persiste a incerteza sobre suas repercussões sociais. Os avanços tecnológicos não ocorrem no vácuo mas são moldados pelas forças sociais. Um exemplo disso é que a indústria reconhece que a aceitação de novas tecnologias é movida pela sensibilização dos consumidores, suas necessidades, seus estilos de vida, seus valores e uma série de outros fatores de mercado (HALAL et al. 1997 citado por Oniszk-Poplawska et al., 2003).

$\mathrm{Na}$ análise do processo de geração de riqueza por meio da ciência, tecnologia e inovação, utiliza-se um instrumento simples e prático para se identificar e entender um processo de mudança que é a curva $S$. A curva $S$ descreve o processo de mudança de um sistema através do "fator conhecimento". 
A Figura 2-1 ilustra a Curva $S$ mostrando como uma determinada variável se comporta ao longo do tempo. Em geral a evolução tecnológica apresenta um comportamento evolutivo na forma de uma curva composta por quatro fases muito distintas: uma primeira fase, na qual a evolução é relativamente pequena ao longo do tempo, ou seja, é necessário realizar um investimento muito significativo para se gerar um resultado relativamente modesto; a segunda fase, em que se experimenta uma grande evolução em termos de resultados e desempenho, com um investimento (de tempo, recursos, etc.) menor, a terceira fase, na qual novamente se observa uma queda na taxa de evolução ao longo do tempo; e, finalmente, uma quarta fase, caracterizada por um "salto" para uma nova curva ou uma "falência" do sistema (FIATES, 2005).

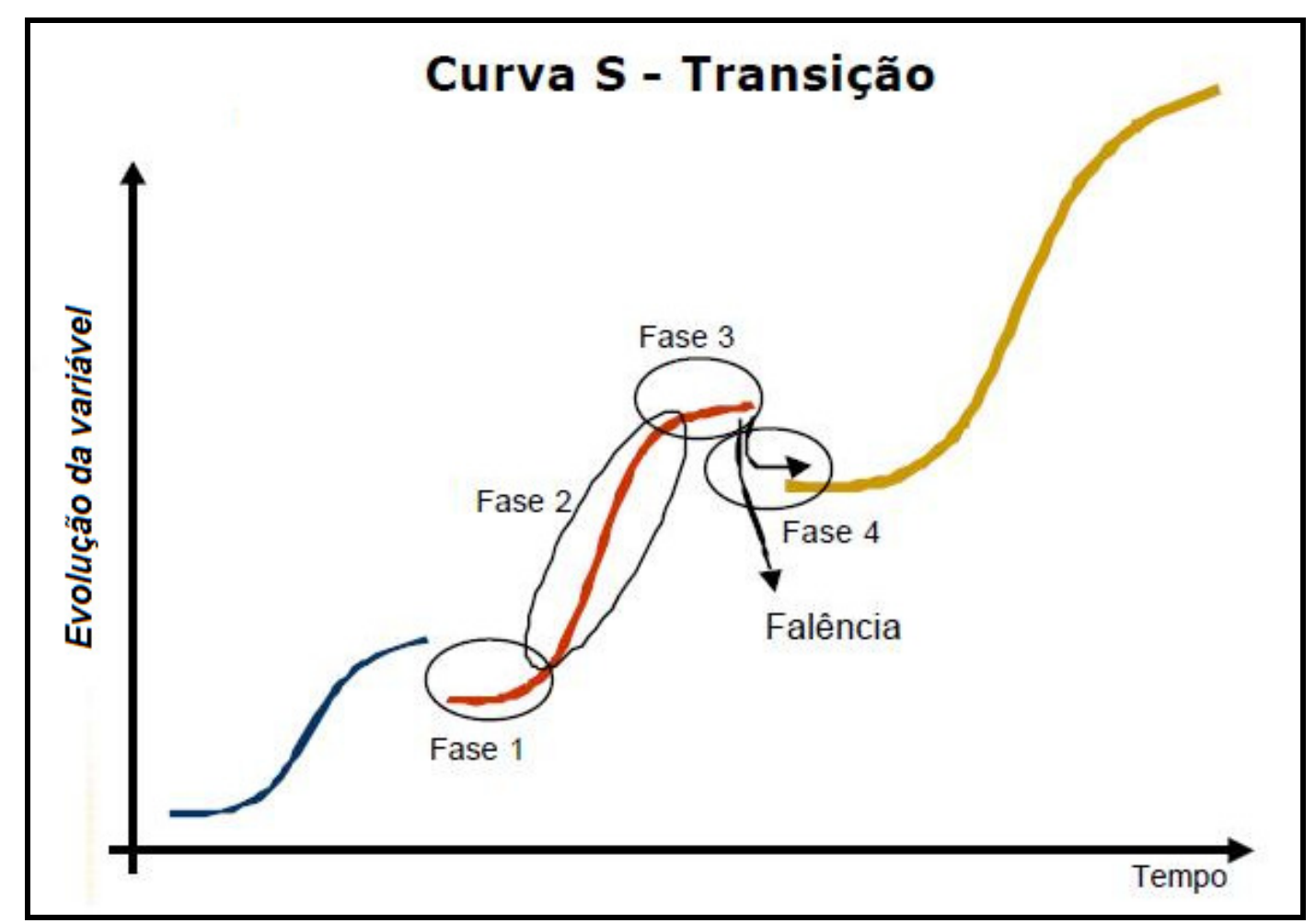

Figura 2-1 - Evolução de uma variável ao longo do tempo representada pela curva S (FIATES, 2005).

A Curva $S$ também mostra a relação entre o esforço monetário despendido (fundos) em melhorar um produto ou método e os resultados obtidos (desempenho) como retorno desse investimento.

As técnicas da prospecção tecnológica oferecem meios para reforçar as relações e as interações de modo transversal aos limites institucionais, de modo que o conhecimento possa fluir mais livremente entre os atores 
constituintes, melhorando a eficiência do conhecimento do sistema como um conjunto. (MILES AND KEENAN 2002). Na Figura 2-2 está ilustrada a combinação dos processos que resulta na prospecção.

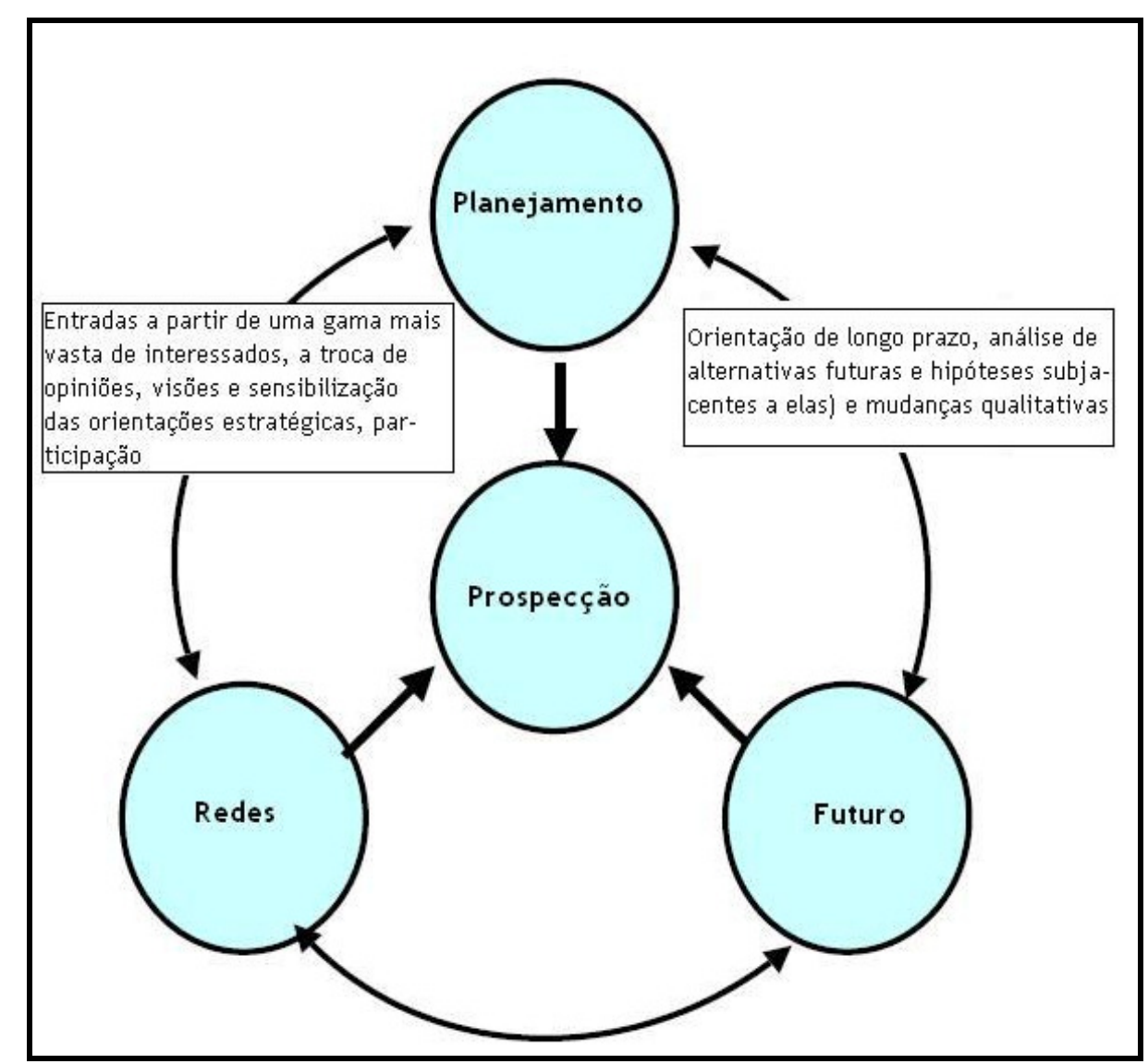

Figura 2-2 - Ilustração do esquema dos processos combinados que resultam na prospecção. (MILES AND KEENAN, 2002)

A combinação de processos da análise e comunicação nos exercícios de prospecção tecnológica cumpre diversas funções:

- Ser um processo coletivo e de consulta, sendo o processo em si mesmo tão importante quanto os resultados (ONISZK-POPLAWSKA et al., 2003).

- Identificar tecnologias emergentes importantes que são necessárias para alcançar riquezas e qualidade de vida (HALAL et al 1997).

- Fornecer suporte às decisões para definição de prioridades em pesquisa e desenvolvimento a fim de fornecer tecnologia necessária para o futuro, em época de orçamentos apertados. (MARTIN AND JOHNSTON 1999).

As aproximações utilizadas na prospecção envolvem reflexões sobre as oportunidades emergentes, mudanças, tendências, alterações nas tendências 
e similares. Mas a meta não se restringe apenas a produzir estudos futuros mais perspicazes, cenários mais atraentes e modelos econométricos precisos. A prospecção tecnológica reúne os agentes principais da mudança e as fontes de conhecimento, a fim de desenvolver visões estratégicas e a inteligência antecipadora. Também é importante citar que a prospecção tecnológica tem freqüentemente a intenção explícita de estabelecer redes de agentes "conhecedores". Estas redes devem responder melhor à política e aos outros desafios, por causa da melhoria na inteligência antecipadora que tem sido nelas desenvolvidas, e também devido à melhoria na consciência dos recursos do conhecimento e orientações estratégicas de outros membros da rede. As empresas, governos, setores do comércio, organizações voluntárias, movimentos sociais e especialistas técnicos podem ser considerados como os atores principais envolvidos na prospecção.

As previsões podem freqüentemente ser super pessimistas e isto tem ocorrido na área de tecnologia da informação. O desenvolvimento de microprocessadores tem tido tanto sucesso que agora são muito mais rápidos que o previsto no início da década de 80. O uso de memórias "flash" é tão corriqueiro nos nossos dias, mas há 20 anos alguém diria que poderíamos carregar no bolso um chaveiro memória de $16 \mathrm{~Gb}$ ? O problema do pessimismo é tão notório que as atitudes de cientistas famosos freqüentemente são vistas como excentricidades. Em 1923, Robert Milikin, ganhador do prêmio Nobel de Física, bradou "não existe probabilidade de que o homem possa explorar o poder do átomo". Em 1895, Lord Kelvin, presidente da Royal Society, disse "é impossível voar com máquinas mais pesadas que o ar".

O lado oposto freqüentemente reflete um otimismo próximo da inocência. Muitas pessoas ainda refazem previsões dos anos 50 de que nós voaríamos em jatos pessoais para chegar ao trabalho e retornaríamos, após 20h de trabalho semanal, para o lar onde nos esperariam robôs domésticos que preparariam nosso jantar automaticamente.

Otimismo e pessimismo são obstáculos normais para a previsão, mas eles podem ser atenuados por intermédio do rigor metodológico. Acidentes, fatos fortuitos e "coringa" ("wildcards" são avanços tecnológicos que têm uma chance relativamente baixa de ocorrência, mas que terão um grave impacto sobre o sistema como um todo) também devem ser avaliados para que seja possível a 
obtenção de previsões sólidas, além de avaliar a influencia dos horizontes de tempo. A prospecção para o intervalo dos próximos 5 a 10 anos são freqüentemente mais fáceis e confiáveis porque caem dentro do domínio da pesquisa de mercado, ao passo que aquelas para mais que 30 ou 40 anos são mais especulativas.

Os contextos nos quais a prospecção tecnológica pode ser empregada são variados. Muitos trabalhos prévios focalizam na competitividade nacional e especialmente na definição de prioridades e metas estratégicas para áreas de pesquisa em ciência e tecnologia. Mas a prospecção tecnológica também é utilizada com freqüência nas áreas sociais, políticas e culturais, tais como alterações demográficas, assuntos relacionados aos problemas ambientais e de transporte. Com efeito, uma das principais lições dos exercícios de prospecção tecnológica é que as questões relacionadas à ciência e tecnologia estão intimamente ligadas a uma gama maior de fatores sociais, pois são as forças sociais que moldam o desenvolvimento, utilização e as implicações sociais da ciência e da tecnologia. Do mesmo modo, é impossível considerar o desenvolvimento a longo prazo das questões sociais sem considerar a relevância da evolução do conhecimento científico e tecnológico. (MILES AND KEENAN, 2002)

A prospecção tecnológica envolve cinco elementos essenciais:

- Estruturação antecipada e projeções, a longo prazo, do desenvolvimento e necessidades sociais, econômicas e tecnológicas.

- Métodos interativos e participativos de debate, análise e estudo de tais necessidades e desenvolvimento, envolvendo uma larga gama de intervenientes (muitas vezes que vão muito além dos estreitos conjuntos de peritos empregados em muitos estudos tradicionais de prospecção futura).

- Estas abordagens interativas envolvem a construção de novas redes sociais. Alguns programas de prospecção utilizam as redes somente para auxílio aos seus produtos formais (tais como relatórios e listas de pontos de ação), mas outros tomam o estabelecimento das redes como uma realização.

- Os produtos formais da prospecção vão além da apresentação de cenários (os quais podem ser estimulantes) e além da preparação dos planos. O fundamental é a elaboração de visões estratégicas orientadoras, em torno das quais possa haver um sentimento comum de compromisso (alcançado, em parte, 
através dos processos de rede).

- Esta visão não é uma utopia: a viabilidade e a vontade têm de ser combinados. Tem de haver reconhecimento explícito e explicação das implicações das decisões atuais nas ações que são efetuadas.

\section{1-Métodos de previsão para tecnologias futuras}

Esta seção aborda as principais variedades de métodos de prospecção e suas características. Estas informações auxiliam na decisão sobre quais métodos de prospecção são mais adequados em cada caso.

Existem diversos métodos de prospecção tecnológica e uma revisão bibliográfica dos diversos métodos de prospecção tecnológica pode ser obtida no relatório do Projeto Tendências do CTPETRO (Fundo Setorial de Petróleo e Gás Natural) através da referência INT (2003).

Inúmeros modelos têm sido propostos para classificar os métodos de prospecção tecnológica; todos contêm ambigüidades, nenhum é inteiramente satisfatório.

Para contrabalançar a ambigüidade e a incerteza inerentes à prospecção foram desenvolvidas algumas metodologias que auxiliam na tarefa. Em geral, quando uma tecnologia sai de seu estado inicial de desenvolvimento em laboratório para ampla aceitação do mercado, as metodologias de prospecção que são mais apropriadas deslocam-se das técnicas qualitativas para as quantitativas. Segundo INT (2003) como regra geral quanto mais complementares forem as formas utilizadas para se efetuar uma prospecção, mais confiáveis são seus resultados.

Antes de se implantar a estratégia de prospecção os métodos devem ser avaliados. A estratégia para selecionar a metodologia está no sistema de pesquisa a ser usado para realizar o estudo. Sistemas de pesquisa podem variar de científicos a dialéticos e globais, baseados num enfoque filosófico da geração do conhecimento, conforme Tabela 2-1.

Na prospecção, comumente, utiliza-se uma combinação de estratégias formais e informais gerando informações qualitativas e quantitativas. Alguns métodos formais são: entrevistas estruturadas, as análises morfológicas, discussões organizadas sobre questões pré-determinadas, Delphi, construção e análise de cenários. Como métodos informais podemos ter comitês especialistas 
em discussões desestruturadas (“workshops").

Tabela 2-1 - Enfoque filosófico da geração do conhecimento (INT, 2003)

\begin{tabular}{|c|c|c|}
\hline Tipo de Enfoque & Descrição & $\begin{array}{l}\text { Mais adequado para } \\
\text { problemas }\end{array}$ \\
\hline A priori & $\begin{array}{l}\text { Modelos formais através dos quais se têm } \\
\text { percepções / intuições sobre o mundo, com } \\
\text { pouca ou nenhuma necessidade de dados } \\
\text { brutos. }\end{array}$ & $\begin{array}{ll}\text { bem } & \text { definidos } \\
\text { conceitualmente. } & \end{array}$ \\
\hline Empírico & $\begin{array}{l}\text { Começam com a coleta de dados, } \\
\text { constroem-se modelos empíricos para } \\
\text { explicar o que está ocorrendo. }\end{array}$ & $\begin{array}{l}\text { bem definidos e com dados } \\
\text { disponíveis. }\end{array}$ \\
\hline Sintético & $\begin{array}{l}\text { Combina os enfoques "a priori" e "empírico" } \\
\text { de tal forma que as teorias são baseadas } \\
\text { em dados e a coleta de dados é estruturada } \\
\text { pela pré-existência de uma teoria ou } \\
\text { modelo. }\end{array}$ & $\begin{array}{l}\text { mais complexos e mal } \\
\text { estruturados. }\end{array}$ \\
\hline Dialético & $\begin{array}{l}\text { Interpretações contraditórias de um } \\
\text { conjunto de dados são confrontadas em um } \\
\text { debate ativo, buscando soluções criativas. }\end{array}$ & $\begin{array}{l}\text { mal estruturados e quando } \\
\text { há conflito. }\end{array}$ \\
\hline Global & $\begin{array}{l}\text { Uma ampliação holística da pesquisa é feita } \\
\text { questionando enfoques e suposições. }\end{array}$ & $\begin{array}{lrr}\text { não estruturados e } & \text { que } \\
\text { necessitam de } & \text { um } \\
\text { raciocínio reflexivo. } & \\
\end{array}$ \\
\hline
\end{tabular}

Os métodos também podem ser classificados em quantitativos, geralmente emergindo de técnicas estatísticas (p. ex. extrapolação de tendências) ou qualitativas, na maioria das vezes envolvendo a opinião de especialistas (Delphi, painel de especialistas, etc.).

Existem muitos tipos de métodos de previsão. Num extremo, há métodos baseados em programas de computador com base em esforços para quantificar tendências e suas consequências, a fim de prever o "futuro mais provável". Por outro, existem muitas técnicas baseadas no diálogo e na discussão, e que se destinam a analisar possibilidades alternativas, gerar visões dos futuros desejáveis, ou definir eventos inesperados. Muitas pessoas identificam alguns destes métodos de previsão. Por exemplo, a metodologia Delphi tem sido muitas vezes vista como um método de previsão.

Outra classificação adotada para os métodos de prospecção, os divide em: métodos subjetivos e métodos adaptativos. Os métodos subjetivos são baseados no julgamento de um ou vários especialistas; e os métodos adaptativos baseiam-se em bancos de dados de projetos ou processos comparáveis que são, para efeitos de previsão, aplicáveis aos componentes mais relevantes.

Os métodos de prospecção/previsão descritos abaixo foram agrupados 
em dois conjuntos principais, conforme EUROFOUND (2003). Primeiro são apresentados os métodos que são baseados notadamente no julgamento de peritos e, em seguida, são apresentados aqueles baseados mais em métodos de análise e estatísticas.

\subsection{1-Métodos de previsão baseados notadamente na opinião de peritos}

O julgamento de especialistas é particularmente importante quando os temas em questão são complexos, nos quais existam incertezas sobre os dados ou sobre a interpretação dos mesmos, quando esteja sujeito a desenvolvimentos futuros que possam resultar de atividades altamente especializadas e não amplamente compreendidas. Por estas razões, as opiniões dos peritos são geralmente a parte principal dos exercícios de prospecção. A obtenção da opinião dos peritos ocorre frequentemente por meio de:

- audiências públicas de comissões parlamentares ou governamentais;

- processos judiciais ou semijudiciais;

- entrevistas estruturadas que observam um mínimo de certos critérios relativos à opinião dos peritos; esta pode ser considerada como um subconjunto mínimo do procedimento anterior.

A seguir são descritos os métodos de prospecção baseados na obtenção de visões de especialistas a longo prazo. Estes métodos não são muito conhecidos, embora muitas vezes as pessoas tenham ouvido falar de termos como 'Delphi'. A escolha de qualquer um dos métodos de obtenção de opiniões, descritos a seguir, deve ser estabelecida conforme os termos de referência definidos pelo programa patrocinador. Se a opinião do perito é necessária, em termos de probabilidades, então outra espécie de procedimento deve ser adotado.

Duas questões importantes que devem ser analisadas ao utilizar a opinião de peritos. A primeira está na localização dos peritos importantes. No caso da prospecção tecnológica, é particularmente importante identificar a verdadeira especialização no domínio das questões em causa e não apenas identificar "suspeitos usuais". Isso pode significar o contato com profissionais e organizações científicas, conselhos de pesquisa e similares. Dada a importância dos profissionais na execução de mudanças sociais, os peritos podem ser nomeados por organizações de voluntários, por parceiros sociais, etc. 0 importante aqui é identificar as pessoas que possam falar por experiência, tanto 
se baseada na pesquisa como na experiência da ação, e que possam ir além de apenas apresentar a posição de um determinado grupo de interesses.

A segunda grande questão diz respeito às relações entre os peritos e 0 público em geral. Além das questões óbvias como evitar o jargão técnico em excesso, há a necessidade de evitar a entrada de pessoas que possuam algum tipo de timidez. Como exemplo pode-se citar as encenações de defensores de teses com retórica muito boa, que, deixam tímidos os profissionais que podem até possuir bons argumentos técnicos para discordas, mas não o fazem devido à sua timidez. Outras pessoas podem entrar numa reunião como agentes criadores de tumulto que impedem a discussão técnica produtiva.

\subsubsection{1- Métodos de previsão de "gênios"}

O termo "previsão de gênio" é utilizado para descrever uma visão, ou várias visões do futuro, através das percepções de uma pessoa talentosa e respeitada. Um dos problemas da "pesquisa de futuro" tem sido o aparecimento de tempos em tempos de figuras de "guru" que atraem a atenção e interesse como profetas ou como defensores de mudanças específicas. Geralmente, as pesquisas que levam às suas visões não são explicadas de modo claro. E muitas pesquisas de futuro são identificadas, na mente da opinião pública, com o trabalho dessas figuras e isso é um fator de suspeita sobre "futurologia", por parte de muitos acadêmicos e políticos, uma suspeita que tem se espalhado sobre vários trabalhos de previsão em muitas ocasiões (EUROFOUND, 2003).

A previsão de "gênios" é prontamente rejeitada quando reflete apenas um ponto de vista de uma pessoa. Não são apenas os indivíduos susceptíveis de serem partidários; é provável que poucas pessoas tenham o leque de conhecimentos necessários para cobrir toda a gama de fatores que pode mudar o futuro. Entretanto, é inegável que alguns indivíduos podem fornecer um pensamento novo, e podem assumir perspectivas que de outro modo seriam negligenciadas no trabalho das comissões e painéis.

A previsão é considerada de "gênio" convencional, quando esses números sintetizam idéias de outras equipes de pesquisa de maneiras novas, estampando fortemente as suas próprias opiniões sobre elas. Como exemplos deste tipo de influência podemos incluir: o "Choque do Futuro" e "A terceira onda" de Alvin Toffler, além de Megatendências de John Naisbitt. 
Uma fonte de informação relacionada é a ficção científica. Embora grande parte deste gênero seja pouco mais do que o uso de suportes fantástico para racionalizar aventuras infantis, os melhores trabalhos fornecem imagens desafiantes das possibilidades futuras. Algumas das extrapolações dos desenvolvimentos sociais e tecnológicos provêm dessa fonte e alguns escritores de ficção científica são eles próprios futuristas - Arthur C. Clarke e Brian Stapleford são apenas dois exemplos. A amostragem criteriosa da ficção científica - que exigirá um conselho de peritos no gênero - pode auxiliar a sugerir modos de pensar e apresentar imagens do futuro.

\subsubsection{2- Técnica de análise morfológica}

A análise morfológica é provavelmente um dos métodos normativos de previsão mais conhecidos, sendo desenvolvida dentro do contexto de grandes esforços gerenciais e tecnológicos. Muitas técnicas deste tipo nasceram ou foram elaboradas no decurso do programa espacial.

A análise morfológica funciona através da criação de listas de todas as combinações possíveis das características ou formatos de um determinado objeto com a finalidade de determinar as diferentes categorias de aplicação ou efeito. Representa um método para descobrir novos produtos e novas possibilidades dos processos. Os usuários determinam em primeiro lugar as funções essenciais do produto ou processo. Em seguida, listam os diferentes meios pelos quais cada uma destas funções poderia ser satisfeita. Finalmente, usam a matriz para identificar novas e razoáveis combinações que poderiam resultar em novos produtos ou processos. Essa técnica pode ser usada para identificar novas oportunidades não óbvias.

O mapeamento por meio da análise morfológica envolve "todas as soluções possíveis" para um problema, de modo a determinar diferentes possibilidades de futuro. Tem sido usada para novos produtos em desenvolvimento e na construção de cenários.

Ambos os métodos são ferramentas para um estudo sistemático do tema em avaliação. Eles podem gerar possibilidades inesperadas, novas visões do futuro, e novas opções. É por esta razão que eles são descritos como previsão técnicas, e não apenas como ferramentas de planejamento, apesar de ter claramente aspectos deste último. 
Estas abordagens estão longe de serem de uso fácil. Elas requerem uma análise em profundidade, por pessoas familiarizadas com as técnicas, e com base na perícia do problema real. Um trabalho moroso pode estar envolvido, visto que as alternativas e combinações dos elementos envolvidos podem ser inúmeras. A assimilação e o uso dos resultados de tais exercícios por outros grupos podem ser bastante difícil, porque o resultado é normalmente uma massa de detalhes técnicos.

\subsubsection{3- A técnica Delphi}

A metodologia Delphi será tratada em detalhes no capítulo 5, mas neste item será dada apenas uma definição inicial, por ser a metodologia utilizada neste estudo.

A técnica Delphi envolve uma sondagem de opiniões. Em princípio, esta sondagem deve revelar a opinião de peritos. Mas é uma pesquisa que se destina a retro-alimentar a informação para os respondentes, e não apenas para fornecer matéria-prima para processamento de dados pelos analistas. $O$ que torna a técnica Delphi diferente das outras sondagens é a forma pela qual ela é realizada.

A Delphi apenas não envolve um levantamento único das perguntas, embora os exames de opinião, às vezes convencionais, sejam descritos equivocadamente como Delphis. O questionário é circulado para o mesmo conjunto dos respondentes, pelo menos, duas vezes (no estudo clássico são comuns várias interações). Juntamente com o mesmo conjunto de questões, os respondentes, em etapas posteriores recebem o retorno das respostas obtidas em rodadas anteriores.

\subsection{2-Métodos de previsão baseados notadamente em análise matemática ou estatística}

Existem alguns métodos de previsão que se baseiam em dados numéricos, variáveis quantitativas, como uma maneira de representar problemas. Uma declaração que diz: $x \%$ das pessoas estarão fazendo alguma coisa no ano $Y$ é mais impressionante do que simplesmente dizer que se espera que a proporção de pessoas que exerçam a atividade crescerá no futuro.

Os métodos tais como a Delphi e matrizes de impacto cruzado 
processam o julgamento de peritos de forma quantitativa e apresentam seus resultados em termos de probabilidades subjetivas e tendências.

Neste item serão abordados os métodos com aspectos pesadamente dependentes da análise de dados estatísticos e similares. Entretanto muitos pontos também se aplicam a métodos tais como a Delphi.

Os dados quantitativos têm vantagens e desvantagens. As três grandes vantagens são as seguintes:

- As estatísticas e os indicadores similares devem tornar evidente a forma como a informação resultante foi obtida. A metodologia deverá ser devidamente explicada. As estatísticas oficiais são geralmente eficientes a este respeito, mas os relatórios ou dados da consulta utilizados em artigos de jornal são muitas vezes menos confiáveis. Isto não quer dizer que os indicadores estatísticos são sempre muito bons guias do ponto de vista real. Assim, por exemplo, as estatísticas de violência doméstica podem decorrer do número de casos relatados à polícia, e não na realidade. Contudo, as boas estatísticas são reprodutíveis, e por isso deve ser muito clara a forma como os indicadores foram produzidos e como se produzem os resultados.

Os dados quantitativos podem ser manipulados em forma consistente e reprodutível. Existe um arsenal completo de técnicas matemáticas para a análise dos dados com auxílio dos poderosos softwares estatísticos disponíveis. Isso permite ao usuário fazer comparação precisa entre casos, apresentar estimativas em termos de níveis de mudança, e verificar a coerência dos diferentes elementos de uma estimativa.

A quantificação também permite a visualização de dados em gráficos e tabelas, e de novo, já existem programas disponíveis para produzi-los facilmente.

Os principais problemas com abordagens quantitativas são os seguintes:

- Alguns fatores são difíceis de representar numericamente, e estes podem ser os mais importantes. Não se deve assumir que uma variável seja central apenas porque uma coisa é mensurável. Existe uma tendência a dar mais atenção aos indicadores quantitativos do que a uma boa imagem qualitativa.

- Existem perigos de "precisão espúria". Só porque alguma coisa pode ser expressa de vários pontos decimais, não significa que a estimativa seja bem fundada. Na verdade, muitas vezes os valores são expressos com mais precisão 
do que é significativo,

- Habilidades para trabalhar com os dados quantitativos são desigualmente desenvolvidas. Algumas pessoas consideram descabido o mais básico de informação estatística e muitos acham difícil de analisar criticamente os dados.

- Os métodos quantitativos mais sofisticados requerem considerável perícia em sua aplicação. Para pessoas estranhas à área é necessário, por vezes, empregar os seus próprios peritos para obter uma idéia do que está acontecendo.

- Finalmente, as técnicas estatísticas escondem muitas hipóteses sobre a natureza dos dados e os métodos mais adequados de análise. E é comum que os analistas de dados sigam as práticas comuns, ao invés de examinar antes se são realmente adequadas para a tarefa em questão.

A modelagem matemática constitui numa poderosa alternativa para 0 caso dos dados empíricos não estarem disponíveis é a aplicação de um sistema de modelagem. A modelagem pode ser aplicada em diferentes tipos de sistemas de produtos, p.ex., sistemas econômicos, nos quais são analisados: o mercado, o sistema do produto e suas interações com variáveis exógenas ou sistemas físicos cuja modelagem é baseada em leis naturais.

A seguir são descritos alguns métodos de modelagem matemática.

\subsubsection{1- A extrapolação de tendências}

A extrapolação da tendência é um dos métodos mais amplamente utilizados de todas as técnicas de previsão matemática. Os métodos estatísticos formais da extrapolação da tendência foram desenvolvidos com vários graus de sofisticação. Muitas previsões que resultam de julgamento de peritos provavelmente são um tipo de extrapolação de tendência impressionista.

Para usar o método, primeiramente deve ser identificada uma tendência. Isso pode ser qualquer fenômeno que possa ser expresso em termos quantitativos, e no qual seja visível um padrão de desenvolvimento. Entre as variáveis que têm sido sujeitas à extrapolação de tendência estão: a população, os dados de atitude, o desempenho tecnológico e até mesmo o tamanho dos impérios. Uma tendência refere-se aos dados históricos, já a extrapolação significa que estes dados estão projetados para o futuro. Isto pode ser feito através da adaptação de uma curva ou reta para uma série de pontos de dados, ou, em análises contemporâneas, pela equação matemática ou estatística 
(EUROFOUND, 2003).

A adaptação a uma curva de uma série de pontos de dados à mão é frequentemente uma boa forma de obter informações sobre o desenvolvimento de uma tendência. Mas também é responsável por vários tipos de erros pois podem ser identificados padrões onde não existem, ou ignorar arbitrariamente pontos de dados que não correspondam a uma previsão de tendência. A adaptação de uma curva a mão é particularmente difícil quando há uma grande quantidade de "ruído" nos dados, ou em se tratando de fenômenos cíclicos (por exemplo, o ciclo econômico pode causar tendências obscuras de crescimento a longo prazo). Existem várias técnicas estatísticas que permitem que retas ou várias curvas adaptem um conjunto de pontos de dados, e sejam projetadas para o futuro.

A extrapolação pode indicar a escala de mudança que ocorrerá a partir da continuação de uma tendência no longo prazo. Uma taxa de crescimento rápida pode fazer um pequeno fenômeno transformar-se em grande, num intervalo de tempo suficiente. Tendências que são desprezadas por atualmente serem de importância menor podem revelar-se extremamente importantes nos próximos anos, e a extrapolação pode informar isso. Às vezes, porém, a extrapolação surge com resultados que parecem ser implausíveis. Isto pode representar uma falta de imaginação das pessoas, ou pode indicar que a extrapolação é problemática.

Existem também várias técnicas estatísticas que permitem a adaptação de uma curva na forma de $S$ à tendência de dados. Tais métodos são frequentemente utilizados para análise e previsão de fenômenos como a difusão de produtos de consumo - ou a propagação de doenças contagiosas - em uma população. Sempre que há um limite óbvio, tais aproximações podem ser muito poderosas, mas no caso de muitos dos fenômenos sociais, há uma boa dose de adivinhação para decidir se o teto máximo foi alcançado.

A extrapolação de tendências é amplamente utilizada, e razoavelmente fácil de empregar e explicar. Mas, a fim de assumir uma tendência que irá continuar a evoluir no futuro, deve haver uma boa razão para acreditar que ela se persistirá ao invés de alterar o seu curso. Naturalmente, o fato de que algo tenha acontecido por muito tempo pode criar uma base plausível para supor que continuará a fazê-lo, mas as mudanças quantitativas podem tornar-se subitamente qualitativas. Por exemplo, o gelo quando aquecido se transforma em 
água após alcançar uma determinada temperatura, e a água, por sua vez, transformar-se-á em vapor (EUROFOUND, 2003).

Assim, é aconselhável identificar quais forças motrizes estão conduzindo uma tendência e, depois, considerar se estas são susceptíveis de persistir e se terão os mesmos efeitos.

A elaboração da extrapolação de tendências pode ser problemática quando:

- Estão fundamentadas em dados inadequados. Os dados podem ser fracos e não confiáveis. Por exemplo: dados históricos podem não terem sido medidos mas estimados;

- Substituem o espaço por um tempo em maneiras altamente enganadoras. Por exemplo, o fato de que pessoas mais ricas são propensas a contratar serventes não significa que se a sociedade crescer e ficar mais rica então o número de serventes crescerá. $O$ argumento correto deve ser o de que as pessoas mais ricas não vão querer para si as vagas de serventes;

- Falham na avaliação das forças motrizes básicas de modo que haja uma incapacidade para antecipar as mudanças nestas forças. Por exemplo, tendências a longo prazo, no uso da energia foram interrompidas a partir da crise do petróleo na década de 1970 (primeiro choque em 1973 e o segundo choque em 1978);

- Não examinam se as transformações qualitativas poderiam perturbar ou modificar radicalmente os indicadores quantitativos. Por exemplo: as estatísticas de propriedade de casas nos EUA pareciam conflitantes com os dados de formação de famílias na década de 70. Isto por que mais pessoas estavam vivendo em "trailers"/casas móveis e estas pessoas não estavam sendo capturadas pelas estatísticas.

- Fazem suposições sobre se, e quando, o teto será atingido baseando-se em informações muito pobres ( $p$. ex. generalizar valendo-se de fenômenos aparentemente similares).

Estas não são razões para se abandonar o uso da extrapolação. São razões para que sua utilização seja criticamente informada

\subsubsection{2- A modelagem por simulação}

Nas últimas décadas, computadores poderosos e de baixo custo tornaram-se amplamente disponíveis. Na sequência vieram as ferramentas como 
planilhas, e um grande número de linguagens de programação para modelagem de uso fácil. Estes desenvolvimentos significaram que a simulação computacional não se restringe apenas às equipes altamente especializadas trabalhando em computadores grandes e caros, produzindo análises que poucas outras pessoas possam estudar ou testar.

Os modelos de larga escala ainda são rotineiramente utilizados na projeção dos modelos econômicos, e para modelar processos como explosões nucleares e os impactos das reformas da segurança social, entre outros.

Assim o que são simulações de computador? São modelos. Imagine um modelo físico, como comboio de trem. Cada um dos vários elementos do sistema mundo real são reproduzidos em miniatura. O modelo consiste, essencialmente, de vários objetos com características específicas, algumas fixas, algumas variáveis e com relacionamento entre eles: a locomotiva puxa os vagões, uma mudança nos pontos afeta o caminho seguido pelo trem.

Modelos de computador têm sido amplamente desenvolvidos para sistemas que possuem propriedades facilmente quantificáveis. Os modelos mais conhecidos de sistemas sociais lidam com questões econômicas nas quais as principais variáveis podem essencialmente ser expressas em termos de fluxos de valores monetários ou estão relacionados com "contagens de cabeças", tais como níveis de emprego. Podem ser simulados os movimentos de pessoas entre estados, categorias etárias, acontecimentos como nascimento, morte, idade, ou localização em termos econômicos ou geográficos.

A simulação computacional está lentamente tornando-se uma atividade mais familiar e menos mistificada. Existem grandes vantagens, e também alguns inconvenientes, associados à modelagem. Em seu favor, a abordagem possui as seguintes vantagens:

- Obriga as pessoas a pensar sistematicamente sobre hipóteses relativas à dinâmica de um sistema, e torná-los uma pesquisa de dados relevantes com os quais testa, explica ou elabora tais hipóteses.

- Faz o usuário definir as hipóteses numa linguagem formal, que muitas vezes também pode ser representada em termos gráficos, diagramas e figuras que definem os subsistemas e as relações envolvidas.

- Permite a exploração de alternativas de condições de partida, eventos e intervenções, além de permitir ao utilizador hipóteses de experiência e com 
alterações comparar os comportamentos dos modelos do mesmo sistema, com base em diferentes compreensões da forma como ele opera.

- Lida simultaneamente com um número muito maior de variáveis que as pessoas comuns são capazes de fazer, de uma maneira sistemática e meticulosa, com inúmeros cálculos.

- Permite a apresentação de resultados detalhados de forma gráfica, permitindo uma comparação de resultados para diferentes momentos e condições.

Concluindo, a modelagem da simulação é uma ferramenta valiosa na previsão, embora até agora desenvolvimentos tenham sido restritos às abordagens mais tradicionais, ou para questões muito específicas. Algumas das abordagens mais modernas estão sendo usadas para fins práticos de planejamento.

Apesar de desafiadora a modelagem torna-se cada vez mais acessível, e várias novas abordagens que estão sendo desenvolvidas superam algumas das características dos modelos tradicionais irrealistas.

\subsubsection{3- Técnica de árvores de relevância}

As árvores da relevância são conhecidas como um método normativo de previsão, tendo sido desenvolvido dentro do contexto de grandes esforços gerenciais e tecnológicos.

A árvore de relevância subdivide um tema vasto em subtemas cada vez menores. Ela é representada por um diagrama na forma de árvore. $\mathrm{O}$ resultado é um mapeamento dos diversos aspectos críticos de um sistema, ou de um problema, ou as possíveis soluções para um problema.

O método da árvore de relevância se baseia nos métodos de análise de sistemas. Inicia-se com problemas e necessidades futuras e, então, identificase o desempenho tecnológico necessário para satisfazer essas necessidades. As árvores de relevância são usadas para analisar situações em que se podem identificar diferentes níveis de complexidade ou hierarquia. Cada nível inferior, sucessivamente, envolve uma distinção ou subdivisões mais elaboradas. A técnica de árvores de relevância pode ser usada para identificar problemas, soluções, deduzir necessidades de desempenho de tecnologias específicas e determinar a importância relativa dos esforços para se aumentar o desempenho 
tecnológico.

Este método é uma ferramenta para um estudo sistemático de determinado tema em avaliação. Ele pode gerar possibilidades inesperadas, novas visões do futuro, e novas opções. É por esta razão que este método é descrito como técnica de previsão, e não apenas como ferramenta de planejamento, apesar de ter claramente aspectos deste último.

A árvore de relevância está longe de ser de uso fácil. Ela requer uma análise em profundidade, por pessoas familiarizadas com as técnicas, e com base na perícia do problema real. E o uso dos resultados de tal exercício, por outros grupos podem ser bastante difícil, porque o resultado é normalmente uma massa de detalhes técnicos.

\subsubsection{4- Análise de regressão}

Um método de previsão comum é a análise de regressão iniciando com base numa função que correlaciona uma variável dependente, e uma ou mais independentes usando coeficientes que são minimizados, p.ex. usando o método dos mínimos quadrados. Para usar a análise de regressão, tanto as relações de causa-efeito devem ser conhecidas, por exemplo, uma função exponencial para o processo de crescimento, ou no mínimo, um conceito empírico deve ser utilizado, por exemplo, uma curva $S$ para processos saturados ou uma curva de aprendizagem correlacionando produção acumulada com redução de custo conseguida. Para que seja possível efetuar uma análise de regressão os dados do passado devem estar disponíveis em quantidade suficiente. Também, não podem ocorrer descontinuidades em desenvolvimentos futuros causados por efeitos inesperados ou amarras físicas. A análise de regressão é uma ferramenta muito simples e é aplicada extrapolando a função regressão para tempos futuros. A dificuldade da aplicação está na coleta de dados do passado.

\section{2-Problemas metodológicos na prospecção de tecnologias futuras}

Os problemas da avaliação de tecnologias futuras estão associados com o desenvolvimento de produtos em estágio inicial de desenvolvimento. $\mathrm{O}$ problema, que é comum a muitos produtos de importância estratégica, é a discrepância entre a importância da avaliação tecnológica de produtos em estágio de desenvolvimento inicial, no qual existem muitas opções de desenvolvimento e 
o estado de conhecimento sobre os sistemas do produto (HUNGERBUHLER, 1999). Este problema que é comum a vários métodos de investigação usados na área de avaliação tecnológica tem sido denominado, conforme Pehnt (2003a), como o "dilema do controle". Em avaliação tecnológica pode-se efetuar uma avaliação antecipada e compreensiva com a finalidade de orientar a tomada de decisão (PASCHEN AND PETERMANN, 1991), citado em Pehnt (2003a). Esta avaliação antecipada requer uma análise prospectiva, pois somente o estado atual ou avaliação retrospectiva do tipo contábil não é suficiente (WEIDEMA AND FREES, 1999). Entretanto o caráter futuro do sistema investigado leva a problemas metodológicos inerentes ao sistema.

Inevitavelmente a avaliação do impacto ambiental deve ser interpretada como um processo de investigação com fases interativas, atualização constante e interação entre os analistas e pesquisadores da tecnologia investigada. Entretanto este processo não é totalmente realizável para todos os casos, podendo-se também utilizar deduções.

O uso de elementos de previsão deve também aplicar ferramentas de previsão desenvolvidas para gerenciamento científico. A meta não é encontrar a previsão correta, tal qual apontado por Grunwald: "A antecipação do futuro apenas como realidade futura não pode ser bem sucedida. Ela deve servir como suporte para decisões futuras, além de focalizar as hipóteses de impactos utilizadas para a prospecção e os resultados singulares" (GRUNWALD AND LANGEBACH, 1999) citado por Pehnt, (2003a).

Ascher, apud Porter et al. (1981) e INT (2003), sugerem que os seguintes fatores devem ser considerados quando se faz a previsão tecnológica:

- Dependência em rupturas científicas básicas.

- Limites físicos da taxa de desenvolvimento.

- Maturidade da ciência e aplicações da tecnologia.

- Sensibilidade do ritmo de inovação para os níveis altos de decisão política.

- Relevância do financiamento para Pesquisa e Desenvolvimento.

- Extensão da possibilidade de substituição por outros produtos ou inovações paralelas.

- Relevância da difusão.

- Oportunidades para se apropriar de avanços de tecnologias relacionadas. 


\section{3- Critérios de escolha para o método}

A escolha do melhor procedimento de previsão depende fortemente de diferentes fatores, conforme apresentado por Pehnt (2003), na Tabela 2-2. Notese nesta Tabela 2-2 que métodos subjetivos são aqueles baseados no julgamento de um ou mais especialistas e métodos adaptativos são aqueles baseados no uso de bancos de dados de projetos comparáveis.

Tabela 2-2 Critério para seleção do método de prospecção.

\begin{tabular}{|c|c|c|c|c|c|c|c|}
\hline \multirow[b]{2}{*}{ Critério } & & \multicolumn{6}{|c|}{ Métodos } \\
\hline & & 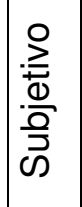 & $\begin{array}{l}\stackrel{0}{\frac{0}{\pi}} \\
\frac{0}{0} \\
\frac{\pi}{0} \\
\frac{0}{4}\end{array}$ & 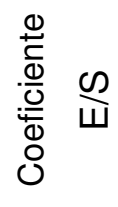 & 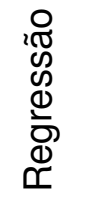 & $\varepsilon$ & $\begin{array}{l}\frac{0}{2} \\
\frac{1}{0} \\
\frac{1}{0}\end{array}$ \\
\hline Horizonte de tempo & & PML & PM & PM & PML & PML & PML \\
\hline \multirow[t]{3}{*}{ Fontes necessárias } & Informações necessárias & + & -10 & + & $-/+$ & 0 & - \\
\hline & $\begin{array}{c}\text { Qualificações necessárias do } \\
\text { usuário }\end{array}$ & - & 0 & + & + & - & - \\
\hline & Velocidade de uso & $+/-\varphi$ & + & + & 0 & - & - \\
\hline \multirow{3}{*}{$\begin{array}{l}\text { Qualidade } \\
\text { resultados }\end{array}$} & Confiabilidade & - & -10 & + & + & + & irr \\
\hline & Teor das informações & + & $+/ 0$ & 0 & $+/ 0$ & + & + \\
\hline & Erros sistemáticos & o/+ & 0 & - & + & + & + \\
\hline \multirow[t]{2}{*}{ Flexibilidade } & Espectro de aplicabilidade & + & + & + & 0 & + & + \\
\hline & Adaptabilidade a mudanças & $+/ 0$ & + & + & 0 & 0 & 0 \\
\hline
\end{tabular}

Legenda da Tabela:

P-Curto prazo; M médio prazo; L longo prazo;

+ vantagem do método / o método neutro / - desvantagem do método / irr irrelevante

$\checkmark+$ para entrevista única / $\vee$ - para método Delphi

- + se a equação da regressão estiver disponível na literatura, / - se a equação da regressão necessita de ser pesquisada.

A disponibilidade de dados restringe a aplicação de certos métodos de previsão. O horizonte de tempo também influencia a seleção do melhor método. Por exemplo, métodos baseados em extrapolações, tais como a análise de regressão, são mais convenientes para previsões em curto prazo, ao passo que os métodos de modelagem ou adaptativos podem também ser utilizados em desenvolvimentos em longo prazo. Outros critérios de seleção podem incluir flexibilidade e aplicabilidade a diferentes sistemas de produtos ou processos de produção, requerendo qualificação do usuário e confiabilidade. Na prática uma 
combinação de métodos, pode ser a solução mais apropriada. Na forma mais simples os dados do processo substituto podem ser transferidos sem adaptação posterior. Isto pode ser efetuado na forma de coeficientes. Estes coeficientes são obtidos pela divisão da quantidade por um parâmetro adequado relacionado com a quantidade. O coeficiente obtido pode ser transferido, ou seja, ser utilizado por outro processo análogo, mas em escala diferente. $O$ exemplo mais comum é o método de estimativa de custo denominado kilograma por custo, o qual assume que uma parcela do custo de materiais em relação ao custo de produção total é similar para produtos comparáveis. Para uso dos métodos adaptativos deve ser necessária uma grande base de dados. E uma vez que os bancos de dados estejam disponíveis, então a principal vantagem do método adaptativo é a facilidade na aplicação.

Dados obtidos com base em processos ou componentes comparáveis podem ser transferidos, por meio de coeficientes generalizados obtidos a partir de outras fontes de dados. Por exemplo, baseado em extrapolações e coeficientes de entrada/saída (E/S) pode-se obter os valores de emissões para processos similares.

\subsection{1-Problemas metodológicos no uso de ACV ou LCA}

No caso de se utilizar a avaliação do impacto ambiental de tecnologias ainda em desenvolvimento, através do ACV existem vários problemas metodológicos, tais como:

- Aumento da necessidade de expansão ou alocação do sistema em razão do aumento da complexidade e aumento do uso de produtos combinados graças a um conjunto de exigências ambientais. Por exemplo, a cogeração com pilhas combustíveis ou produção conjunta de carvão e hidrogênio no processo Kvaerner CB\&H. Adicionalmente torna-se cada vez mais difícil ,em razão da perspectiva de estudo a longo prazo, a determinação de sistema de créditos convenientes em um sistema em expansão, evitando queimas.

- Aumento na dificuldade de distinção entre os sistemas "foreground" (processos posteriores que estão sob controle de tomadas de decisões para o qual o ACV é executado e suprido por uma unidade funcional) e sistemas "background" (processos anteriores), por causa dos múltiplos mecanismos de realimentação. Por exemplo, diferentes trens de potência preferem diferentes 
combustíveis, e combustíveis em diferentes qualidades são fortemente influenciados pelo sistema anterior de fornecimento de combustível.

- Aumento na necessidade de considerar a infra-estrutura por causa de tendência em direção à descentralização na produção de energia (significa que a importância da infra-estrutura pode aumentar, pois pequenos sistemas frequentemente requerem materiais específicos mais sofisticados e maiores consumo de energia); tendência em direção a sistema de energia limpos com menores impactos diretos (p.ex. emissões diretas por plantas térmicas) também levam a um aumento na importância relativa dos sistemas de manufatura; sistemas mais eficientes e limpos freqüentemente requerem componentes mais sofisticados com impactos maiores para sua produção (p.ex. Catalisador na pilha a combustível). Além disso, muitas vezes infra-estrutura nova deve ser construída (p.ex. Infraestrutura de abastecimento de hidrogênio para veículos movidos a pilha a combustível).

Em razão da grande variedade de falta de dados, Pehnt (2003a) sugeriu que se catalogasse a falta de dados conforme as suas causas, tal qual apresentado na Tabela 2-3.

A falta de dados do tipo 1 pode ser evitada pela concordância com a confidencialidade e através da coleta de dados em publicações. A do tipo 2 pode ser ultrapassada por meio de simplificações, hipóteses ou métodos de previsão. As abordagens do tipo 3 e 4 são descritas a seguir e as do tipo 5 só podem ser minimizadas pela coleta sistemática de dados, mas a princípio, não podem ser evitadas.

As previsões, para sistemas futuros na área de geração de energia, são necessárias tanto para avaliação ambiental dos processos relevantes como para avaliar o impacto ambiental dos componentes destes sistemas com base num padrão de tecnologia muitas vezes ainda sem escala de produção industrial.

Freqüentemente as previsões de uso, ou seja, desempenho, fatores de emissão, etc. podem ser derivados da modelagem do processo, dados alvo a partir das informações do fabricante, ou níveis de emissão requeridos pela legislação ambiental. Entretanto é mais difícil a determinação do impacto dos sistemas futuros para produção de energia que sejam, na época da confecção do LCA, freqüentemente produzidas somente em escala de laboratório, ou ainda sem larga escala de produção. 
Dessa forma, o procedimento para avaliar tais tecnologias deve ser iniciado tomando-se por base um LCA preliminar empregando o sistema utilizado no momento da avaliação. Assim os dados faltantes são identificados.

Tabela 2-3 - Classificação da falta de dados na produção dos processos investigativos do ciclo da vida. (PEHNT, 2003a)

\begin{tabular}{|c|c|c|c|c|}
\hline TIPO & $\begin{array}{c}\text { Causa da falta de } \\
\text { dados }\end{array}$ & Descrição & Tempo & Aplicação \\
\hline 1 & $\begin{array}{l}\text { Confidencialidade dos } \\
\text { fatos }\end{array}$ & $\begin{array}{l}\text { Os dados são conhecidos } \\
\text { mas não totalmente dis- } \\
\text { poníveis em razão da } \\
\text { confidencialidade. }\end{array}$ & $\mathrm{P}, \mathrm{Pr}$ & $\begin{array}{l}\text { Processos inova- } \\
\text { dores, mercados } \\
\text { competitivos (pilhas } \\
\text { combustível), } \\
\text { aplicações milita- } \\
\text { res. }\end{array}$ \\
\hline 2 & $\begin{array}{l}\text { Complexidade dos } \\
\text { fatos }\end{array}$ & $\begin{array}{l}\text { Processos complexos cuja } \\
\text { aquisição de dados ainda } \\
\text { consumirá muito tempo ou } \\
\text { com relações causais não } \\
\text { conhecidas. }\end{array}$ & $\mathrm{P}, \mathrm{Pr}$ & $\begin{array}{l}\text { Processos indus- } \\
\text { triais integrados } \\
\text { (separação de } \\
\text { metais do grupo } \mathrm{Pt} \text { ). }\end{array}$ \\
\hline 3 & $\begin{array}{lr}\text { Produtos em estágio } \\
\text { inicial } & \text { de } \\
\text { desenvolvimento de } \\
\text { mercado. }\end{array}$ & $\begin{array}{l}\text { Processos e tecnologias } \\
\text { ainda não bem desenvol- } \\
\text { vidas. }\end{array}$ & $F$ & $\begin{array}{l}\text { Novos produtos } \\
\text { (conjunto membra- } \\
\text { na }+ \text { eletrodo) em } \\
\text { SOFC. }\end{array}$ \\
\hline 4 & $\begin{array}{ll}\text { Contexto } & \text { no } \\
\text { desconhecimento } & \text { do } \\
\text { produto. } & \\
\end{array}$ & \begin{tabular}{|llr} 
Sistemas & de & produção \\
anteriores & dificultam as \\
previsões. & &
\end{tabular} & $F$ & $\begin{array}{lr}\text { Mercados } & \text { emer- } \\
\text { gentes } & \text { (desregu- } \\
\text { lamentação } & \text { de } \\
\text { mercados de } & \text { ele- } \\
\text { tricidade). } & \end{array}$ \\
\hline 5 & $\begin{array}{l}\text { Falta de } \\
\text { conhecimento }\end{array}$ & $\begin{array}{l}\text { Devido à falta de conhe- } \\
\text { cimentos dos processos, } \\
\text { componentes não podem ser } \\
\text { considerados }\end{array}$ & $\begin{array}{l}\mathrm{P}, \mathrm{Pr} \\
\mathrm{F}\end{array}$ & \\
\hline
\end{tabular}

A análise de relevância mostra se estas falhas nos dados causam um efeito significativo no resultado do LCA. Dois aspectos são importantes nesta fase:

as fases do processo a ser investigado devem ser as que possuem relevância ambiental e;

- os parâmetros do processo devem exibir uma dependência considerável no tempo.

Para determinadas fases, como por exemplo, a etapa de sinterização ou a etapa de montagem, as quais possuem relevância ambiental, deve ser efetuada uma prospecção. Se necessário as etapas ou componentes do 
processo, que são importantes, podem ser desagregados em componentes elementares. E para estes componentes é que é efetuada a previsão. Tem sido comum o uso de métodos de previsões independentes e depois se verifica se os resultados são consistentes. Uma das seguintes condições deve ser preenchida:

- Resultados diferentes de métodos de previsão independentes são consistentes, isto é, não diferem significativamente. Então os dados de um dos métodos de previsão podem ser usados.

- Se os resultados não são consistentes, uma análise de sensibilidade deve ser efetuada usando resultados dos diferentes métodos de previsão para avaliar se os resultados do LCA estão alterados.

Se as conclusões do LCA são influenciadas pelos métodos de previsão, então diferentes cenários devem ser criados com afirmações do tipo: "Se a previsão A é correta, então a conclusão do LCA é esta".

Um problema similar ao de previsão do LCA para sistemas futuros é a previsão de custos. Vários métodos de estimativa de custo têm sido desenvolvidos na ciência de gerenciamento. Estes métodos geralmente assumem que produtos com características similares mostram estruturas de custo similares.

Os métodos de previsão tal qual desenvolvidos na prospecção tecnológica incluem: os métodos de avaliação subjetivos e os adaptativos.

Nos LCA, os métodos de avaliação subjetivos, especialmente na forma de entrevistas com especialistas, são comumente utilizados devido à falta de fontes de dados. Estes métodos são freqüentemente de natureza heurística ou intuitiva (p. ex. "brainstorming"). Entrevistas com especialistas em grupos ou pesquisas Delphi podem ser realizadas em projetos maiores (Contandini, 2002). Entretanto a qualidade das estimativas resultantes é fortemente dependente do modo como a entrevista é efetuada, da escolha dos especialistas e da qualificação dos entrevistadores.

No caso de se utilizar os métodos adaptativos então todos os processos analisados têm que ser desmembrados em processos separados para os quais estão disponíveis informações no banco de dados. Processos substitutos podem ser processos com materiais ou parâmetros de processamento similares. Entretanto para a qualidade da previsão é essencial que as relações casuais para ambos os processos, substitutos e analisados, sejam similares, p.ex., o tratamento térmico de um material a temperaturas similares, em quantidades 
similares, tipos de fornos e cargas.

A decisão de se utilizar a metodologia Delphi como uma ferramenta suplementar ao estudo do impacto ambiental e não somente um LCA para previsões a longo prazo reside notadamente nos fatores apresentados acima, pois a tecnologia das células a combustível ainda não permite o levantamento dos fatores confiáveis que são necessários para que o resultado do LCA também seja confiável. 


\section{TIPOS DE PILHAS E COMBUSTÍVEIS UTILIZADOS}

Este capítulo tem o objetivo de apresentar um resumo das características mais importantes dos diversos tipos de pilhas a combustível de média e baixa temperaturas e os combustíveis mais utilizados, a fim de avaliar as conseqüências de sua fabricação, operação e deposição final ao término de sua vida útil.

\section{1- Tipos de pilhas}

Uma classificação possível das pilhas é a classificação quanto ao tipo de eletrólito.

Os tipos de pilhas mais comuns são: Pilha tipo PEM ("Proton Exchange Membrane"), pilha a carbonato fundido ou MCFC ("Molten Carbonate Fuel Cell"), pilha a ácido fosfórico, pilha alcalina ou AFC ("Alkaline Fuel Cell"), pilha com metanol direto (DMFC), pilha SOFC ("Solid Oxide Fuel').

Outra classificação possível das pilhas é quanto à mobilidade. Assim elas podem ser classificadas em:

- Pilhas utilizadas com finalidades móveis: utilizadas em veículos automotores e equipamentos móveis

- Pilhas utilizadas com finalidades estacionárias: utilizadas na geração de energia elétrica centralizada ou em local fixo.

A seguir estão as principais características dos tipos de pilhas mais importantes. A Tabela 3-1 apresenta resumidamente as principais características das células a combustível. 
Tabela 3-1 - Características dos principais tipos de pilhas.

\begin{tabular}{|c|c|c|c|c|c|c|c|c|c|}
\hline 항 & 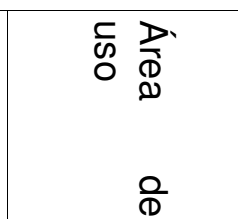 & $\begin{array}{l}\frac{m}{\bar{D}} \\
\overrightarrow{\overrightarrow{0}} \\
\overline{\bar{\partial}}\end{array}$ & 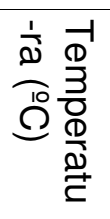 & $\begin{array}{l}\frac{m}{\mathrm{~m}} \\
\frac{\mathrm{a}}{\overline{0}} \\
\frac{0}{0}\end{array}$ & 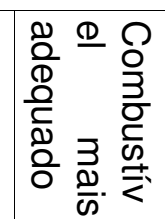 & 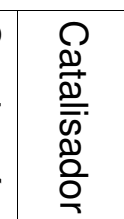 & 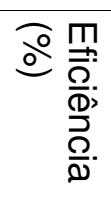 & 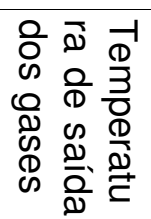 & 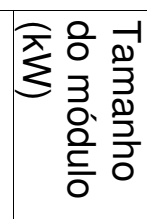 \\
\hline $\begin{array}{l}\text { Álcalina } \\
\text { (AFC) }\end{array}$ & \begin{tabular}{|l} 
Viagens \\
espaciais, \\
transporte, \\
pequenas \\
unidades \\
potência, \\
aplicações \\
domésticas.
\end{tabular} & $\begin{array}{l}\mathrm{NaOH} \\
\mathrm{Ou} \\
\mathrm{KOH}\end{array}$ & $\begin{array}{l}\text { ज } \\
\text { 'े } \\
\text { ஸे }\end{array}$ & $\begin{array}{l}\text { Metal } \\
\text { ou } \\
\text { Carbo } \\
\text { no }\end{array}$ & $\mathrm{H}_{2}$ puro & $\begin{array}{l}\mathrm{Ni}, \\
\mathrm{Ag}\end{array}$ & $\begin{array}{l}8 \\
8 \\
8\end{array}$ & $\begin{array}{l}\hat{8} \\
\text { i̊ } \\
0\end{array}$ & $\frac{\hat{1}}{\dot{\tilde{O}}}$ \\
\hline $\begin{array}{l}\text { Metanol } \\
\text { Direto } \\
\text { (DMFC) }\end{array}$ & $\begin{array}{l}\text { Transporte, } \\
\text { equipamento } \\
\text { s móveis. }\end{array}$ & $\begin{array}{l}\text { Polí- } \\
\text { mero }\end{array}$ & $\tilde{\delta}_{0}^{\infty}$ & $\begin{array}{l}\text { Carbo } \\
\text { no }\end{array}$ & $\mathrm{CH}_{3} \mathrm{OH}$ & $\mathrm{Pt}$ & & & \\
\hline $\begin{array}{l}\text { Mem- } \\
\text { brana } \\
\text { Polimé- } \\
\text { rica } \\
\text { (PEM) }\end{array}$ & $\begin{array}{l}\text { Viagens } \\
\text { espaciais, } \\
\text { transporte, } \\
\text { pequenos } \\
\text { CHP, } \\
\text { equipa- } \\
\text { mentos } \\
\text { móveis, } \\
\text { substituição } \\
\text { de baterias. }\end{array}$ & $\begin{array}{l}\text { Polí- } \\
\text { mero }\end{array}$ & $\begin{array}{l}\text { जo } \\
0 \\
0 \\
0\end{array}$ & $\begin{array}{l}\text { Carbo } \\
\text { no }\end{array}$ & $\mathrm{H}_{2}$ puro & $\mathrm{Pt}$ & $\begin{array}{l}\omega \\
心 \\
\grave{0} \\
\Delta\end{array}$ & $\begin{array}{l}\hat{0} \\
\text { ò } \\
\text { in }\end{array}$ & $\frac{\Lambda}{\dot{\prime}}$ \\
\hline $\begin{array}{l}\text { Ácido } \\
\text { fosfó- } \\
\text { rico } \\
\text { (PAFC) }\end{array}$ & $\begin{array}{l}\text { CHP, plantas } \\
\text { de térmicas } \\
\text { de potência, } \\
\text { pequena } \\
\text { escala. }\end{array}$ & $\mathrm{H}_{3} \mathrm{PO}_{4}$ & $\begin{array}{l}\vec{\varphi} \\
\dot{0} \\
\overrightarrow{0}\end{array}$ & $\begin{array}{l}\text { Carbo } \\
\text { no }\end{array}$ & $\begin{array}{l}\mathrm{H}_{2} \mathrm{com} \\
\mathrm{CO}_{2}\end{array}$ & $\mathrm{Pt}$ & $\begin{array}{l}\omega \\
心 \\
\stackrel{N}{N}\end{array}$ & $\begin{array}{l}\hat{N} \\
8 \\
0 \\
0\end{array}$ & $\begin{array}{l}\text { 1̀ } \\
\text { ஸे }\end{array}$ \\
\hline $\begin{array}{l}\text { Carbo- } \\
\text { nato } \\
\text { fundido } \\
\text { (MCFC) }\end{array}$ & $\begin{array}{l}\text { CHP, plantas } \\
\text { de potência } \\
\text { térmicas, pe- } \\
\text { quena e } \\
\text { larga escala. }\end{array}$ & $\begin{array}{l}\text { KLiCO } \\
3\end{array}$ & $\begin{array}{l}\text { : } \\
\text { o } \\
\text { के } \\
\text { जn }\end{array}$ & $\begin{array}{l}\text { Base } \\
\text { metáli } \\
\text { ca }\end{array}$ & $\begin{array}{l}\mathrm{H}_{2} \text { com } \\
\mathrm{CO}\end{array}$ & $\begin{array}{l}\mathrm{Ni}, \\
\mathrm{Ni} / \mathrm{Cr}\end{array}$ & $\begin{array}{l}\text { O } \\
0 \\
\text { O } \\
\text { G }\end{array}$ & $\begin{array}{l}\text { ? } \\
8 \\
\circ \\
10\end{array}$ & $\begin{array}{l}\text { N } \\
\text { O } \\
\text { ì } \\
\text { ठ }\end{array}$ \\
\hline $\begin{array}{l}\text { Óxido } \\
\text { Sólido } \\
\text { (SOFC) }\end{array}$ & $\begin{array}{l}\text { CHP, plantas } \\
\text { térmicas de } \\
\text { potência de } \\
\text { pequena e } \\
\text { larga escala, } \\
\text { aplicações } \\
\text { domésticas. }\end{array}$ & $\begin{array}{l}\mathrm{ZrO}_{2} \\
\text { com } \\
\mathrm{Y}_{2} \mathrm{O}_{3}\end{array}$ & 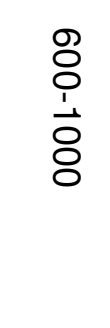 & & $\begin{array}{l}\mathrm{H}_{2} \mathrm{com} \\
\mathrm{CO}\end{array}$ & $\begin{array}{l}\mathrm{Ni} / \\
\mathrm{ZrO}_{2}( \\
\mathrm{Y})\end{array}$ & $\begin{array}{l}\text { ज़ } \\
\text { İ }\end{array}$ & $\begin{array}{l}2 \\
\infty \\
\text { O } \\
0 \\
10 \\
0\end{array}$ & $\begin{array}{l}\text { ci } \\
\text { ஸे } \\
\text { ठ̀ }\end{array}$ \\
\hline
\end{tabular}




\subsection{1-Pilha tipo PEM}

As células do tipo PEM consistem de quatro elementos básicos:

- O ânodo é o eletrodo carregado negativamente. No ânodo os elétrons são liberados por moléculas do hidrogênio de modo que elas podem operar em um circuito elétrico externo.

- O catodo é o eletrodo carregado positivamente e, no qual os elétrons são conduzidos do circuito elétrico para o catalisador, onde eles reagem com os íons de oxigênio e hidrogênio, formando água.

O eletrólito é uma membrana de troca de prótons. Esta membrana consiste de um polímero especialmente tratado para ser capaz de conduzir prótons de um lado para outro.

O catalisador é o material que acelera a reação mas não é consumido diretamente na mesma. O catalisador mais comum é a Platina. Ela é suportada em torno de pequenas partículas de carbono, a fim de usar a menor quantidade possível de Platina e para criar a maior área superficial possível. Também é necessária uma placa ou fio condutor para fornecer contacto entre os eletrodos.

Na Fig. 3-1 está mostrado um esquema da operação da célula tipo PEM.

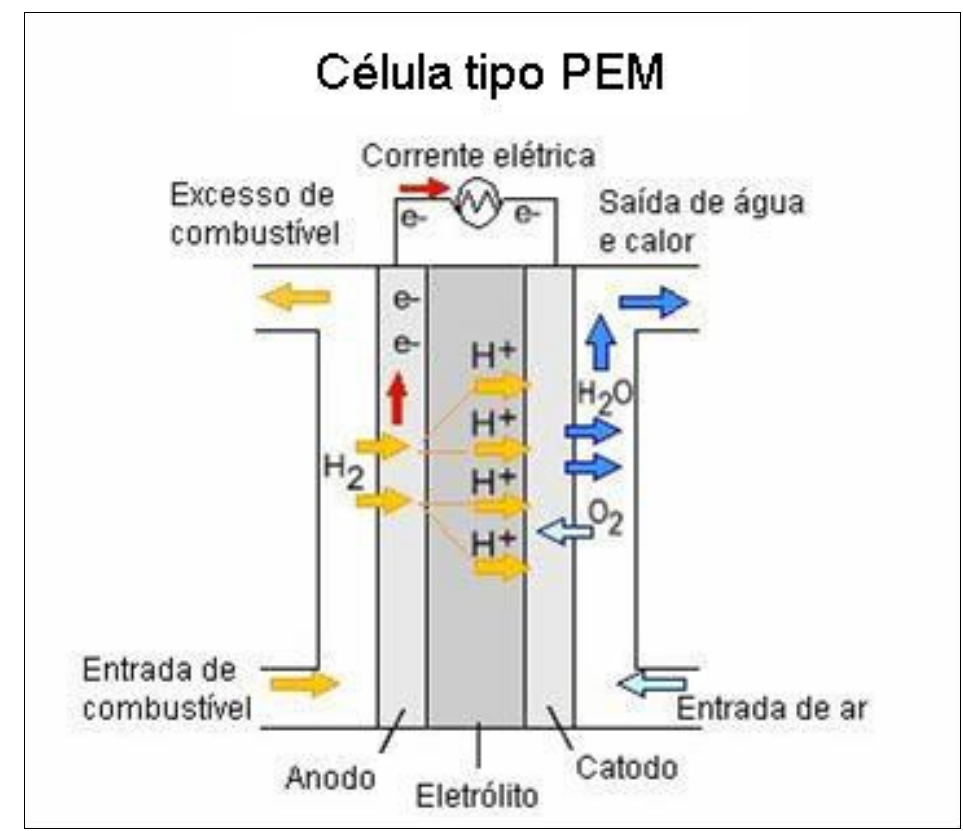

Figura 3-1 Esquema da célula tipo PEM (EERE, 2005).

A célula tipo PEM opera colocando a molécula de hidrogênio em 
contacto com o catalisador de Platina, e quebrando a molécula em dois íons de hidrogênio (prótons) e dois elétrons. Os elétrons são conduzidos pelo eletrodo para o circuito externo onde eles podem, por exemplo, movimentar um motor elétrico. $\mathrm{E}$ depois retorna para o catodo onde o oxigênio do ar quebra-se em dois átomos de oxigênio quando entra em contacto com o catalisador. Os dois íons hidrogênio combinam-se com um átomo de oxigênio e dois elétrons do condutor para criar a molécula de água. A reação na célula apresenta tensão máxima ao redor de0,6- de 0,7V. Para se obter a potência necessária devem ser conectadas algumas células em série para atender á potência de saída necessária. As células conectadas em série são denominadas pilhas a combustível ("stacks").

A temperatura de operação da PEM é aproximadamente $80^{\circ} \mathrm{C}$, o que permite sua utilização em residências, podendo gerar eletricidade e calor. A pilha tipo PEM também é mais eficiente que baterias para aplicações móveis, especialmente por:

- serem leves,

- serem robustas,

- o fato do eletrólito ser sólido também a faz mais segura,

-responderem rapidamente a uma necessidade de aumento de carga, o que favorece a aceleração de veículos,

Na Figura 3-2 é apresentado um esquema do projeto de uma célula combustível tipo PEM contendo os seus componentes.

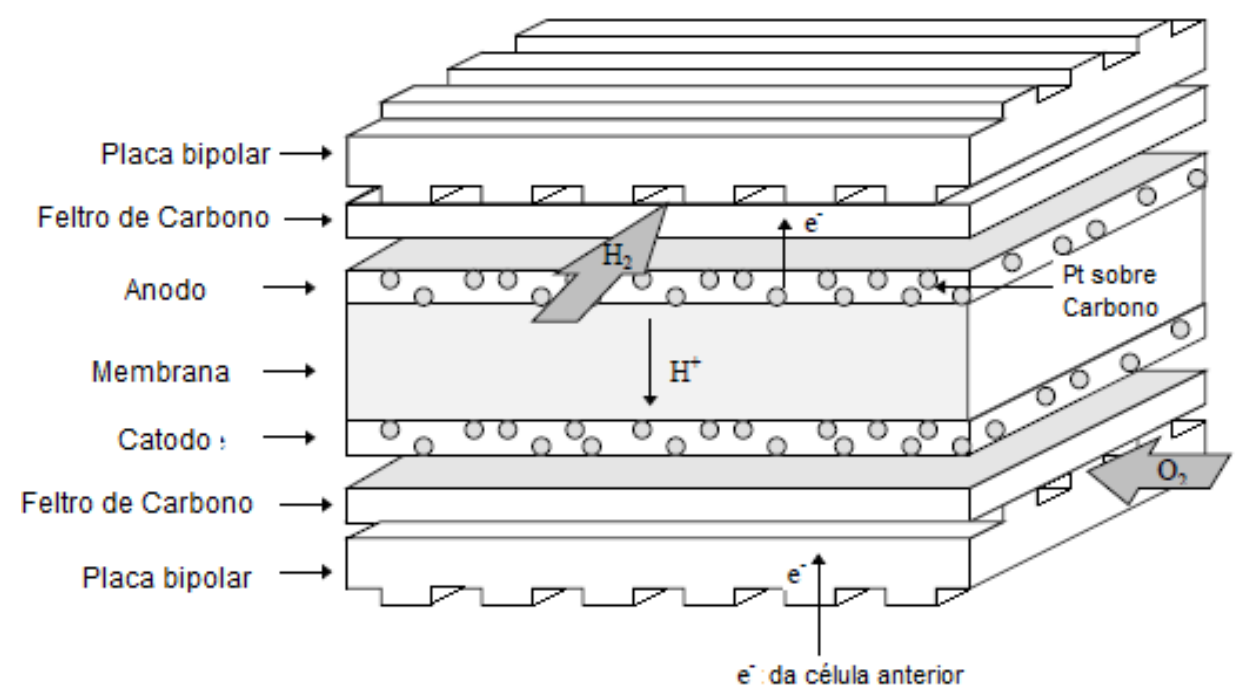

Figura 3-2 - Esquema do projeto de uma célula combustível PEM (NADAL, 1997). 
Uma desvantagem da pilha PEM é a utilização da Platina como catalisador. Apesar da quantidade de Platina utilizada por pilha a combustível ter diminuído sensivelmente nos últimos anos, conforme apresentado na Fig. 3-3, a tendência de queda promete continuar ainda nos próximos anos.

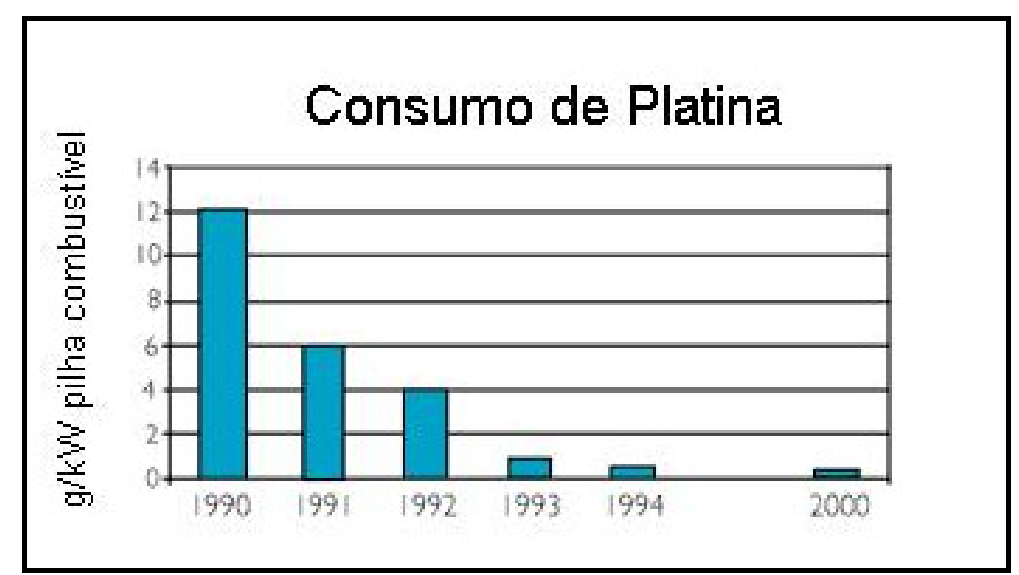

Figura 3-3 - Uso da Platina nos últimos anos (Räde, 2001).

As pilhas PEM toleram $\mathrm{CO}_{2}$, mas são sensíveis a $\mathrm{CO}$, o qual pode reduzir sua eficiência. Este é o grande problema quando se deseja utilizar hidrocarboneto reformado como combustível na pilha PEM ao invés de hidrogênio puro.

As pilhas tipo PEM foram desenvolvidas notadamente pela GE ("General Electric") no período entre 1959 e 1982. A empresa Ballard, no Canadá, iniciou o desenvolvimento das pilhas PEM em 1983, e tem contribuído muito no desenvolvimento após a GE ter abandonado este projeto. O desenvolvimento de membranas melhores, com menores quantidades de Platina e um melhor aproveitamento do ar de exaustão fizeram com que a PEM fosse considerado o tipo de pilha líder no desenvolvimento.

O aumento da eficiência está então ligado ao desenvolvimento de materiais, mas mesmo assim a pilha tipo PEM já é competitiva em muitas áreas e tem sido fabricada para venda em escala comercial para aplicações estacionárias de pequena potência.

\subsection{2- Pilhas Alcalinas}

As pilhas alcalinas foram utilizadas como fornecedoras de potência nas naves Apollo e são normalmente utilizadas nos ônibus espaciais da NASA. Os 
principais pesquisadores das pilhas alcalinas foram F. T. Bacon, Energy Conversions, Pratt Whitney e Elenco. A tecnologia Elenco e suas patentes foram transferidas para a Zetek. Esta companhia tem fornecido pilhas para táxis de Londres, para barcos de passageiros em Bonn, entre outros. Uma vantagem deste tipo de pilha é que é possível usar um catalisador barato tal como o níquel.

As pilhas alcalinas são extremamente sensíveis a $\mathrm{CO}_{2}$. Se for utilizado 0 ar ao invés de oxigênio puro, o ar deve ser limpo para retirar $0 \mathrm{CO}_{2}$. Outra desvantagem é que os eletrólitos são líquidos e corrosivos.

No programa de ônibus espaciais as pilhas alcalinas da UTC Fuel Cells demonstraram boa disponibilidade, de aproximadamente $99 \%$. As pilhas alcalinas já operaram por 2600horas em 13 missões espaciais (UTC Fuel Cells, 2006).

Na Fig. 3-4 é apresentado um esquema da operação da célula Alcalina.

As pilhas alcalinas usam hidrogênio muito puro como combustível e $\mathrm{KOH}$ como eletrólito. Podem alcançar eficiências altas (70\%) e operam a temperaturas relativamente baixas $\left(70^{\circ} \mathrm{C}\right)$. Em razão do eletrólito ser aquoso a temperatura de operação da pilha está limitada a $100^{\circ} \mathrm{C}$. Estas baixas temperaturas de operação possuem a vantagem de poder utilizar materiais de baixo custo, tais como eletrodos de níquel e teflon ligado a carbono, e polímeros em outras partes da pilha.

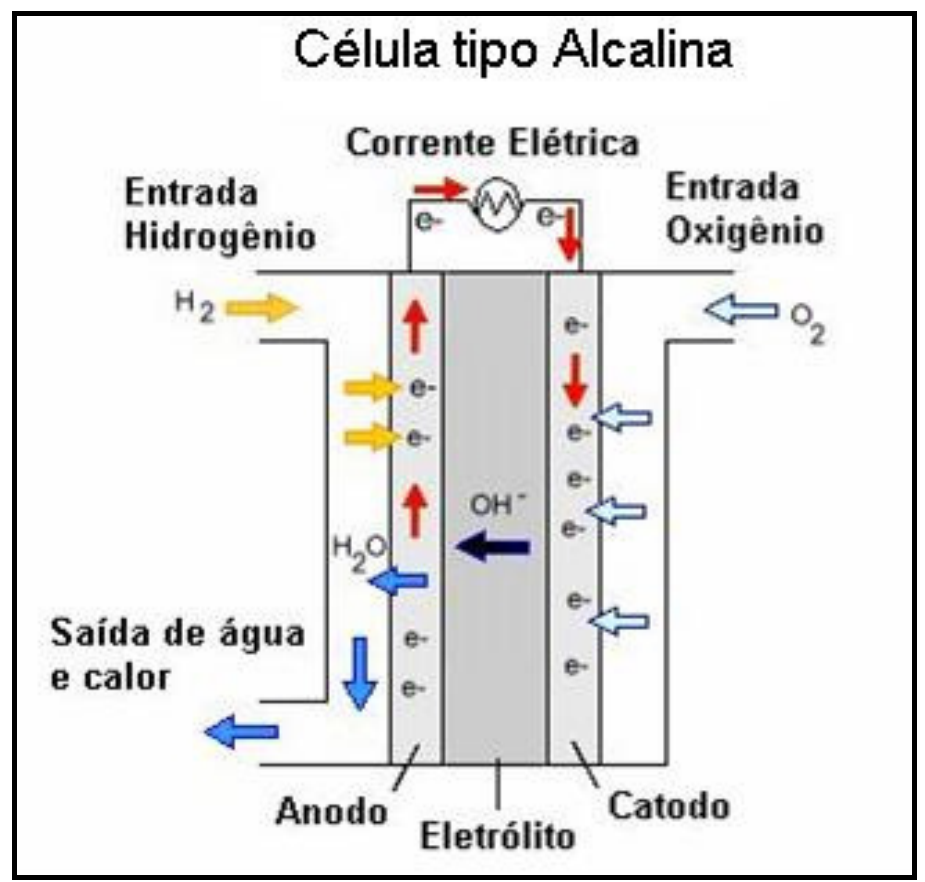

Figura 3-4 - Esquema da célula alcalina (EERE, 2005). 
Na Fig. 3-5 é apresentada uma pilha alcalina utilizada em ônibus espacial.

Figura 3-5 - Pilha Alcalina utilizada em ônibus espacial (UTC Power, 2005)

\subsection{3-Pilha a ácido fosfórico}

As pilhas a ácido fosfórico estão sendo desenvolvidas desde o início da década de 1960. Este tipo de pilha é a que é mais facilmente encontrada para venda, nos dias de hoje, no caso de pilhas estacionárias. Mais de 200 sistemas de pilhas estão instalados no mundo, com o Japão liderando as vendas. Hospitais, clínicas médicas, hotéis, prédios de escritórios, escolas, plantas de geração de energia elétrica e terminais de aeroportos possuem sistemas de pilhas a ácido fosfórico.

Este tipo de pilha utiliza o ácido fosfórico como eletrólito e é tolerante a $\mathrm{CO}_{2}$. A eficiência elétrica das pilhas de ácido fosfórico é relativamente baixa, em torno de 35 a $45 \%$. Mas o excesso de calor produzido geralmente é utilizado em aquecimento. As pilhas a ácido fosfórico requerem certo tempo de aquecimento, por isso são utilizadas normalmente em plantas estacionárias.

As reações eletroquímicas que ocorrem nas pilhas são:

Ânodo: $\quad \mathrm{H}_{2} \rightarrow 2 \mathrm{H}++2 \mathrm{e}-$

Equação 3-1

Catodo: $\quad 1 / 2 \mathrm{O}_{2}+2 \mathrm{H}++2 \mathrm{e}-\rightarrow \mathrm{H}_{2} \mathrm{O}$ Equação 3-2

Global: $\quad 1 / 2 \mathrm{O}_{2}+\mathrm{H}_{2} \rightarrow \mathrm{H}_{2} \mathrm{O}$ Equação 3-3

Observe-se que a pilha opera com $\mathrm{H}_{2}$, e o $\mathrm{CO}$ é um veneno quando presente em concentração maior que $0,5 \%$. Se um hidrocarboneto, como o gás 
natural, for usado como combustível é necessário reformar o combustível através da reação:

$$
\mathrm{CH}_{4}+\mathrm{H}_{2} \mathrm{O} \rightarrow 3 \mathrm{H}_{2}+\mathrm{CO}
$$

e utilizar uma reação de deslocamento ("shift"):

$$
\mathrm{CO}+\mathrm{H}_{2} \mathrm{O} \rightarrow \mathrm{H}_{2}+\mathrm{CO}_{2}
$$

que é necessária para gerar o hidrogênio para a pilha e remover o $\mathrm{CO}$ transformando-o em $\mathrm{CO}_{2}$. Qualquer contaminação por Enxofre deve ser removida antes do uso na pilha (após a reforma), tendo uma concentração máxima de 0,1 ppmV. No combustível o limite na concentração de CO é $0.5 \%$.

O eletrólito utilizado é o $\mathrm{H}_{3} \mathrm{PO}_{4}$ na concentração de $100 \%$ e a temperatura de $200^{\circ} \mathrm{C}$. A pressão de operação deve exceder oito atm em uma planta de demonstração de $11 \mathrm{MW}$.

É importante observar que no caso das pilhas PAFC o eletrólito ácido fosfórico é solido a temperatura ambiente e consequentemente deve ser estocado sob condições especiais para prevenir danos à célula. No período em que a célula não está operando deve existir uma fonte de fornecimento de energia para a pilha de modo a prevenir a solidificação do ácido fosfórico.

Na Fig. 3-6 é mostrado o esquema da operação de uma célula de ácido fosfórico. 


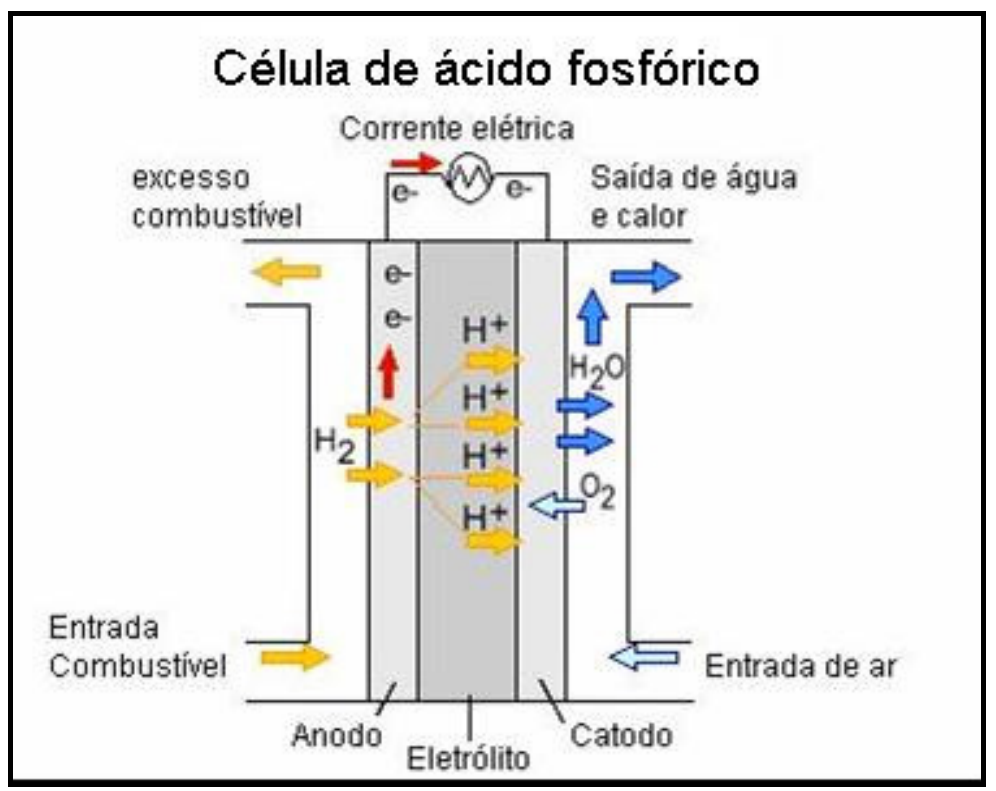

Figura 3-6 - Esquema da célula de ácido fosfórico (EERE, 2005)

Nas pilhas PAFC utiliza-se eletrodo poroso contendo uma mistura de eletrocatalisador, suportado em negro de fumo e um ligante polimérico para ligar as partículas de Carbono e também para formar uma estrutura integral. Um substrato de papel com carbono poroso serve como suporte estrutural para a camada de eletrocatalisador e como coletor de corrente.

Na Figura 3-7 é apresentado um esquema do projeto de uma célula combustível tipo PAFC contendo os seus componentes.

A estrutura de compósitos consiste de uma camada de ligante/Carbono em substrato de Carbono e papel, com o eletrólito em um dos lados e os gases reagentes no outro lado do papel de carbono. Apesar de sua eficiência ser menor que a das pilhas a carbonato fundido e óxido sólido, sua menor temperatura de operação $\left(160-200^{\circ} \mathrm{C}\right)$ é considerada mais adequada para unidades pequenas e médias.

O calor gerado durante a operação da pilha normalmente é removido tanto por refrigerantes líquidos como gasosos, os quais circulam pelos canais da pilha. 


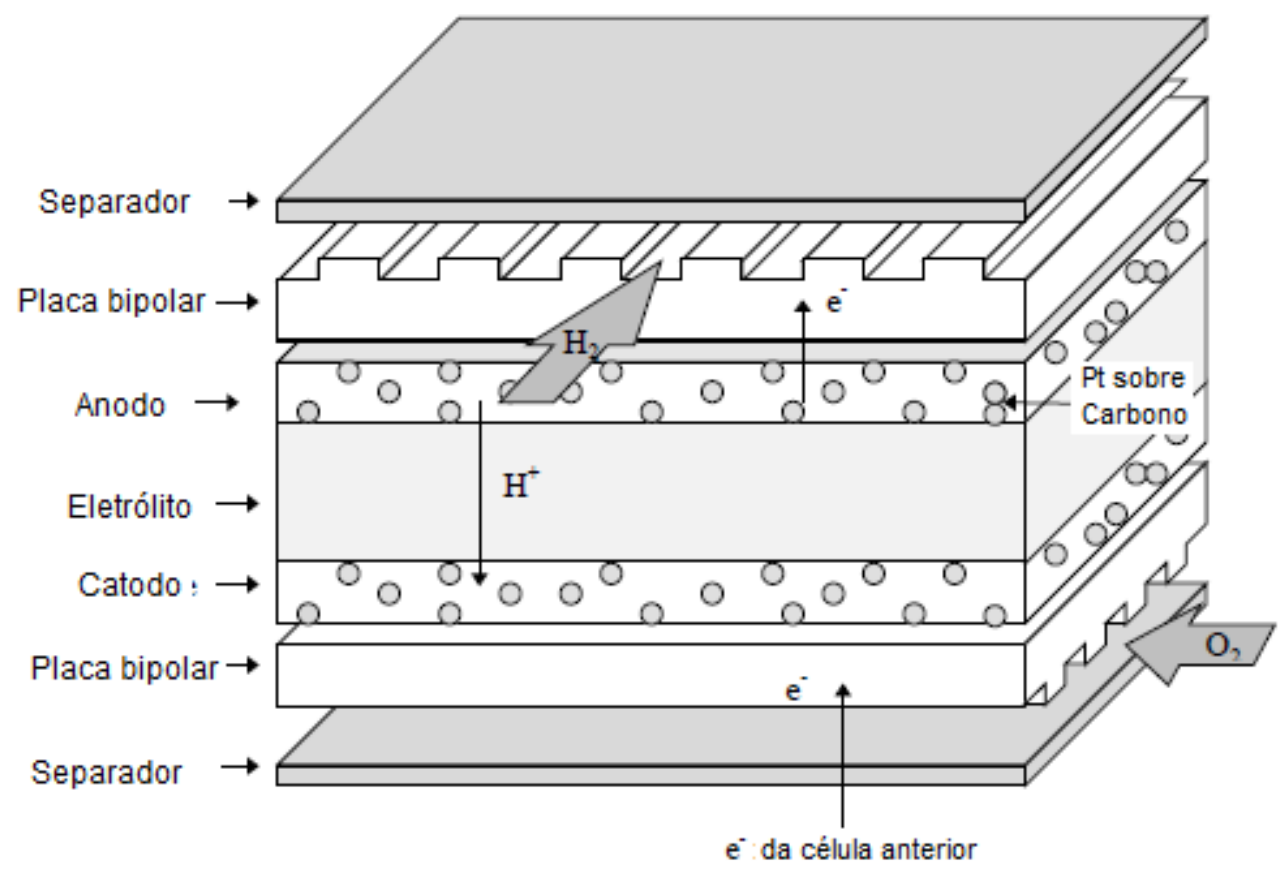

Figura 3-7 - Esquema do projeto de uma célula combustível PAFC (NADAL, 1997).

A eficiência de conversão do combustível para eletricidade na PAFC é tipicamente de 40 a $47 \%$ para o gás natural, em base LHV ("Low Heat Value”).

As Figuras 3-8 e 3-9 mostram pilhas PAFC já instaladas.

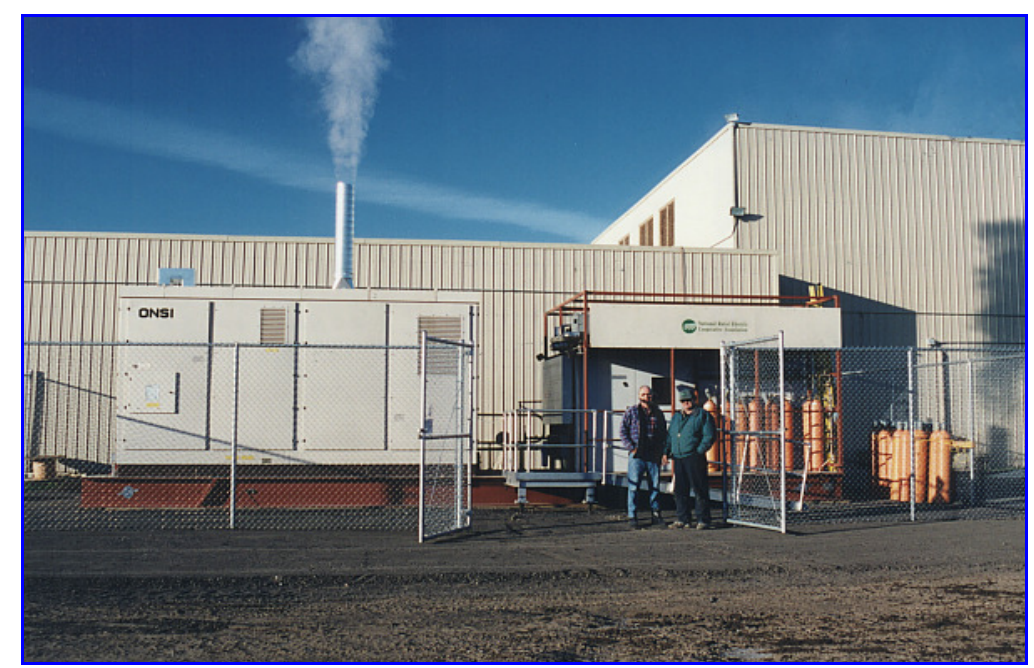

Figura 3-8 - Pilhas de ácido fosfórico instaladas no Alaska. O sistema gera $1 \mathrm{MW}$ 


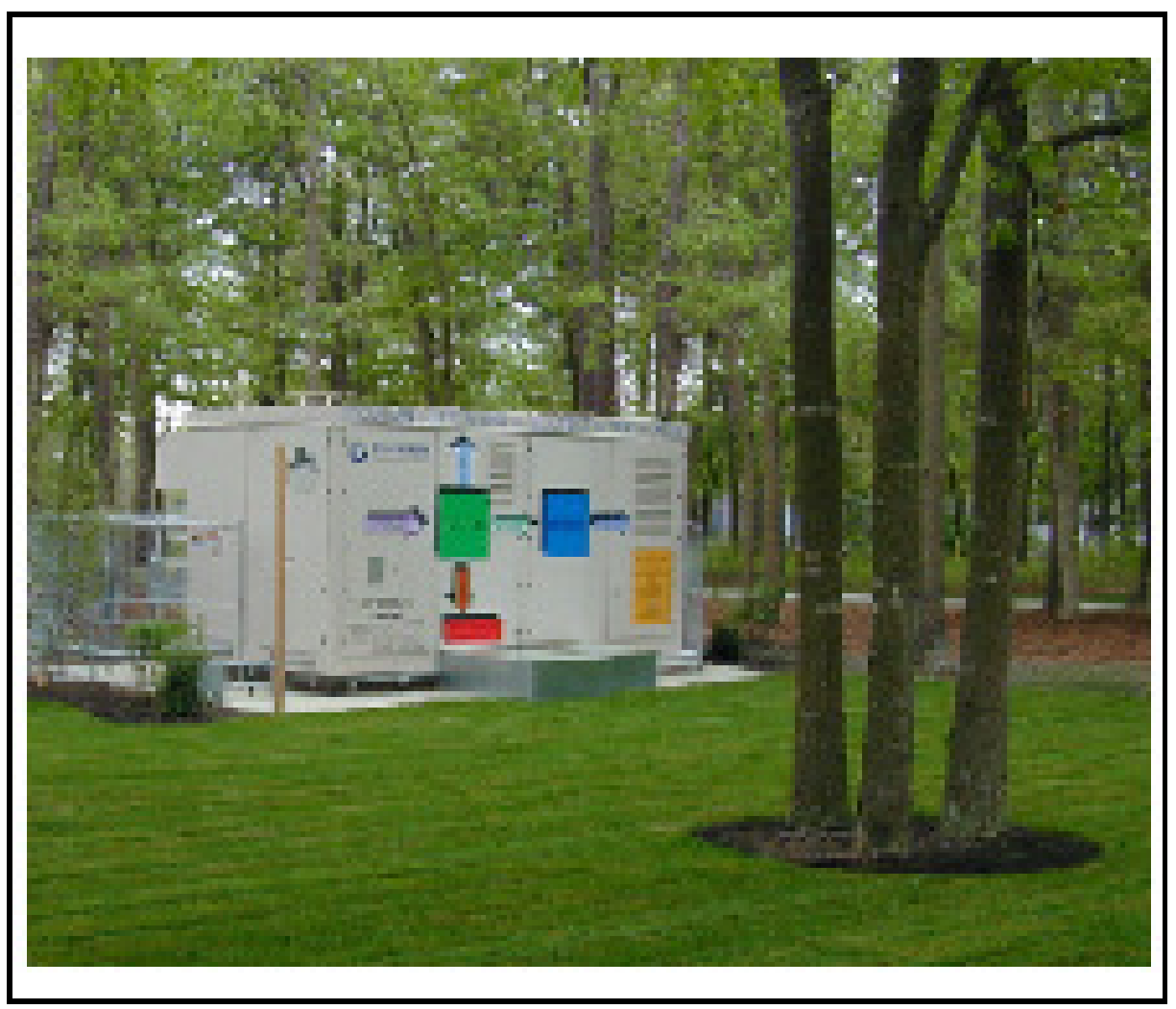

Figura 3-9 - Pilha de ácido fosfórico da UTC Power (200kW), Stockton College, N. Jersey

\subsection{4-Pilhas de Carbonato Fundido (MCFC)}

Numa pilha de Carbonato Fundido o eletrólito tipicamente consiste numa combinação de carbonatos ( $\mathrm{Na}$ e $\mathrm{K}$ ) que estão retidos numa matriz cerâmica de $\mathrm{LiAlO}_{2}$. A pilha opera a temperatura entre $600-700^{\circ} \mathrm{C}$, para manter os carbonatos básicos na forma de sais fundidos altamente condutivos. Desta forma os íons de carbonato fornecem condução iônica. O anodo é feito de Níquel ao passo que os catodos são produzidos de óxido de Níquel.

As reações eletroquímicas que ocorrem nas pilhas são:

$$
\begin{array}{lll}
\text { Ânodo: } & \mathrm{H}_{2}+\mathrm{CO}_{3}{ }^{2-} \rightarrow \mathrm{H}_{2} \mathrm{O}+\mathrm{CO}_{2}+2 \mathrm{e}- & \text { Equação 3-6 } \\
\text { Catodo: } & 1 / 2 \mathrm{O}_{2}+\mathrm{CO}_{2}+2 \mathrm{e}-\rightarrow \mathrm{CO}_{3}{ }^{2-} & \text { Equação 3-7 } \\
\text { Global: } & 1 / 2 \mathrm{O}_{2}+\mathrm{H}_{2}+\mathrm{CO}_{2} \rightarrow \mathrm{H}_{2} \mathrm{O}+\mathrm{CO}_{2} & \text { Equação 3-8 }
\end{array}
$$

Para que a reação se mantenha é necessário alimentar não somente Oxigênio no lado catodo, mas também $\mathrm{CO}_{2}$, o qual também se forma no lado anodo.

Uma vantagem da temperatura de operação alta, além de 
proporcionarem eficiências superiores a $55 \%$, é não ser necessário adicionar catalisadores de metal nobres para promover as reações. Os próprios materiais do eletrodo agem como catalisador. No anodo é o níquel poroso e no catodo o óxido de níquel. Outra vantagem da alta temperatura é a possibilidade de decomposição do metano em hidrogênio e monóxido de carbono via reação de reforma do vapor:

$$
\mathrm{CH}_{4}+\mathrm{H}_{2} \mathrm{O} \rightarrow 3 \mathrm{H}_{2}+\mathrm{CO} \text {, }
$$

Equação 3-9

e a reação de deslocamento:

$$
\mathrm{CO}+\mathrm{H}_{2} \mathrm{O} \rightarrow \mathrm{H}_{2}+\mathrm{CO}_{2}
$$

Na Fig. 3-10 tem-se um esquema da célula de carbonato fundido.

Também devido às altas temperaturas é dispensável a introdução de um equipamento externo para reforma do combustível, a qual pode ser realizada internamente, na própria câmara do anodo.

Como a reação de reforma é endotérmica então contribuirá para o resfriamento da pilha. A desvantagem é a necessidade de introdução de um catalisador específico para a reação. Em muitos casos a refrigeração provocada pela reação de reforma é insuficiente sendo necessária uma refrigeração adicional. Isto é conseguido passando uma corrente adicional da mistura ar/oxigênio no lado catodo.

Mas se a temperatura tem seus benefícios, também tem seus custos, que se apresentam na forma de corrosão e estabilidade do eletrodo. As partes metálicas usadas na construção estão sujeitas a corrosão severa induzida pelo carbonato e a dissolução do óxido de níquel no anodo, limitando o tempo de vida deste tipo de pilha.

Uma das principais características das células MCFC que as diferenciam das demais é o envolvimento do dióxido de carbono (CO2) nas reações eletroquímicas. Outra peculiaridade interessante das células MCFC é que o monóxido de carbono normalmente existente no gás de entrada do ânodo vai funcionar como um gás combustível da mesma forma que o hidrogênio, sofrendo um processo de oxidação e liberando $\mathrm{CO}_{2}$ e elétrons adicionais. 


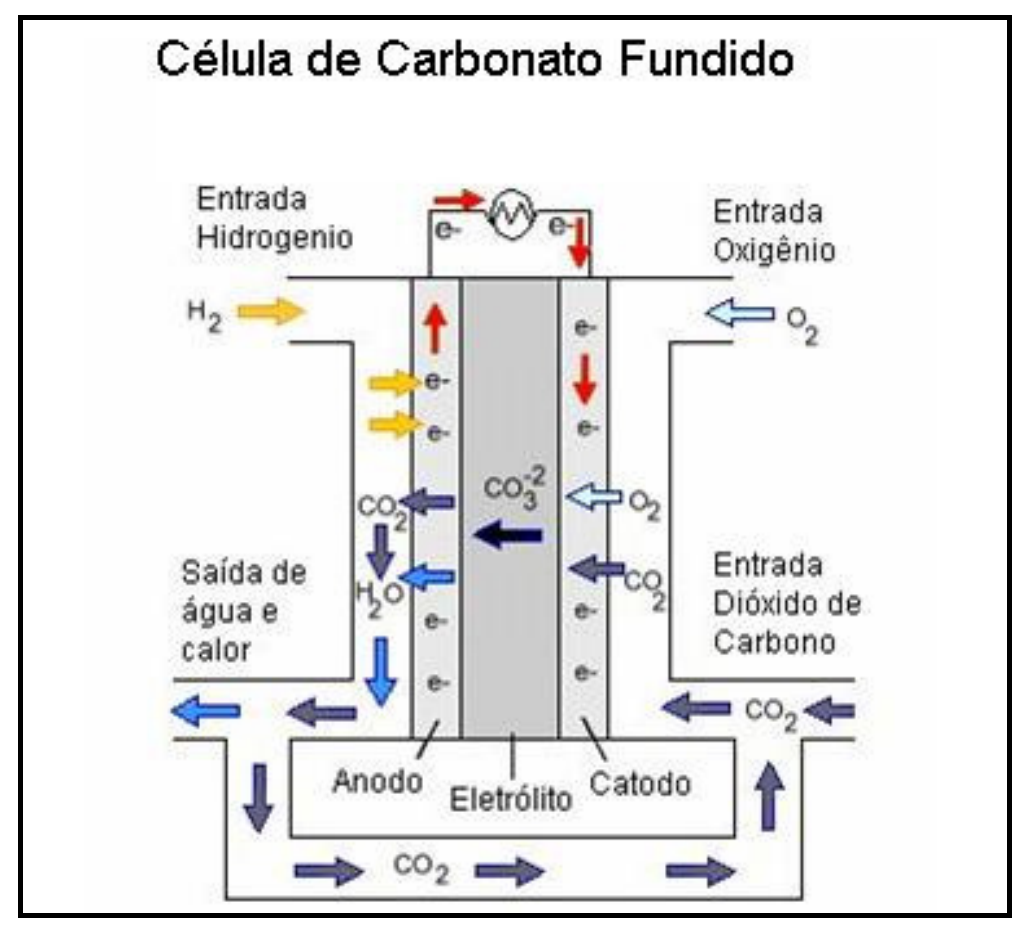

Figura 3-10 - Esquema da célula Carbonato fundido (EERE, 2005)

Na Figura 3-11 é mostrada uma pilha MCFC na Expo AICHI em 2005.

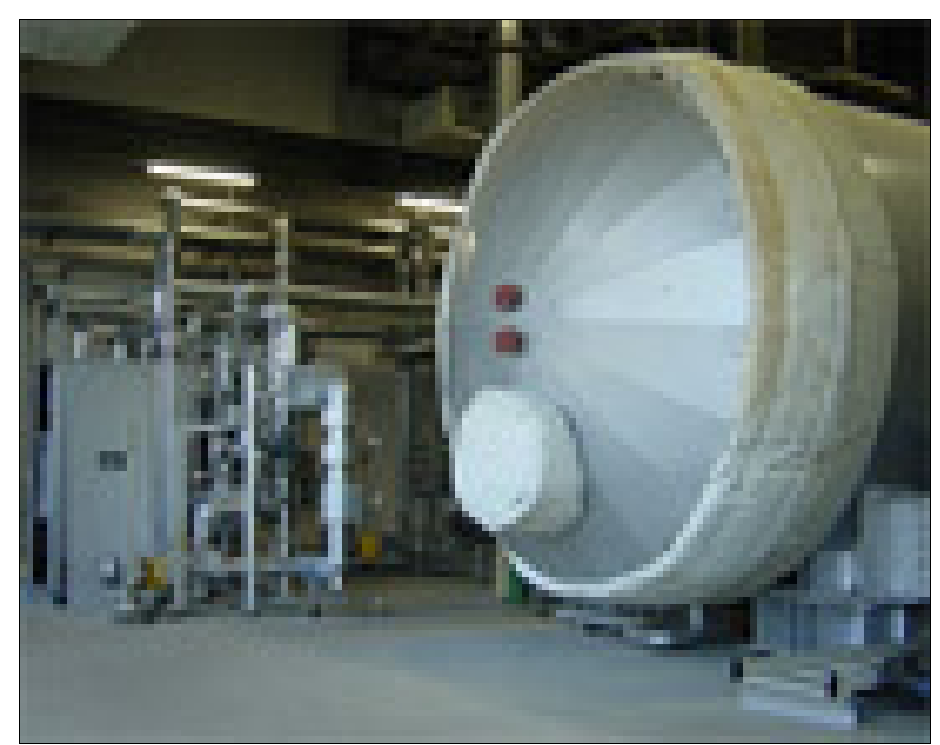

Figura 3-11 - Pilha MCFC - Expo AICHI 2005 
Na Figura 3-12 é mostrada uma pilha MCFC em corte.

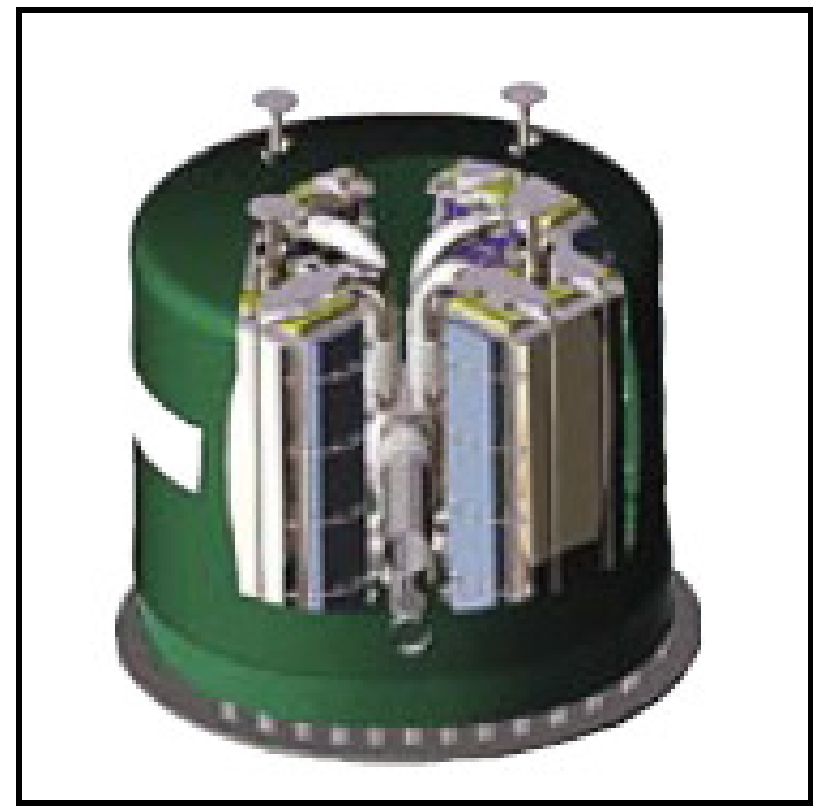

Figura 3-12 - Visão em corte de uma pilha MCFC

Na Figura 3-13 é mostrada uma usina com capacidade de 1MW, em King Court - Seattle - USA, que usa a pilha MCFC.

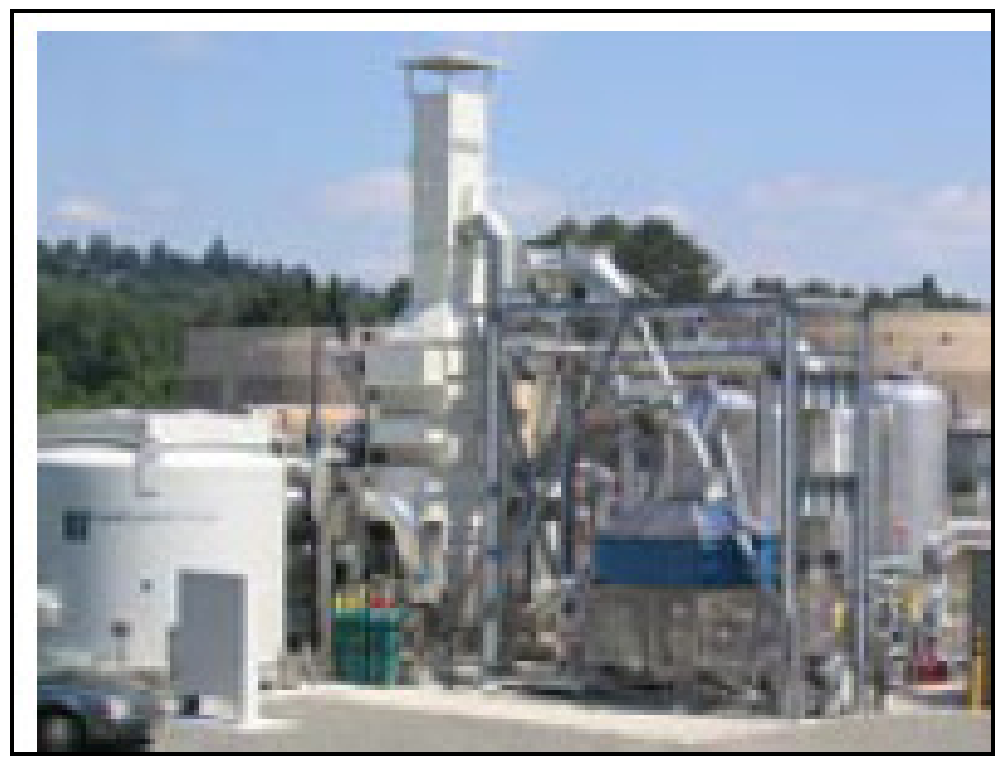

Figura 3-13 - Unidade de produção de energia utilizando MCFC de 1MW , South Treatment Plant .

\section{2- Combustíveis utilizados nas pilhas}

A cadeia de produção dos combustíveis utilizados nas pilhas foi muito pesquisada, tendo sido produzidos diversos estudos sobre o assunto abordando 0 
impacto ambiental destas cadeias em diversos países e aplicações (PEHNT, 2003c). No caso das pilhas a combustível são utilizados em especial três tipos de combustíveis: hidrogênio, metanol, gasolina e no caso do Brasil tem sido estudado o caso do etanol.

Quatro fatores são de grande relevância para a análise do impacto ambiental causado pelos combustíveis utilizados nas pilhas:

-A energia primária associada com as conseqüências no aquecimento global e no uso de fontes abióticas. Por exemplo, a conversão de óleo cru para gás natural causa diminuição na intensidade de $\mathrm{CO}_{2}$ pois a relação hidrogênio para Carbono é maior no gás natural. Naturalmente a utilização de energia primária renovável diminuiria mais ainda este impacto ao longo da cadeia de produção.

- As eficiências e impactos do processamento também são muito importantes. Atualmente os combustíveis baseados em petróleo possuem uma eficiência energética de produção de aproximadamente $90 \%$. O vapor ou a reforma combinada do gás natural para produção de hidrogênio e metanol, respectivamente, possuem, comparativamente, eficiências menores. Neste caso também é importante distinguir entre a produção de gasolina em refinarias médias e as plantas marginais (unidades novas construídas para atender o aumento da demanda de um produto específico e que exibem um desempenho significativamente maior).

-O terceiro fator importante na avaliação ambiental são as correntes anteriores e posteriores ao processo, por exemplo, os diferentes requisitos para transporte e distribuição dos combustíveis. A possibilidade de utilização de produtos de ligação, como o negro de fumo para fabricação de hidrogênio no processo Kvaern, pode reduzir os impactos ambientais caso exista mercado para os subprodutos.

Segue uma análise mais detalhada do impacto da produção e do uso do combustível $\mathrm{H}_{2}$.

\subsection{1-O hidrogênio}

O gás hidrogênio, como combustível para pilhas combustíveis, poderá ser produzido, no futuro, em estações centralizadas por meio de vários processos: eletrólise, a partir de combustíveis fósseis por meio da reforma de gás natural, a 
partir de biomassa pela gaseificação e pirólise, além de vários outros processos. Os processos de produção do gás hidrogênio podem ser efetuados a partir de várias fontes de energia.

$\mathrm{Na}$ Figura 3-14 está apresentado um esquema dos diferentes processos de produção de hidrogênio.

No caso de pilhas para uso em veículos, o hidrogênio poderá ser obtido através da reforma, efetuada no próprio carro, utilizando gás natural ou outros tipos de combustíveis ou recebendo diretamente o combustível hidrogênio, que será abastecido em postos, tal qual existem para os combustíveis atuais.

Uma das vantagens do hidrogênio é que existem diversos métodos de produzi-lo. Os combustíveis fósseis e outros combustíveis que contém Carbono podem ser descarbonados para produzir $\mathrm{H}_{2}$. A descarbonação dos combustíveis para produzir $\mathrm{H}_{2}$ puro reduz enormemente a poluição do ar no local de uso do $\mathrm{H}_{2}$, ao separar $\mathrm{O}_{\mathrm{CO}_{2}}$ (que pode ser possivelmente isolado da atmosfera) e também permite que a energia seja utilizada de modo mais eficiente, pois os processos químicos que ocorrem dentro da pilha a combustível são mais eficientes que a combustão.

Nas próximas subseções são apresentadas descrições sucintas dos vários processos de produção de hidrogênio tanto em uso comercial como os próximos do uso comercial.

\subsubsection{1 - Produção de hidrogênio a partir de combustíveis fósseis}

A maior parte dos processos de produção de hidrogênio utilizam, na atualidade, combustíveis fósseis em processos que, em sua maioria, baseiam-se no aquecimento de hidrocarbonetos, vapor e algumas vezes ar e oxigênio, que então se combinam no reator.

Nestes processos a molécula de água e a molécula de matéria prima são quebradas resultando em hidrogênio, monóxido de carbono e dióxido de carbono. Ou seja, o gás hidrogênio forma-se a partir do vapor e de um hidrocarboneto. Outro método consiste no aquecimento do hidrocarboneto sem a presença de ar, até que ele se quebre em hidrogênio e carbono.

A seguir são apresentados os principais métodos de produção de gás hidrogênio a partir de combustíveis fósseis. 


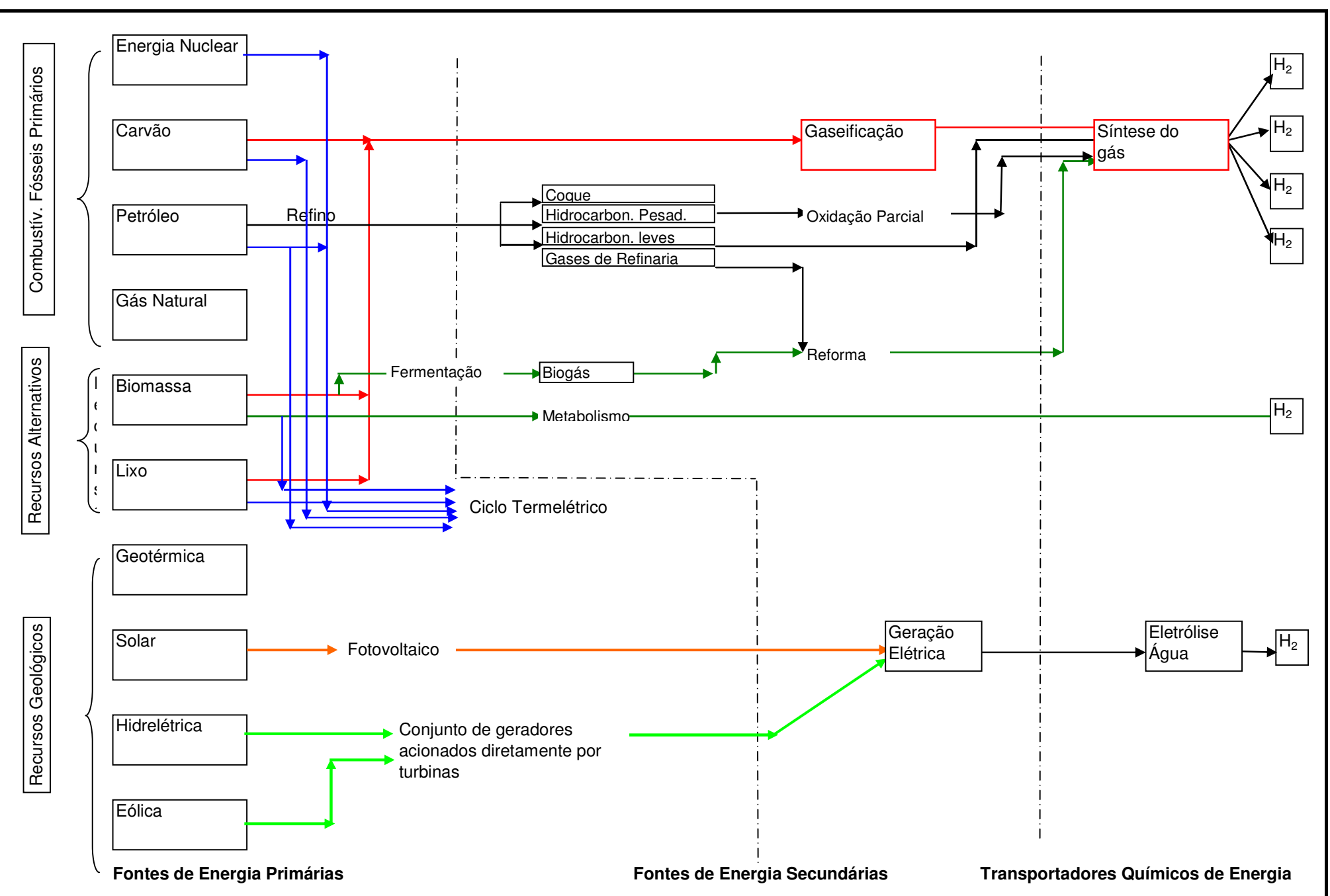

Figura 3-14 - Processos de Produção de hidrogênio a partir de diferentes fontes de energia. 


\subsubsection{1-A gaseificação do carvão.}

É o método mais antigo utilizado na produção do gás hidrogênio. Neste processo o carvão geralmente é aquecido a aproximadamente $900^{\circ} \mathrm{C}$, tornandose gás e então é misturado ao vapor. Esta mistura então é enviada para um reator onde existe um catalisador (geralmente Níquel).

O carvão é a matéria prima mais barata (aproximadamente 3 vezes mais barato que o gás natural e 10 vezes mais barato que a eletricidade nos EUA) e historicamente seu preço tem se mantido estável e mais baixo que o do gás natural. Uma das razões do baixo custo é que existem muitas reservas espalhadas pelo mundo todo.

O processo global de gaseificação do carvão segue a reação:

$\mathrm{CH}_{0,8}+0,6 \mathrm{H}_{2} \mathrm{O}+0,7 \mathrm{O}_{2} \rightarrow \mathrm{CO}_{2}+\mathrm{H}_{2} \quad$ Equação 3-11

A primeira etapa é a de gaseificação do carvão através da combinação com vapor e oxigênio, produzindo a mistura que é a matéria prima. Então as cinzas são removidas e o gás é dessulfurizado produzindo o gás de síntese ("syn gas'), contendo $\mathrm{CO}_{2}, \mathrm{H}_{2}$ e $\mathrm{CO}$. O CO é convertido a $\mathrm{CO}_{2}$ e $\mathrm{H}_{2}$ usando a reação de deslocamento ("shift").

Existem processos mais complexos para gaseificação do carvão, mas todos possuem em comum as etapas de gaseificação, tratamento com vapor a altas temperaturas e fornecem hidrogênio, $\mathrm{CO}$ e $\mathrm{CO}_{2}$. Também ocorre liberação de compostos de enxofre que não devem ser liberados para o meio ambiente sem tratamento.

Os danos ambientais e à saúde nas etapas de mineração e deposição final dos rejeitos para este processo são maiores que em todas as outras etapas. A eficiência na conversão para $\circ \mathrm{H}_{2}$ é de aproximadamente $50-75 \%$ com produção adicional de $5 \%$ de energia que é convertida em eletricidade a partir do processo (BRINKMAN, 2003).

Existem grandes unidades de gaseificação de carvão na Europa, USA e sul da África.

\subsubsection{2- Reforma a vapor do gás natural.}

Este é atualmente o processo mais comum de obtenção do gás hidrogênio.

Nos EUA a reforma a vapor do gás natural produz a maior parte do 
hidrogênio utilizado na indústria e é a forma mais comum de produção utilizada no mundo todo. A maior incerteza com relação a este processo reside no preço do gás natural, que tem historicamente variado bastante.

O gás natural é uma mistura de metano, $\mathrm{CO}_{2}$ e outros hidrocarbonetos mais pesados. A primeira etapa do processo envolve a combinação do metano com vapor para produzir uma mistura de gás que consiste notadamente de hidrogênio com aproximadamente $12 \%$ de $\mathrm{CO}$ e $10 \%$ de $\mathrm{CO}_{2}$ (KIRK-OTHMER 1996b). Este processo consiste no aquecimento do gás natural com vapor (700 a $\left.1000^{\circ} \mathrm{C} @ 3-25 \mathrm{bar}\right)$, na presença de catalisador, resultando em hidrogênio e óxidos de carbono. A reação química é a que segue:

$$
\mathrm{CH}_{4}+\mathrm{H}_{2} \mathrm{O} \rightarrow \mathrm{CO}+3 \mathrm{H}_{2}
$$

A próxima etapa é denominada de reação de deslocamento ("shift") e envolve a combinação do monóxido de carbono com água para produzir hidrogênio e dióxido de carbono.

$$
\mathrm{CO}+\mathrm{H}_{2} \mathrm{O} \rightarrow \mathrm{CO}_{2}+\mathrm{H}_{2}
$$

Verifica-se então a produção de quatro moles de hidrogênio para cada mol de metano e a reforma do gás natural produz $7.05 \mathrm{~kg} \mathrm{CO}_{2}$ por $\mathrm{kg}$ de hidrogênio.

$\mathrm{O} \mathrm{H}_{2}$ é separado do $\mathrm{CO}_{2}$ resultando em $\mathrm{H}_{2}$ com pureza superior a $99,9 \%$. E a purga do sistema pode ser responsável por mais que $90 \%$ do combustível requerido pelos queimadores do reformador.

A eficiência da conversão para hidrogênio utilizando este processo está entre 80 e 90\%. A eficiência é medida em função da energia contida no hidrogênio produzido dividida pela energia contida na matéria prima (BRINKMAN, 2003).

Existem reformadores de vapor para produção de hidrogênio em pequena escala: especialmente construídos para pilhas a combustível. Estes reformadores operam a temperatura e pressão mais baixas que os reformadores convencionais e são mais compactos.

\subsubsection{3-Autorreforma do gás natural e óleo}

A queima de hidrocarbonetos em presença de quantidades reduzidas 
de oxigênio é denominada oxidação parcial. A autorreforma é uma combinação da oxidação parcial com a reforma a vapor. $O$ termo reflete a troca de calor que ocorre entre o processo de reforma a vapor que é endotérmico e o processo de oxidação parcial que é exotérmico. Estes sistemas podem ser muito produtivos, de partida rápida e compactos visto que a energia das reações de oxidação parcial supre o calor necessário para a reação de reforma. As reações envolvidas são:

$2 \mathrm{CH}_{4}+\mathrm{H}_{2} \mathrm{O}+0,5 \mathrm{O}_{2} \rightarrow 2 \mathrm{CO}+5 \mathrm{H}_{2}$

Equação 3-14

$2 \mathrm{CH}_{4}+2 \mathrm{H}_{2} \mathrm{O}+\mathrm{O}_{2} \rightarrow 2 \mathrm{CO}_{2}+6 \mathrm{H}_{2}$ Equação 3-15

Os hidrocarbonetos reagem com uma mistura de oxigênio e vapor num termo-reator na presença de catalisador.

Para todos os processos mencionados anteriormente (gaseificação do carvão, reforma a vapor do gás natural e autorreforma do gás natural e óleo), são necessárias as reações de deslocamento e a separação do $\mathrm{CO}_{2}$, descritas a seguir:

Reação de deslocamento ("Shift")

Todos os processos acima mencionados exigem a reação de deslocamento para retirada do $\mathrm{CO}$.

A reação $\mathrm{CO}+\mathrm{H}_{2} \mathrm{O} \rightarrow \mathrm{CO}_{2}+\mathrm{H}_{2}$ Equação 3-16

Esta reação ocorre em duas etapas:

1a.- Adição de vapor a alta temperatura $\left(300-500^{\circ} \mathrm{C}\right)$

2a. - Etapa de baixa temperatura $\left(200^{\circ} \mathrm{C}\right)$

As duas etapas utilizam diferentes catalisadores.

Separação do $\mathrm{CO}_{2}$

Os processos acima mencionados também necessitam de uma etapa de separação do $\mathrm{CO}_{2}$.

O processo convencional mais utilizado é o processo baseado na absorção em amina.

Existem métodos baseados em membranas seletivas e adsorção que estão em desenvolvimento.

Deposição de $\mathrm{CO}_{2}$

Após a separação do $\mathrm{CO}_{2}$, pode-se evitar a sua liberação para 0 ambiente. Para isso o $\mathrm{CO}_{2}$ pode ser armazenado de modo permanente. 
Os possíveis locais para depósito seriam reservatórios de gás e óleo vazios ou reservatórios de água no subsolo (aqüíferos).

\subsubsection{1.-Dissociação Térmica}

O processo baseia-se no aquecimento de hidrocarbonetos sem oxigênio, a temperaturas muito altas que possibilitam a separação do hidrogênio e carbono.

$\mathrm{CH}_{4} \rightarrow \mathrm{C}+2 \mathrm{H}_{2}$

1 mol metano $\rightarrow 2$ moles hidrogênio

Equação 3-17

Este processo possui a vantagem de não emitir $\mathrm{CO}_{2}$, mas produz a deposição permanente de carbono.

\subsubsection{5-Processo Kvaerner}

A Kvaerner desenvolveu um processo denominado "Processo de produção de hidrogênio e negro de fumo Kaverner". A primeira planta comercial baseada neste processo iniciou sua produção em junho de 1999. A principal característica deste processo é que ele não emite gases responsáveis pelo efeito estufa visto que os métodos tradicionais de produção de negro de fumo são muito poluentes. O hidrogênio, neste caso, é um subproduto do processo e o produto principal costuma ser o negro de fumo.

O processo ocorre num reator à alta temperatura, onde a quantidade necessária de energia é fornecida, por meio de um queimador para formar um plasma, com a finalidade de quebrar os compostos de hidrogênio. O gás utilizado para o plasma é o hidrogênio reciclado do processo. O processo é uma decomposição térmica, não catalisada, de hidrocarbonetos.

$$
\mathrm{CH}_{4} \rightarrow \mathrm{C}+2 \mathrm{H}_{2}
$$

Equação 3-18

Um trocador de calor aquece o fluxo do processo e a potência teórica utilizada no processo Kvaerner CB\&H é $1,01 \mathrm{kWh} / \mathrm{m}^{3}$, mas na realidade utiliza-se uma quantidade duas vezes maior devido à alta temperatura da reação (KRUSE et al., 2002). A temperatura na qual ocorre a reação é aproximadamente $1600^{\circ} \mathrm{C}$ (LARSEN et al., 2004) e a energia excedente pode, até certo grau, ser aproveitada na forma de vapor. A matéria prima utilizada neste processo são os 
hidrocarbonetos, desde os gases leves até frações pesadas de óleo.

A vantagem deste processo é que não existe emissão de $\mathrm{CO}_{2}, \mathrm{E}$ a principal desvantagem reside em que o processo necessita de combustíveis fósseis ricos em hidrocarbonetos cuja extração polui tanto o ar como a água. $O$ processo também requer grandes quantidades de energia elétrica, que se for gerada por fontes sujas, implica numa fonte significativa de emissão de gases responsáveis pelo efeito estufa.

\subsubsection{6- Plasmatron}

No MIT ("Massachusetts Institute of Technology") foi desenvolvido um reformador que também utiliza plasma para reforma de hidrocarbonetos. A vantagem na utilização do plasma é que se pode utilizar o mesmo reator para diferentes hidrocarbonetos, incluindo as frações mais pesadas de óleo.

O reformador a plasma também pode operar no modo pirolítico (decomposição térmica do material orgânico sem ar ou oxigênio) como no caso do processo Kvaerner descrito anteriormente, transformando o Carbono em cinzas. Isto elimina a formação de $\mathrm{CO}_{2}$.

A tecnologia do plasma permite projetos mais compactos e leves que os reformadores tradicionais porque as reações ocorrem muito rápido. A temperatura de operação é aproximadamente $2000{ }^{\circ} \mathrm{C}$ e $\mathrm{o}$ teor de $\mathrm{H}_{2}$ está entre 80 a $90 \%$.

Atualmente o MIT estuda o reformador Plasmatron tanto para a pirólise como para o modo da oxidação parcial e da reforma a vapor.

$\mathrm{Na}$ Figura 3-15 é apresentado o conversor de combustível ultracompacto desenvolvido pelo MIT em conjunto com a empresa ArvinMeritor.

A maior desvantagem do reformador a plasma é sua dependência da energia elétrica. 


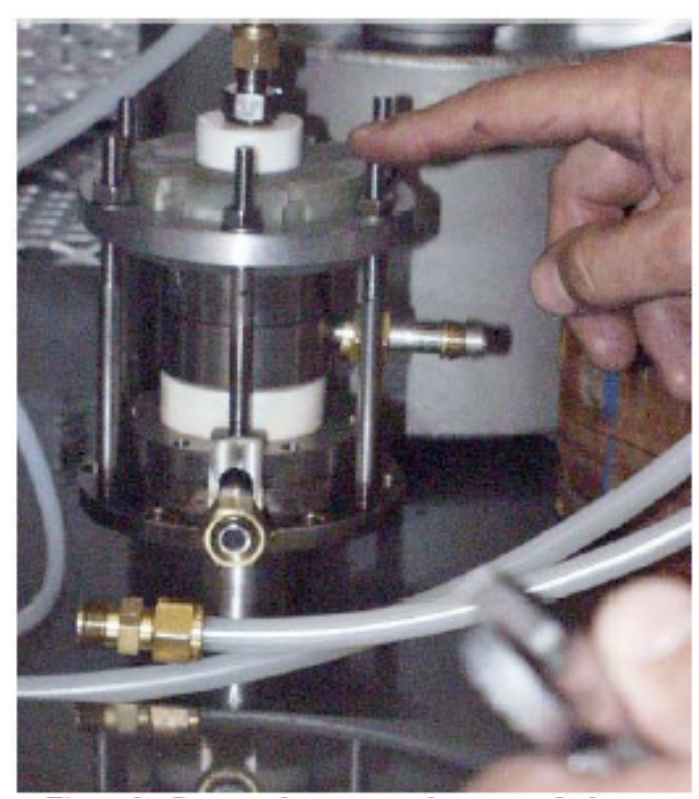

Figura 3-15 - Conversor de combustível Plasmatron, ultracompacto, desenvolvido pelo MIT.

\subsubsection{7- A energia nuclear}

Entre os vários processos, para uso futuro, para produção do $\mathrm{H}_{2}$ estão os que utilizam a energia nuclear para produção de hidrogênio em larga escala os quais usam a decomposição termoquímica da água assistida pela energia nuclear ("nuclear assisted thermochemical water splitting").

Existem três alternativas de produção de $\mathrm{H}_{2}$, utilizando a energia nuclear:

-Eletrólise da água - primeiro se produz a eletricidade e então esta energia é utilizada para se efetuar a eletrólise;

-Reforma do gás natural - no qual apenas o calor é fornecido através da energia nuclear, mas está baseada na mesma tecnologia utilizada na reforma do gás natural.

-Decomposição termoquímica da água assistida pela energia nuclear na qual a energia térmica fornece altas temperaturas para um processo químico que quebra a água em seus dois componentes: hidrogênio e oxigênio.

A principal diferença entre estes três métodos reside na temperatura de saída do refrigerante do reator nuclear quando sai do mesmo. É possível se efetuar a eletrólise com a tecnologia atual, com a temperatura de saída dos reatores modernos a água pressurizada (PWR). A desvantagem desta tecnologia é que a eficiência está limitada pela eficiência elétrica da usina nuclear, em torno 
de $33 \%$, para reatores PWR, e adicionalmente ocorre perda de eficiência no processo de eletrólise reduzindo a eficiência global para aproximadamente $24 \%$ (SCHULTZ, 2003).

A decomposição termoquímica da água é uma opção realista para a produção de $\mathrm{H}_{2}$ em larga escala, no futuro, e um dos processos mais atraentes é o denominado ciclo lodo-Enxofre (I-S). Este processo necessita que a temperatura de saída do refrigerante esteja acima de $850^{\circ} \mathrm{C}$ e, portanto isto implica na existência de uma nova tecnologia de reatores para suprir este calor. Existem diferentes propostas de tecnologias para que se alcance tais temperaturas.

A empresa General Atomics (SOLI, 2005) efetuou um estudo de viabilidade e concluiu que o reator de alta temperatura refrigerado a Hélio é o mais conveniente para esta tarefa devido à alta temperatura requerida $\left(950^{\circ} \mathrm{C}\right)$. Este reator utilizaria o Urânio como combustível com enriquecimento de aproximadamente $13 \% \quad U_{235}$, com alguns a $19,9 \% \quad U_{235}$ e alguns com Urânio natural $\left(\begin{array}{lll}0,71 \% & \mathrm{U}_{235}\end{array}\right)$. As reações envolvidas no processo de produção de hidrogênio estão apresentadas na Figura 3-16 que mostra o fornecimento de calor e água para o processo do ciclo S-I e a extração de hidrogênio e oxigênio.

Uma visão simplificada global do sistema de produção de hidrogênio, utilizando a energia nuclear, é apresentada por meio de um diagrama de blocos do ciclo nuclear na Figura 3-17.

Soli (2005) efetuou um estudo comparativo de avaliação ambiental entre o processo nuclear de produção do hidrogênio e a reforma a vapor do gás natural. Além disso, Utgikar e Thiesen (2006) efetuaram um estudo de impacto ambiental dos diferentes processos de produção do $\mathrm{H}_{2}$, inclusive usando a energia nuclear e os resultados estão apresentados na Figura 3-18. Eles mostram o menor impacto do uso do processo nuclear (eletrólise a alta temperatura), tanto em relação à emissão dos gases responsáveis pelo efeito estufa como em relação ao potencial de acidificação. 


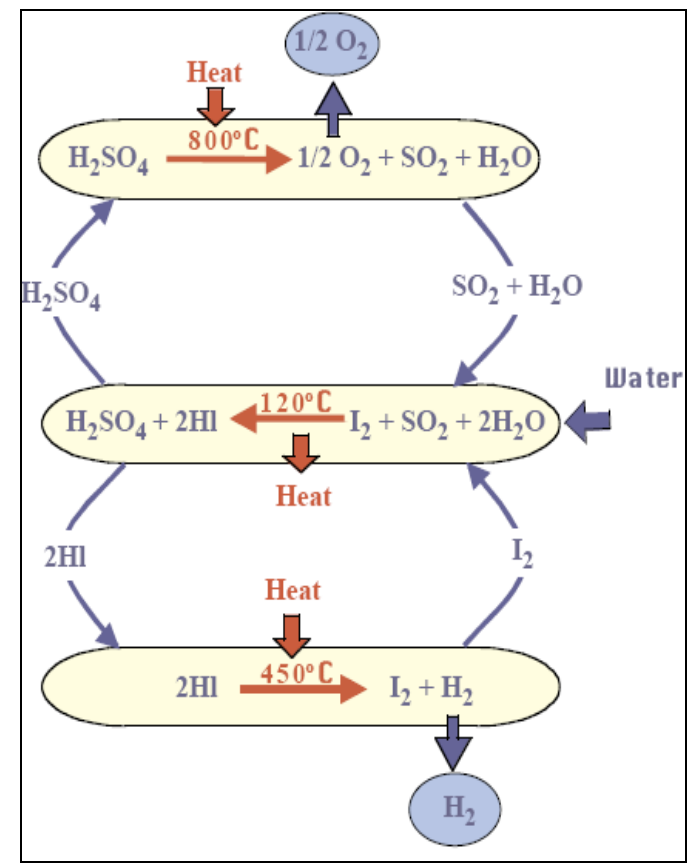

Figura 3-16 - Ciclo S-I (Enxofre - lodo) termoquímico de decomposição da água

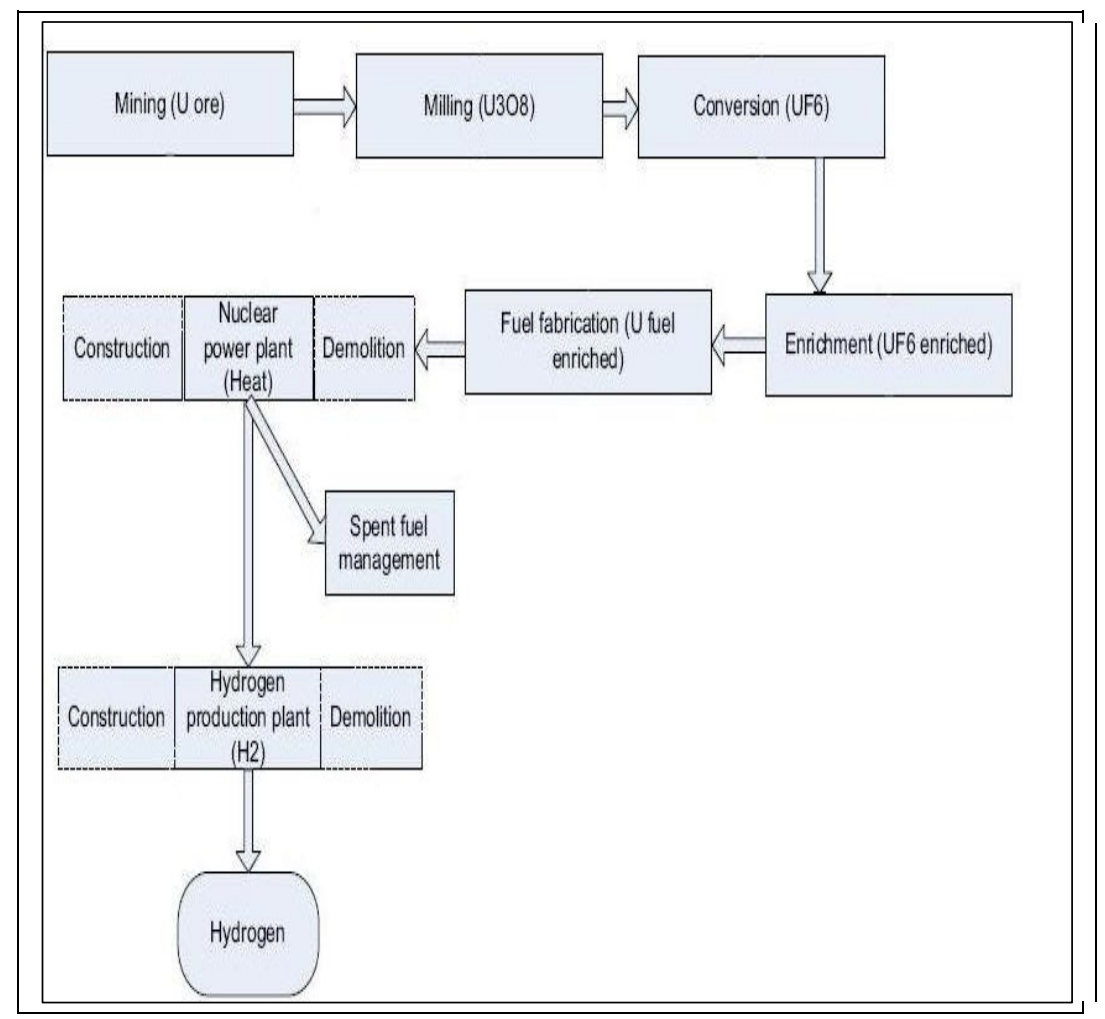

Figura 3-17 - Visão geral do sistema de produção nuclear do hidrogênio. 


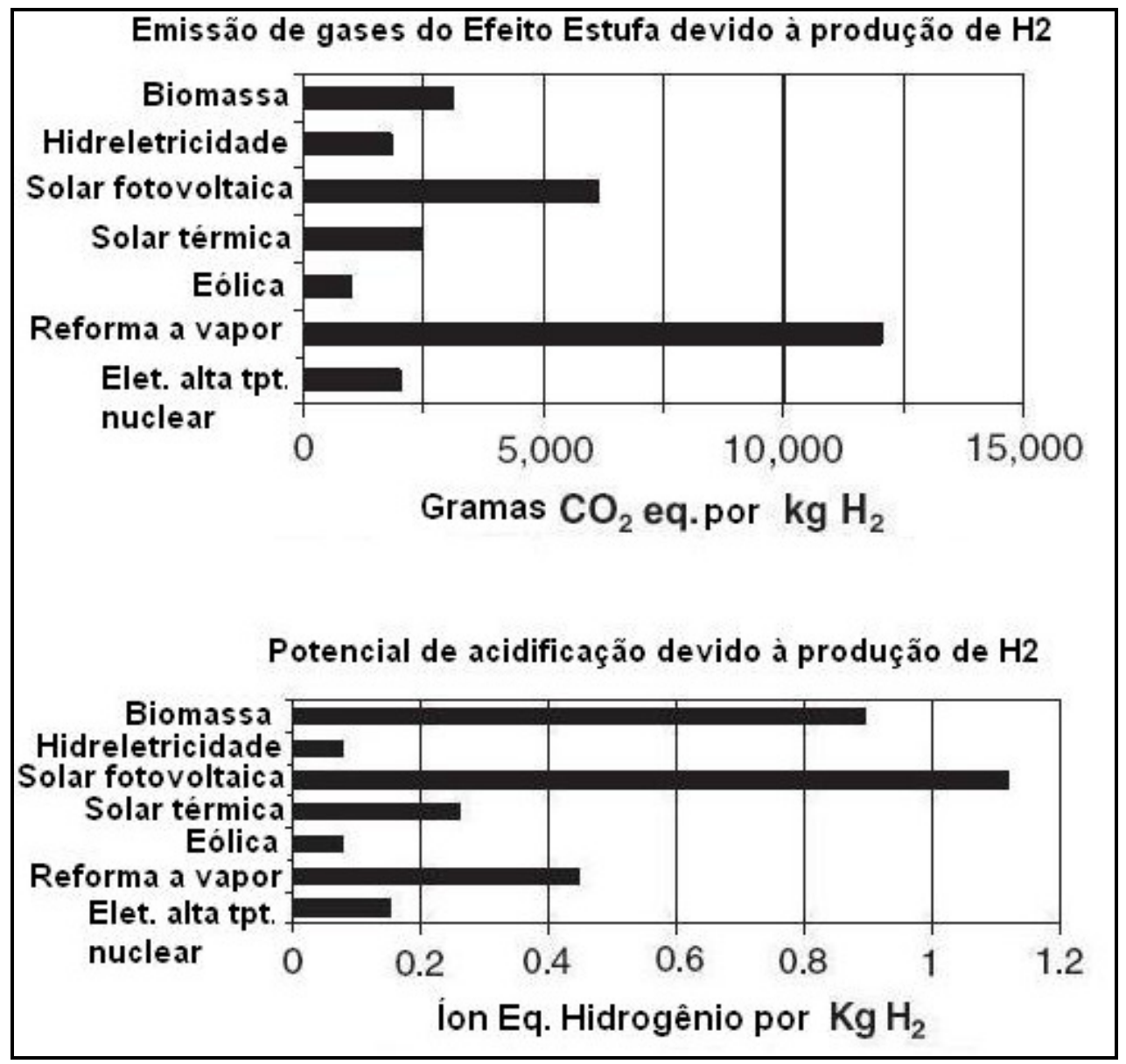

Figura 3-18 - Impacto ambiental dos diferentes processos de produção do $\mathrm{H}_{2}$.

\subsubsection{2- Produção de hidrogênio a partir de combustíveis renováveis}

É importante lembrar que o hidrogênio não é um gás poluente, mas que seu processo de produção é que pode ser. Assim se a matéria prima a partir da qual se produziu o hidrogênio for renovável esta poluição será muito menor, ou nenhuma, em muitos processos. A seguir estão listados os processos que produzem hidrogênio a partir de combustíveis renováveis.

\subsubsection{1- Eletrólise da água}

A quebra da água em hidrogênio e oxigênio é um processo que necessita de energia. Podem ser utilizados o calor, a eletricidade, a luz ou a energia química. Se for utilizada energia renovável para produzir o hidrogênio, então o resultado será um transportador de energia limpo.

$2 \mathrm{H}_{2} \mathrm{O}+$ energia $\rightarrow 2 \mathrm{H}_{2}+\mathrm{O}_{2}$

O eletrolisador é o dispositivo onde ocorre a eletrólise. 
É comum classificar o eletrolisador conforme o eletrólito utilizado.

Eletrolisador Alcalino: Utiliza um eletrólito alcalino, normalmente solução de hidróxido de potássio. Na Noruega possui eletrolisadores alcalinos alcançando a eficiência de aproximadamente $80 \%$ (HHV). A eficiência é muito importante em razão do custo da energia elétrica ser o maior custo na eletrólise.

Eletrolisador tipo PEM: São eletrolisadores que utilizam como eletrólito as membranas poliméricas. Todo desenvolvimento que tem sido efetuado nas pilhas tipo PEM são aplicáveis a este tipo de eletrolisador.

Alguns tipos de eletrolisador PEM já estão sendo vendidos, mas são uma tecnologia relativamente nova comparada à tecnologia dos eletrolisadores alcalinos. O valor teórico de eficiência para este tipo de eletrolisador está estimado em $94 \%$.

Eletrolisadores a vapor: É um tipo de eletrolisador que utiliza como eletrólito um tipo de cerâmica condutora de íons.

Note-se que se a eletricidade for de qualquer fonte renovável, então o processo eletrolítico é de 3 a 10 vezes mais caro que o custo nos processos que utilizam combustíveis fósseis.

A eficiência deste processo está na faixa entre $80-90 \%$. Se $\circ \mathrm{H}_{2}$ for produzido por meio da eletrólise da água, usando a eletricidade obtida a partir dos combustíveis fósseis, o processo não é competitivo com $\circ \mathrm{H}_{2}$ produzido diretamente a partir dos combustíveis fósseis (por meio da produção do gás de síntese) porque a eficiência na produção de energia elétrica é baixa.

A Eletrólise pode vir a ser um processo de produção viável para conversão de eletricidade de usinas geradoras fora do período de pico.

\subsubsection{2- Fotoeletrólise}

Ao invés de converter a luz solar em energia elétrica e depois produzir hidrogênio a partir da água, pode-se combinar as duas etapas.

A célula fotovoltaica combinada com um catalisador age como um eletrolisador e forma hidrogênio e oxigênio diretamente na superfície da célula. Este pode ser um sistema comercialmente viável para produzir hidrogênio.

A Fotoeletrólise é um processo em fase única no qual a luz do sol é absorvida por um semicondutor, resultando em par elétron-lacuna que quebra a água em $\mathrm{H}_{2}$ e $\mathrm{O}_{2}$. 
A vantagem deste sistema é a eliminação do custo do eletrolisador e aumento na eficiência do processo. Na Figura 3-19 é mostrado o esquema de uma célula solar operando em conjunto com pilha a combustível (GRIMES et al., 2007).

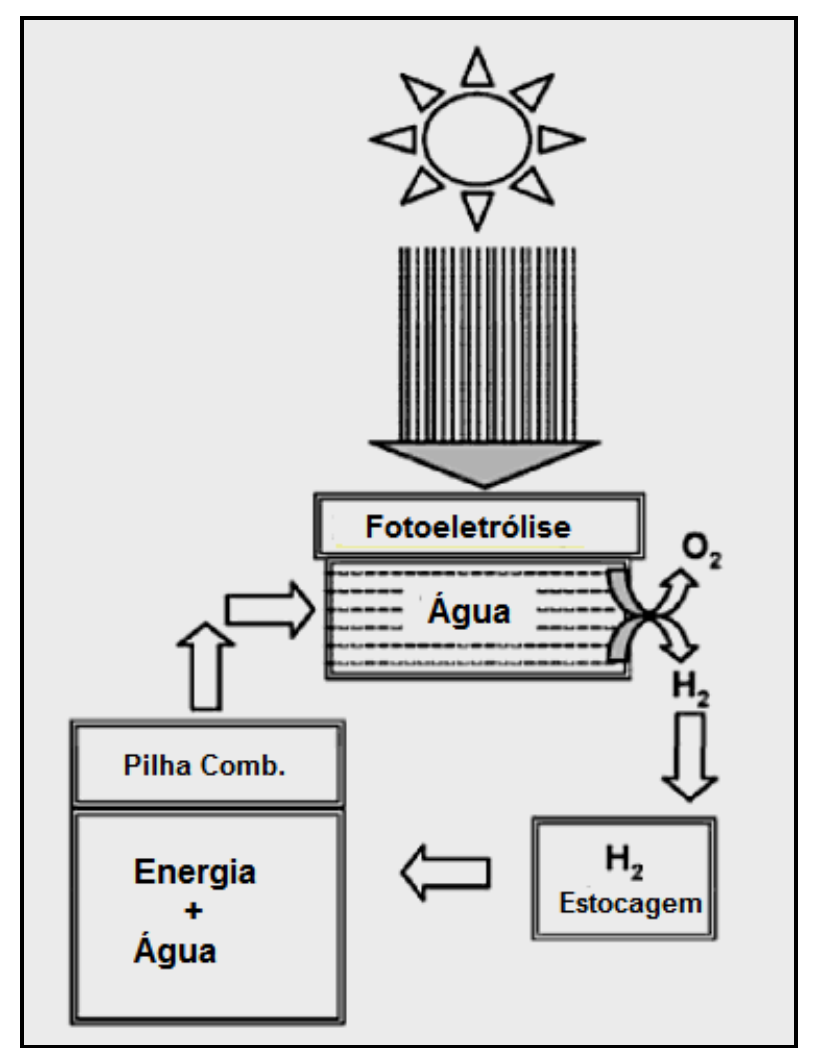

Figura 3-19 - Produção solar de $\mathrm{H}_{2}$ via fotoeletrólise.

Testes efetuados com células fotovoltaicas baseadas em silício mostraram uma eficiência de $7,8 \%$ em luz natural. Estão sendo efetuadas pesquisas para aumentar o fator de eficiência e a vida útil destas células.

\subsubsection{3- Decomposição térmica da água}

Aquecendo a água a $2000^{\circ} \mathrm{C}$ ocorre a quebra da molécula em hidrogênio e oxigênio. Este é considerado o processo mais interessante e barato para produzir hidrogênio diretamente a partir da energia solar.

Em uma planta térmica solar, com um coletor central tal qual o Solar Two (10MW), na Califórnia, a temperatura pode alcançar $3000^{\circ} \mathrm{C}$.

Muitas pesquisas têm procurado um catalisador para reduzir a temperatura para dissociação. Um dos problemas centrais é a separação dos gases a altas temperaturas para evitar a recombinação. A eficiência do processo ainda é incerta. 


\subsubsection{4- Gaseificação de biomassa.}

A gaseificação da biomassa é um processo similar à gaseificação do carvão. Assim o hidrogênio também pode ser produzido a partir da gaseificação térmica de biomassa, tais como esgotos, subprodutos florestais, lixo, etc.

A quantidade de hidrogênio presente na biomassa é de aproximadamente 6 a $6.5 \%$ em peso, ao passo que no gás natural é de aproximadamente $25 \%$.

Os processos envolvidos na fabricação de hidrogênio a partir da biomassa são equivalentes aos utilizados para produzir hidrogênio a partir de combustíveis fósseis.

O processo de gaseificação da biomassa inicia-se pelo aquecimento da biomassa a altas temperaturas, para produzir um gás, que consiste notadamente de hidrogênio, metano e $\mathrm{CO}$.

Introduz-se o vapor para reformar o $\mathrm{CH}_{4}$ para $\mathrm{H}_{2}$ e $\mathrm{CO}$. O $\mathrm{CO}$ é então modificado para $\mathrm{CO}_{2}$, que é o subproduto deste processo. Mas a biomassa é considerada neutra em relação à produção de gases que causam o efeito estufa, pois também absorve $\mathrm{CO}_{2}$ durante a sua vida.

A mistura de gases pode ser usada em pilhas combustíveis com a finalidade de produzir eletricidade. Comparado aos processos convencionais de produção de energia a partir de biomassa ou lixo, os sistemas integrados pilhas combustíveis + gaseificação são preferíveis por terem a possibilidade de maior eficiência.

Os reatores de gaseificação foram desenvolvidos para produzir metanol a partir de biomassa. Muitos destes reatores podem ser utilizados na produção de hidrogênio, especialmente aqueles que utilizam ar ao invés de oxigênio, que são economicamente mais viáveis.

A biomassa tem algumas vantagens sobre o carvão para a produção de $\mathrm{H}_{2}$, pois é mais reativa e contém menos enxofre, o que requer equipamentos caros para sua remoção.

Outro processo desenvolvido na NREL ("National Renewable Energy Laboratory"), Estados Unidos, transforma a biomassa, através da pirólise, em bioóleo. Este óleo pode ser convertido em hidrogênio e $\mathrm{CO}_{2}$, por meio da reforma. $\mathrm{O}$ bio-óleo, tal qual o combustível fóssil, é composto de diferentes elementos, que 
podem ser quebrados em vários produtos de valor, incluindo o hidrogênio (MAGRINI-BAIR et al., 2002).

Outra vantagem do bio-óleo é que ele reduz a necessidade de transporte de grandes quantidades de biomassa. Pequenos centros de pirólise produzindo o bio-óleo podem ser colocados próximos ao local onde exista a biomassa e então o combustível produzido pode ser transportado por caminhão tanque, por exemplo.

Este bio-óleo poderia ser estocado nos postos de distribuição e reformados produzindo hidrogênio conforme a necessidade. Além disso, onde não exista infra-estrutura de distribuição de gás natural, o hidrogênio produzido a partir do bio-óleo seria mais barato.

\subsubsection{5- Produção biológica de hidrogênio}

A fotossíntese é a base para toda a vida existente na terra. A primeira etapa na fotossíntese envolve a quebra da água em hidrogênio e oxigênio. $O$ hidrogênio é então misturado com o $\mathrm{CO}_{2}$ e formam-se os hidrocarbonetos.

A decomposição da água utilizando a energia solar não é obviamente uma nova idéia, pois foi a base para a criação da atmosfera terrestre, e portanto a base de toda a vida em nosso planeta. Este também é o processo bioquímico mais comum na terra. A luz solar não pode quebrar natural e diretamente a água, mas com a ajuda dos compostos especiais presentes no organismo, que produzem a fotossíntese, a energia solar pode ser utilizada. Como mencionado anteriormente $o$ hidrogênio produzido pela fotossíntese é geralmente, espontaneamente transformado em hidrocarboneto. Mas existem alguns microorganismos que são capazes de liberar o hidrogênio livre no ar. Isto foi descoberto em 1896, quando uma cultura de algas azuis esverdeadas Anabaena foi estocada em uma jarra selada e exposta a luz solar.

Teoricamente a alga pode produzir hidrogênio com eficiência $25 \%$. O problema é que durante este processo o oxigênio também é produzido. $O$ oxigênio inibe a enzima hidrogenase produtora de hidrogênio, de modo que apenas pequenas quantidades de hidrogênio são produzidas.

A equipe de pesquisa da Universidade de Berkeley na Califórnia e do "National Renewable Energy Laboratory" (NREL) mostrou que as algas Chlamydomonas reinhardtii quando mantidas sem sulfatos não mantém o 
complexo de proteína necessário para produzir oxigênio durante a fotossíntese. Para a alga então só restou o processo alternativo onde é liberado hidrogênio. Depois de quatro dias produzindo $\mathrm{H}_{2}$ foi permitido que as algas retornassem ao seu processo normal de fotossíntese. Este processo pode ser repetido muitas vezes com a mesma alga, na unidade de produção, mas é conveniente substituir as culturas de algas de tempos em tempos de modo a manter uma produção otimizada. Como as algas possuem um alto teor de proteína, então podem ser utilizadas, por exemplo, como alimento animal após seu uso no processo de produção de hidrogênio.

A equipe de pesquisa encontrou um valor de eficiência em torno de $10 \%$, que é muito maior que os valores anteriores. (KRUSE et al., 2002).

A principal meta agora é desenvolver o novo processo bem como equipamentos convenientes para a produção. Os testes de produção em escala maior que a de laboratório serão decisivos para desenvolvimento de unidades economicamente viáveis. Os custos de investimento devem cobrir $90 \%$ das despesas envolvidas neste tipo de produção.

A bactéria Rodobacter speriodes também apresentou sucesso na produção de hidrogênio a partir de rejeitos orgânicos provenientes de frutas e vegetais do comércio. A bactéria tem sido testada em esgoto com resultados promissores. $\mathrm{O}$ processo ainda encontra-se em estágio de laboratório e ainda faltam estudos para aumentar a eficiência e a viabilidade.

O Institut für Bioverfahrenstechnik in RWTH-Aachen, na Alemanha, desenvolveu dois bioreatores diferentes para produzir hidrogênio.

Finalmente a Figura 3-20 resume as várias possibilidades de rota de produção de $\mathrm{H}_{2}$ (MORENO 2007). 


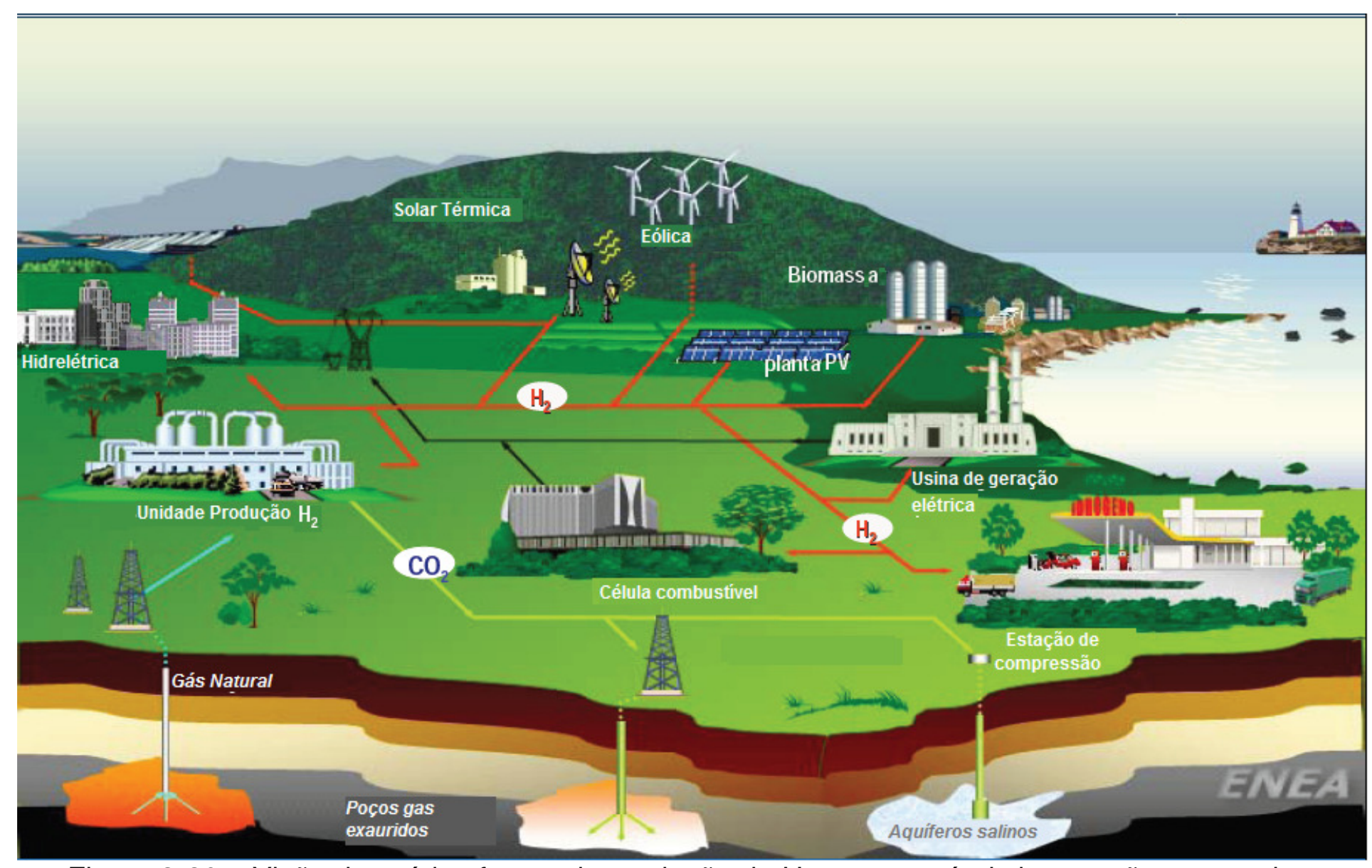

Figura 3-20 - Visão das várias fontes de produção de $\mathrm{H}_{2}$ e as possíveis integrações entre elas. 


\section{IMPACTO AMBIENTAL DAS PILHAS}

A tecnologia das células a combustível tem sido considerada como quase isenta de emissão de poluentes, especialmente durante a etapa de operação desta tecnologia. No entanto, a questão-chave é a forma como as pilhas são fabricadas e a emissão durante todo o seu ciclo de vida (ou seja, durante as etapas de produção das pilhas de combustível, durante sua operação, e durante a sua eliminação). Portanto há a necessidade de uma investigação para determinar o impacto ambiental da célula a combustível, com uma análise do "berço-aotúmulo" (que é também conhecido como uma Análise do Ciclo de Vida - ACV).

Neste capítulo é apresentada uma revisão dos estudos de impacto ambiental efetuados para os tipos de pilhas abrangidos neste trabalho que são: pilhas tipo PEM, Ácido Fosfórico e pilhas de Carbonato Fundido.

\section{1-Impacto ambiental das pilhas PEM}

Pehnt (2001), em estudo detalhado, analisou o impacto ambiental da PEMFC, durante a fase da manufatura, desde a prospecção das matérias primas até sua fase de disposição final/reciclagem após o término da vida útil.

Neste estudo Pehnt (2001) adotou as hipóteses listadas a seguir:

- O consumo de energia primária foi calculado baseando-se no teor de energia dos transportadores utilizados considerando as melhores tecnologias disponíveis, ou seja, com os maiores valores de capacidade calorífica do carvão, lignita, gás natural, óleo cru e a energia obtida pela fissão nuclear de urânio obtido por meio de minérios.

- O potencial de aquecimento global foi calculado para $\mathrm{CO}_{2}, \mathrm{CH}_{4}(21 \mathrm{~kg} \mathrm{CO}$. eq $/ \mathrm{kg} \mathrm{CH}_{4}$ ) e $\mathrm{N}_{2} \mathrm{O}\left(310 \mathrm{~kg} \mathrm{CO}\right.$ 2-eq $/ \mathrm{kg} \mathrm{N}_{2} \mathrm{O}$ ) usando o tempo de referência de 100 anos.

- O potencial de acidificação (AP) avalia o aumento da acidez através da emissão de ácidos e compostos que podem ser convertidos para ácidos. Os fatores usados foram obtidos de Heijungs et al. (citado por PEHNT (2001)). 
Os principais contribuintes são as substâncias de referência $\mathrm{SO}_{2}$ e $\mathrm{NO}_{x}$ (fator $0,7 \mathrm{~kg} \mathrm{SO}$ 2-eq $/ \mathrm{kg} \mathrm{NO}$ ).

A seguir é apresentada a influência dos diversos materiais, que compõem a pilha, no impacto ambiental.

\subsection{1-Catalisador}

A Platina é um metal precioso pertencente ao grupo dos metais Platina (PGM) sendo largamente utilizada no campo automotivo, joalheiro, químico e elétrico. Suas propriedades fazem com que seja utilizada como catalisador na indústria petrolífera, bem como em motores a gasolina, diesel e também em pilhas combustíveis.

Os metais do grupo PGM não são apenas importantes na pilha em si, mas também como componentes de outras etapas no ciclo da pilha, tais como queimadores catalíticos na reforma ou como parte de eventual membrana para limpeza dos gases de saída da reforma. Entretanto a Platina é usada nas pilhas a combustível (que utilizam hidrogênio como combustível) e nos catalisadores para motores a diesel na forma pura. As ligas de Platina com Rutênio são utilizadas nos reformadores de hidrocarbonetos. As cargas de Platina em pilhas a combustível têm caído dramaticamente nos últimos anos.

O maior consumidor de Platina no mundo é a indústria automotiva, que a utiliza como catalisador dos motores, e $41 \%$ da demanda mundial de Platina, no ano de 2001, foram para esta finalidade. Geralmente a Platina está associada a outros metais do grupo tais como Ródio ou Paládio, para formar os catalisadores.

O fornecimento de Platina é feito por apenas alguns países e as reservas são limitadas geograficamente e o preço é alto, sendo tratado como "commodities", e como tal, seus preços estão sujeito a flutuações de mercado.

A África do Sul e a Rússia dominam o fornecimento mundial de metais do grupo Platina, sendo a África do Sul responsável por $70 \%$ e a Rússia $22 \%$. As reservas têm aumentado de um fator de quatro nas últimas três décadas. Isto não foi em razão dos maiores preços ou novas descobertas, mas somente em razão dos avanços tecnológicos que permitiram a mineração a maiores profundidades. A partir de agora, para que se aumente a produção então será necessária a mineração a profundidades muito maiores, a qual será cada vez mais difícil e cara. Após vários estudos (RADE, 2001) concluiu como estimativa que as 
reservas de Platina são da ordem de 30-53 Gg.

Na Figura 4-1 é apresentado um esquema do processo de produção da Platina. O processo de produção do colóide de Platina está na Fig. 4-2.

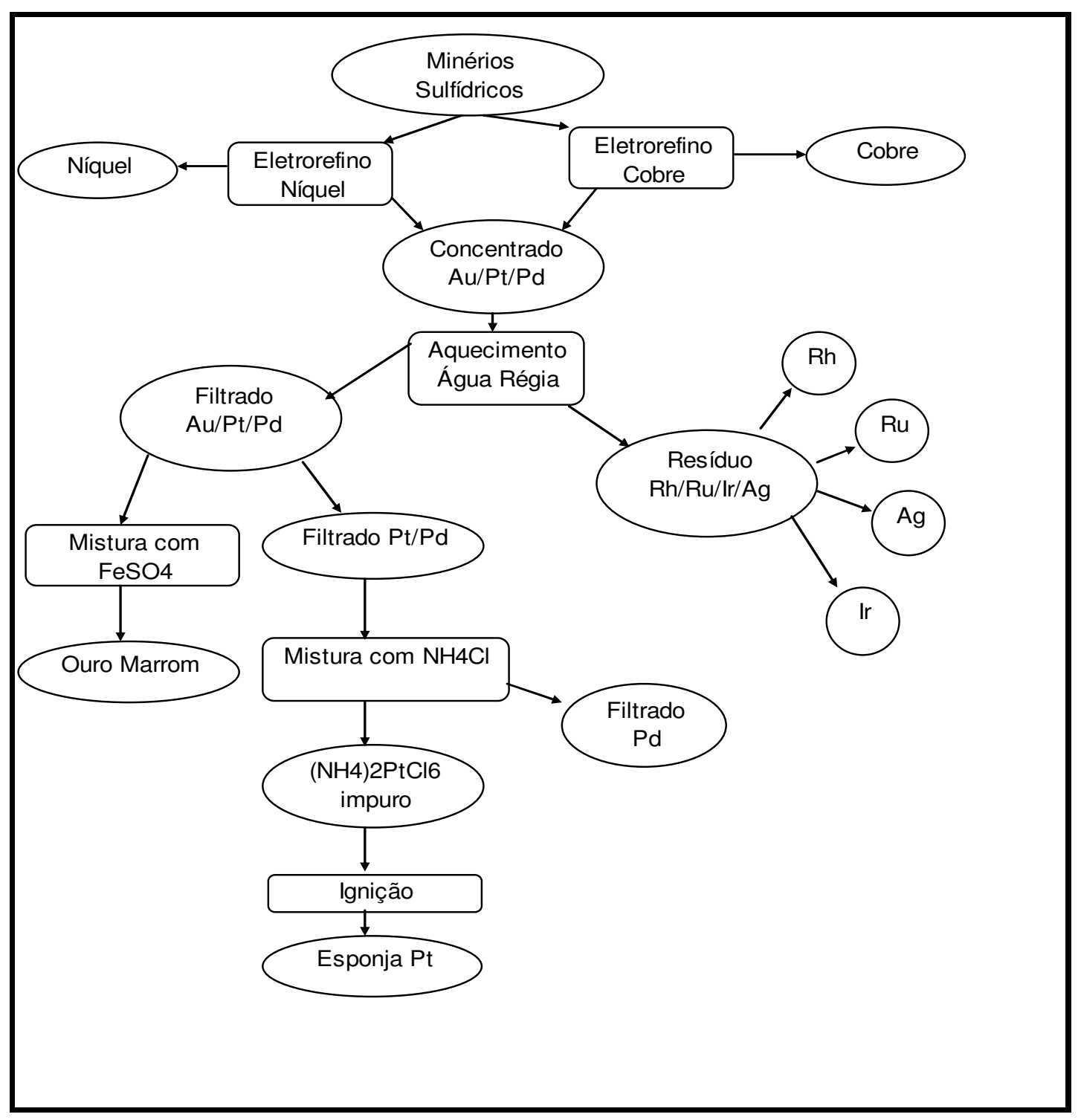

Figura 4-1 - Esquema do processo de produção da Platina.

De acordo com Friends of Earth (FoE, 1996), para cada onça $(28,3 \mathrm{~g})$ de Platina produzida são extraídos $12,7 \mathrm{t}$. de minério. A poluição da água e do ar são os problemas mais sérios associados com a mineração e o processamento da Platina. Os gases amônia, cloro e cloretos de hidrogênio são liberados como emissões do processo. O efluente mais significativo é deixado no final do processo, sendo composto de uma mistura de sais metálicos, tais como Ferro e Zinco, que são removidos como metais residuais e são precipitados. 
Posteriormente, este precipitado é estocado no solo.

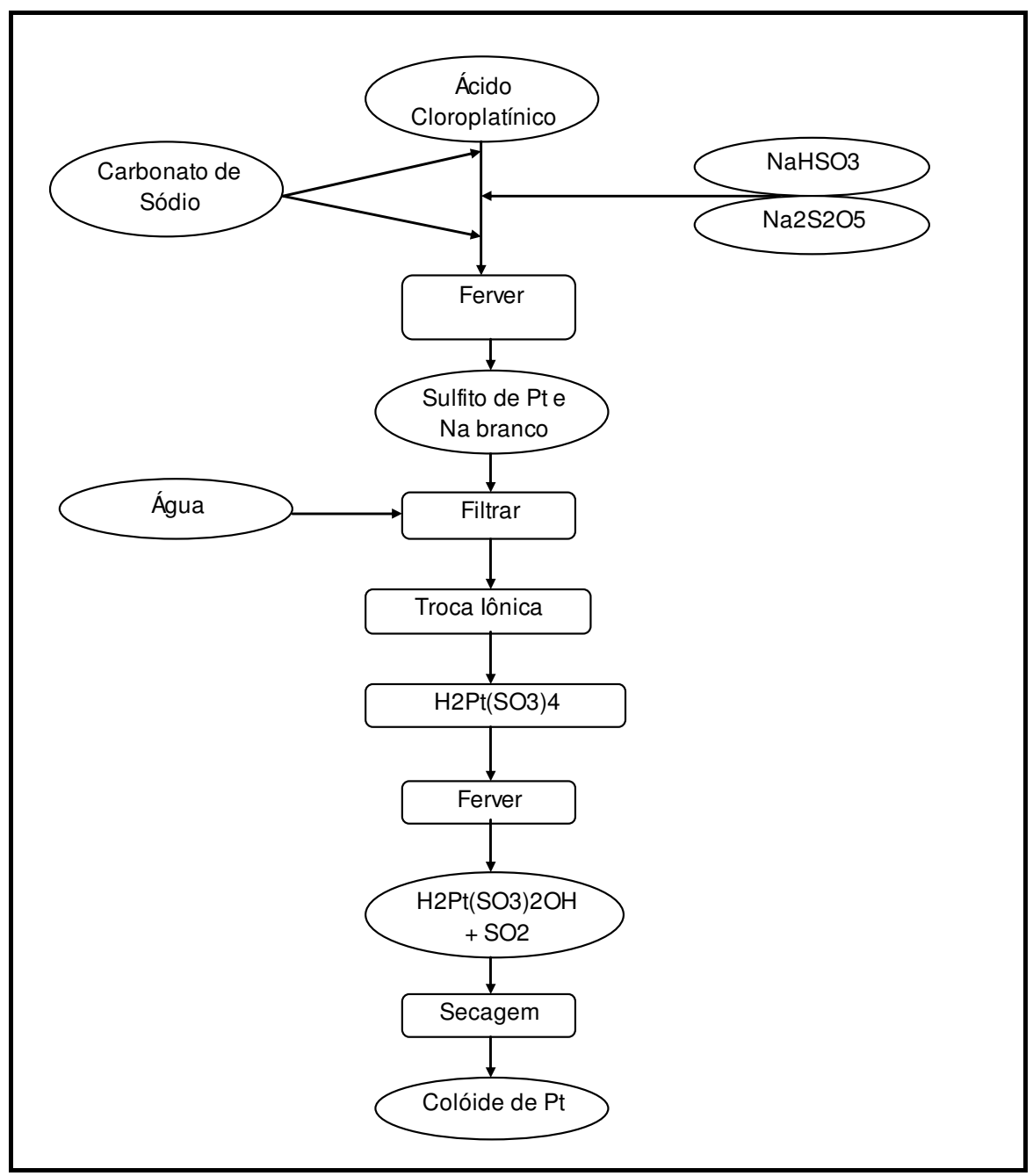

Figura 4-2 - Esquema de produção do colóide de Platina.

A presença deste material pode então contaminar a água do subsolo e causar problemas de erosão. Este processo ainda gera sulfatos que são convertidos para sulfato de sódio. Este material pode ainda ser vendido para fabricação de detergentes e vidros, ou simplesmente descartado.

O impacto ambiental da mineração e do processamento destes materiais depende do grau de concentração dos minérios e do processo utilizado. $\mathrm{Na}$ África do Sul, um país que tem maiores preocupações com o meio ambiente, os processos causam baixo impacto, pois existem processos remediadores do impacto causado ao meio ambiente. A Rússia tradicionalmente tem menores preocupações ambientais, mas a situação tem melhorado.

Um estudo alemão efetuado pelo Okoinstitute em1997, patrocinado 
pelo UK Department for Transport (2003) sobre a utilização de Platina em catalisadores de automóveis relata que a mineração e processamento de cada grama de Platina requeriam 23,76 kWh de eletricidade e 10,45 MJ de gás natural. Baseado nos fatores médios de emissão da África do Sul isto equivale a $6,4 \mathrm{~kg} \mathrm{C}$ por carro.

No caso da pilha a combustível conter $56,6 \mathrm{~g}$ de Platina isto equivalerá a uma emissão de $360 \mathrm{~kg} \mathrm{C}$ por carro. Se a carga de Platina na pilha a combustível atingir a meta de 5,66 g, a emissão de Carbono equivalente será de $36 \mathrm{~kg} \mathrm{C}$ por carro.

Atualmente as pilhas combustíveis não são recicladas em nível comercial, mas no futuro esta reciclagem está prevista (UK DEPARTMENT FOR TRANSPORT, 2003), prevendo-se até que seja um processo economicamente viável. Hoje a Platina já é normalmente recuperada, nos países mais desenvolvidos, a partir dos catalisadores dos automóveis e o processo para as pilhas será mais simples.

Como o reuso das pilhas não é possível, só resta a possibilidade de recuperar e reciclar a Platina. $O$ balanço material previsto para a reciclagem nas pilhas será melhor que $98 \%$, ou seja, somente $2 \%$ do metal seriam perdidos no processo.

A reciclagem da Platina a partir das pilhas combustíveis será efetuada em três etapas: incineração para separar a Platina, derretimento e posterior extração por solvente. Neste caso seria necessária a remoção da placa e da membrana da pilha a combustível a fim de evitar a emissão de fluoreto de hidrogênio devido à incineração.

Numa análise do ciclo de vida da pilha a combustível para automóveis, quando ocorre a reciclagem da Platina, então a demanda de energia primária é reduzida por um fator de 20 e o dióxido de enxofre emitido diminui de um fator de 100. Esta economia de energia fará com que a reciclagem da Platina seja, no futuro, mais econômica ainda.

Quanto a alternativas para substituição da Platina, as existentes são alternativas baseadas na mistura de Platina com os materiais do grupo PMG. $O$ principal competidor da Platina é o Paládio, cujo preço é praticamente o mesmo da Platina (UK DEPARTMENT FOR TRANSPORT, 2006).

A quantidade de catalisador utilizado na pilha a combustível diminuiu 
de aproximadamente 100 vezes desde a pilha utilizada na Gemini, na década de 1960, até a década de 80 . E da década de 80 até 90 , a quantidade diminuiu novamente de um fator de 100, diminuindo para 0,2 g/kW (RADE, 2001).

Rade (2001) estimou o consumo de 0,39g Pt/kW para pilhas utilizadas em carros. Assumindo que veículos pequenos ou híbridos podem utilizar pilhas de $50 \mathrm{~kW}$, resultariam em consumo de $19 \mathrm{~g}$ de Platina. Assumindo uma vida útil de 10 anos e posterior recuperação via reciclagem de $90 \%$ da Platina utilizada na pilha e supondo uma perda de $20 \%$ neste processo, a fim de avaliar o consumo deste metal para o próximo século. Considerando essas hipóteses e os valores de reservas avaliados, Rade (2001) estimou que pudessem ser construídos 1,5 a 2,6 bilhões de veículos (sem considerar outros usos da Platina nem a reciclagem). Mas devem-se considerar os outros consumos, visto que qualquer aumento no crescimento econômico pode causar aumento no consumo da Platina graças aos usos industriais e em joalherias.

O consumo estimado para a indústria e para a joalheria é da ordem de 1,5 Gg, para cada uma, durante o próximo século. Os deslocamentos técnicos e modificações de preferências podem alterar significativamente a estimativa de consumo, sobretudo para o setor de joalherias. Por exemplo, caso a China siga a mesma intensidade no crescimento de consumo de Platina, tal qual o Japão, então pode ocorrer um crescimento $70 \%$ maior no consumo pelo setor de joalheria.

Então este cenário mostra claramente a insuficiência das reservas para suprir o mercado, incluindo os veículos movidos à pilha a combustível. Não quer dizer que as reservas terminarão em agosto/2053 ou maio /2063, mas quer dizer que existe risco no suprimento de Platina para satisfazer a demanda dos veículos movida à pilha a combustível. Isto pode ocorrer entre 2030 e 2050. Tal situação pode induzir um choque de preços que impeçam uma expansão continuada e os riscos podem ser agravados por causa do suprimento de Platina ser dominado por dois países.

O tempo de vida das pilhas e a eficiência da reciclagem são cruciais para minimizar a quantidade de platina para o sistema da pilha a combustível.

Desde 1993 todos automóveis no Reino Unido estão sendo fornecidos com conversores catalíticos, contendo Platina, Paládio e Ródio para atender a uma determinação da Comissão européia que limita as emissões dos poluentes 
regulamentados: monóxido de carbono, hidrocarbonetos e óxidos de nitrogênio.

A avaliação do impacto ambiental dos PGM leva a um grande número de questões metodológicas: a atribuição de emissões, as emissões de cada país, a antecipação de intervenções e a falta de dados.

$\mathrm{Na}$ África do Sul a mineração de $1 \mathrm{~kg}$ de Platina também produz $0,5 \mathrm{~kg}$ de Paládio, 0,1 kg de Ródio, $300 \mathrm{~kg}$ de Níquel e $200 \mathrm{~kg}$ de Cobre, (PEHNT, 2001). A atribuição das emissões conforme a massa do produto não é comum, pois não reflete a motivação da companhia mineradora para operar a mina. A produção total das minas da África do Sul fornece somente $0,2 \%$ em peso da Platina que produz com mais de $50 \%$ de retorno, para as emissões. O critério da atribuição das emissões com o inverso da concentração seria desvantajoso para as minas nas quais a Platina é somente um subproduto. $O$ cálculo de emissões conforme $o$ preço de mercado é, neste caso, uma avaliação mais sensível. A desvantagem em se relacionar as emissões com preços flutuantes pode ser minimizada utilizando-se preços médios por um período de tempo adequado.

A análise de inventário também varia conforme o país de produção considerado porque o "mix" de energia, bem como a tecnologia considerada, por exemplo, a utilização de unidade de dessulfurização, e os equipamentos necessários são diferentes em países diferentes. Pehnt (2001) escolheu a África do Sul, porque existiam contratos entre os fabricantes de pilhas e os fornecedores de PGM. Por outro lado os fornecedores russos são, em grande parte, exportadores para empresas do ramo de joalheria japonesas.

Um exemplo de antecipação de intervenções futuras é o da indústria Flaconbridge Canadian, que reduziu as emissões de $\mathrm{SO}_{2}$ de 190.000t/a em 1968 para 29000 t/a em 1993.

O outro problema é a falta de dados ambientais devido à confidencialidade encontrada, por exemplo, nos dados relativos a emissões de $\mathrm{SO}_{2}$ e metais pesados nas correntes de rejeitos.

\subsection{2-Membrana}

O processo de síntese do Nafion é longo e complexo, envolvendo compostos precursores muito diferentes e existe a dificuldade na obtenção de quaisquer informações sobre a energia requerida para obtenção dos mesmos. É desejável que a Du Pont e outros permitam a disponibilização destas 
informações.

A produção da membrana condutora pode seguir vários processos. Como exemplo pode ser citado o processo de produção da Ballard, baseado no trifluorestireno e copolímero de trifluorestireno. O processo de produção inclui a produção de monômero, a polimerização, a extração sólido-líquido, secagem e reação com $\mathrm{SO}_{3}$ em solventes orgânicos. Para o futuro planeja-se o uso de processos com utilização de menos solventes. Os polímeros sulfonados são então isolados, lavados, secos e embebidos em estrutura porosa.

Na Figura 4-3 está apresentado o processo de produção do PTFE.

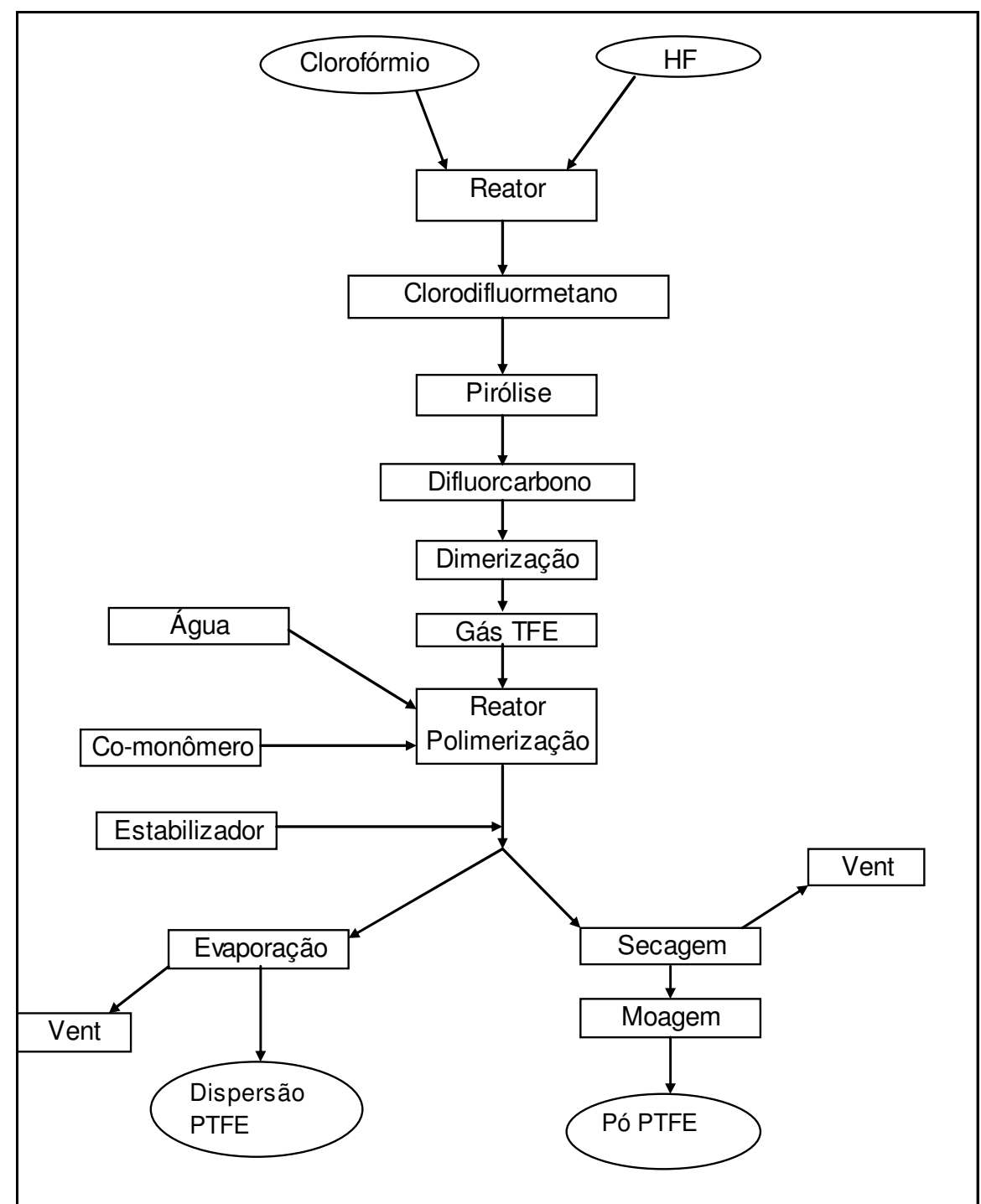

Figura 4-3 - Processo de produção do PTFE (NADAL, 1997).

E na Figura 4-4 é apresentado o processo de produção da membrana, a partir do PTFE. 


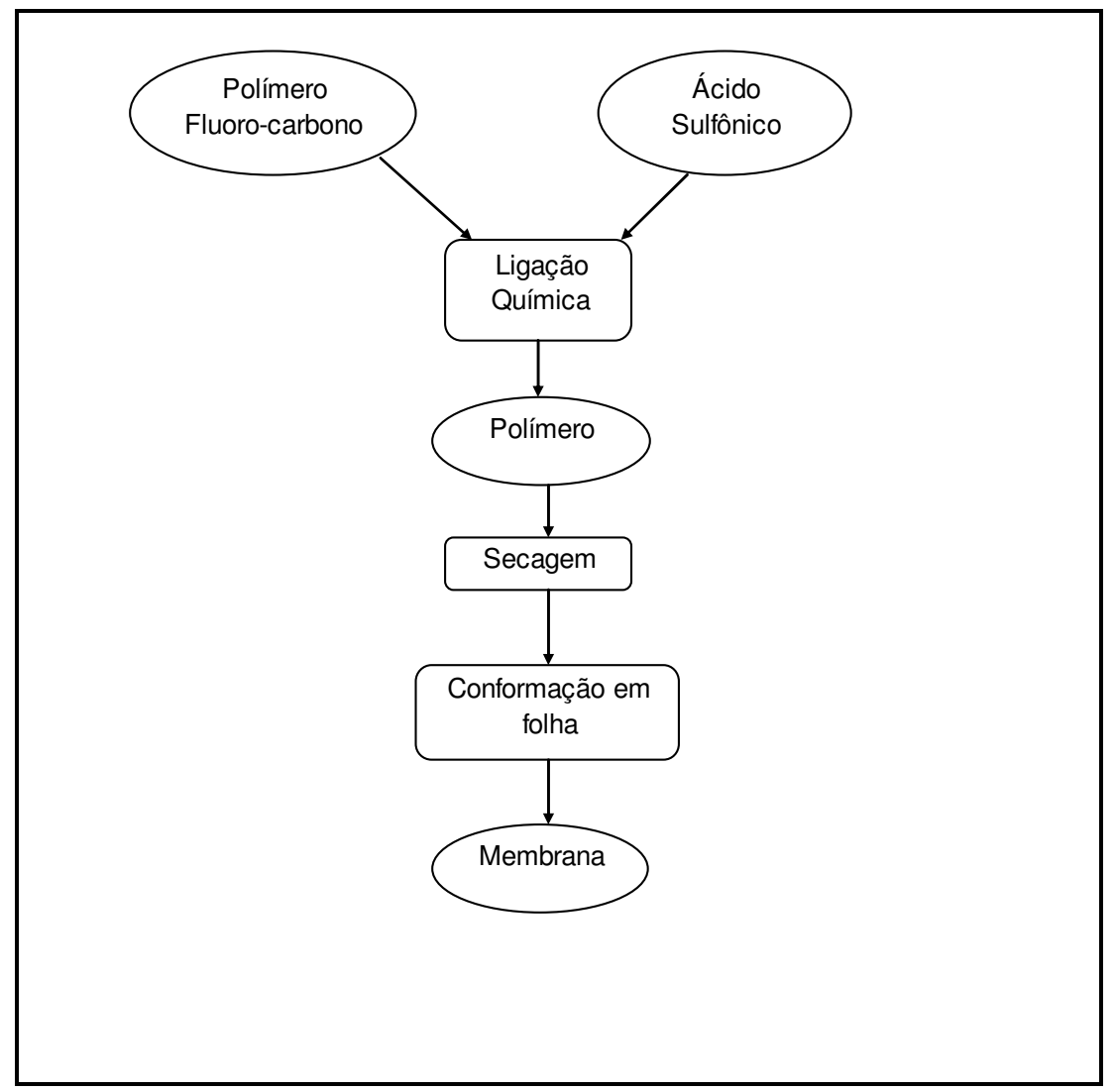

Figura 4-4 - Processo de produção da membrana (Nadal, 1997).

O material da membrana pode potencialmente ser recuperado em dois pontos do processo: como parte da pintura do catalisador e após o processo de corte.

As emissões de solvente resultante do processo de destilação são normalmente coletadas e enviadas para local previamente autorizado. Em grandes plantas o solvente pode ser recuperado e usado na dissolução das folhas de eletrólito, para fabricar a solução de eletrólito utilizada na pintura com catalisador.

Do ponto de vista ecológico a membrana não é um material muito importante, pois o consumo de energia é baixo e o processo de produção é um ciclo fechado com recuperação de solvente.

A membrana pode ser delaminada, a partir dos eletrodos, dissolvida em uma solução e reutilizada para membranas de dessalinização ou remoção de metais pesados. Entretanto ainda não está totalmente estabelecido se as membranas serão remanufaturadas com sucesso para novas aplicações.

Com referência a reciclagem, a rota via piro-metalurgia significa que as membranas seriam queimadas para liberar Pt. A incineração das membranas 
resulta em emissões de ácido fluorídrico (HF), que devem ser removidas cuidadosamente, mas provavelmente resultariam num alto impacto ambiental associado.

O processo de pintura com catalisador é digno de atenção pois nesta etapa ainda pode-se reduzir em $90 \%$ a utilização dos materiais, principalmente através da redução de rejeitos nesta etapa. Por exemplo, a tinta residual presente nos tanques de mistura, peneiras, entre outros locais, podem ser lavados e os materiais do grupo da Platina podem ser recuperados na planta.

\subsection{3-Grafite}

A grafite é um material utilizado nas placas de fluxo, sendo de particular importância para a produção da pilha a combustível.

A grafite é basicamente derivada de materiais que contêm carbono, e que sofrem processos a alta temperatura, aumentando a ordem da estrutura cristalográfica e fornecendo melhores propriedades elétricas e térmicas, além de melhor resistência à corrosão que o próprio Carbono. Ela pode ser produzida por meio de dois caminhos: a grafite natural e a fabricada conforme Figura 4-5.

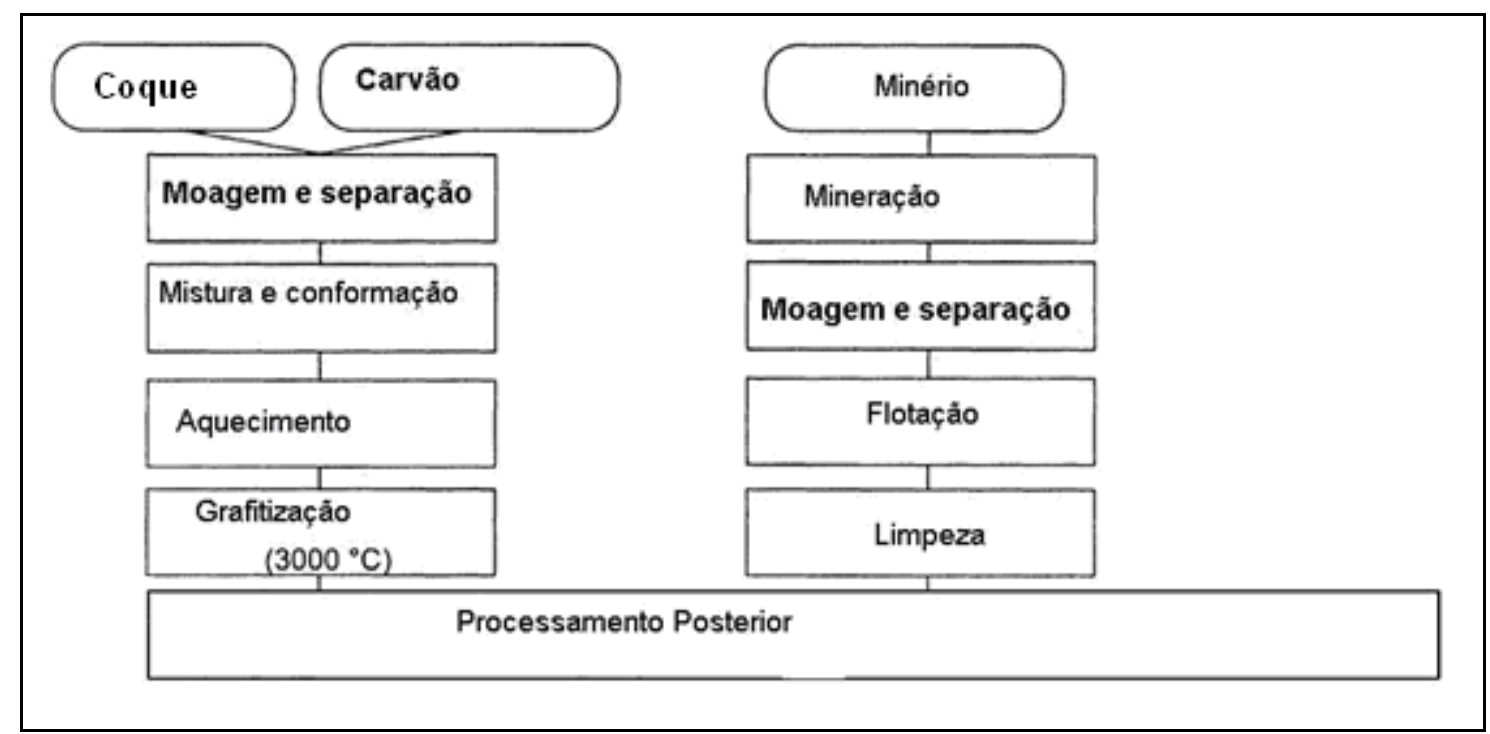

Figura 4-5 - Processos de produção da grafite.

A grafite natural existe em várias regiões do mundo. A China é o maior produtor mundial. As emissões, na etapa de mineração e produção, variam conforme o país produtor de Grafite. Isto porque o consumo de energia, os meios e distâncias de transporte variam conforme o país produtor, o "mix" elétrico do 
respectivo país e a pureza do minério.

A grafite sintética pode ser produzida com base, tipicamente a partir de materiais carbonosos, tais como coque, carvão e negro de fumo, os quais são aquecidos juntamente com materiais ligantes, como alcatrão de carvão, ou breu de petróleo, a temperaturas entre 2400 e $3000^{\circ} \mathrm{C}$.

Na Figura 4-6 está apresentado o processo de fabricação das placas de grafite.

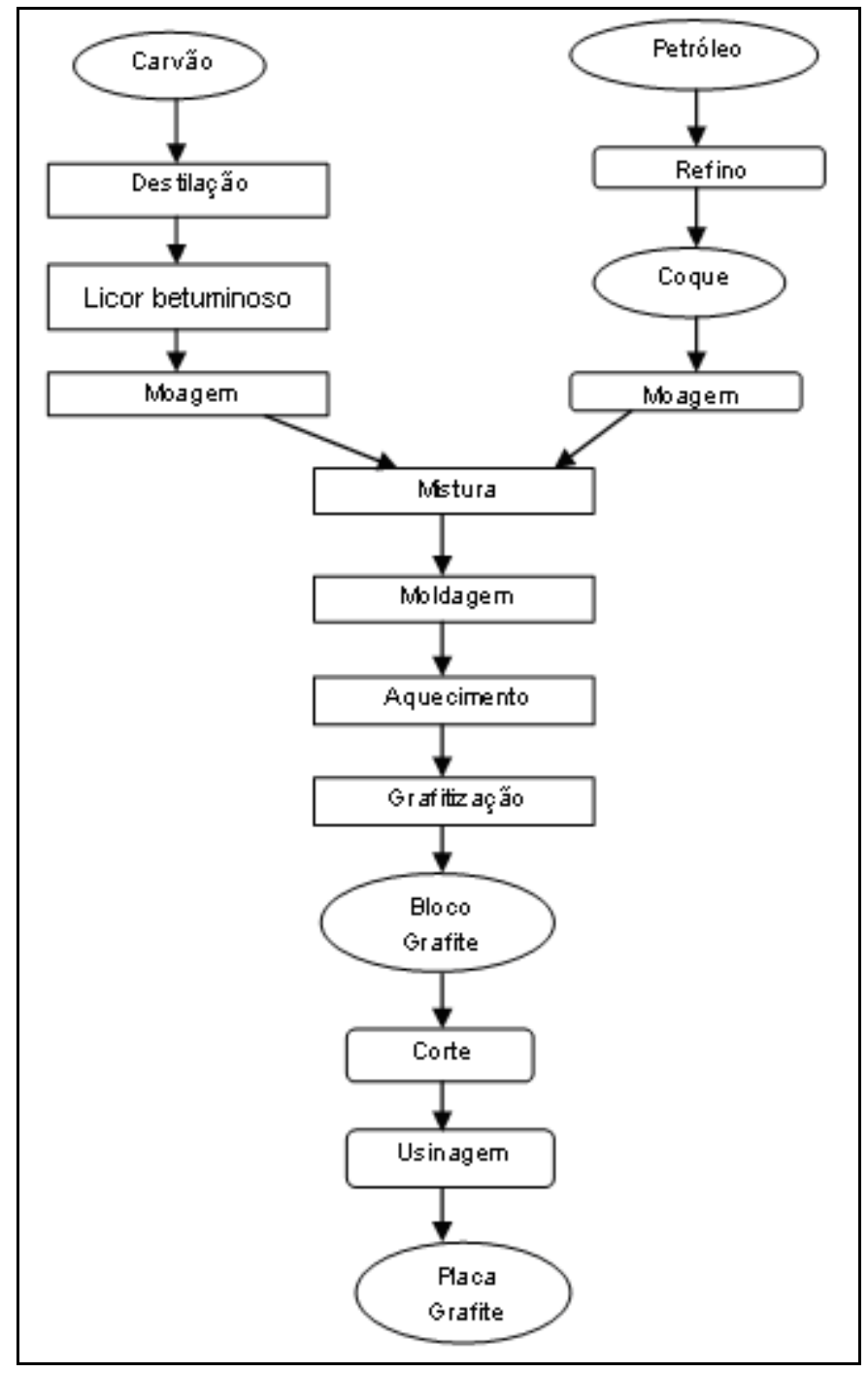

Figura 4-6 - Processo de fabricação das placas de grafite (NADAL, 1997).

Ambos os tipos de grafite, natural e artificial, consomem grande quantidade de energia. Aproximadamente $160 \mathrm{MJ}$ de fontes de energia não renovável por kilograma de grafite são consumidos na fabricação.

O consumo de energia para a grafite fabricada é dominado pelo consumo de eletricidade na etapa de grafitização que ocorre em fornos. No caso 
da grafite natural, a eletricidade para mineração e moagem são os principais fatores.

\subsubsection{Outros materiais na etapa de fabricação}

Podem-se utilizar as fibras de Carbono em substituição à grafite. As fibras de carbono são produzidas por meio de tratamento a alta temperatura, utilizando normalmente como matéria prima a poli-acrilonitrila, mas também é possível usar breu. As fibras de grafite são misturadas com a resina fenólica e o compósito então produzido é aquecido e moldado para produzir as placas bipolares para as pilhas PEM. E neste caso a usinagem não é necessária, pois os canais de passagem do gás já estão incluídos no molde de fabricação das placas. Este processo é simples e mais barato que a usinagem das placas a partir de um bloco sólido, mas possui vários entraves tecnológicos.

O negro de fumo, utilizado nas pilhas PEM como suporte preferido para o catalisador Platina, é outro material carbonoso utilizado nas pilhas a combustível. Existem alguns tipos de negro de fumo obtidos por processos que se diferem pouco, envolvendo a reação de hidrocarbonetos em atmosfera limitada em Oxigênio a temperaturas entre 1320 e $1540^{\circ} \mathrm{C}$.

O negro de fumo de alta qualidade é comumente obtido usando acetileno ou gás natural como matéria prima. Quando a qualidade do negro de fumo não é alta o suficiente para sua aplicação nas pilhas a combustível ele pode ser tratado a temperaturas altas $\left(1200\right.$ a $\left.2500^{\circ} \mathrm{C}\right)$ para melhorar sua resistência a corrosão.

Os outros materiais que são usados nas pilhas são notadamente os materiais metálicos, notadamente aços e outros materiais ferrosos.

\subsubsection{Ciclo da vida de uma pilha PEM}

As pilhas tipo PEM estão sendo desenvolvidas de muitas formas e por muitos fabricantes e pesquisadores. A estrutura interna deste tipo de pilha está evoluindo, sendo o projeto planar o mais popular.

Para avaliar o impacto ambiental da pilha PEM é necessário avaliar todo o ciclo de produção da pilha, bem como os combustíveis utilizados, as matérias primas, a operação e a disposição final após o término da vida útil.

Na Figura 4-7 está mostrado um esquema do processo de produção de 
uma pilha tipo PEM na empresa Ballard (PEHNT, 2001).

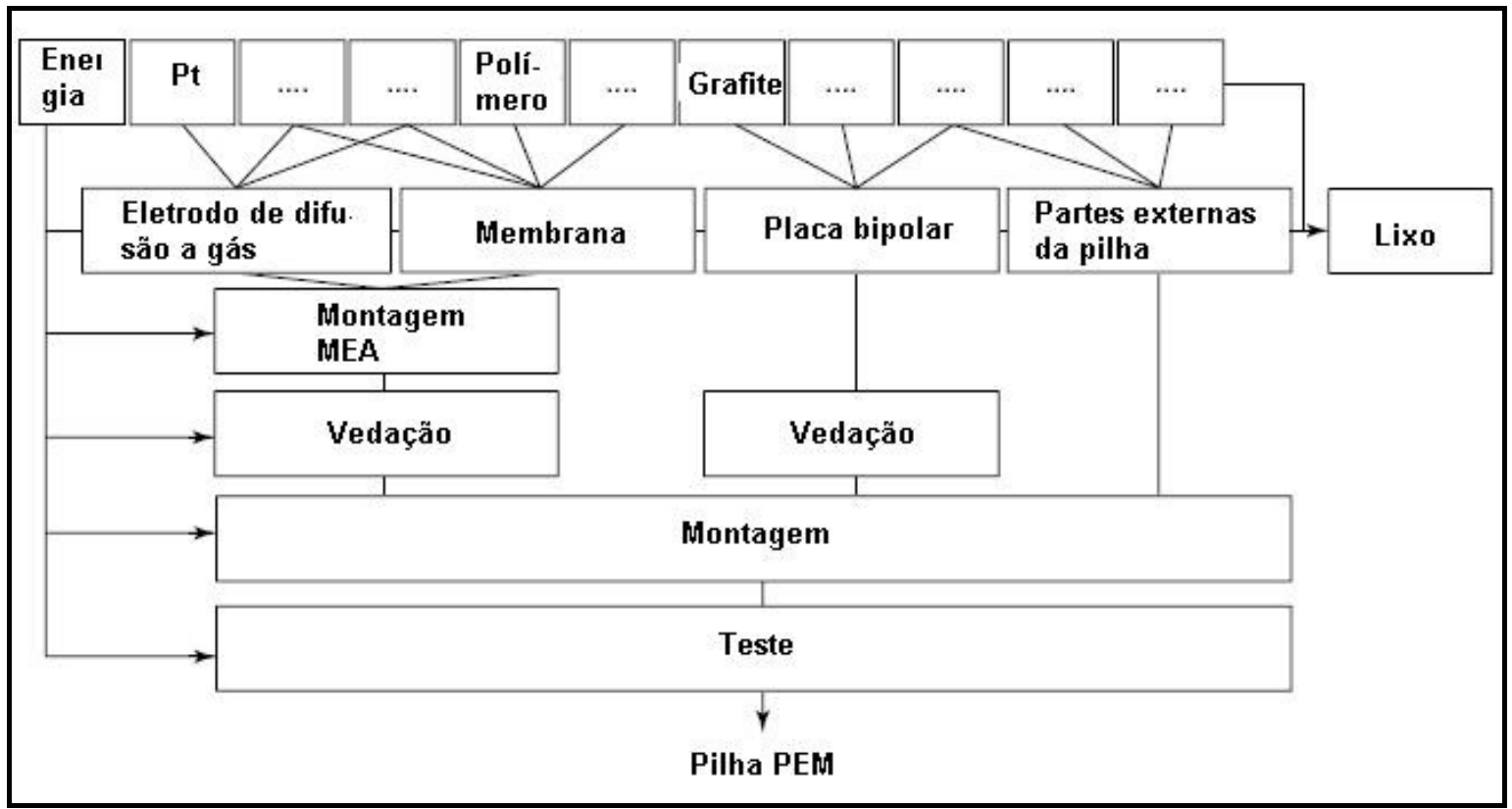

Figura 4-7 - Esquema do processo de produção de uma pilha tipo PEM na empresa Ballard (PEHNT, 2003).

$\mathrm{Na}$ Tab.4-1 estão apresentados os dados da pilha de referência utilizados por PEHNT (2001).

O processo de produção da planta piloto da Ballard consiste das seguintes etapas:

- produção do eletrodo de difusão a gás incluindo a aplicação do catalisador,

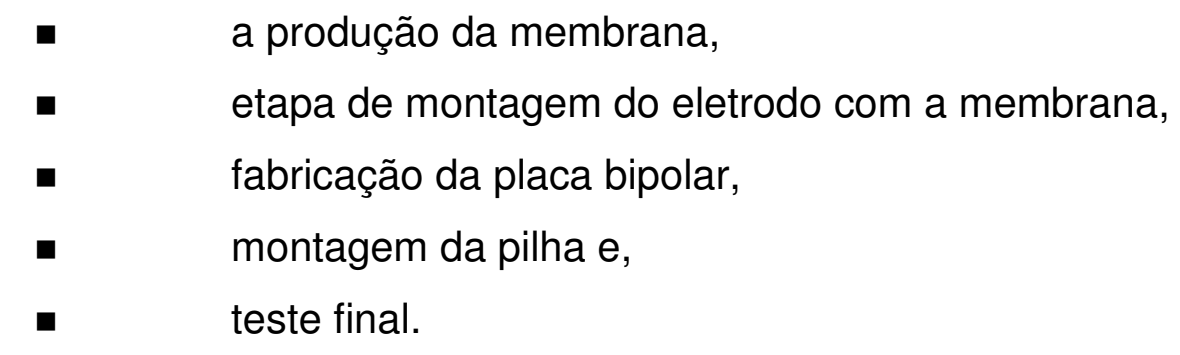

Para cada uma destas fases foram obtidos todos os valores de entrada, incluindo materiais, substâncias anteriores, eletricidade, bem como as emissões diretas durante a produção, para uma pilha referência com aplicação automotiva. 
Tabela 4-1 - Pilha de referência e análise de sensibilidade utilizada por Pehnt, (2001).

\begin{tabular}{|c|c|c|}
\hline Pilha Referência & & Fontes de dados \\
\hline Energia elétrica & $\begin{array}{l}75 \mathrm{~kW}_{\mathrm{e}} \text { (móvel) } / 275 \text { kW } \text { e (estacionária) } \\
\text { Futura produção em série } \\
\text { Importante para consumo de energia } \\
\text { Carga de catalisador, produção }\end{array}$ & \\
\hline \multicolumn{3}{|l|}{ Materiais } \\
\hline \multicolumn{3}{|l|}{$P G M$} \\
\hline $\begin{array}{l}\text { Carga de PGM } \\
\text { País de produção }\end{array}$ & $\begin{array}{l}0.3 \mathrm{mg} / \mathrm{cm}^{2} \text { (móvel) / } \\
1 \mathrm{mg} / \mathrm{cm}^{2} \text { (estacionária) } \\
\text { África do Sul }\end{array}$ & $\begin{array}{l}\text { Ballard/ (PEHNT, } \\
\text { 2000) }\end{array}$ \\
\hline \multicolumn{3}{|l|}{ Grafite } \\
\hline & $\begin{array}{l}\text { Grafite Natural } \\
\text { Grafite manufaturada }\end{array}$ & $\begin{array}{l}\text { LCA conforme (SGL, } \\
\text { 1997) }\end{array}$ \\
\hline \multicolumn{3}{|l|}{ Membrana } \\
\hline & Membrana BAM & $\begin{array}{l}\text { Ballard, } \\
\text { 2000) }\end{array}$ \\
\hline \multicolumn{2}{|l|}{ PTFE } & (PEHNT, 2001) \\
\hline \multicolumn{2}{|l|}{ Fibra de Carbono } & (PEHNT, 2001) \\
\hline
\end{tabular}

Paralelamente Pehnt (2002) efetuou um LCA para uma pilha estacionária. As pilhas estacionárias possuem requisitos mais exigentes quanto à longevidade e eficiência. Por outro lado não estão limitadas em termos de peso e volume. As pilhas estacionárias mostram características diferentes, especialmente as placas de fluxo são mais pesadas, as membranas são mais finas e recebem maior carga de PGM, na ordem de $1 \mathrm{mg} / \mathrm{cm}^{2}$, operando com densidades de corrente mais baixas e maior peso por $\mathrm{kW}$.

Todos os materiais envolvidos nas pilhas estacionárias também foram analisados. Como as informações disponíveis referiam-se apenas a uma linha protótipo, nem todas as entradas foram consideradas.

Os resultados dos impactos ambientais estão na Tabela 4-2. Note que na construção do LCA é necessário se incluir a energia utilizada para a fabricação da pilha. Esta energia hipoteticamente foi considerada como sendo oriunda de diversas fontes tais como:

- "Mix" de energia da Alemanha, ou seja, a energia gerada na Alemanha, no ano 2001, contendo as participações de todos os tipos de energia gerada. 
- Hidroeletricidade, ou seja, a hipótese em que toda energia consumida no processo de produção seria oriunda de hidrelétricas.

Tabela 4-2 - Resultados de avaliação de impacto e inventário para uma pilha a combustível (PEHNT, 2001)

\begin{tabular}{|c|c|c|c|c|c|c|}
\hline \multirow{2}{*}{ Eletricidade p/ produção } & \multicolumn{4}{|c|}{ Pilha móvel } & \multicolumn{2}{|c|}{ Pilha estacionária } \\
\hline & Caso 1 & Caso 2 & Caso 3 & Caso 4 & Caso 1 & Caso 3 \\
\hline Ocorre reciclagem de PGM? & Não & Não & $\begin{array}{c}\operatorname{Sim}(75 \\
\%)\end{array}$ & $\operatorname{Sim}(75 \%)$ & Não & $\begin{array}{c}\operatorname{Sim}(90 \\
\%)\end{array}$ \\
\hline $\begin{array}{l}\text { Energia 1a. não renovável } \\
\text { (MJ/kWel) }\end{array}$ & 940 & 581 & 744 & 369 & 5100 & 1446 \\
\hline \multicolumn{7}{|l|}{ Emissões Globais (kg/kWel) } \\
\hline $\mathrm{CO}_{2}$ & 57 & 38 & 40 & 20 & 275 & 78 \\
\hline $\mathrm{CH}_{4}$ & 0.1 & 0.1 & 0.1 & 0.0 & 0.5 & 0.2 \\
\hline $\mathrm{N}_{2} \mathrm{O}$ & 0.005 & 0.004 & 0.005 & 0.004 & 0.019 & 0.014 \\
\hline \multicolumn{7}{|l|}{$\begin{array}{l}\text { Emissões } \quad \text { Locais/regionais } \\
(\mathrm{kg} / \mathrm{kWel})\end{array}$} \\
\hline $\mathrm{SO}_{2}$ & 0.17 & 0.14 & 0.10 & 0.06 & 0.73 & 0.17 \\
\hline $\mathrm{CO}$ & 0.02 & 0.02 & 0.02 & 0.02 & 0.14 & 0.10 \\
\hline $\mathrm{NO}_{x}$ & 0.17 & 0.15 & 0.07 & 0.05 & 0.74 & 0.14 \\
\hline$\hat{N M H C}$ & 0.02 & 0.02 & 0.02 & 0.02 & 0.09 & 0.04 \\
\hline Poeira e particulados & 0.03 & 0.03 & 0.01 & 0.01 & 0.14 & 0.03 \\
\hline $\mathrm{NH}_{3}$ & $1.4 \mathrm{E}-3$ & $1.3 \mathrm{E}-3$ & 1.4E-2 & 1.3E-3 & 2.5E-3 & 2.0E-3 \\
\hline Benzeno & 2.7E-5 & 2.7E-5 & 2.7E-5 & 2.7E-5 & 4.3E-4 & 3.6E-4 \\
\hline \multicolumn{7}{|l|}{$\begin{array}{llr}\begin{array}{l}\text { Categorias } \\
\text { (Kg/kWel) }\end{array} & \text { impacto }\end{array}$} \\
\hline $\begin{array}{l}\text { Potencial aquec. Global }\left(\mathrm{CO}_{2}^{-}\right. \\
\text {eq) }\end{array}$ & 61 & 41 & 43 & 22 & 293 & 86 \\
\hline Acidificação $\left(\mathrm{SO}_{2}-\mathrm{eq}\right)$ & 0.29 & 0.25 & 0.15 & 0.10 & 1.25 & 0.27 \\
\hline \multicolumn{7}{|l|}{ Notas: } \\
\hline \multicolumn{7}{|c|}{ 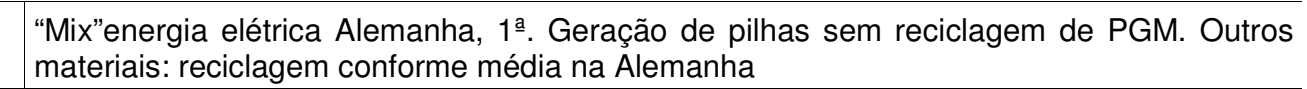 } \\
\hline \multicolumn{7}{|c|}{ Hidro-eletricidade, 1․ Geração de pilhas } \\
\hline \multicolumn{7}{|c|}{$\begin{array}{l}\text { Eletricidade obtida a partir do "mix: da Alemanha, 75\% PGM são reciclados (móvel) e 90\% } \\
\text { de reciclagem de PGM (estacionárias) }\end{array}$} \\
\hline \multicolumn{7}{|c|}{$\begin{array}{l}\text { Hidro-eletricidade, } 75 \% \text { PGM são reciclados (móvel) e 90\% de reciclagem de PGM } \\
\text { (estacionárias) }\end{array}$} \\
\hline
\end{tabular}

Para analisar os resultados é interessante considerar as contribuições dos componentes e materiais no impacto ambiental total. Na Figura 4-8 estes dados estão apresentados e demonstram que dois componentes têm especial importância: o eletrodo de difusão gasosa (GDE) e as placas de fluxo. 
A platina presente no eletrodo de difusão gasosa (GDE) é responsável por $74 \%$ da acidificação total e por mais da metade das emissões de gases responsáveis pelo aquecimento global. $\mathrm{O}_{\mathrm{SO}_{2}}$ e $\mathrm{NOx}$ emitidos durante $\mathrm{O}$ processamento de PGM causam acidificação. Se fosse utilizado PGM produzido na Rússia estas emissões seriam dominantes por causa da falta do dispositivo de dessulfurização.

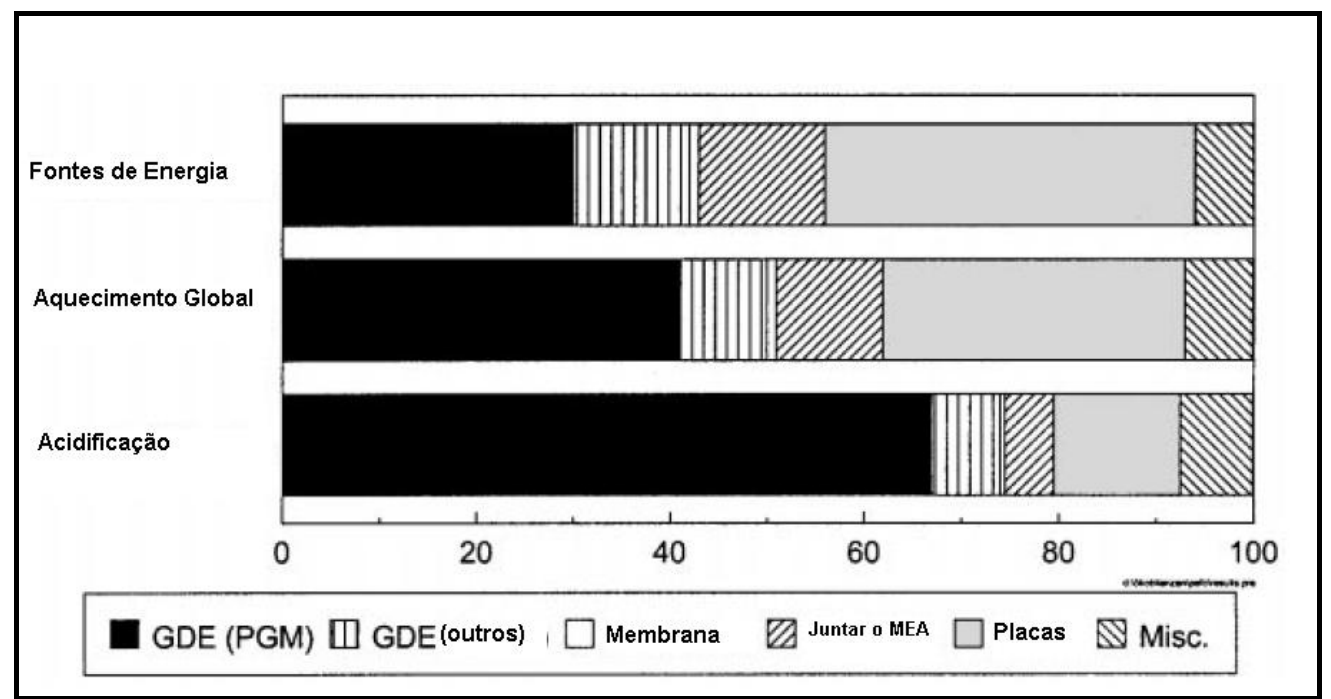

Figura 4-8 - Contribuição dos componentes da pilha nos impactos ambientais considerados (para pilha móvel no caso 1) (PEHNT, 2001)

A fibra de Carbono causa 5-7\% do impacto ambiental. Dado o baixo peso das fibras de carbono esta é uma contribuição considerável, que é causada pelo alto consumo de alta energia na produção do precursor e sua estabilização.

As placas de fluxo são o segundo componente mais importante por causa do consumo de eletricidade na etapa de impregnação com resina. Neste caso se o volume de produção aumentar pode ser obtido valores menores (até metade) para o consumo específico de energia no processo. É interessante que as placas de grafite, geralmente consideradas como o principal fator ecológico, contribuem com $13 \%$ do potencial de aquecimento global, comparado com $17 \%$ do consumo de eletricidade. Este é também um resultado dos esforços para reduzir o peso das placas de fluxo. Estes 13\% são parcialmente causados pela produção de grafite e parcialmente pelo uso da impregnação por resina.

A membrana não é, do ponto de vista ecológico, muito importante pois o consumo de energia é baixo e o processo de produção é um ciclo fechado (com reciclagem do solvente). 
As emissões NMVOC (Non-Methane Volatile Organic Compounds) são causadas notadamente pela produção da fibra de carbono (30\%) e pelo acrilato de metila (25\%). Este cálculo assume que as emissões referentes à impregnação de resina nas placas são feitas em queima posterior. Se isto não foi efetuado nas séries futuras então as emissões NMVOC poderão diminuir em até $40 \%$.

As pilhas estacionárias resultam, em termos de demanda por energia primária, no aquecimento global e acidificação em impactos específicos (por kW) que são aproximadamente maiores em fator da ordem de 2-5. Isto se deve notadamente devido à maior carga de PGM maior consumo de energia da grafite e menor densidade de potência. Comparada com a contribuição dos componentes da pilhas móveis existe uma tendência num impacto maior das placas de fluxo.

\subsubsection{1-Potencial de melhorias na pilha PEM}

Os resultados permitiram que PEHNT (2001), identificasse uma hierarquia de melhorias que podem ser desenvolvidas para as pilhas combustíveis.

\subsubsection{1- Platina e metais do grupo PGM}

A redução do impacto no uso dos metais do grupo PGM é importante tanto ecologicamente quanto economicamente. Existem diferentes opções para reduzir o efeito dos metais do grupo PGM. Entre elas as mais importantes seriam:

a) Redução da carga de PGM,

Comparada com as primeiras gerações de pilhas a carga de PGM reduziu-se substancialmente de 8 para 1 e $0,3 \mathrm{mg} / \mathrm{cm}^{2}$ para as futuras gerações. O limite inferior da carga é determinado pela facilidade de reciclagem e perda de desempenho. A influência da carga de PGM pode ser observada na Figura 4-9. Neste caso quando se reduz a carga de platinam, considerando que ocorre uma diminuição da eficiência da pilha, e implica num aumento maior no consumo de combustível. Isto porque uma maior emissão ácida no ciclo da vida do PGM leva a uma maior acidificação. 


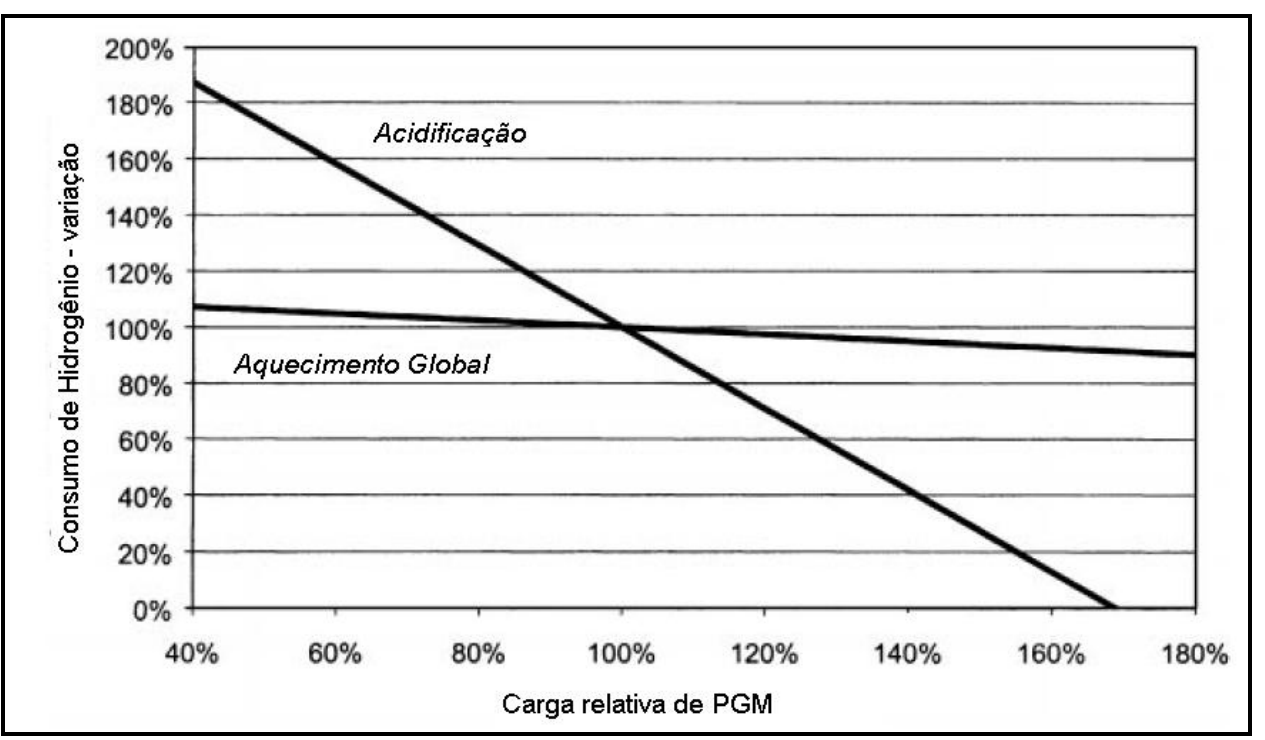

Figura 4-9 - Consumo de hidrogênio como função da carga de PGM (PEHNT, 2001). Por exemplo, se a carga de PGM for reduzida em $50 \%$ da carga de referência, o consumo de hidrogênio pode aumentar de 5 a $70 \%$, tal que o potencial de aquecimento global e as emissões contribuintes da acidificação permanecem a mesma.

b) Maximização do rendimento de PGM durante a produção,

O rendimento dos metais do grupo PGM nos processos produtivos já é muito alto. A deposição seletiva da tinta de catalisador e a minimização de rejeitos (alternativa ao processo de corte é o corte a laser para aperfeiçoar a geometria dos eletrodos) levam a um aumento no rendimento de até $99 \%$.

\section{c) Reciclagem.}

Uma reciclagem eficiente é necessária por razões tanto ecológicas como econômicas. Um sistema de reciclagem eficiente já existe bem estabelecido nos países mais desenvolvidos em razão da reciclagem do catalisador, já utilizado nos automóveis. A reciclagem dos catalisadores automotivos reduz o impacto ambiental dos PGM de um fator de 20 (demanda por energia primária) a 100 (emissões $\mathrm{SO}_{2}$ ).

A quota de reciclagem global depende, em grande parte, do rendimento do próprio processo de reciclagem. Existem vários processos, tais como o processo hidrometalúrgico, usando ácidos fortes ou processos pirometalúrgicos, no qual os substratos são derretidos em fornos.

Mas os processos convencionais de recuperação da Platina não são adequados para os componentes da pilha pois:

a baixa taxa de recuperação do método do solvente ácido porque as partículas de Platina são cobertas pelo ionômero; 
a presença de Nafion, um polímero que contém fluoretos, que se decompõem a alta temperatura, resultando na liberação de ácido fluorídrico, o qual é tóxico e corrosivo.

Assim para as pilhas combustíveis o processo mais adequado vem sendo desenvolvido por Grot (2005), com incentivo do DOE ("USA Department of Energy"). Este processo permitirá a extração e reuso tanto da Platina como do ionômero.

Neste processo, primeiro a pilha é desmontada e o MEA é colocado numa autoclave, para formar uma "lama" que contém o Nafion dissolvido juntamente com as partículas de Platina e do suporte de negro de fumo. Numa segunda etapa está sendo desenvolvida a tecnologia que separa estes dois compostos valiosos: o Nafion e a Platina. Idealmente por meio deste processo a Platina recuperada poderia ser re-depositada em uma nova membrana de pilha a combustível.

A quota de reciclagem, entretanto, depende de vários fatores adicionais, tais como:

incentivo econômico (dependendo do preço da PGM);

a disponibilidade da infra-estrutura de reciclagem, a quota de exportação nos países sem tais infra-estruturas (p. ex. aproximadamente um terço dos veículos descomissionados na Alemanha, são exportados para países da Europa Oriental);

o crescimento do número de veículos movidos a pilha a combustível e, portanto da disponibilidade insuficiente da Platina secundária.

Em 2001, 52\% dos catalisadores dos carros na Alemanha, eram reciclados (PEHNT, 2001). Entre 20\% (Platina) e 5\% (Paládio) de PGM usado para a produção do catalisador na Alemanha são metais secundários. E esta percentagem aumentará na mesma proporção em que aumentar o número de carros que serão descartados com catalisador. Assim será normal que quanto maior o uso das pilhas em automóveis maior será a necessidade da reciclagem, prevendo-se até a introdução de novas medidas que assegurem a reciclagem, tais como o "leasing". Assim devem ser assumidas cotas de reciclagem maiores, e PENHT (2001) assumiu uma cota de $75 \%$ para pilhas móveis e $90 \%$ para as estacionárias. O resultado está apresentado na Tabela 4-2 para vários casos. 


\section{d) Maximização da eficiência}

É claro que a maximização da eficiência através da melhoria do desempenho da pilha reduz a quantidade de carga de PGM em razão da redução da área de cada célula combustível.

\subsubsection{2- Fontes de eletricidade para a produção}

O "mix" de eletricidade tem uma influência substancial na avaliação do impacto ambiental. A planta de referência, para o LCA efetuado por PEHNT (2001), está baseada em lignita (28\%), carvão (25\%), energia nuclear (35\%), gás natural (6\%) e fontes de energia renováveis (5\%).

Se as pilhas forem produzidas em outros países, então deverá ser utilizado o respectivo "mix" elétrico. A influência está mostrada na Tabela 4-3, caso 2, na qual a hidroeletricidade foi assumida para a produção das pilhas, representando a planta de Vancouver, Canadá. O potencial de aquecimento global diminui de $33 \%$ e a acidificação de $14 \%$.

\subsubsection{3- Potenciais de melhoria a longo prazo}

Existem opções adicionais para reduzir o impacto ambiental devido à produção da pilha:

- eliminação dos componentes e sua integração na pilha, por exemplo, umidificadores, compressores a ar, reformadores e gerenciadores de fluxo,

reciclagem dos componentes: Adicionalmente a reciclagem dos PGM, pode-se também reciclar outros componentes, como por exemplo, as placas de fluxo em pilhas estacionárias, que podem ser reutilizadas. O tempo de vida esperado destas placas é de aproximadamente 160.000 horas, para pilhas estacionárias.

A membrana pode ser delaminada a partir dos eletrodos, dissolvida em solução e reutilizada para dessalinização ou remoção de metais pesados. A incineração das membranas, similar a incineração do PTFE, resulta em emissão de ácido fluorídrico (HF) que deve ser cuidadosamente removido na planta de incineração. 
Tabela 4-3 - Resultado comparativo entre o carro movido a pilha a combustível utilizando hidrogênio obtido a partir de: (a) reforma do gás natural e (b) metanol, em um ciclo de direção misto, conforme Figura 4-10 sem considerar a produção do veículo (PEHNT, 2001).

\begin{tabular}{|c|c|c|}
\hline \multicolumn{3}{|c|}{ Combustível } \\
\hline $\begin{array}{l}\text { Pilha a combustível no carro ( } 750 \mathrm{~kg} \\
\text { peso base). }\end{array}$ & $\begin{array}{l}\text { Hidrogênio a partir do } \\
\text { gás natural. }\end{array}$ & $\begin{array}{l}\text { Hidrogênio a partir do } \\
\text { metanol. }\end{array}$ \\
\hline $\begin{array}{l}\text { Energia primária não renovável } \\
(\mathrm{MJ} / \mathrm{km})\end{array}$ & 1.8 & 2.32 \\
\hline \multicolumn{3}{|l|}{ Emissões Globais (mg/km) } \\
\hline $\mathrm{CO}_{2}$ & 97585 & 119430 \\
\hline $\mathrm{CH}_{4}$ & 239.0 & 160.5 \\
\hline $\mathrm{N}_{2} \mathrm{O}$ & 0.29 & 0.42 \\
\hline \multicolumn{3}{|l|}{ Emissões Locais/Regionais (mg/km) } \\
\hline $\mathrm{SO}_{2}$ & 34 & 72 \\
\hline $\mathrm{CO}$ & 32 & 33 \\
\hline $\mathrm{NO}_{\mathrm{x}}$ & 63 & 94 \\
\hline NMHC & 73 & 79 \\
\hline Poeiras e particulados & 4 & 8 \\
\hline $\mathrm{NH}_{3}$ & 9.0E-3 & $3.5 \mathrm{E}-2$ \\
\hline Benzeno & 2.6E-2 & $8.2 \mathrm{E}-2$ \\
\hline \multicolumn{3}{|l|}{ Categorias de impacto } \\
\hline $\begin{array}{l}\text { Potencial de aquecimento global } \\
\left(\mathrm{CO}_{2 \text {-eq }}\right)\end{array}$ & 102694 & 122930 \\
\hline Acidificação $\left(\mathrm{SO}_{2 \text {-eq }}\right)$ & 78 & 138 \\
\hline
\end{tabular}

\subsubsection{2- Comparação entre o impacto de produção e o uso das pilhas combustíveis móveis em carros}

É importante comparar o impacto ambiental da etapa de operação das pilhas em relação à etapa de produção. Por isso são apresentados a seguir os resultados obtidos por PEHNT (2001) que efetuou a comparação entre o impacto da produção da pilha móvel e seu uso em automóveis. 
Na Tabela 4-4 estão apresentados os resultados do LCA para uma pilha a combustível em carro movido a hidrogênio, obtido a partir da reforma do gás natural ou através da reforma direta do metanol ("on-board") em um ciclo de direção misto. A direção em ciclo misto inclui a direção dentro da cidade, o ciclo extra urbano e o ciclo de direção em rodovias de alta velocidade ("highways"). Nesta tabela os dados apresentados permitem a comparação do impacto ambiental durante a fase de operação e a de produção da pilha a combustível.

E termos de aquecimento global as emissões dos carros movidos a pilha combustível, usando metanol, não apresentam vantagem significativa, considerando a o ciclo médio de direção adotado por Pino (2001). As principais razões são a menor eficiência na produção do metanol e o maior peso dos veículos, quando comparados com os veículos ICE.

Na Figura 4-10 está apresentado o ciclo de direção adotado.

Tabela 4-4 - Impacto ambiental (LCA) de pilha a combustível em carro movido a pilha a combustível e motores a combustão (PEHNT, 2001).

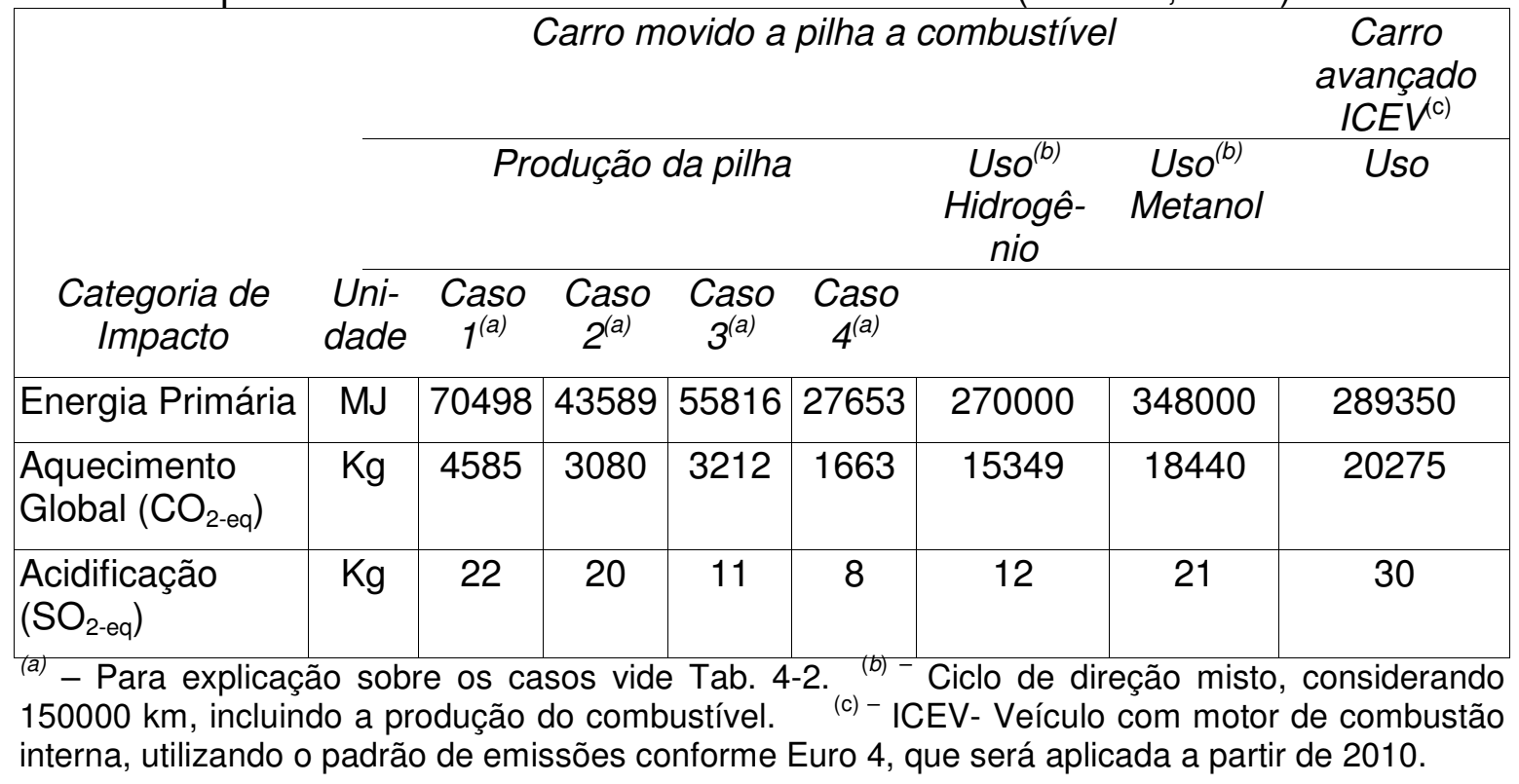




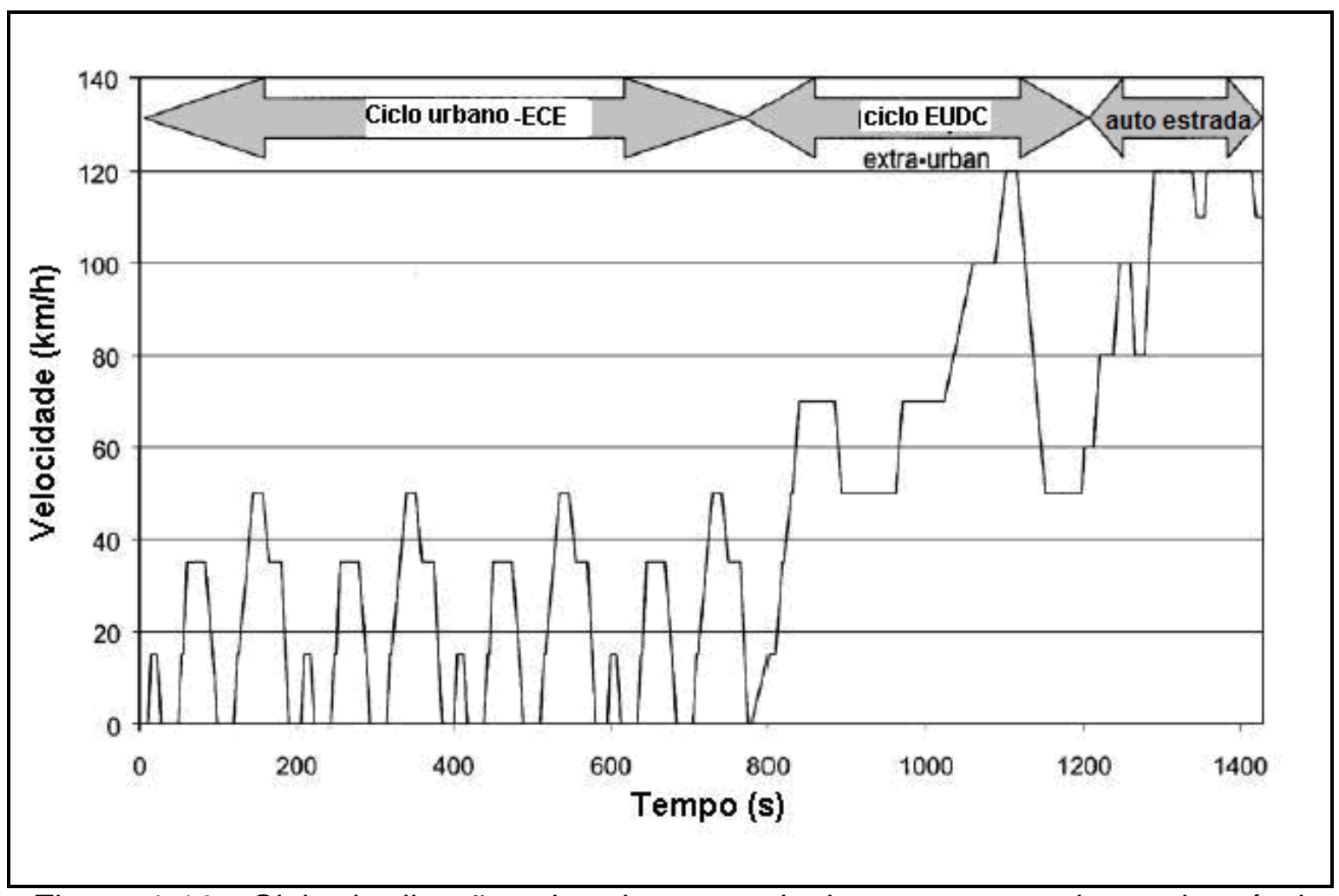

Figura 4-10 - Ciclo de direção adotado para calcular o consumo de combustível (PEHNT, 2001).

Notas da Figura 4-10: ECE - ("Economic Commission for Europe")

ECE R49- Norma antiga da Comissão Econômica Européia (anterior a 2000) para emissões veiculares, EUDC- Ciclo de direção fora do centro urbano ("Extra-Urban driving cycle"), ICEVVeículo com motor de combustão interna, utilizando o padrão de emissões conforme Euro 4, que será aplicada a partir de 2010.

Assim Pehnt (2001) concluiu que a produção da pilha leva a um impacto ambiental que não pode ser desprezado, comparado ao impacto da fase de utilização. $O$ aquecimento global e o consumo de energia primária de fontes não renováveis, na primeira geração de pilhas (caso 1) são da ordem de $1 / 4 \mathrm{da}$ emissão durante a fase de uso do carro. A acidificação é da mesma ordem de grandeza que a referente à fase de uso do carro.

É importante notar que, em adição à produção da pilha, também é necessário o cálculo do impacto ambiental referente ao sistema de controle e periféricos, bem como do corpo do automóvel. A produção do veículo a pilha a combustível, entretanto, ainda não pode ser avaliada visto que a configuração periférica ainda é incerta e os dados não são disponibilizados devido à confidencialidade. Está claro que a pilha a combustível representa aproximadamente $10 \%$ em peso do veículo total, mas um impacto ambiental substancialmente maior (estimativa: $>50 \%$ ) porque materiais ecologicamente 
críticos estão envolvidos.

No caso de um carro a pilha a combustível, utilizando metanol com reforma "on-board", muito mais PGM (na ordem de 10-20g) será utilizado nos conversores catalíticos e eventuais sistemas de limpeza do gás, por exemplo Membranas $\mathrm{Pd} / \mathrm{Ag}$ ). O Paládio, entretanto está associado com emissões menores. A comparação detalhada da produção de um carro a pilha a combustível com um carro ICE ("Internal Combustion Engine") a gasolina poderá ser efetuada tão logo os primeiros veículos forem fabricados. Para uma primeira estimativa PENHT (2001) utilizou um estudo detalhado efetuado pela Volkswagen em 1999.

Quando ocorre a reciclagem dos PGM e uso da hidroeletricidade a situação muda ocorrendo uma redução nas emissões. A comparação com o caso 3 indica que 0 impacto pode ser drasticamente reduzido pela reciclagem dos PGM. Isto é um fenômeno comum a muitos sistemas inovadores. Durante a introdução destas tecnologias, as vantagens inerentes, isto é emissões locais próximas a zero, provenientes da pilha a combustível dos carros, podem ser encobertas por efeitos não equilibrados, tais como a falta de infra-estrutura de reciclagem. Uma vez que estas tecnologias tenham sido estabelecidas, por exemplo: a reciclagem esteja implantada e operando, as vantagens, neste caso a redução drástica do impacto, aparecerá. Desenvolvimentos similares podem ser observados, p. ex., no caso dos veículos de baixo peso nos quais a reciclagem do alumínio reduz o impacto da construção destes veículos.

Assumindo que as pilhas utilizem PGM reciclados e hidroeletricidade, (caso 4), então a emissão local será próxima a zero levando a uma clara vantagem sobre o potencial de acidificação, mesmo se a produção for mais importante ecologicamente. Os carros a gasolina ICE emitem $30 \mathrm{~kg} \mathrm{SO}$ 2-eq $p$ para $150.000 \mathrm{~km}$ rodados, ao passo que o carro a pilha a combustível emite apenas $12-22 \mathrm{~kg}$. Mesmo adicionando-se $8 \mathrm{~kg}$ referentes à produção da pilha e assumindo que o impacto seja o mesmo para os dois tipos de carros, as emissões de $\mathrm{SO}_{2}$-eq são menores para carros que utilizam a pilha a combustível.

Para emissões referentes a gases que provocam o aquecimento global, os carros a pilha a combustível que usam metanol, não possuem, entretanto, vantagem significativa na média do ciclo de direção. A maior razão é a menor eficiência da produção do metanol e o maior peso do veículo, comparado aos 
veículos ICE.

\subsubsection{3- Comparação entre o impacto de produção e o uso das pilhas combustíveis estacionárias}

Embora o impacto ambiental das pilhas estacionárias, por kW, seja mais alto que o das pilhas móveis, em virtude do seu peso mais alto e maior carga catalítica, por outro lado as pilhas estacionárias possuem tempo de vida maior (40000 horas ao invés de 4000h), e também o maior potencial de reciclagem de partes da pilha. Como exemplo disso pode-se citar a reciclagem das placas de fluxo.

Assumindo um balanço similar ao das plantas de pilhas de ácido fosfórico, PENHT (2001) efetuou uma avaliação do impacto ambiental para um sistema CHP ("Combined Heat and Power"), queimando gás natural e incluindo o sistema periférico. Para a maior parte das categorias de impacto, a produção do sistema total, assumindo a reciclagem de PGM na ordem de $90 \%$, contribui menos que $8 \%$ das emissões do ciclo de vida. Se não ocorrer a reciclagem, então a produção contribuirá menos que $13 \%$. Portanto o estudo concluiu que, nos sistemas estacionários, o impacto da produção é relativamente menor que para os sistemas móveis.

Karakoussis et al. (2000) estudou o impacto ambiental de uma pilha estacionária desenvolvida pela Alstom em conjunto com a Ballard, operando em ciclo combinado, com potência de $250 \mathrm{~kW}$. O sistema foi projetado para operar com gás natural a partir de fornecimento padrão, e inclui um reformador a vapor e sistema de limpeza dos gases, pilha a combustível com fornecimento de ar e componentes de gerenciamento térmico e condicionamento de potência.

A Tabela 4-5 mostra um resumo das emissões globais durante a etapa de manufatura da pilha Alstom/Ballard. 
Tabela 4-5 - Emissões ocorridas durante a etapa de fabricação da pilha para aplicações estacionárias.

\begin{tabular}{|c|c|c|c|c|c|c|c|c|}
\hline & $\begin{array}{c}\text { Materiais } \\
\text { MEA \& } \\
\text { Placas } \\
\text { Bipolares }\end{array}$ & $\begin{array}{c}\text { Energia no } \\
\text { processo } \\
\text { de obten- } \\
\text { ção } \\
\text { MEA\&Placa } \\
\text { s Bipolares }\end{array}$ & \begin{tabular}{|c} 
Materiai \\
s para \\
compo- \\
nentes \\
auxiliare \\
$s$
\end{tabular} & $\begin{array}{c}\text { Energia } \\
\text { no } \\
\text { process } \\
\text { o dos } \\
\text { compo- } \\
\text { nentes } \\
\text { auxiliare } \\
s\end{array}$ & $\begin{array}{c}\text { Materiai } \\
s \\
\text { BoP } \\
\text { (balan- } \\
\text { ço da } \\
\text { Planta) }\end{array}$ & $\begin{array}{c}\text { Energia } \\
\text { no } \\
\text { process } \\
\text { o do } \\
\text { BoP } \\
\text { (balan- } \\
\text { ço da } \\
\text { planta) }\end{array}$ & $\begin{array}{c}\text { Sistema } \\
\text { global } \\
(\mathrm{g} / \mathrm{kW})\end{array}$ & $\begin{array}{c}\text { Sistema } \\
\text { total } 250 \mathrm{~kW} \\
\text { (g) }\end{array}$ \\
\hline \multicolumn{9}{|c|}{ Emissão total no ar (mg/kW) } \\
\hline Particulados & 14139,97 & 0,00 & 1,51 & 0,00 & 10,53 & 0,00 & 14152,01 & 3538002,00 \\
\hline $\mathrm{CO}$ & 18467,86 & 0,63 & 4,18 & 0,03 & 46,34 & 0,65 & 18519,68 & 4629919,91 \\
\hline $\mathrm{CO}_{2}$ & $\begin{array}{r}23815942, \\
6 \\
\end{array}$ & 651,11 & 597,03 & 26,12 & 6124,29 & 677,27 & $\begin{array}{r}23824018 \\
4\end{array}$ & $\begin{array}{r}5956004623, \\
26 \\
\end{array}$ \\
\hline sox & 3987128,2 & 0,02 & 4,39 & 0,00 & 104,38 & 0,02 & 3987237,0 & $\begin{array}{r}996809269,0 \\
5 \\
\end{array}$ \\
\hline NOX & 40289,06 & 1,14 & 1,21 & 0,05 & 6,33 & 1,19 & 40298,97 & 14212373,27 \\
\hline $\begin{array}{l}\text { Hidrocarbonet } \\
\text { os }\end{array}$ & 56833,36 & 0,65 & 2,91 & 0,03 & 11,87 & 0,67 & 56849,49 & 14212373,27 \\
\hline $\mathrm{H}_{2} \mathrm{~S}$ & 27,60 & & 0,00 & & 0,03 & & 27,3 & 6908,61 \\
\hline $\mathrm{HCl}$ & 2732,13 & & 0,05 & & 0,40 & & 2732,57 & 683142,51 \\
\hline $\mathrm{HF}$ & 384,59 & & 0,00 & & 0,03 & & 384,63 & 96157,18 \\
\hline Metais & 3568,40 & & 0,01 & & 0,14 & & 3568,55 & 892138,25 \\
\hline $\begin{array}{l}\text { Hidrocarb. } \\
\text { Aromáticos }\end{array}$ & 95,80 & & 0,00 & & 0,03 & & 95,83 & 23957,17 \\
\hline CFC/HCFC & 0,00 & & 0,02 & & 0,12 & & 0,15 & 36,52 \\
\hline VOC & 44,66 & & 0,00 & & 0,02 & & 44,69 & 11171,52 \\
\hline \multicolumn{9}{|c|}{ Emissão tot. na água (mg/kW) } \\
\hline COD & 82,32 & & 0,05 & & 0,12 & & 82,49 & 20622,80 \\
\hline $\mathrm{BOD}$ & 25,23 & & 0,01 & & 0,01 & & 25,24 & 6310,75 \\
\hline Ácido $\left(\mathrm{H}^{+}\right)$ & 1,21 & & 0,01 & & 0,03 & & 1,26 & 313,87 \\
\hline $\begin{array}{l}\text { Sólidos } \\
\text { dissolvidos }\end{array}$ & 1,78 & & 0,02 & & 0,05 & & 1,85 & 463,52 \\
\hline $\begin{array}{l}\text { Hidrocarbo- } \\
\text { netos }\end{array}$ & 9,74 & & 0,03 & & 0,02 & & 9,79 & 2446,85 \\
\hline $\mathrm{NH}_{4}$ & 29,66 & & 0,01 & & 0,03 & & 188,36 & 47090,23 \\
\hline $\begin{array}{l}\text { Sólidos } \\
\text { suspensos }\end{array}$ & 1906,18 & & 5,02 & & 110,88 & & 2022,08 & 505521,13 \\
\hline Metais & 54006,78 & & 0,27 & & 2,90 & & 54009,94 & 13502486,06 \\
\hline NO3- & 188,32 & & 0,01 & & 0,03 & & 188,36 & 47090,23 \\
\hline $\begin{array}{l}\text { Outros } \\
\text { Nitrogênios }\end{array}$ & 0,04 & & 0,00 & & 0,03 & & 0,08 & 20,47 \\
\hline ClO3- & 0,18 & & 0,08 & & 0,00 & & 0,27 & 66,61 \\
\hline $\begin{array}{l}\text { Fosfato como } \\
\text { P2O5 }\end{array}$ & 658,99 & & 0,00 & & 0,03 & & 659,02 & 164754,11 \\
\hline
\end{tabular}




\begin{tabular}{|c|c|c|c|c|c|c|c|c|}
\hline & $\begin{array}{c}\text { Materiais } \\
\text { MEA \& } \\
\text { Placas } \\
\text { Bipolares }\end{array}$ & \begin{tabular}{|c|} 
Energia no \\
processo \\
de obten- \\
ção \\
MEA\&Placa \\
s Bipolares
\end{tabular} & $\begin{array}{c}\text { Materiai } \\
\text { s para } \\
\text { compo- } \\
\text { nentes } \\
\text { auxiliare } \\
s\end{array}$ & \begin{tabular}{|c|} 
Energia \\
no \\
process \\
o dos \\
compo- \\
nentes \\
auxiliare \\
$s$
\end{tabular} & $\begin{array}{c}\text { Materiai } \\
s \\
\text { BoP } \\
\text { (balan- } \\
\text { ço da } \\
\text { Planta) } \\
\end{array}$ & \begin{tabular}{|c|} 
Energia \\
no \\
process \\
o do \\
BoP \\
(balan- \\
ço da \\
planta)
\end{tabular} & \begin{tabular}{c|} 
Sistema \\
global \\
$(\mathrm{g} / \mathrm{kW})$
\end{tabular} & $\begin{array}{c}\text { Sistema } \\
\text { total } 250 \mathrm{~kW} \\
(\mathrm{~g})\end{array}$ \\
\hline $\begin{array}{l}\text { Detergente/óle } \\
\text { o } \\
\end{array}$ & 307,94 & & 0,10 & & 0,54 & & 308,57 & 77143,13 \\
\hline $\begin{array}{l}\text { Orgânicos } \\
\text { solúveis }\end{array}$ & 0,27 & & 0,00 & & 0,00 & & 0,28 & 69,57 \\
\hline $\begin{array}{l}\text { Outros } \\
\text { orgânicos }\end{array}$ & 15152,47 & & 0,03 & & 0,20 & & 15152,70 & 3788175,27 \\
\hline Íons Cl- e F- & 72867,82 & & 2,89 & & 17,40 & & 72888,10 & 18222025,90 \\
\hline SO4-- & 52866,13 & & 0,98 & & 6,34 & & 52873,45 & 13218363,71 \\
\hline \multicolumn{9}{|c|}{ Emissões tot. no solo (g/kW) } \\
\hline Minerais & 5,76 & & 27,84 & & 1668,89 & & 1702,49 & 425622,72 \\
\hline $\begin{array}{l}\text { Mistura } \\
\text { industrial }\end{array}$ & 18,91 & & 0,73 & & 10,18 & & 29,82 & 7455,68 \\
\hline Sodas/cinzas & 1,69 & & 9,29 & & 271,73 & & 282,72 & 70679,24 \\
\hline $\begin{array}{l}\text { Prod. } \\
\text { Químicos } \\
\text { regulados }\end{array}$ & 0,20 & & 0,00 & & 0,02 & & 0,22 & 55,30 \\
\hline $\begin{array}{l}\text { Prod. } \\
\text { Químicos } \\
\text { inertes }\end{array}$ & 1,89 & & 0,81 & & 0,27 & & 2,97 & 742,44 \\
\hline
\end{tabular}




\section{2 - Materiais utilizados nas pilhas a ácido fosfórico e seu impacto}

Nas pilhas PAFC o eletrólito é o ácido fosfórico líquido, a aproximadamente $200{ }^{\circ} \mathrm{C}$, em uma matriz de carbeto de silício (SiC), que é um material cerâmico. Devido à presença do eletrólito ácido, a degradação dos materiais é maior nos sistemas da PAFC que nas pilhas PEM. Como consequência a grafite, nas pilhas PAFC, necessita ser de melhor qualidade.

A seguir são apresentados os dados de impacto ambiental dos principais materiais que constituem a PAFC e que implicam em razoável impacto ambiental da mesma.

\subsection{1-0 ácido fosfórico}

O ácido fosfórico combina-se facilmente com muitos outros produtos químicos com interações danosas ao meio ambiente, especialmente o rural, ainda não muito bem conhecidas.

O ácido dilui-se rapidamente no ambiente e não existe toxicidade diretamente a partir dos produtos de sua quebra. Existem problemas relacionados com o excesso de fosfato em águas poluídas que causam o crescimento excessivo de algas, por causa do valor nutritivo para elas, além de causar problemas para os outros organismos presentes no ambiente. Mas estes problemas não podem ser diretamente relacionados com o uso do ácido fosfórico podendo ser causados pelo uso de detergentes e esgotos industriais contendo fosfatos além de outras fontes.

Na década de 80 o consumo de fosfatos era de $90 \%$ para fertilizantes, ao passo que 4,5\% referiam-se à produção de detergentes, incluindo outros agentes de limpeza como o fosfato tri-sódico.

Não existe impacto ambiental extremamente violento na mineração do fosfato. Esta mineração ocorre em diversos locais do mundo. A segurança dos trabalhadores é primordial no processo ácido úmido no qual o fósforo elementar é utilizado em razão de sua acidez, ao calor liberado na neutralização e a liberação de gases tóxicos. As plantas são equipadas com equipamentos e procedimentos de segurança a fim de evitar os perigos anteriormente citados.

Os fosfatos inorgânicos não são perigosos para ingestão, sendo de fato minerais nutrientes essenciais. O ácido fosfórico não diluído pode ser muito perigoso e deve ser manuseado com cuidado; é extremamente corrosivo e não 
pode entrar em contacto com olhos e pele. $\mathrm{O}$ ácido pode produzir gases tóxicos corrosivos quando aquecidos e deve-se ter cuidado para prover ventilação e roupas protetoras para os trabalhadores.

Na Figura 4-11 está apresentado o esquema do processo de produção do ácido fosfórico.

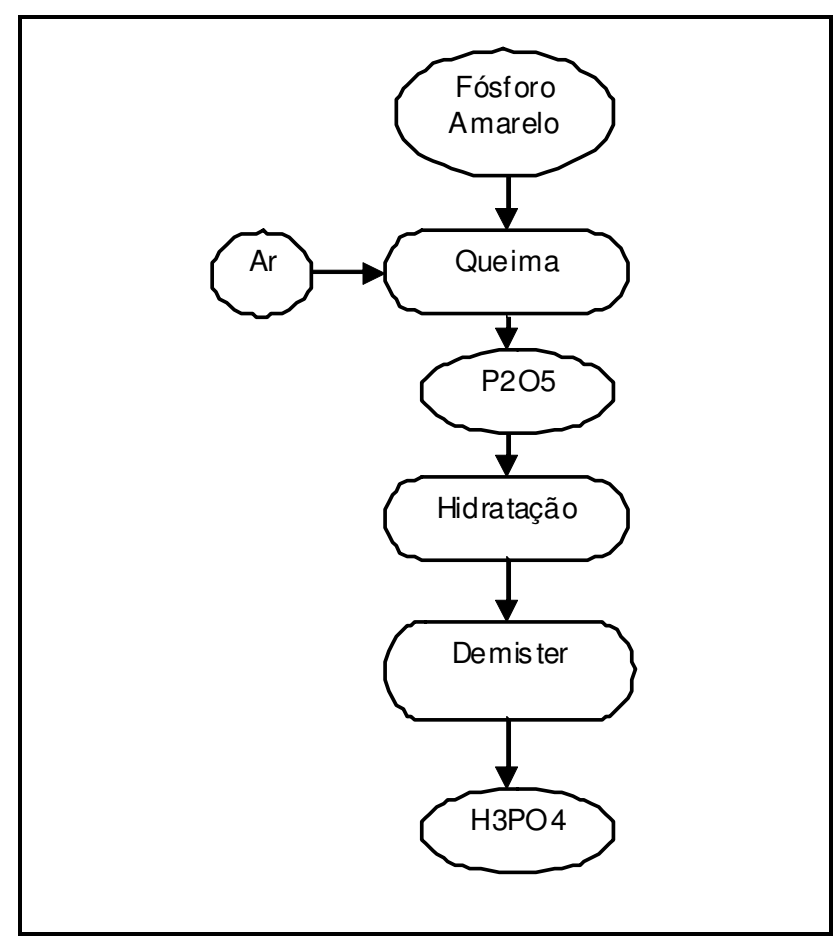

Figura 4-11 - Processo de produção do ácido fosfórico (Nadal, 1997).

No caso da PAFC a matriz/eletrólito, que é um material cerâmico, é preenchida com ácido fosfórico como eletrólito, após a montagem das diferentes partes da pilha. Na Figura 4-12 está mostrado o processo de fabricação da matriz/eletrólito.

\subsection{2- As Placas Bipolares}

As placas bipolares são, na maior parte dos casos das pilhas PAFC, fabricadas a partir de grafite. Existem vários métodos de fabricação para as placas bipolares e o mais comum é que sejam cortadas e usinadas, a partir de blocos sólidos de grafite.

Devido à presença do eletrólito ácido, a degradação dos materiais é maior nos sistemas da PAFC que nas pilhas PEM. Como consequência a grafite, nas pilhas PAFC, necessita ser de melhor qualidade. 


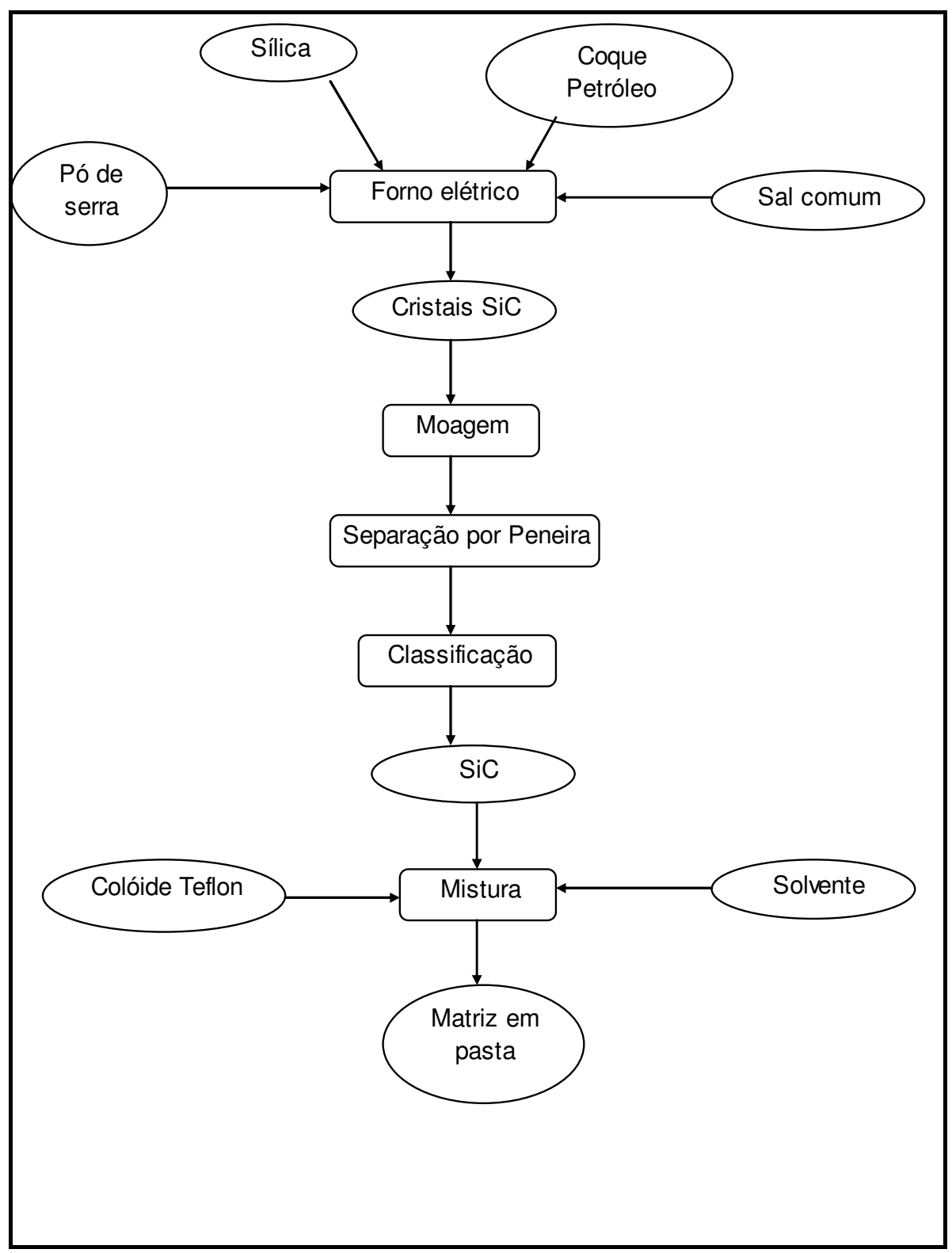

Figura 4-12 - Produção da Matriz de eletrólito para pilha PAFC (Nadal, 1997).

Algumas resinas sintéticas também são usadas como produtos impermeáveis tais como "carbono vitrificado" ("glassy carbon") ou grafite impermeabilizada, usada como separadores entre as células para as pilhas PAFC.

Outro material utilizado nas pilhas PAFC é o negro de fumo, sendo o suporte preferido para ao catalisador Platina. A pasta de eletrocatalisador é formada por Platina, negro de fumo e PTFE, sendo comumente aplicada sobre a placa bipolar utilizando a técnica de pintura por rolos. 


\subsection{3- Estudo de um caso de ciclo da vida para PAFC}

O ciclo da vida para uma pilha PAFC é apresentado na Figura 4-13 e foi obtido a partir de um estudo efetuado por Nadal (1997), para comparação entre as emissões a partir das pilhas PAFC e de turbinas. No caso estudado as pilhas PAFC tinham potência de $1 \mathrm{MW}_{\mathrm{e}}$ trabalhando a pressão atmosférica, com alimentação de gás natural.

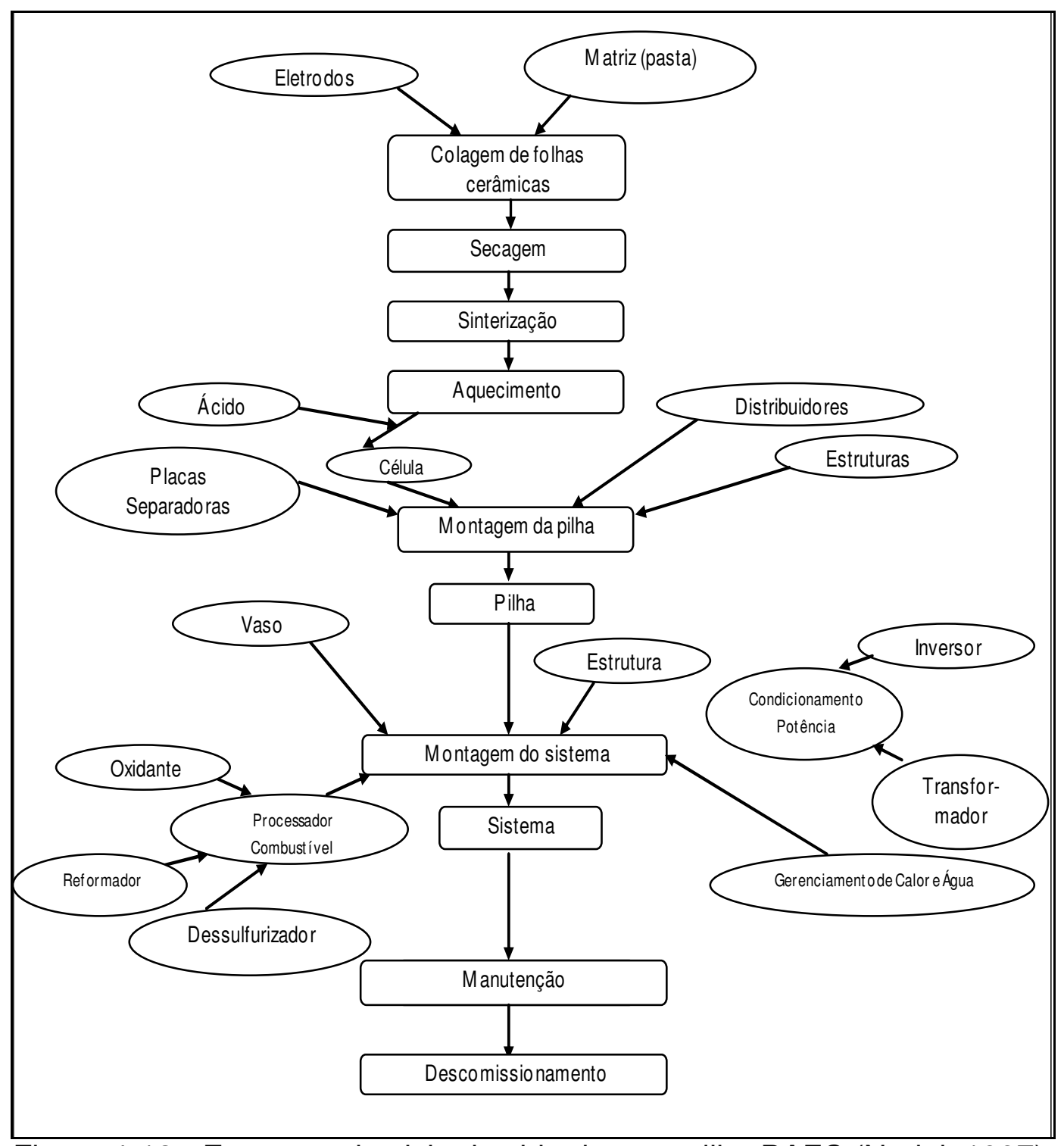

Figura 4-13 - Esquema do ciclo da vida de uma pilha PAFC (Nadal, 1997).

$\mathrm{Na}$ Tabela 4-6 estão apresentadas as quantidades de material utilizadas, por Nadal (1997) para a pilha PAFC. 
Tabela 4-6 - Composição da célula PAFC (NADAL, 1997).

\begin{tabular}{|l|l|}
\hline $\begin{array}{l}\text { Células/pilha (só as partes abaixo } \\
\text { listadas) }\end{array}$ & 828 \\
\hline Grafite $(\mathrm{kg})$ & 4645,08 \\
\hline Ácido fosfórico (kg) & 2235,60 \\
\hline Platina $(\mathrm{kg})$ & 4,97 \\
\hline SiC $(\mathrm{kg})$ & 238,71 \\
\hline Negro de fumo (kg) & 82,80 \\
\hline Teflon $(\mathrm{kg})$ & 78,41 \\
\hline Peso/pilha $(\mathrm{kg})$ & 7285,57 \\
\hline
\end{tabular}

E, na Tabela 4-7 são apresentados os pesos dos componentes utilizados na pilha PAFC, no estudo de Nadal (1997).

Tabela 4-7 - Peso dos componentes do sistema PAFC (NADAL, 1997).

\begin{tabular}{|l|l|}
\hline Peso dos componentes & $\mathrm{t}$ \\
\hline Montagem da pilha & 22 \\
\hline Reformador & 11 \\
\hline Subsistema processamento combustível & 23 \\
\hline Gerenciamento térmico & 34 \\
\hline Transformador & 9 \\
\hline Inversor & 7 \\
\hline Unidade de controle & 2,5 \\
\hline Gerador elétrico & 5,5 \\
\hline Peso total & 114,00 \\
\hline
\end{tabular}

Na Tabela 4-8 estão os pesos dos diversos materiais utilizados na pilha PAFC, adotados no estudo de Nadal (1997).

Tabela 4-8 - Peso dos materiais utilizados no sistema PAFC (NADAL, 1997).

\begin{tabular}{|l|l|}
\hline Peso dos componentes & $\mathrm{kg}$ \\
\hline Grafite & 4645,08 \\
\hline PTFE & 78,41 \\
\hline Platina & 4,97 \\
\hline Ácido fosfórico & 2235,60 \\
\hline Negro de fumo & 82,80 \\
\hline Resina fenólica & 4098,60 \\
\hline Ferro & 4210,00 \\
\hline Aço carbono & 55635,00 \\
\hline Cobre & 2825,00 \\
\hline Alumínio & 930,00 \\
\hline Cerâmica & 1038,71 \\
\hline Plástico & 750,00 \\
\hline Total & 117384,17 \\
\hline
\end{tabular}


Na Fig. 4-14 são apresentados dados de emissão por etapa da vida de uma pilha a ácido fosfórico, cujos dados foram apresentados por Nadal (1997).

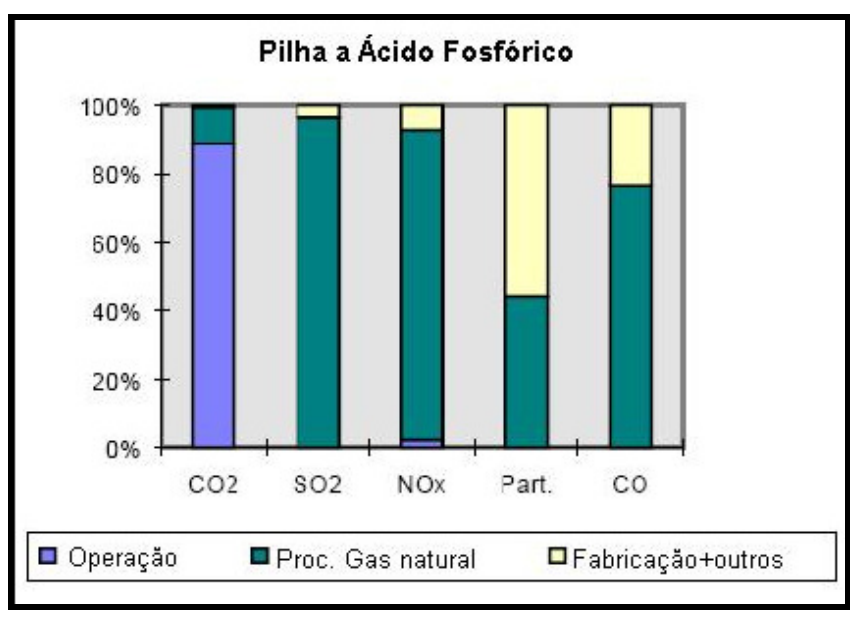

Figura 4-14 - Emissões para PAFC, separadas por etapa durante a vida (Nadal, 1997).

Na Figura 4-15 é apresentada a variação da eficiência da pilha a ácido fosfórico em função da carga. No mesmo gráfico é mostrada a curva de uma turbina a gás, o que mostra que a PAFC é mais eficiente que uma turbina a gás operando em ciclo simples (ou aberto) notadamente a baixas cargas.

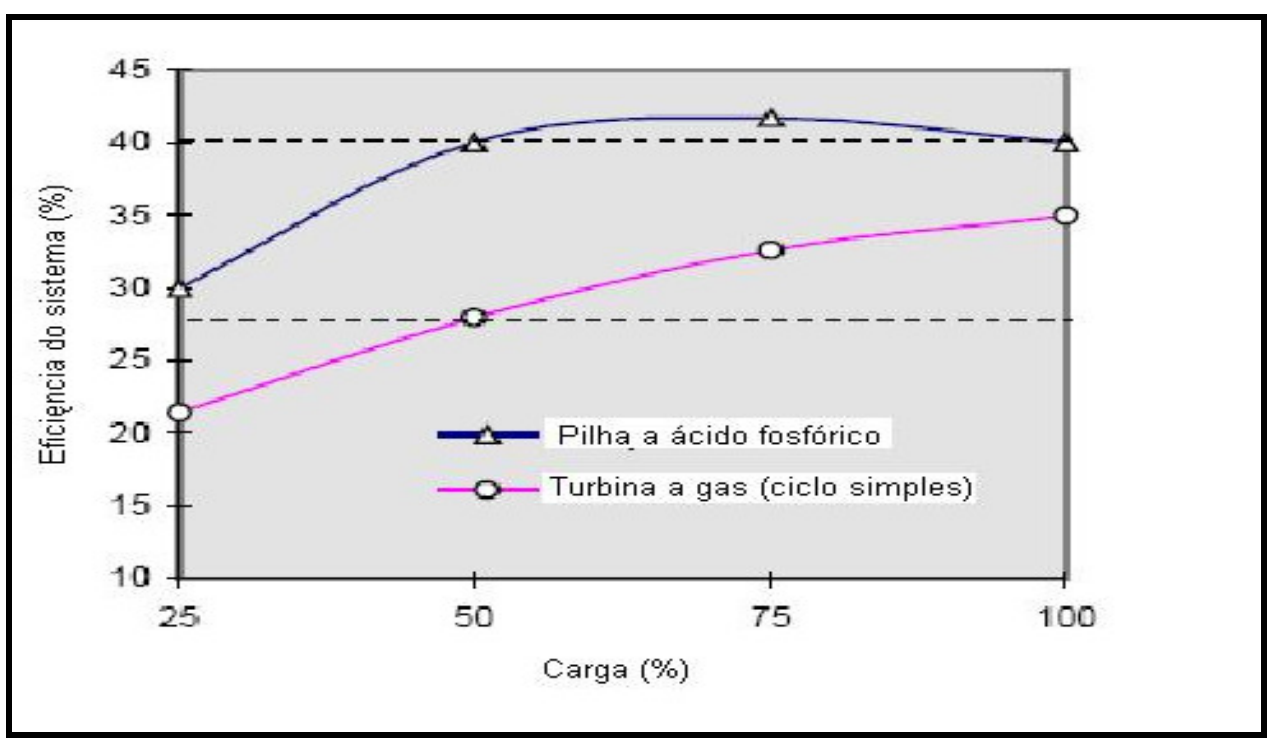

Figura 4-15 - Variação da eficiência do sistema da PAFC e turbina a gás (ciclo simples) em função da carga (Nadal, 1997).

Nas Figuras 4-16 e 4-17 são apresentadas comparações entre as emissões de $\mathrm{SO}_{2}, \mathrm{NO}_{x}$ e $\mathrm{CO}_{2}$ durante o ciclo da vida de diferentes sistemas, tais como: Pilha de ácido fosfórico (PAFC-), Pilha de polímero sólido (SPFC), Turbina 
a gás radial (RGT - "Radial Gas Turbine"), Turbina a gás axial (AGT-"Axial Gas Turbine"), Turbina a gás em ciclo combinado (CCGT - "Combined Cycle Gas Turbine"), Fonte de gás natural (NG - "Natural Gas"), Pilha de alta temperatura (HTFC - "High Temperature Fuel Cell'), Conversão fotovoltaica (PV), Hidrogênio $\left(\mathrm{H}_{2}\right)$. Para o cálculo destas emissões foram utilizadas hipóteses para o suprimento de energia aos processos:

- energia obtida a partir da rede elétrica da Suíça;

- energia obtida a partir de combustíveis fósseis.

O valores de emissões do "grid" representam os valores das emissões, em g/kWhe, de $\mathrm{SO}_{2}, \mathrm{NO}_{x}$ e $\mathrm{CO}_{2}$, referentes a esta energia obtida a partir da rede elétrica da Suíça (que tem as menores emissões) e da energia obtida a partir dos combustíveis fósseis.
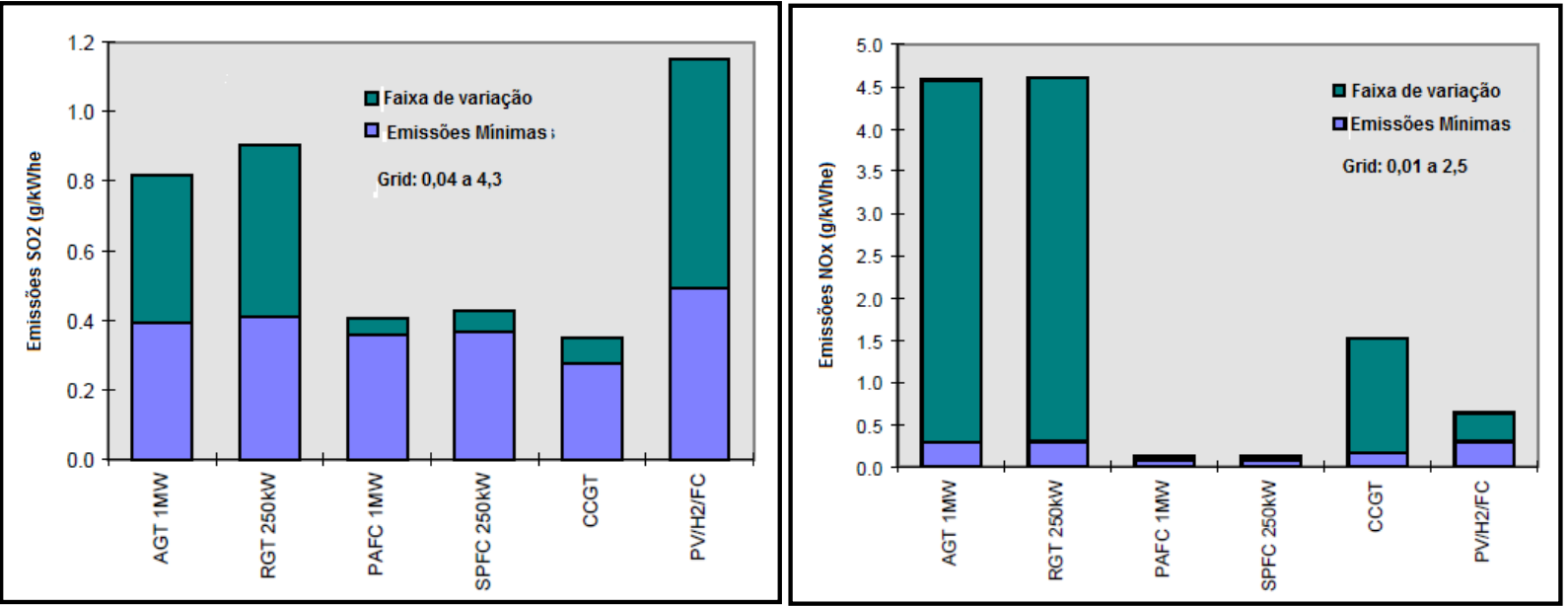

Figura 4-16 - Emissões de $\mathrm{SO}_{2}$ e NOx de vários sistemas durante os respectivos ciclos de vida (NADAL, 1997).

Legenda: PAFC- pilha de ácido fosfórico, SPFC- pilha PEM, RGT- turbina a gás radial, AGT turbina a gás axial, CCGT- turbina a gás em ciclo combinado, PV- conversão fotovoltaica, H2hidrogênio

Os resultados mostrados nas Figuras 4-16 e 17, não consideraram as emissões que seriam evitadas pelo uso do calor em excesso, produzido pelo sistema PAFC, ou seja, através da operação em cogeração ou ciclo combinado. A eficiência térmica do sistema PAFC é de aproximadamente $40 \%$.

Conforme cálculos efetuados pelo NYSERDA ("New York State Energy Research and Development Authority, 1997'), citado por Nadal (1997), aproximadamente $4 \mathrm{MJ}$ de gás natural sai da PAFC, na forma de energia térmica, por kWhe produzido. 


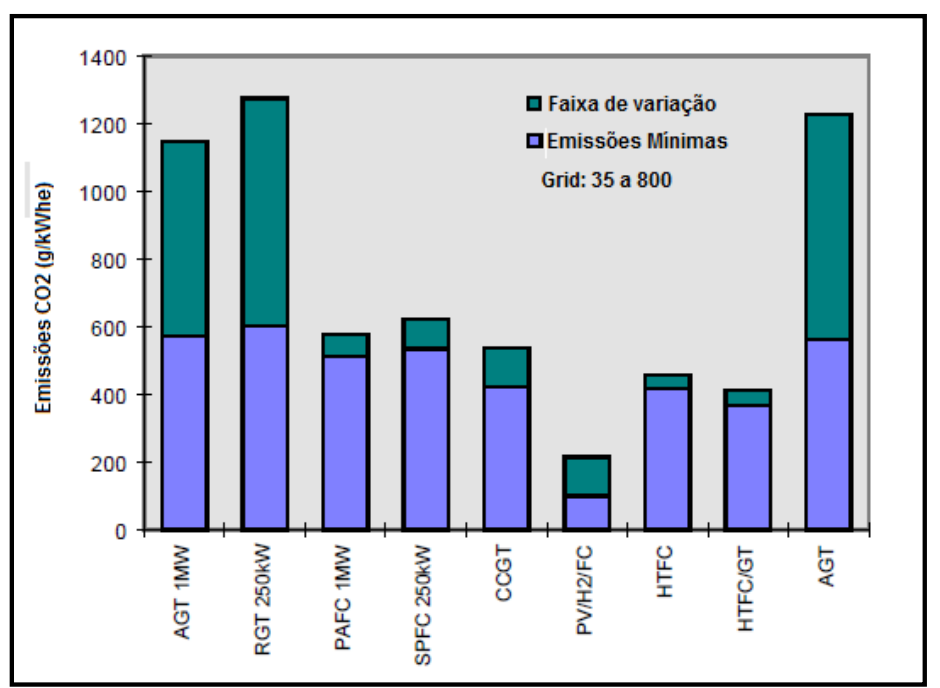

Legenda:

PAFC- Pilha de ácido fosfórico, SPFC- Pilha de polímero sólido, RGT- Turbina a gás radial, AGT-Turbina a gás axial, CCGT- Turbina a gás em ciclo combinado,

NG- Fonte de gás natural, HTFC- Pilha de alta temperatura, PV- conversão fotovoltaica, $\mathrm{H}_{2}$-Hidrogênio.

Figura 4-17 - Emissões de $\mathrm{CO}_{2}$ de vários sistemas durante os respectivos ciclos de vida (Nadal, 1997).

Se for considerada a combustão dos gases quentes que saem da pilha numa caldeira resultaria em diminuição das emissões, pois a combustão dos gases quentes evitaria um maior consumo de combustível (emissões evitadas).

Na Figura 4-18 estão mostrados os valores de créditos das emissões referentes à energia térmica que pode ser aproveitada numa pilha PAFC.

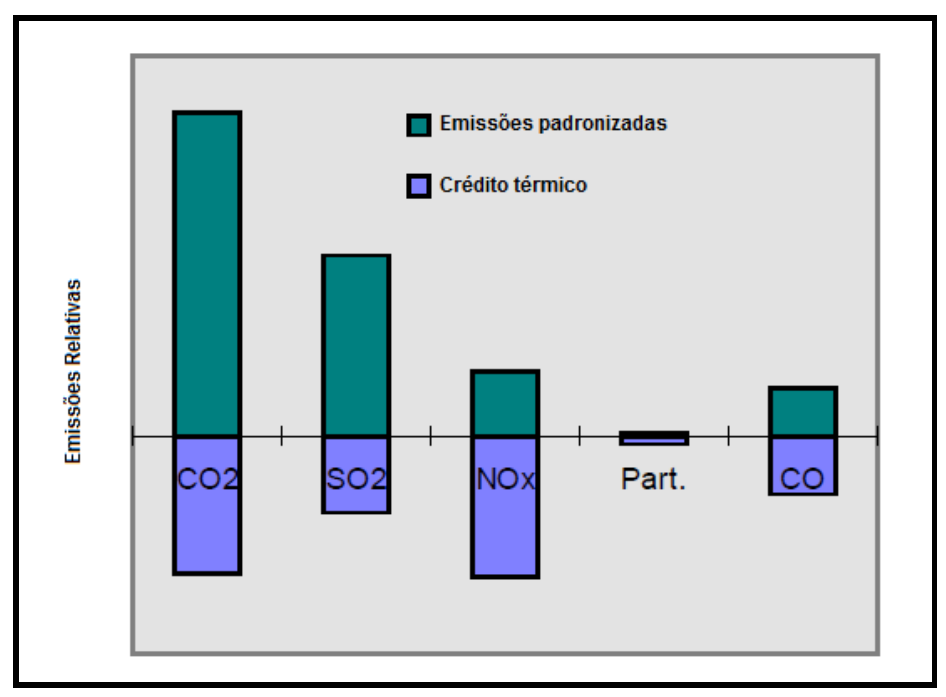

Figura 4-18 - Crédito de emissões referente ao uso da energia térmica oriunda da PAFC, em relação ao caso em que esta energia não é utilizada (Nadal, 1997).

O valor das emissões evitadas varia de caso para caso dependendo dos coeficientes de emissão da caldeira utilizada e da eficiência com a qual a carga térmica possa ser compensada com a produção a partir da PAFC. 
O trabalho de Nadal (1997) avaliou que as emissões ambientais das pilhas PAFC são apenas um pouco menores, quando operam em carga total, quando comparado com as emissões das novas gerações de turbinas a gás operando em ciclo aberto (simples). Quando opera em carga de $50 \%$, a PAFC apresenta emissões de $\mathrm{CO}_{2}$ e $\mathrm{SO}_{2}$ menores que as emissões das novas gerações de turbinas a gás quando operam em ciclo aberto. Nadal (1997) também concluiu que as pilhas PAFC e as turbinas a gás, quando operando em ciclo combinado, podem ter as emissões reduzidas através da diminuição do consumo de combustível, entre $30 \%$ e $15 \%$ respectivamente. É claro que se as pilhas PAFC pudessem operar a temperaturas mais altas aumentariam esta eficiência o que diminuiria as emissões. Este é um dos possíveis desenvolvimentos para este tipo de pilha.

\subsection{4-Impacto ambiental por causa do término da vida útil}

No final da vida útil a pilha deverá ser descomissionada e uma avaliação inicial deste estágio indica que não existem impactos ambientais adversos ou perigosos.

A chave para diminuir os impactos do descomissionamento é a reciclagem.

Nesta etapa será importante a recuperação da Platina presente tanto no anodo como no catodo, conforme já discutido anteriormente no item 4.1. Também pode ser recuperado o catalisador presente no reformador, que é o Níquel.

A maior parte do sistema de célula combustível é construída a partir de metais ferrosos e pode ser possível reciclá-las ou, em alguns casos, usá-las como peças sobressalentes. 


\section{3 - Impacto ambiental por causa do uso da Pilha de Carbonato Fundido}

Em 2004, Lunghi et al. (2004b) publicaram trabalho sobre avaliação do impacto ambiental de pilhas de carbonato fundido, alimentada por gás natural e por gases de aterro.

Na Fig. 4-19 a seguir está mostrado o sistema analisado de uma pilha de carbonato fundido.

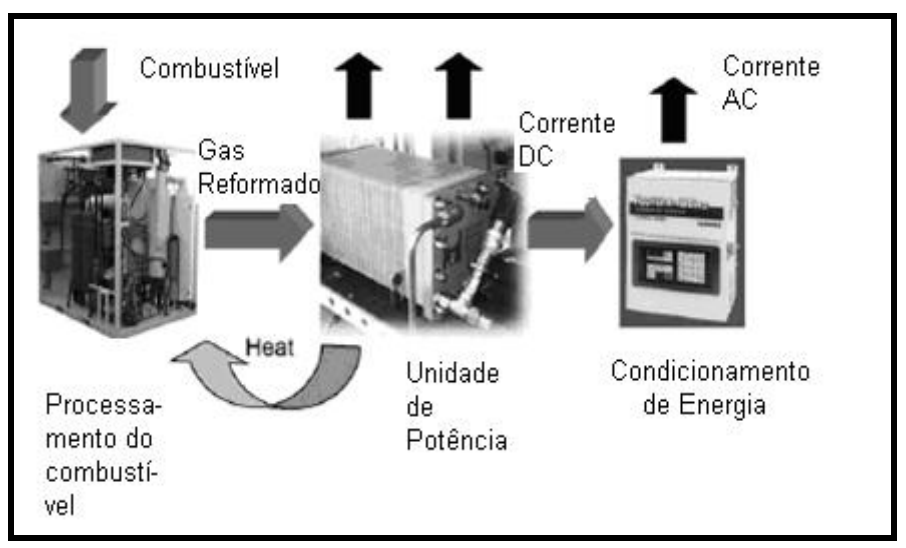

Figura 4-19 - Sistema de uma pilha de carbonato fundido (LUNGHI et al., 2004b)

Neste trabalho Lunghi et al., (2004b) efetuaram a comparação de emissões pela pilha MCFC utilizando dois cenários, a saber:

Cenário 1 - cenário em que a produção de hidrogênio é efetuada em uma grande unidade afastada do local de operação da pilha.

Cenário 2 - a produção de hidrogênio é efetuada em pequenas unidades localizadas próximas a pilha.

No caso do cenário 1 foram obtidos os valores de emissões por fase da vida da pilha conforme apresentado na Figura 4-20. O alto impacto da produção do hidrogênio no item fontes de energia é por causa do consumo de energia muito alto na etapa da reforma do vapor. Pode-se concluir o mesmo para o item aquecimento global. Já para a acidificação a maior contribuição provém da fase de produção da pilha, e a operação contribui de modo não significativo.

No cenário 2 a queima de gás natural e a reforma ocorrem dentro da própria pilha, o que implica numa diminuição das emissões de $\mathrm{CO}_{2}$. Na Figura 421 são apresentados os resultados de emissões. 


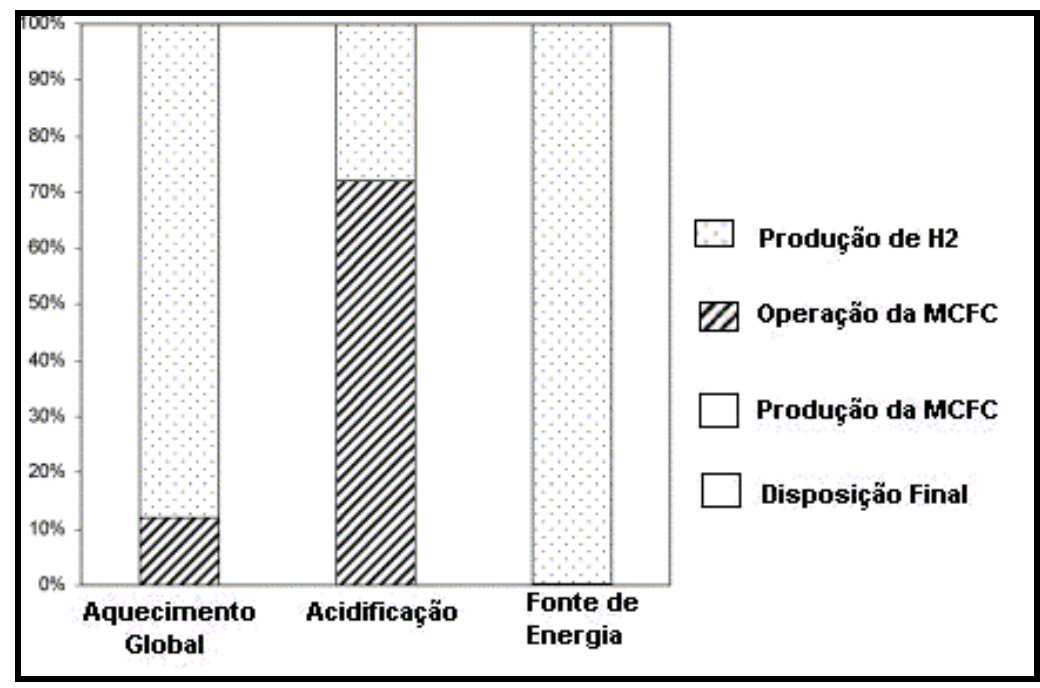

Figura 4-20 - Resultados para o cenário 1 com a pilha MCFC (LUNGHI et al., 2004b).

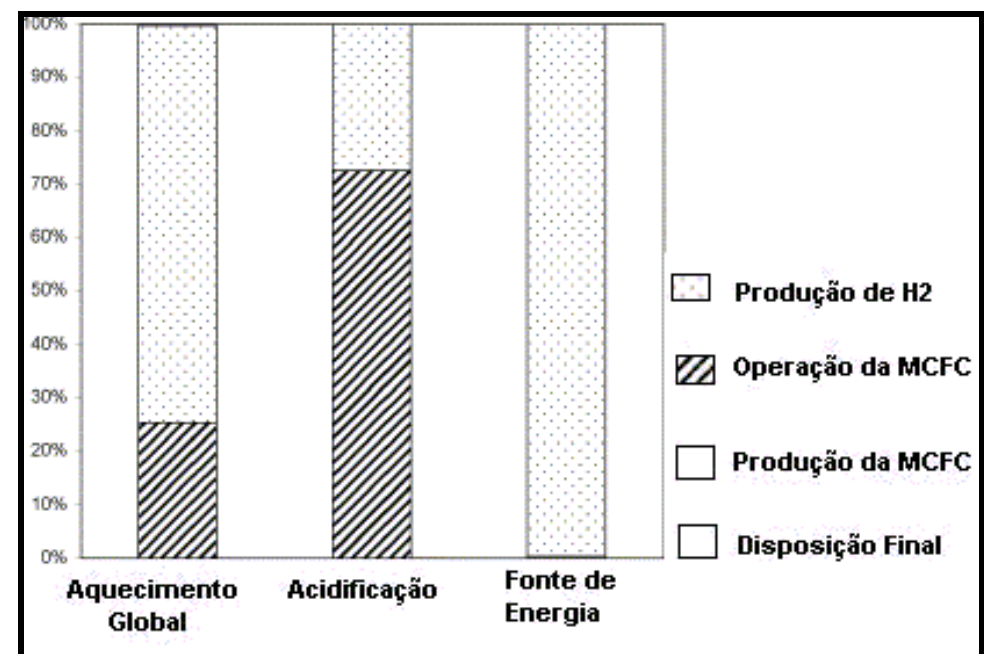

Figura 4-21 - Resultados para o cenário 2 com a pilha MCFC (LUNGHI et al., 2004b).

Lunghi et al. (2004b) também consideraram importante a influência das fontes de energia elétrica utilizadas na etapa de produção das pilhas MCFC. Assim neste trabalho foram considerados diversos cenários para estas fontes:

- sistema elétrico italiano (2003);

- pelo sistema da MCFC cenário 1;

- pelo sistema da MCFC cenário 2;

- por turbinas a gás.

A Figura 4-22 mostra que a quantidade de $\mathrm{SO}_{2}$-eq emitida nos quatro cenários acima listados. Como pode ser observada a utilização do sistema MCFC pode levar a uma redução em relação ao valor emitido pelo sistema elétrico da Itália, mas é maior que os valores para emissões de plantas com Turbinas a gás. 
Isto ocorre por causa do efeito dos gases durante a produção da pilha MCFC e durante a reforma do vapor. Na Tabela 4-9 são apresentados os valores das emissões de vários gases para os 4 cenários considerados.

Figura 4-22 - Comparação da quantidade de SO2-eq emitida pelos sistemas

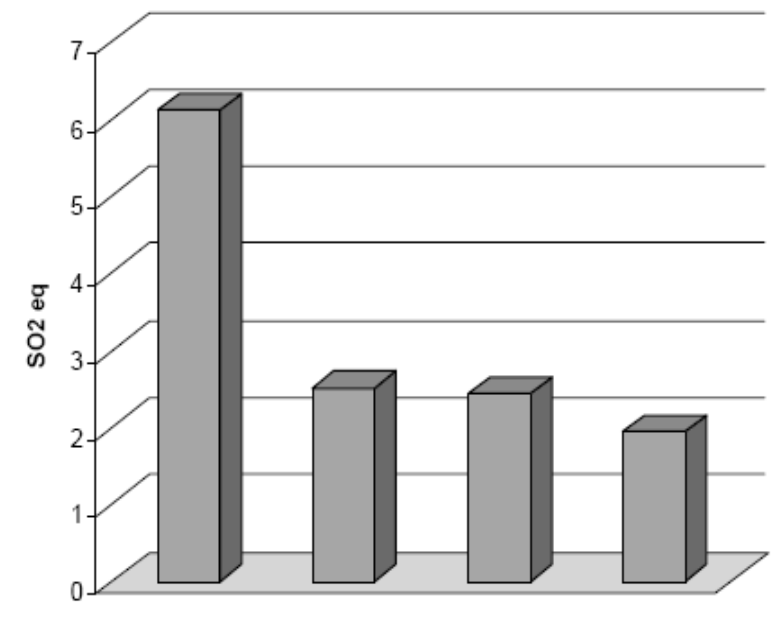

Itália MCFC 1 MCFC 2 GT

Figura 4-22 - Comparação da quantidade de SO2-eq emilida pelos sistemas

Tabela 4-9 - Comparação entre os vários cenários

\begin{tabular}{|c|c|c|c|c|}
\hline \multicolumn{5}{|c|}{ Comparação entre os vários cenários } \\
\hline Substância & Mistura Itália & MCFC 1 & MCFC 2 & GT \\
\hline Metano: $(\mathrm{g})$ & 1.01 & 6.35 & 6.35 & 1.32 \\
\hline $\mathrm{N}_{2} \mathrm{O}(\mu \mathrm{g})$ & 12.00 & 0.48 & 0.48 & 5.63 \\
\hline $\mathrm{CO}_{2}(\mathrm{~g})$ & 767.07 & 1150.61 & 528.43 & 1323.91 \\
\hline $\mathrm{gCO}_{2}-\mathrm{eq}$ & 788.28 & 1284.10 & 661.93 & 1353.37 \\
\hline $\mathrm{SO}_{2}(\mathrm{~g})$ & 4.90 & 1.57 & 1.57 & 0.18 \\
\hline $\mathrm{NO}_{x}(\mathrm{~g})$ & 1.69 & 1.34 & 1.24 & 2.51 \\
\hline $\mathrm{H}_{2} \mathrm{~S}(\mu \mathrm{g})$ & 0.86 & 0.01 & 0.01 & 4.07 \\
\hline $\mathrm{HCl}(\mu \mathrm{g})$ & 23.30 & 0.34 & 0.34 & 0.63 \\
\hline $\mathrm{HF}(\mu \mathrm{g})$ & 5.67 & 0.08 & 0.08 & 0.08 \\
\hline $\mathrm{gSO}_{2}$-eq & 6.11 & 2.50 & 2.43 & 1.94 \\
\hline
\end{tabular}

A Figura 4-23 mostra os valores de emissão de gases responsáveis pelo aquecimento global para os casos considerados. 


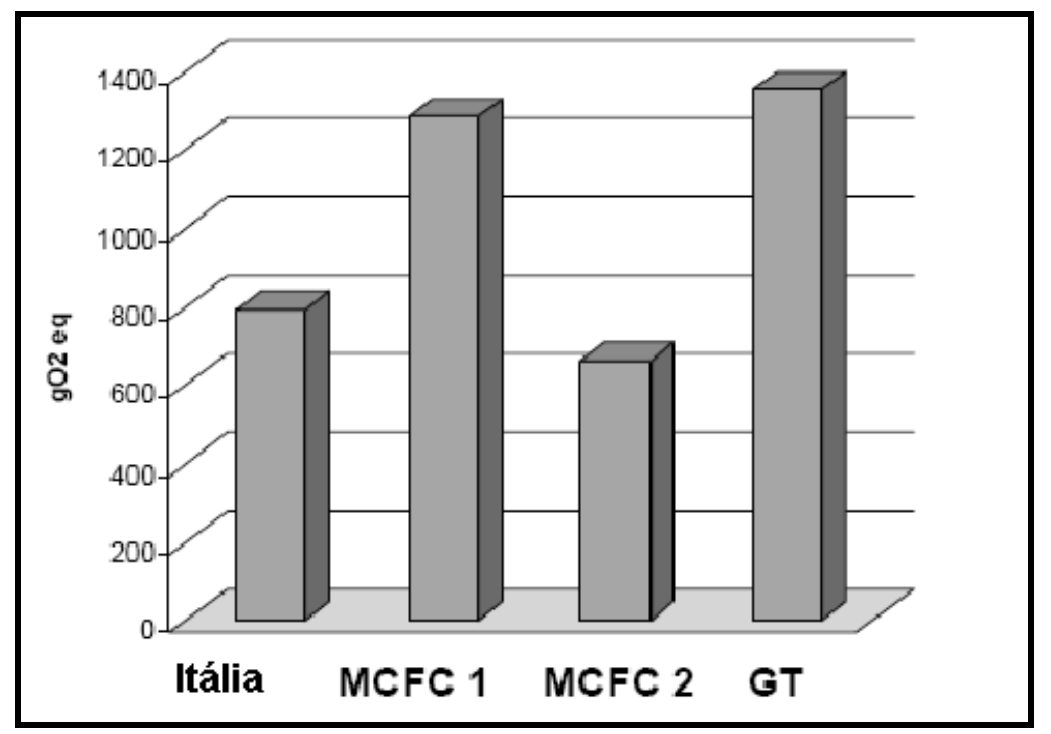

Figura 4-23 - Comparação da emissão de gases CO2-eq para vários cenários (LUNGHI et al., 2004b).

Se $\circ \mathrm{H}_{2}$ for produzido em uma unidade centralizada, a quantidade total de gases responsáveis pelo aquecimento global irá aumentar, no caso em estudo para a Itália, para valores maiores que os atuais. Este resultado é muito importante, pois as pilhas combustíveis são consideradas instrumentos importantes para diminuição do aquecimento global, justamente porque durante sua operação a emissão de poluentes é quase nula.

De qualquer modo a reforma do gás natural com vapor é uma tecnologia estar matura, sendo difícil enxergar grandes avanços na redução da emissão de $\mathrm{CO}_{2}$. Um alto desempenho ambiental para as pilhas só deve ser obtido através da utilização de combustíveis obtidos com base em fontes renováveis. A reforma do gás natural pode ser utilizada como uma fase de transição entre a economia baseada em combustíveis fósseis para uma economia baseada no hidrogênio.

A Fig. 4-24 a seguir mostra um esquema de pilha MCFC operada utilizando os gases provenientes de aterros. 


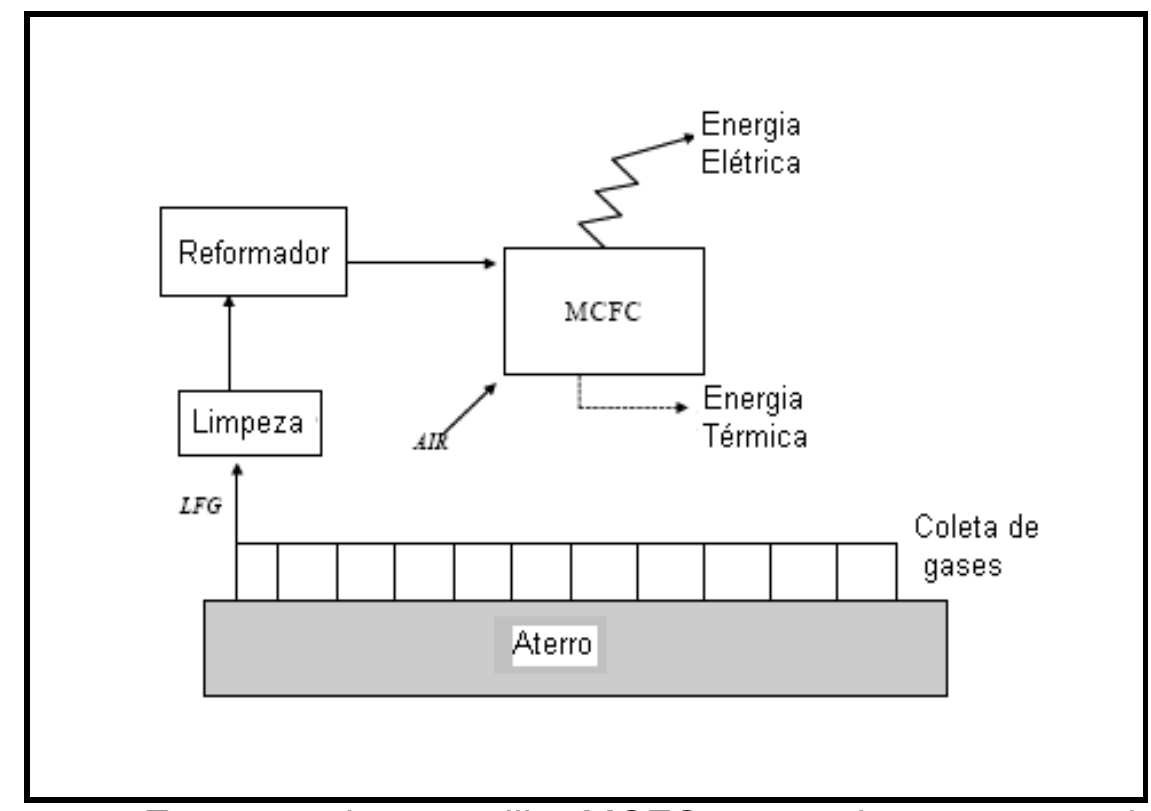

Figura 4-24 - Esquema de uma pilha MCFC operando com gases de aterro.

Na Figura 4-25 são mostrados os valores obtidos para aquecimento global comparando uma pilha MCFC operada com gás natural e com gás proveniente de aterro.

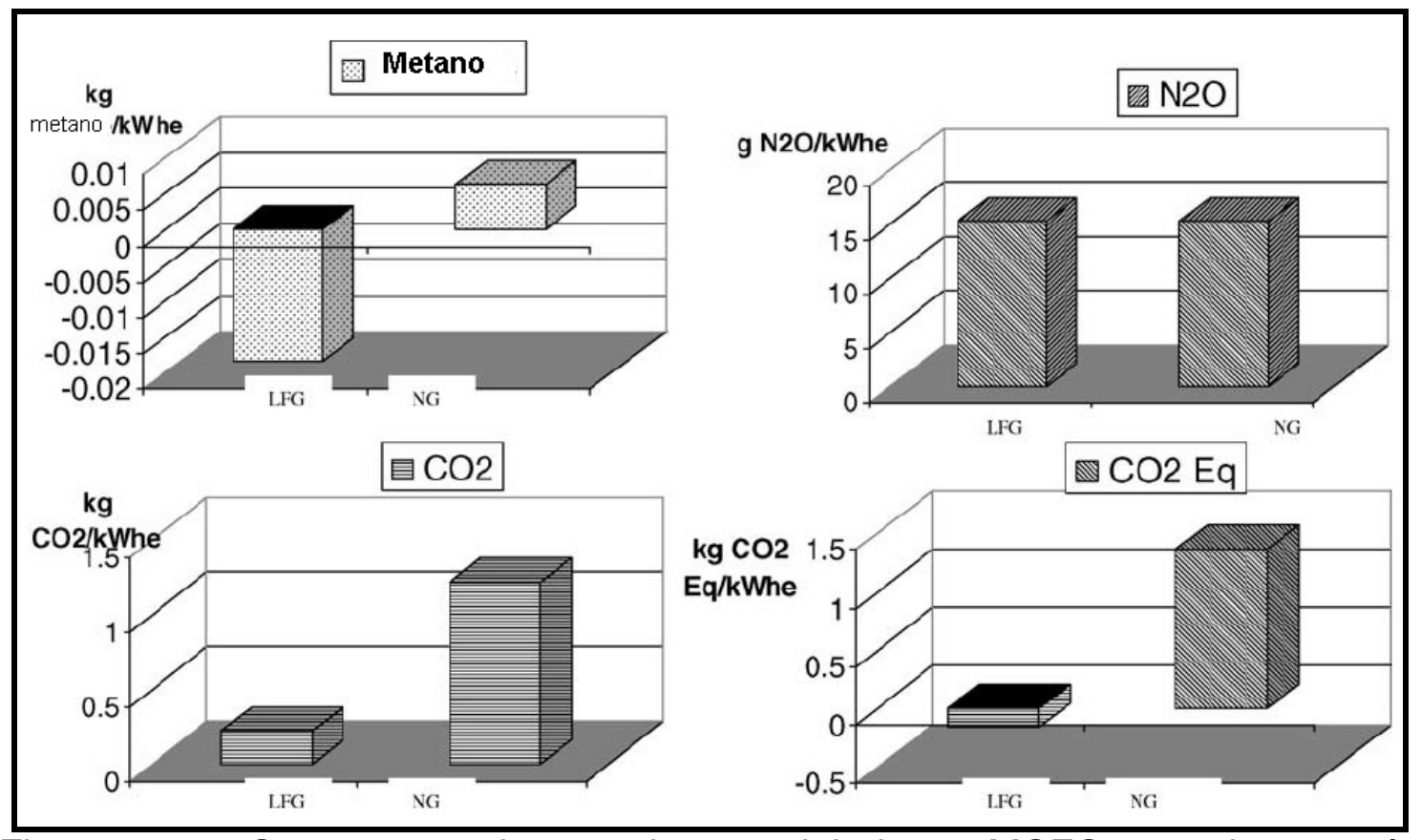

Figura 4-25 - Comparação do aquecimento global para MCFC operada com gás natural (NG) e com gases obtidos valendo-se de aterros (LFG)

(LUNGHI et al., 2004a).

Na Fig. 4-26 são apresentados os dados de acidificação para uma pilha MCFC operando com gás natural e com gases obtidos em aterros. 


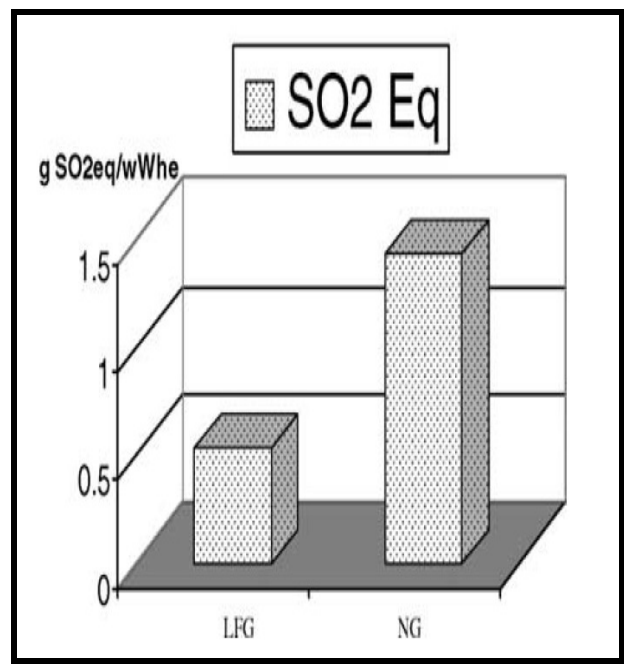

Figura 4-26 - Acidificação com comparação entre pilha de Carbonato fundido operada com gás natural (NG) e com gases obtidos valendo-se de aterros (LFG) (LUNGHI et al., 2004a)

Note-se que o uso de gases provenientes de aterro não será suficiente para prover energia suficiente para substituição dos combustíveis fósseis. O que se pode é substituir parcialmente os combustíveis fósseis por renováveis

Raugei et al. (2004) apresentou uma avaliação do impacto ambiental de pilhas de carbonato fundido, utilizando um protótipo de $500 \mathrm{~kW}$. Os dados operacionais e de produção foram fornecidos pela ENEA e Ansaldo. Visto que a planta de $500 \mathrm{~kW}$ ainda está em desenvolvimento, alguns dados foram extrapolados através dos dados da pilha protótipo (unidade de $50 \mathrm{~kW}$ ). O sistema analisado contém um reformador externo que transforma o gás natural em uma corrente gasosa rica em gás hidrogênio. Esta mistura é alimentada no anodo da pilha planar na temperatura de $650^{\circ} \mathrm{C}$ e o calor em excesso da pilha é utilizado no reformador. Para maiores detalhes vide Raugei et al. (2004).

Na Tabela 4-10 estão apresentados os dados de emissões em escala global, nos estados sólido, líquido e gasoso, relacionadas com a produção de eletricidade via MCFC.

As emissões de $\mathrm{CO}_{2}$ apresentadas pelas pilhas MCFC são da mesma ordem de grandeza de turbinas a gás trabalhando em co-geração. Isto se deve especialmente à utilização do gás natural como combustível que gera 0 hidrogênio. As emissões de NOx no caso da pilha MCFC, são menores que a das plantas térmicas, pois a pilha MCFC opera em temperaturas menores que a das caldeiras e turbinas das plantas térmicas. 
Tabela 4-10 - Características e desempenho da pilha MCFC utilizada por Raugei et al. (2004)

\begin{tabular}{|c|c|}
\hline Características e Fluxos & Pilha MCFC 500MW \\
\hline \multicolumn{2}{|l|}{ Características da Planta } \\
\hline Potência elétrica nominal (MW) & 0.5 \\
\hline Tempo de operação (s/ano) & $2,40 \times 10^{7}$ \\
\hline Tempo de vida (anos) & 6 \\
\hline \multicolumn{2}{|l|}{ Fluxos materiais e exergéticos (somente processo) } \\
\hline Fornecimento de combustível (kg/ano) & $4,50 \times 10^{5}$ \\
\hline Exergia específica do combustível (J/kg) & $5,20 \times 10^{7}$ \\
\hline Exergia total do combustível fornecido (J/ano) & $2,39 \times 10^{13}$ \\
\hline Demanda de água do processo (Kg/ano) & $1,80 \times 10^{6}$ \\
\hline Fluxo de ar do processo (kg/ano) & $2,07 \times 10^{6}$ \\
\hline Massa da planta (aço, kg/ano) & $6,20 \times 10^{3}$ \\
\hline Massa da planta (concreto, kg/ano) & 0 \\
\hline Massa da planta (especialmente $\mathrm{Al} 2 \mathrm{O} 3$ e Níquel) & $1,19 \times 10^{3}$ \\
\hline \multicolumn{2}{|l|}{ Emissões no ar } \\
\hline Liberações de CO2(kg/MWh) & 486 \\
\hline Liberações de CO (kg/MWh) & 0,19 \\
\hline Liberações de NOx (kg/MWh) & 0,32 \\
\hline \multicolumn{2}{|l|}{ Indicadores de desempenho em escala local } \\
\hline \multicolumn{2}{|l|}{ Eficiência conforme a 2a. Lei } \\
\hline Eficiência exergética elétrica & $38 \%$ \\
\hline Eficiência exergética total & $66 \%$ \\
\hline Perdas exergéticas (fase operacional) (J/ano) & $8,07 \times 10^{12}$ \\
\hline
\end{tabular}

$\mathrm{Na}$ Tabela 4-11 são apresentadas as principais emissões sólidas, 
líquidas e gasosas associadas com a produção de energia elétrica via pilha MCFC de 500MW (RAUGEI et al., 2004).

Tabela 4-11 - Principais emissões sólidas, líquidas e gasosas associadas com a produção de energia elétrica via pilha MCFC de 500MW (RAUGEI et al., 2004).

\begin{tabular}{|ll|}
\hline & $g / k W h$ \\
\hline Rejeito sólido & 18,5 \\
\hline Rejeito Mineral (incluindo Ni, Cr, Li, Al, minérios) & 0,00156 \\
Na2CrO4 (sem reagir) & 0,000744 \\
Cr(OH)3 (sem reagir) & 0,000207 \\
Cr2O3 (sem reagir) & 0,0812 \\
Rejeitos do processo a & 1,58 \\
Máquinas utilizadas b & 2,02 \\
\hline Estrutura da planta C & \\
\hline Rejeitos líquidos & 1263 \\
\hline Água de flotação resultante da extração de minérios e processamento & \\
\hline Rejeitos gasosos & 0,0212 \\
\hline Tetracloroetileno & 0,0106 \\
Ni(CO)4 (sem reagir) & 0,0704 \\
SO2 do processamento e transporte & 0,197 \\
CO do processamento e transporte & 486 \\
CO2 do processamento e transporte & 0,319 \\
NOx do processamento e transporte & 0,00583 \\
Hidrocarbonetos não queimados a partir do processamento e transporte & 0,00486 \\
\hline Particulado do processamento e transporte & \\
\hline
\end{tabular}

A eficiência exergética apresentada pela pilha MCFC ainda pode ser aumentada, após algum desenvolvimento, utilizando-se a contribuição térmica cogenerativa.

Apesar da pouco tempo de vida das pilhas MCFC algumas melhorias já podem ser visualizadas, como por exemplo, redução nos metais empregados 
como $\mathrm{Ni}, \mathrm{Cr}$, aumento do tempo de vida útil da pilha e centralização da fase da reforma, para obter hidrogênio em maior escala, possibilitando o seqüestro de $\mathrm{CO}_{2}$ e sua estocagem.

\section{4-Impacto ambiental do hidrogênio}

Aproximadamente $48 \%$ da produção de hidrogênio mundial é efetuada a partir da reforma do gás natural, 30\% através do processamento de petróleo cru, $18 \%$ pelo processamento de carvão e $3 \%$ como subproduto da fabricação de Cloro. Entretanto existem vários processos inovadores, tais como o processo de hidrogênio e carbono desenvolvido por Kvaerner com produção paralela de negro de fumo, a eletrólise a partir de várias fontes de eletricidade ou gaseificação de biomassa. E mais, o seqüestro de $\mathrm{CO}_{2}$, ou mesmo o seu uso comercial, tem sido mencionado como um dos métodos de diminuição da emissão de gases causadores do aquecimento global, através da fabricação de hidrogênio.

As várias etapas de fornecimento diferem em termos de patamares de distribuição podendo ter:

- o transporte do gás natural e a reforma no local de uso da pilha,

- o transporte do hidrogênio gasoso $\left(\mathrm{GH}_{2}\right)$,

-o transporte do hidrogênio líquido $\left(\mathrm{LH}_{2}\right)$ por meio de barcos ou ferrovias,

- o transporte de eletricidade (HVDC- "High Voltage Direct Current") com a conversão direta do hidrogênio no local do uso.

A Figura 4-27 mostra uma comparação do potencial de aquecimento global e acidificação para diferentes cenários de transporte de hidrogênio gerado a partir de fontes de energia renováveis (PEHNT, 2003c). O cenário considerado foi o da produção de hidrogênio, na Noruega, a partir da eletricidade renovável, sendo posteriormente transportado para a Alemanha.

A reforma do gás natural é um dos processos mais comuns e a eficiência da conversão depende o uso do vapor produzido como subproduto. Penth (2003c) informa a existência de eficiências do processo apontadas por vários autores, sendo a mais otimista de $89 \%$ (o maior valor com o vapor sendo exportado), ao passo que outros autores informam o valor de eficiência de $81 \%$ (quando o vapor produzido é usado para um processo posterior).

No caso da reforma é importante salientar que para evitar poluição do 
meio ambiente, deverá existir no reformador um seqüestro de $\mathrm{CO}_{2}$, evitando enviar este gás diretamente para a atmosfera. Na reforma também é utilizado catalisador, o qual poderá conter Níquel, Platina, Paládio ou Ródio.

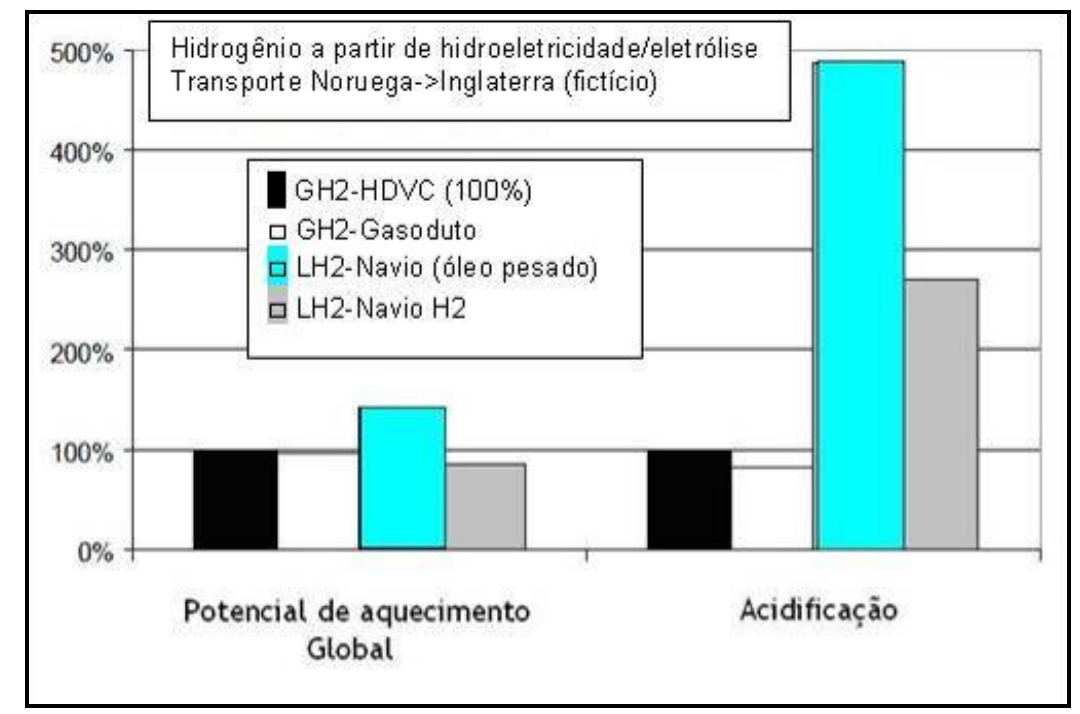

Figura 4-27 - Comparação do potencial de aquecimento global e acidificação para diferentes cenários de transporte de hidrogênio gerado a partir de fontes de energia renováveis

Após o término da vida útil deste catalisador será necessário efetuar sua reciclagem a fim de evitar a contaminação do solo, água e ar, conforme será tratado do capítulo referente a materiais do grupo da Platina.

A gaseificação de biomassa e a eletrólise da água, utilizando energia elétrica renovável, são opções atrativas para produção de hidrogênio como energia primária renovável. Entretanto os potenciais de energia renovável devem ser analisados com cuidado, pois poderiam ser utilizados mais eficientemente na geração de calor ou em pilhas estacionárias. Como exemplo Penth (2003c) cita que $1 \mathrm{kWh}$ de energia térmica convencional substituída por eólica, na Alemanha, diminui a emissão em $700 \mathrm{~g}$ de equivalentes a $\mathrm{CO}_{2}$., mas a substituição de gasolina por hidrogênio produzido através da energia eólica pelos mesmos 1 $\mathrm{kWh}$, através da eletrólise diminui a emissão em $320 \mathrm{~g}$ de equivalentes a $\mathrm{CO}_{2}$. No futuro, com a energia elétrica tornando-se menos intensiva em $\mathrm{CO}_{2}$. E a extração de petróleo tornado-se cada vez mais difícil pode ser que esta situação seja alterada.

De qualquer modo o importante é que fique claro que o hidrogênio não é um combustível com emissão zero de $\mathrm{CO}_{2}$. Assim o fornecimento de hidrogênio 
também deve ser considerado para determinar as emissões e suas conseqüências ambientais.

\subsection{1 - Mecanismos de Impacto Ambiental do hidrogênio}

A seguir estão detalhados os mecanismos de impacto ambiental do hidrogênio.

A molécula de hidrogênio $\left(\mathrm{H}_{2}\right)$ é um componente da camada inferior da atmosfera que está presente como traço. Estudos demonstram que, a alturas limitadas, a abundância é de aproximadamente 500ppbv, a qual está aumentando em aproximadamente 5ppbv/ano-1 (UK DEPT. FOR TRANSPORT, 2006).

O hidrogênio na forma molecular pode contribuir para modificar 0 ambiente através dos seguintes mecanismos:

- produção de Ozônio ao nível do solo;

- produção de Ozônio na troposfera;

- alterações climáticas;

- química do Ozônio na estratosfera.

\subsubsection{2- Produção de Ozônio ao nível do solo}

Durante o verão, ocorrem atualmente episódios de poluição caracterizados pela concentração de Ozônio, excedendo os padrões de qualidade para proteção da vida humana e nos vegetais. O Ozônio não é emitido diretamente para a troposfera, mas é um poluente secundário formado pela oxidação, iniciada pela luz solar, de compostos orgânicos voláteis na presença de óxidos de Nitrogênio (NOx).

Um dos fatores principais para avaliar a produção episódica de Ozônio é a velocidade de reação dos compostos precursores do Ozônio com $\mathrm{OH}^{`}$ :

$$
\mathrm{OH}^{-}+\mathrm{H}_{2} \rightarrow \mathrm{H}^{+}+\mathrm{H}_{2} \mathrm{O} \quad \text { Equação 4-1 }
$$

A reação do $\mathrm{H}_{2} \mathrm{com} \mathrm{OH}^{-}$é lenta e comparável à velocidade da reação do $\mathrm{OH}^{-}$com metano. A vida do metano na atmosfera, e portanto do $\mathrm{H}_{2}$, relativa a esta reação é de aproximadamente 10 anos. Portanto o hidrogênio molecular fará uma contribuição insignificante para a produção episódica de Ozônio ao nível do solo. 


\subsubsection{3 - Produção de Ozônio na troposfera}

A oxidação completa do hidrogênio para água, na troposfera leva a produção de Ozônio, como mostrado abaixo:

$$
\mathrm{H}_{2}+2 \mathrm{O}_{2}+\mathrm{hy} \rightarrow \mathrm{H}_{2} \mathrm{O}+\mathrm{O}_{3} \quad \text { Equação 4-2 }
$$

A química do hidrogênio na troposfera está ligada à química do metano, visto que a oxidação do metano produz formaldeído ( $\mathrm{HCHO}$ ) como intermediário. Uma das reações de foto dissociação do formaldeído produz hidrogênio molecular.

$$
\begin{array}{ll}
\mathrm{HCHO}+\mathrm{hy} \rightarrow \mathrm{H}_{2}+\mathrm{CO} & \text { Equação 4-3 } \\
\mathrm{HCHO}+\mathrm{hy} \rightarrow \mathrm{H}^{+}+\mathrm{HCO}^{-} & \text {Equação 4-4 }
\end{array}
$$

A rota da equação 4-3 é a responsável pela maior fonte de hidrogênio atmosférico. Já a rota da equação 4-4 é um patamar significativo da formação de Ozônio.

Além das fontes fotoquímicas, ou seja, a partir da oxidação do metano e outros compostos orgânicos, existem duas fontes de combustão (combustão de combustíveis fósseis e de biomassa). Estas fontes representam aproximadamente $90 \%$ da fonte de hidrogênio atmosférico, sendo o restante atribuído às emissões vulcânicas, dos oceanos, e produção de leguminosas.

A oxidação por radicais hidroxila $\left(\mathrm{OH}^{-}\right)$atua como um importante sumidouro de hidrogênio na troposfera. O outro sumidouro principal de hidrogênio é a deposição na terra. A deposição no solo é motivada biologicamente, provavelmente, utilizando as enzimas do solo.

Note-se que a concentração média de hidrogênio no hemisfério Norte é menor que no Sul. Novelli et al. (citado em PRATER et al., 2001), efetuou uma balanço do tempo de vida do hidrogênio na atmosfera como sendo entre 2-3 anos.

\subsubsection{4 - Alterações Climáticas}

O hidrogênio não é um gás que cause alterações climáticas, como o efeito estufa em razão da sua vibração fundamental não estar na faixa do infravermelho ativo e porque o comprimento de onda da vibração $(2,3 \mu)$ está fora 
da região da janela da atmosfera $(7-13 m \mu)$.

Mas o hidrogênio tem impacto indireto nas alterações climáticas em razão da:

- Estar envolvido na produção de Ozônio na troposfera;

- Poder modificar a concentração de metano através do efeito na concentração do radical hidroxila $\mathrm{OH}^{-}$.

Derwent (2001) usou o módulo químico do software troposférico denominado Stochem global 3D para calcular os efeitos indiretos do hidrogênio, e também $\mathrm{CO}, \mathrm{CH}_{4}$ e $\mathrm{NO}_{x}$, nas mudanças climáticas. Neste trabalho foram apresentados os potenciais de aquecimento global resultantes das alterações:

- na concentração do radical $\mathrm{OH}^{-}$e suas conseqüências para o metano;

- no Ozônio produzido;

- $\quad$ no $\mathrm{CO}_{2}$ produzido na oxidação completa do metano e CO2.

Os cálculos foram efetuados baseados na emissão de um pulso de uma tonelada de gás das espécies precursoras do Ozônio, num horizonte de 100 anos. O valor do potencial de aquecimento global (GWP) para o hidrogênio foi 5,4 que é superior se comparado ao do CO cujo GWP é 1 (um) e inferior ao do metano $\left(\mathrm{CH}_{4}\right)$ que é 21 .

É importante entender que a quebra dos compostos orgânicos e óxidos do Nitrogênio (originados a partir da combustão dos combustíveis fósseis), através da luz solar, a níveis mais baixos da atmosfera (troposfera) pode levar a um aumento excessivo do Ozônio (O3). Este Ozônio pode danificar a vegetação, os materiais de construção e a saúde humana. Na parte superior da troposfera, o Ozônio pode agir como um gás que contribui para o efeito estufa.

\subsubsection{5- Química do Ozônio na Estratosfera}

Assumindo que ocorram vazamentos de hidrogênio na troposfera e que este hidrogênio não seja totalmente consumido, ele pode atingir a estratosfera. Também existe a possibilidade de aviões, no futuro, serem movidos a hidrogênio e então estes vazamentos poderiam vir a ocorrer na própria estratosfera (KIKUCHI, 2006).

Juntamente com o vapor de água e com metano, o hidrogênio molecular é uma fonte de gás importante, a qual controla o vapor de água na 
estratosfera. Estas três espécies agem como fonte de hidrogênio livre (na forma de $\mathrm{H}, \mathrm{OH}$ ), que podem catalisar a destruição do ozônio na parte superior da estratosfera. A reação de combinação do hidrogênio com o ozônio na estratosfera pode ser resumida como:

$$
\mathrm{H}_{2}+\mathrm{O}_{3} \rightarrow \mathrm{H}_{2} \mathrm{O}+\mathrm{O}_{2} \quad \text { Equação 4-5 }
$$

O impacto do hidrogênio na estratosfera é também importante dado seu potencial de destruição catalítica do ozônio e portanto o potencial para atrapalhar todas as medidas para diminuição do buraco de Ozônio na estratosfera. Entretanto o impacto do hidrogênio na estratosfera não pode ter sua escala visualizada claramente sem que sejam efetuados estudos mais detalhados.

Mas mesmo sem um estudo detalhado pode-se avaliar antecipadamente que o uso de hidrogênio como combustível de aviação poderá trazer um impacto adverso, mas pequeno, para a parte superior da estratosfera.

A substituição dos combustíveis fósseis pelo hidrogênio pode reduzir estes impactos negativos, resultando numa redução na emissão de poluentes. Entretanto a situação é mais complicada porque o hidrogênio influencia a capacidade redutora da atmosfera e, portanto sua presença na atmosfera afeta os processos de quebra que criam o Ozônio.

Particularmente se os níveis de emissão de poluentes orgânicos continuarem a ser emitidos e juntamente ocorrer uma emissão adicional de hidrogênio para a atmosfera, então poderá ser alterada toda química natural e exacerbar o problemas relativos à poluição fotoquímica (Ozônio) e as alterações climáticas.

Um estudo do "Defra's Climate Change Research Program" (DERWENT, 2004) estimou que caso todo sistema de produção de energia a base de combustíveis fósseis seja substituído pelo hidrogênio (produzido sem emissão de $\mathrm{CO}_{2}$ ) e ocorra vazamento de $1 \%$ de hidrogênio, então o impacto do hidrogênio no clima será de $0,6 \%$ do impacto dos combustíveis fósseis. Assim teríamos uma redução de $99 \%$ no efeito de alterações climáticas causadas pelos combustíveis fósseis.

A conclusão é que como o hidrogênio não é uma fonte primária de energia e sim um "carregador" ou "transportador", o impacto ambiental do 
processo de produção depende da matéria prima (energia primária) a partir da qual se fabrica o mesmo. Caso o hidrogênio seja fabricado a partir de combustíveis fósseis então as perdas do processo causam um aumento na emissão de gases poluentes que causam o efeito estufa, comparando com o uso direto do combustível fóssil para fornecimento de energia elétrica.

É sempre citado que grandes unidades de produção de hidrogênio poderão seqüestrar $0 \mathrm{CO}_{2}$, e o mesmo é verdade em relação à geração de energia elétrica. Pode-se seqüestrar $\mathrm{O}_{\mathrm{CO}_{2}}$ gerado por qualquer planta de geração movida a carvão. Entretanto não é certo que isto significa que exista a capacidade de seqüestrar essas enormes quantidades de $\mathrm{CO}_{2}$ para sempre.

Até o momento já se recuperam cerca de 50 milhões de toneladas de $\mathrm{CO}_{2}$ a partir de plantas de hidrogênio. Mas outras plantas geram mais outros cem milhões de toneladas por ano de $\mathrm{CO}_{2}$ obtido a partir da reforma do gás natural e de plantas de amônia, e este $\mathrm{CO}_{2}$ é liberado sem nenhuma tentativa de seqüestro.

\subsubsection{6 - Metanol}

O metanol é considerado um armazenador de hidrogênio líquido. Se o metanol for produzido a partir do gás natural então a eficiência das plantas de conversão será de grande importância para o impacto global, especialmente para a demanda de energia primária e emissões de gases poluentes.

O valor médio de eficiência deste tipo de planta está abaixo de $65 \%$ (LHV), deixando as emissões de $\mathrm{CO}_{2}$ na ordem de $30-40 \mathrm{gCO}_{2} / \mathrm{MJ} \mathrm{LHV}$, ao passo que as plantas modernas alcançam eficiências maiores que $65 \%$, dependendo do processo.

Muitos estudos assumem eficiências na faixa entre 67 e $68 \%$, que é consistente com o valor de $66 \%$ para as novas plantas novas construídas, tal qual a Statoil na Noruega, bem como as plantas futuras ainda em projeto. O que mais importa em termos de LCA não é a eficiência no ponto de operação ótimo, mas a eficiência média sobre o tempo de vida útil, incluindo efeitos de degradação, partida após manutenção, etc..

Na Figura 4-28 está mostrada a contribuição dos componentes para a energia primária de uma pilha a combustível que utiliza metanol. Neste gráfico foi utilizada a hipótese de reciclagem da platina em 75\%. (PEHNT, 2003b). 


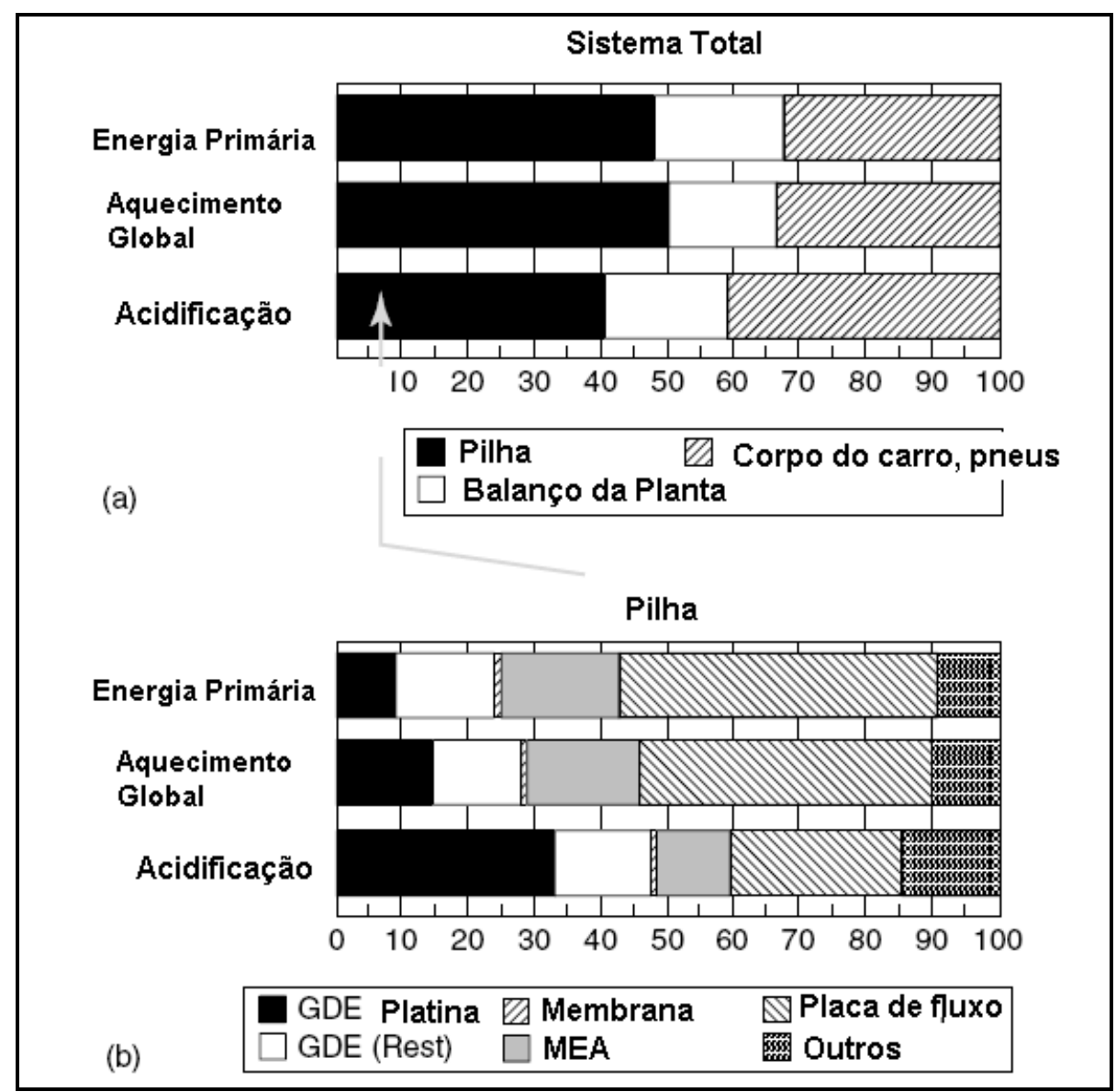

Figura 4-28 - Contribuição dos componentes para a energia primária, aquecimento global e acidificação. Produção de veículo baseado em pilha a combustível a metanol. 


\section{A TÉCNICA DELPHI}

Este capítulo tem por objetivo apresentar uma revisão resumida sobre a técnica Delphi, como ferramenta de prospecção tecnológica.

Conforme Hejden (2000) apud Sant'Ana (2005), todas as pessoas estão acostumadas a prever o futuro, senão não seria possível nem mesmo atravessar a rua porque não saberíamos que um carro poderia nos atingir. Portanto as pessoas prevêem e ajustam suas ações conforme uma dedução lógica desenvolvida durante a vida. Quando algum evento ocorre, tentamos sempre explicá-lo por meio de uma relação causa-efeito, e tentamos usar o nosso conhecimento para manipular o mundo ao redor. Na verdade, temos uma tendência em confiar mais em nossa habilidade de manipular os eventos como uma fonte de conhecimento, do que na mera correspondência espaço-tempo.

O método Delphi vem sendo um dos instrumentos privilegiados na execução de processos de prospecção. Delphi é um nome proveniente de referência ao oráculo da cidade de Delfos, na antiga Grécia, dedicado à adoração do deus Apolo. E foi um procedimento desenvolvido pela RAND Corporation, nos EUA, na década de 50, em um projeto financiado pela Força Aérea dos EUA, que procurava um método que obtivesse um consenso nas opiniões de vários especialistas militares sobre os efeitos de um grande ataque nuclear, GORDON (1964). A Rand Corporation (Research ANd Development) é uma instituição americana sem fins lucrativos que auxilia a melhorar as decisões políticas através da investigação e análise, para maiores detalhes da sua história vide Campbell (2004).

No Brasil o uso da prospectiva é mais recente, mas já há um acúmulo de experiências que é considerado significativo. Organizações importantes e empresas brasileiras já a utilizam, tais como a Marinha, Petrobrás, Banco do Brasil e Embrapa.

Entre as áreas que já foram objeto de estudos prospectivos importantes são citadas as de energia (prospecção de petróleo em águas profundas, programa nacional do álcool), telecomunicações, várias cadeias 
produtivas do agronegócio, além de aplicações na área científica e tecnológica.

Entre as instituições de pesquisa brasileiras que contam com grupos atualmente ativos nessa área destacam-se, além da EMBRAPA, a Faculdade de Economia e Administração da USP, que desenvolve um Programa de Estudos de Futuro, já com vários trabalhos realizados, a Unicamp, a Escola Politécnica da USP, a Universidade Federal de São Carlos e a Universidade Federal do Rio de Janeiro (CARDOSO et al., 2005) .

Nos anos 60 e 70 o método Delphi foi largamente aplicado em previsões sobre desenvolvimento na área de ciência e tecnologia. Nas décadas de 60 e 70 o método Delphi foi largamente aplicado. Isto é exemplificado pela pesquisa na prospecção de desenvolvimento científico e tecnológico e como afeta à sociedade. Num estudo com 800 aplicações da metodologia Delphi, Brockhaus and Michelsen (1977) descobriram que, neste período a Delphi foi a metodologia mais aplicada em prospecção científica.

Gupta e Clarke (1996) efetuaram uma revisão bibliográfica de 463 publicações referentes à metodologia Delphi (1975 a 1994), na qual são apresentadas aplicações em comércio, educação, tratamentos médicos, engenharia, meio ambiente, ciências sociais, turismo e transporte.

A técnica Delphi foi projetada para aproveitar os benefícios de um grupo e a troca de opinião entre os respondentes, os quais podem aprender com as visões dos outros participantes. Isto ocorre sem a influência do face a face convencional no qual algumas pessoas tipicamente dominam porque se expressam muito bem e possuem prestígio. A estrutura da técnica visa utilizar os elementos positivos dos grupos de especialistas e minimizar os seus inconvenientes, como os conflitos político-sociais. O método é geralmente recomendado para realizar previsões quando modelos puramente matemáticos não podem ser utilizados e também quando o julgamento pessoal é pertinente.

Assim, cada indivíduo completa o questionário e então está apto a receber um retorno do conjunto de todas as respostas e preencher o questionário novamente, após ter recebido as informações. Essencialmente, dependendo do tipo de técnica Delphi aplicada, o mesmo questionário poderá ser completado várias vezes pelo conjunto de especialistas. Aos que possuem visões divergentes do consenso é pedido que expliquem suas razões para estas visões e serve como inteligência comum. A idéia é que as visões dissonantes estejam baseadas em 
informações raras ou privilegiadas, que podem pesar para a maioria.

A Delphi explora a experiência coletiva dos membros de um grupo, num processo interativo, assim como nos encontros para discussões presenciais. Entretanto, o método evita as armadilhas das conferências presenciais ao estruturar a comunicação num único formato. Segundo Linstone \& Turoff (2002), "a metodologia Delphi pode ser caracterizada como um método para estruturar um processo de comunicação de um grupo, de modo que o processo seja efetivo em permitir que este, como um todo, lide com um problema complexo".

Comparando a Delphi com conferências ou comitês de discussão, a metodologia possui a vantagem de fornecer comunicação estruturada, anonimato dos participantes, retorno aos participantes após cada etapa do processo interativo e respostas estatísticas baseadas no grupo.

As principais vantagens da utilização do método Delphi são que ele permite a identificação de muitos modelos e percepções pelos especialistas que não seriam factíveis por métodos matemáticos, além de permitir uma componente intuitiva na prospecção. As principais desvantagens são que muitas vezes é difícil identificar os especialistas e as previsões podem ser tendenciosas (ROWE, e WRIGHT, 1999; HEIJDEN, 1998).

A base do método envolve um questionário que é elaborado por uma equipe de coordenação (monitores ou facilitadores) e enviado a um grupo de especialistas participantes previamente selecionados. Assim que estes retornam, a equipe coordenadora contabiliza as respostas, elabora um novo questionário e envia os resultados e as questões revisadas aos mesmos participantes para uma nova interação. Os especialistas têm então a oportunidade de rever suas opiniões à luz das de outros participantes, em anonimato, fornecendo um novo julgamento, agora revisado. O processo se repete até que se atinja um "estado estacionário", isto é, o consenso (WEBLER et al., 1991).

É importante salientar que atualmente se reconhece que as razões apresentadas por participantes que se mantêm como não concordantes também trazem informações importantes; assim opiniões dissidentes também são levadas em consideração, em detrimento ao imperativo do consenso (GEORGHIU, 1996).

A seleção dos participantes envolve dois aspectos: identificar os especialistas e selecionar quais devem participar. Ao passo que erros do questionário podem ser corrigidos rodada a rodada, um grupo incapacitado ou 
sub-representado poderá comprometer todo o processo. Para se atingir resultado legítimo é importante que todos os pontos de vista relacionados estejam representados. Deve-se estar atento a diferenças culturais e de caráter cognitivo. Os questionários inevitavelmente carregam um alto grau de subjetivismo, e se os especialistas não compartilharem da mesma cultura, as questões poderão ser interpretadas diferentemente. Para aliviar estas distorções, deve-se assegurar a diversidade na composição do grupo de participantes, para que elas se cancelem mutuamente.

Também se deve ter cuidado para que a coordenação não seja tendenciosa, fato que pode comprometer todo o processo. A coordenação encontra-se em posição privilegiada, porque ao compor o questionário inicial e suas versões subseqüentes, pode incorporar informações falaciosas alterando o julgamento dos participantes. A coordenação também está sujeita as interpretações subjetivas e vieses culturais quando analisa os resultados e tira suas conclusões.

\section{1 - Tipos de Delphi}

A forma original da metodologia Delphi, a denominada Delphi "clássica", procura obter a estabilidade das respostas, entre os peritos, sobre um determinado assunto (isto é, quando não ocorre mais mudança nas respostas de um assunto quando se passa de uma interação para outra).

Já nos anos setenta emergiu uma nova abordagem da metodologia denominada "Delphi política", em inglês "Policy Delphi". Este tipo de Delphi procura a formulação de metas e indicação de prioridades, por exemplo, em programas e participações políticas ou orçamentos. Este tipo de Delphi teve seu leque de aplicações substancialmente alargado e tornou-se um instrumento de desenvolvimento de políticas. O mais importante não é obter a estabilidade das respostas entre os peritos, mas, pelo contrário, os elementos centrais desde tipo de Delphi é o esclarecimento das opiniões divergentes e a elucidação dos argumentos (VAN ZOLINGEN AND KLAASSEN, 2003).

Também foram desenvolvidos outros tipos de Delphi. Gupta e Clarke (1996) efetuaram uma revisão bibliográfica abrangendo 463 relatórios referentes à metodologia Delphi, e verificaram a aplicação em várias áreas tais como: educação, cuidados médicos, engenharia, ambiente, ciências sociais, turismo e 
transporte, entre outras. O largo uso da metodologia Delphi em projetos de prospecção claramente servem como um processo de comunicação para aumentar a consciência entre os planejadores e formuladores de políticas públicas de meio ambiente no futuro.

É conveniente não só prever os desenvolvimentos futuros e/ou eventos, mas também para gerar alternativas políticas ou a tomada de decisões sobre elas.

Existem variações na metodologia Delphi e a convencional é a base para muitas variações posteriores que vêm sendo desenvolvidas, dada a flexibilidade inerente do método e as necessidades específicas de cada caso de aplicação.

A seguir apresenta-se a descrição sobre os quatro tipos de metodologia Delphi mais utilizados, conforme Zolingen et al. (2002): o Delphi clássico, o "Policy Delphi”, o "Decision Delphi” e o Delphi em grupo.

No Delphi clássico os dados são coletados em certo número de rodadas e em cada estágio os resultados das etapas precedentes são fornecidos até que o procedimento apresente certa estabilidade nas respostas, que em geral resulta em um aumento do consenso. Este tipo de Delphi tem cinco características básicas:

- O anonimato: é conseguido através da utilização de questionários enviados aos entrevistados, permitindo que eles expressem suas opiniões sem serem influenciados por terceiros;

- As interações: aliadas ao anonimato permitem que os respondentes possam mudar de opinião ou julgamento sem a perda de credibilidade com os outros participantes;

- O "feedback" controlado: abrange a todos os respondentes, permitindo que todos tenham suas opiniões expressas igualmente, não apenas os membros mais extrovertidos ou com maior influência;

- O tratamento estatístico das respostas: usualmente a média, mediana e desvio padrão dos julgamentos dos grupos no decorrer das interações, pode mostrar um aumento do consenso das respostas, e a estabilidade entre os especialistas é freqüentemente expressa pela variação das opiniões deles em torno da média ou mediana;

- A estabilidade das respostas entre os especialistas sobre uma questão 
específica.

A Figura 5-1 mostra o esquema da técnica Delphi clássica.

O segundo tipo é chamado de "Policy Delphi", que é amplamente utilizado em questões políticas e sociais. A principal diferença entre este e 0 Delphi clássico é que neste existe a coleção de informações dos especialistas individualmente no decorrer das interações. Nele é também utilizado o feedback controlado, mas não existe o objetivo de se alcançar uma estabilidade das respostas sobre uma questão específica. O principal objetivo deste tipo de Delphi é gerar alternativas para políticas utilizando um diálogo estruturado. Suas principais características são:

- O anonimato seletivo: acontece porque inicialmente os especialistas respondem aos questionários individualmente, e posteriormente diferentes pontos de vista são trocados entre eles;

- As interações: a necessidade das interações é baseada nas opiniões dos especialistas sobre os tópicos do questionário respondido.

- O "feedback" controlado;

- Respostas polarizadas do grupo de respondentes: são fornecidas durante as interações, isto é, o moderador compila as opiniões dos especialistas e as fornece antes da rodada subseqüente;

- Conflito estruturado: é geralmente uma reunião entre os especialistas e os pesquisadores. 


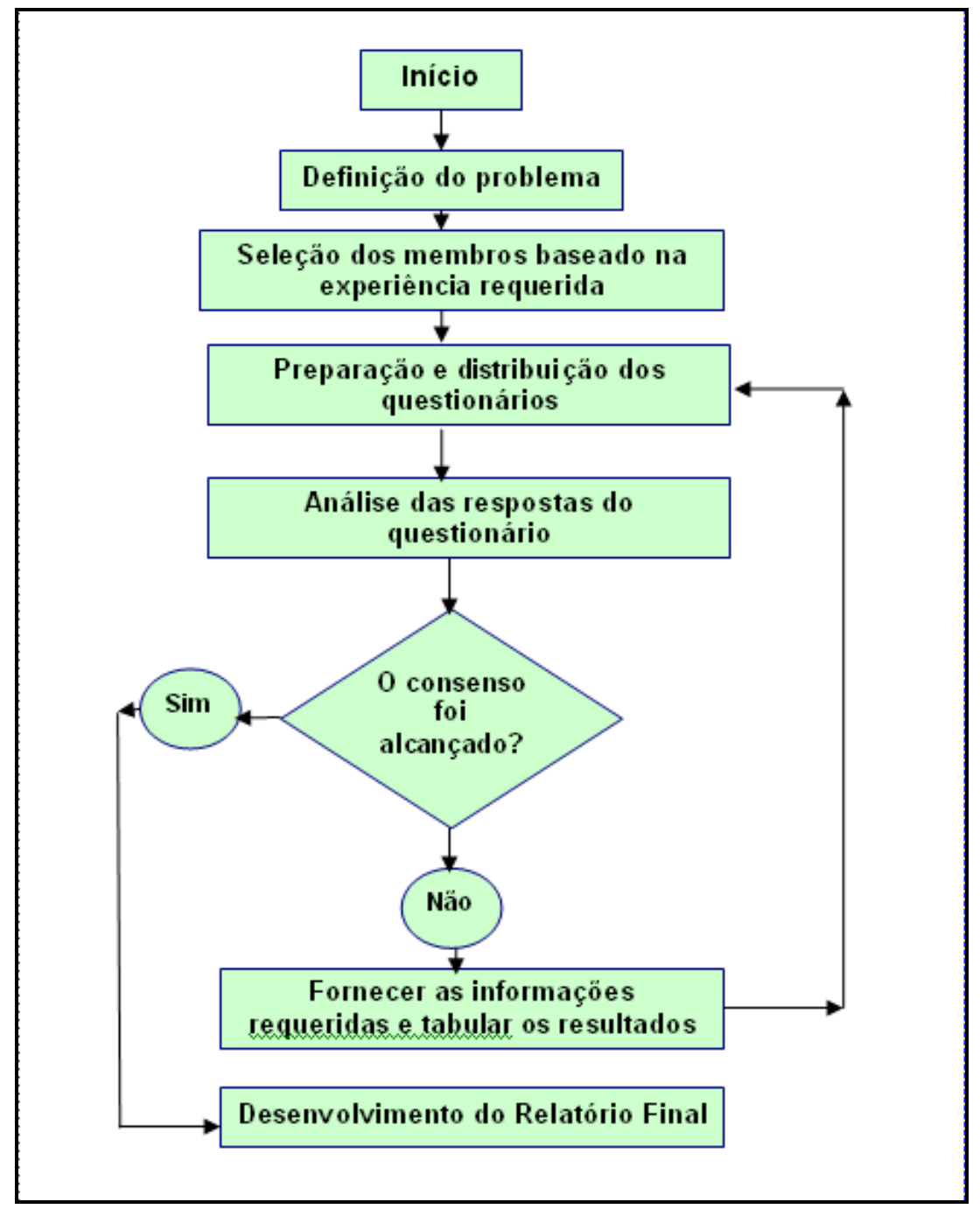

Figura 5-1 - Diagrama explicativo das etapas do Delphi clássico

A Figura 5-2 ilustra as etapas do "Policy Delphi".

O terceiro tipo é chamado de "Decision Delphi". A única diferença deste para o Delphi clássico é que no "Decision Delphi" existe um anonimato parcial, isto é, no começo do estudo os especialistas são mencionados pelos seus nomes e são conhecidos por todos, apesar das respostas do questionário serem mantidas anônimas. Este procedimento tem como objetivo motivar os especialistas a responderem eles mesmos, não deixando para assistentes ou outros.

O quarto tipo chamado de Delphi em grupo, ou ainda pode ser classificado como um painel de especialistas adaptado. A única diferença entre este Delphi e o clássico, é que neste não existe o anonimato. Os trabalhos de um Delphi em grupo são realizados durante um dia com um grupo de especialistas que interagem entre si. 


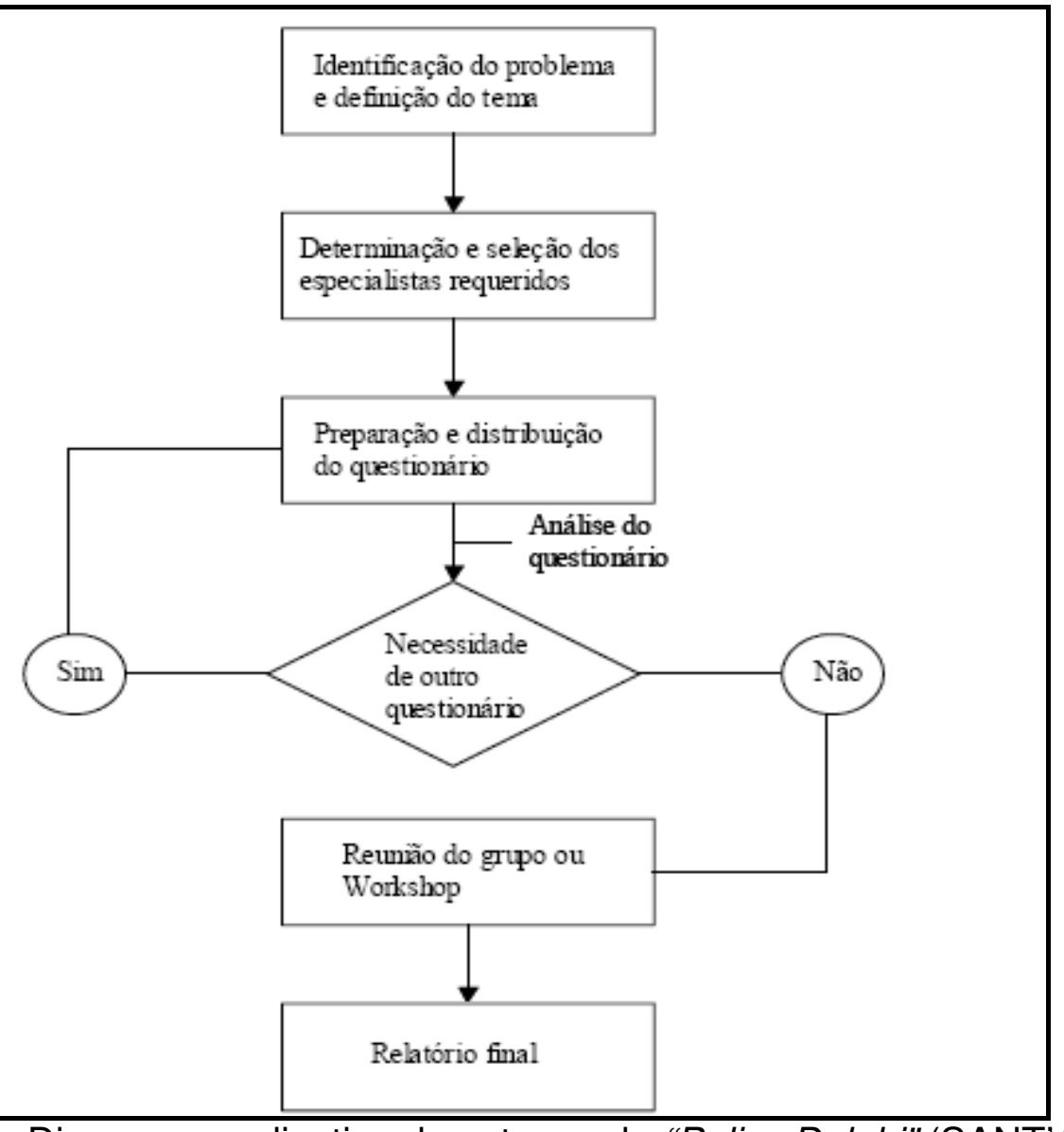

Figura 5-2 - Diagrama explicativo das etapas do "Policy Delphi” (SANT'ANA, 2005).

Portanto, de acordo com Zolingen et al., (2003), existem quatro modelos de Delphi básicos, que apesar de sua aparente rigidez, permitem algumas modificações que ocorrem com certa freqüência por causa da grande gama de aplicações desta técnica.

Os estudos de alguns casos, efetuado por Zolingen et al. (2003), mostram que não existe uma forma rígida para a pesquisa Delphi, pois a variedade de áreas e temas em que ela pode ser utilizada é muito ampla. Além disso, os resultados esperados, recursos humanos, orçamento e tempo disponíveis para a pesquisa são fatores limitantes na decisão da forma como a técnica é desenvolvida. Estudos sobre saúde pública, P\&D, comércio eletrônico, administração rural, odontologia e energia são apenas alguns exemplos da utilização deste método, que se mostra uma ferramenta interessante para a análise e prospecção de temas que seriam dificilmente quantificáveis. É interessante notar que todos os estudos apresentam pelo menos uma iteração 
com os especialistas, fornecendo o "feedback" das respostas entre as rodadas.

Um dos principais argumentos da utilização do método Delphi é de que o consenso aumenta no decorrer das interações. Graham et al. (2003) mostraram que em duas rodadas já existiu um aumento do consenso em uma pesquisa Delphi que eles realizaram. 57 médicos foram convidados a participar da consulta para atingir um consenso de qual seria o melhor diagnóstico para um tipo de síndrome. Na primeira rodada, para cada pergunta, os respondentes analisaram a importância de um determinado item no diagnóstico da síndrome. A média e o desvio padrão de cada membro foram calculados e fornecidos na segunda rodada, e posteriormente os especialistas responderam novamente às mesmas perguntas. Foi utilizado um indicador denominado a de Cronbach para quantificar o consenso entre os respondentes, o qual quanto mais próximo de 1, maior é o consenso. Na pesquisa de Graham et al.(2003) o indicador cresceu de 0,86 na primeira rodada para 0,91 na segunda, indicando aumento do consenso das respostas dos especialistas da primeira para a segunda rodada.

O motivo deste consenso ainda é muito discutível, e poucos estudos tentam entender como as opiniões dos especialistas mudam. Parenté e Anderson-Parenté apud Armstrong et al.(2001) têm uma teoria de que as rodadas Delphi aumentam a precisão das respostas porque os respondentes mais especializados mantêm suas opiniões no decorrer das rodadas, ao passo que os menos especializados alteram o seu julgamento no sentido da média do grupo. Mas outras teorias podem ser construídas para explicar o comportamento dos respondentes como, por exemplo, talvez os respondentes menos confiantes mudem suas respostas.

\section{2- O especialista}

A seleção dos participantes envolve dois aspectos: identificar os especialistas e selecionar quais devem participar. Ao passo que erros do questionário podem ser corrigidos rodada a rodada, um grupo incapacitado ou sub-representado poderá comprometer todo o processo. Para se atingir um resultado legítimo é importante que todos os pontos de vista relacionados estejam representados. Deve-se estar atento a diferenças culturais e de caráter cognitivo. Os questionários inevitavelmente carregam um alto grau de subjetivismo, e se os especialistas não compartilharem da mesma cultura, as questões poderão ser 
interpretadas diferentemente. Para diminuir estas distorções, deve ser assegurada uma diversidade na composição do grupo de participantes, para que elas se cancelem mutuamente.

$\mathrm{Na}$ técnica Delphi um dos pontos cruciais é a seleção dos especialistas, já que é por meio de suas respostas que os resultados são analisados. Okoli et al. (2004) descreveram um procedimento para a seleção dos especialistas, em que se identificam especialistas de diversos setores de atuação (ONG's, academia, empresa e governo) para uma posterior categorização baseada em seus níveis de conhecimento.

Considerando que todos os conselhos dizem respeito ao futuro, as características de um "perito orientador", conforme Loveridge (2001) devem ser:

- Conhecimento real na área de interesse;

- Avaliação da sua esfera de conhecimentos;

- Imaginação, já que lida com o alargamento de visão futura.

Os dois primeiros podem ser caracterizados numericamente, mas a imaginação só é possível de avaliação no julgamento face a face, como numa entrevista. E é a imaginação que permite aos peritos abordar as inter-relações entre os desenvolvimentos e eventos que ainda não aconteceram.

Em quase qualquer campo do conhecimento, existe um «colégio dos cardeais" ou "peer group" (grupo de irmãos), e que no nível nacional e / ou internacionais os membros destes grupos podem discordar veementemente e podem não se conhecer pessoalmente, mas eles compartilham duas características: podem identificar outros membros do grupo irmão ("peer group") e eles sabem a posição dos outros e deles mesmos na atual "Ordem de mérito" do grupo. (LIPINNSK AND LOVERIDGE, 1982).

O encontro dos primeiros contatos geralmente é experimental, por tentativa e erro, buscando por meio de diferentes redes grupos irmãos até que a recomendação repetida aponte para determinadas pessoas.

Este método de obter os especialistas é também denominado método da co-nominação, e foi utilizado para descobrir um grande número de especialistas num estudo Delphi realizado pela "UK Technology Foresight Program" (TFP) de 1994 a 1995 (LIPINNSK AND LOVERIDGE, 1982). O processo prático foi descrito por Loveridge (2002a).

Outro estudo realizado por Loveridge (2001) para subsidiar a escolha 
de especialistas utilizou estudos estatísticos nos quais um questionário é fornecido aos potenciais especialistas de diversos setores de atuação, e baseado em suas respostas eles são escolhidos para participar da consulta Delphi ou de um painel de especialistas.

Outros estudos, Loveridge (2002), realizaram questionários baseados em estudos estatísticos em que um questionário é fornecido aos potenciais especialistas de diversos setores de atuação, e baseado em suas respostas eles são escolhidos para participar da consulta Delphi ou de um painel de especialistas.

O comum entre todos os estudos é que os especialistas sejam selecionados em vários setores de atuação (como academia, empresa e governo), para que todos tenham certa representatividade na pesquisa, permitindo então uma maior credibilidade ao estudo (SANT'ANNA, 2005).

\subsection{1- A Co-nominação}

Descobrir pessoas com especialização demonstrada é difícil e descobrir várias delas é muito mais. Existem vários processos para descobrir pessoas especiais em qualquer sociedade através das perguntas feitas para pessoas ao redor após ter identificado um ponto de partida. O processo tem certa inevitabilidade, pois tende sempre a levar na direção de um grupo particular de pessoas reconhecidas em qualquer lugar como "grandes e boas" numa comunidade.

O princípio da co-nominação lida com a geração de uma rede baseada na recorrência de pares de nomes (revelada a partir do questionário). Assume-se que a similaridade na nominação de pessoas e na co-nominação implique numa ligação cognitiva. Então se:

-A nomina B, C e D

-As ligações presumidas são B-C, B-D e C-D

A nominação, por si só, é uma indicação da influência que o nominado tem sobre o respondente (o nominador) levando naturalmente à hipótese de que a co-nominação freqüente identifique os atores influentes no campo e por meio de uma rede que ilustre a inter-relação. O questionário não faz referência à qualidade do trabalho individual, e a noção de popularidade é indesejada.

A co-nominação é preferível ao invés da nominação, pois evita efeitos 
de prestígio, quando os respondentes ligam-se a atores chaves ao passo que isso também possibilita uma escala que permite um exame da força das ligações, em diferentes níveis. As pessoas que são altamente co-nominadas claramente ocupam posições especiais na comunidade envolvida. Deste modo a identificação dos participantes potenciais é colocada firmemente na mão da comunidade envolvida.

\section{3-Questões no Método Delphi}

As questões que compreendem os elementos de um questionário Delphi inevitavelmente refletem as atitudes culturais, a tendência subjetiva e o conhecimento daqueles que as formulam. Isto foi reconhecido por Gordon e Helmer (1964) e levou-os a iniciar a primeira rodada com um questionário em "branco".

A elaboração do questionário Delphi não é a tarefa simples como pode parecer, mas tem de ser feito dentro de um conjunto de regras pré-estabelecidas. Primeiro, porém é necessário estar claro em qual tipo de processo Delphi o questionário será realizado: se para o Delphi clássico, Delphi 'tecnológico', 'político' ou outro tipo.

Loveridge (2002b) também avaliou que as perguntas normalmente devem respeitar as seguintes regras comuns:

- Não deve haver ambigüidade;

- Não deve haver nenhuma declaração condicional faça a questão primária dependente do cumprimento de uma série de condições. Perguntas nas quais isso ocorra devem ser divididas em duas ou mais questões separadas;

- Quaisquer termos científicos ou tecnológicos devem ser corretos;

- Todos os parâmetros devem ter definições claramente acordadas.

Grabe \& Pike (1972) apresentaram exemplos de afirmativas Delphi pobres e boas. As afirmativas podem ser muito longas, levando a excessivas variações na interpretação ou muito concisas requerendo a assimilação de muitos elementos.

Na Figura 5-3 apresenta o resultado da análise de 60 questões da primeira rodada da pesquisa Delphi para a "Skandia Insurance Company Ltda."e executado pelo "Institute for the Future" (SALANCIK et al., 1971). Com base também nos estudos de Salancik et al. (1971), Loveridge (2002b) avaliou que 
uma questão não deve ter menos que 10 palavras e não mais que 30 pois:

- o respondente que é um especialista no assunto reconhecerá rapidamente a intenção da questão e ficará frustrado pela adição de informações desnecessárias.

- o respondente menos informado necessitará de informação adicional para compreender a questão claramente, mas necessitará de maiores informações.

- o respondente desinformado não compreenderá a questão independente de quanta informação for fornecida.

Alguns detalhes no questionário são considerados por Loveridge (2002b) como importantes:

- Endereço, idade, gênero, afiliação, função (escolhida com base num conjunto de categorias) e outras informações similares.

- Declaração de campo e nível de especialização escolhidas com base em padrões de especialização por auto-avaliação.

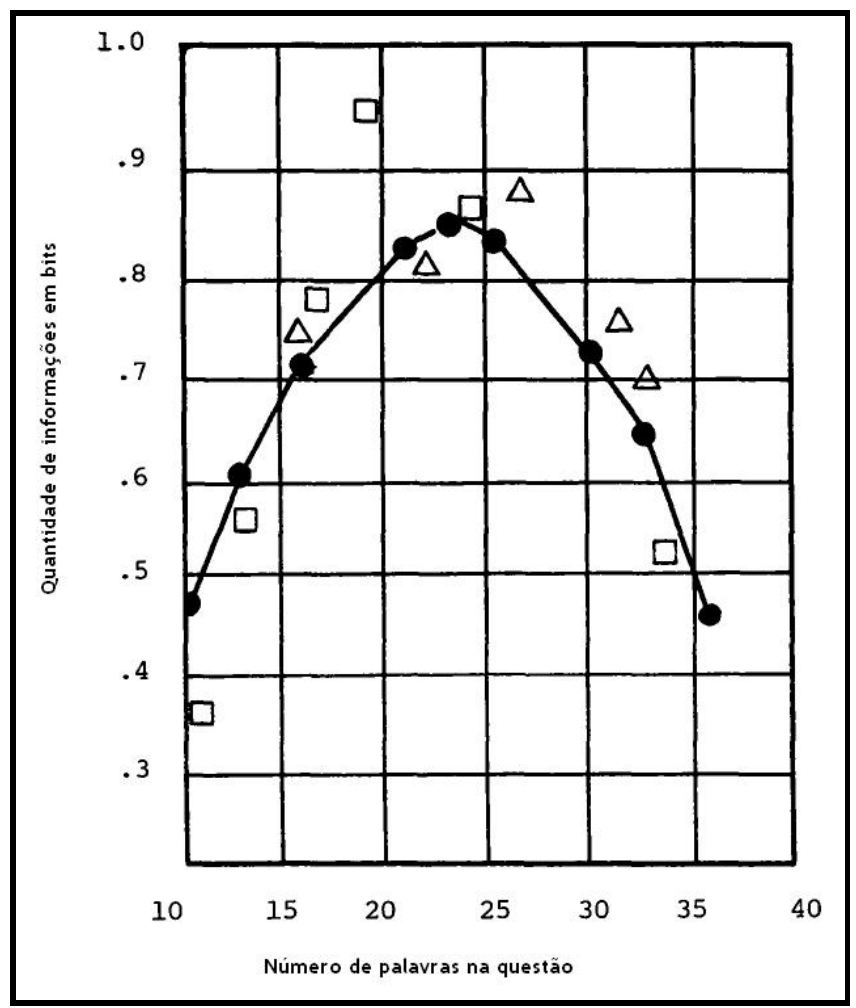

Figura 5-3 - Relação entre o número de palavras usadas numa descrição de evento e a quantidade de informação obtida sobre o tempo provável de ocorrência desses eventos.

O questionário deve ser preenchido por um indivíduo, sem supervisão nem em grupo. 
Do acima exposto, a elaboração de perguntas para um questionário Delphi exige cuidado e paciência. O procedimento tem o efeito importante de incutir disciplina na discussão. Outro requisito importante para a preparação da perguntas da Delphi é um exame independente das perguntas para verificar se podem ser facilmente entendidas e se são 'tecnicamente' corretas.

Visto que o inquirido será confrontado com um questionário com várias perguntas, talvez até 50 , se cada uma não for facilmente compreendida e pior se forem tecnicamente incorretas, os respondentes rapidamente perderão 0 interesse no estudo, que corre o risco de perder a sua credibilidade.

Tradicionalmente as pesquisas que utilizam a técnica Delphi têm sido realizadas notadamente por meio de questionários enviados via correio. Eles também eram usados dentro de reuniões de grupo. Ultimamente a internet já tem sido utilizada como método para que os participantes completem os questionários on-line.

\section{4-A influência da opinião dominante}

Pesquisadores holandeses (KLUCHAREVet al., 2009) desvendaram a atividade cerebral que existe por trás da tendência de imitar as opiniões e 0 comportamento alheios. Imagens obtidas com ressonância magnética funcional revelaram quais regiões do cérebro atuam, quando surge um, conflito entre a percepção do indivíduo e a norma estabelecida pelo grupo.

Esta pesquisa identificou as raízes biológicas do mal-estar causado por se divergir da opinião da maioria. Estes resultados revelam os limites e condicionamentos da liberdade humana.

\section{5-A precisão}

A precisão e a confiabilidade do método são difíceis de avaliar. A razão disto é que os julgamentos não podem ser equiparados a medições. A medição pode ser dividida em valores reais com uma componente de erro. O componente de erro pode ser considerado como constituído por variáveis aleatórias. Estas variáveis aleatórias tendem a anular-se mutuamente no longo prazo, dando a expectativa de um componente de erro zero. Pode-se pensar que o julgamento também possa ser composto de um valor real com uma componente de erro.

O caminho mais viável para avaliar a precisão do Delphi é compará-lo 
diretamente a outros métodos de julgamento na mesma situação. As principais fontes de ruídos que permanecem são efeitos de quando os participantes são os mesmos utilizados nos diferentes métodos. Estes efeitos podem ser minimizados com a devida randomização.

Ao passo que a maioria dos estudos utiliza a metodologia Delphi com um consenso opinião, outros estudos desenvolvem um conjunto de cenários futuros alternativos. E este quadro de cenários representa desenvolvimento um segundo tipo de aplicação da Delphi método. Esses modelos tipicamente envolvem um estudo em duas fases, começando com a identificação / elaboração de um conjunto de cenários para em seguida desenvolver a metodologia Delphi. 


\section{DESCRIÇÃO DA PESQUISA DELPHI REALIZADA COM ESPECIALIS- TAS E APRESENTAÇÃO DOS RESULTADOS}

\subsection{Linhas Gerais da Pesquisa}

Esta seção descreve como foi efetuada a consulta Delphi, incluindo os tópicos tecnológicos, os critérios e métricas adotadas, o questionário, os especialistas selecionados e a metodologia de envio do questionário utilizada nas duas rodadas da pesquisa Delphi com especialistas da academia, empresa e governo.

A explicação da metodologia desta consulta é importante para que as futuras análises desta tese sejam compreendidas com maior clareza.

Conforme a proposta do trabalho a prospecção do impacto ambiental das pilhas a combustível de média e baixa temperatura foi efetuada por meio do uso do questionário no qual o tema principal foi o impacto ambiental das pilhas a combustível no futuro, quando deverão ser usadas em larga escala, considerando o desenvolvimento tecnológico dos materiais e processos.

A consulta Delphi em impacto ambiental das pilhas a combustível de média e baixa temperatura possuiu estreita semelhança com o Delphi clássico descrito no Capítulo 5. No Delphi clássico os dados são coletados em determinado número de rodadas, e em cada estágio os resultados das etapas precedentes são fornecidos até que o procedimento apresente certa estabilidade que, em geral, resulta em um aumento do consenso. As características principais do Delphi clássico são o anonimato, as interações, a realimentação ("feedback") controlada, o tratamento estatístico e a estabilidade das respostas entre os especialistas sobre uma questão específica. Assim como o Delphi clássico, a consulta Delphi em impacto ambiental das pilhas a combustível permitiu o anonimato, pois os respondentes não tinham conhecimento dos outros participantes e suas respostas foram tratadas de forma sigilosa. E ainda sobre a semelhança, foram realizadas duas interações na consulta, fornecendo na segunda rodada uma realimentação ("feedback") na forma de gráficos que apresentavam a distribuição das respostas obtidas na primeira fase. Desta 
maneira o especialista pode manter sua resposta ou mudá-la em razão de uma nova leitura ou reflexão sobre a questão. Poderiam também ser efetuados comentários, num campo específico para isso, caso o respondente julgasse necessário.

\subsubsection{Bases do Projeto}

A Figura 6-1 fornece uma visão global das fases principais do trabalho.

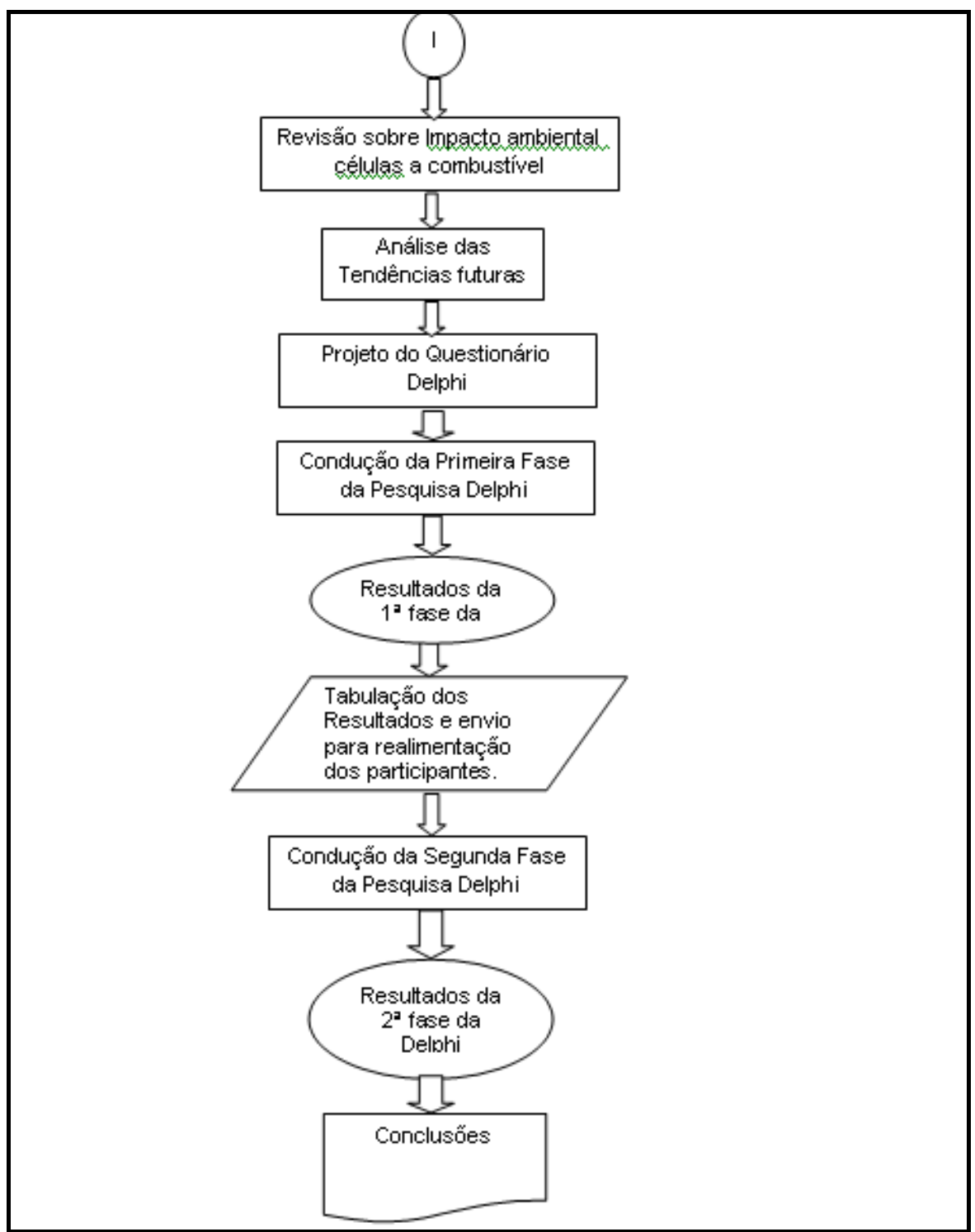

Figura 6-1 - Principais fases da pesquisa. 
Soa como trivial afirmar que o desenvolvimento tecnológico não pode ser considerado como uma caixa preta, que segue seu próprio caminho, obedecendo a regras próprias. O desenvolvimento tecnológico é interdependente do desenvolvimento social e econômico. Portanto não é surpreendente que quando os peritos preencham um questionário Delphi eles próprios ou os projetistas do questionário, avaliam as afirmativas sob algumas premissas. De acordo com a metodologia Delphi, entretanto não são explicitados cenários e, por exemplo, não existe diretiva se os peritos podem ou não assumir, por exemplo, que o Protocolo de Kyoto será ratificado.

Os peritos podem avaliar as afirmativas, tendo em suas próprias mentes as suas hipóteses pessoais do que ocorrerá no futuro. Consequentemente os peritos estão dando seu próprio julgamento sobre como certas tecnologias se desenvolverão e cada um deles tem um cenário individual em mente - uma moldura do futuro no qual a previsão do desenvolvimento tecnológico ocorrerá.

É importante observar que a Delphi tende a negligenciar as crises. Catástrofes, crises ou grandes descobertas tecnológicas ("breakthroughs") não são geralmente previstas pelos peritos.

\subsection{Condução da Pesquisa e População}

A pesquisa Delphi foi conduzida eletronicamente usando o programa do Questionpro (www.questionpro.com). A primeira rodada foi conduzida no período entre 10 de fevereiro a 10 de outubro de 2007.

\subsection{1 - O programa utilizado}

QuestionPro é um programa ("software") baseado na internet para a criação e distribuição de questionários e pesquisas. Consiste em um assistente com uma interface intuitiva para criar questionário e possui ferramentas de distribuição do questionário por e-mail, além de ferramentas de análise e visualização de seus resultados. O usuário constrói o questionário e o sistema 0 envia para uma lista de potenciais respondentes. O QuestionPro efetua o registro das respostas e os resultados ficam disponíveis em tempo real.

O "Relatório resumo" em tempo real é o tipo mais básico de relatório. $O$ relatório é constituído de dados estatísticos simples e gráficos dos dados 
recolhidos até o momento.

O programa também permite a emissão de relatórios comparativos dos resultados para os diferentes grupos de inquiridos. O relatório vai mostrar os resultados globais, bem como os resultados de cada grupo que você definiu.

Em muitos casos, é necessária a análise dos dados por meio de um relatório detalhado. De qualquer ponto da análise "on-line", você tem a opção de consultar as respostas e fazer opção para consulta para as respostas de cada respondente. Os dados também incluem o endereço IP, data e hora, e qualquer variável personalizada que você pode ter adquirido do inquirido.

O programa também possui uma ferramenta de exportação para o MS Excel, que inclui os dados brutos existente no banco de dados da pesquisa. $O$ relatório também inclui todos os dados da frequêencia, bem como a freqüência de dados para quaisquer grupos que tenham sido definidos previamente para comparação.

Na Figura 6-2 é mostrado um exemplo de uma das telas do questionário, tal qual visualizada pelo respondente.

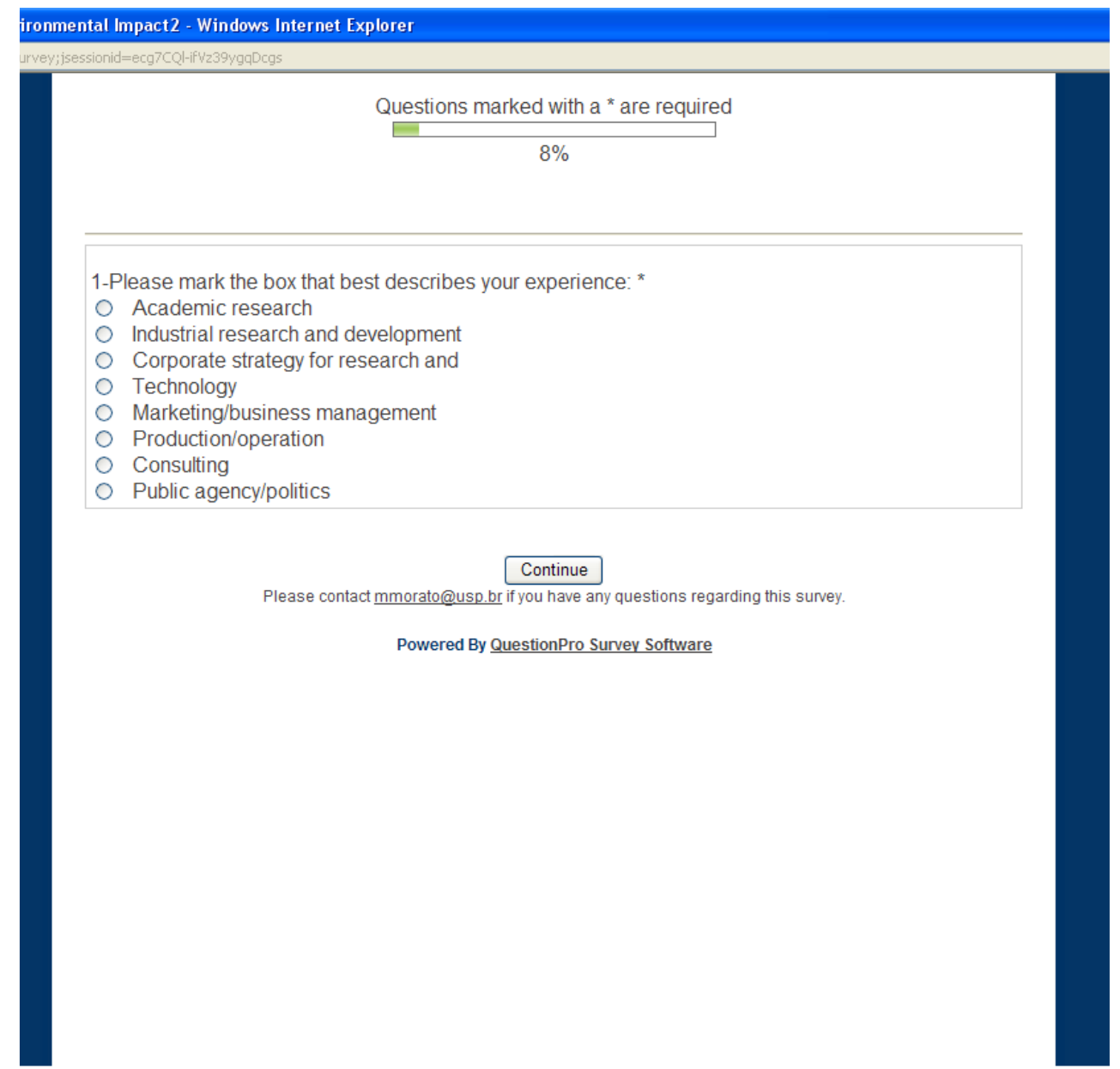

Figura 6-2 - Tela do questionário, tal qual visualizada pelo respondente. 


\subsection{2 - A condução da pesquisa}

Conforme previsto nos objetivos do trabalho o alvo da pesquisa considera o potencial tecnológico, e foi necessário que se incluísse uma mistura de peritos. O critério de seleção dos participantes foi:

- Diversidade dos peritos a fim de cobrir os campos usados na pesquisa. Isto compreende não somente a experiência tecnológica nos vários itens tecnológicos cobertos pela pesquisa, relacionados à pilha a combustível.

- Diversidade de instituições desde pesquisadores acadêmicos, engenheiros, tanto da administração governamental como da não governamental.

- Diversidade de origem geográfica a fim de obter a capacidade de representação mundial.

Para a primeira rodada foi formado um banco de dados de 3500 pessoas que possuíam alguma relação com o assunto pilha a combustível. Este banco de dados foi formado tomando por base: organizações com "sites" na internet relacionadas com 0 assunto pilhas a combustível, associações, organizações acadêmicas ou não relacionadas com as pilhas a combustível e indicações individuais e coletivas de outros participantes, evidenciando que o indivíduo ao menos era no mínimo conhecedor de parte do assunto pilhas a combustível. Assim os especialistas foram escolhidos procurando representar os setores da academia, indústria e governo.

Além dos especialistas foram escolhidos 4 grupos de tópicos tecnológicos abrangendo as principais áreas de atuação, e contendo no total 54 itens. A escolha destes tópicos foi efetuada com base na revisão bibliográfica efetuada durante o estudo. A análise de vários estudos "Análise do Ciclo da Vida" (ACV ou LCA na sigla em inglês) das pilhas a combustível, que foram efetuados considerando o estado da arte atual, mostrou que a etapa de fabricação das pilhas de média e baixa temperatura influencia o impacto ambiental das mesmas e não pode ser desprezada. Assim tanto os materiais que compõem a pilha como os processos de produção destes são importantes para o impacto ambiental. A revisão bibliográfica também mostrou que a etapa de produção dos combustíveis utilizados nas pilhas é considerada um dos maiores fatores de impacto ambiental. Assim o questionário foi elaborado baseado nos pontos cruciais levantados pelos estudos de impacto ambiental, para os processos atuais, com a finalidade de avaliar como o desenvolvimento tecnológico, a longo prazo, pode diminuir o 
impacto ambiental das pilhas a combustível.

Assim os grupos foram designados:

- O grupo 1 abrange os tópicos relacionados com a expectativa de alterações tecnológicas a longo prazo para as pilhas PEM. Os itens da pilha PEM foram separados em: catalisador, membrana, placas bipolares e outros materiais, e este último item engloba todos os outros materiais utilizados na construção da pilha, tais como os utilizados na carcaça, parafusos, gaxetas, entre outros. Este item possui o mesmo significado para todas as outras pilhas. Possui um total de 13 itens tecnológicos;

O grupo 2 abrange os tópicos relacionados com a expectativa de alterações tecnológicas a longo prazo para as pilhas PAFC. Os itens da pilha PAFC foram separados em: catalisador, matriz/eletrólito, placas bipolares e outros materiais. Possui11 itens tecnológicos;

- O grupo 3 abrange os tópicos relacionados com a expectativa de alterações tecnológicas a longo prazo para as pilhas MCFC. Os itens da pilha MCFC foram separados em: catalisador, matriz/eletrólito, placas bipolares e outros materiais. Possui 9 itens tecnológicos e;

- O grupo 4 abrange os tópicos relacionados com os combustíveis utilizados para as pilhas a combustível. Possui 21 itens tecnológicos.

A Tabela 6-1 mostra os grupos adotados para a realização da pesquisa além dos itens pesquisados em cada grupo. Em cada grupo procurou-se separar as perguntas de acordo com componentes referentes ao grupo. Assim o grupo 1 terá itens sobre partes da pilha tipo PEM, tais como: catalisadores, membrana, placas bipolares e "outros materiais". O item "outros materiais" refere-se a todos os outros materiais utilizados na pilha tais como: carcaça, parafusos, porcas, gaxetas, entre outros.

O questionário utilizado na primeira fase da consulta foi composto de 21 perguntas que estão integralmente apresentadas no Apêndice B-1. E o questionário para a segunda fase está apresentado no Apêndice B-2. Todos foram redigidos em inglês, visto que o questionário foi respondido por pessoas do mundo todo. 
Tabela 6-1 - Descrição dos Grupos e os respectivos itens pesquisados.

\begin{tabular}{|c|c|c|}
\hline Grupo & Descrição & \\
\hline \multirow{4}{*}{$\begin{array}{c}\text { Grupo } \\
1\end{array}$} & \multirow{4}{*}{$\begin{array}{l}\text { Impacto ambiental devido à } \\
\text { fabricação, operação e disposição } \\
\text { final da PEMFC }\end{array}$} & Catalisador \\
\hline & & Placas Bipolares \\
\hline & & Membrana \\
\hline & & $\begin{array}{l}\text { Outros materiais (Plásticos, aço, alumínio, } \\
\text { resina fenólica, negro de fumo, etc.) }\end{array}$ \\
\hline \multirow{4}{*}{$\begin{array}{l}\text { Grupo } \\
\quad 2\end{array}$} & \multirow{4}{*}{$\begin{array}{c}\text { Impacto ambiental devido à } \\
\text { fabricação, operação e disposição } \\
\text { final da PAFC }\end{array}$} & Catalisador \\
\hline & & Placas Bipolares \\
\hline & & Matriz/eletrólito \\
\hline & & $\begin{array}{l}\text { Outros materiais (Plásticos, aço, alumínio, } \\
\text { resina fenólica, negro de fumo, etc.) }\end{array}$ \\
\hline \multirow{4}{*}{$\begin{array}{c}\text { Grupo } \\
3\end{array}$} & \multirow{4}{*}{$\begin{array}{l}\text { Impacto ambiental devido à } \\
\text { fabricação, operação e disposição } \\
\text { final da MCFC }\end{array}$} & Catalisador \\
\hline & & Placas Bipolares \\
\hline & & Matriz/eletrólito \\
\hline & & $\begin{array}{l}\text { Outros materiais (Plásticos, aço, alumínio, } \\
\text { resina fenólica, negro de fumo, etc.) }\end{array}$ \\
\hline \multirow[b]{2}{*}{$\begin{array}{c}\text { Grupo } \\
4\end{array}$} & \multirow{2}{*}{$\begin{array}{l}\text { Impacto ambiental devido à } \\
\text { produção de hidrogênio }\end{array}$} & \\
\hline & & Processos, matérias primas \\
\hline
\end{tabular}

A primeira pergunta a ser respondida, a cada conjunto de perguntas referentes a cada um dos 4 grupos de tópicos tecnológicos, era sobre o nível de conhecimento do respondente sobre o tópico em questão, cujas opções de respostas eram:

(1) Perito: assinale se você se considerar dentro do grupo de pessoas que atualmente se dedica a este tópico com profundidade.

(2) Conhecedor: use essa classificação nos seguintes casos:

a. Se você está se tornando um perito, mas falta alguma experiência para dominar o tópico.

b. Se você já foi um perito no tópico há alguns anos, mas se considera no momento pouco atualizado no tópico.

c. Se você trabalha em área próxima, mas contribui regularmente com temas relacionados a esse tópico.

(3) Familiarizado: assinale se você conhece a maioria dos argumentos usados nas discussões sobre o tópico, leu sobre o assunto, e tem uma opinião sobre ele.

(4) Não familiarizado: marque esta opção se você não se enquadra em nenhuma das categorias anteriores. 
Esta auto-avaliação dos respondentes permitiu que as respostas fossem separadas dependendo do nível de especialidade do respondente, possibilitando análises na investigação de sua influência no decorrer da consulta Delphi. Utilizando a análise de variância, por exemplo, foi possível avaliar se existiu a necessidade da atribuição de pesos de acordo com o grau de especialidade do respondente.

Após a compreensão das questões, outro ponto importante foi a métrica utilizada nas respostas. Para ilustrar como foi realizada esta quantificação para o tratamento estatístico que subsidiou a $2^{\text {a }}$ rodada, a questão 1 (Grupo 1) é utilizada como exemplo; as métricas, bem como os critérios utilizados para todas as questões estão disponíveis no item 6.6.

Questão 4 - Grupo 1 (Pilhas tipo PEM)

Considerando o desenvolvimento tecnológico e a descoberta de novos materiais, qual é a sua expectativa de substituição dos materiais utilizados atualmente por novos materiais, com menor impacto ambiental, para um horizonte de 20 anos?

Item: Catalisador

\begin{tabular}{l|c|c|c|c|c}
\hline Catalisador & $\begin{array}{c}\text { Probabilidade } \\
\text { Alta }\end{array}$ & $\begin{array}{c}\text { Probabilidade } \\
\text { Média Alta }\end{array}$ & $\begin{array}{c}\text { Probabilidade } \\
\text { Média }\end{array}$ & $\begin{array}{c}\text { Probabilidade } \\
\text { Média Baixa }\end{array}$ & $\begin{array}{c}\text { Probabilidade } \\
\text { Baixa }\end{array}$ \\
\hline Pesos & 1 & 2 & 3 & 4 & 5 \\
\hline
\end{tabular}

Neste exemplo as respostas da questão foram consideradas como números para os cálculos numa amplitude de "1" à "5", ou seja, se um especialista respondesse "Probabilidade alta" ("High Probability"), sua resposta na questão seria computada como "1", ou se fosse "Probabilidade baixa" ("Low Probability"), seria computada como " 5 ". Esta métrica é útil para a realização da análise de variância (ANOVA).

Em todas outras questões que envolviam respostas múltiplas as alternativas tiveram o mesmo peso.

Enfim, as 21 perguntas da primeira rodada foram enviadas aos 471 especialistas da academia, indústria e governo. Todo o questionário Delphi foi realizado em tempo por meio da internet, os participantes receberam um e-mail contendo o convite e um "link" direto para acessar o questionário por meio da página do QuestionPro (vide Figura 6-3). Quando os inquiridos acessavam a pesquisa por meio do "link", o sistema detectava o seu cadastro de e-mail 
existente no banco de dados, além de também detectar o país de origem por meio do sistema "geo-coding". Este sistema permite detectar, por meio do endereço IP do computador utilizado, em qual país o respondente se encontra. A lista dos códigos de países e continentes pode ser obtida nas referências ISO3166 (2006), no site da Maxmind (2009) e na Wikipédia (2009). Esta informação foi utilizada para analisar os grupos de respondentes por continente.

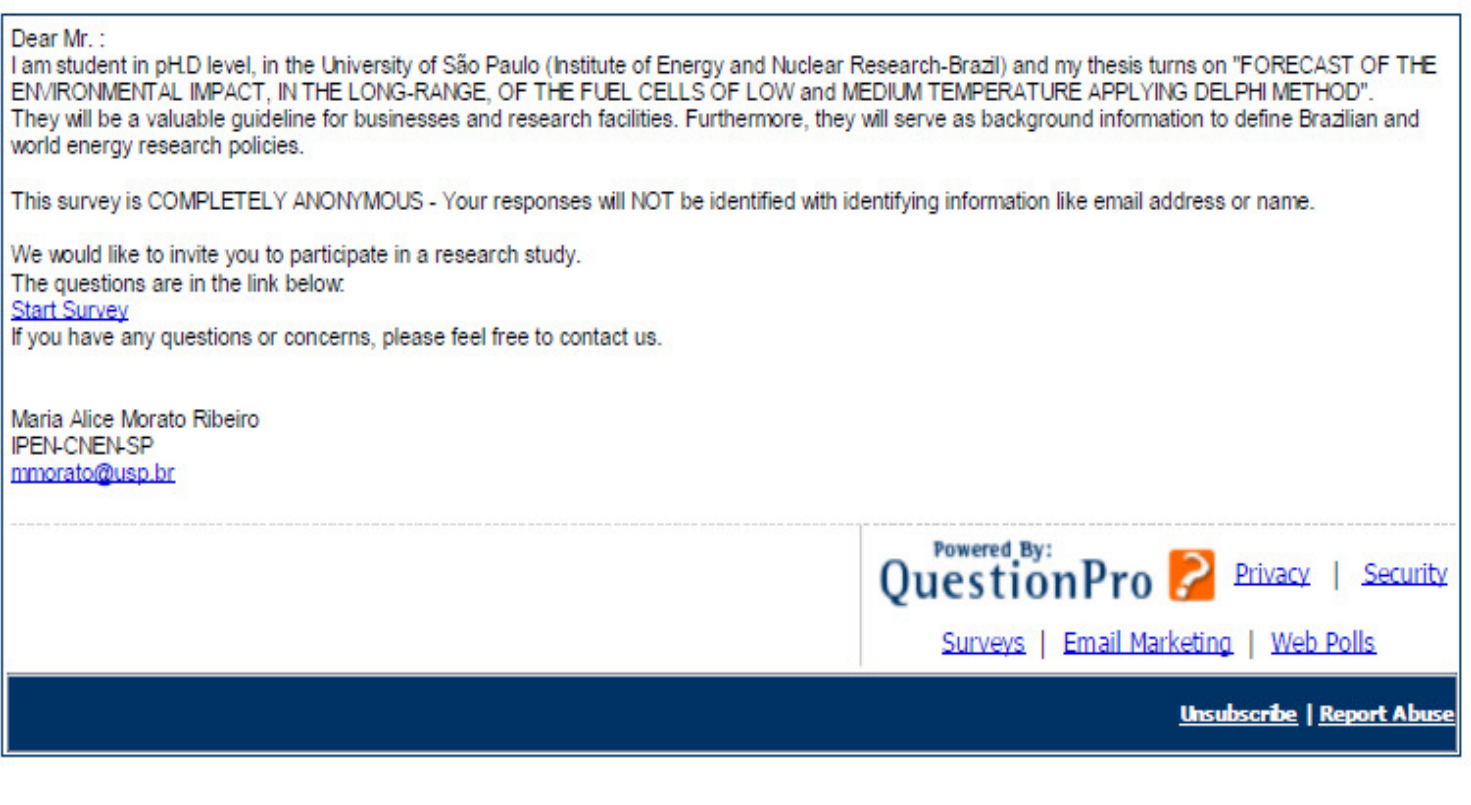

Figura 6-3 - Exemplo de email de envio da pesquisa para o respondente.

O sistema fornecido pela QuestionPro também apresenta as alternativas de modo aleatório para o respondente, de modo que, para cada questão, a ordem das alternativas era diferente para cada respondente.

Além da comunicação automática via e-mail, por meio do QuestionPro, existiu também uma comunicação por e-mail direta entre o candidato a respondente e o realizador da pesquisa, a fim de salientar a importância de sua participação e se necessário solucionar dúvidas do respondente.

Por meio da construção do banco de dados inicial pôde ser obtida a informação de sexo dos respondentes, mas quando o respondente não se identificou (fornecendo o seu e-mail, por exemplo) e não acessou o questionário via o "link" fornecido dentro do e-mail de envio, foi impossível reconhecer o respondente, e assim definir o seu sexo. Mas a quantidade dos dados disponíveis de sexo dos respondentes foi suficiente para que se avaliasse a influência do 
sexo nas respostas, na primeira rodada.

Após o término da primeira rodada os resultados foram compilados. Os gráficos dos resultados também acompanharam respectivamente cada pergunta efetuada novamente. Assim todos os respondentes da primeira rodada receberam o novo questionário no qual cada pergunta estava acompanhada do gráfico com as estatísticas da primeira rodada, conforme Figura 6-4. Caso os respondentes julgassem necessário poderiam mudar sua opinião e no caso de haver um aumento do consenso da primeira para a segunda rodada, a diferença das variâncias dos grupos analisados diminui.

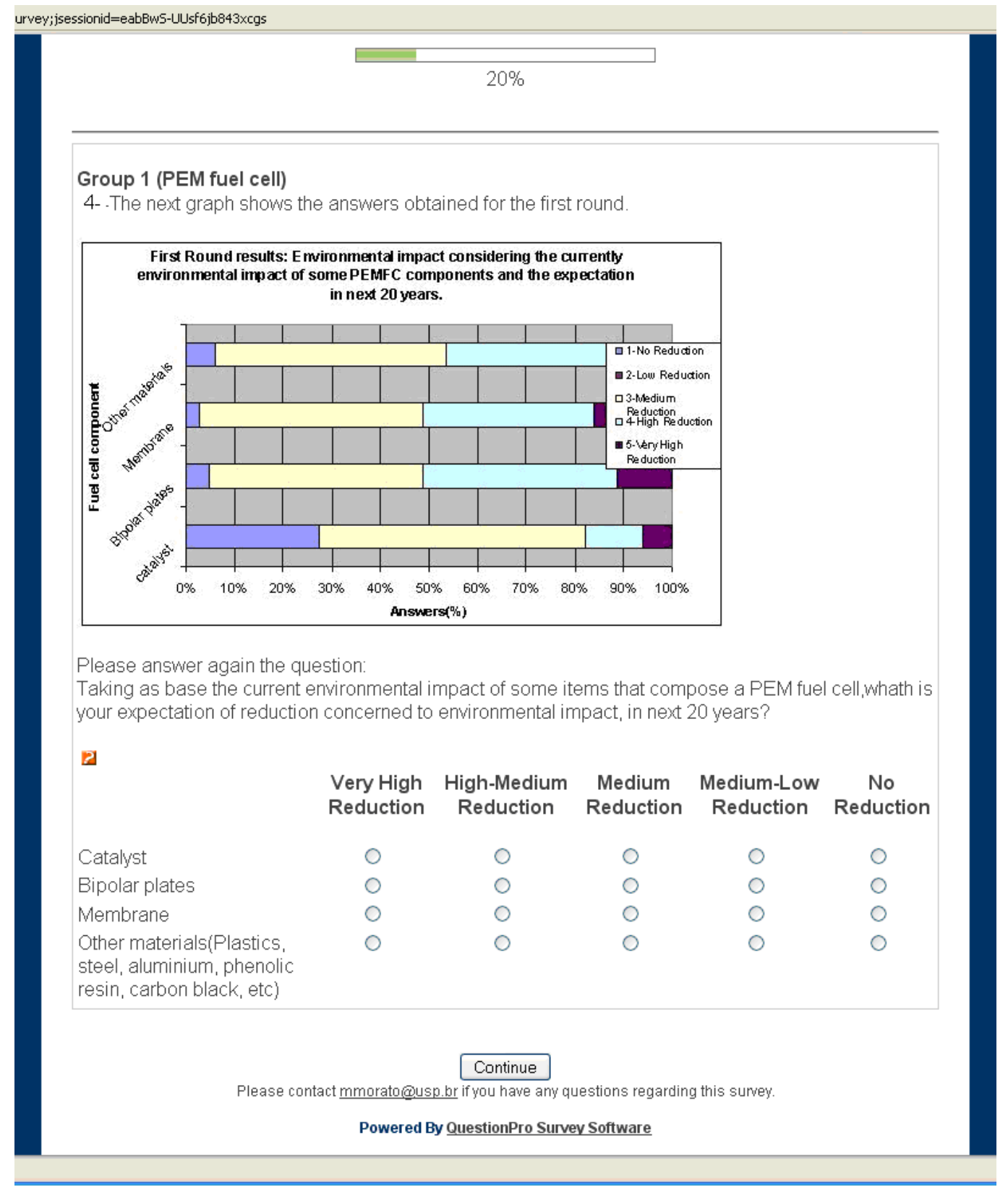

Figura 6-4 - Apresentação da questão 4 na segunda rodada. 


\section{3 - Análise de variância da primeira rodada na pesquisa Delphi}

A ferramenta estatística análise de variância ANOVA, descrita no Anexo $A$, foi utilizada para verificar a existência de diferenças significativas de opinião para diferentes características dos respondentes, na primeira rodada da pesquisa Delphi em energia. As características analisadas foram:

- Diferentes graus de especialidade dos respondentes (especialista, conhecedor, familiarizado e não familiarizado);

- Diferentes setores de atividade dos respondentes (academia, desenvolvimento industrial, tecnologia, produção e operação da indústria e governo);

- Diferentes continentes onde está o respondente ou;

- Diferentes sexos dos respondentes.

Os dados destas diferentes características foram obtidos por meio da compilação das respostas obtidas na primeira rodada da pesquisa. Assim foi possível separar a especialização dos respondentes, bem como os diferentes setores de atividade, o continente e o sexo.

Do Anexo A deve ser lembrado que a ANOVA é uma ferramenta que serve para detectar a diferença da variabilidade entre diferentes grupos, mas devem ser sempre observadas as hipóteses necessárias para a sua correta aplicação:

1- As observações para julgamentos individuais: os respondentes não podem ter a oportunidade de ouvirem, verem ou serem influenciados pelas respostas dos outros participantes.

2- A distribuição das médias dos subgrupos deve se aproximar de uma distribuição normal.

3- $O$ teste $F$ é baseado na hipótese de que as variâncias das populações sejam iguais, porque para se realizar uma ANOVA é necessário ter amplitudes de respostas semelhantes entre as populações.

A hipótese 1 é satisfeita apenas na primeira rodada da pesquisa Delphi em impacto ambiental das pilhas a combustível, pois os questionários foram respondidos individualmente sem que os respondentes pudessem interagir entre si. Na segunda rodada isto já não ocorreu porque os dados de todos os respondentes foram compilados e novamente enviados para nova análise. A hipótese 2 é satisfeita por meio do "teorema do limite central", explicado com 
maiores detalhes no Anexo $\mathrm{A}$ deste trabalho. A hipótese 3 é válida porque a amplitude das respostas entre as diferentes populações dos respondentes é a mesma, visto que as respostas foram quantificadas por meio de valores discretos para as análises; conforme apresentado no item 6.2.

Todos os cálculos da ANOVA foram efetuados com o auxílio de dados exportados do Questionpro por meio de planilhas do Microsoft Excel. Os dados das planilhas são então separados por:

-grau de especialização,

-ramo de atividade,

-continente e,

-sexo.

Estes dados são então convertidos para arquivos no formato csv. Estes dados são então importados pelo programa Matlab que efetuou o cálculo da ANOVA. Após o cálculo os dados são novamente exportados para o formato csv e depois convertido para o Microsoft ${ }^{\circledR}$ Office Excel, $O$ resultado são as tabelas conforme a mostrada na Tabela 6-2, como exemplo.

A Tabela 6-2 apresenta os dados referentes a dois tópicos de diferentes questões comparando a influência da qualificação do respondente no tipo de resposta apresentado.

Tabela 6-2 - Exemplo do quadro final de ANOVA

\begin{tabular}{l|r|l|l|l|l}
\hline QUESTÃO 8 & $\begin{array}{l}\text { Soma dos } \\
\text { Quadrados }\end{array}$ & $\begin{array}{l}\text { Graus de } \\
\text { Liberdade }\end{array}$ & $\begin{array}{l}\text { Médias } \\
\text { Quadradas }\end{array}$ & Razão & F (5\%) \\
\hline ÍTEM 1 & 13,93 & 3 & 4,64 & 4,26 & 2,75 \\
\cline { 2 - 7 } CATALISADOR & 71,90 & 66 & 1,08 & & \\
\hline \multicolumn{7}{l}{ QUESTÃO 10 } & $\begin{array}{l}\text { Soma dos } \\
\text { Quadrados }\end{array}$ & $\begin{array}{l}\text { Graus de } \\
\text { Liberdade }\end{array}$ & $\begin{array}{l}\text { Médias } \\
\text { Quadradas }\end{array}$ & Razão & F (5\%) \\
\hline ÍTEM 1 & 3,68 & 3 & 1,22 & 0,81 & 2,75 \\
\cline { 2 - 7 } CATALISADOR & 94,93 & 63 & 1,50 & & \\
\hline
\end{tabular}

A tabela apresenta então a razão, que é comparada com o teste de distribuição $F$ com os graus de liberdade indicados na segunda coluna. No primeiro caso a razão dos grupos fornece um valor (4,26 no exemplo), que é comparado com o teste de distribuição $\mathrm{F}$ com 3 e 63 graus de liberdade, resultando num valor superior à $\mathrm{F}$ para um nível de significância de $5 \%$, que foi adotado neste trabalho. De acordo com Anderson e Finn (1996), um valor de nível 
de significância de $5 \%$ pode ser considerado confiável, ou seja, se os resultados do valor da razão forem superiores ao valor de $F$, em nível de significância $(\alpha)$ de $5 \%$, pode-se dizer que as respostas dos diferentes grupos de respondentes são diferentes com uma boa confiabilidade (maiores detalhes vide Anexo A). Já no segundo caso (para a questão 10), a razão encontrada foi de 0,81 , que é inferior ao valor de $F$ para $5 \%=2,75$, ou seja, a razão é inferior a $F(5 \%)$ o que leva a concluir que a qualificação do respondente não influiu na resposta.

É importante relembrar que todas as análises foram realizadas separadamente para os grupos 1 (pilhas PEM), 2 (pilhas PAFC), 3 (pilhas MCFC) e 4 (combustíveis utilizados nas pilhas a combustível). Isto porque, em sua maioria, os respondentes e suas qualificações dentro dos vários grupos não coincidem, sendo então consideradas amostras diferentes de populações diferentes (além do mais os grupos 1, 2, 3 e 4 correspondem a diferentes áreas do conhecimento). Além disso, muitos responderam parcialmente, não respondendo as questões de alguns grupos.

\section{4 - Medição do consenso e mudança de opinião na pesquisa Delphi}

Numa consulta Delphi, talvez a questão mais relevante seja sobre a mudança de opinião no decorrer das duas rodadas. Um método de avaliação desta mudança é por meio da variação das médias das respostas da primeira para a segunda rodada. Mas ocorre um problema em razão dos valores serem discretos. Assim uma variação das médias deve ser previamente definida a fim de evitar discrepâncias. Neste trabalho utilizamos uma mudança mínima nas médias maior que 0,5 para considerar a ocorrência de uma mudança de opinião. Para estas análises foram utilizadas planilhas do programa Microsoft Excel (v.2003).

Para saber como o consenso variou da primeira para a segunda rodada, pode-se utilizar a variação do desvio padrão das respostas entre as rodadas. Mas é importante salientar que esta análise foi apenas para testar se o consenso no decorrer das rodadas aumentou ou diminuiu; não é possível apenas com a análise do desvio padrão saber se houve uma convergência das respostas, já que as médias podem ter variado de forma diferente (a Figura 6-5 ilustra um exemplo desta situação). Se o desvio padrão diminuir da primeira para a segunda rodada, então é porque existiu um maior consenso da questão e do tópico 
analisado.

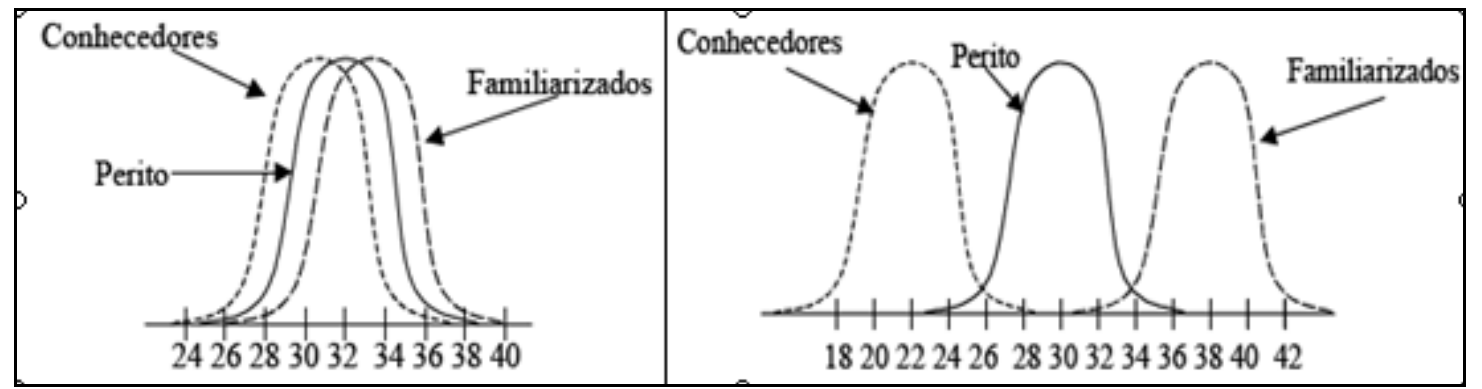

Figura 6-5 - Exemplo de como as médias e os desvios padrão podem variar de forma diferente (SANT'ANNA, 2005).

Para se realizar as análises da variação dos desvios padrão, foram utilizadas as respostas válidas das duas rodadas da pesquisa Delphi em energia. A fórmula do desvio padrão amostral é:

$$
s=\sqrt{\frac{\sum\left(x_{i}-\bar{x}\right)}{n-1}}
$$

Equação 6-1

e a equação utilizada para medir a variação do desvio padrão:

Variação_do_desvio_padrão $=1-\frac{s_{2}}{s_{1}}$ Equação 6-2

na qual $s_{1}$ e $s_{2}$ são os desvios padrão das respostas da primeira e segunda rodadas, respectivamente. Valores positivos significam uma diminuição do desvio padrão da primeira para a segunda rodada, indicando um aumento do consenso; valores negativos, o inverso.

Os grupos, a população e as amostras de cada grupo foram considerados diferentes nas análises. Isto porque um respondente pode ter diferentes qualificações em cada grupo, bem como teve a opção de responder ou não a um determinado grupo.

As análises da variação das médias, dos desvios padrão (consenso) e da convergência visam mostrar a eficácia da técnica Delphi como uma ferramenta que permite a mudança de opinião, um aumento do consenso e que permite a convergência das respostas no decorrer das duas rodadas.

A escolha deste tipo de análise foi efetuada ao invés de outros métodos mais tradicionais, como a relação entre quartis ou o coeficiente de 
variação da média (média/desvio padrão) porque o número de respostas por item às vezes foi pequeno (WRIGHT e GIOVINAZZO, 2000).

\section{5 - Análise de convergência das respostas na pesquisa Delphi}

A metodologia utilizada para medir a convergência das respostas da primeira para a segunda rodada da pesquisa Delphi foi analisada considerando dois grupos de respondentes: os mais especializados e os menos especializados. Os mais especializados consistem dos respondentes que se declararam peritos ou conhecedores. Os menos especializados são todos os respondentes que se declararam familiarizados ou não familiarizados.

O princípio adotado foi fixar a resposta da primeira rodada da consulta Delphi. Depois de fornecer os histogramas com a distribuição das respostas obtidas na primeira fase, na segunda rodada, foi investigado se as respostas do grupo menos especializado (familiarizados e não familiarizados) convergiram na direção do grupo mais especializado (peritos e conhecedores) da primeira para a segunda rodada da pesquisa. Esta análise fixou as respostas da primeira rodada dos peritos e conhecedores, para uma posterior comparação com a variação das respostas da primeira para a segunda rodada dos familiarizados e não familiarizados.

\section{6 - Apresentação dos resultados da primeira rodada da consulta Delphi}

Após a apresentação da metodologia utilizada nesta dissertação, esta seção apresenta o resultado da participação dos especialistas convidados na pesquisa Delphi em impacto ambiental das pilhas a combustível. E a segunda rodada é apresentada na seção 6.7 .

Antes do primeiro envio do questionário foram transmitidos e-mails para todos os candidatos a respondentes (conforme item 6.2.1), que respondiam se desejavam ou não participar da pesquisa resultando num banco de dados de 471 de participantes que aceitaram participar da pesquisa. Destes 471 candidatos que receberam o convite para a $1^{\underline{a}}$ rodada, apenas 226 iniciaram o questionário e destes somente 83 responderam integralmente à pesquisa, 39 responderam de modo parcial, além de 49 que estavam com o endereço eletrônico errado. Os que não responderam à pesquisa, pois se consideraram incapazes, tecnicamente, de participar por motivos variados foram 245. Assim a taxa de resposta líquida foi de 
25,6\%, que é baixa, mas aceitável conforme Shin (1998).

Na Tabela 6-3 é mostrada a quantidade de respondentes na primeira rodada. Eles foram sobretudo homens (88\%) que correspondem à dominação masculina no setor de pilhas a combustível.

Tabela 6-3 - Visão geral da população de respondentes na primeira rodada

\begin{tabular}{l|l|l}
\hline \multirow{2}{*}{} & \multicolumn{2}{|c}{ 1 a - Rodada } \\
\cline { 2 - 3 } & Número & $\%$ \\
\hline População total & 471 & \\
\hline Respondentes & $83+39$ & $25,6 \%$ \\
\hline Feminino & 11 & $12 \%$ \\
\hline Masculino & 84 & $88 \%$ \\
\hline Sem identificação & 27 & \\
\hline
\end{tabular}

Como as pilhas a combustível ainda são uma tecnologia emergente num mundo globalizado, a avaliação do impacto ambiental por meio da pesquisa Delphi necessita de opiniões globalizadas para participar na pesquisa e por isso, utilizando a internet como meio de comunicação, foram convidados peritos de várias partes do mundo para participar da pesquisa. A distribuição dos respondentes entre os países não foi homogênea até porque a participação era voluntária.

A maioria dos respondentes (42\%) reside sobretudo na América do Norte e Central, e em segundo lugar na Europa (37\%). Na Figura 6-6 são apresentados os dados dos respondentes por continente dos respondentes que participaram da pesquisa e na Figura 6-6 as percentagens de respondentes por país onde reside.

Resolveu-se separar as Américas em dois grupos: América do Norte+Central e a América do Sul. 


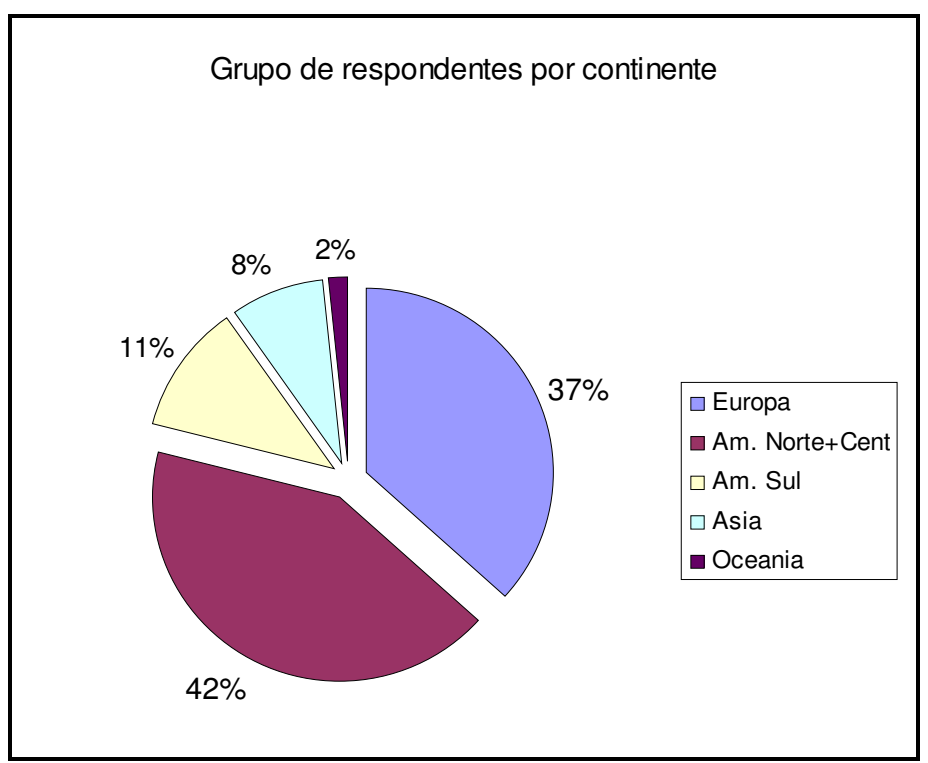

Figura 6-6 - Respondentes por continente na primeira rodada.

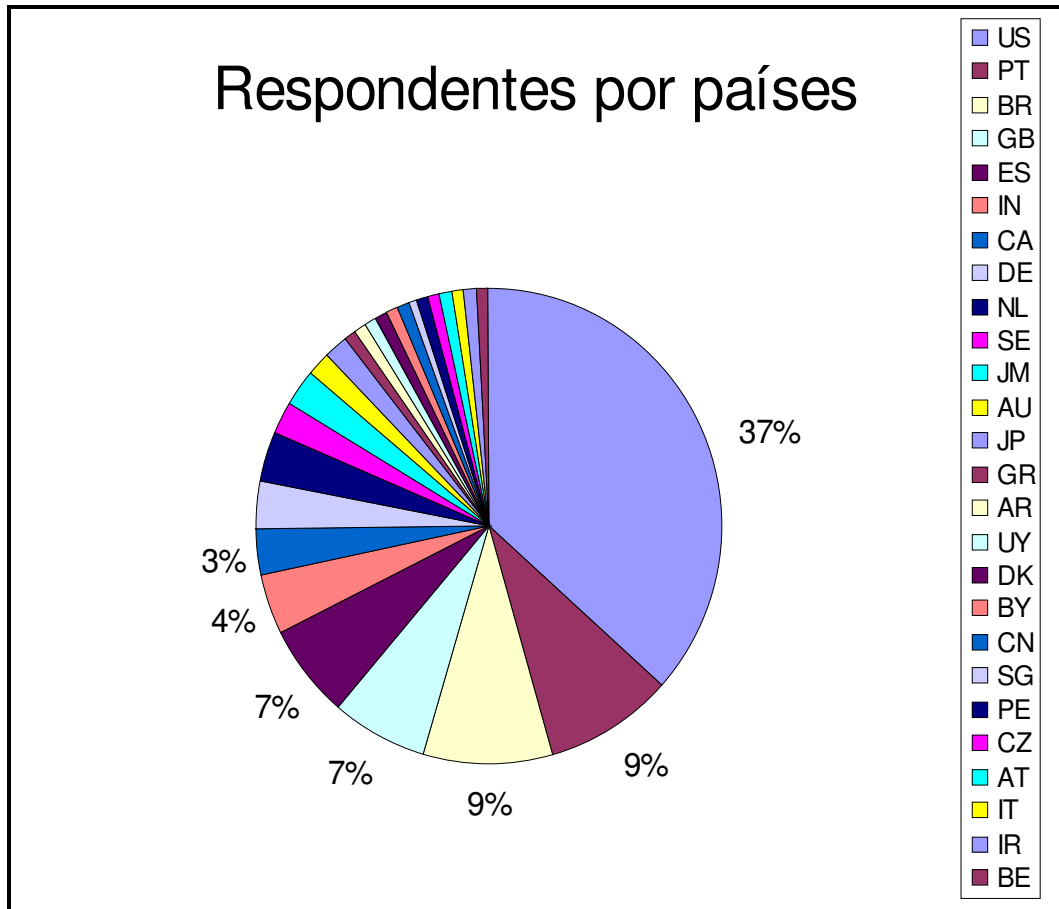

Figura 6-7 - Respondentes por país, na primeira rodada

\begin{tabular}{|l|c|c|c|c|c|c|c|c|c|}
\hline US & Estados Unidos & BR & Brasil & ES & Espanha & CA & Canadá & NL & Holanda \\
\hline PT & Portugal & GB & Grã Bretanha & IN & Índia & DE & Alemanha & SE & Suécia \\
\hline JM & Jamaica & AU & Austrália & JP & Japão & GR & Grécia & AR & Argentina \\
\hline UY & Uruguai & DK & Dinamarca & BY & Bielo-Rússia & CN & China & SG & Singapura \\
\hline PE & Peru & CZ & Checoslováquia & AT & Áustria & IT & Itália & IR & Irã \\
\hline BE & Bélgica & EU & Europa & LT & Lituânia & & & & \\
\hline
\end{tabular}

Obs.: o código EU só é utilizado quando o sistema não conseguiu localizar um país específico mas somente o continente. 


\subsubsection{Dados dos respondentes às questões do grupo 1}

A seguir são apresentados, na Figura 6.8, os dados de qualificação e ramo de atividade dos respondentes para o grupo 1 (pilhas PEM).

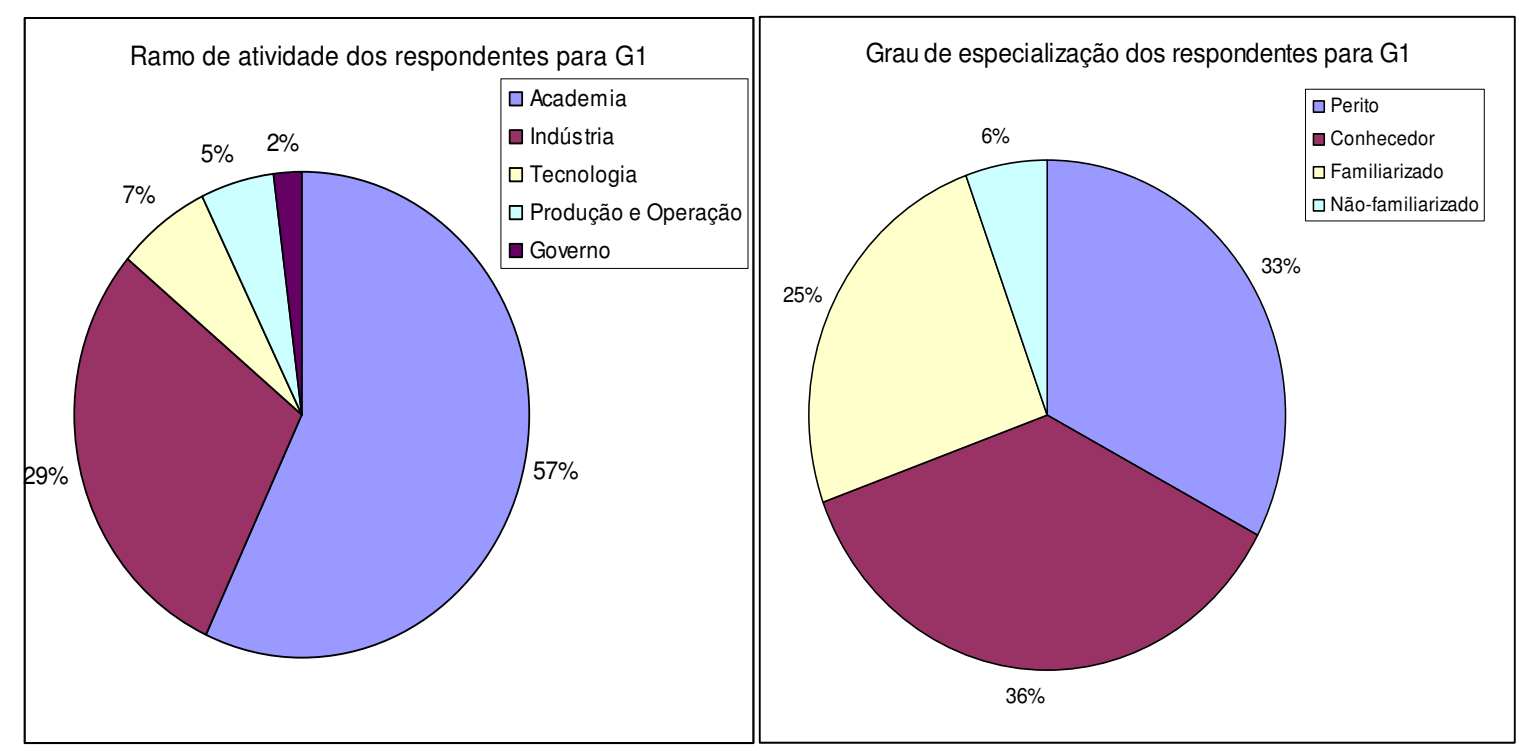

Figura 6-8 - Nível de especialização e área de atuação dos respondentes na primeira rodada, para o grupo 1.

Para cada questão serão apresentados os resultados percentuais para cada opção de resposta e os resultados das análises de ANOVA para avaliar a influência das características dos respondentes no tipo de resposta. As características analisadas foram: especialização, ramo de atuação, continente e sexo do respondente.

\subsubsection{Grupo 1 - Questão 3}

A questão 3 versa sobre a expectativa de redução do impacto ambiental da pilha PEM a longo prazo. A questão exigia respostas separadas para cada um dos itens considerados na composição da pilha: catalisador, membrana, placas bipolares e "outros materiais".

A seguir é apresentada, como exemplo, a questão 3 tal qual foi apresentada na internet para os respondentes.

Para efeito de cálculos estatísticos foi considerado um valor para cada resposta. Os resultados percentuais referentes às opções de respostas estão apresentados a seguir, na Tabela 6-4. 
Tabela 6-4 - Opções de resposta para os itens da questão 3 (\%).

\begin{tabular}{c|c|c|c|c|c}
\hline & $\begin{array}{c}\text { Redução Muito } \\
\text { Alta }\end{array}$ & $\begin{array}{c}\text { Redução Média } \\
\text { Alta }\end{array}$ & $\begin{array}{c}\text { Redução } \\
\text { Média }\end{array}$ & $\begin{array}{c}\text { Redução Média } \\
\text { Baixa }\end{array}$ & $\begin{array}{c}\text { Sem } \\
\text { Redução }\end{array}$ \\
\hline & 1 & 2 & 3 & 4 & 5 \\
\hline Catalisador & $18,3 \%$ & $33,3 \%$ & $36,5 \%$ & $7,9 \%$ & $4,0 \%$ \\
\hline Membrana & $14,3 \%$ & $30,9 \%$ & $40,5 \%$ & $11,9 \%$ & $2,4 \%$ \\
\hline $\begin{array}{c}\text { Placas } \\
\text { bipolares }\end{array}$ & $9,5 \%$ & $34,1 \%$ & $37,3 \%$ & $15,1 \%$ & $4,0 \%$ \\
\hline $\begin{array}{c}\text { Outros } \\
\text { Materiais }\end{array}$ & $10,5 \%$ & $27,4 \%$ & $38,7 \%$ & $18,6 \%$ & $4,8 \%$ \\
\hline
\end{tabular}

Nota: as opções com fundo verde são as mais escolhidas e as com fundo amarelo as menos escolhidas.

Da análise de variância com os grupos respondentes resultaram as características dos respondentes, para as quais existe correlação com o tipo de resposta apresentado. Na Tabela 6-5 são apresentados os dados resultantes desta análise.

Tabela 6-5 - Correlação entre respostas e características do respondente.

\begin{tabular}{c|c|l|l|l}
\hline Item & \multicolumn{4}{|c}{ Características do respondente } \\
\hline & Qualificação & Ramo de atuação & Continente & Sexo \\
\hline Catalisador & & & & \\
\hline Membrana & & & & \\
\hline Placas Bipolares & & & & \\
\hline Outros materiais & & & & \\
\hline
\end{tabular}

\begin{tabular}{|l} 
Existe correlação \\
Não existe correlação
\end{tabular}

A Figura 6-9 mostra a avaliação da diminuição do impacto ambiental da pilha tipo PEM, a longo prazo, por especialização do respondente (autoavaliação). E para o item catalisador da questão 3, a análise de variância mostrou que para o caso da qualificação do respondente, considerando um nível de significância de $5 \%$, a qualificação do respondente influiu no tipo de resposta. Para as características: continente, o ramo de atividade e sexo, a análise de variância não encontrou relação entre estas características e as respostas. 

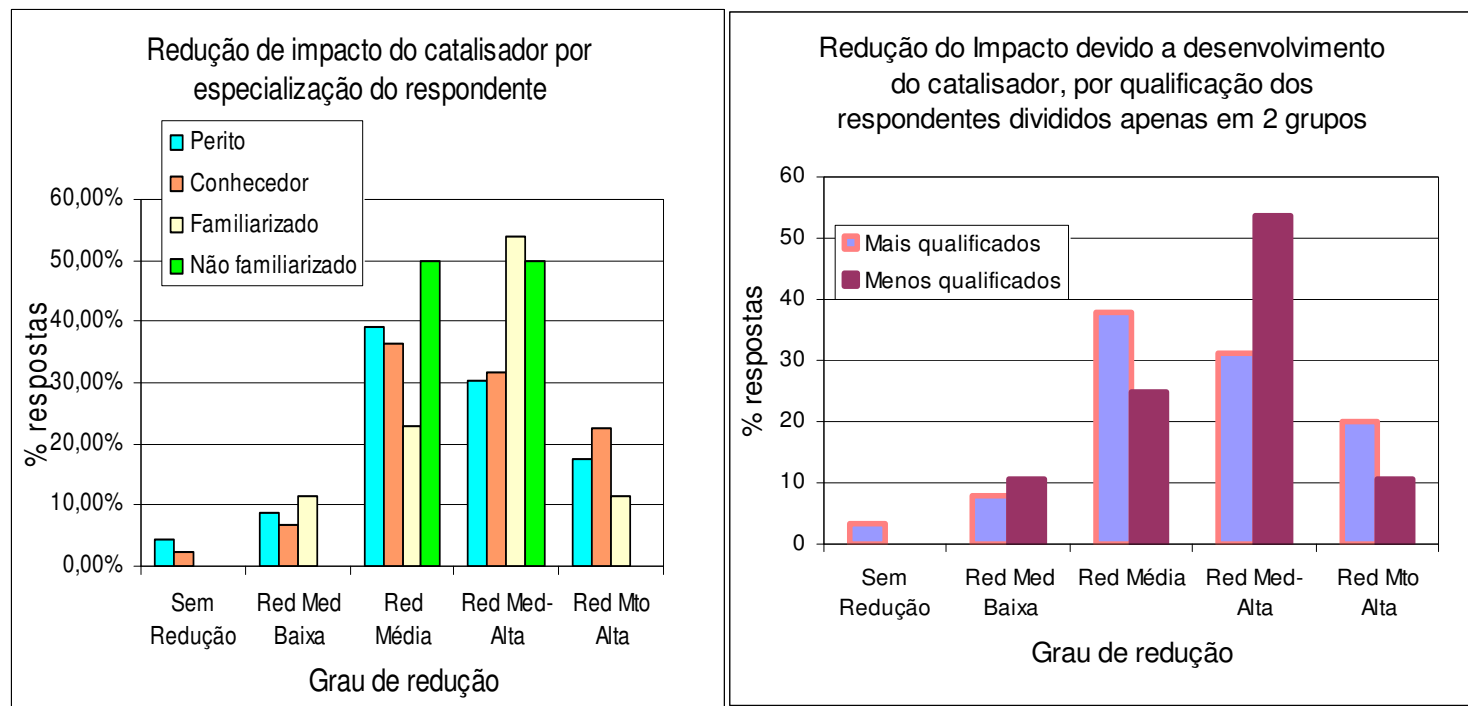

Figura 6-9 - Expectativa de redução do impacto ambiental das pilhas tipo PEM, por causa do catalisador, a longo prazo, por especialização do respondente.

Já para o item placas bipolares, por meio da análise de variância, conforme estabelecido no Anexo $\mathrm{A}$, e considerando um nível de significância de $5 \%$ verificou-se que a qualificação do respondente influiu no tipo de resposta. E a Figura 6-10 apresentada a expectativa da diminuição do impacto ambiental devido às placas bipolares, a longo prazo, por especialização do respondente (autoavaliação).
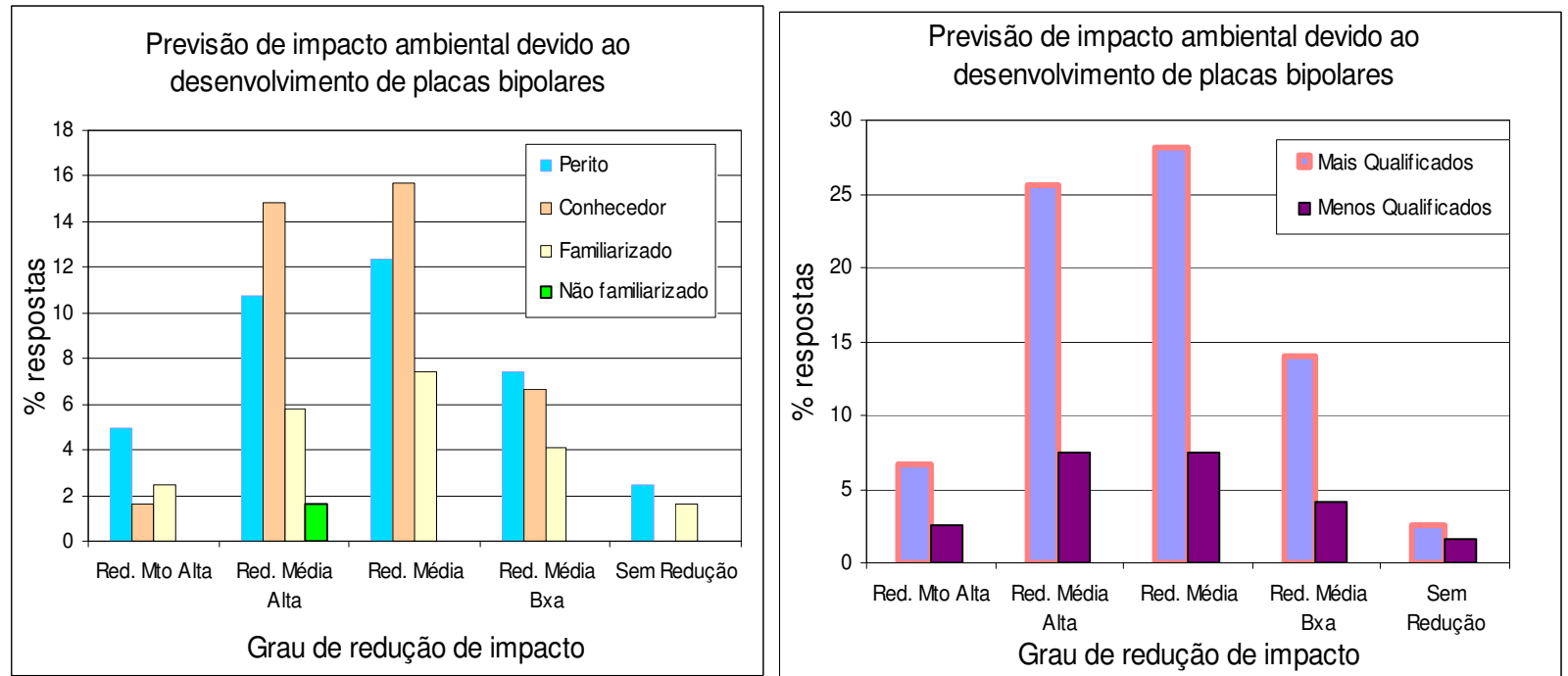

Figura 6-10 - Expectativa do impacto ambiental por causa do desenvolvimento na área de placas bipolares, a longo prazo, por especialização do respondente.

Finalmente, para se ter uma idéia de como o desenvolvimento de materiais pode influir no impacto ambiental das pilhas a combustível, a longo prazo, a Figura 6-11 mostra a comparação entre as respostas obtidas para cada 
item abordado na questão: catalisador, membrana, placas bipolares e outros materiais.

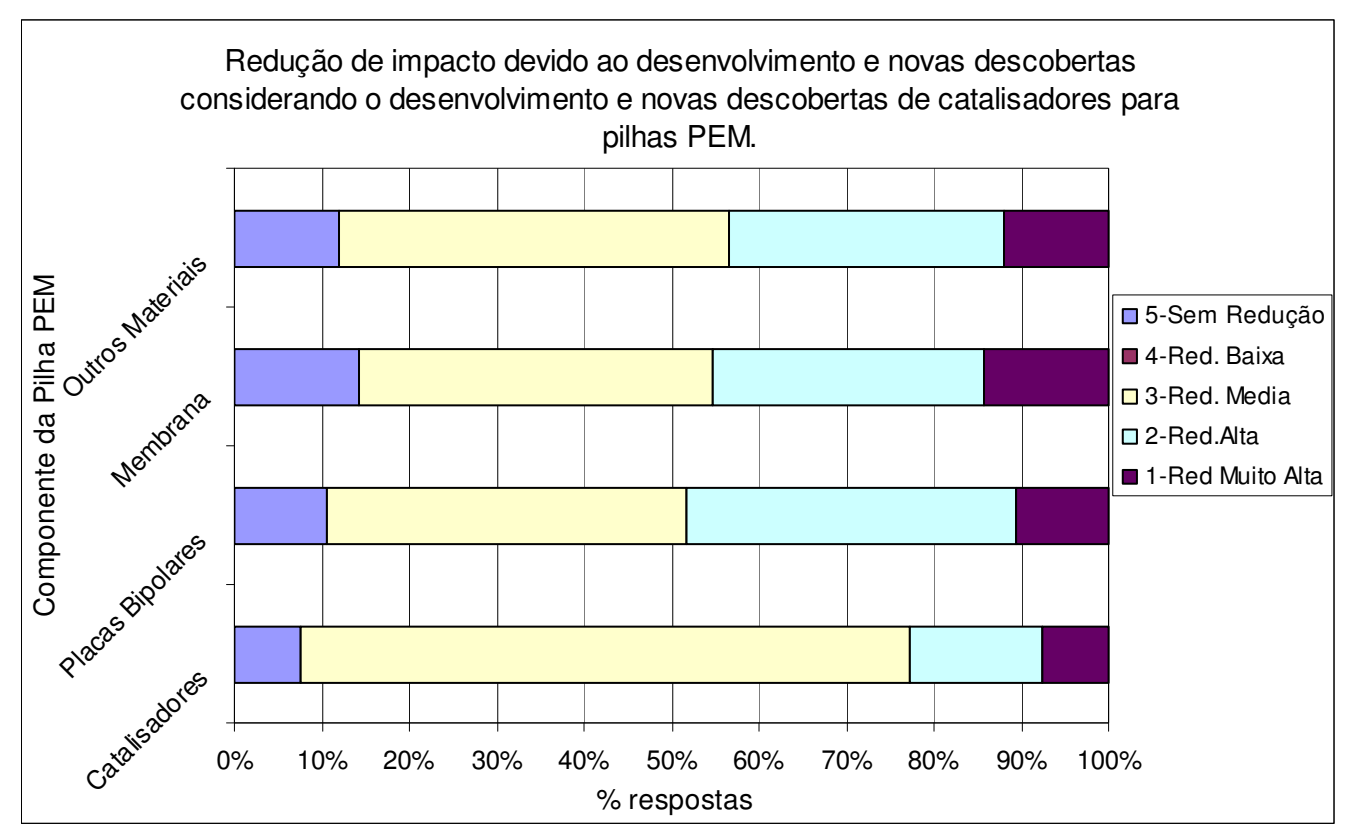

Figura 6-11 - Comparação das respostas para os quatro itens considerados na questão 3: Catalisador, Membrana, Placas Bipolares e Outros Materiais.

A Figura 6-12 apresenta uma comparação entre as médias e desvios padrão para todos os itens da pilha, mostrando que os respondentes não conseguiram identificar um item que especificamente possa ser o mais responsável pela diminuição do impacto ambiental, a longo prazo. E também se pode concluir que não existiu divergência muito grande entre as opiniões.

A análise de variância mostrou que para os itens catalisadores e placas bipolares, a qualificação dos respondentes mostrou influência sobre as respostas obtidas. Para os outros itens esta relação não existiu. Também não existiu nenhuma relação entre as outras características dos respondentes (ramo de atividade, sexo e continente do respondente) e as respostas sobre todos os itens. 


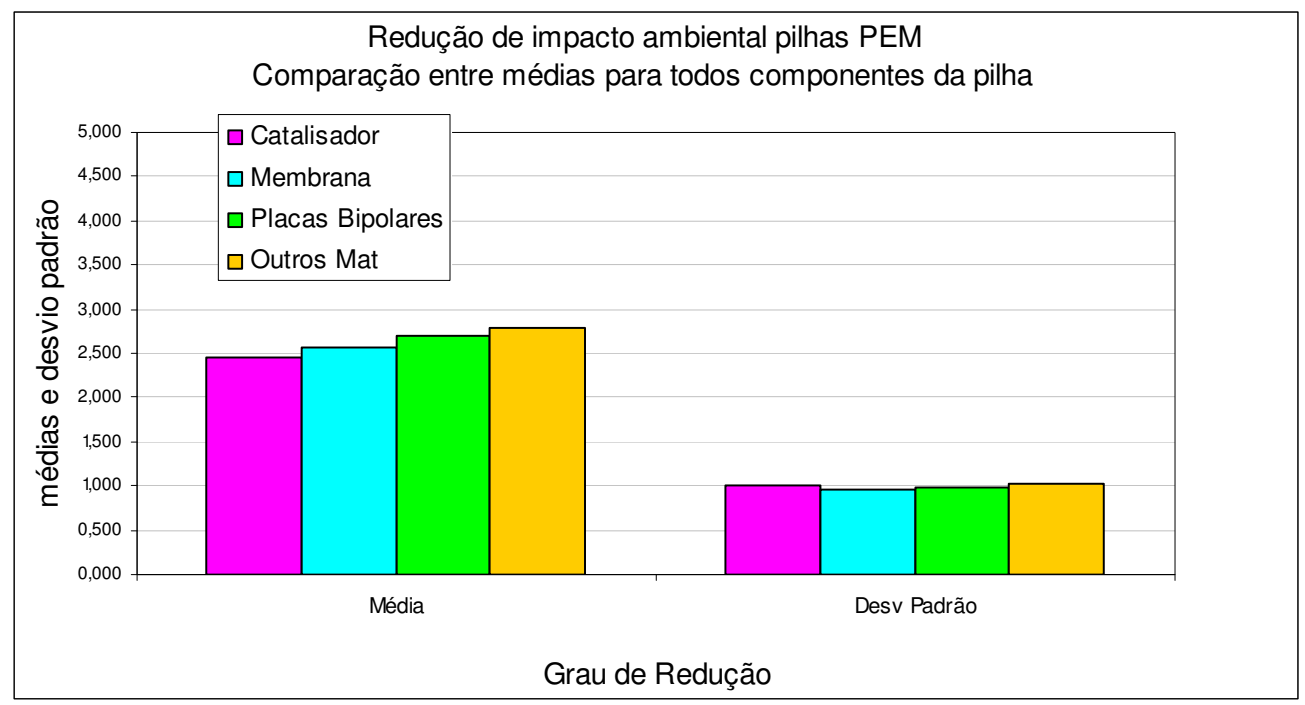

Figura 6-12 - Comparação entre médias e desvio padrão das respostas para os itens da pilha: Catalisador, Membrana, Placas Bipolares e Outros Materiais.

Nota: 1- Redução Muito Alta, 2- Redução Média Alta, 3- Redução Média, 4- Redução Média Baixa e 5-Sem redução.

\subsubsection{Questão 4- Grupo 1}

A questão 4 versa sobre a expectativa de substituição dos materiais para redução do impacto ambiental devido à substituição dos materiais atualmente utilizados e sua consequência no impacto ambiental da pilha a longo prazo. A questão 4, tal qual foi originalmente apresentada aos respondentes encontra-se no Anexo B-1.

Do mesmo modo que para a questão 3, para efeito de cálculos estatísticos foi considerado um valor para cada resposta. Os resultados percentuais referentes às opções de respostas estão apresentados a seguir, na Tabela 6-6.

Tabela 6-6 - Resposta para os itens da questão 4 (\%)

\begin{tabular}{c|c|c|c|c|c}
\hline & $\begin{array}{c}\text { Probabilidade } \\
\text { Alta }\end{array}$ & $\begin{array}{c}\text { Probabilidade } \\
\text { Média Alta }\end{array}$ & $\begin{array}{c}\text { Probabilidade } \\
\text { Média }\end{array}$ & $\begin{array}{c}\text { Probabilidade } \\
\text { Média Baixa }\end{array}$ & $\begin{array}{c}\text { Probabilidade } \\
\text { Baixa }\end{array}$ \\
\hline Catalisador & 1 & 2 & 3 & 4 & 5 \\
\hline Membrana & $30,3 \%$ & $32,7 \%$ & $26,1 \%$ & $8,4 \%$ & $2,5 \%$ \\
\hline $\begin{array}{c}\text { Placas } \\
\text { bipolares }\end{array}$ & $17,5 \%$ & $31,4 \%$ & $24,8 \%$ & $9,9 \%$ & $0,8 \%$ \\
\hline $\begin{array}{c}\text { Outros } \\
\text { Materiais }\end{array}$ & $18,0 \%$ & $23,1 \%$ & $36,6 \%$ & $11,7 \%$ & $1,7 \%$ \\
\hline
\end{tabular}

Nota: as opções com fundo verde são as mais escolhidas e as com fundo amarelo as menos escolhidas.

Da análise de variância com os grupos respondentes resultaram as 
características dos respondentes, para as quais existe correlação com o tipo de resposta apresentado. Na Tabela 6-7 são apresentados os dados resultantes desta análise.

Tabela 6-7 - Correlação entre respostas e características do respondente para questão 4.

\begin{tabular}{c|l|l|l|l}
\hline Item & \multicolumn{4}{|c}{ Características do respondente } \\
\hline & Qualificação & Ramo de atuação & Continente & Sexo \\
\hline Catalisador & & & & \\
\hline Membrana & & & & \\
\hline Placas Bipolares & & & & \\
\hline Outros materiais & & & & \\
\hline
\end{tabular}

Existe correlação Não existe correlação

$\mathrm{Na}$ Figura 6-13 é mostrada a expectativa de substituição dos componentes para redução do impacto ambiental em razão do desenvolvimento tecnológico e à descoberta de novos materiais que possam vir a substituir a membrana, para as pilhas tipo PEM, a longo prazo, considerando a especialização do respondente (as \% foram calculadas sobre a quantidade total de respostas). Neste caso por meio da análise de variância verificou-se que existia uma relação entre a resposta e a qualificação do respondente, considerando um nível de significância de 5\%, verificou-se que a qualificação do respondente influiu no tipo de resposta.

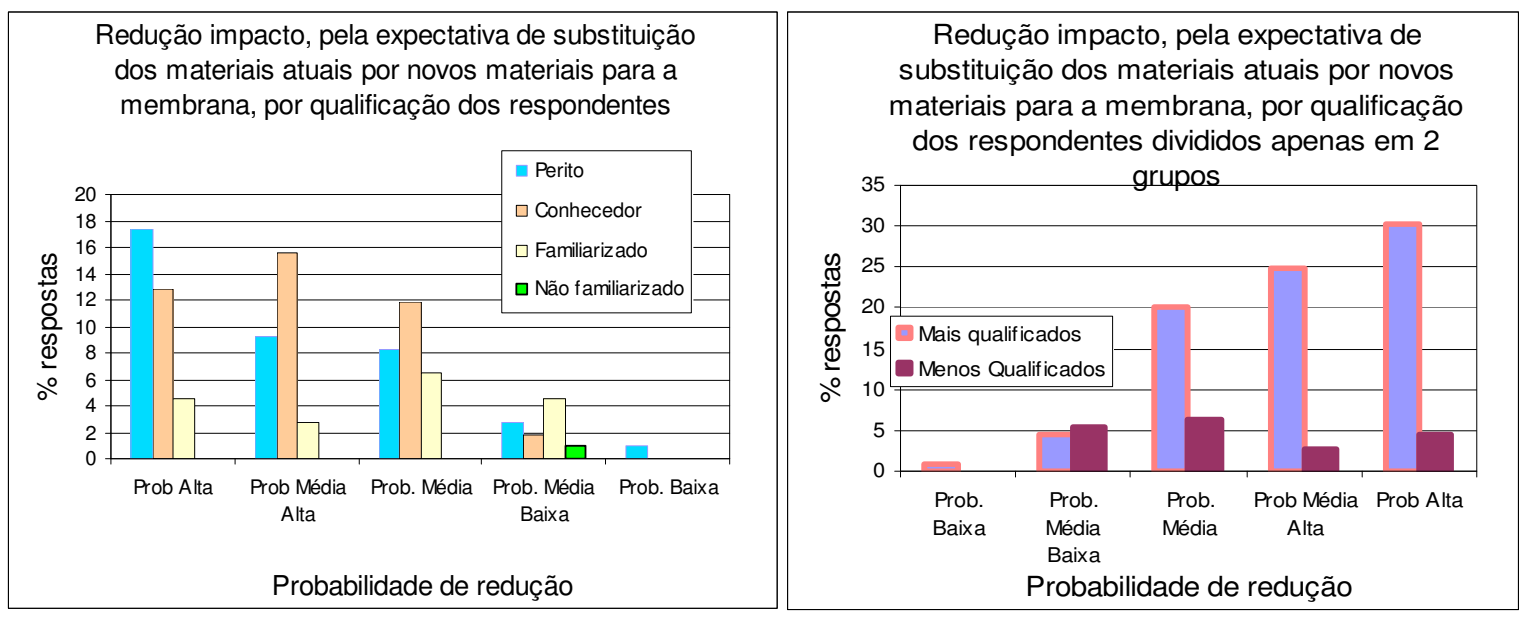

Figura 6-13 - Expectativa de diminuição do impacto ambiental devido à substituição da membrana, para as pilhas tipo PEM, a longo prazo, considerando a especialização do respondente.

A expectativa de substituição dos componentes para redução do 
impacto ambiental em razão do desenvolvimento tecnológico e à descoberta de novos materiais que possam vir a substituir os materiais utilizados atualmente nas placas bipolares, para as pilhas tipo PEM, é mostrada na Figura 6-14, com as respostas separadas por especialização do respondente. Neste caso por meio da análise de variância verificou-se que existia uma relação entre a resposta e a qualificação do respondente, considerando um nível de significância de $5 \%$.
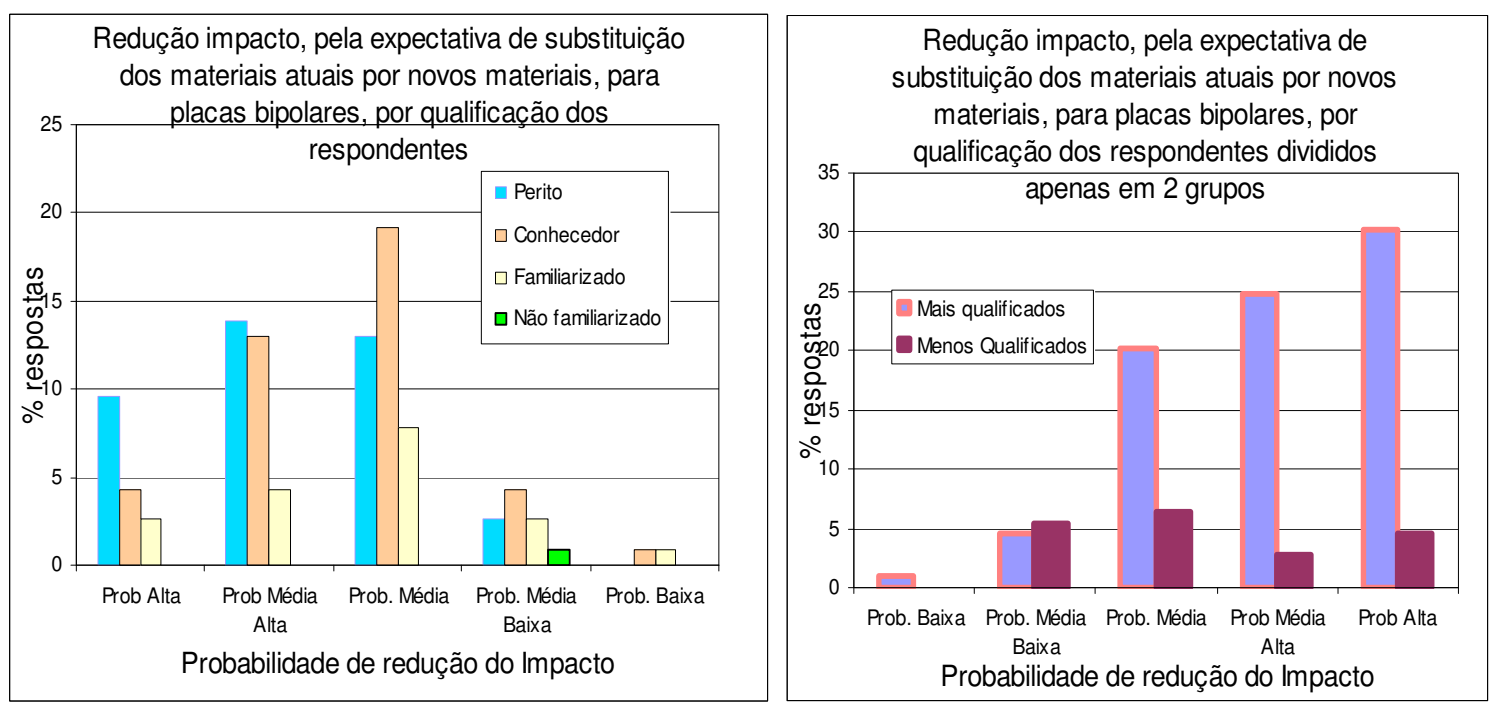

Figura 6-14 - Expectativa da diminuição do impacto ambiental devido à substituição das placas bipolares, para as pilhas tipo PEM, a longo prazo, considerando a especialização do respondente.

Finalmente, para se ter uma idéia de como o desenvolvimento tecnológico de materiais pode influir na probabilidade de redução do impacto ambiental das pilhas a combustível, a longo prazo, a Figura 6-15 mostra a comparação entre as respostas (percentagem) obtidas para cada item abordado na questão: catalisador, membrana, placas bipolares e outros materiais. 


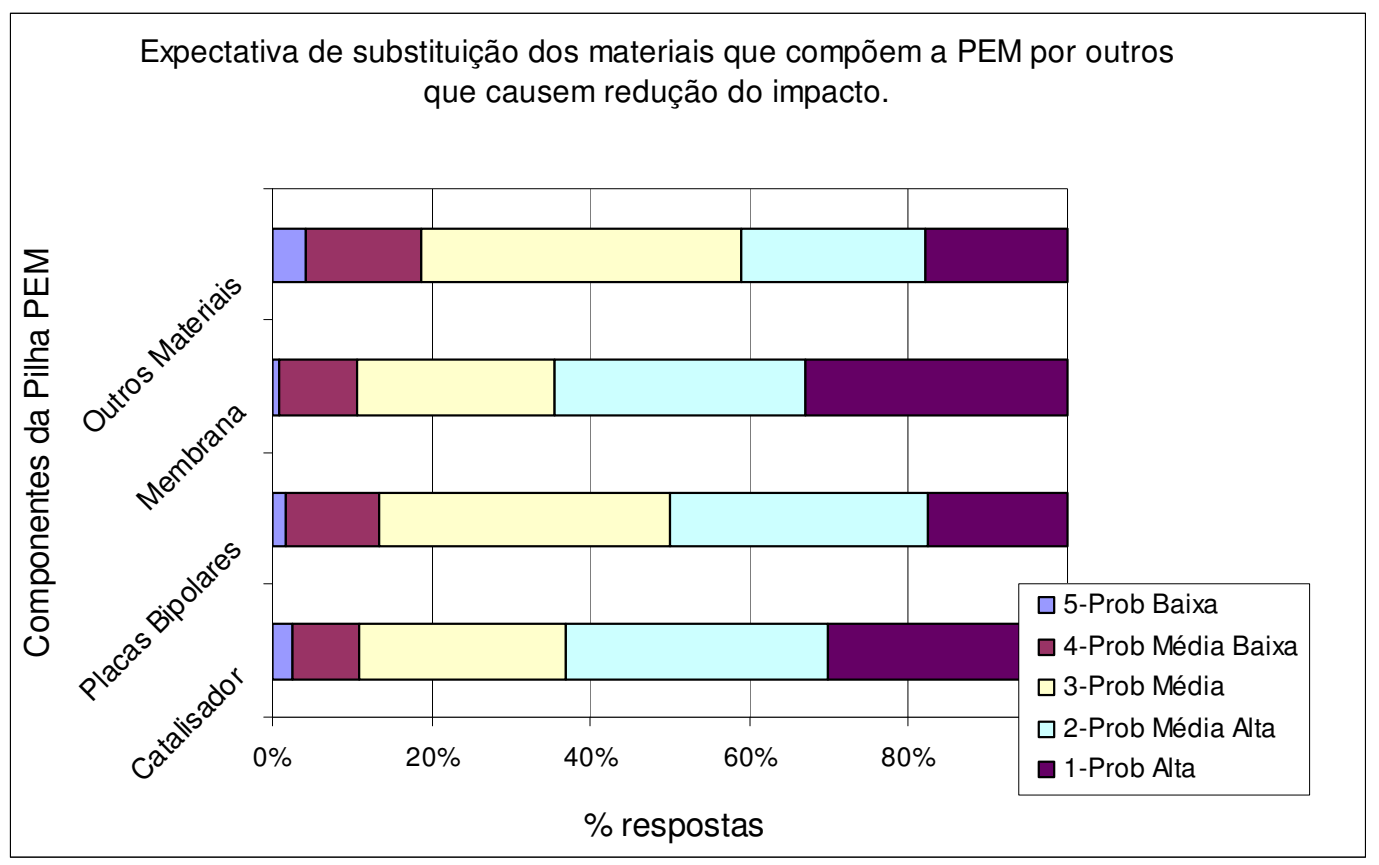

Figura 6-15 - Expectativa de diminuição do impacto ambiental devido à substituição dos materiais de vários itens das pilhas PEM, a longo prazo.

Também pode ser verificado, como mostra a Figura 6-16, que os respondentes não conseguiram identificar um item que possa, no futuro a longo prazo, ser substituído por outro tipo de material, com impacto ambiental muito menor. E pode-se concluir que não existe divergência muito grande entre as opiniões.

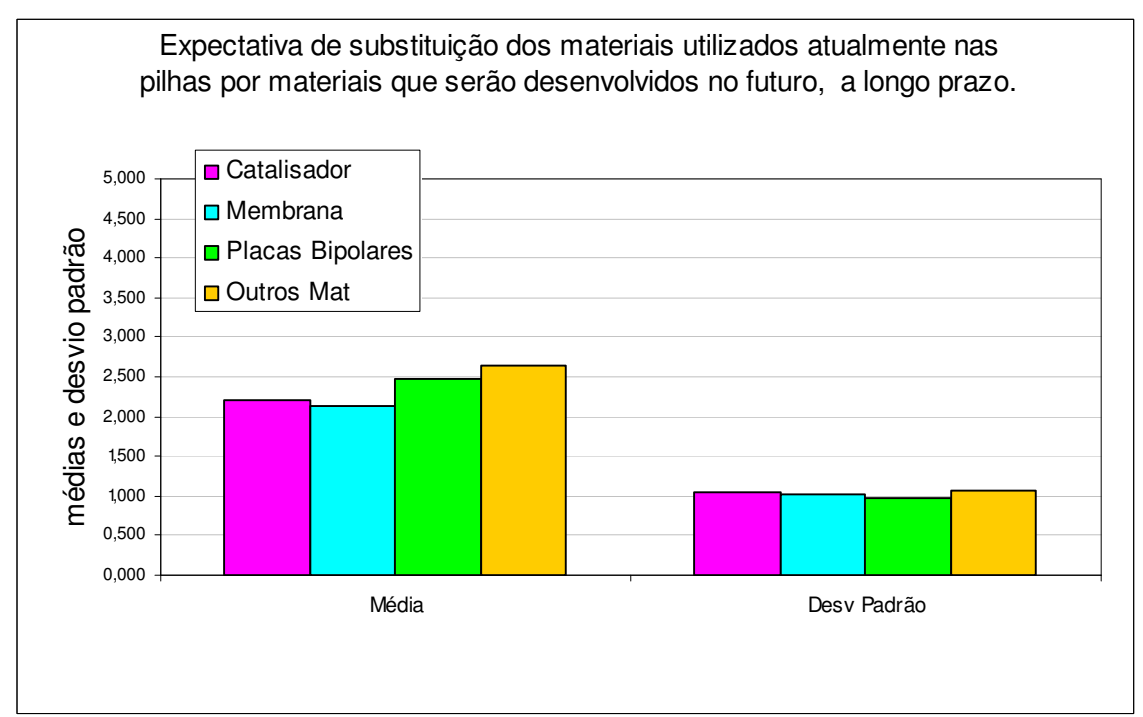

Figura 6-16 - Valores de médias e desvios padrão para os itens que compõem a pilha PEM, para a questão 4.

Para os outros itens (catalisador e "outros materiais) não existiu relação entre as respostas e a qualificação dos respondentes. Também não existiu 
nenhuma relação entre as outras características dos respondentes (ramo de atividade, sexo e continente do respondente) e as respostas sobre todos os itens.

\subsubsection{Questão 5- Grupo 1}

A questão 5 versa sobre as expectativas de abolição/substituição de componentes que causem a redução do impacto ambiental como consequência da evolução para um novo tipo de projeto, no qual algum item que compõe a pilha possa ser substituído ou abolido no impacto ambiental da pilha a longo prazo. A questão 5, tal qual foi originalmente apresentada aos respondentes encontra-se no Anexo B-1.

Do mesmo modo que para os outros itens, para efeito de cálculos estatísticos foi considerado um valor para cada resposta. Os resultados percentuais referentes às opções escolhidas pelos respondentes estão apresentados a seguir, na Tabela 6-8.

Tabela 6-8 - Opções escolhidas pelos respondentes para os itens da questão 5.

\begin{tabular}{c|c|c|c|c|c}
\hline & $\begin{array}{c}\text { Probabilidade } \\
\text { Alta }\end{array}$ & $\begin{array}{c}\text { Probabilidade } \\
\text { Média Alta }\end{array}$ & $\begin{array}{c}\text { Probabilidade } \\
\text { Média }\end{array}$ & $\begin{array}{c}\text { Probabilidade } \\
\text { Média Baixa }\end{array}$ & $\begin{array}{c}\text { Probabilidade } \\
\text { Baixa }\end{array}$ \\
\hline Catalisador & 1 & 2 & 3 & 4 & 5 \\
\hline Membrana & $18,4 \%$ & $22,0 \%$ & $24,7 \%$ & $18,4 \%$ & $16,5 \%$ \\
\hline $\begin{array}{c}\text { Placas } \\
\text { bipolares }\end{array}$ & $7,4 \%$ & $20,4 \%$ & $38,0 \%$ & $20,4 \%$ & $13,9 \%$ \\
\hline $\begin{array}{c}\text { Outros } \\
\text { Materiais }\end{array}$ & $10,1 \%$ & $19,3 \%$ & $42,2 \%$ & $20,2 \%$ & $8,2 \%$ \\
\hline
\end{tabular}

Da análise de variância com os grupos respondentes resultaram as características dos respondentes, para as quais existe correlação com o tipo de resposta apresentado. Na Tabela 6-9 são apresentados os dados resultantes desta análise.

E a Figura 6-17 apresenta a expectativa da abolição/substituição de componentes que causam a diminuição do impacto ambiental em razão do desenvolvimento de novos projetos que possam vir a abolir ou substituir o catalisador, para as pilhas tipo PEM, a longo prazo, por especialização do respondente (autoavaliação). As \% foram calculadas sobre a quantidade total de respostas. Para este caso foi utilizada a análise de variância, conforme 
estabelecido no anexo A, a fim de verificar a existência de uma relação entre a resposta e a qualificação do respondente. Considerando um nível de significância de $5 \%$, verificou-se que a qualificação do respondente influiu no tipo de resposta.

Tabela 6-9 - Correlação entre respostas e características do respondente, para questão 5.

\begin{tabular}{l|l|l|l|l|l}
\hline Item & \multicolumn{4}{|c}{ Características do respondente } \\
\hline & \multicolumn{2}{|c|}{ Qualificação } & Ramo de atuação & Continente & Sexo \\
\cline { 2 - 6 } & 4 grupos & 2 grupos & & & \\
\hline Catalisador & & & & & \\
\hline Membrana & & & & & \\
\hline Placas Bipolares & & & & & \\
\hline Outros materiais & & & & & \\
\hline
\end{tabular}

Existe correlação

Não existe correlação
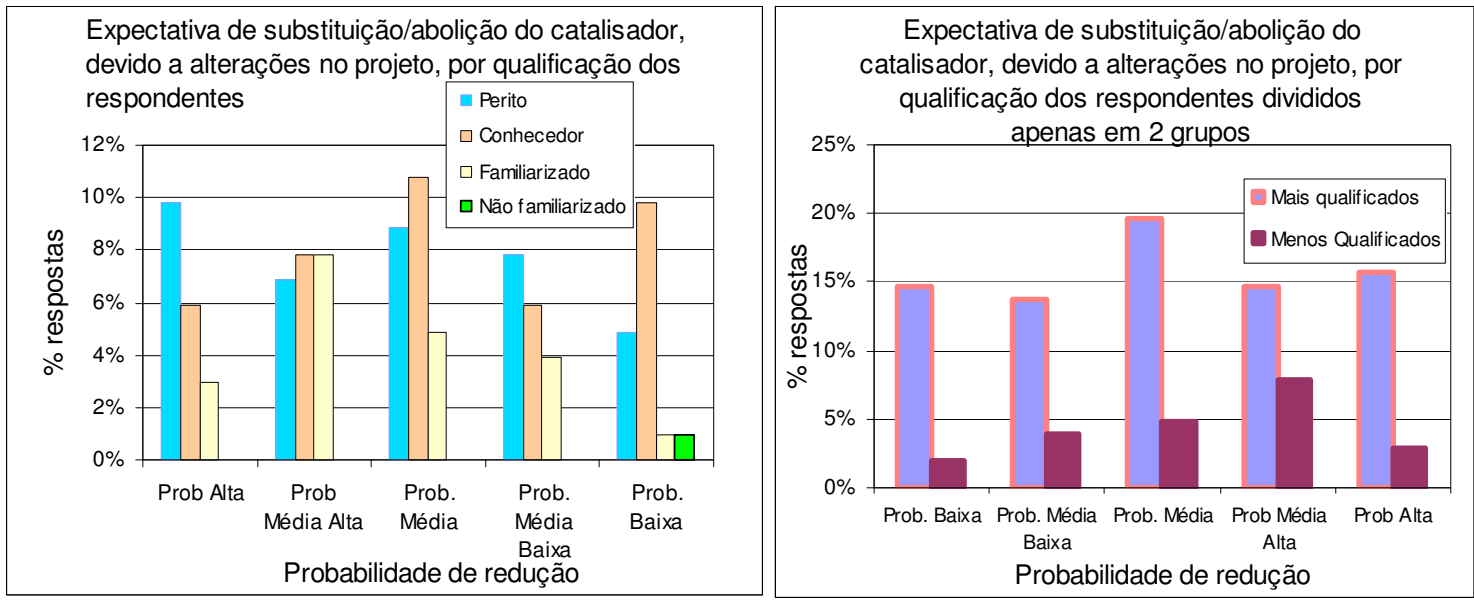

Figura 6-17 - Expectativa da diminuição do impacto ambiental devido à evolução/alterações no projeto que possam vir a abolir ou substituir o catalisador,

para as pilhas tipo PEM, I a longo prazo, por especialização do respondente.

E na Figura 6-18 são apresentadas as respostas separadas por especialização do respondente, para o item membrana. Neste caso por meio da análise de variância verificou-se que existia uma relação entre a resposta e a qualificação do respondente, considerando um nível de significância de 5\%, verificou-se que a qualificação do respondente influiu no tipo de resposta. 

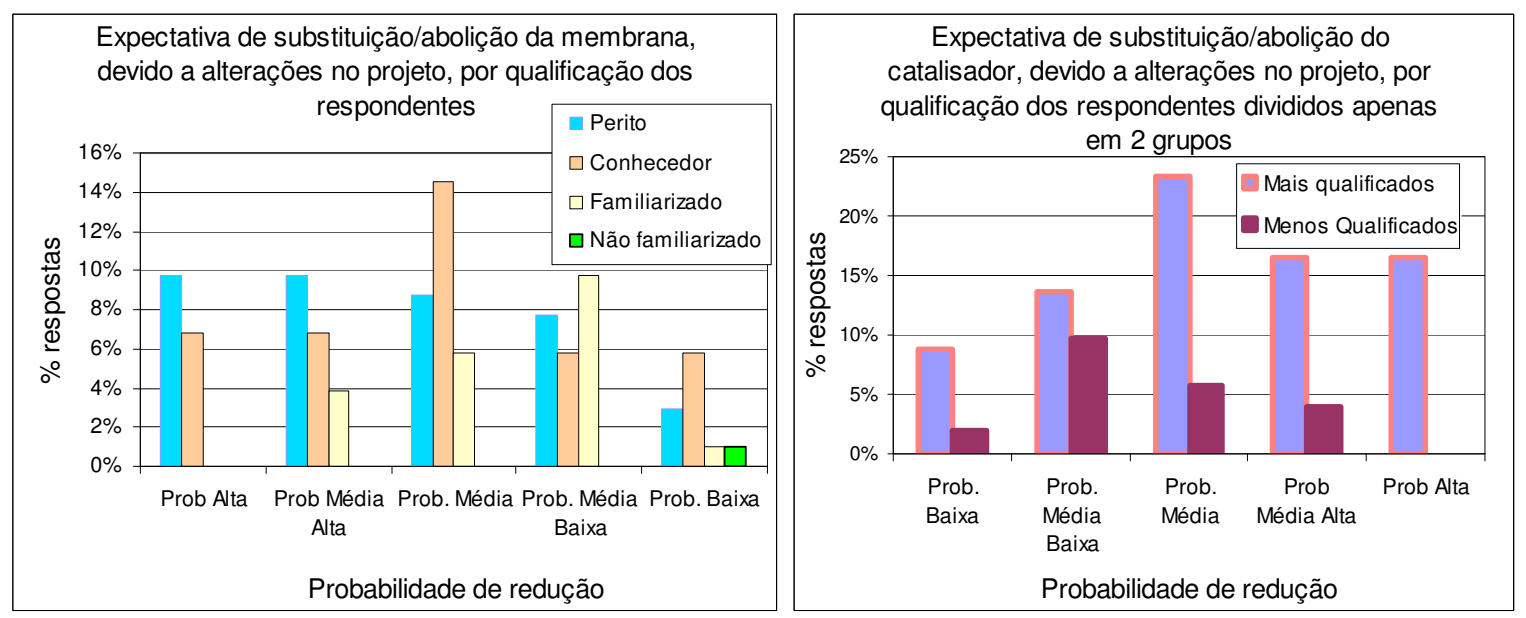

Figura 6-18 - Expectativa da redução do impacto ambiental por causa dos novos projetos que venham a abolir ou substituir a membrana, para as pilhas PEM, a longo prazo, considerando a qualificação do respondente.

Também para o item membrana foi efetuada a separação por continente onde reside o respondente, mostrada na Figura 6-19. Após análise de variância e, considerando o nível de significância de 5\%, pode-se concluir que o continente onde o respondente reside influi nas respostas sobre a probabilidade de redução do impacto ambiental da pilha a combustível, em razão do desenvolvimento de novos projetos que possam vir a abolir ou substituir a membrana.

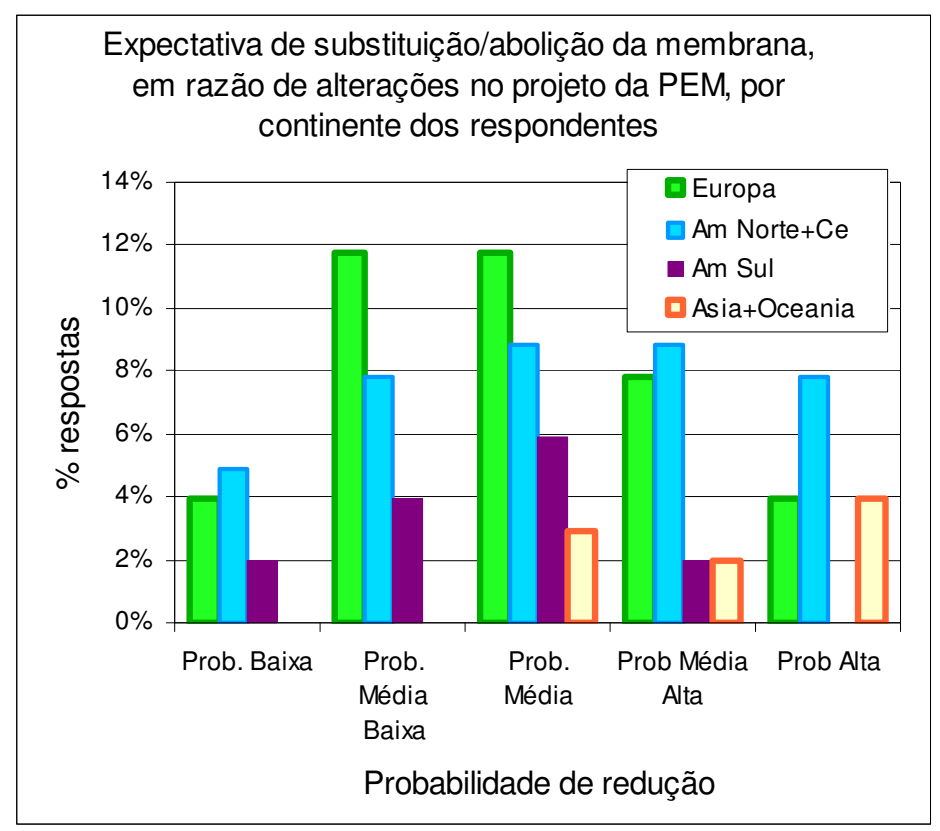

Figura 6-19 - Expectativa da probabilidade de redução do impacto ambiental em razão dos novos projetos que possam vir a abolir ou substituir a membrana, a longo prazo, por continente onde o respondente reside. 
Finalmente, para se ter uma idéia de como as alterações de projeto ou de novos projetos podem influir no impacto ambiental das pilhas tipo PEM, a longo prazo, a Figura 6-20 mostra a comparação entre as respostas obtidas para cada item abordado na questão: catalisador, membrana,placas bipolares e outros materiais. Neste caso a \% foi calculada considerando o total de cada item. Também pode ser verificado, como mostra a Figura 6-21, que os respondentes não conseguiram identificar um item específico que possa, no futuro em longo prazo, ter seu projeto alterado, num futuro em longo prazo, de modo a diminuir o impacto ambiental. $E$ também não ocorreu divergência muito grande entre as opiniões. Os valores das médias entre 2,92 e 3,13 mostram que os respondentes consideram existir probabilidade entre média e média alta de que o projeto da pilha se altere e com isto ocorra diminuição do impacto ambiental da mesma.

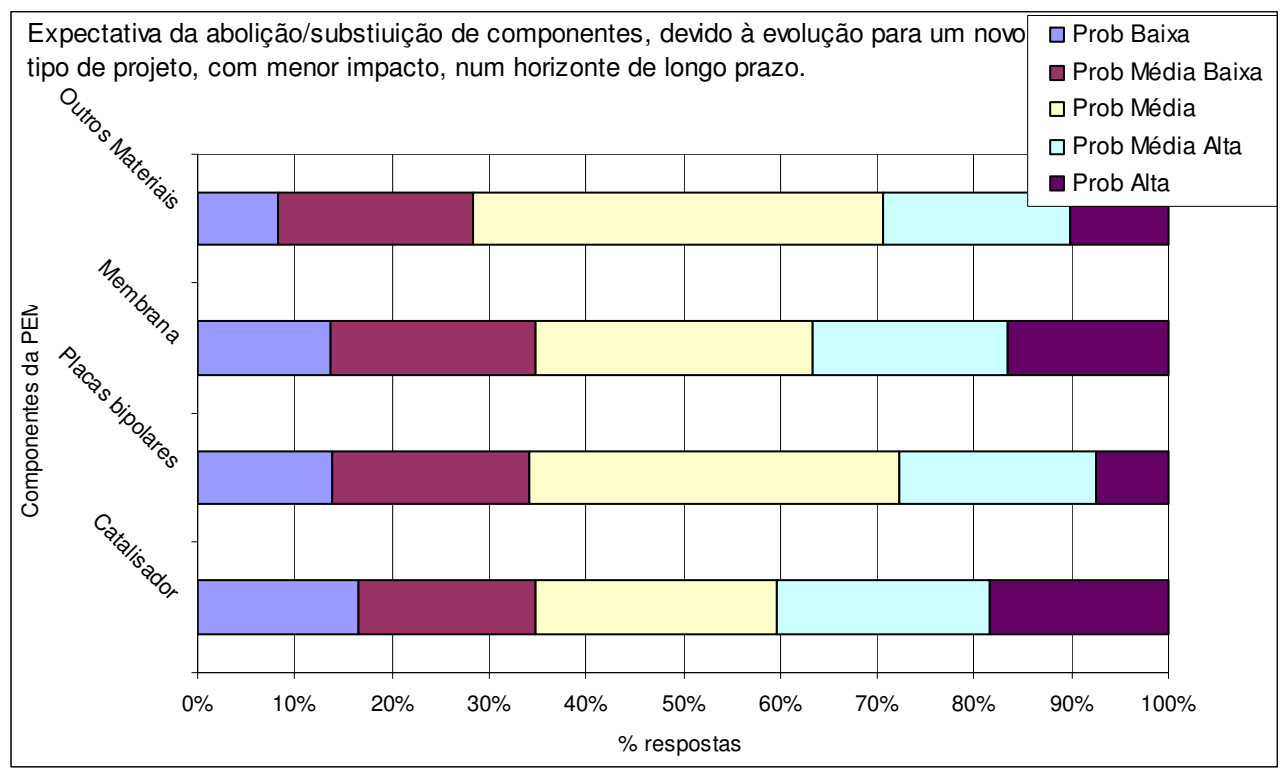

Figura 6-20 - Comparação das respostas para os quatro itens considerados na questão 5: Catalisador, Membrana, Placas Bipolares e Outros Materiais.

A análise de variância mostrou que para os itens membranas e placas bipolares, a qualificação dos respondentes mostrou influência sobre as respostas obtidas. Para os outros itens (catalisador e "outros materiais) esta relação não existiu. Também não existiu nenhuma relação entre as outras características dos respondentes (ramo de atividade, sexo e continente do respondente) e as respostas sobre todos os itens. 


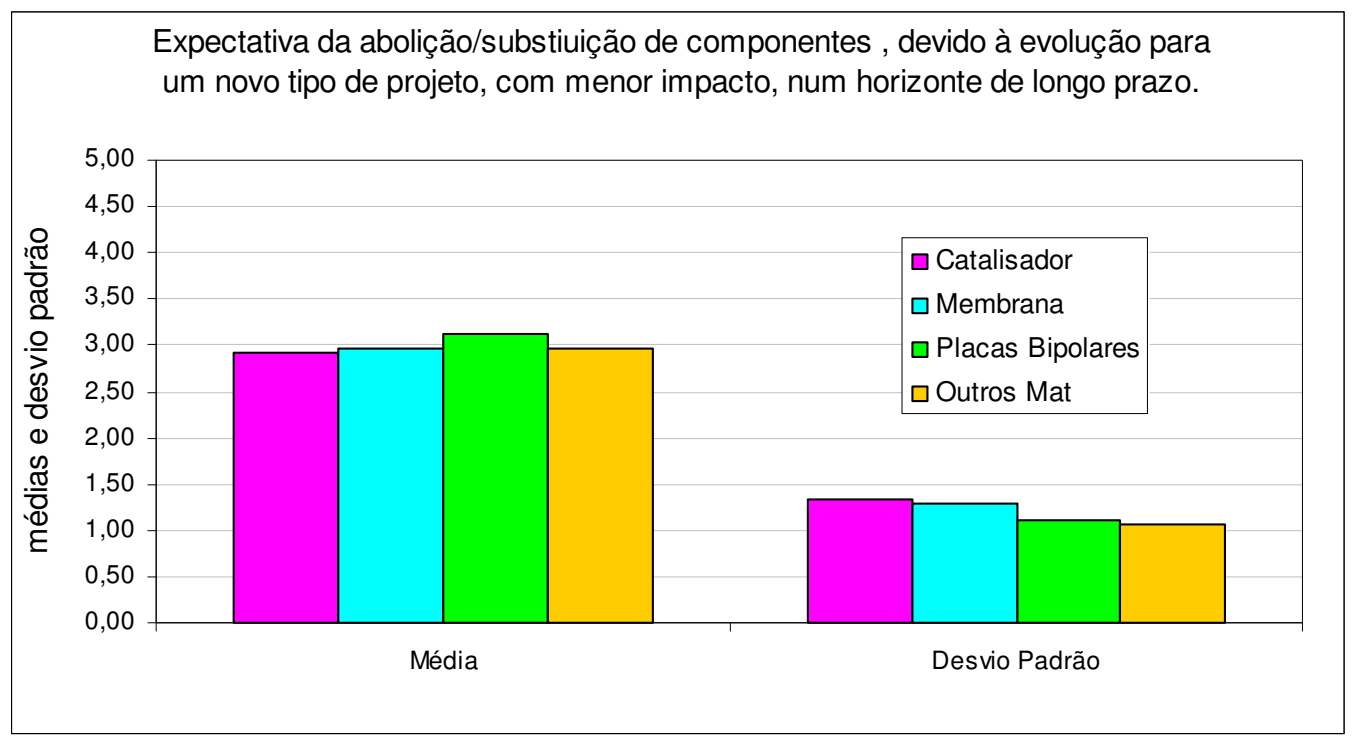

Figura 6-21 - Valores médios e desvios padrão das respostas à questão 5 para os itens que compõem as pilhas tipo PEM.

\subsubsection{4- Questão 6- Grupo 1}

A questão 6 versa sobre as expectativas de redução do impacto ambiental como consequência da substituição ou não do uso de materiais do grupo PGM como catalisadores $A$ questão 6 , tal qual foi originalmente apresentada aos respondentes encontra-se no Anexo B-1.

Para efeito de cálculos estatísticos foi considerado um valor para cada resposta e os resultados percentuais das opções escolhidas estão apresentados na Tabela 6-10, a seguir.

Tabela 6-10 - Opções escolhidas pelos respondentes para os itens da questão 6.

No qual:

\begin{tabular}{c|c|c|c|c}
\hline & A & B & C & D \\
\hline & 1 & 2 & 3 & 4 \\
\hline$\%$ respostas & $49,0 \%$ & $17,6 \%$ & $5,6 \%$ & $27,8 \%$ \\
\hline
\end{tabular}

A $\quad$ Ocorrerá substituição do catalisador

B Não ocorrerá a substituição do catalisador, mas ocorrerá uma redução grande na concentração.

C Não ocorrerá a substituição do catalisador e ocorrerá uma redução pequena na concentração.

D Não ocorrerá a substituição do catalisador, mas ocorrerá uma redução na concentração, através da mistura com outros materiais de menor impacto ambiental.

As opções A e D foram as preferidas por $76,8 \%$ dos respondentes, implicando na previsão de que o catalisador será substituído ou será misturado com outros metais de modo a que se utilize uma quantidade muito pequena de 
metais do grupo PGM, que causam um grande impacto ambiental devido à etapa da mineração.

$\mathrm{Na}$ Figura 6-22 são apresentadas as respostas de todos os respondentes para a questão 6 do questionário. Por meio do cálculo das médias 0 resultado foi 2,120, desvio padrão 1,288 e pode ser observado que entre as opções mais escolhidas $76,8 \%$ preferiram as opções Ocorrerá substituição do catalisador (A) e Não ocorrerá substituição do catalisador mas terá uma redução através da mistura com outros materiais de menor impacto ambiental (D). E a menos escolhida foi a opção (C) com 5, 6\%.

A análise de variância efetuada mostrou que as características dos respondentes, considerando um nível de significância de 5\%, não influenciam o tipo de resposta à questão. As características analisadas foram: ramo de atividade, especialização, sexo e continente do respondente.

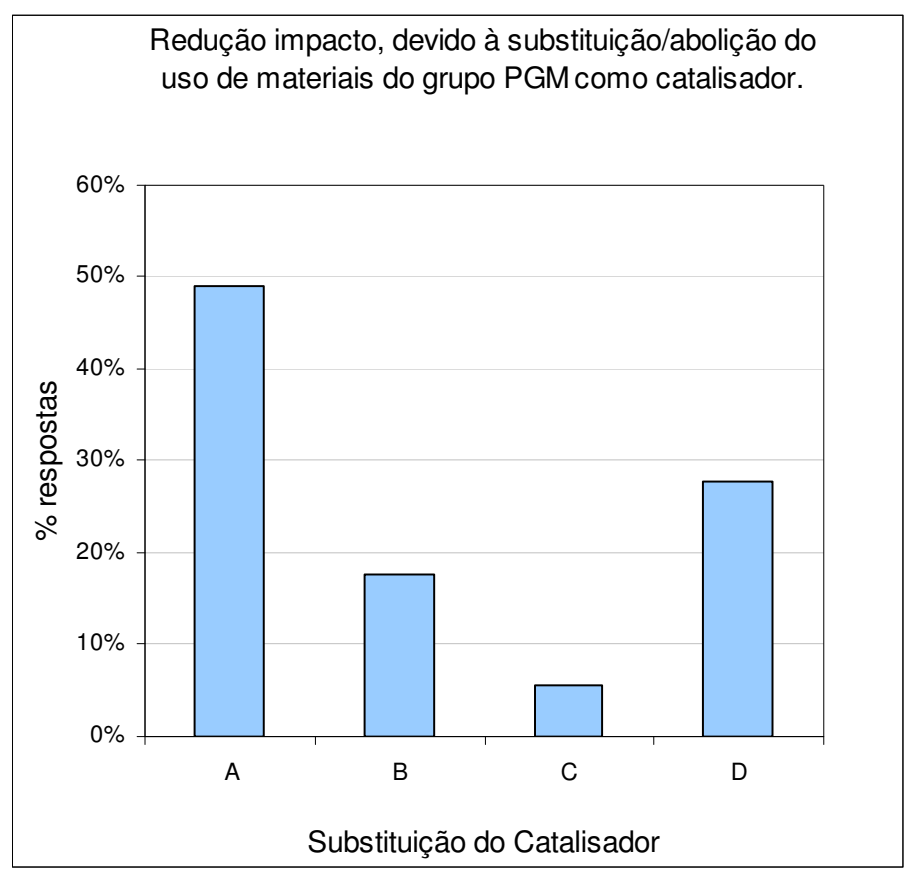

Figura 6-22 - Avaliação da substituição do uso de catalisadores do grupo PGM, a longo prazo, para pilhas tipo PEM.

$\mathrm{Na}$ Figura 6-23 são apresentadas as respostas separadas por continente de residência do respondente e pode-se notar que os respondentes de todos os continentes, exceto os da América do Sul, escolheram como opção de maior votação a opção $A$. (o catalisador será substituído). Os respondentes da América do Sul escolheram a opção $C$ (Não ocorrerá a substituição do catalisador e ocorrerá uma redução pequena na concentração). 


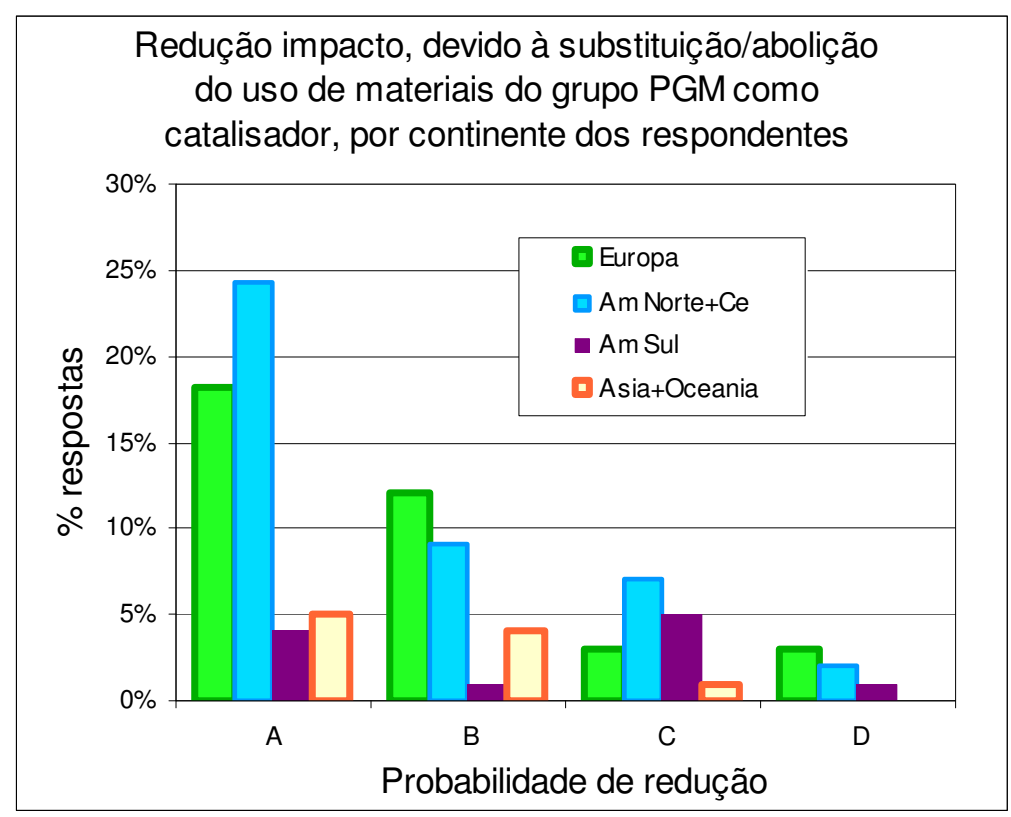

Figura 6-23 - Gráfico mostrando as respostas por continente, para a questão 5.

\subsubsection{Dados do Grupo 2}

A seguir são apresentados os dados de qualificação e ramo de atividade dos respondentes para o grupo 2 (pilhas PAFC), na Figura 6-24.

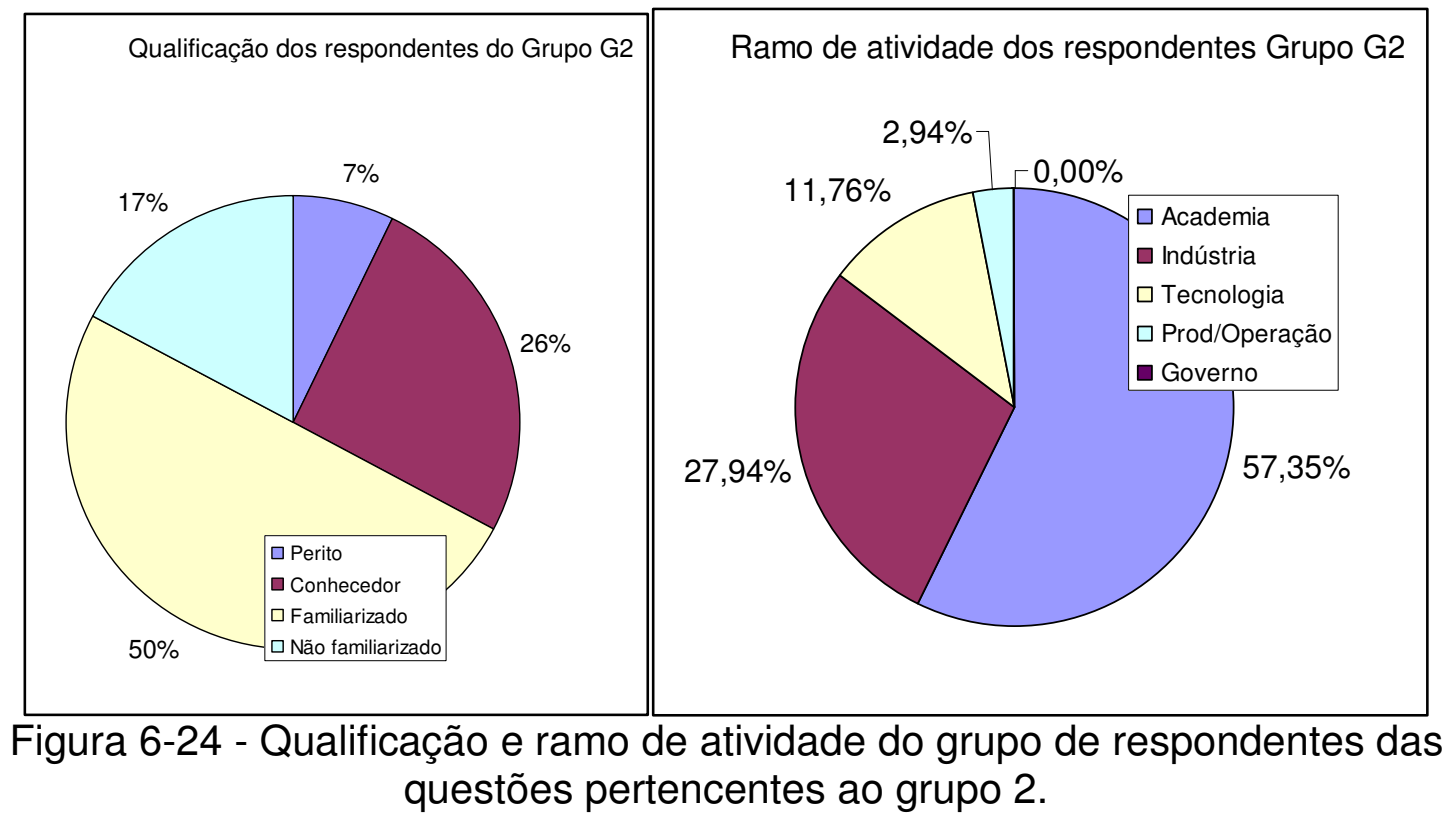

\subsubsection{Questão 8- Grupo 2}

A questão 8 versa sobre a expectativa de redução do impacto ambiental dos vários itens que compõem a pilha tipo PAFC, para um horizonte de longo prazo. A questão 8 , tal qual foi originalmente apresentada aos respondentes encontra-se no Anexo B-1. 
Para efeito de cálculos estatísticos foi considerado um valor para cada resposta. Os resultados percentuais referentes às opções de respostas estão apresentados a seguir, na Tabela 6-11.

Tabela 6-11 Respostas para os itens da questão 8.

\begin{tabular}{c|c|c|c|c|c}
\hline & $\begin{array}{c}\text { Redução Muito } \\
\text { Alta }\end{array}$ & Redução Alta & Redução Média & $\begin{array}{c}\text { Redução Média } \\
\text { Baixa }\end{array}$ & Sem Redução \\
\hline & 1 & 2 & 3 & 4 & 5 \\
\hline Catalisador & $11,7 \%$ & $24,7 \%$ & $35,0 \%$ & $20,8 \%$ & $7,8 \%$ \\
\hline $\begin{array}{c}\text { Matriz Ele- } \\
\text { trólito }\end{array}$ & $12,8 \%$ & $20,5 \%$ & $28,2 \%$ & $28,2 \%$ & $10,3 \%$ \\
\hline $\begin{array}{c}\text { Placas } \\
\text { bipolares }\end{array}$ & $5,2 \%$ & $23,4 \%$ & $31,2 \%$ & $32,4 \%$ & $7,8 \%$ \\
\hline $\begin{array}{c}\text { Outros } \\
\text { Materiais }\end{array}$ & $12,7 \%$ & $21,5 \%$ & $35,4 \%$ & $21,5 \%$ & $8,9 \%$ \\
\hline
\end{tabular}

Da análise de variância com os grupos respondentes resultaram as características dos respondentes, para as quais existe correlação com o tipo de resposta apresentado. Na Tabela 6-12 são apresentados os dados resultantes desta análise.

A coluna "com 4" considera o grau de especialização com as seguintes categorias: perito, conhecedor, familiarizado e não-familiarizado. A coluna "com 2" considera 2 grupos: "mais qualificados" e "menos qualificados".

Tabela 6-12 - Correlação entre respostas e características do respondente.

\begin{tabular}{c|c|c|c|c|c}
\hline Item & \multicolumn{5}{|c}{ Características do respondente } \\
\hline & Qualificação & Ramo de atuação & Continente & Sexo \\
\hline & com 4 & com 2 & & & \\
\hline Catalisador & & & & & \\
\hline Matriz/eletrólito & & & & & \\
\hline Placas Bipolares & & & & & \\
\hline Outros materiais & & & & & \\
\hline
\end{tabular}

Existe correlação

Não existe correlação

Na Figura 6-25 são apresentadas as respostas para o item catalisador, separadas por qualificação do respondente. Neste caso por meio da análise de variância verificou-se que, considerando um nível de significância de 5\%, a qualificação do respondente influiu no tipo de resposta. 


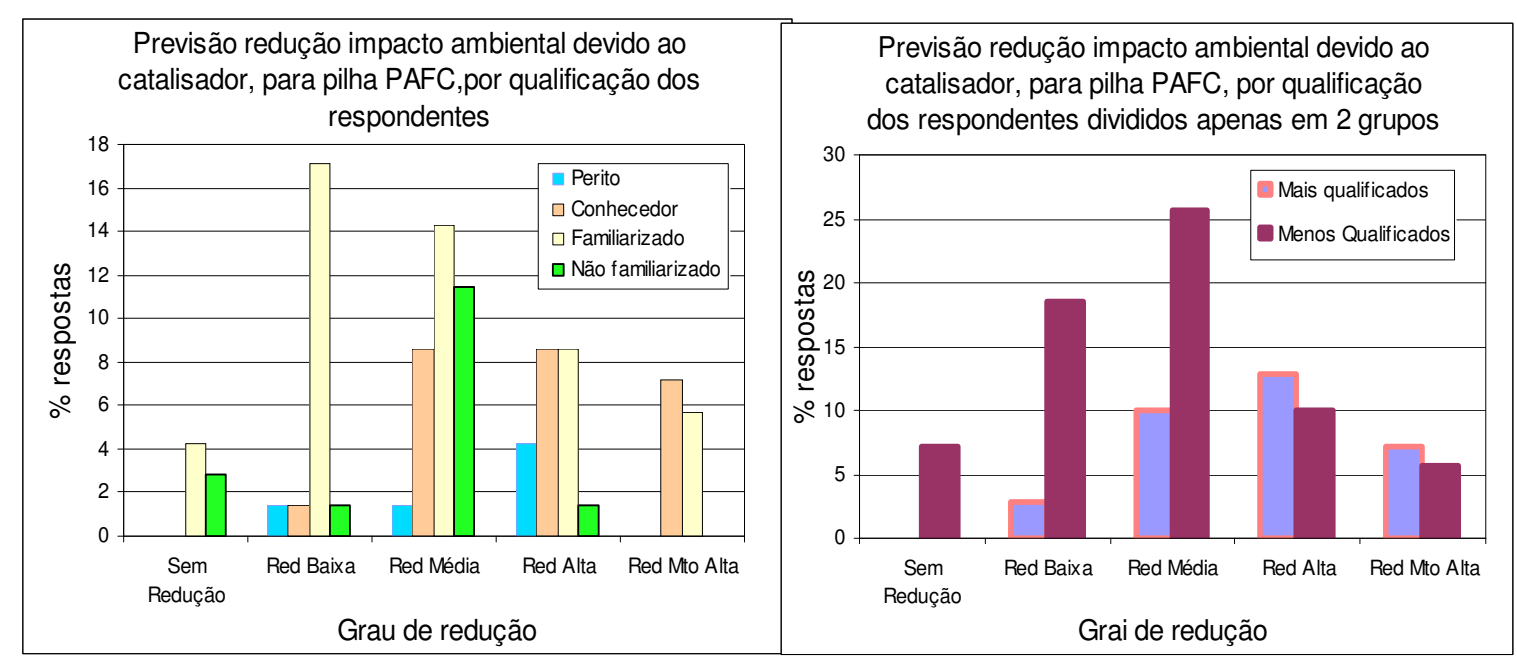

Figura 6-25 - Expectativa do impacto ambiental por causa do catalisador, na pilha PAFC, a longo prazo, com as respostas separadas por qualificação dos respondentes.

A análise de variância mostrou que apenas para o item catalisador, a qualificação dos respondentes mostrou influência sobre as respostas obtidas. Para os outros itens (placas bipolares, matriz/eletrólito e "outros materiais) esta relação não existiu. Também não existiu nenhuma relação entre as outras características dos respondentes (ramo de atividade, sexo e continente do respondente) e as respostas sobre todos os itens.

A variação da resposta conforme o continente mostrou que não existe muita diferença entre os respondentes dos vários continentes, conforme a Figura 6-26. 


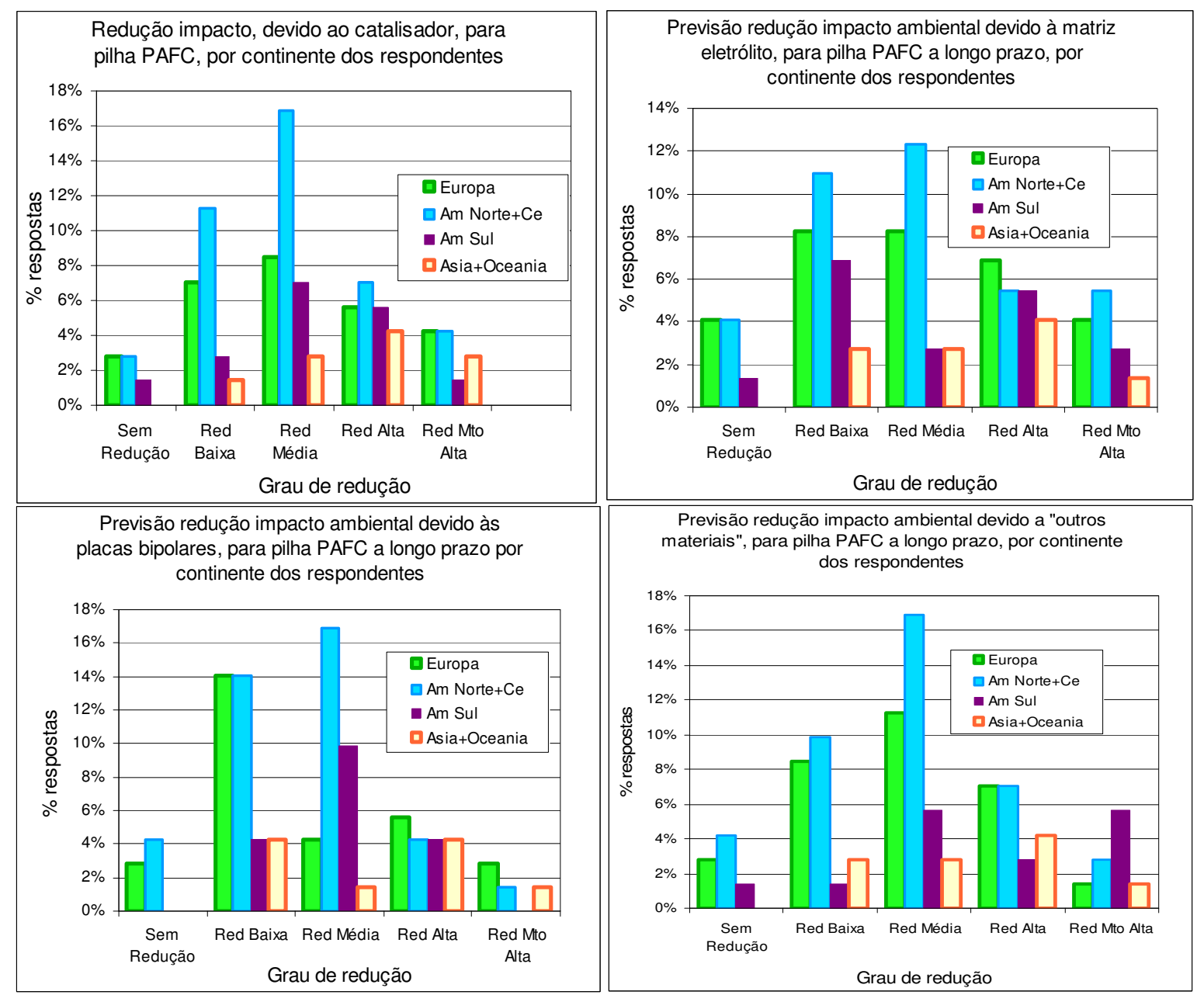

Figura 6-26 - Respostas para a questão 8 por local de residência do respondente.

E para se ter uma idéia da expectativa de redução do impacto ambiental das pilhas tipo PAFC, a longo prazo, a Figura 6-26 mostra a comparação entre as respostas obtidas para cada item abordado na questão: catalisador, matriz/eletrólito, placas bipolares e outros materiais. Neste caso a \% foi calculada considerando o total de cada item.

Também pode ser verificado, como mostra a Figura 6-28, que os respondentes não conseguiram identificar um item que se destaque, no futuro a longo prazo, na diminuição do impacto ambiental. 


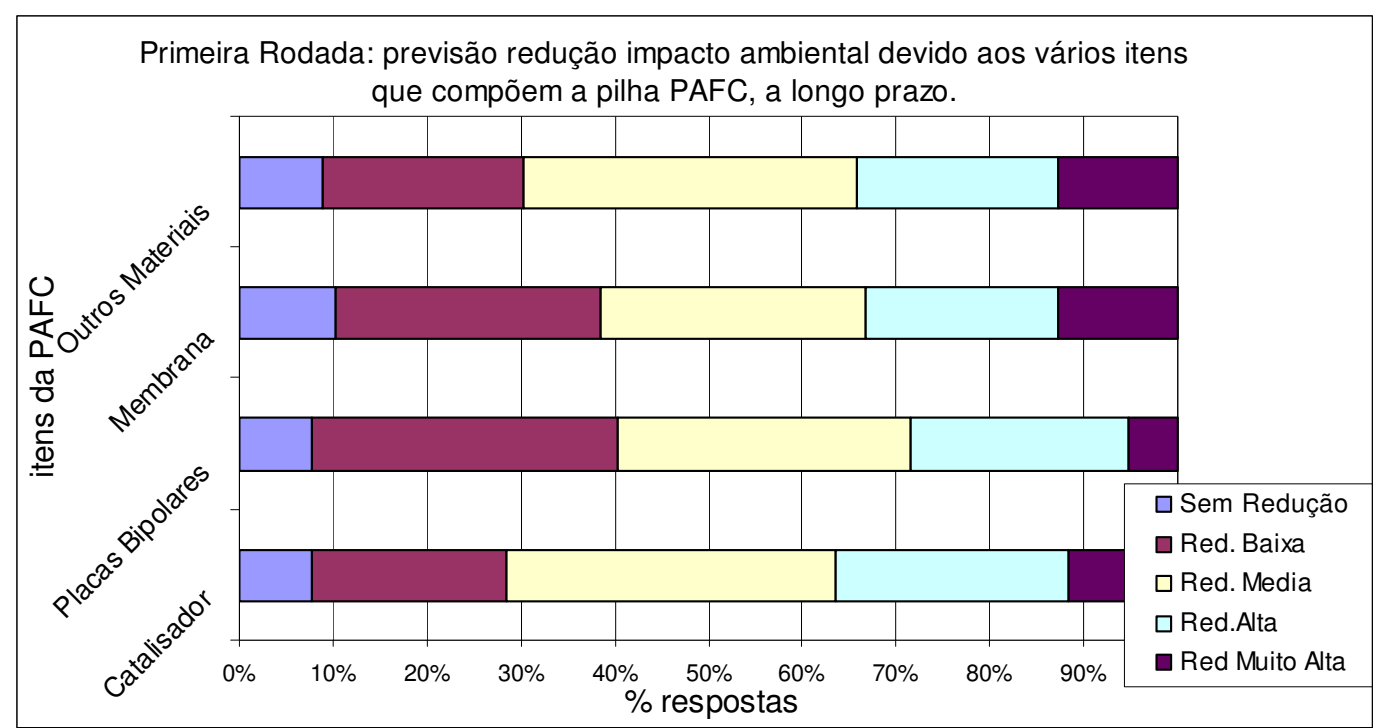

Figura 6-27 - Avaliação do impacto ambiental por causa dos vários itens que compõem as pilhas PAFC, considerando os avanços tecnológicos a longo prazo.

Os valores das médias entre 2,88 (catalisadores) e 2,92 (placas bipolares) mostram que os respondentes consideram existir expectativa de Redução entre Média e Baixa do impacto ambiental, a longo prazo, como conseqüência do desenvolvimento tecnológico e novas descobertas.

$E$ também não ocorreu divergência muito grande entre as opiniões. $O$ menor desvio padrão foi encontrado no caso das placas bipolares, que também teve a maior média, ou seja, aproxima-se mais de "redução baixa".

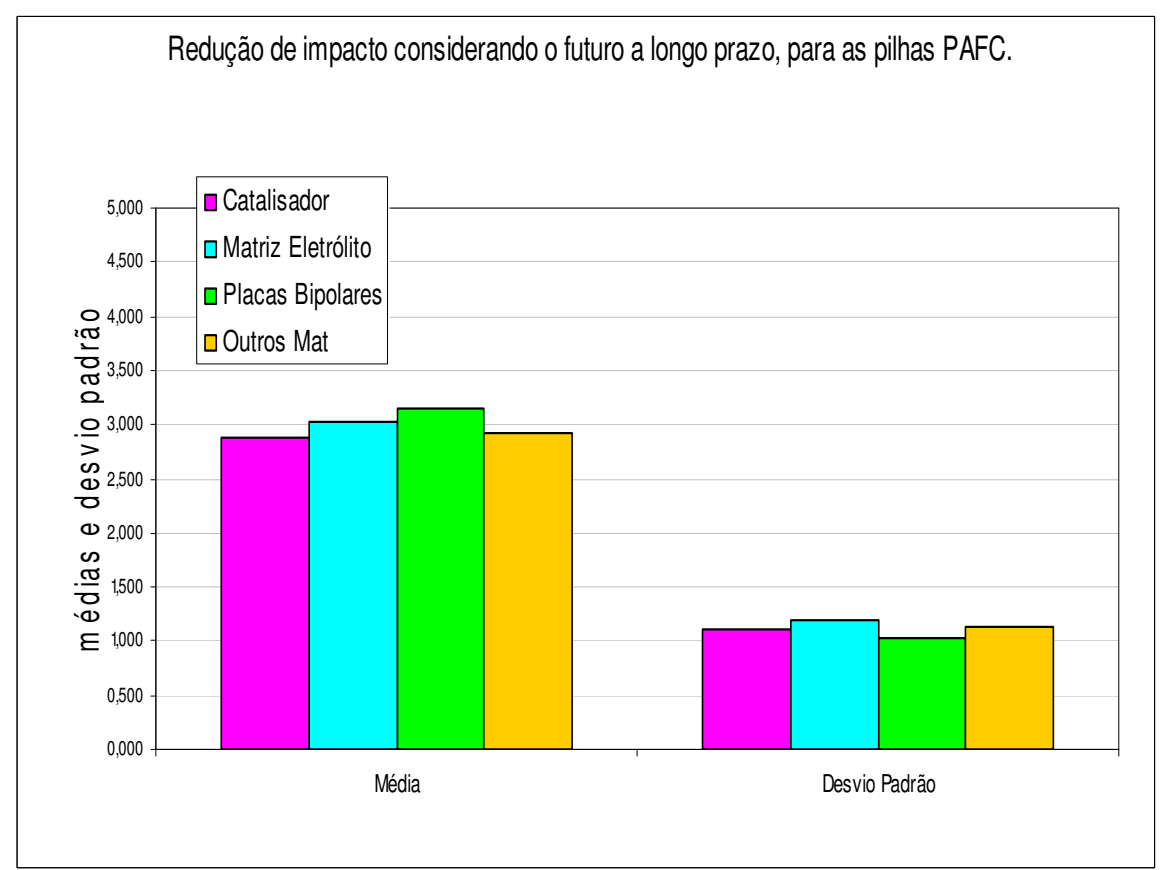

Figura 6-28 - Valores médios e desvios padrão para redução de impacto, a longo prazo, para os diversos itens que compões as pilhas PAFC, a longo prazo. 


\subsubsection{Questão 9- Grupo 2}

A questão 9 versa sobre a expectativa de substituição ou abolição do catalisador da pilha PAFC, considerando uma evolução para outro tipo de projeto, considerando um futuro de 20 anos. A questão 9 , tal qual foi originalmente apresentada aos respondentes encontra-se no Anexo B-1.

Para efeito de cálculos estatísticos foi considerado um valor para cada resposta e os resultados percentuais das opções estão apresentados na Tabela $6-13$, a seguir.

- Tabela 6-13 - Respostas obtidas para os itens da questão 9 (\%)

No qual:

\begin{tabular}{c|c|c|c|c}
\hline & A & B & C & D \\
\hline & 1 & 2 & 3 & 4 \\
\hline \% respostas & $40,2 \%$ & $16,9 \%$ & $14,3 \%$ & $28,6 \%$ \\
\hline
\end{tabular}

\begin{tabular}{l|l}
\hline A & Ocorrerá substituição do catalisador \\
\hline B & Não ocorrerá a substituição do catalisador e ocorrerá uma redução grande na concentração. \\
\hline C & Não ocorrerá a substituição do catalisador, e ocorrerá uma redução pequena na concentração. \\
\hline D & $\begin{array}{l}\text { Não ocorrerá a substituição do catalisador, mas ocorrerá uma redução na concentração } \\
\text { através da mistura com outros materiais de menor impacto ambiental. }\end{array}$ \\
\hline
\end{tabular}

As opções $A$ e $D$ foram as preferidas por $68,8 \%$ dos respondentes, implicando na expectativa dos respondentes de que o catalisador será substituído ou será misturado com outros metais de modo a que se utilize uma quantidade muito pequena de metais do grupo PGM, que causam um grande impacto ambiental devido à etapa da mineração.

Por meio do cálculo das médias o resultado foi 2.312, desvio padrão 1,20 e pode ser observado que entre as opções mais escolhidas $68,8 \%$ preferiram as opções A e D. E a menos escolhida foi a opção C (14,3\%).

Na Figura 6-29 são apresentados os resultados considerando os respondentes mais e menos qualificados. 


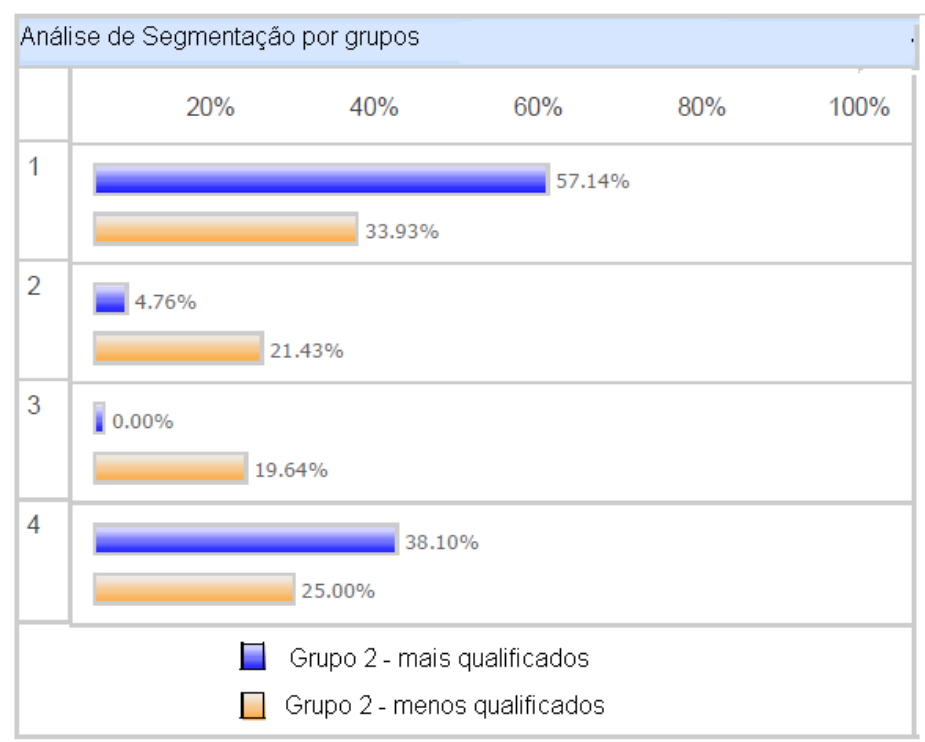

Figura 6-29 - Expectativa de substituição/abolição do uso de materiais do grupo PGM como catalisador para pilhas PAFC, considerando os avanços tecnológicos a longo prazo.

Na Tabela 6-14 são apresentados os dados resultantes da análise de variância para os grupos de respondentes, com relação às características dos respondentes.

Tabela 6-14 - Correlação entre respostas e características do respondente, para a questão 9.

\begin{tabular}{|c|l|l|l|l|}
\hline \multicolumn{5}{|c}{ Características do respondente } \\
\cline { 1 - 2 } Qualificação & Ramo de atuação & Continente & Sexo \\
\cline { 1 - 2 } com 4 & com 2 & & & \\
\hline
\end{tabular}

Existe correlação

Não existe correlação

As respostas separadas por continente dos respondentes, representadas na Figura 6-30, não mostra muita variação nas respostas conforme o local de residência do respondente, sendo a opção A a mais votada, exceto para os respondentes da América do Sul que consideraram a opção B como a mais votada. 


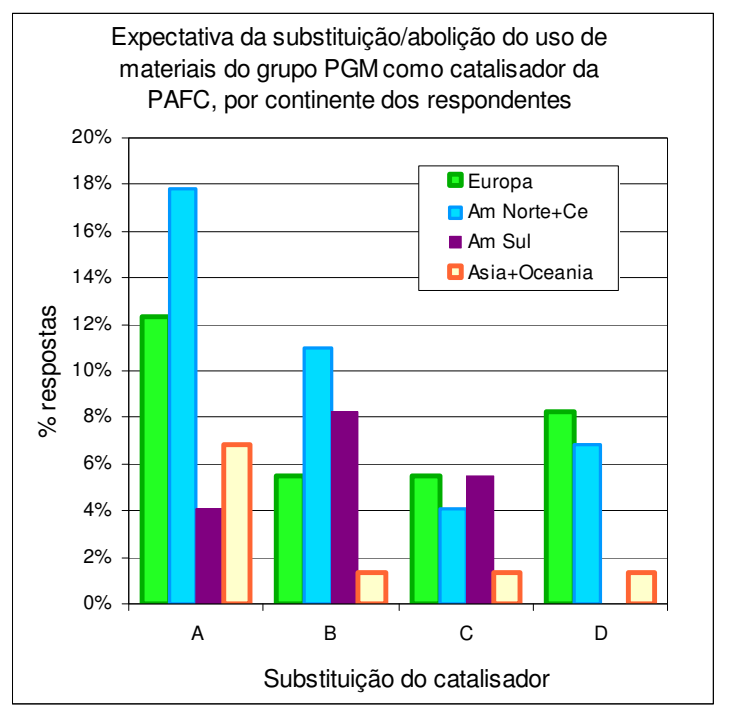

Figura 6-30 - Respostas obtidas para a questão 9, separadas por continente do respondente.

Com relação à qualificação a análise de variância mostrou que ela influi nas respostas quando se consideram os respondentes divididos em dois grupos: "mais qualificados" e "menos qualificados". A Figura 6-31 mostra a expectativa de redução do impacto devido à expectativa de substituição do catalisador do grupo PGM.
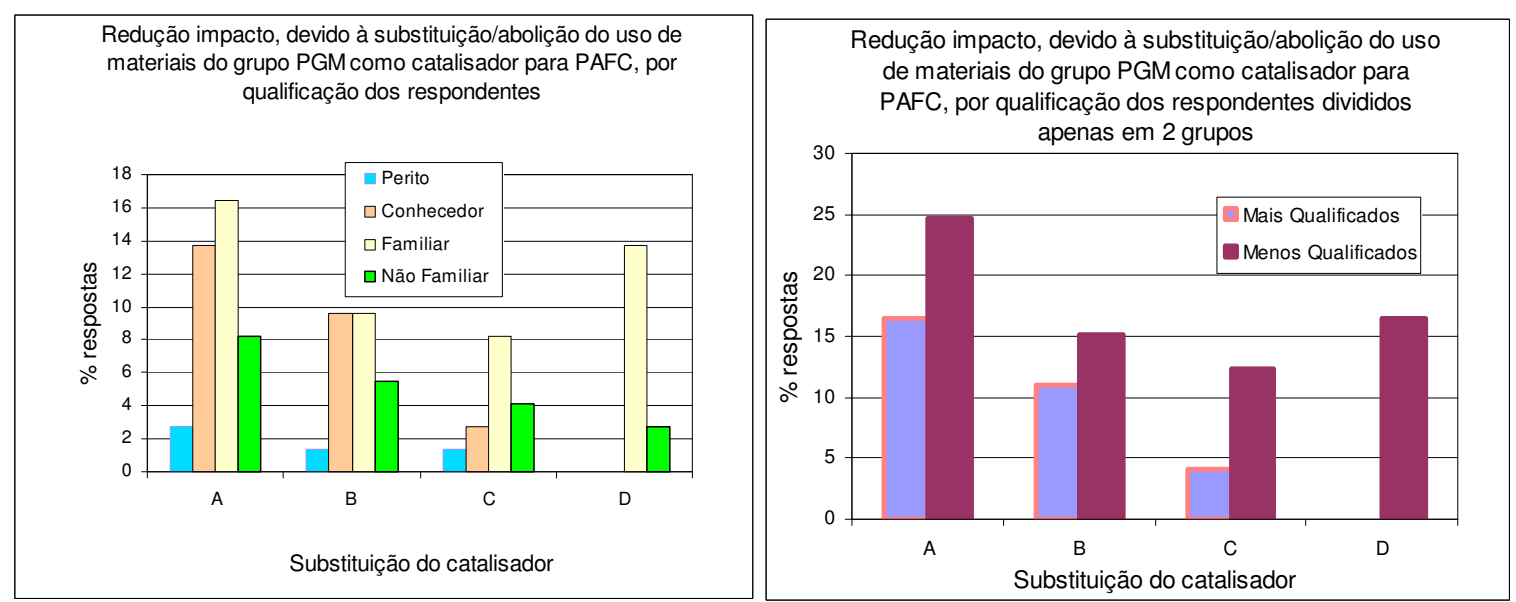

Figura 6-31 - Respostas obtidas para a questão 9, separadas por grau de especialização do respondente.

Na Figura 6-32 são apresentadas as respostas separadas por sexo do respondente. Utilizando a análise de variância verificou-se que, considerando um nível de significância de 5\%, o sexo do respondente influiu no tipo de resposta. As outras características dos respondentes: ramo de atividade, qualificação e continente onde reside não influíram no tipo de resposta, considerando um nível de significância de $5 \%$. 


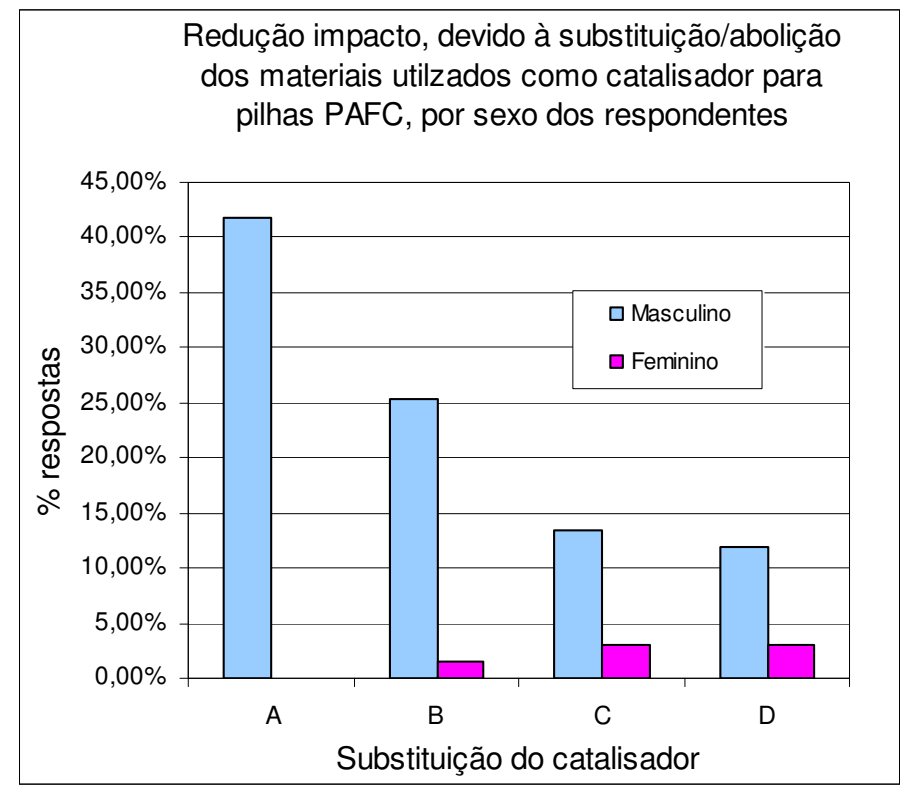

Figura 6-32 - Expectativa de substituição/abolição dos materiais utilizados como catalisador para pilhas PAFC, a longo prazo, com as respostas separadas por sexo do respondente.

\subsubsection{Questão 10- Grupo 2}

A questão 10 versa sobre a expectativa de redução do impacto ambiental frente à evolução para outro tipo de projeto, para as pilhas tipo PAFC, num horizonte de longo prazo. A questão 10 , tal qual foi originalmente apresentada aos respondentes encontra-se no Anexo B-1.

Para efeito de cálculos estatísticos foi considerado um valor para cada resposta. Os resultados percentuais referentes às opções de respostas estão apresentados a seguir, na Tabela 6-14.

Tabela 6-15 - Respostas para os itens da questão 10 (\%).

\begin{tabular}{l|l|l|l|l|l}
\hline & $\begin{array}{c}\text { Probabilidade } \\
\text { Alta }\end{array}$ & $\begin{array}{c}\text { Probabilidade } \\
\text { Média Alta }\end{array}$ & $\begin{array}{c}\text { Probabilidade } \\
\text { Média }\end{array}$ & $\begin{array}{c}\text { Probabilidade } \\
\text { Média Baixa }\end{array}$ & $\begin{array}{c}\text { Probabilidade } \\
\text { Baixa }\end{array}$ \\
\hline Catalisador & 1 & 2 & 3 & 4 & 5 \\
\hline Matriz/eletrólito & $4,4 \%$ & $28,2 \%$ & $26,8 \%$ & $21,1 \%$ & $15,5 \%$ \\
\hline $\begin{array}{l}\text { Placas } \\
\text { bipolares }\end{array}$ & $2,9 \%$ & $15,7 \%$ & $45,7 \%$ & $14,3 \%$ & $20,0 \%$ \\
\hline $\begin{array}{l}\text { Outros } \\
\text { Materiais }\end{array}$ & $12,5 \%$ & $21,7 \%$ & $40,6 \%$ & $23,2 \%$ & $11,6 \%$ \\
\hline
\end{tabular}

Conforme pode ser observado nesta Tabela 6-14 os respondentes consideraram a opção Redução Média para quase todos os itens como a mais provável, exceto para o catalisador, para o qual consideraram a opção entre 
média e média baixa.

Da análise de variância com os grupos respondentes resultaram as características dos respondentes, para as quais existe correlação com o tipo de resposta apresentado. Na Tabela 6-15 são apresentados os dados resultantes desta análise.

Tabela 6-16 - Correlação entre respostas e características do respondente, para a questão 10.

\begin{tabular}{l|l|l|l|l}
\hline \multicolumn{1}{c|}{ Item } & \multicolumn{4}{c}{ Características do respondente } \\
\hline & Qualificação & Ramo de atuação & Continente & Sexo \\
\hline Catalisador & & & & \\
\hline Membrana & & & & \\
\hline Placas Bipolares & & & & \\
\hline Outros materiais & & & & \\
\hline
\end{tabular}

$\square$ Existe correlação $\square$ Não existe correlação

Para se ter uma idéia da expectativa de redução do impacto ambiental das pilhas tipo PAFC, a longo prazo, a Figura 6-33 mostra a comparação entre as respostas obtidas para cada item abordado na questão: catalisador, matriz/eletrólito, placas bipolares e outros materiais. Neste caso a \% foi calculada considerando o total de cada item.

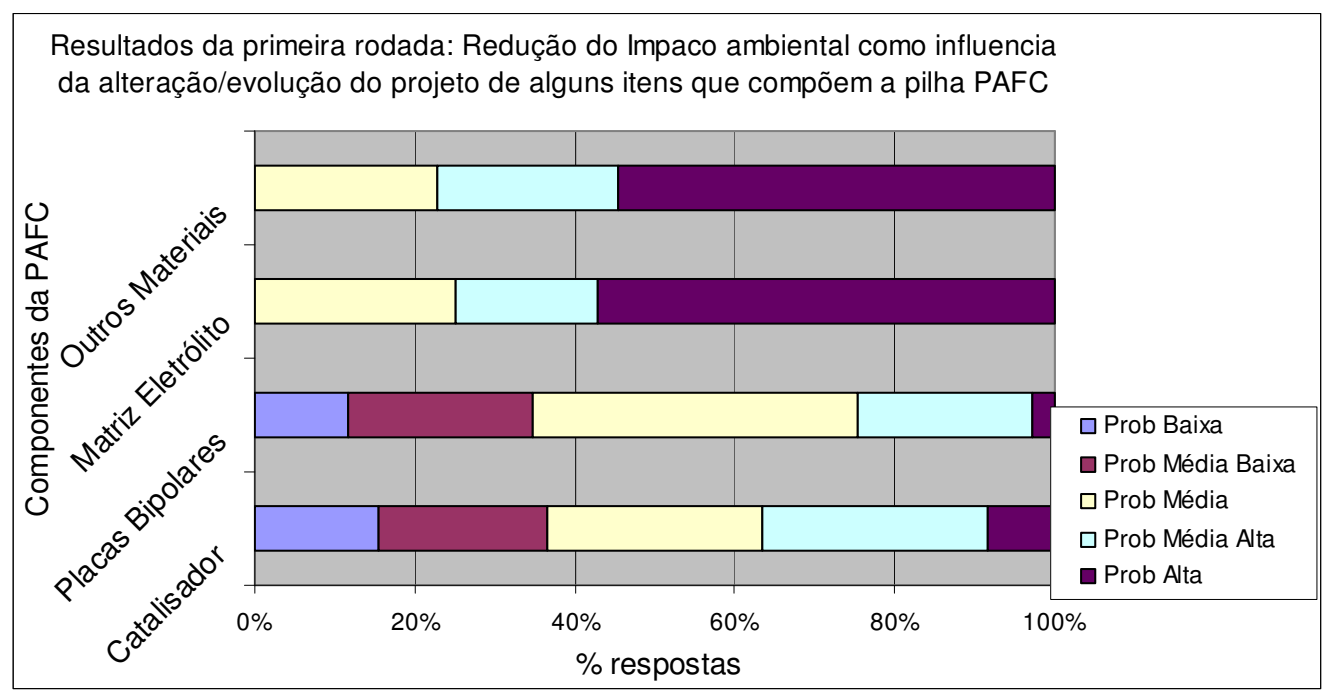

Figura 6-33 - Avaliação da probabilidade de redução do impacto ambiental das pilhas PAFC, considerando a evolução do projeto, a longo prazo.

A separação das respostas por continente do respondente, no caso dos catalisadores, mostrou uma variação das escolhas por continente. Ao passo que a Europa considera a Probabilidade Média Alta, os da América do Norte + 
Central e Ásia+Oceania escolheram como opção mais votada a opção Média e a América do Sul escolheu a Probabilidade Média Baixa (Figura 6-34).

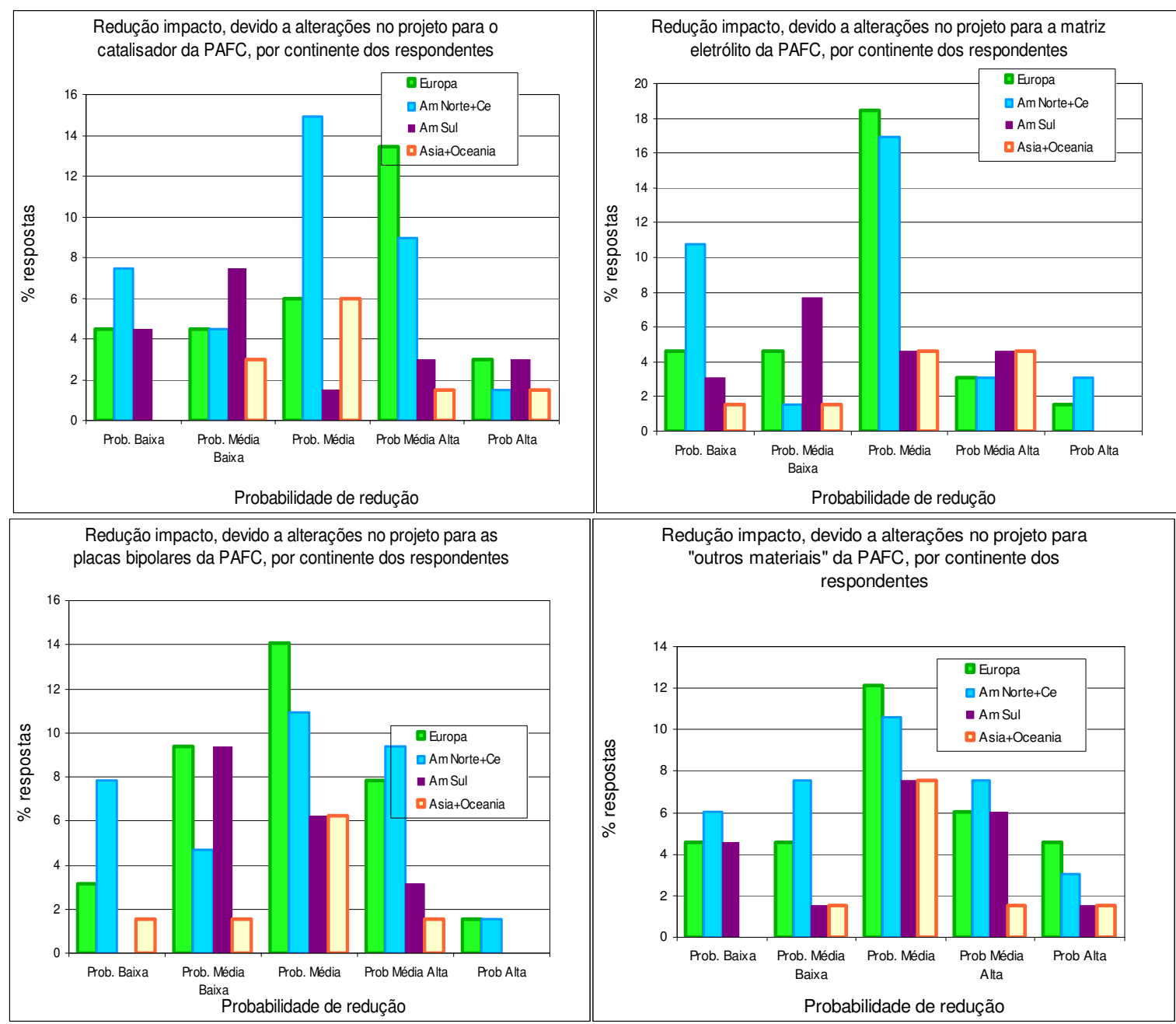

Figura 6-34 - Respostas para a questão 10, separadas por continente do respondente.

Também pode ser verificado, como mostra a Figura 6-35, que os respondentes não conseguiram identificar um item que se destaque para que, no futuro a longo prazo, possa vir a diminuir o impacto ambiental. E também não ocorreu divergência muito grande entre as opiniões. Os valores das médias entre 2,90 e 3,30 mostram que os respondentes consideram existir expectativa de Probabilidade entre Média Alta e Média Baixa de que ocorra redução do impacto ambiental, a longo prazo como conseqüência de alterações no projeto. $O$ item com menor probabilidade de redução é o referente à Matriz/Eletrólito, o qual teve média 3,30.

Para o item outros materiais todos os respondentes de todos os continentes a opção mai votada foi Probabilidade Média. 
A análise de variância mostrou que para todos os itens das pilhas PAFC (catalisador, placas bipolares, matriz/eletrólito e "outros materiais) não existiu relação entre todas as características estudadas dos respondentes e as respostas obtidas. As características estudadas dos respondentes foram: nível de especialização, ramo de atividade, sexo e continente do respondente.

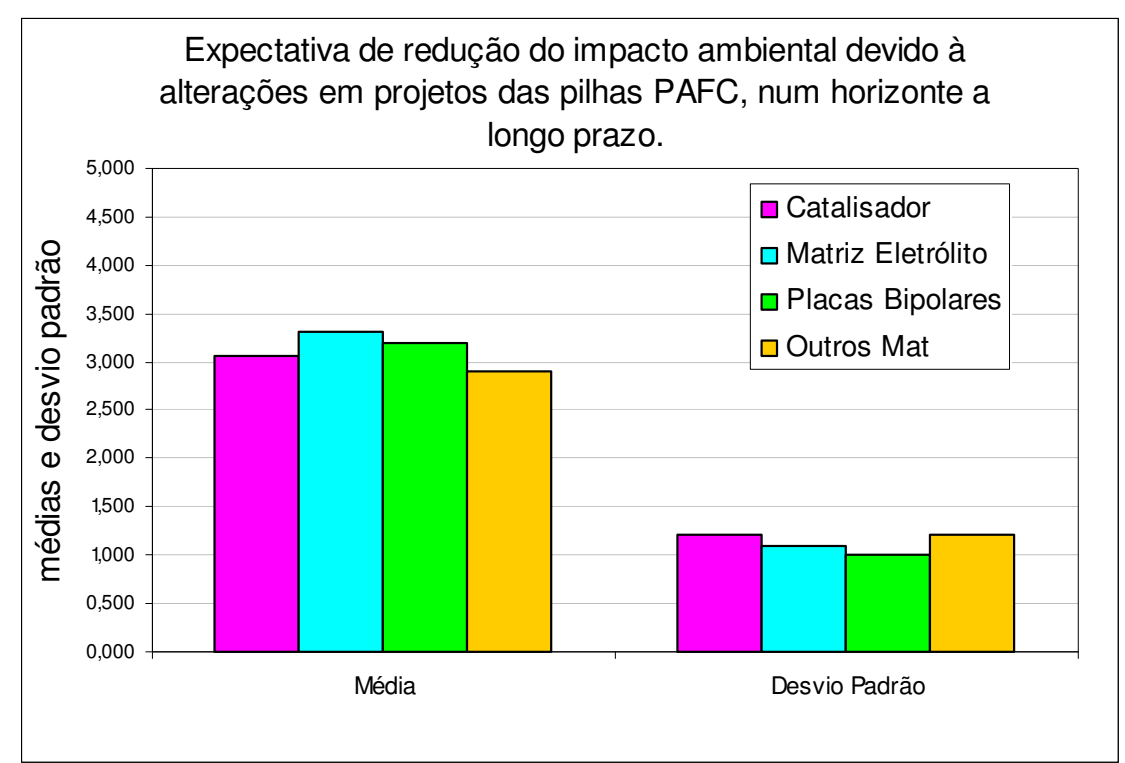

Figura 6-35 - Média e desvio padrão da expectativa de redução do impacto ambiental em razão de alterações em projetos das pilhas PAFC.

\subsubsection{Questão 11 - Grupo 2}

A questão 11 versa sobre a expectativa de melhoria no desempenho dos catalisadores do grupo PGM, a longo prazo. A questão 11 , tal qual foi originalmente apresentada aos respondentes encontra-se no Anexo B-1.

Para efeito de cálculos estatísticos foi considerado um valor para cada resposta e os resultados percentuais das opções estão apresentados na Tabela 6-16, a seguir.

Como as opções C e D foram as preferidas por $66,67 \%$ dos respondentes, isto implica na expectativa dos respondentes de que a evolução do desempenho do catalisador está na redução entre 100 e 400\%, que não parece ser muito grande. 
Tabela 6-17 - Resposta para os itens da questão 11.

No qual:

\begin{tabular}{c|c|c|c|c}
\hline & A & B & C & D \\
\hline & 1 & 2 & 3 & 4 \\
\hline$\%$ respostas & $10,7 \%$ & $22,6 \%$ & $40,5 \%$ & $26,2 \%$ \\
\hline
\end{tabular}

A Ocorrerá uma evolução com redução dos metais de até $1200 \%$.

B Ocorrerá uma grande evolução com redução dos metais de até $700 \%$.

C Ocorrerá evolução média com redução dos metais de até $400 \%$.

D Ocorrerá uma pequena evolução com redução dos metais de até $100 \%$.

$\mathrm{Na}$ Figura 6-36 são apresentadas as respostas de todos os respondentes para a questão 11 do questionário. Por meio do cálculo das médias o resultado foi 2.821 , desvio padrão 0,946 e pode ser observado que entre as opções mais escolhidas $66.67 \%$ preferiram as opções "C" e "D". E a menos escolhida foi a opção "A" (10,71\%).

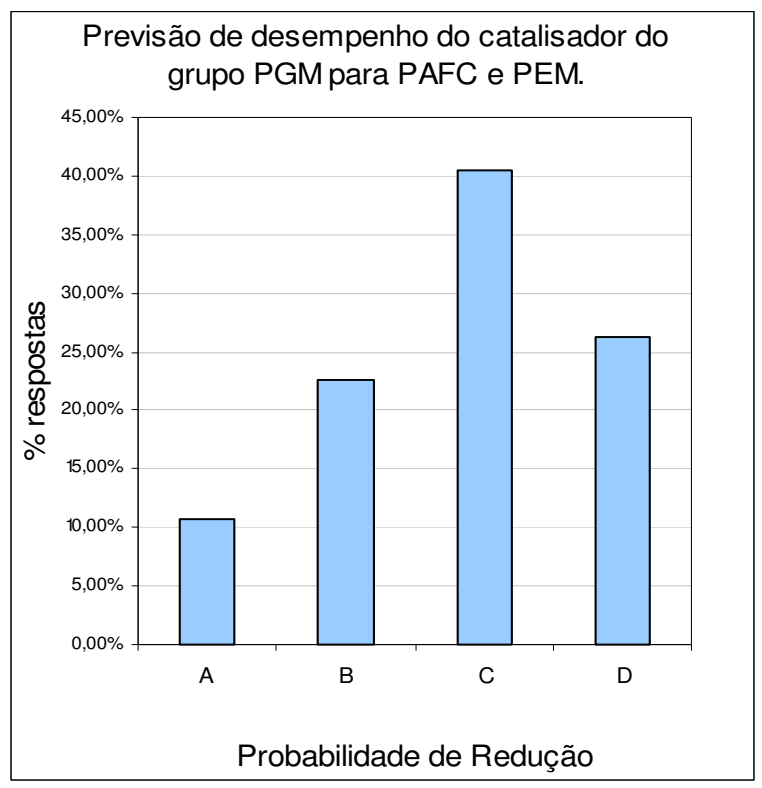

Figura 6-36 - Expectativa do desempenho dos catalisadores pertencentes ao grupo PGM, a longo prazo, para pilhas PAFC e PEM.

E a separação das respostas por continente dos respondentes está mostrada na Figura 6-37. Os Europeus parecem mais otimistas pois na escolheram preferencialmente a opção A. Já os respondentes da América do Norte e Central dividiram-se entre as opções A e D. 


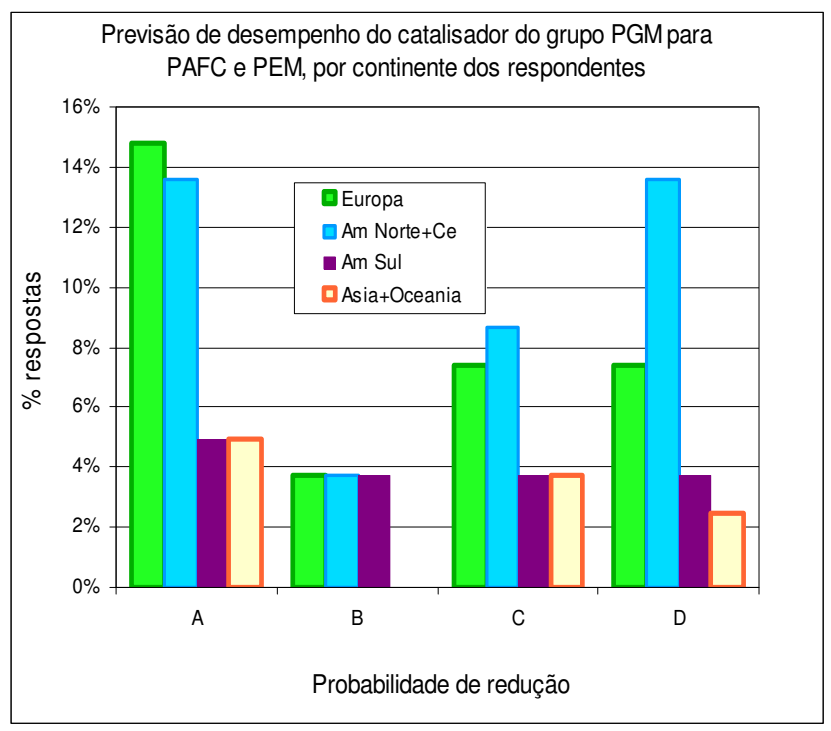

Figura 6-37 - Respostas à questão 11, separadas por continente do respondente.

Na Figura 6-38 são apresentadas as respostas separadas por atividade do respondente.

Para as outras características dos respondentes, tais como: ramo de atividade, qualificação, sexo e continente onde reside também não foram encontradas influências entre estas atividades e o tipo de resposta obtido na questão 11. Para tanto se utilizou a análise de variância considerando-se um nível de significância de $5 \%$.

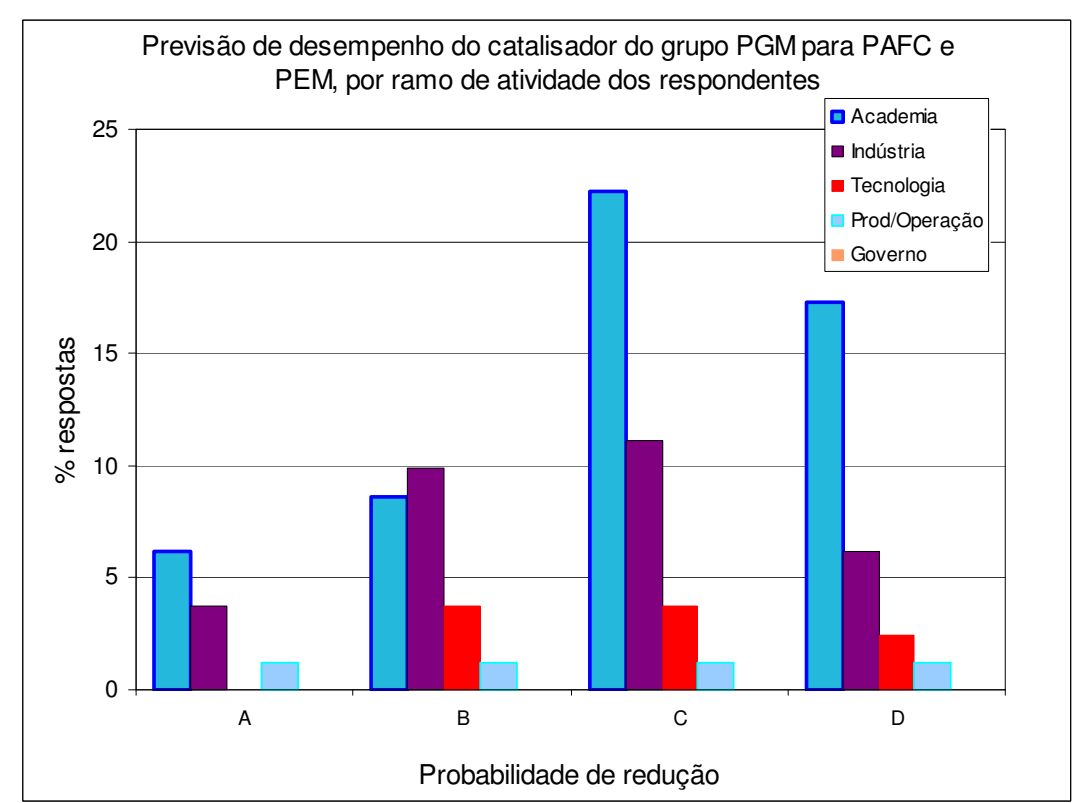

Figura 6-38 - Expectativa do desempenho dos catalisadores pertencentes ao grupo PGM, a longo prazo para pilhas PAFC e PEM, separados por atividade do respondente. 


\subsubsection{Questão 12- Grupo 2}

A questão 12 versa sobre a expectativa sobre a evolução da tecnologia atual de reciclagem do catalisador pertencente ao grupo da Platina (PGM), a longo prazo, para pilhas PAFC e PEM. A questão 12, tal qual foi originalmente apresentada aos respondentes encontra-se no Anexo B-1.

Para efeito de cálculos estatísticos foi considerado um valor para cada resposta e os resultados percentuais estão apresentados na Tabela 6-17.

Tabela 6-18 - Respostas para os itens da questão $12(\%)$.

No qual:

\begin{tabular}{c|c|c|c}
\hline & A & B & C \\
\hline & 1 & 2 & 3 \\
\hline$\%$ respostas & $38,4 \%$ & $41,8 \%$ & $19,8 \%$ \\
\hline
\end{tabular}

\begin{tabular}{l|l}
\hline A & Grande evolução com recuperação de até $99 \%$ do catalisador. \\
\hline B & Evolução média com recuperação de até $80 \%$ do catalisador. \\
\hline C & Evolução pequena com recuperação de até $60 \%$ do catalisador. \\
\hline
\end{tabular}

$\mathrm{Na}$ Figura 6-39 são apresentadas as respostas separadas por 2 grupos: os mais qualificados e os menos qualificados, para a questão 12 do questionário. Por meio do cálculo das médias o resultado foi 1.814, desvio padrão 0,744 e pode ser observado que entre as opções mais escolhidas $80.23 \%$ preferiram as opções "B" e "A". E a menos escolhida foi a opção "C" (19,77\%).

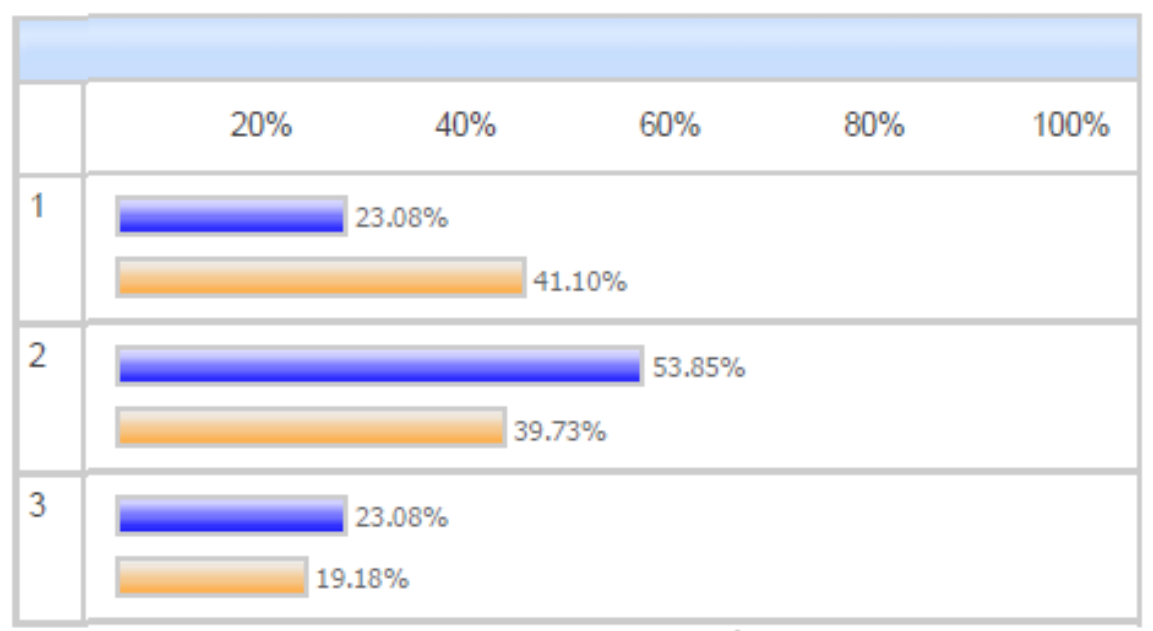

Grupo Mais Qualificados

Grupo Menos Qualificados

Figura 6-39 - Expectativa da reciclagem dos catalisadores pertencentes ao grupo PGM, a longo prazo para grupos "mais" e "menos qualificados". 
Para as atividades do respondente, tais como: qualificação, ramo de atividade, sexo e continente onde reside não foram encontradas influências entre estas atividades e o tipo de resposta obtido na questão 12. Para tanto, utilizou-se a análise de variância considerando um nível de significância de 5\%. A Figura 640 mostra que os respondentes da Europa escolheram a opção A como a preferencial, ao passo que os da América do Norte+Central, Ásia+Oceania e América do Sul escolheram a B.

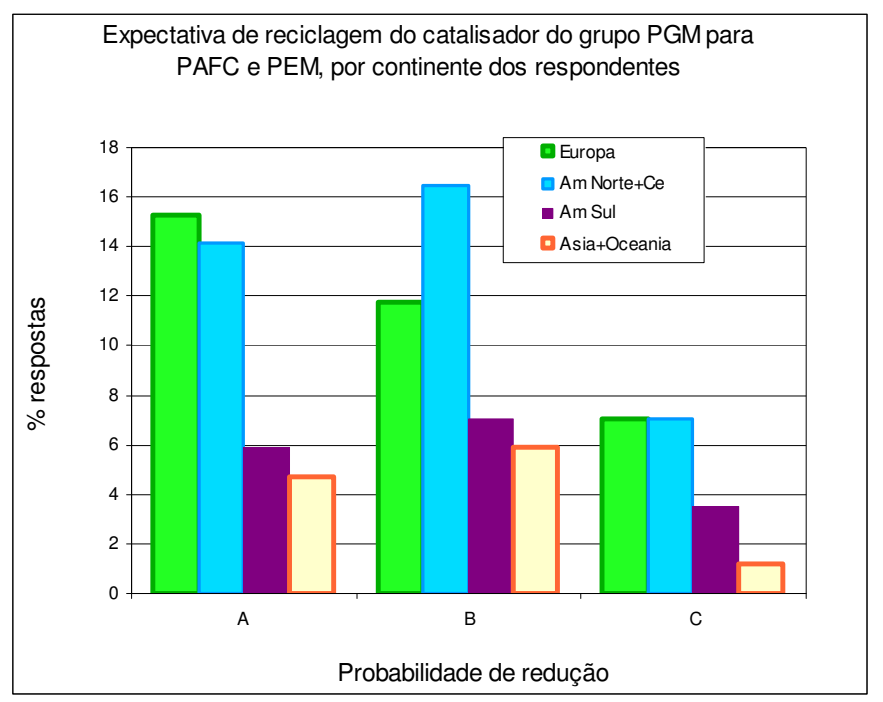

Figura 6-40 - Respostas à questão 12 separadas por continente do respondente.

A expectativa de recuperação dos metais PGM é apresentada na Figura 6-41. Pode-se notar que os respondentes não possuem uma visão tão otimista pois sua opção preferencial é a B (recuperação de até $80 \%$ ).

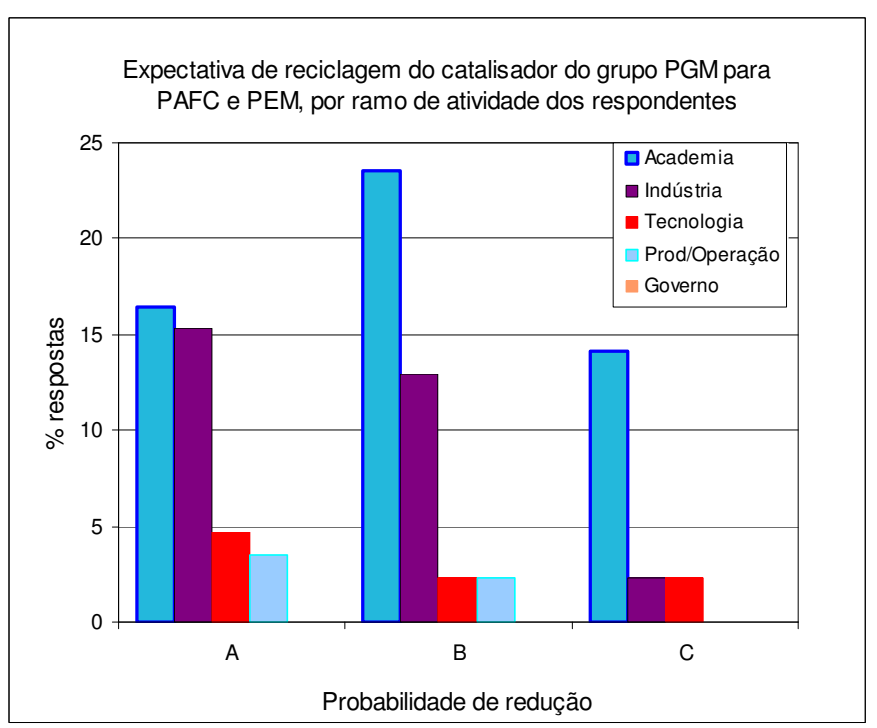

Figura 6-41 -Expectativa de reciclagem do catalisador do grupo da Platina por ramo de atividade do respondente. 
A conclusão é que a expectativa dos respondentes é que ocorra reciclagem do catalisador com recuperação entre $80-99 \%$ do catalisador, o que implica em razoável diminuição na etapa de fabricação das pilhas a combustível.

\subsubsection{Dados do Grupo 3}

A seguir são apresentados os dados de qualificação e ramo de atividade dos respondentes para o grupo 3 (pilhas MCFC), na Figura 6-37.
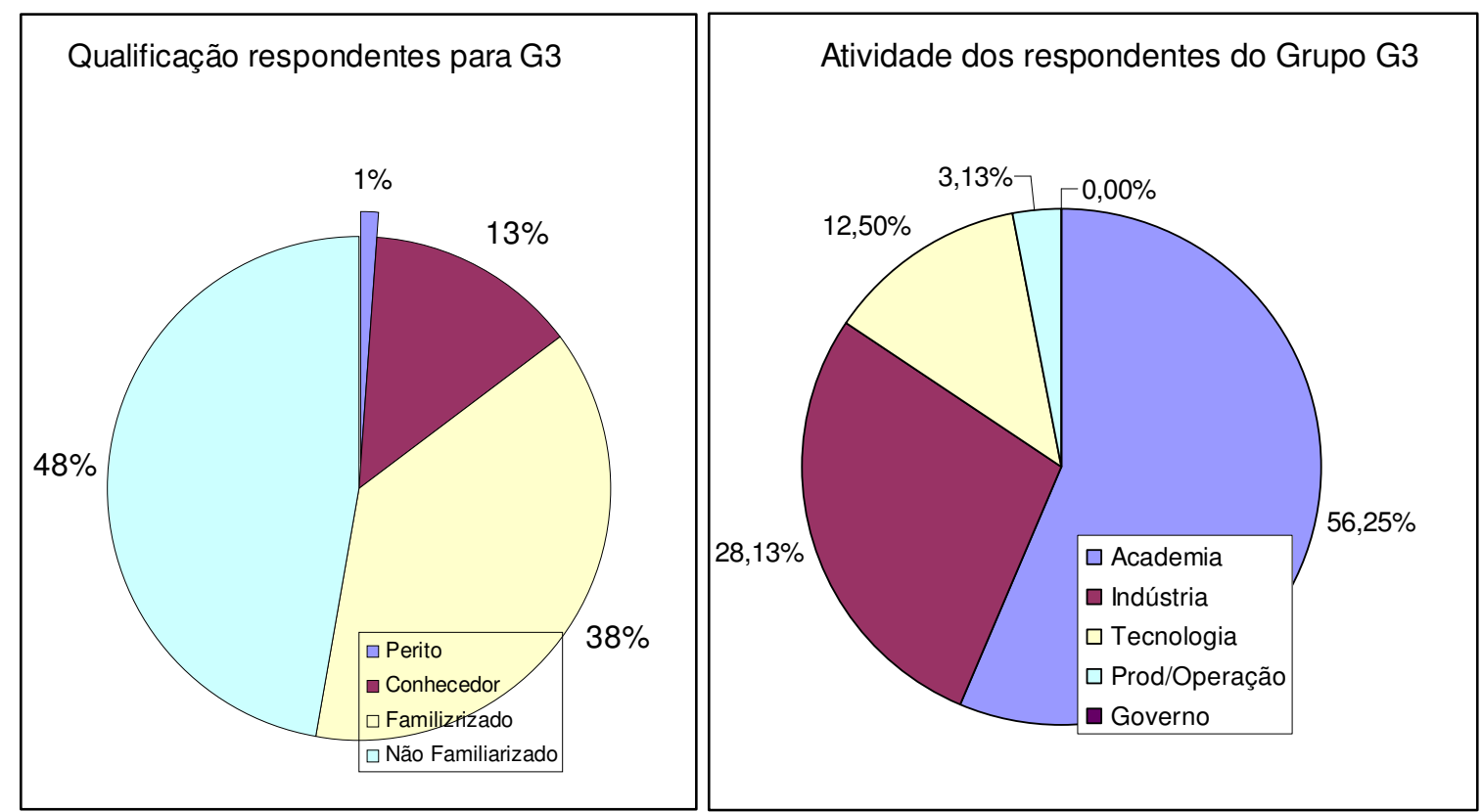

Figura 6-42- Qualificação e ramo de atividade dos respondentes das questões pertencentes ao grupo 3

\subsubsection{Questão 14- Grupo 3}

A questão 14 versa sobre a expectativa do impacto ambiental das pilhas MCFC a longo prazo. A questão 14, tal qual foi originalmente apresentada aos respondentes encontra-se no Anexo B-1.

Para efeito de cálculos estatísticos foi considerado um valor para cada resposta. Os resultados percentuais referentes às opções de respostas estão apresentados a seguir, na Tabela 6-18.

Da análise de variância com os grupos respondentes resultaram as características dos respondentes, para as quais existe correlação com o tipo de resposta apresentado. Na Tabela 6-19 são apresentados os dados resultantes desta análise. 
Tabela 6-19 - Respostas para os itens da questão 14.

\begin{tabular}{l|l|l|c|c|c}
\hline & $\begin{array}{c}\text { Redução Muito } \\
\text { Alta }\end{array}$ & $\begin{array}{c}\text { Redução Média } \\
\text { Alta }\end{array}$ & $\begin{array}{c}\text { Redução } \\
\text { Média }\end{array}$ & $\begin{array}{c}\text { Redução } \\
\text { Baixa }\end{array}$ & $\begin{array}{c}\text { Sem } \\
\text { Redução }\end{array}$ \\
\hline & 1 & 2 & 3 & 4 & 5 \\
\hline Catalisador & $7,4 \%$ & $27,9 \%$ & $41,2 \%$ & $20,6 \%$ & $2,9 \%$ \\
\hline Matriz Eletrólito & $10,3 \%$ & $20,6 \%$ & $38,2 \%$ & $26,5 \%$ & $4,4 \%$ \\
\hline Placas bipolares & $8,8 \%$ & $19,1 \%$ & $47,1 \%$ & $20,6 \%$ & $4,4 \%$ \\
\hline Outros Materiais & $11,9 \%$ & $20,9 \%$ & $34,3 \%$ & $28,4 \%$ & $4,5 \%$ \\
\hline
\end{tabular}

Foi efetuada a separação das respostas por continente onde reside 0 respondente, para todos os itens da questão e na Figura 6-43 é mostrado o gráfico para matriz/eletrólito e "outros materiais". E para o item ("outros materiais") os respondentes da América do Sul, na média são mais otimistas que os dos outros continentes.

Tabela 6-20 - Correlação entre respostas e características do respondente para questão 14.

\begin{tabular}{c|l|l|l|l}
\hline Item & \multicolumn{4}{|c}{ Características do respondente } \\
\hline & Qualificação & Ramo de atuação & Continente & Sexo \\
\hline Catalisador & & & & \\
\hline Matriz/eletrólito & & & & \\
\hline Placas Bipolares & & & & \\
\hline Outros materiais & & & & \\
\hline
\end{tabular}

\section{Existe correlação}

Não existe correlação

E por meio da análise de variância e, considerando o nível de significância de $5 \%$, pode-se concluir que o continente onde o respondente reside não influi nas respostas sobre o grau de redução do impacto ambiental da pilha a combustível, a longo prazo.

E na Figura 6-44 são apresentadas as respostas separadas por sexo. Note-se que o sexo foi avaliado previamente por meio dos e-mails e perfis iniciais e não constava das perguntas da primeira rodada. Utilizando a análise de variância e, considerando o nível de significância de $5 \%$, pode-se concluir que 0 sexo do respondente influi nas respostas sobre o grau de redução do impacto ambiental da pilha a combustível, em razão do desenvolvimento na área de "outros materiais". 

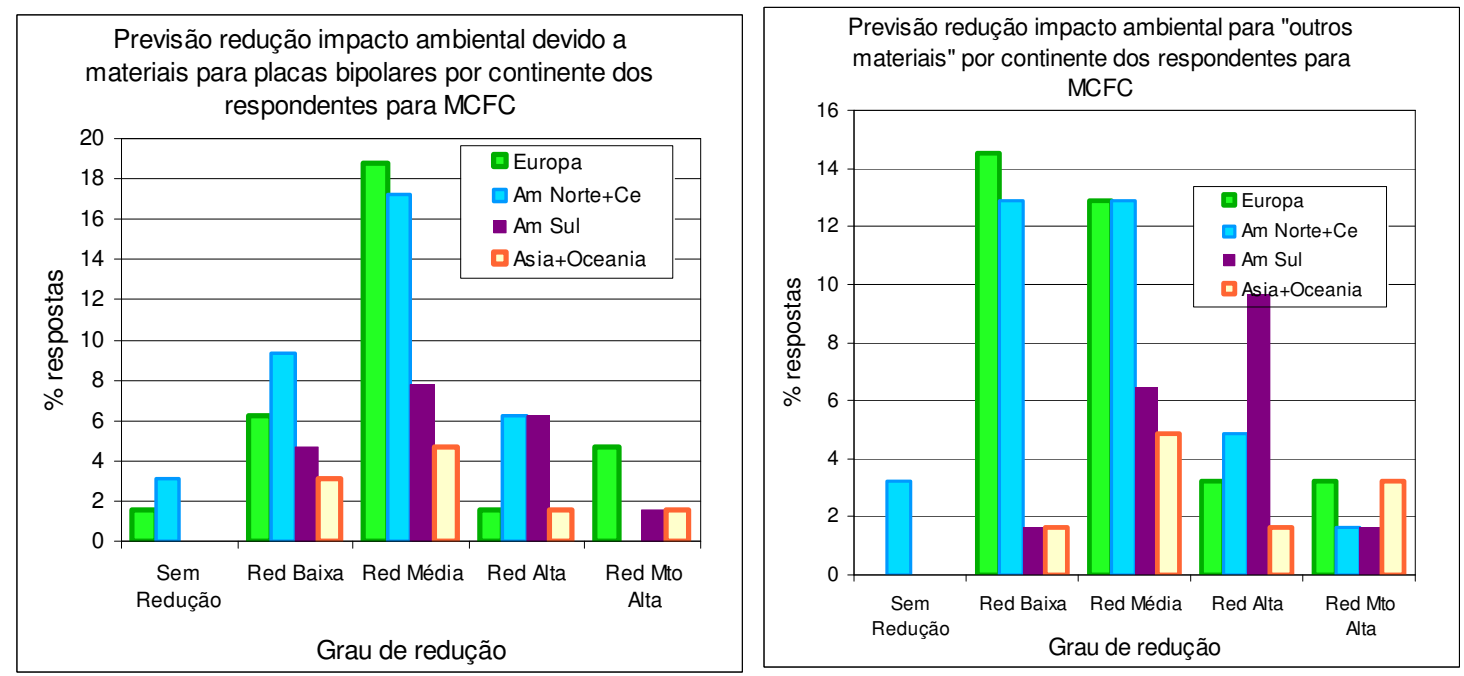

Figura 6-43 - Expectativa da redução do impacto ambiental, em razão dos catalisadores, para as pilhas MCFC, por continente onde o respondente reside.

E para que se tenha uma idéia de como o desenvolvimento de materiais pode influir no impacto ambiental das pilhas a combustível, a longo prazo, a Figura 6-45 mostra a comparação entre as respostas obtidas para cada item abordado na questão: catalisador, membrana, placas bipolares e outros materiais.

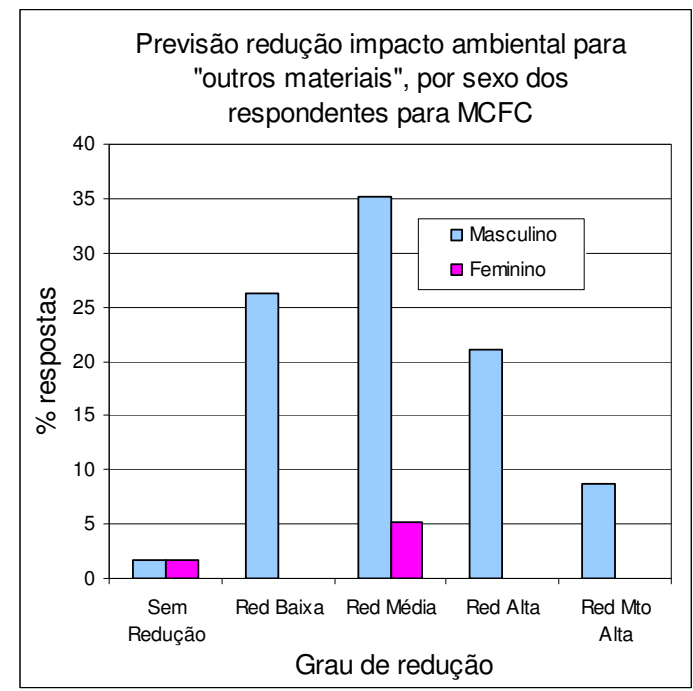

Figura 6-44 - Avaliação da diminuição do impacto ambiental em razão dos "outros materiais", a longo prazo para pilhas MCFC, por sexo do respondente. 


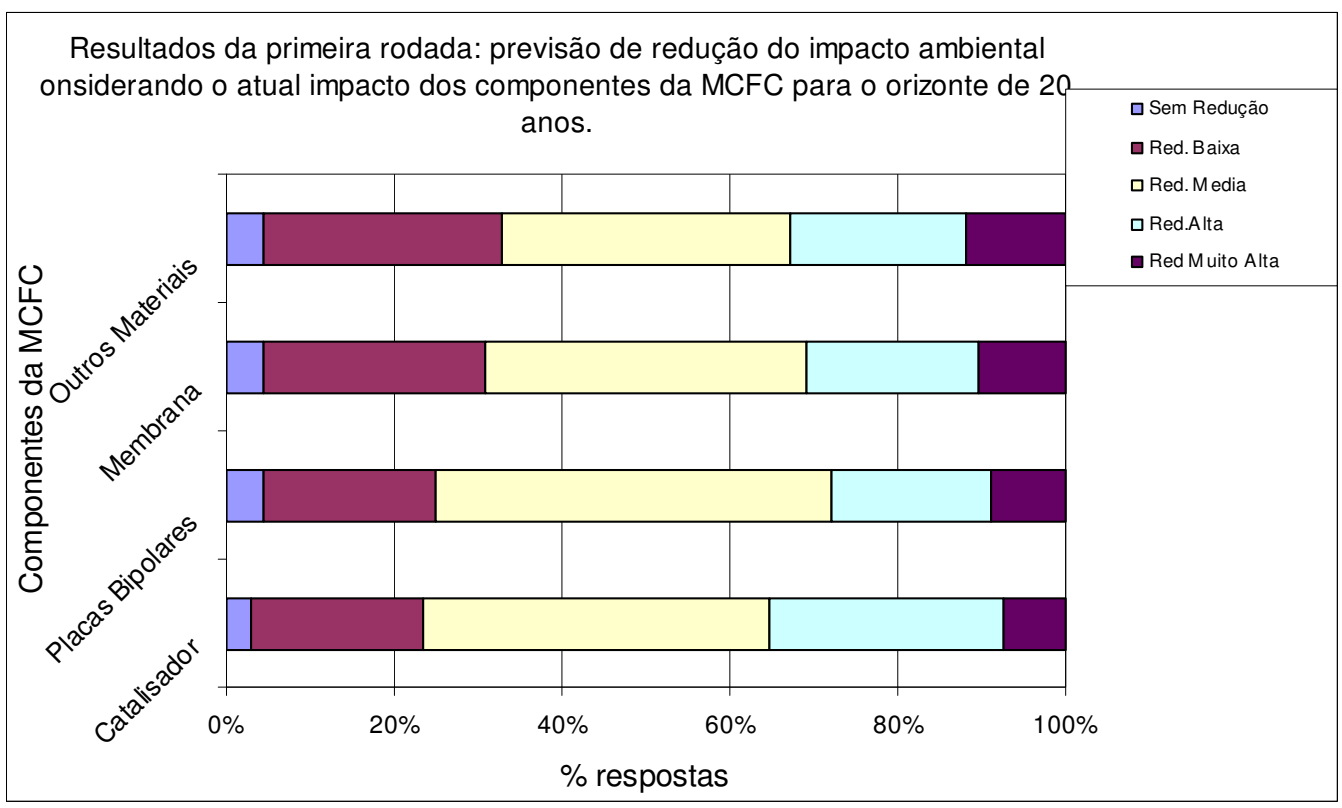

Figura 6-45 - Comparação das respostas para os quatro itens considerados na questão 14: Catalisador, Membrana, Placas Bipolares e Outros Materiais.

Também pode ser verificado, como mostra a Figura 6-46, que os respondentes não conseguiram identificar um item que se destaque para que, no futuro a longo prazo, possa vir a diminuir o impacto ambiental. E também não ocorreu divergência muito grande entre as opiniões. Os valores das médias entre 2,84 e 2,94 mostram que os respondentes consideram existir expectativa de Redução do impacto ambiental entre Alta e Média de que ocorra redução do impacto ambiental, a longo prazo como conseqüência do desenvolvimento dos itens da pilha MCFC.

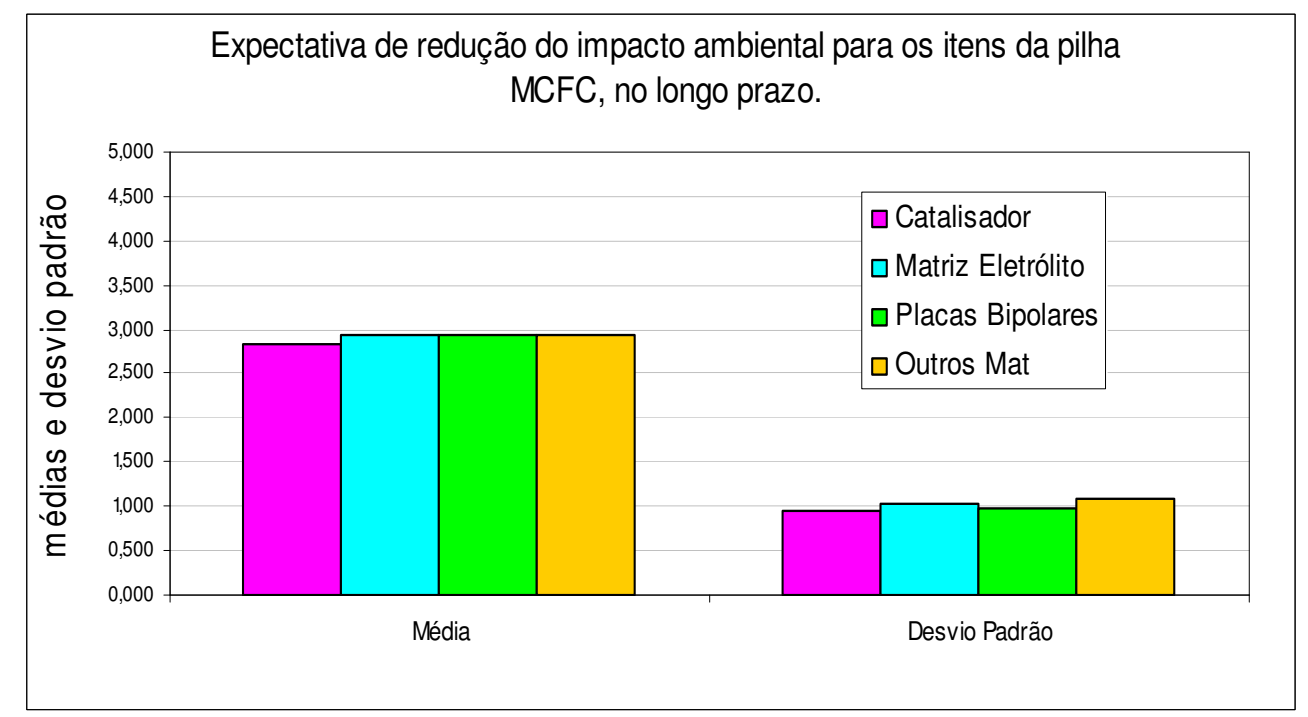

Figura 6-46 - Média e desvio padrão das respostas obtidas para os vários itens das pilhas MCFC, na questão 14. 
A análise de variância mostrou que para o item "outros materiais" das pilhas MCFC tanto o continente como o sexo do respondente influi no tipo de resposta. Para os outros itens das pilhas MCFC (catalisador, placas bipolares, e matriz/eletrólito) não existiu relação entre todas as características estudadas dos respondentes $\mathrm{e}$ as respostas obtidas. As características estudadas dos respondentes foram: nível de especialização, ramo de atividade, sexo e continente do respondente.

\subsubsection{Questão 15- Grupo 3}

A questão 15 versa sobre a expectativa de substituição ou abolição do catalisador da pilha MCFC, considerando uma evolução para outro tipo de projeto, considerando um futuro de 20 anos. A questão 15 , tal qual foi originalmente apresentada aos respondentes encontra-se no Anexo B-1.

Para efeito de cálculos estatísticos foi considerado um valor para cada resposta e os resultados percentuais das opções estão apresentados na Tabela 6-20, a seguir.

Tabela 6-21 - Opções de resposta para os itens da questão 15

No qual:

\begin{tabular}{c|c|c|c|c}
\hline & A & B & C & D \\
\hline & 1 & 2 & 3 & 4 \\
\hline$\%$ respostas & $31,9 \%$ & $14,5 \%$ & $20,3 \%$ & $33,3 \%$ \\
\hline
\end{tabular}

\begin{tabular}{l|l}
\hline A & Ocorrerá substituição do catalisador \\
\hline B & $\begin{array}{l}\text { Não ocorrerá a substituição do catalisador, mas ocorrerá uma redução grande na } \\
\text { concentração. }\end{array}$ \\
\hline C & Não ocorrerá a substituição do catalisador, e ocorrerá uma redução pequena na concentração. \\
\hline D & $\begin{array}{l}\text { Não ocorrerá a substituição do catalisador, mas ocorrerá uma redução na concentração } \\
\text { através da mistura com outros materiais de menor impacto ambiental. }\end{array}$ \\
\hline
\end{tabular}

Por meio do cálculo das médias o resultado foi 2,551, desvio padrão 1,255 e pode ser observado que entre as opções mais escolhidas $65,2 \%$ preferiram as opções "D" e "A". E a menos escolhida foi a opção "B" com 14,5\%.

$\mathrm{Na}$ Figura 6-47 são apresentadas as expectativas para a questão 15, para 2 grupos: "mais" e "menos" qualificados. 


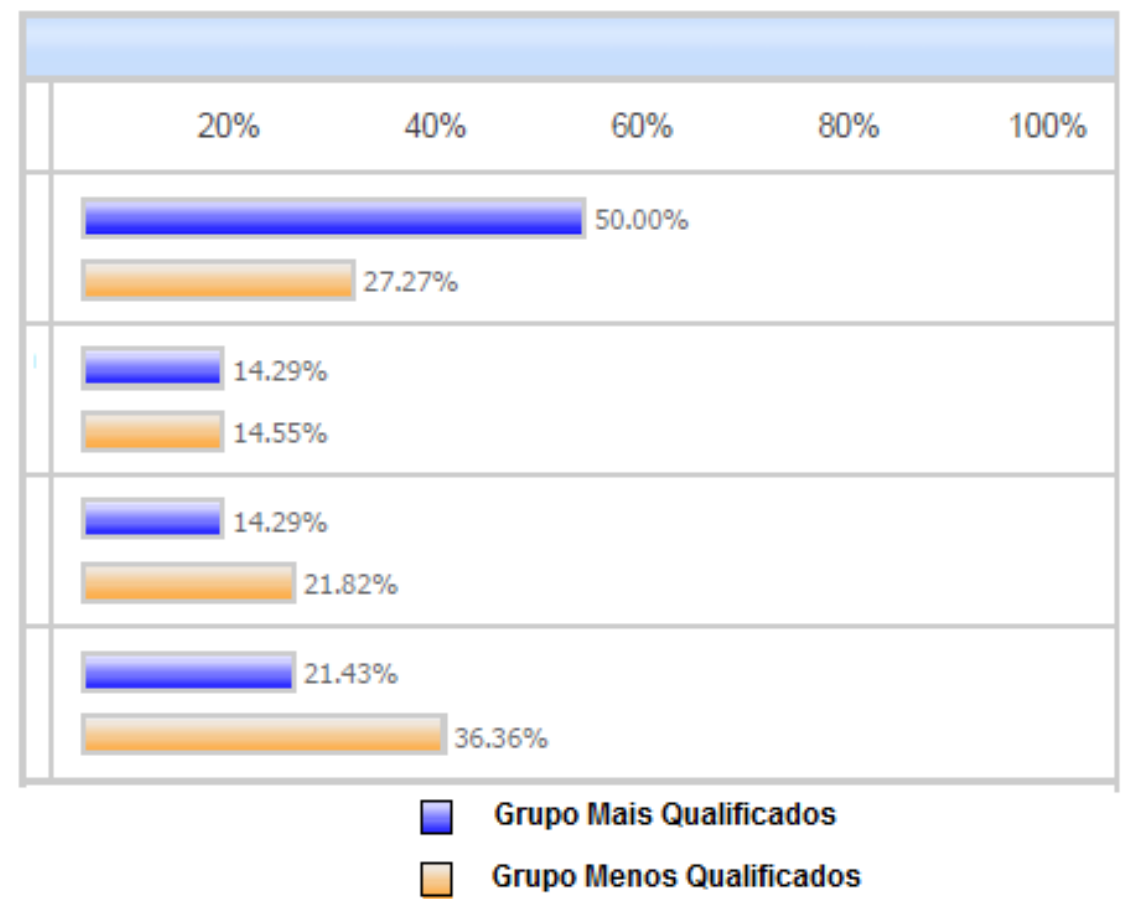

Figura 6-47 - Expectativa de substituição/abolição do uso de materiais do grupo PGM como catalisador para MCFC, para grupos mais e menos qualificados.

Neste caso por meio da análise de variância também se verificou que, considerando um nível de significância de $5 \%$, as características analisadas dos respondentes não influem no tipo de resposta. As características analisadas foram: qualificação, ramo de atividade, sexo e continente do respondente.

$\mathrm{Na}$ Figura 6-48 são apresentadas as respostas à questão 15 separadas por continente do respondente, onde os respondentes da América do Sul aparentam ser mais pessimistas que os dos outros continentes.

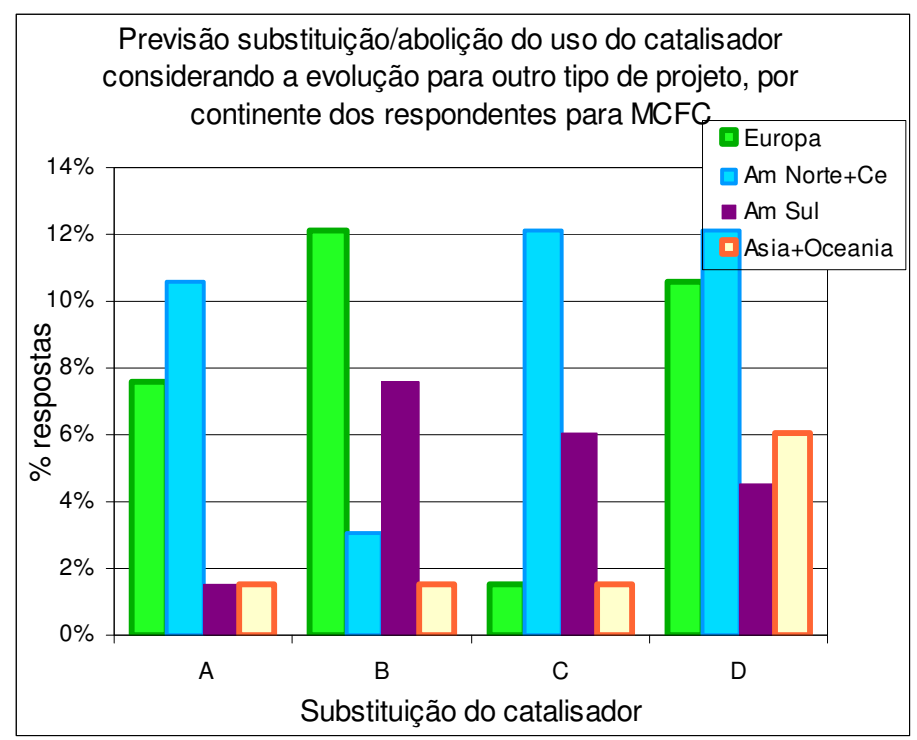

Figura 6-48 - Respostas à questão 15 separadas por continente do respondente. 


\subsubsection{Questão 16- Grupo 2}

A questão 16 versa sobre a expectativa de redução do impacto ambiental frente à evolução para outro tipo de projeto, onde um dos vários itens que compõem a pilha tipo MCFC, possam ser substituídos ou abolidos, para um horizonte de longo prazo. A questão 16, tal qual foi originalmente apresentada aos respondentes encontra-se no Anexo B-1.

Para efeito de cálculos estatísticos foi considerado um valor para cada resposta. Os resultados percentuais referentes às opções de respostas estão apresentados a seguir, na Tabela 6-21.

Tabela 6-22 - Opções de resposta para os itens da questão 16 (\%)

\begin{tabular}{c|c|c|c|c|c}
\hline & $\begin{array}{c}\text { Probabilidade } \\
\text { Alta }\end{array}$ & $\begin{array}{c}\text { Probabilidade } \\
\text { Média Alta }\end{array}$ & $\begin{array}{c}\text { Probabilidade } \\
\text { Média }\end{array}$ & $\begin{array}{c}\text { Probabilidade } \\
\text { Média Baixa }\end{array}$ & $\begin{array}{c}\text { Probabilidade } \\
\text { Baixa }\end{array}$ \\
\hline & 1 & 2 & 3 & 4 & 5 \\
\hline Catalisador & $4,3 \%$ & $29,0 \%$ & $37,7 \%$ & $18,8 \%$ & $10,1 \%$ \\
\hline Matriz/eletrólito & $4,5 \%$ & $26,9 \%$ & $38,8 \%$ & $23,9 \%$ & $6,0 \%$ \\
\hline $\begin{array}{c}\text { Placas } \\
\text { bipolares }\end{array}$ & $2,9 \%$ & $17,4 \%$ & $49,3 \%$ & $18,8 \%$ & $11,6 \%$ \\
\hline $\begin{array}{c}\text { Outros } \\
\text { Materiais }\end{array}$ & $8,7 \%$ & $18,8 \%$ & $46,4 \%$ & $17,4 \%$ & $8,7 \%$ \\
\hline
\end{tabular}

Da análise de variância com os grupos respondentes resultaram as características dos respondentes, para as quais existe correlação com o tipo de resposta apresentado. Na Tabela 6-22 são apresentados os dados resultantes desta análise.

Tabela 6-23 Correlação entre respostas e características do respondente.

\begin{tabular}{c|c|c|c|c|c}
\hline Item & \multicolumn{4}{|c}{ Características do respondente } \\
\hline & \multicolumn{2}{|c|}{ Qualificação } & Ramo de atuação & Continente & Sexo \\
\hline Catalisador & 4 grupos & 2 grupos & & & \\
\hline Matriz/eletrólito & & & & & \\
\hline Placas Bipolares & & & & & \\
\hline Outros materiais & & & & & \\
\hline
\end{tabular}

Existe correlação

Não existe correlação

Na Figura 6-49 são apresentadas, em conjunto, as respostas obtidas para os vários itens da pilha MCFC, da questão 16. 


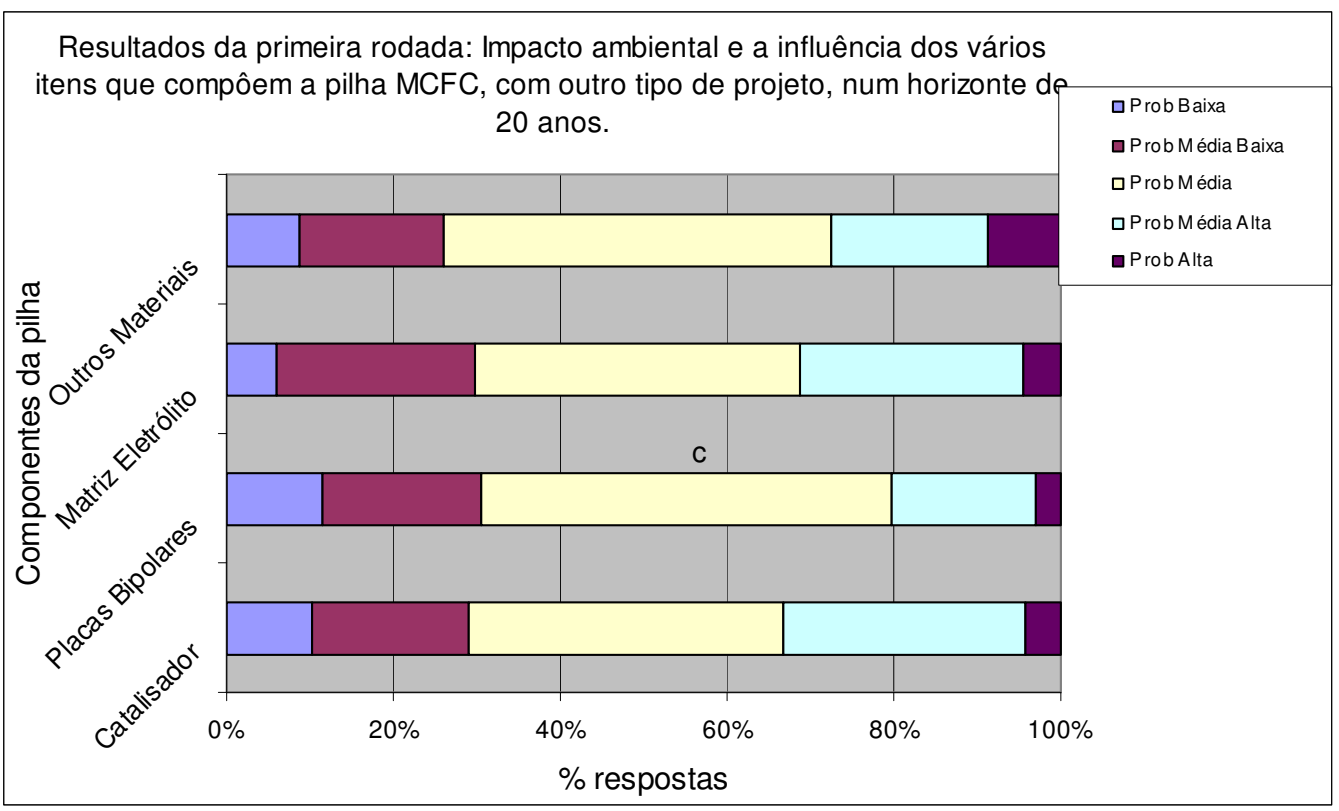

Figura 6-49 - Expectativa de redução do impacto ambiental frente à evolução para outro tipo de projeto, no qual os vários itens que compõem a pilha tipo MCFC, possam ser substituídas ou abolidas, para um horizonte de longo prazo.

Para os itens: Catalisador e Matriz/Eletrólito os respondentes da Ásia e Oceania são um pouco mais otimistas. Na Figura 6-50 são apresentadas as respostas à questão 16 , separadas por continente do respondente.

Também pode ser verificado, como mostra a Figura 6-51, que os respondentes não conseguiram identificar um item que se destaque para que, no futuro a longo prazo, possa vir a diminuir o impacto ambiental. $E$ também não ocorreu divergência muito grande entre as opiniões. Os valores das médias entre 2,99 e 3,19 mostram que os respondentes consideram existir expectativa de Probabilidade entre Média Baixa e Média de redução do impacto ambiental, a longo prazo como conseqüência de um novo projeto para os vários itens que compõem a pilha MCFC.

A análise de variância mostrou que para todos os itens das pilhas MCFC não existiu correlação entre as respostas e as características estudadas dos respondentes. As características estudadas dos respondentes foram: nível de especialização, ramo de atividade, sexo e continente do respondente. 


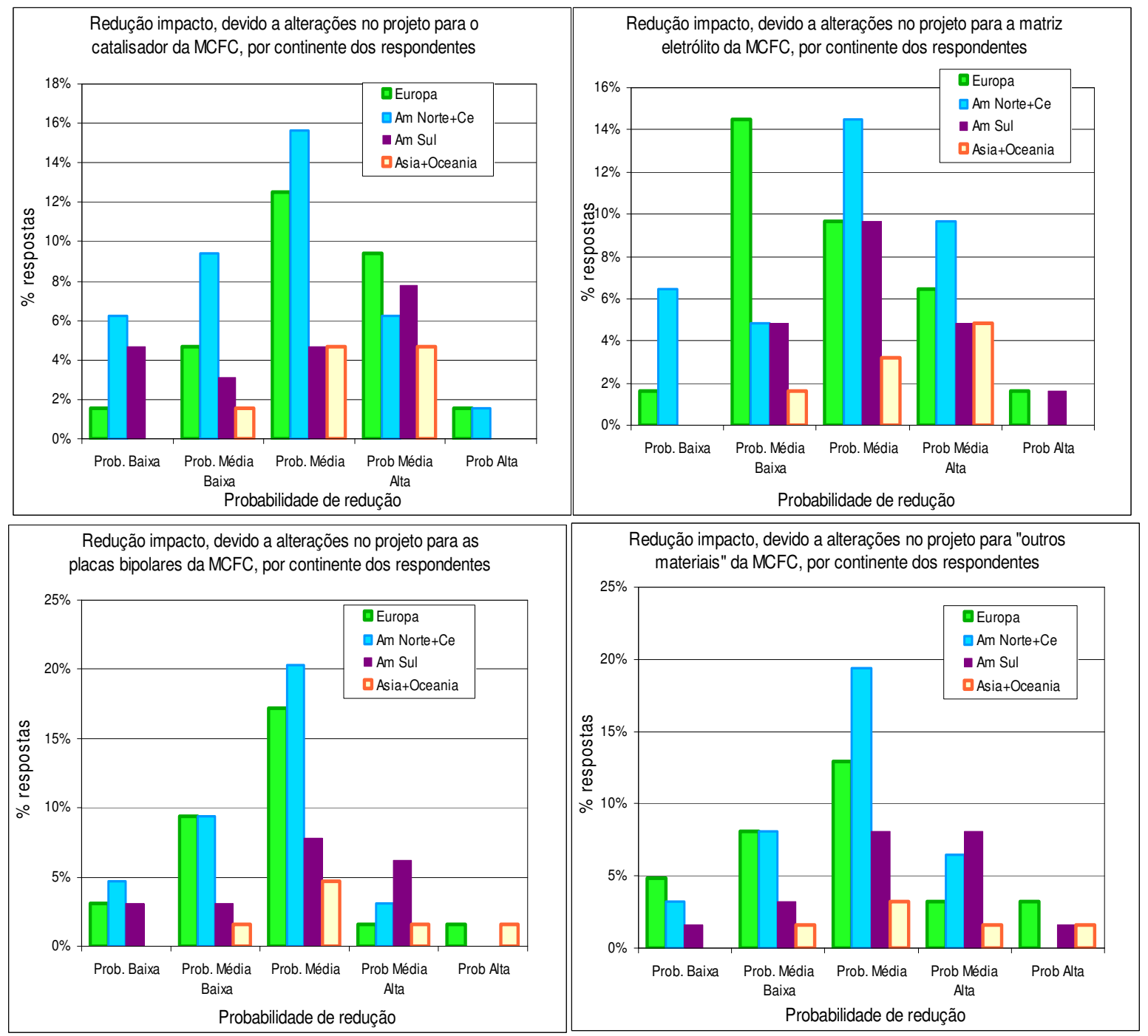

Figura 6-50 - Respostas à questão 16, separadas por continente do respondente.

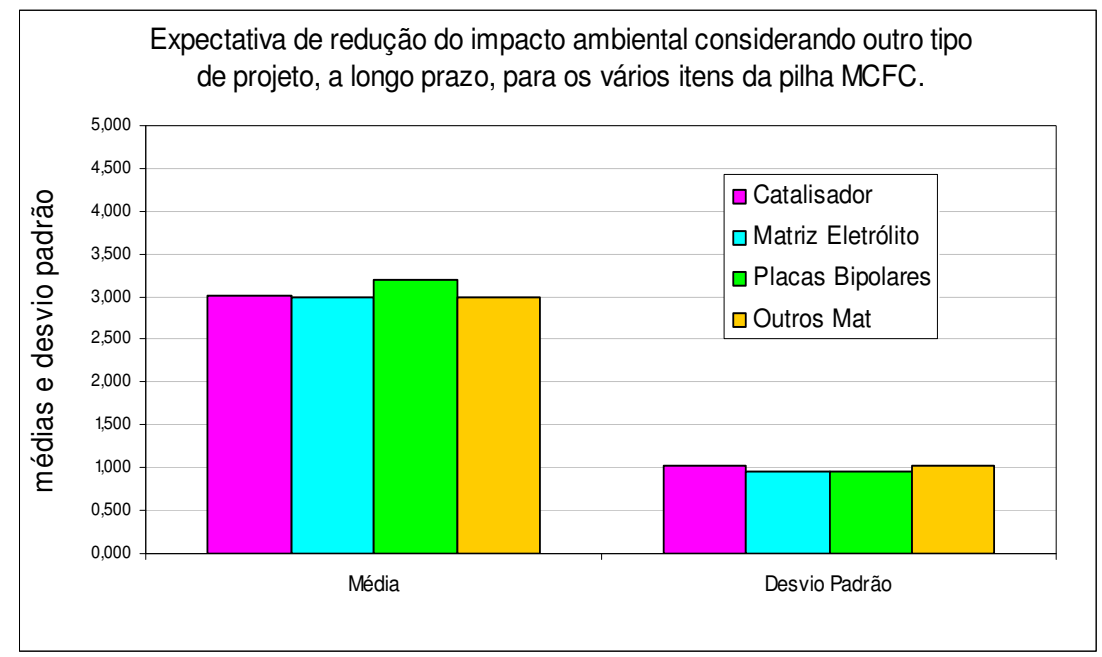

Figura 6-51 - Médias e Desvios Padrão para expectativa de redução do impacto ambiental considerando outro tipo de projeto, para os diversos itens das pilhas MCFC, a longo prazo. 


\subsubsection{Dados do Grupo 4}

A seguir são apresentados os dados de qualificação e ramo de atividade dos respondentes às questões do grupo 4 (Combustíveis para pilhas), na Figura 6-52.

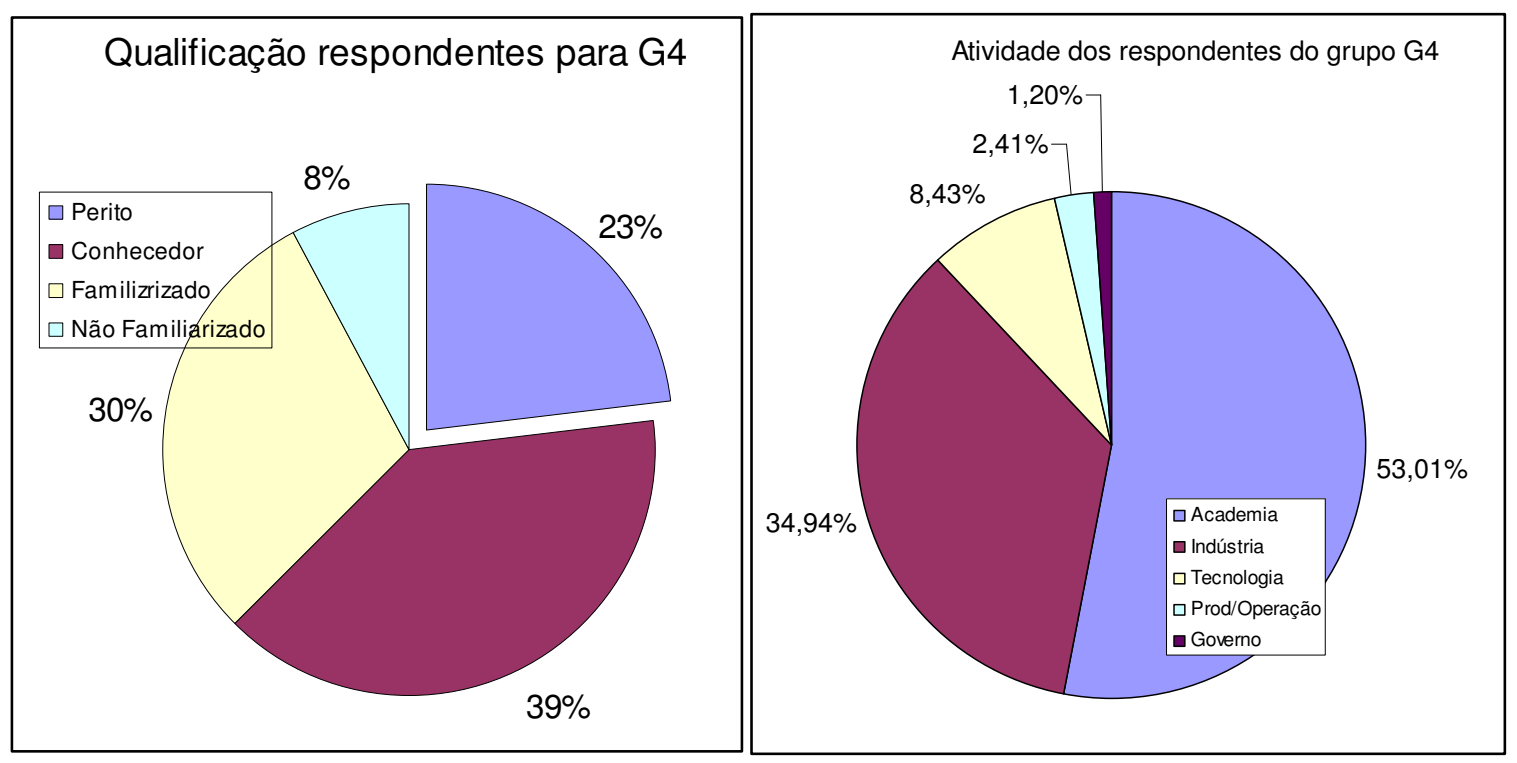

Figura 6-52 - Qualificação e ramo de atividade dos respondentes das questões pertencentes ao grupo 4

\subsubsection{Questão 18- Grupo 4}

A questão 18 versa sobre a expectativa de impacto ambiental em razão do processo de produção do hidrogênio em função de dois tipos de produção: a produção próxima ao local de consumo ou dentro do processo do próprio consumidor ("onboard") e a produção em local distante do consumo. A questão 18, tal qual foi originalmente apresentada aos respondentes encontra-se no Anexo B-1.

Para efeito de cálculos estatísticos foi considerado um valor para cada resposta. Os resultados percentuais referentes às opções de respostas estão apresentados a seguir, na Tabela 6-23.

Tabela 6-24 - Opções de resposta para os itens da questão 16 (\%)

\begin{tabular}{l|c|c|c|c|c}
\hline & $\begin{array}{c}\text { Redução } \\
\text { Muito Alta }\end{array}$ & $\begin{array}{c}\text { Redução } \\
\text { Alta }\end{array}$ & $\begin{array}{c}\text { Redução } \\
\text { Média }\end{array}$ & $\begin{array}{c}\text { Redução } \\
\text { Baixa }\end{array}$ & $\begin{array}{c}\text { Sem } \\
\text { Redução }\end{array}$ \\
\hline & 1 & 2 & 3 & 4 & 5 \\
\hline "ONBOARD" & $26,1 \%$ & $31,5 \%$ & $28,3 \%$ & $10,9 \%$ & $3,3 \%$ \\
\hline $\begin{array}{l}\text { Distante do local de } \\
\text { consumo }\end{array}$ & $27,6 \%$ & $26,4 \%$ & $32,2 \%$ & $13,8 \%$ & $0,00 \%$ \\
\hline
\end{tabular}


Da análise de variância com os grupos respondentes resultaram as características dos respondentes, para as quais existe correlação com o tipo de resposta apresentado. $\mathrm{E}$ os dados resultantes desta análise são apresentados na Tabela 6-24.

Tabela 6-25 - Correlação entre respostas e características do respondente.

\begin{tabular}{l|l|l|l|l}
\hline Item & \multicolumn{4}{|c}{ Características do respondente } \\
\hline & Qualificação & Ramo de atuação & Continente & Sexo \\
\hline "ONBOARD” & & & & \\
\hline Distante do local de consumo & & & & \\
\hline
\end{tabular}

$\square$ Existe correlação $\square$ Não existe correlação

Na Figura 6-53 são apresentadas, em conjunto, todas as respostas para os dois itens da questão 18 e na Figura 6-54 são apresentadas as médias e desvios padrão para os itens 1 e 2 da questão 18.

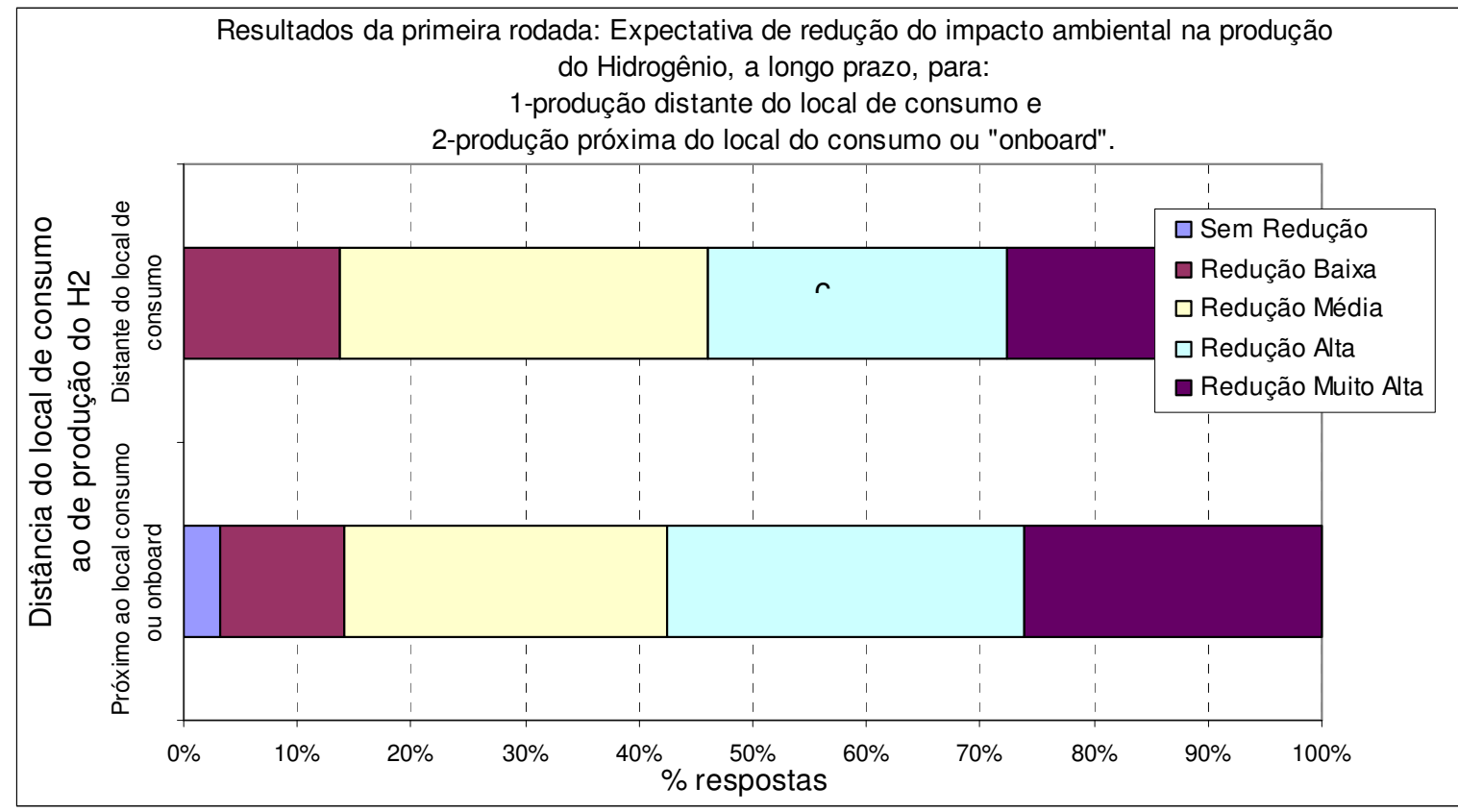

Figura 6-53 - Expectativa de redução do impacto ambiental em razão do processo de produção de hidrogênio ser efetuado: 1-em local distante do consumo e 2- em local próximo ao consumo ou "onboard", a longo prazo.

Na Figura 6-54 são mostradas as respostas separadas por continente a que pertence o respondente. Neste caso os respondentes da América do Norte e Central indicam uma redução maior no uso do processo distante do local de consumo que o processo "Onboard". Já os respondentes dos países da Europa não possuem expectativa muito diferente entre produção "onboard" e produção 
distante do local de consumo.
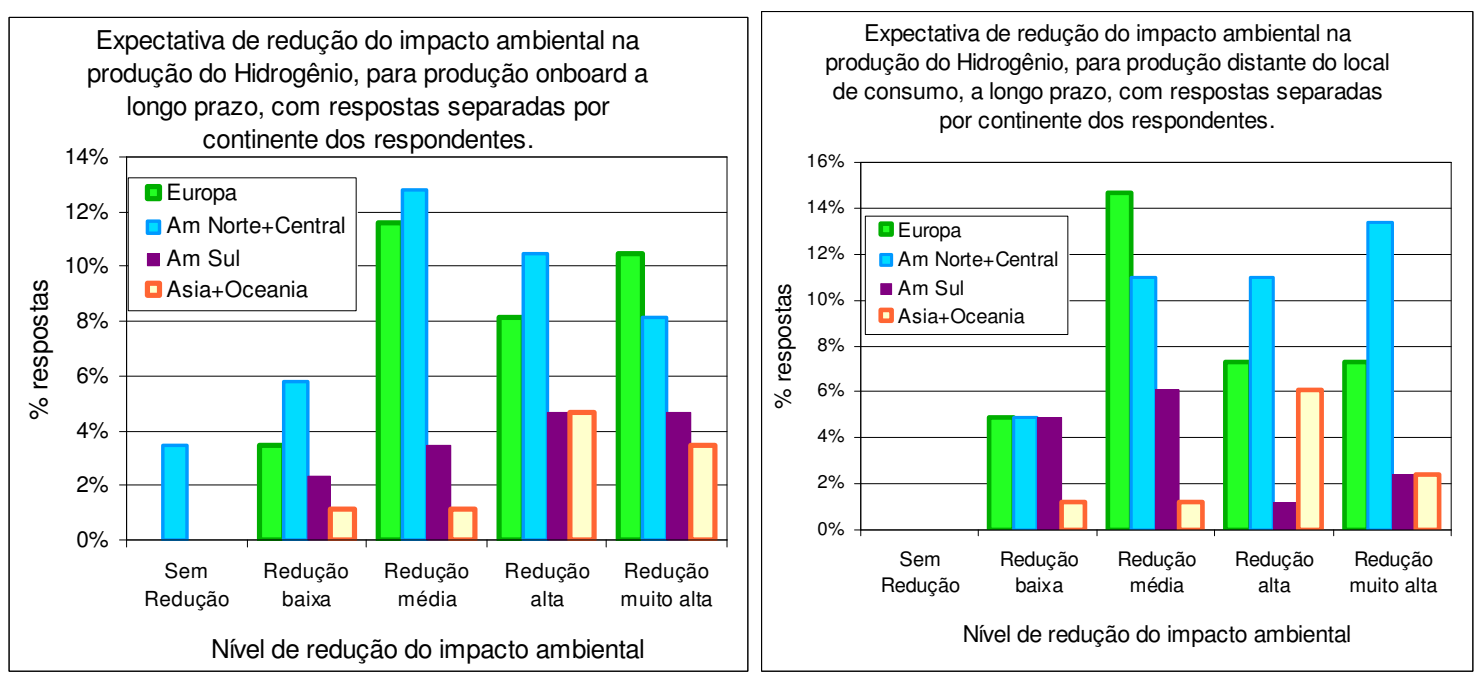

Figura 6-54 - Respostas à questão 19 separadas por continente do respondente.

É provável que a diferença dos respondentes seja função da maior experiência, para uso em larga escala, que os países da América do Norte já possuem com os processos de produção de $\mathrm{H}_{2}$ para uso em pilhas a combustível móveis.

Pela Figura 6-55 também pode ser verificado que não ocorreu uma divergência muito grande entre os respondentes, pois os valores das médias entre 2,34 ("onboard") e 2,32 (longe do local de consumo), bem como o desvio padrão também não é muito diferente: 1,08 e 1,03 para processo “onboard" e longe do local de consumo, respectivamente.

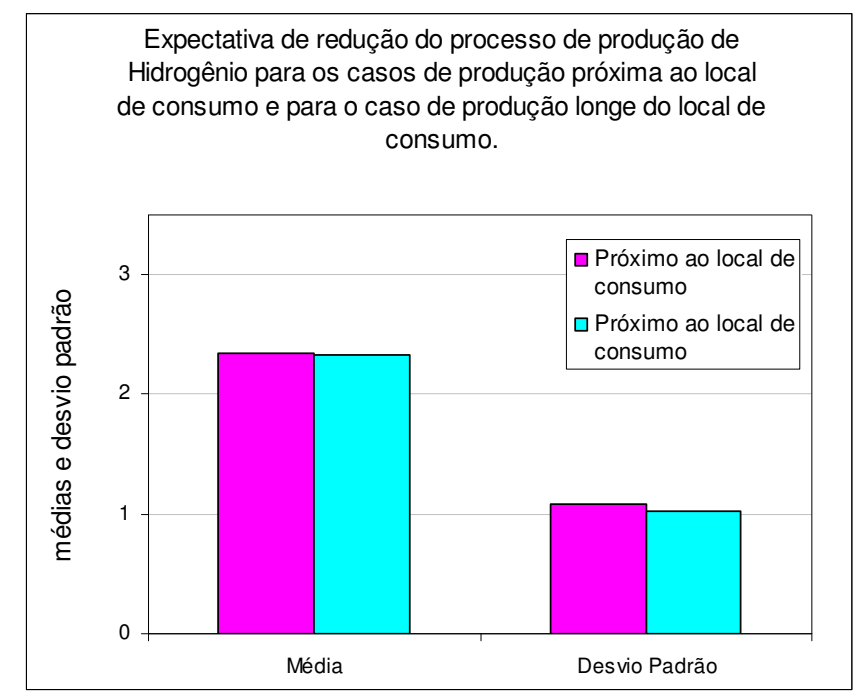

Figura 6-55 - Médias e Desvio padrão das respostas para expectativa de redução do impacto ambiental em razão do processo estar próximo ou longe do consumidor. 
A análise de variância não mostrou nenhuma correlação com as características estudadas dos respondentes (atividade, continente, especialização e sexo).

\subsubsection{Questão 19- Grupo 4}

A questão 19 versa sobre a expectativa de redução do impacto ambiental em razão do processo de produção do hidrogênio em função da descoberta e uso de novos materiais e novos processos de produção de hidrogênio. A questão 19, tal qual foi originalmente apresentada aos respondentes encontra-se no Anexo B-1.

Para efeito de cálculos estatísticos foi considerado um valor para cada resposta. Os resultados percentuais referentes às opções de respostas estão apresentados a seguir, na Tabela 6-25.

Tabela 6-26 - Opções de resposta para os itens da questão 19 (\%)

\begin{tabular}{l|c|c|c|c|c}
\hline & $\begin{array}{c}\text { Redução Muito } \\
\text { Alta }\end{array}$ & $\begin{array}{c}\text { Redução } \\
\text { Alta }\end{array}$ & $\begin{array}{c}\text { Redução } \\
\text { Média }\end{array}$ & $\begin{array}{c}\text { Redução } \\
\text { Baixa }\end{array}$ & $\begin{array}{c}\text { Sem } \\
\text { Redução }\end{array}$ \\
\cline { 2 - 6 } & 1 & 2 & 3 & 4 & 5 \\
\hline $\begin{array}{l}\text { Novos } \\
\text { Processos }\end{array}$ & $37,0 \%$ & $30,4 \%$ & $21,7 \%$ & $9,8 \%$ & $1,1 \%$ \\
\hline $\begin{array}{l}\text { Novos } \\
\text { Materiais }\end{array}$ & $27,2 \%$ & $33,7 \%$ & $23,9 \%$ & $12,0 \%$ & $3,3 \%$ \\
\hline
\end{tabular}

Da análise de variância com os grupos respondentes revelou que nenhuma das características dos respondentes apresenta correlação com o tipo de resposta apresentado. A Tabela 6-26 apresenta os dados resultantes desta análise.

Tabela 6-27 - Correlação entre respostas e características do respondente.

\begin{tabular}{l|l|l|l|l}
\hline Item & \multicolumn{3}{|c}{ Características do respondente } \\
\hline Novos Processos & Qualificação & Ramo de atuação & Continente & Sexo \\
\hline Distante do local de consumo & & & & \\
\hline \multicolumn{4}{|l}{$\begin{array}{l}\text { Existe correlação } \\
\text { Não existe correlação }\end{array}$} & \\
\cline { 2 - 4 }
\end{tabular}

Na Figura 6-56 são apresentadas, em conjunto, todas as respostas 
para os dois itens da questão 19.

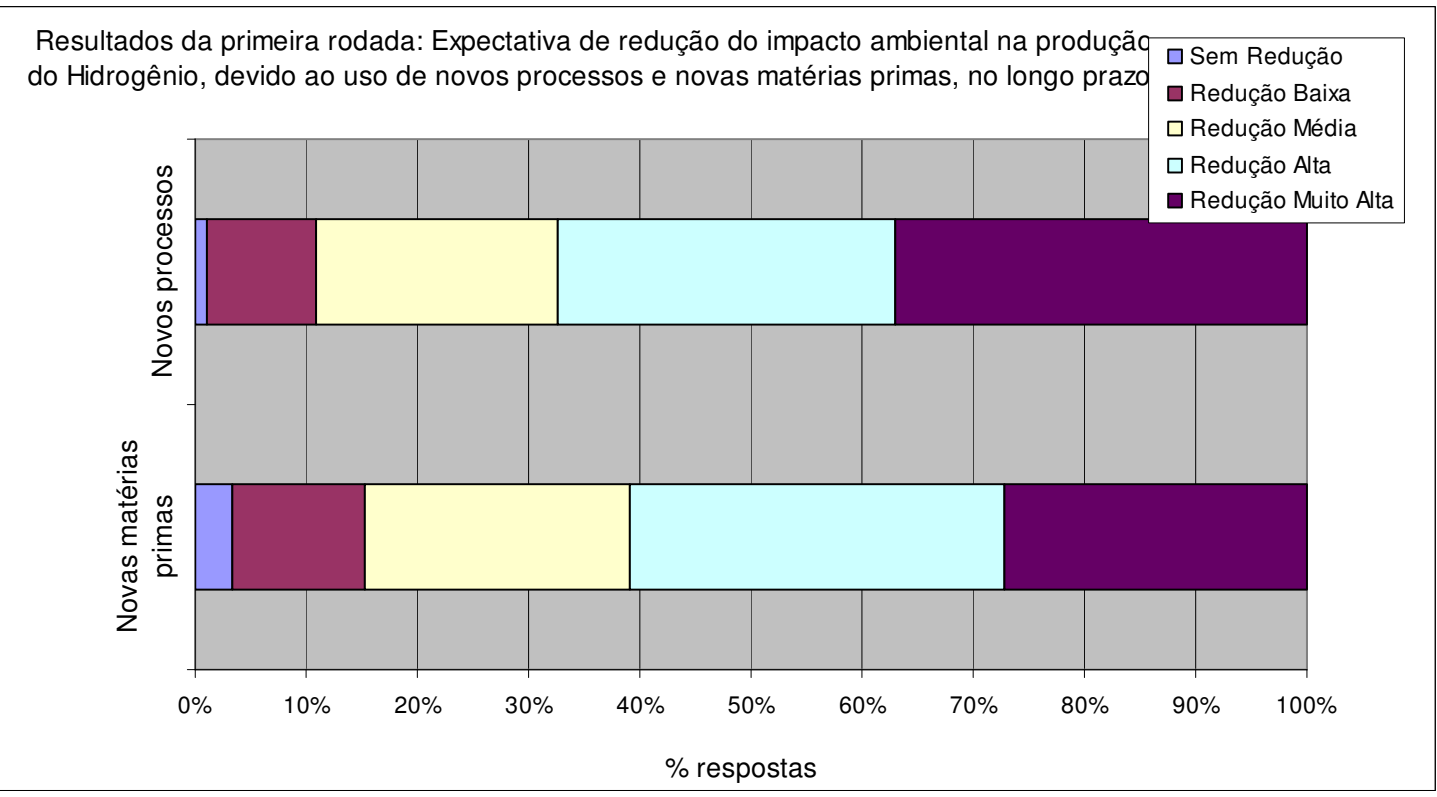

Figura 6-56 - Expectativa de redução do impacto ambiental devido à: 1- novos processos de produção de H2, 2-novas matérias primas utilizadas no processo de produção de $\mathrm{H} 2$, a longo prazo.

$\mathrm{Na}$ Figura 6-57 são apresentadas as respostas separadas por qualificação do respondente, para o item "novos processos".
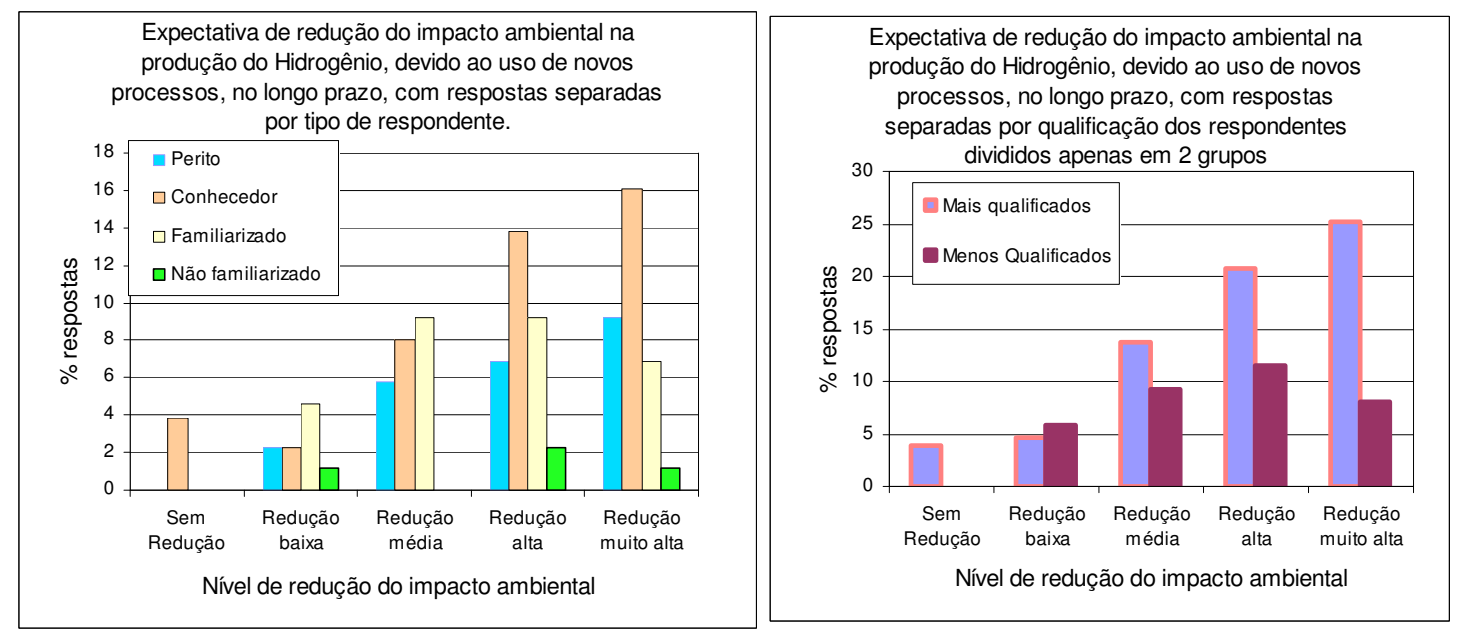

Figura 6-57 - Expectativa de redução do impacto ambiental devido à produção de hidrogênio por meio de novos processos a longo prazo, com as respostas separadas por qualificação dos respondentes.

E na Figura 6-58 são apresentadas as respostas separadas por atividade do respondente. Utilizando a análise de variância verificou-se que, considerando um nível de significância de 5\%, a atividade do respondente não influiu no tipo de resposta. 

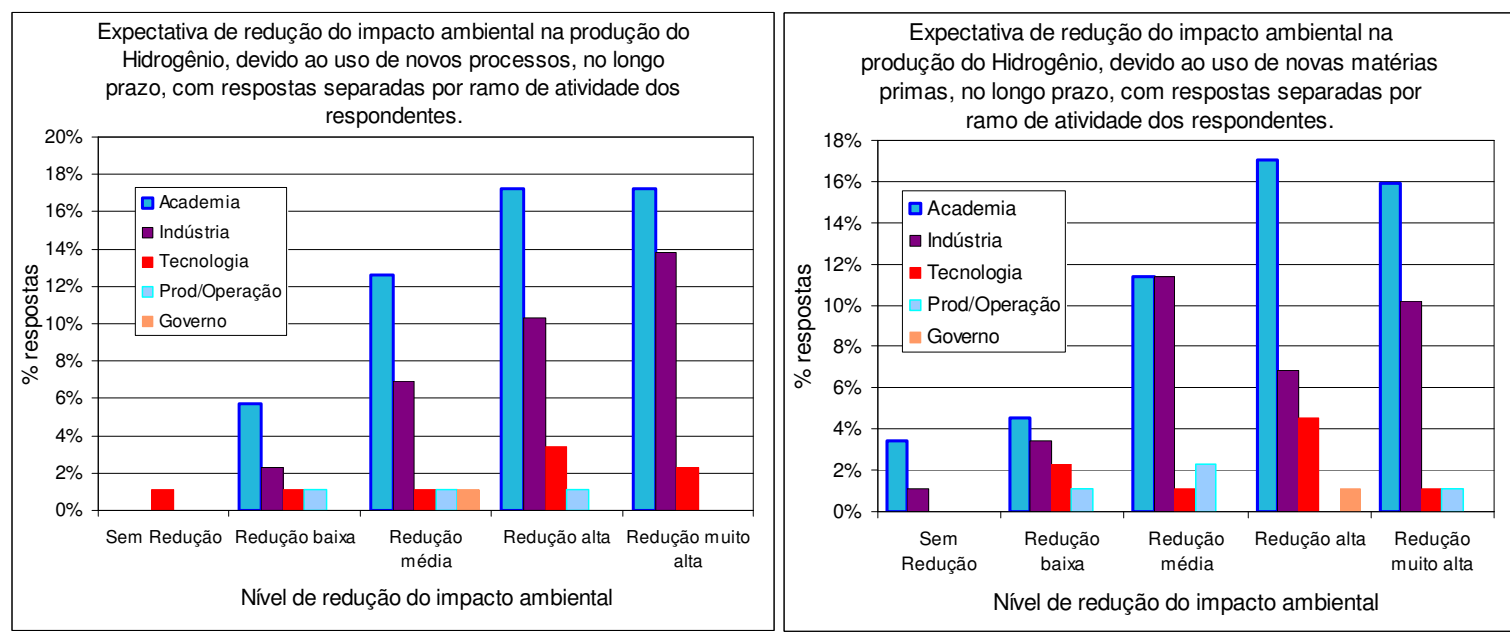

Figura 6-58 - Expectativa de redução do impacto ambiental em razão do uso de novos processos e novas matérias primas na produção de hidrogênio, a longo prazo, com as respostas separadas por atividade do respondente.

E na Figura 6-59 são apresentadas as respostas separadas por continente do respondente e os mais otimistas parecem ser os respondentes da Ásia e Oceania.

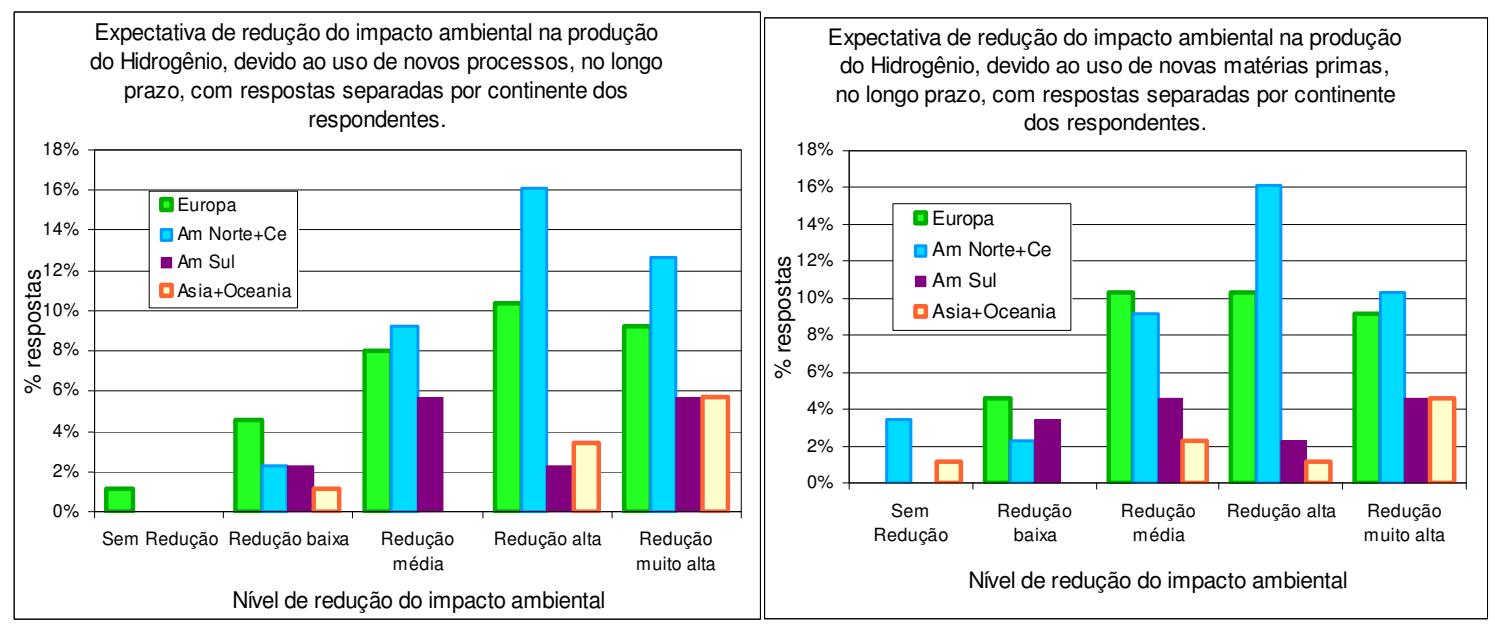

Figura 6-59 - Respostas à questão 19 separadas por continente do respondente.

A conclusão é que a maior parte dos respondentes possui a expectativa de redução Alta e Muito Alta para impacto ambiental em razão dos novos processos e materiais utilizados na produção de $\mathrm{H}_{2}$.

\subsubsection{Questão 20- Grupo 4}

A questão 20 versa sobre a expectativa de continuidade, a longo prazo, do uso dos vários processos de produção utilizados atualmente para a produção de hidrogênio. A questão 20, tal qual foi originalmente apresentada aos 
respondentes encontra-se no Anexo B-1.

Para efeito de cálculos estatísticos foi considerado um valor para cada resposta. Os resultados percentuais referentes às opções de respostas estão apresentados a seguir, na Tabela 6-28.

Tabela 6-28 - Opções de resposta para os itens da questão 20 (\%).

\begin{tabular}{l|c|c|c|c|c}
\hline & $\begin{array}{c}\text { Redução } \\
\text { Muito Alta }\end{array}$ & $\begin{array}{c}\text { Redução } \\
\text { Alta }\end{array}$ & $\begin{array}{c}\text { Redução } \\
\text { Média }\end{array}$ & $\begin{array}{c}\text { Redução } \\
\text { Baixa }\end{array}$ & $\begin{array}{c}\text { Sem } \\
\text { Redução }\end{array}$ \\
\hline Gaseificação do carvão & 1 & 2 & 3 & 4 & 5 \\
\hline Reforma do Gás Natural & $25,3 \%$ & $24,1 \%$ & $15,7 \%$ & $20,5 \%$ & $14,4 \%$ \\
\hline $\begin{array}{l}\text { Reforma de combustíveis } \\
\text { renováveis }\end{array}$ & $18,1 \%$ & $24,1 \%$ & $31,3 \%$ & $7,2 \%$ & $19,3 \%$ \\
\hline Dissociação Térmica & $6,9 \%$ & $22,8 \%$ & $24,1 \%$ & $17,7 \%$ & $21,5 \%$ \\
\hline Fotolítico & $15,4 \%$ & $23,1 \%$ & $24,4 \%$ & $18,0 \%$ & $19,2 \%$ \\
\hline Kvaerner & $3,4 \%$ & $15,2 \%$ & $45,8 \%$ & $28,8 \%$ & $6,8 \%$ \\
\hline Plasmatron & $1,7 \%$ & $20,3 \%$ & $35,6 \%$ & $23,7 \%$ & $18,7 \%$ \\
\hline Eletrolítico & $17,8 \%$ & $23,8 \%$ & $21,4 \%$ & $16,8 \%$ & $20,2 \%$ \\
\hline Decomposição Térmica & $6,9 \%$ & $28,7 \%$ & $28,7 \%$ & $20,6 \%$ & $15,1 \%$ \\
\hline Gaseificação de Biomassa & $13,3 \%$ & $34,9 \%$ & $12,1 \%$ & $10,8 \%$ & $28,9 \%$ \\
\hline Biológico & $12,4 \%$ & $25,9 \%$ & $14,8 \%$ & $17,3 \%$ & $29,6 \%$ \\
\hline
\end{tabular}

Da análise de variância com os grupos respondentes resultaram as características dos respondentes, para as quais existe correlação com o tipo de resposta apresentado. Na Tabela 6-29 são apresentados os dados resultantes desta análise.

Tabela 6-29 - Correlação entre respostas e características do respondente.

\begin{tabular}{l|l|l|l|l}
\hline Item & \multicolumn{3}{|c}{ Características do respondente } \\
\hline & Qualificação & $\begin{array}{l}\text { Ramo de } \\
\text { atuação }\end{array}$ & Continente & Sexo \\
\hline Gaseificação do carvão & & & & \\
\hline Reforma do Gás Natural & & & & \\
\hline $\begin{array}{l}\text { Reforma de combustíveis } \\
\text { renováveis }\end{array}$ & & & & \\
\hline Dissociação Térmica & & & & \\
\hline Fotolítico & & & & \\
\hline Kvaerner & & & & \\
\hline Plasmatron & & & & \\
\hline Eletrolítico & & & & \\
\hline Decomposição Térmica & & & & \\
\hline Gaseificação de Biomassa & & & & \\
\hline Biológico & & & & \\
\hline
\end{tabular}


$\mathrm{Na}$ Figura 6-60 são apresentadas todas as respostas num único gráfico, para efeito de comparação dos resultados.

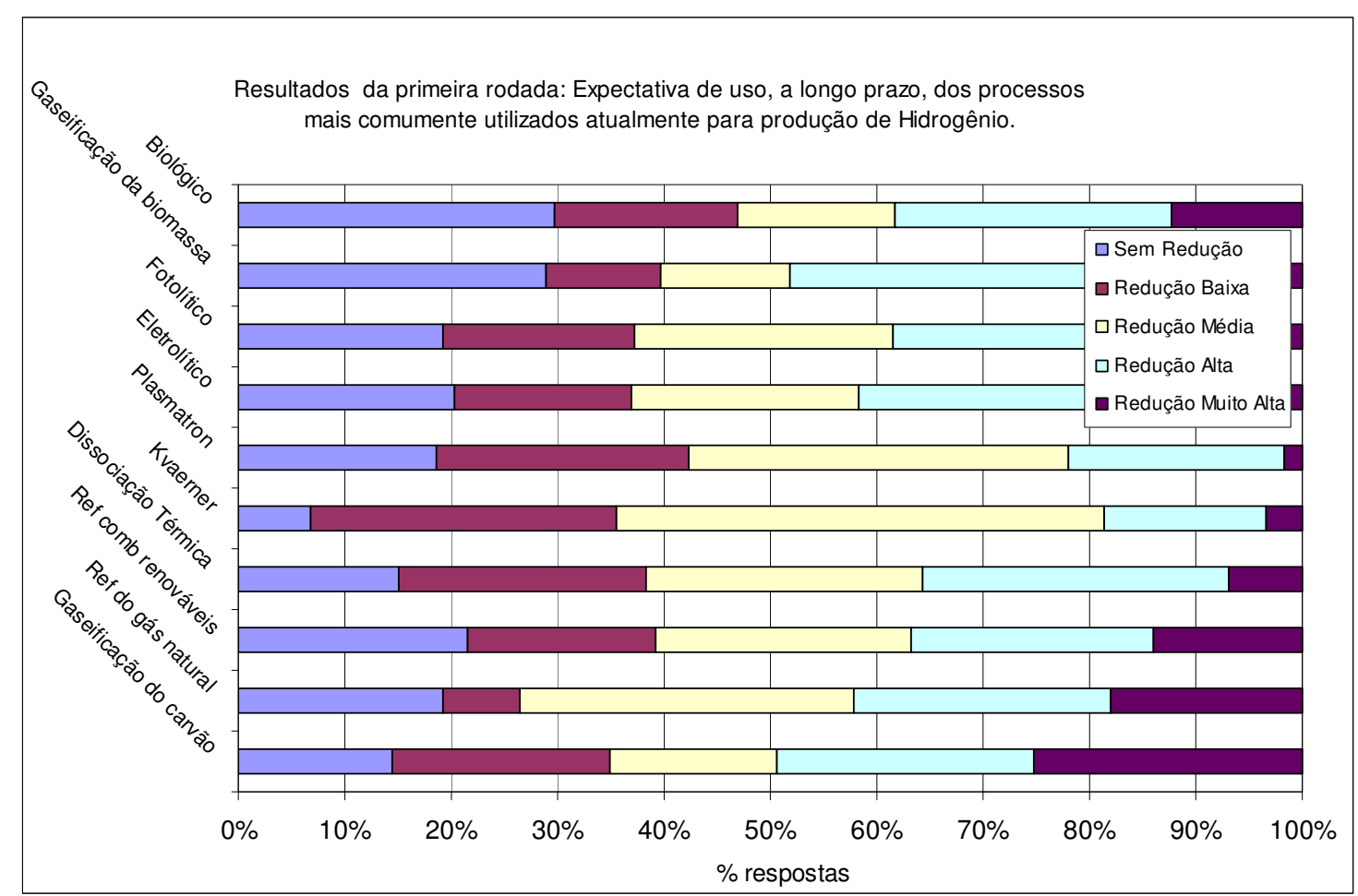

Figura 6-60 - Expectativa de uso dos processos mais comumente utilizados para produção de hidrogênio, a longo prazo.

Na Figura 6-61 são apresentadas as respostas separadas por atividade do respondente para o processo Eletrolítico. Utilizando a análise de variância verificou-se que, considerando um nível de significância de $5 \%$, a atividade do respondente influiu no tipo de resposta. E na Figura 6-62 estão os dados por qualificação do respondente. 


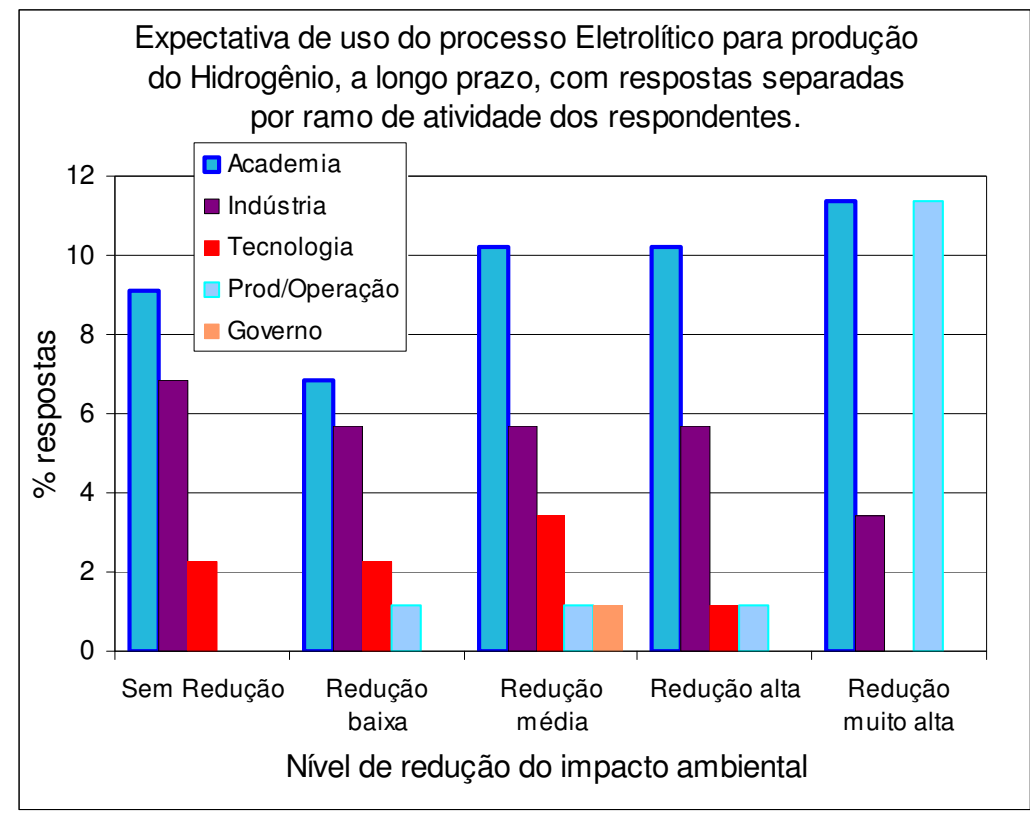

Figura 6-61- Expectativa de continuidade do uso do processo Eletrolítico para produção de hidrogênio, a longo prazo, com as respostas separadas por atividade do respondente.
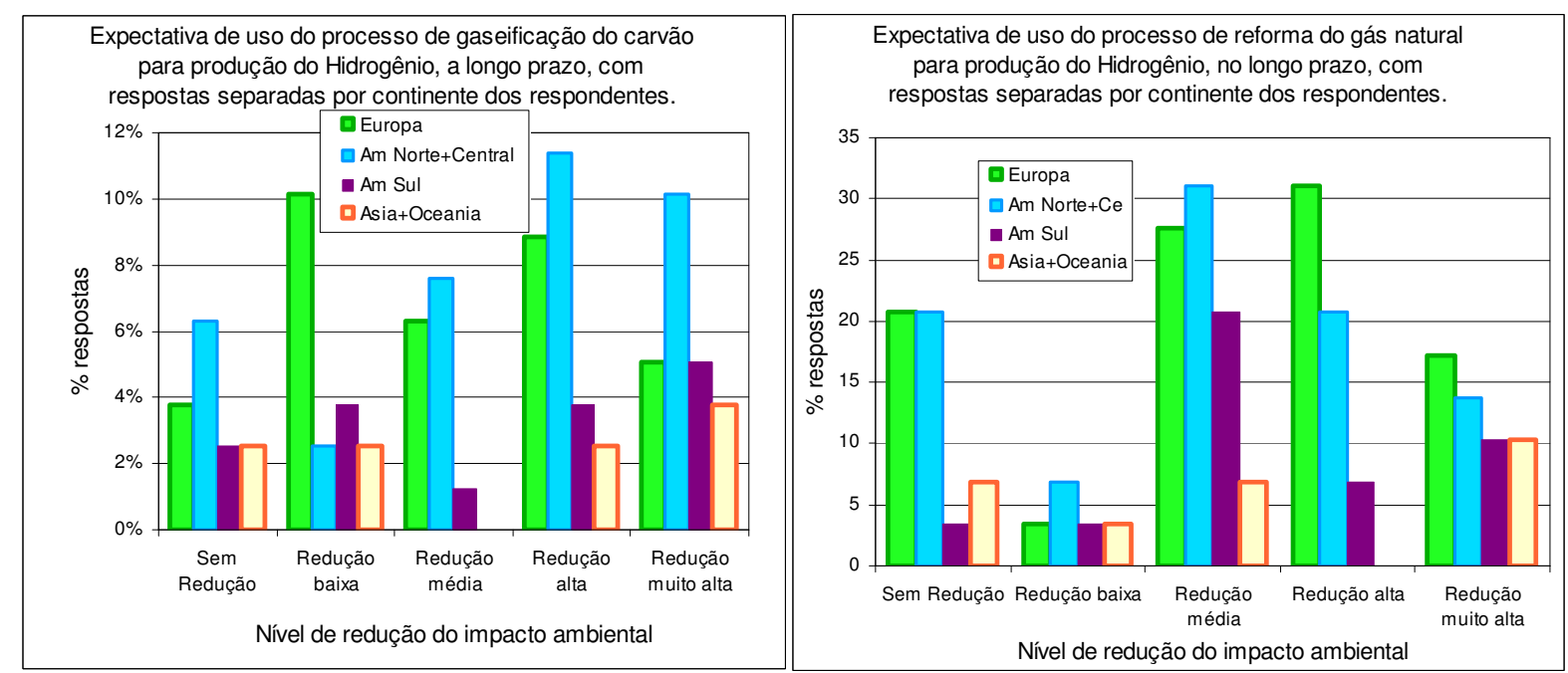

Figura 6-62 - Expectativa de continuidade do uso dos processos: gaseificação do carvão e reforma do gás natural, para produção de hidrogênio, a longo prazo, com as respostas separadas por continente do respondente.

\subsubsection{Questão 21- Grupo 4}

A questão 21 versa sobre a expectativa sobre o tipo de energia que será utilizada no processo de produção de hidrogênio, a longo prazo. A questão 21, tal qual foi originalmente apresentada aos respondentes encontra-se no Anexo B-1.

Para efeito de cálculos estatísticos foi considerado um valor para cada resposta. Os resultados percentuais referentes às opções de respostas estão apresentados a seguir, na Tabela 6-30. 
Tabela 6-30 - Opções de resposta para os itens da questão 21 (\%)

\begin{tabular}{l|c|c|c|c|c}
\hline & $\begin{array}{c}\text { Redução } \\
\text { Muito Alta }\end{array}$ & Redução Alta & Redução Média & Redução Baixa & Sem Redução \\
\hline Fotovoltaica & 1 & 2 & 3 & 4 & 5 \\
\hline Solar Térmica & $15,2 \%$ & $13,9 \%$ & $30,4 \%$ & $15,2 \%$ & $25,3 \%$ \\
\hline Eólica & $12,5 \%$ & $20,5 \%$ & $14,7 \%$ & $27,3 \%$ & $25,0 \%$ \\
\hline Hidroelétrica & $9,3 \%$ & $20,9 \%$ & $23,3 \%$ & $19,8 \%$ & $26,7 \%$ \\
\hline Biomassa & $13,6 \%$ & $27,3 \%$ & $29.5 \%$ & $14,8 \%$ & $14,8 \%$ \\
\hline Gás Natural & $12,1 \%$ & $26,5 \%$ & $30,1 \%$ & $15,6 \%$ & $15,7 \%$ \\
\hline
\end{tabular}

Da análise de variância com os grupos respondentes resultaram as características dos respondentes, para as quais existe correlação com o tipo de resposta apresentado. Na Tabela 6-31 são apresentados os dados resultantes desta análise.

Tabela 6-31 - Correlação entre respostas e características do respondente.

\begin{tabular}{l|l|l|l|l}
\hline Item & \multicolumn{3}{|c}{ Características do respondente } \\
\hline & Qualificação & Ramo de atuação & Continente & Sexo \\
\hline Fotovoltaica & & & & \\
\hline Solar Térmica & & & & \\
\hline Eólica & & & & \\
\hline Hidroelétrica & & & & \\
\hline Biomassa & & & & \\
\hline Gás Natural & & & & \\
\hline
\end{tabular}

Existe correlação

Não existe correlação

Na Figura 6-63 são apresentadas as respostas separadas por atividade do respondente. Utilizando a análise de variância verificou-se que, considerando um nível de significância de 5\%, a atividade do respondente parece influir no tipo de resposta. 


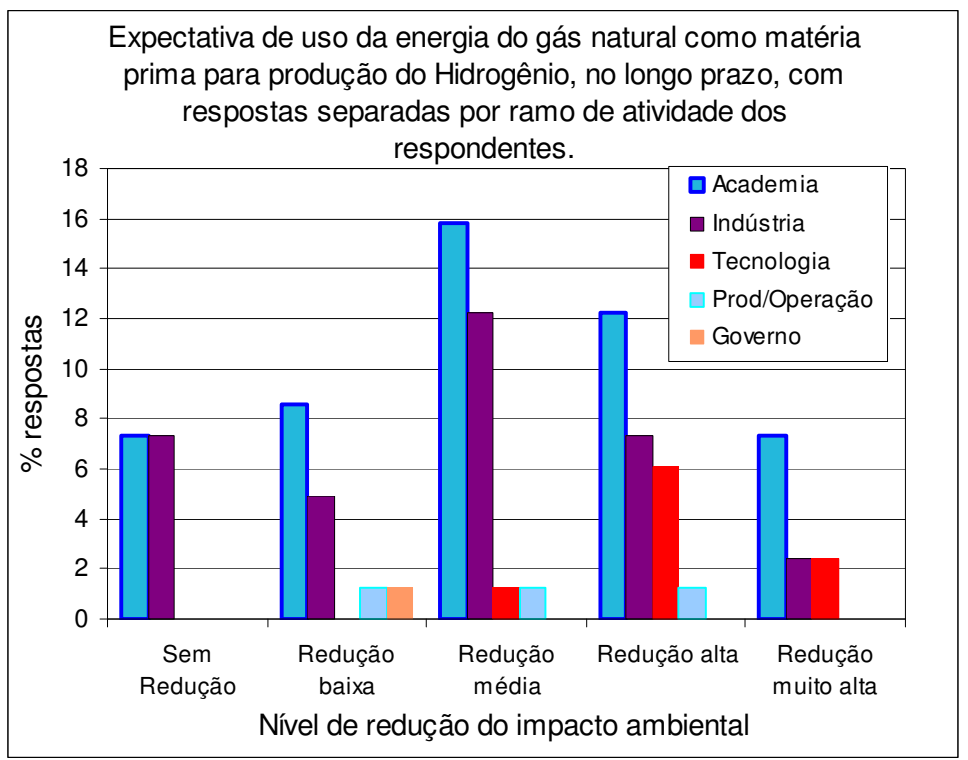

Figura 6-63 - Expectativa do uso da energia do gás natural como insumo no processo de produção de hidrogênio, a longo prazo, com as respostas separadas por atividade do respondente.

Na Figura 6-64 são apresentadas todas as respostas num único gráfico, para efeito de comparação dos resultados.

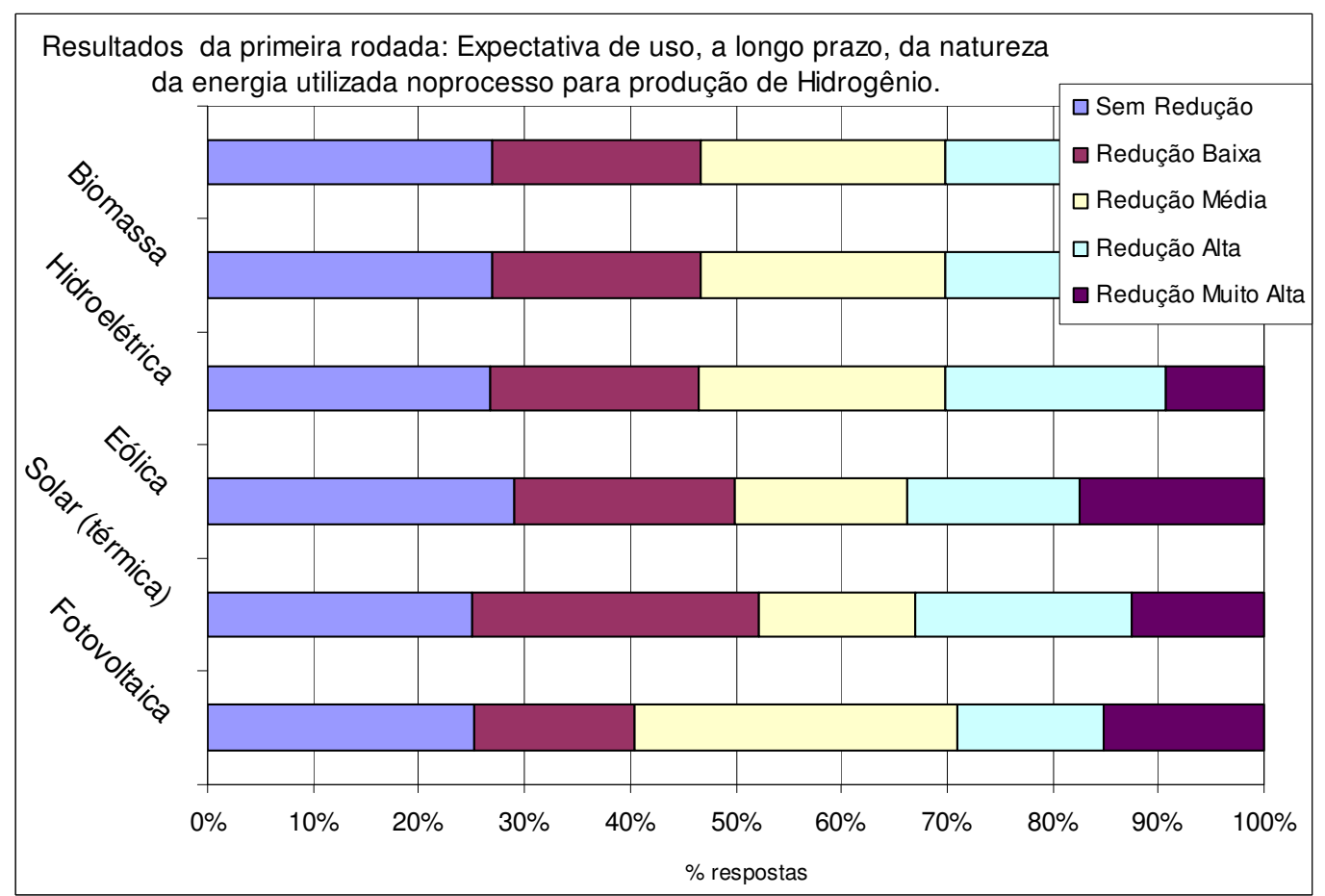

Figura 6-64 - Expectativa do uso da energia de várias fontes como insumo no processo de produção de hidrogênio, a longo prazo. 


\section{7 - Apresentação dos resultados da segunda rodada da consulta Delphi sobre impacto ambiental das pilhas a combustível}

A segunda rodada da pesquisa incluiu a apresentação para os respondentes dos resultados da primeira rodada juntamente com o questionário similar ao da primeira rodada, contendo apenas alguns ajustes. Estes ajustes são provenientes dos comentários efetuados pelos respondentes na primeira rodada. Uma alteração importante foi a inclusão de uma questão sobre a produção de hidrogênio por meio do uso de energia nuclear e seu impacto ambiental. A íntegra do questionário, contendo também os resultados da primeira rodada, está no Apêndice B-2.

Ela foi enviada para os 95 participantes da primeira rodada entre 12 de outubro de 2008 e 30 de abril de 2009. Um total de 37 respondentes completou a pesquisa resultando numa taxa de resposta de $38,95 \%$, sendo esta proporção aceitável, conforme Sant'Anna (2005). Na Tabela 6-32 é apresentada uma comparação entre o número dos respondentes da primeira e a segunda rodadas.

A distribuição dos respondentes entre os países continuou não homogênea até porque a participação era voluntária e a seguir, na Figura 6-60 são apresentados os dados dos respondentes por continente e por sexo dos respondentes que participaram da pesquisa.

Tabela 6-32 - Visão geral da população de respondentes na primeira e segunda rodadas.

\begin{tabular}{l|l|l|l|l}
\hline & \multicolumn{2}{|l|}{$1^{\text {a }}$. Rodada } & \multicolumn{2}{l}{$2^{\text {a }}$. Rodada } \\
\hline & Número & $\%$ & Número & $\%$ \\
\hline População total & 471 & & 95 & \\
\hline Respondentes & $83+39$ & $25,6 \%$ & 37 & $39,0 \%$ \\
\hline
\end{tabular}

Nas subseções a seguir são apresentados e analisados os dados referentes à segunda rodada da metodologia Delphi.

Uma nota importante sobre as respostas obtidas é que o respondente poderia optar por não responder a todo o questionário. Assim, muitas vezes o respondente optou por responder a apenas um grupo ou respondeu a três grupos, por exemplo. Assim a população de respondentes por grupo pode não ser a mesma e por isso a análise foi efetuada de modo separado para cada um dos 
grupos. Os dados dos respondentes por sexo e continente estão na Figura 6-65.

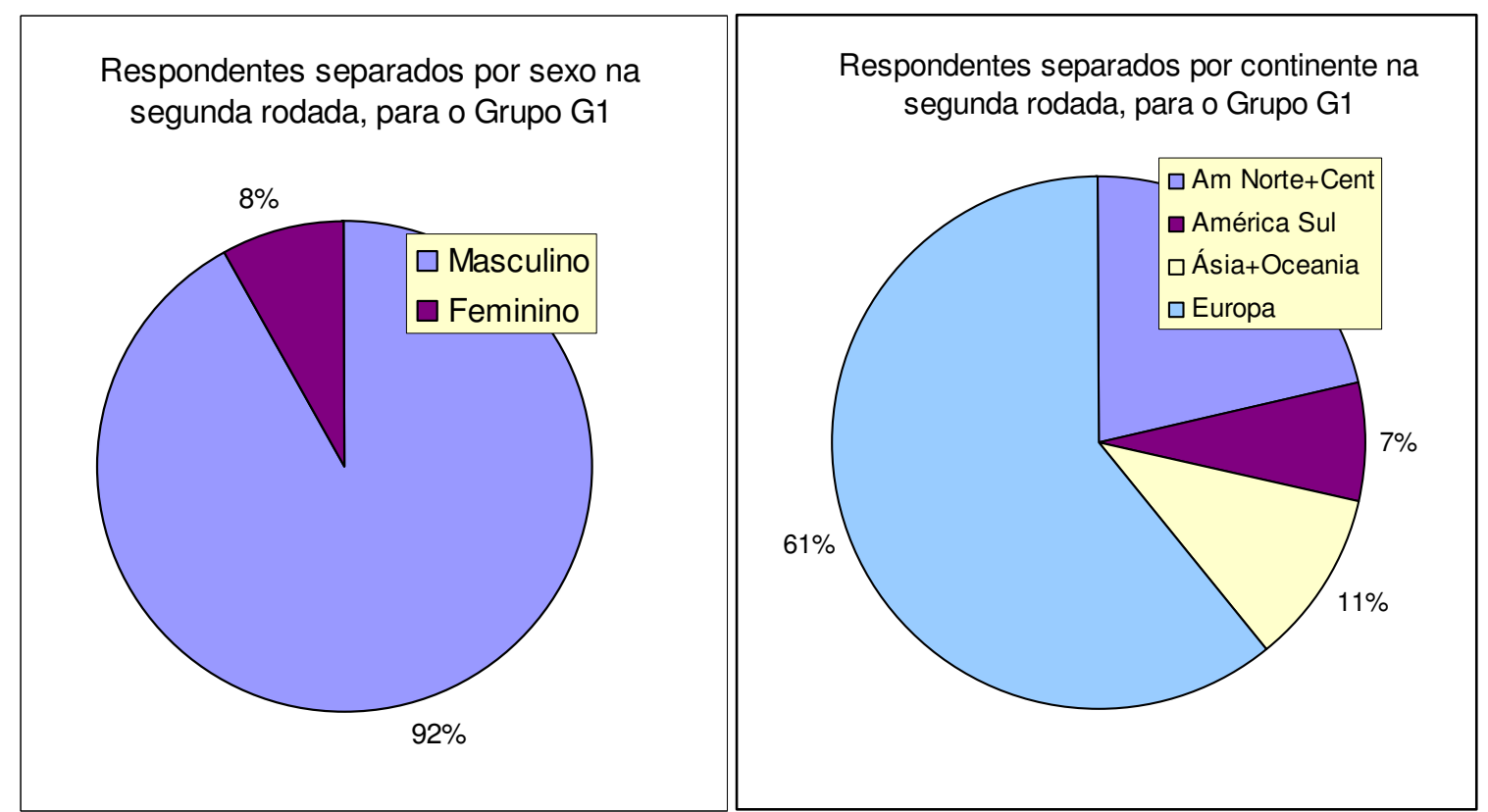

Figura 6-65 -Dados de sexo e continente onde residem todos os respondentes na segunda rodada.

\subsubsection{Dados dos respondentes às questões do grupo 1}

A seguir são apresentados, na Figura 6-66, os dados de qualificação e ramo de atividade dos respondentes para o grupo 1 (pilhas PEM).

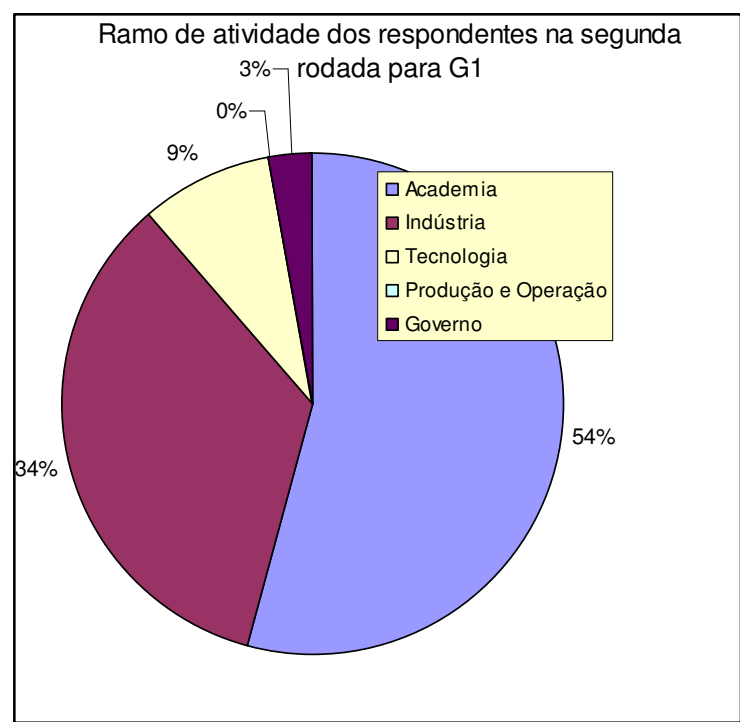

Grau de especialização dos respondentes na segunda rodada para G1

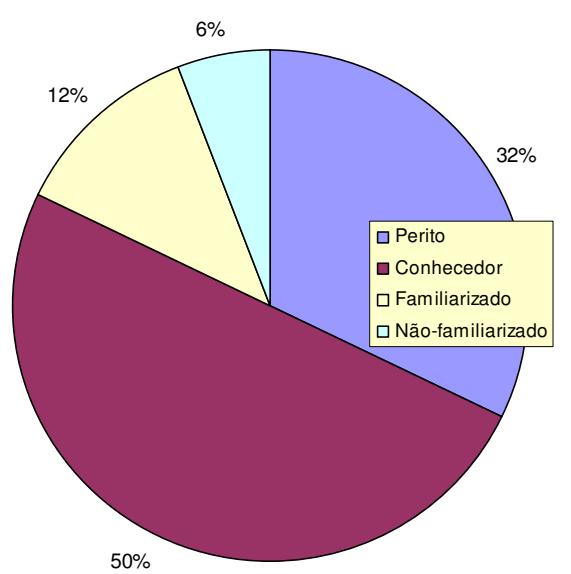

Figura 6-66 -Nível de especialização e Área de atuação dos respondentes na primeira rodada, para o grupo 1.

\subsubsection{1- Grupo 1 - Questão 3}

Aos respondentes foi efetuada a mesma pergunta do questionário da 
primeira rodada, além de apresentar um gráfico contendo os dados das respostas obtidas na primeira rodada (vide Apêndice B-2).

Os resultados da segunda rodada para o item catalisador, referentes à questão 3 (redução de impacto em razão do desenvolvimento e novas descobertas na área de catalisadores) estão apresentados na Figura 6-67, na qual também são mostrados, para efeito comparativo os dados da primeira rodada.

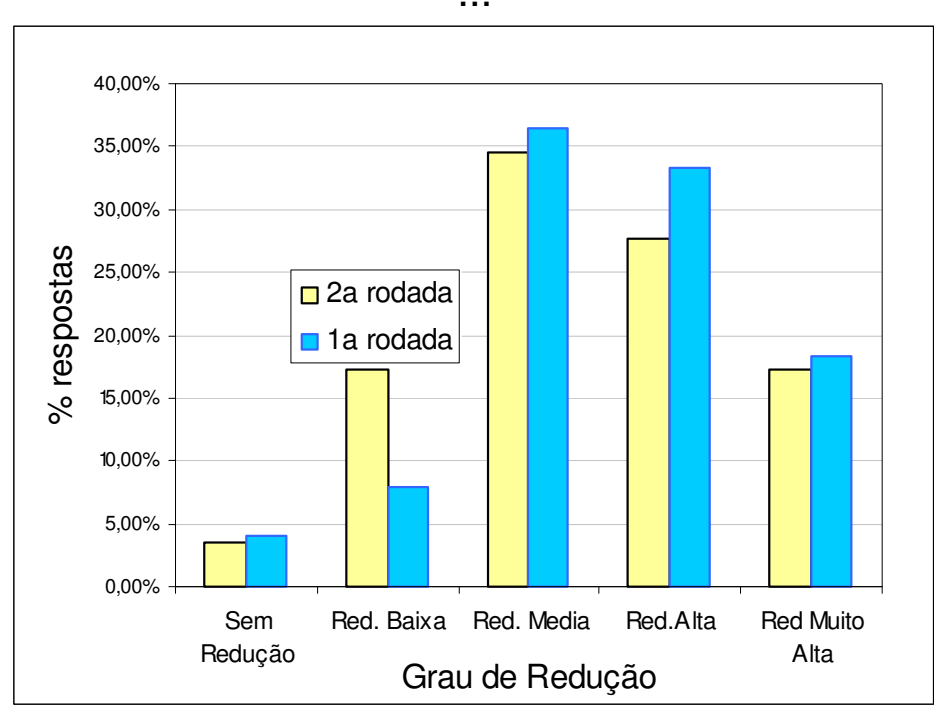

Figura 6-67 - Redução de impacto em razão do desenvolvimento e novas descobertas na área de catalisadores (1a e $2 a$ rodadas)

Com o intuito de analisar a variação das médias da primeira para a segunda rodada, os dados referentes a estas variações estão apresentadas, por cada item, na Tabela 6-33. Como as variações da média ficaram inferiores a 0,5 então se pode concluir que não ocorreram mudanças de opinião significativas, para esta questão. As variações no desvio padrão, calculadas conforme item 6.4, aumentaram na segunda rodada, levando a concluir que não ocorreu o consenso nesta questão.

Tabela 6-33 - Valores de média e desvio padrão para os itens da questão 3.

\begin{tabular}{c|c|c|c|c|c|c}
\hline & \multicolumn{3}{|c|}{ Média } & \multicolumn{3}{c}{ Desvio Padrão } \\
\hline & 1 a rodada & 2a rodada & Diferença & 1a rodada & 2a rodada & Variação $\left.{ }^{*}\right)$ \\
\hline Catalisadores & 2,46 & 2,62 & 0,16 & 1,01 & 1,08 & $-0,07$ \\
\hline Membrana & 2,57 & 2,66 & 0,08 & 0,96 & 0,97 & $-0,02$ \\
\hline Placas Bipolares & 2,70 & 2,86 & 0,16 & 0,97 & 1,25 & $-0,28$ \\
\hline Outros Materiais & 2,80 & 2,76 & $-0,04$ & 1,02 & 1,24 & $-0,22$ \\
\hline
\end{tabular}

$\left({ }^{*}\right)$ Calculado conforme item 6.4.2: $1-\left(\mathrm{s}_{2} / \mathrm{s}_{1}\right)$ 
Também foram efetuadas análises para verificar se os respondentes mais qualificados e menos qualificados mudavam de opinião. Na Tabela 6-34 estão apresentados os dados de valores de média e desvio padrão separados por grupos de respondentes mais qualificados e menos qualificados, para os itens da questão 3.

Tabela 6-34 - Dados de média e desvio padrão por grupos de respondentes mais e menos qualificados (questão 3).

\begin{tabular}{|c|c|c|c|c|c|c|}
\hline & \multicolumn{4}{|c|}{ Convergência em torno das médias } & \multicolumn{2}{|c|}{ Média Geral } \\
\hline & 1a rc & dada & 2a rc & dada & $\begin{array}{c}1 \mathrm{a} \\
\text { rodada }\end{array}$ & $\begin{array}{c}2 \mathrm{a} \\
\text { rodada }\end{array}$ \\
\hline & $\begin{array}{c}\text { Mais } \\
\text { Qualificados }\end{array}$ & $\begin{array}{c}\text { Menos } \\
\text { Qualificados }\end{array}$ & $\begin{array}{c}\text { Mais } \\
\text { Qualificados }\end{array}$ & $\begin{array}{c}\text { Menos } \\
\text { Qualificados }\end{array}$ & & \\
\hline Catalisador & 2,48 & 2,36 & 2,58 & 2,75 & 2,46 & 2,62 \\
\hline Membrana & 2,56 & 2,58 & 2,61 & 3,00 & 2,57 & 2,66 \\
\hline $\begin{array}{l}\text { Placas } \\
\text { Bipolares }\end{array}$ & 2,69 & 2,79 & 2,83 & 3,25 & 2,70 & 2,86 \\
\hline $\begin{array}{l}\text { Outros } \\
\text { Materiais }\end{array}$ & 2,78 & 2,86 & 2,75 & 2,50 & 2,80 & 2,76 \\
\hline
\end{tabular}

Nota: Números na cor vermelha são para os casos em que a média do grupo de respondentes está na direção da média geral.

Com base nestes dados pode-se avaliar se os respondentes mais qualificados, na segunda rodada, convergiram na direção das médias de todos os respondentes ou se convergiram na direção das médias dos respondentes mais qualificados. No caso desta questão 3 foi notada apenas a tendência dos respondentes mais qualificados, na segunda rodada, convergirem para a média global da 1‥ Rodada em metade dos itens (membrana e "outros materiais").

Não ocorreu tendência da média dos respondentes menos qualificados convergir para a média da primeira rodada dos mais qualificados e nem para a média global da primeira rodada.

\subsubsection{2- Grupo 1 - Questões 4 a 6}

Para todas as questões do grupo 1 foi efetuado o mesmo procedimento descrito na subseção anterior. E as questões estão apresentadas no Apêndice B2.

A seguir foram efetuadas as mesmas análises apresentadas no item anterior e apresentadas como tabelas conforme segue: 
Tabela 6-35 com as variações das médias e desvio padrão da primeira para a segunda rodada.

Tabela 6-36 com as percentagens dos itens em que ocorreu convergência da média da segunda rodada para outra média da primeira rodada. Estas percentagens foram calculadas a partir dos dados de médias dos respondentes separados em mais qualificados e menos qualificados e a comparação com a média global.

Tabela 6-35 - Valores de média e desvio padrão para os itens das questões 4, 5 e 6.

\begin{tabular}{c|c|c|c|c|c|c|c}
\hline & & \multicolumn{3}{|c|}{ Média } & \multicolumn{3}{c}{ Desvio Padrão } \\
\hline \multirow{4}{*}{ Q4 } & 1a rodada & 2a rodada & Diferença & 1a rodada & 2a rodada & Variação $\left.{ }^{*}\right)$ \\
\cline { 2 - 8 } & Catalisadores & 2,20 & 2,52 & 0,32 & 1,05 & 1,05 & 0,00 \\
\cline { 2 - 8 } & Membrana & 2,14 & 2,40 & 0,26 & 1,02 & 1,22 & $-0,20$ \\
\cline { 2 - 8 } & Placas Bipolares & 2,48 & 2,60 & 0,13 & 0,97 & 1,04 & $-0,07$ \\
\cline { 2 - 8 } & Outros Materiais & 2,64 & 2,68 & 0,04 & 1,07 & 1,28 & $-0,20$ \\
\hline \multirow{4}{*}{ Q5 } & Catalisadores & 2,97 & 2,88 & $-0,09$ & 1,07 & 1,24 & $-0,16$ \\
\cline { 2 - 8 } & Membrana & 2,95 & 2,60 & $-0,35$ & 1,28 & 1,08 & 0,16 \\
\cline { 2 - 8 } & Placas Bipolares & 3,13 & 2,68 & $-0,45$ & 1,12 & 1,03 & 0,08 \\
\hline \multirow{2}{*}{ Q6 } & Outros Materiais & 2,93 & 2,72 & $-0,21$ & 1,35 & 1,14 & 0,15 \\
\hline & Catalisadores & 2,12 & 1,92 & $-0,20$ & 1,29 & 1,09 & 0,15 \\
\hline
\end{tabular}

${ }^{*}$ ) Calculado conforme item 6.4.2: $1-\left(\mathrm{s}_{2} / \mathrm{s}_{1}\right)$

Da Tabela 6-35 pode-se concluir que como as variações da média ficaram inferiores a 0,5 então não ocorreram mudanças de opinião significativas, para esta questão. As variações no desvio padrão diminuíram na segunda rodada em 5 itens e aumentaram em 4 itens. Considerando todos os itens do grupo 1 ocorreu um aumento do consenso em $38,46 \%$ dos itens. A variação do desvio padrão da segunda rodada em relação á primeira rodada é apresentada na Figura 6-63, para todas as questões do grupo 1.

Tabela 6-36 - Percentagem dos itens em que ocorreu convergência da média da segunda rodada para outra média da primeira rodada.

\begin{tabular}{c|l|c}
\hline & \multicolumn{1}{|c|}{ Grupo 1 } & $\%$ \\
\hline \multirow{4}{*}{ Casos } & A média dos mais qualificados $\rightarrow$ Média total & $46,15 \%$ \\
\cline { 2 - 3 } & A média dos menos qualificados $\rightarrow$ Média total: & $15,38 \%$ \\
\cline { 2 - 3 } & A média dos menos qualificados $\rightarrow$ Média dos mais qualificados & $7,69 \%$ \\
\hline
\end{tabular}

Pelos dados apresentados na Tabela 6-36 verifica-se que a média dos 
respondentes mais qualificados, na segunda rodada, convergiu para a média total em 46,15\% dos casos. Este cálculo foi efetuado fixando-se a média global da primeira rodada e comparando-as com a média dos grupos de respondentes mais e menos qualificados. Já a média dos respondentes menos qualificados convergiu para a média total em $15,38 \%$ dos casos. E a média dos menos qualificados convergiu para a média dos mais qualificados (na primeira rodada) em apenas $7,69 \%$ dos casos. O cálculo, neste caso, foi efetuado fixando-se a média dos respondentes mais qualificados, na primeira rodada, e comparando a média dos menos qualificados.

$\mathrm{Na}$ Figura 6-68 são apresentadas as variações nos desvios padrão calculadas na segunda rodada em relação à primeira rodada, para todas as questões do grupo 1. O cálculo foi efetuado conforme já explicado no item 6.4: 1(s2/s1).

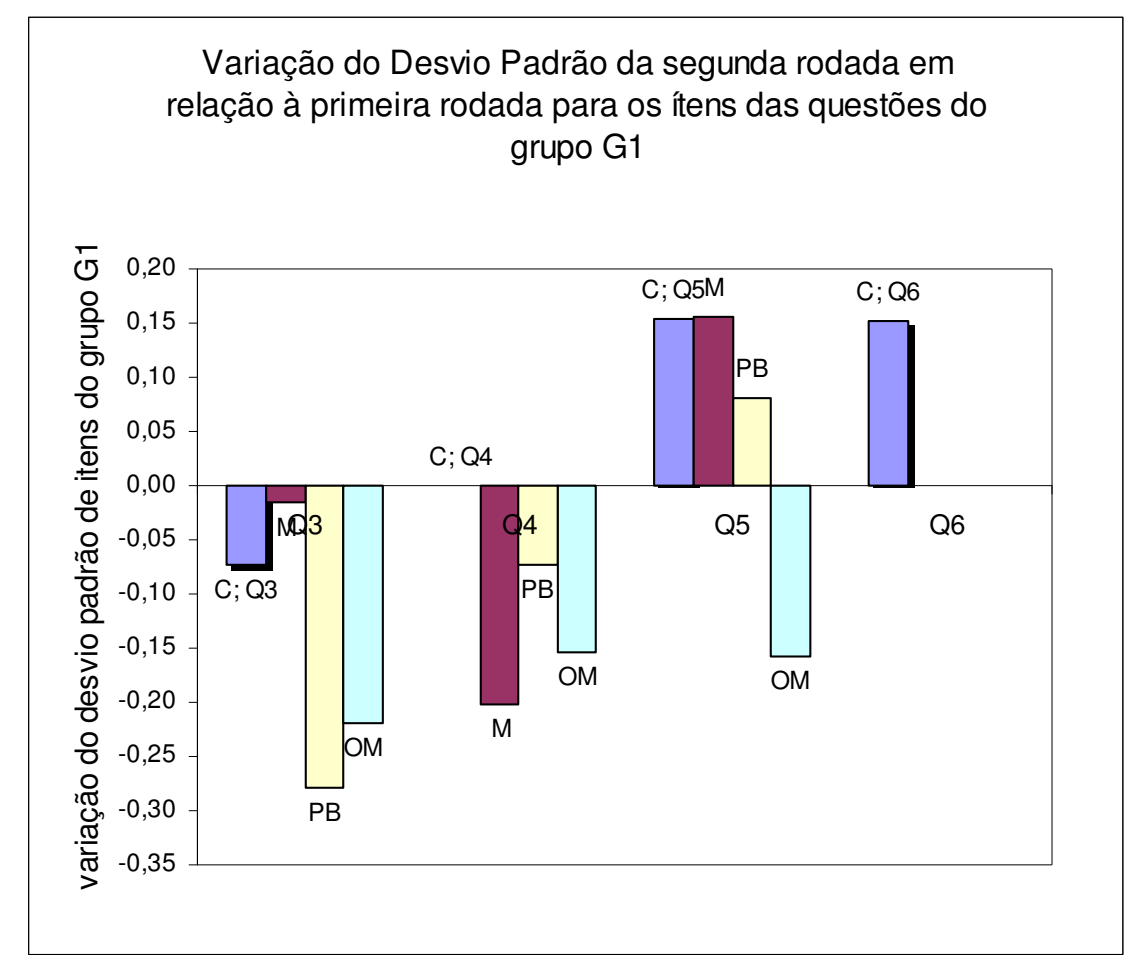

Figura 6-68 - Variação(*) do Desvio Padrão da segunda rodada em relação à primeira rodada para os itens de todas as questões do Grupo 1.

Estes resultados mostram que, para o grupo 2, o grupo de menos qualificados não respondeu, na maioria, convergindo para a média global da primeira rodada e nem para a média dos mais qualificados. 


\subsubsection{Dados dos respondentes às questões do grupo 2}

A seguir são apresentados, na Figura 6-69, os dados de qualificação e ramo de atividade dos respondentes para o grupo 2 (pilhas PAFC).
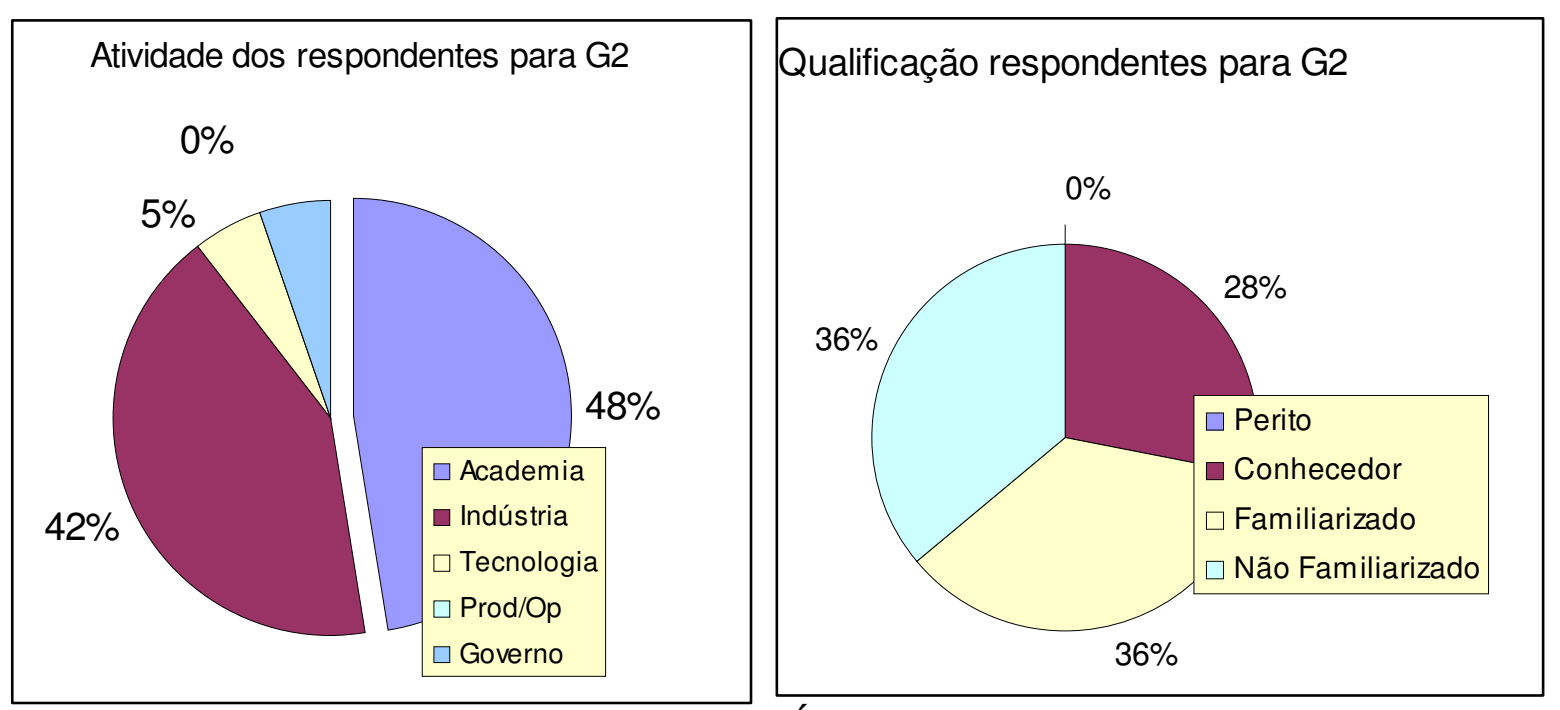

Figura 6-69 - Nível de especialização e Área de atuação dos respondentes na primeira rodada, para o grupo 2 .

\subsubsection{1- Grupo 2 - Questões 8 a 12}

Do mesmo modo que para o Grupo 1 as questões do Grupo 2 foram reenviadas juntamente com os dados resultantes da primeira rodada e também foram efetuadas as mesmas análises apresentadas no item anterior e apresentadas como tabelas conforme segue:

- Tabela 6-37 com as variações das médias e desvio padrão da primeira para a segunda rodada, para todas as questões do Grupo 2.

- Tabela 6-38 com as percentagens dos itens em que ocorreu convergência da média da segunda rodada para outra média da primeira rodada. Estas percentagens foram calculadas a partir dos dados de médias dos respondentes separados em mais qualificados e menos qualificados e a comparação com a média global, para todas as questões do Grupo 2. 
Tabela 6-37 - Valores de média e desvio padrão para os itens das questões 8a12.

\begin{tabular}{c|c|c|c|c|c|c|c}
\hline & & \multicolumn{3}{|c|}{ Média } & \multicolumn{3}{c}{ Desvio Padrão } \\
\hline \multirow{4}{*}{ Q8 } & & 1a rodada & 2a, rodada & Diferença & 1a rodada & 2a rodada & Variação $\left.{ }^{*}\right)$ \\
\cline { 2 - 8 } & Catalisadores & 2,88 & 3,00 & 0,12 & 1,11 & 1,15 & $-0,04$ \\
\cline { 2 - 8 } & Matriz/eletrólito & 3,03 & 2,78 & $-0,25$ & 1,19 & 1,17 & 0,02 \\
\cline { 2 - 8 } & Placas Bipolares & 3,14 & 3,00 & $-0,14$ & 1,04 & 1,15 & $-0,12$ \\
\cline { 2 - 8 } & Outros Materiais & 2,92 & 3,05 & 0,13 & 1,14 & 1,31 & $-0,15$ \\
\hline Q9 & Catalisadores & 2,31 & 2,16 & $-0,15$ & 1,27 & 1,12 & 0,12 \\
\hline \multirow{4}{*}{ Q10 } & Catalisadores & 3,07 & 3,00 & $-0,07$ & 1,21 & 1,29 & $-0,07$ \\
\cline { 2 - 8 } & Matriz/eletrólito & 3,19 & 3,16 & $-0,03$ & 1,00 & 1,01 & $-0,01$ \\
\cline { 2 - 8 } & Placas Bipolares & 3,30 & 3,11 & $-0,19$ & 1,09 & 1,20 & $-0,09$ \\
\cline { 2 - 8 } & Outros Materiais & 2,90 & 3,05 & 0,15 & 1,21 & 1,35 & $-0,12$ \\
\hline \multirow{2}{*}{ Q11 } & Catalisadores & 2,82 & 2,42 & $-0,40$ & 0,95 & 1,02 & $-0,08$ \\
\hline \multirow{2}{*}{ Q12 } & Catalisadores & 1,81 & 1,65 & $-0,16$ & 0,74 & 0,67 & 0,10 \\
\hline
\end{tabular}

$\left(^{*}\right)$ Calculado conforme item 6.4.2: 1-( $\left.\mathrm{s}_{2} / \mathrm{s}_{1}\right)$

Da Tabela 6-37 pode-se concluir que como as variações da média ficaram inferiores a 0,5 então não ocorreram mudanças de opinião significativas, para esta questão. As variações no desvio padrão aumentaram na segunda rodada para 8 itens e diminui para 3 itens.

Tabela 6-38 - Percentagem dos itens em que ocorreu convergência da média da segunda rodada para outra média da primeira rodada.

\begin{tabular}{c|l|c}
\hline & \multicolumn{1}{|c|}{ Grupo 2 } & $\%$ \\
\hline \multirow{3}{*}{ Casos } & A média dos mais qualificados $\rightarrow$ Média total & $45,45 \%$ \\
\cline { 2 - 3 } & A média dos menos qualificados $\rightarrow$ Média total: & $45,45 \%$ \\
\cline { 2 - 3 } & A média dos menos qualificados $\rightarrow$ Média dos mais qualificados & $0,00 \%$ \\
\hline
\end{tabular}

Pelos dados apresentados na Tabela 6-38 verifica-se que a média dos respondentes mais qualificados, na segunda rodada, convergiu para a média total em $45,45 \%$ dos casos, o que também ocorreu para a média dos respondentes menos qualificados, que convergiu para a média total em $45,45 \%$ dos casos. E a média dos menos qualificados não convergiu para a média dos mais qualificados (na primeira rodada) em nenhum caso. O cálculo para estes casos foi efetuado do mesmo modo que explicado na subseção anterior.

Estes resultados mostram que, para o grupo 2, o grupo de menos qualificados não respondeu, na maioria, convergindo para a média global da primeira rodada e nem para a média dos mais qualificados.

A variação do desvio padrão da segunda rodada em relação á primeira rodada está foi calculada e está apresentada na Figura 6-70, para todas as 
questões do grupo 2 .

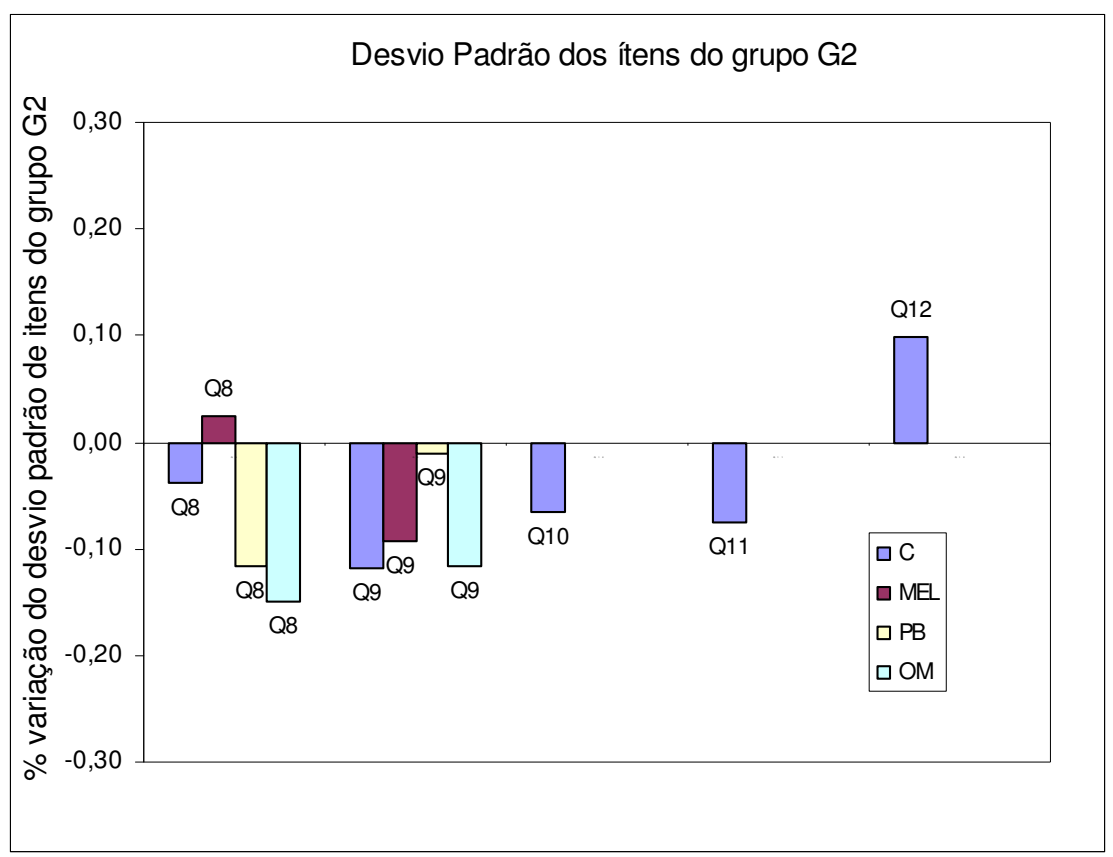

Figura 6-70 - Variação do Desvio Padrão da segunda rodada em relação à primeira rodada para os itens de todas as questões do Grupo 2.

\subsubsection{Dados dos respondentes às questões do grupo 3}

A seguir são apresentados os dados de qualificação e ramo de atividade dos respondentes para o grupo 3 (pilhas MCFC).

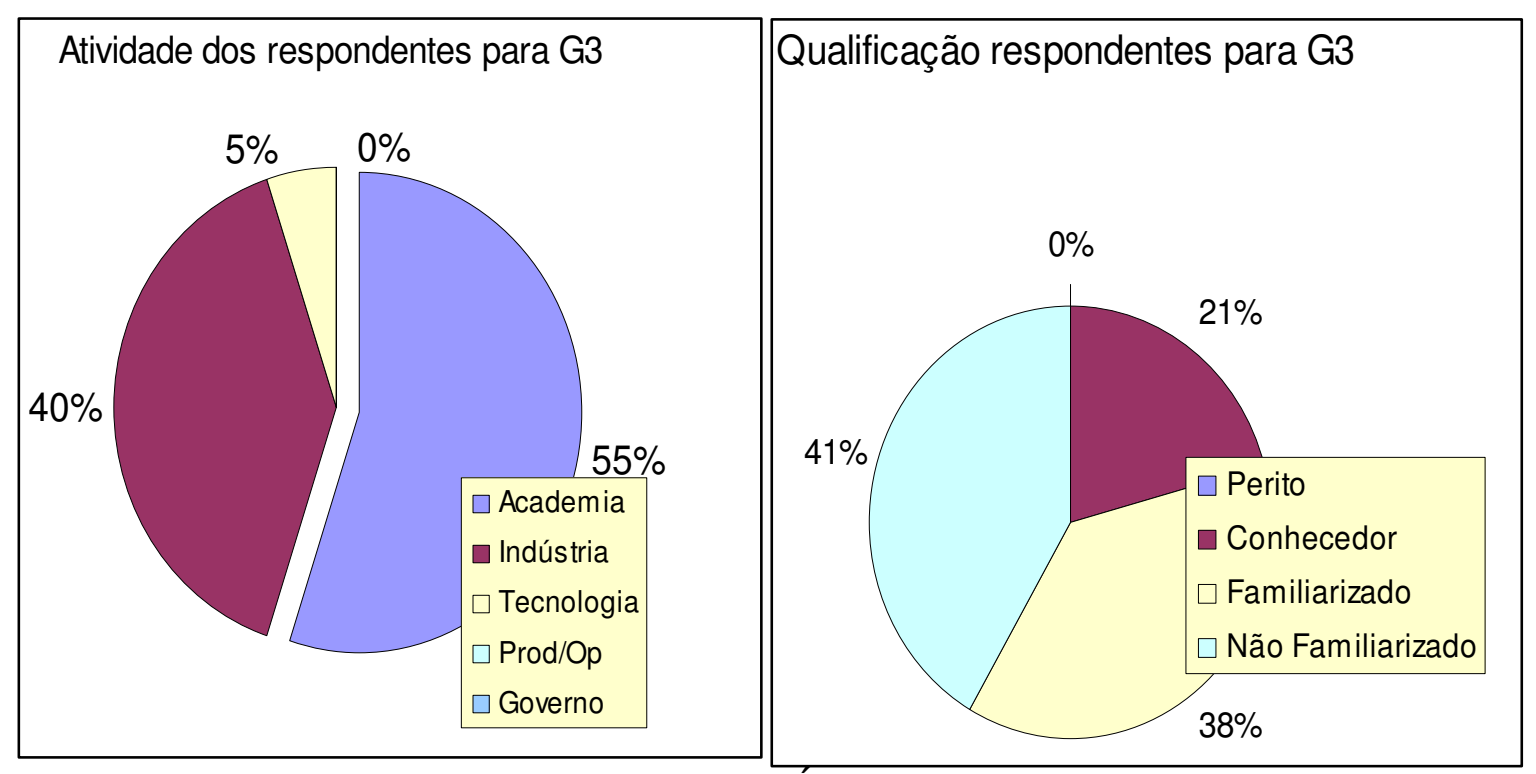

Figura 6-71 - Nível de especialização e Área de atuação dos respondentes na primeira rodada, para o grupo 3 .

\subsubsection{Grupo 3 - Questões 14 a 16}

Neste caso também foram efetuadas as mesmas análises 
apresentadas nos itens anteriores e apresentadas como tabelas conforme segue:

- Tabela 6-39 com as variações das médias e desvio padrão da primeira para a segunda rodada, para todas as questões do Grupo 3.

- Tabela 6-40 com as percentagens dos itens em que ocorreu convergência da média da segunda rodada para outra média da primeira rodada. Estas percentagens foram calculadas a partir dos dados de médias dos respondentes separados em mais qualificados e menos qualificados e a comparação com a média global, para todas as questões do Grupo 3.

Tabela 6-39 - Valores de média e desvio padrão para os itens das questões 14,15 e 16.

\begin{tabular}{c|c|c|c|c|c|c|c}
\hline & & \multicolumn{3}{|c|}{ Média } & \multicolumn{3}{c}{ Desvio Padrão } \\
\hline \multirow{4}{*}{} & & 1 a rodada & 2a, rodada & Diferença & 1a rodada & 2a rodada & ${\text { Variação }\left({ }^{*}\right)}$ \\
\cline { 2 - 8 } & Catalisadores & 2,84 & 3,10 & 0,26 & 0,94 & 1,12 & $-0,19$ \\
\cline { 2 - 8 } & Matriz/eletrólito & 2,93 & 3,05 & 0,12 & 0,97 & 1,00 & $-0,03$ \\
\cline { 2 - 8 } & Placas Bipolares & 2,94 & 2,75 & $-0,19$ & 1,03 & 1,16 & $-0,12$ \\
\cline { 2 - 8 } Q14 & Outros Materiais & 2,93 & 3,05 & 0,12 & 1,08 & 1,32 & $-0,22$ \\
\hline Q15 & Catalisadores & 2,55 & 3,00 & 0,45 & 1,25 & 1,30 & $-0,03$ \\
\hline \multirow{4}{*}{ Q16 } & Catalisadores & 3,01 & 3,20 & 0,19 & 1,04 & 1,20 & $-0,15$ \\
\cline { 2 - 8 } & Matriz/eletrólito & 3,00 & 3,00 & 0,00 & 0,97 & 1,21 & $-0,25$ \\
\cline { 2 - 8 } & Placas Bipolares & 3,19 & 3,20 & 0,01 & 0,96 & 1,06 & $-0,10$ \\
\cline { 2 - 8 } & Outros Materiais & 2,99 & 3,15 & 0,16 & 1,04 & 1,31 & $-0,26$ \\
\hline
\end{tabular}

$\left({ }^{*}\right)$ Calculado conforme item 6.4.2: $1-\left(\mathrm{s}_{2} / \mathrm{s}_{1}\right)$

Pelos dados apresentados na Tabela 6-39 verifica-se que a média dos respondentes mais qualificados, na segunda rodada, convergiu para a média total em $33,33 \%$ dos casos, o que também ocorreu para a média dos respondentes menos qualificados, que convergiu para a média total em $44,44 \%$ dos casos. E a média dos menos qualificados não convergiu para a média dos mais qualificados (na primeira rodada) em apenas $22,22 \%$ dos casos. O cálculo para estes casos foi efetuado do mesmo modo que explicado na subseção

Da Tabela 6-40 pode-se concluir que como as variações da média ficaram inferiores a 0,5 então não ocorreram mudanças de opinião significativas, para esta questão. As variações no desvio padrão aumentaram na segunda rodada para todos os itens e por isso pode se concluir que não houve aumento do consenso para este grupo.

Estes resultados mostram que, para o grupo 3, o grupo de menos qualificados não respondeu, na maioria, convergindo para a média global da primeira rodada e nem para a média dos mais qualificados. 
Tabela 6-40 - Percentagem dos itens em que ocorreu convergência da média da segunda rodada para outra média da primeira rodada.

\begin{tabular}{l|l|c}
\hline & \multicolumn{1}{|c|}{ Grupo 3 } & $\%$ \\
\hline Casos & A média dos mais qualificados $\rightarrow$ Média total & $33,33 \%$ \\
\hline & A média dos menos qualificados $\rightarrow$ Média total: & $44,44 \%$ \\
\hline & A média dos menos qualificados $\rightarrow$ Média dos mais qualificados & $22,22 \%$ \\
\hline
\end{tabular}

A variação do desvio padrão da segunda rodada em relação á primeira rodada está foi calculada e está apresentada na Figura 6-72, para todas as questões do grupo 3.

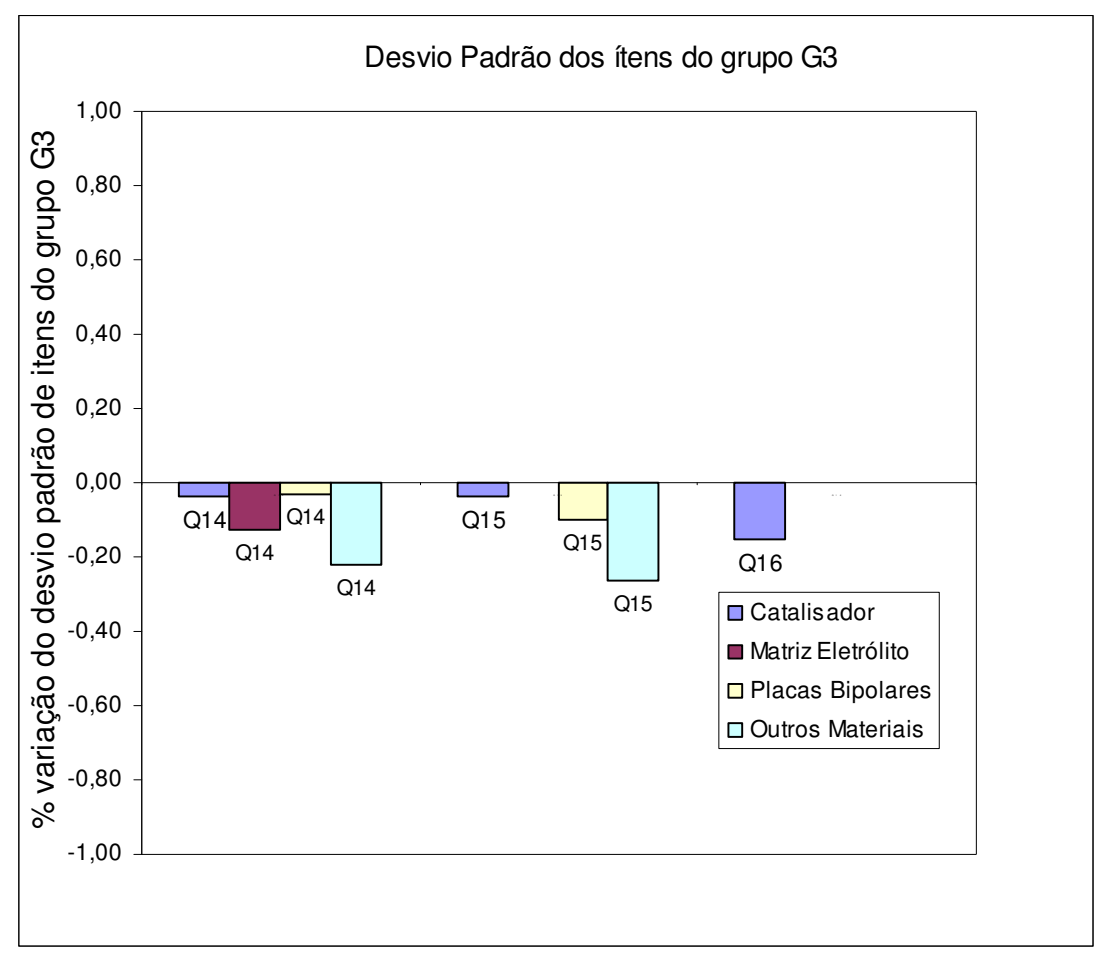

Figura 6-72 - Variação do Desvio Padrão da segunda rodada em relação à primeira rodada para os itens de todas as questões do Grupo 3.

\subsubsection{Dados dos respondentes às questões do grupo 4}

A seguir são apresentados os dados de qualificação e ramo de atividade dos respondentes para o grupo 4 (Combustíveis para pilhas). 


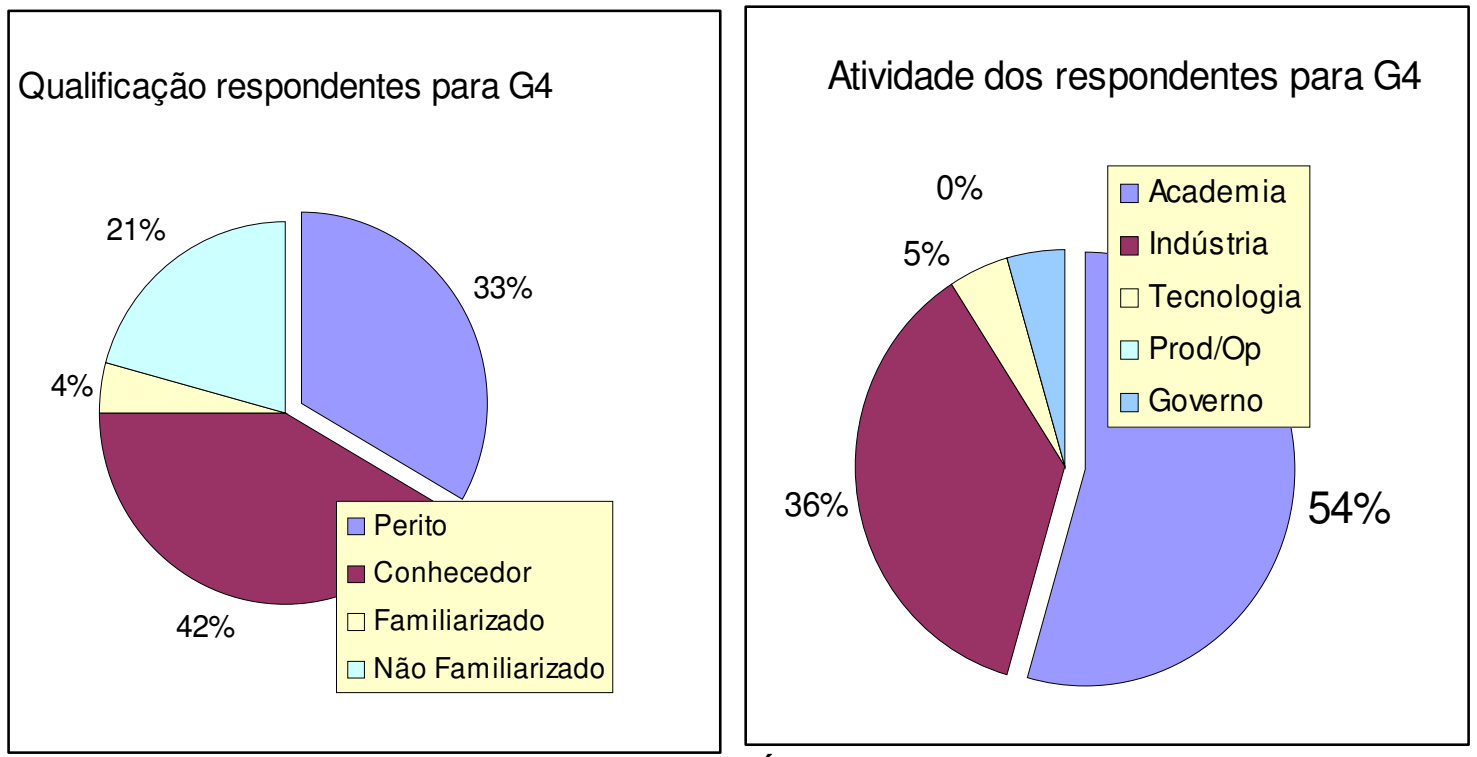

Figura 6-73 - Nível de especialização e Área de atuação dos respondentes na primeira rodada, para o grupo 4.

\subsubsection{1- Grupo 4 - Questões 18 a 21}

Neste caso também foram efetuadas as mesmas análises apresentadas nos itens anteriores e apresentadas como tabelas conforme segue:

- Tabela 6-41 com as variações das médias e desvio padrão da primeira para a segunda rodada, para todas as questões do Grupo 4.

- Tabela 6-42 com as percentagens dos itens em que ocorreu convergência da média da segunda rodada para outra média da primeira rodada. Estas percentagens foram calculadas a partir dos dados de médias dos respondentes separados em mais qualificados e menos qualificados e a comparação com a média global, para todas as questões do Grupo 4.

Da Tabela 6-41 pode-se concluir que como as variações da média ficaram inferiores a 0,5 então não ocorreram mudanças de opinião significativas, para esta questão. As variações no desvio padrão só indicaram consenso em apenas $16 \%$ dos casos. As variações do desvio padrão da segunda rodada em relação á primeira rodada estão apresentadas na Figura 6-74, para todas as questões do grupo 4, e foram calculadas conforme item 6.4: 1-(s2/s1).

Pelos dados apresentados na Tabela 6-42 verifica-se que a média dos respondentes mais qualificados, na segunda rodada, convergiu para a média total somente em 9,09\% dos casos, o que também ocorreu para a média dos respondentes menos qualificados, que convergiu para a média total em $36,36 \%$ 
Tabela 6-41 - Valores de média e desvio padrão para os itens das questões $18,19,20$ e 21.

\begin{tabular}{|c|c|c|c|c|c|c|c|}
\hline \multirow{3}{*}{ Q18 } & & \multicolumn{3}{|c|}{ Média } & \multicolumn{3}{|c|}{ Desvio Padrão } \\
\hline & $\begin{array}{l}\text { Perto do } \\
\text { consumo }\end{array}$ & 2,34 & 2,14 & $-0,20$ & 1,08 & 1,25 & $-0,15$ \\
\hline & $\begin{array}{l}\text { Longe do } \\
\text { consumo }\end{array}$ & 2,32 & 1,82 & $-0,50$ & 1,03 & 1,05 & $-0,02$ \\
\hline \multirow[t]{2}{*}{ Q19 } & Catalisadores & 2,30 & 2,32 & 0,01 & 1,10 & 1,13 & $-0,03$ \\
\hline & Catalisadores & 2,08 & 2,05 & $-0,03$ & 1,04 & 1,13 & $-0,09$ \\
\hline \multirow{12}{*}{ Q20 } & Gaseif. carvão & 2,75 & 2,25 & $-0,50$ & 1,41 & 1,29 & 0,09 \\
\hline & Reforma Gás N & 2,86 & 2,75 & $-0,11$ & 1,34 & 1,45 & $-0,08$ \\
\hline & $\begin{array}{c}\text { Ref. Comb. } \\
\text { Ren. }\end{array}$ & 3,10 & 3,14 & 0,04 & 1,35 & 1,42 & $-0,05$ \\
\hline & $\begin{array}{l}\text { Dissoc. } \\
\text { Térmica }\end{array}$ & 3,11 & 2,70 & $-0,41$ & 1,19 & 1,42 & $-0,20$ \\
\hline & Kvaerner & 3,20 & 2,76 & $-0,44$ & 0,91 & 1,35 & $-0,49$ \\
\hline & Fotolítico & 3,03 & 3,15 & 0,12 & 1,35 & 1,53 & $-0,14$ \\
\hline & Plasmatron & 3,37 & 2,68 & $-0,69$ & 1,07 & 1,29 & $-0,21$ \\
\hline & Biológico & 3,26 & 3,32 & 0,06 & 1,44 & 1,36 & 0,06 \\
\hline & $\begin{array}{c}\text { Decomp. } \\
\text { Térmi. }\end{array}$ & 3,08 & 3,10 & 0,01 & 1,18 & 1,45 & $-0,23$ \\
\hline & Gaseif Bioma. & 3,07 & 3,23 & 0,15 & 1,47 & 1,38 & 0,06 \\
\hline & Eletrolítico & 2,98 & 3,48 & 0,50 & 1,40 & 1,40 & 0,00 \\
\hline & Biológico & 3,26 & 3,32 & 0,06 & 1,44 & 1,36 & 0,06 \\
\hline \multirow[t]{5}{*}{ Q21 } & Energia Eólica & 3,28 & 3,38 & 0,10 & 1,48 & 1,53 & $-0,04$ \\
\hline & Em. Biomassa & 3,19 & 3,48 & 0,29 & 1,41 & 1,57 & $-0,12$ \\
\hline & Em. Hidrelétr. & 3,34 & 3,40 & 0,06 & 1,32 & 1,43 & $-0,08$ \\
\hline & Em. Gás Natur. & 2,90 & 3,00 & 0,10 & 1,25 & 1,55 & $-0,24$ \\
\hline & Fotovoltaica & 3,22 & 3,43 & 0,21 & 1,37 & 1,57 & $-0,14$ \\
\hline
\end{tabular}

$\left(^{*}\right)$ Calculado conforme item 6.4.2: 1-( $\left(\mathrm{s}_{2} / \mathrm{s}_{1}\right)$

$A=$ Gaseificação do carvão $\quad G=P l a s m a t r o n$

$\mathrm{B}=$ Reforma do Gás Natural $\quad \mathrm{H}=$ Biológico

$M=$ Energia Solar (térmica)

$\mathrm{C}=$ Reforma Comb. Renováveis = Decomposicão Térmica $\mathrm{N}=$ Biomassa

D=Dissociacão térmica

$\mathrm{E}=$ Kvaerner

F=Fotolítico

$\mathrm{K}=$ Eletrolítico

$\mathrm{L}=$ Energia Eólica

$\mathrm{Q}=$ Fotovoltaica

Tabela 6-42 - Percentagem dos itens em que ocorreu convergência da média da segunda rodada para outra média da primeira rodada.

\begin{tabular}{l|l|c}
\hline & \multicolumn{1}{|c|}{ Grupo 4 } & $\%$ \\
\hline & & \\
Casos & A média dos mais qualificados $\rightarrow$ Média total & $38,10 \%$ \\
\hline & A média dos menos qualificados $\rightarrow$ Média total: & $19,05 \%$ \\
\hline & A média dos menos qualificados $\rightarrow$ Média dos mais qualificados & $23,81 \%$ \\
\hline
\end{tabular}

dos casos. E a média dos menos qualificados convergiu para a média dos mais qualificados (na primeira rodada) em apenas $18,18 \%$ dos casos. O cálculo para estes casos foi efetuado do mesmo modo que explicado na subseção 6.7.1.2.

Estes resultados mostram que, também para o grupo 4, o grupo de menos qualificados não respondeu, na maioria, convergindo para a média global 
da primeira rodada e nem para a média dos mais qualificados.

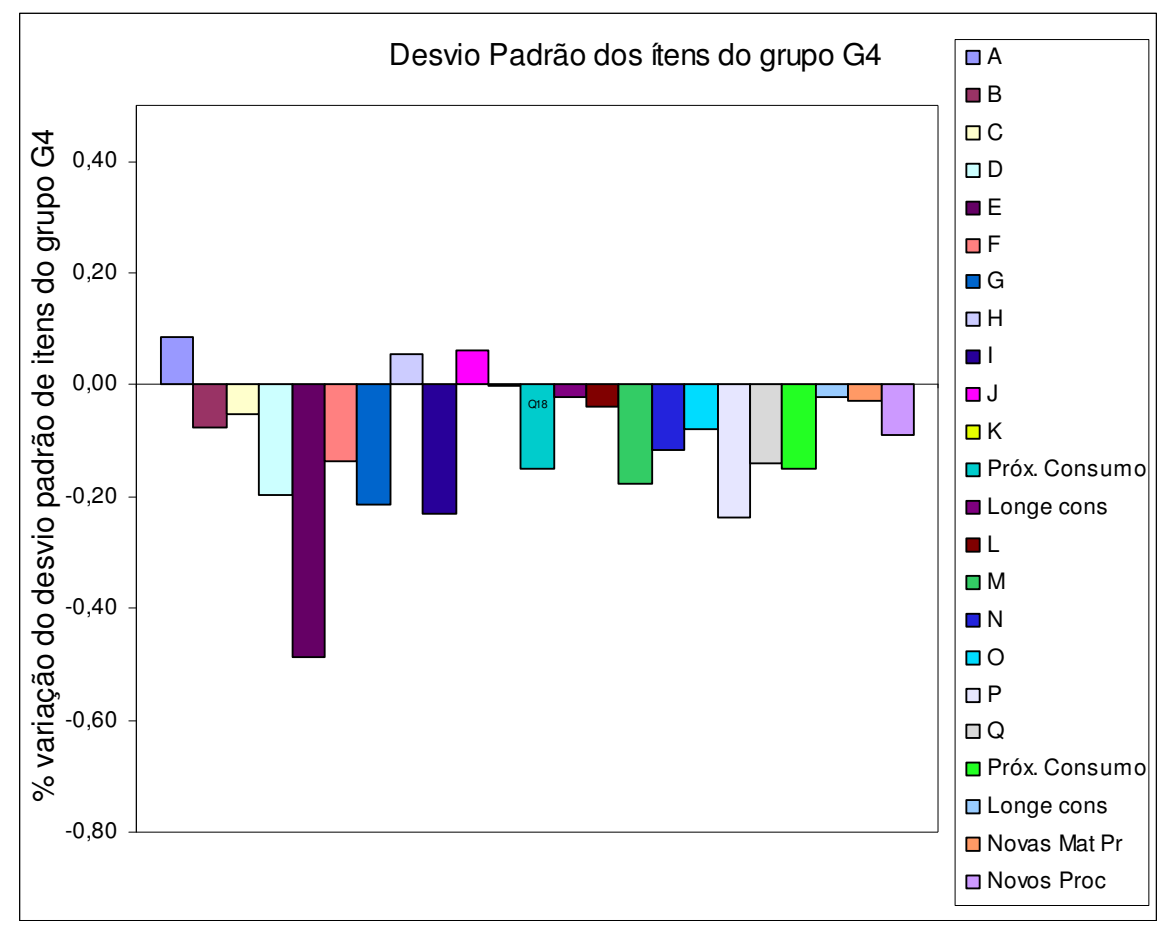

Figura 6-74 - Variação do Desvio Padrão da segunda rodada em relação à primeira rodada para os itens de todas as questões do Grupo 4.

$\begin{array}{lll}\text { A=Gaseificação do carvão } & \text { G=Plasmatron } & \text { M=Energia Solar (térmica) } \\ \text { B=Reforma do Gás Natural } & \mathrm{H} \text { =Biológico } & \mathrm{N}=\text { Biomassa } \\ \text { C=Reforma Comb. Renováveis } & =\text { Decomposição TérmicaO=Hidrelétrica } \\ \text { D=Dissociação térmica } & \mathrm{J}=\text { Gaseif. de Biomassa } & \mathrm{P}=\text { Energia do Gás Natural } \\ \mathrm{E}=\text { Kvaerner } & \mathrm{K}=\text { Eletrolítico } & \mathrm{Q}=\text { Fotovoltaica } \\ \mathrm{F}=\text { Fotolítico } & \mathrm{L}=\text { Energia Eólica } & \end{array}$

\subsubsection{2- Grupo 4 - Questão 22}

Esta questão foi proposta apenas na segunda rodada a partir de comentários recebidos na primeira rodada.

A expectativa de uso do processo de produção de hidrogênio por meio do uso da energia nuclear, a longo prazo, está mostrada na Figura 6-75. Também neste caso a divergência dos respondentes é flagrante. 


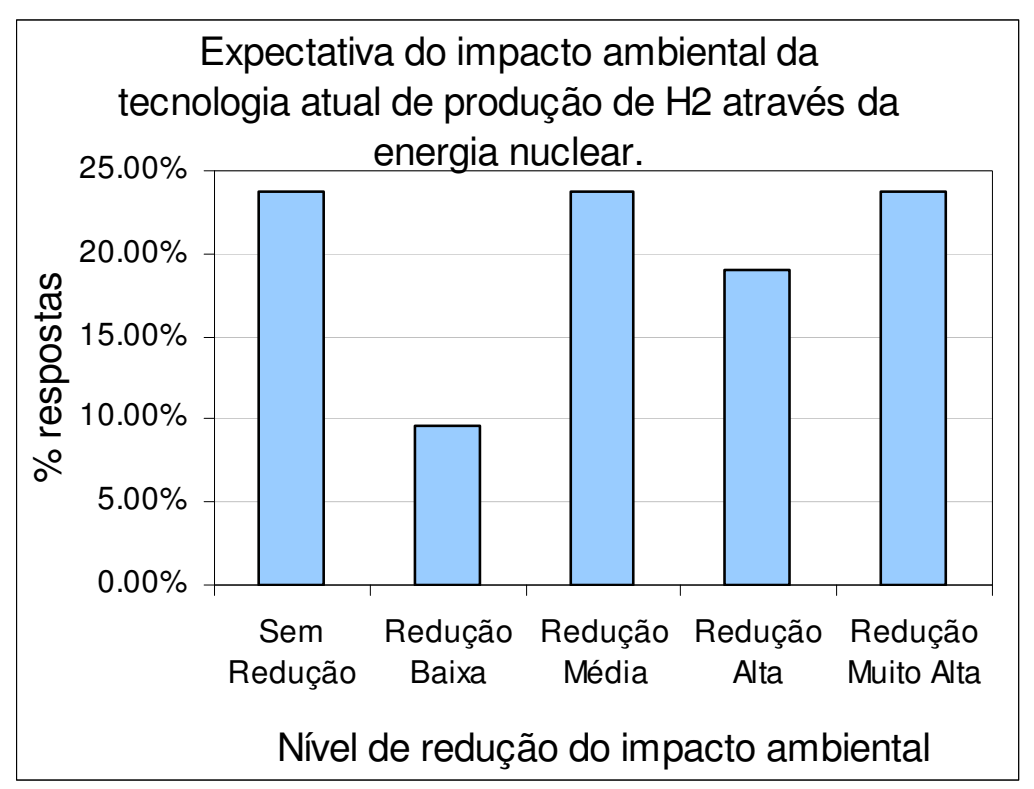

Figura 6-75 - Expectativa do impacto ambiental da tecnologia de produção de hidrogênio através da energia nuclear

Apesar da análise variância não ter demonstrado nenhuma relação entre as características: nível de especialização, atividade, sexo e continente do respondente, os gráficos apresentados na Figura 6-76 demonstram a polarização das opiniões. Os peritos estão polarizados entre Redução Muito Alta e Sem Redução.
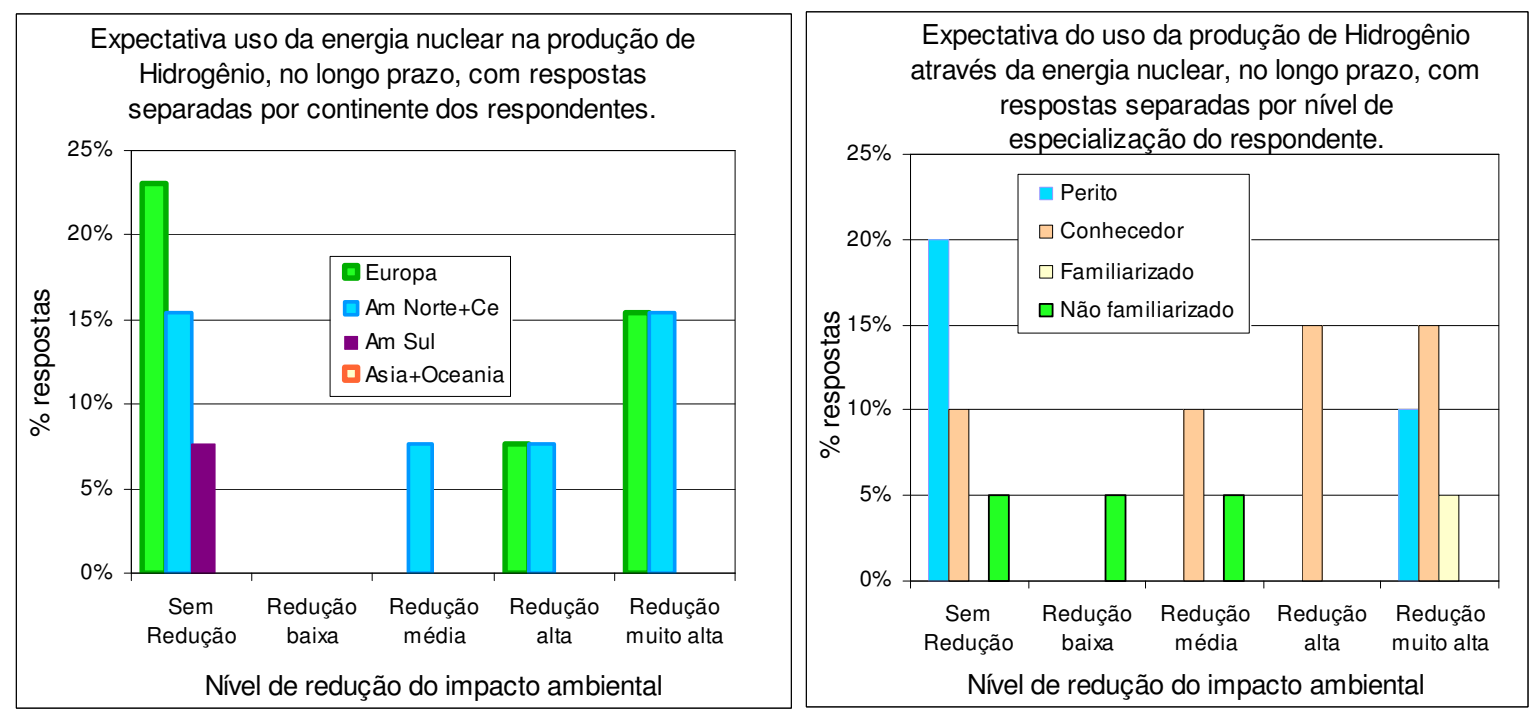

Figura 6-76 - Expectativa do impacto ambiental devido à produção de hidrogênio através da energia nuclear, com respostas separadas por continente dos respondentes. 


\subsection{Resultados do cálculo do fator de Cronbach para o questionário}

No Anexo A (item A.11) encontram-se os dados sobre o cálculo do coeficiente $a$ de Cronbach que foi efetuado por meio do programa Matlab v.7, a partir dos dados obtidos no questionário. Os dados do questionário foram obtidos por meio de uma planilha em Excel fornecida pelo programa QuestionPro. Cronbach (1951) propôs a quantificação da confiabilidade dos respondentes por meio do coeficiente $\alpha$ que varia entre 0 e 1 . Quanto mais perto de 0 estiver o calor de $\alpha$, então menos confiáveis são os respondentes. Assim como uma regra se $\alpha \geq$ 0,8 então os respondentes são considerados confiáveis (Leontitsis and Page, 2006).

Os valores obtidos, no presente trabalho, para o alfa de Cronbach estão entre 0,86 e 0,92 (vide Figura 6-77) o que configura que os respondentes são confiáveis.

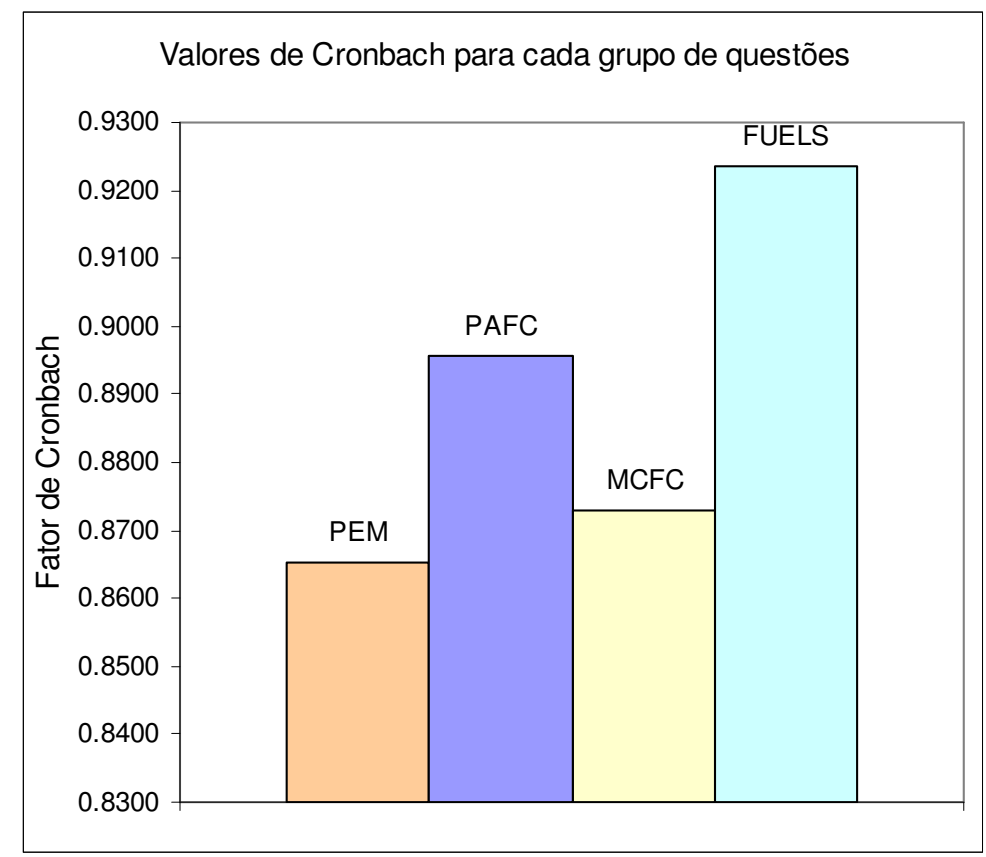

Figura 6-77- Valores do fator de Cronbach calculado para o questionário, separado por partes.

\subsection{Comentários sobre os resultados}

Conforme previsto inicialmente este trabalho de pesquisa Delphi buscou o equilíbrio na representatividade dos diferentes setores de atuação ao se convidar especialistas de várias áreas, tais como: academia, pesquisa industrial, área de operação/produção, tecnologia e governo, mas no final a representatividade dos que efetivamente responderam ao questionário não foi tão 
equilibrada assim. A maior adesão dos especialistas foi da classe ligada à academia (centros de pesquisa e universidades) e a menor participação foi da classe ligada ao governo e certa constância nos especialistas ligados às empresas. No total, dos 471 convidados, 122 responderam à $1^{\text {a }}$ rodada $(25,6 \%)$ e apesar de baixa, conforme Shin (1998) é aceitável. Já na segunda rodada dos 95 convidados 37 responderam (38,95\%), o que confirmam Shin (1998) e Sant'ana (2005) que também é uma percentagem aceitável.

Considerando a variação das médias da primeira para a segunda rodada com o critério adotado (aumento maior do que 0,5), pôde-se notar na grande maioria dos grupos esta mudança de opinião não ocorreu. Algumas hipóteses podem auxiliar na explicação deste comportamento: os grupos podem ser inflexíveis ou ainda que a redação pudesse não ter sido clara.

Analisando a variação do desvio padrão a única conclusão possível foi de que a técnica Delphi permitiu, em parte dos casos, um aumento do consenso na forma de uma diminuição do desvio padrão da primeira para a segunda rodada, conforme mostrado na Figura 6-78.

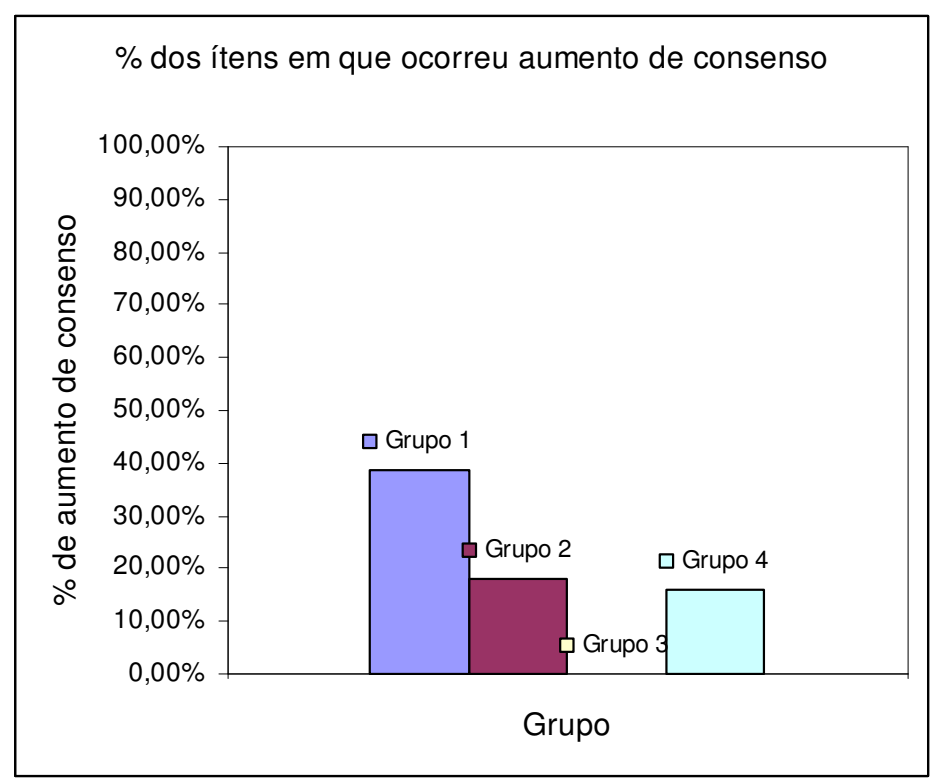

Figura 6-78 - Percentagem das respostas em que ocorreu aumento de consenso.

Os dados obtidos no estudo e resumidos na Figura 6-79 mostram que no grupo1, o grupo menos especializado (familiarizados e não familiarizados) convergiu em apenas 15,38\% das respostas da primeira para a segunda rodada na direção das médias das respostas de todos os respondentes na primeira rodada; no caso dos mais especializados, $53,85 \%$ das respostas convergiram 
apenas. E apenas 7,69\% dos menos especializados convergiram na direção da média dos mais especializados, na primeira rodada. No total $76,92 \%$ das respostas da segunda rodada convergiram para uma das duas possibilidades: para a média global da primeira rodada ou para a média do grupo mais especializado na primeira rodada. Isto indica que ocorreu uma convergência das respostas da primeira rodada, cujos dados foram fornecidos antes da resposta da segunda rodada. $O$ que os dados também mostram é que os respondentes menos especializados não foram na direção dos mais especializados e sim na direção da média global.

No total do questionário, das 1308 respostas recebidas na segunda rodada $85,19 \%$ convergiram para as respostas válidas obtidas na primeira rodada (5616). Estes dados mostram que os respondentes foram suscetíveis às mudanças induzidas pelos dados fornecidos no final da primeira rodada. Mas é importante notar que isto ocorreu da mesma forma tanto para os mais como para os menos qualificados. Uma hipótese para isto ter ocorrido é que os menos qualificados não possuem qualificação muito diferente dos mais qualificados, pois o questionário era muito técnico e específico. Muitos convidados desistiram de responder pois alegavam não saber detalhes específicos sobre as pilhas a combustível. Assim, os que responderam possuíam bastante qualificação. Muitos alegaram ser não familiarizados, por exemplo, para pilhas MCFC, mas eram peritos em pilhas PAFC.

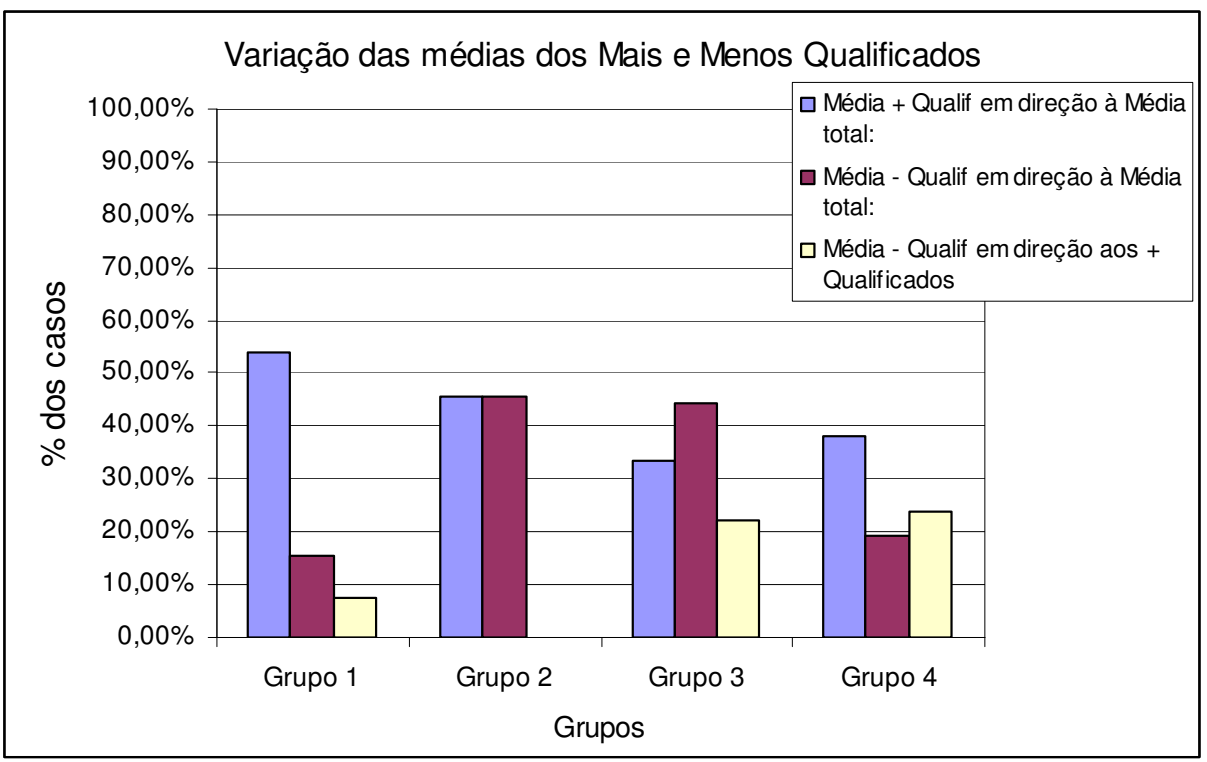

Figura 6-79 - Variação das médias dos grupos de menos e mais qualificados 


\subsection{Discussão dos resultados da pesquisa Delphi efetuada}

A seguir é apresentada uma discussão sobre os resultados da pesquisa efetuada.

\subsubsection{O impacto ambiental das pilhas PEMFC}

A avaliação dos respondentes para a redução do impacto ambiental das pilhas PEMFC, para um futuro de 20 anos, é de que ocorra uma redução entre "redução média" e "média alta" para o conjunto das pilhas.

Já a consideração sobre a possibilidade de um novo tipo de projeto para este tipo de pilha, implicar na redução do impacto ambiental, os respondentes parecem avaliar que a probabilidade que isto ocorra está entre "probabilidade média" e "probabilidade média baixa".

E quanto à possibilidade de que um destes itens seja substituído ou mesmo que seu uso seja abolido, os respondentes preveem uma "Probabilidade Média" e "Média Alta". Ou seja, os respondentes preveem uma probabilidade entre média e média alta para a substituição por materiais de menor impacto ambiental ou abolição do uso de algum dos itens que compõem a pilha. Esta possibilidade inclui a abolição de itens, por exemplo, as placas bipolares ou sua substituição por outro tipo de prováveis novas tecnologias. Na Figura 6-80 são mostradas as médias das expectativas de redução do impacto, a longo prazo para as pilhas tipo PEM.

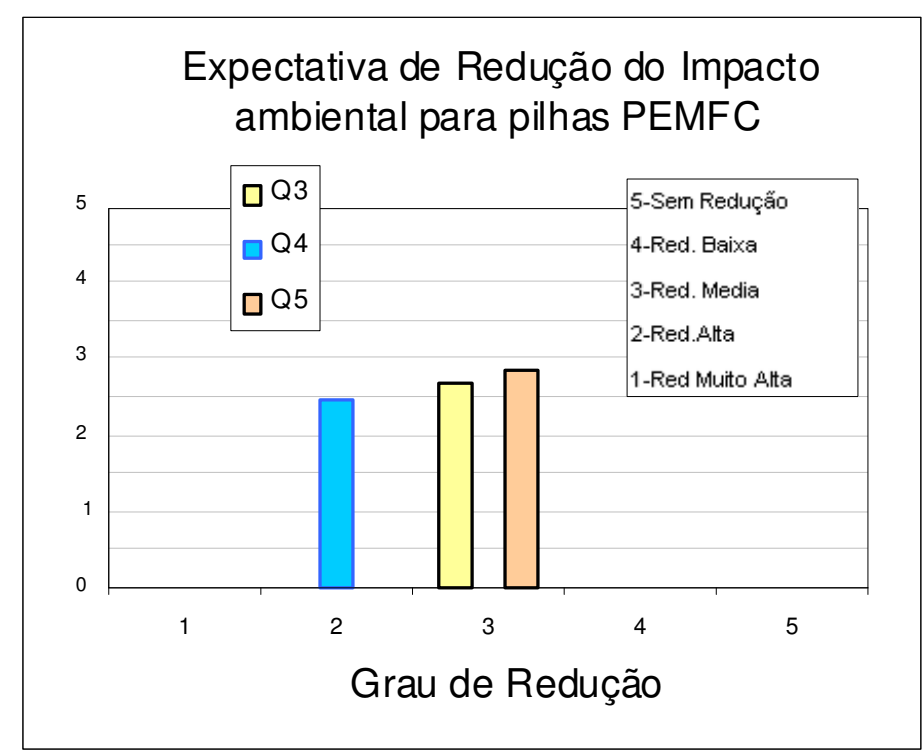

Figura 6-80 - Grau de redução do impacto ambiental para as questões 3 a 5 sobre impacto ambiental das pilhas PEMFC. 
Assim o cenário que se forma a partir destas respostas é uma pilha tipo PEMFC que, a longo prazo apresenta as seguintes características:

-as pilhas PEMFC terão menor impacto ambiental;

-o projeto da PEMFC pode sofrer alterações (probabilidade entre média e média baixa) de modo que este novo projeto reduza o impacto ambiental;

-alguns dos itens utilizados nas pilhas podem ser substituídos por itens de menor impacto ambiental ou mesmo podem ser abolidos.

\subsubsection{Catalisadores para pilhas PEMFC}

Antes de analisar os resultados da pesquisa é interessante lembrar que o impacto ambiental, na etapa de produção da pilha tipo PEMFC, é causado sobretudo pelos metais do grupo da Platina, usados como catalisador e em menor grau pelos materiais e energia usados na produção da placas bipolares Pehnt (2001). Neste estudo Pehnt (2001) avalia que, com base na tecnologia corrente, e considerando a mesma eficiência, uma redução da concentração do catalisador (Pt), por exemplo, para $50 \%$ do valor atual então, acarreta um aumento no consumo de hidrogênio entre 5-70\%. Como consequência a soma das emissões referentes ao aquecimento global e acidificação permaneceria a mesma. Vide Figura 4-9.

No presente trabalho a resposta ao questionário parece remeter, para um futuro 20 anos, que o catalisador seja substituído (46-49\% das respostas). A segunda opção dos respondentes foi que o catalisador não será substituído, mas será utilizado com mistura de outros metais que não são do grupo PGM. As duas opções juntas somam $61-76 \%$ das respostas.

Conforme Borgwardt (2001), em condições muito favoráveis é possível que a transição dos carros comuns para os carros a pilhas combustíveis requeira um tempo da ordem de 66 anos. E neste período a demanda por Platina, somente da indústria automobilística será responsável pelo crescimento da produção mundial em 48\%. O efeito desta demanda fará com que o preço da platina aumente o que deve reduzir a vantagem competitiva dos carros movidos a pilha.

Spiegel (2004) fornece os dados sobre a quantidade de platina utilizada num carro de passageiros, que deve utilizar uma pilha com potência de 50-70 kW (dependendo do tamanho do veículo). Estes motores consomem aproximadamente $20-30 \mathrm{~g}$ de Platina, baseando-se numa carga de $0,3 \mathrm{~g} / \mathrm{cm}^{2}$. A 
meta do DOE é aproximadamente 12 g para um veículo de $70 \mathrm{~kW}$ para 2010, mas a meta da própria indústria é uma carga ainda menor devendo alcançar $10 \mathrm{~g}$ por carro.

Baseado nos dados do programa GREET - "The Greenhouse Gases, Regulated Emissions, and Energy Use in Transportation (GREET) Model" (ARGONNE, 2007), a produção de Platina, desde a fase de mineração até antes da impregnação no eletrodo de difusão gasosa é responsável pelas emissões, mostradas na Figura 6-81, para 2 casos: o caso de uma pilha com inventário de $10 \mathrm{~g}$ de Platina e para o caso da pilha ter seu inventário reduzido para $5 \mathrm{~g}$. O DOE também tem uma meta para em 2015 atingir 0,2 g/cm² (Mock, 2009). Já o caso com $5 \mathrm{~g}$ é para o caso em que ocorra uma diminuição razoável no conteúdo de Platina das mesmas. Note-se que todos estes dados referem-se à mineração efetuada na África do Sul, lembrando que a Rússia também é o grande fornecedor de mercado e que não fornece os dados de emissões de seus processos, por não ter interesse político visto que não possui preocupações ambientais. Assim as emissões provavelmente são muito maiores para a Platina proveniente da Rússia. É bom lembrar também que estes dados não incluem a reciclagem, pois esta não é prevista para a Platina no referido programa (GREET).

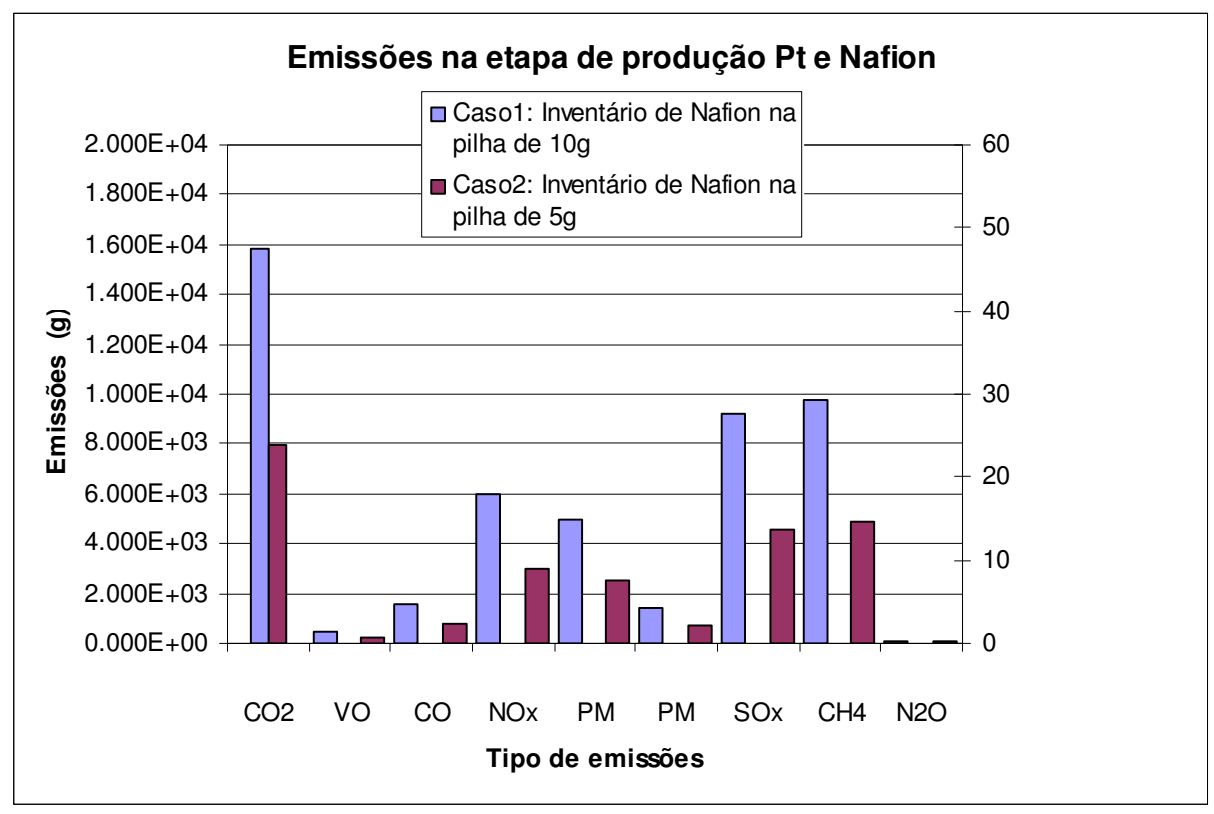

Figura 6-81 - Redução nas emissões relativas à etapa de produção da Platina, para o caso em que se use $10 \mathrm{~g}$ e $5 \mathrm{~g}$ de Pt por pilha, por carro (ARGONNE, 2007). 
É importante notar que os dados apresentados na Figura 6-82 fornecem apenas uma indicação da proporção entre os vários tipos de emissões resultantes da produção dos eletrodos com Platina. Isto porque Cooper et al. (2008), num estudo sobre as métricas utilizadas para se avaliar o impacto ambiental de novas tecnologias de geração elétricas, concluiu que os indicadores de impacto ambiental dos metais dos catalisadores e do material da membrana ainda não foram bem detalhados no programa GREET. Este problema, conforme Cooper et al. (2008), será objeto de trabalho futuro.

Assim a expectativa dos respondentes remete à conclusão que as emissões serão muito reduzidas quando optaram pela opção de substituição dos catalisadores derivados de metais do grupo PGM por outros metais de menor impacto ambiental ou a diminuição da carga através da mistura com outros metais menos poluentes.

\subsubsection{O impacto ambiental das pilhas PAFC}

A avaliação dos respondentes para a redução do impacto ambiental das pilhas PAFC, para um futuro de 20 anos, é de que ocorra uma "Redução baixa" e "Redução média alta" para o conjunto das pilhas, denotando que a expectativa dos respondentes é que o impacto ambiental será menos reduzido que no caso das pilhas PEMFC.

Já a consideração sobre a possibilidade de um novo tipo de projeto para este tipo de pilha, implicar na redução do impacto ambiental, os respondentes parecem avaliar que a probabilidade é "Probabilidade média".

Quanto à quantidade de metais do grupo da Platina, pode-se dizer que o resultado apresentado por Pehnt (2001) pode ser avaliado do mesmo modo para as pilhas PAFC. Assim os respondentes avaliaram com "probabilidade média" que o catalisador ou será substituído ou será utilizado em menor concentração misturado a outros metais. Isto diminuiria o impacto ambiental, na etapa de fabricação de modo razoável.

A redução de concentração prevista para o consumo dos metais do grupo Platina foi de $400 \%$, que é um valor de redução muito maior que o previsto atualmente. 


\subsubsection{Reciclagem de catalisadores}

A outra possibilidade de diminuição do impacto ambiental das pilhas refere-se à possibilidade de reciclagem dos metais do grupo da Platina, utilizado como catalisadores.

A reciclagem da platina é efetuada no Brasil, assim como em vários países do mundo. Aqui no Brasil a empresa do grupo Umicore apenas recebe os resíduos coletados por empresas de sucata, resultantes do catalisador automotivo, coletados em algumas oficinas, sobretudo nas capitais. Este resíduo recebido é enviado para a Bélgica onde é efetivamente realizada a reciclagem da platina. A Umicore não fornece os dados de reciclagem, mas dado o tamanho do nosso país estima-se que não ultrapasse $20 \%$ do total produzido.

No estudo de Rooijen et al. (2006) a avaliação de impacto das pilhas PAFC foi efetuada com base numa pilha PAFC de modelo atual, mas com apenas uma modificação de cenário contendo o reuso de $98 \%$ da Platina de reuso parcial de outros metais. Deste modo o impacto ambiental reduziu-se na ordem de $5 \%$.

Assim, como nossos respondentes avaliaram que a reciclagem, a longo prazo pode estar entre $80-99 \%$ pode-se prever uma diminuição do impacto, somente com relação a este item, na ordem de $4-5 \%$, a partir do estudo de Rooijen et al. (2006).

Este estudo também avaliou a redução do impacto em razão do reuso de diversos componentes da pilha, tais como: ejetor de vapor, vaso de vapor, carcaça e outros subcomponentes da pilha. Este conjunto, quando reusado é responsável por uma redução de $11 \%$.

Spiegel (2004) informa que nos EUA já existe uma taxa de reciclagem maior que $90 \%$ da Platina proveniente dos conversores catalíticos utilizados atualmente nos automóveis. Assim a recuperação de $98 \%$ da platina proveniente das pilhas a combustível, em final de vida, poderá ocorrer no futuro. Mas seus estudos sobre a possibilidade das reservas de Platina atenderem à demanda do mercado não são previsões, mas só um dado de apoio a elas.

Assim o cenário que se forma a partir destas respostas é uma pilha tipo PAFC que, a longo prazo apresenta as seguintes características:

-as pilhas PEMFC terão menor impacto ambiental que as atuais;

-o projeto da PEMFC pode sofrer alterações (probabilidade entre média e média baixa) de modo que este novo projeto reduza o impacto ambiental; 
- em termos de catalisadores a previsão é que exista uma diminuição na quantidade dos metais do grupo da Platina ou mesmo sua substituição.

-em termos de eficiência, a da PAFC é maior que a da PEMFC, atualmente, sobretudo considerando a possibilidade de recuperação do calor na saída da pilha. O impacto atual da PAFC também é pouco inferior ao da PEMFC, conforme estudo do World Energy Council (2004) mostrado na Figura 6-82.

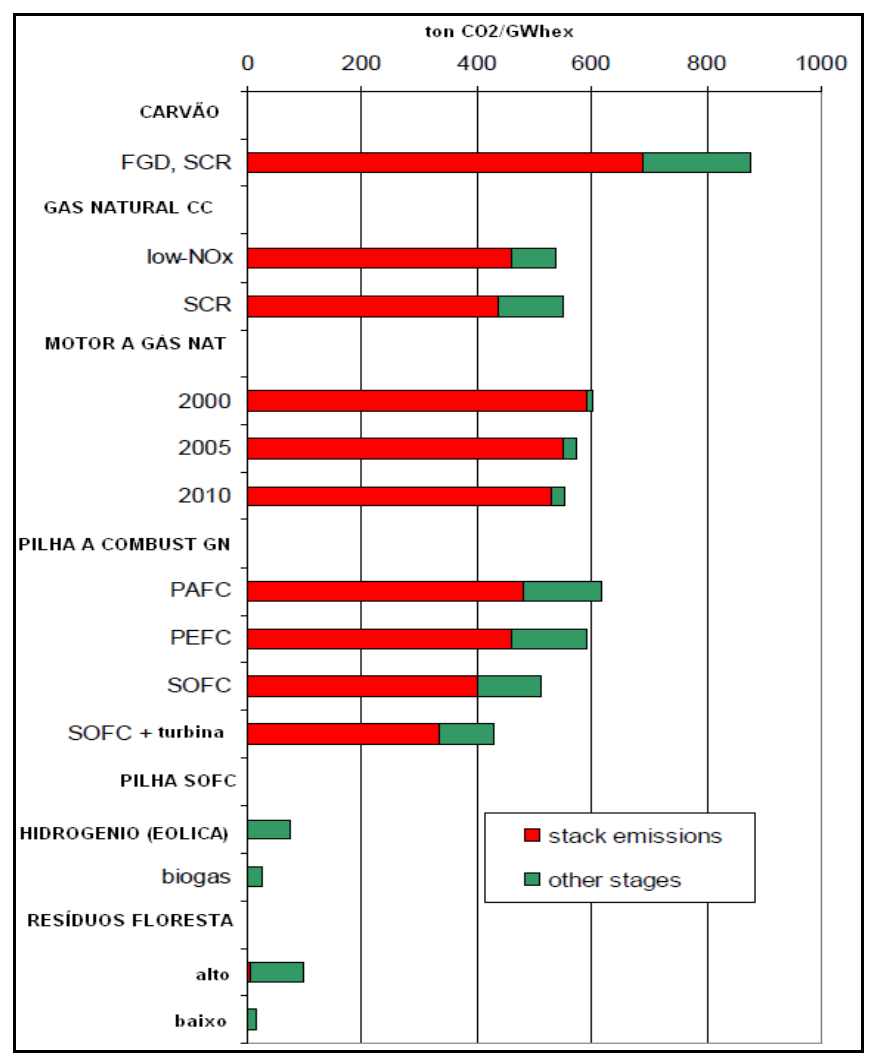

Figura 6-82 - Emissões de emissões de gases do efeito estufa para vários tipos de geração em ciclo combinado. Emissões expressas como ton. $\mathrm{CO}_{2 \text {-eq }}$ por 1

GWh de exergia produzida. Fonte: World Energy Council, 2004.

A Figura 6-83 pode resumir a conclusão sobre as previsões do impacto ambiental, a longo prazo, bem como a perspectiva de diminuição do uso de metais do grupo PGM e aumento da reciclagem destes metais. 


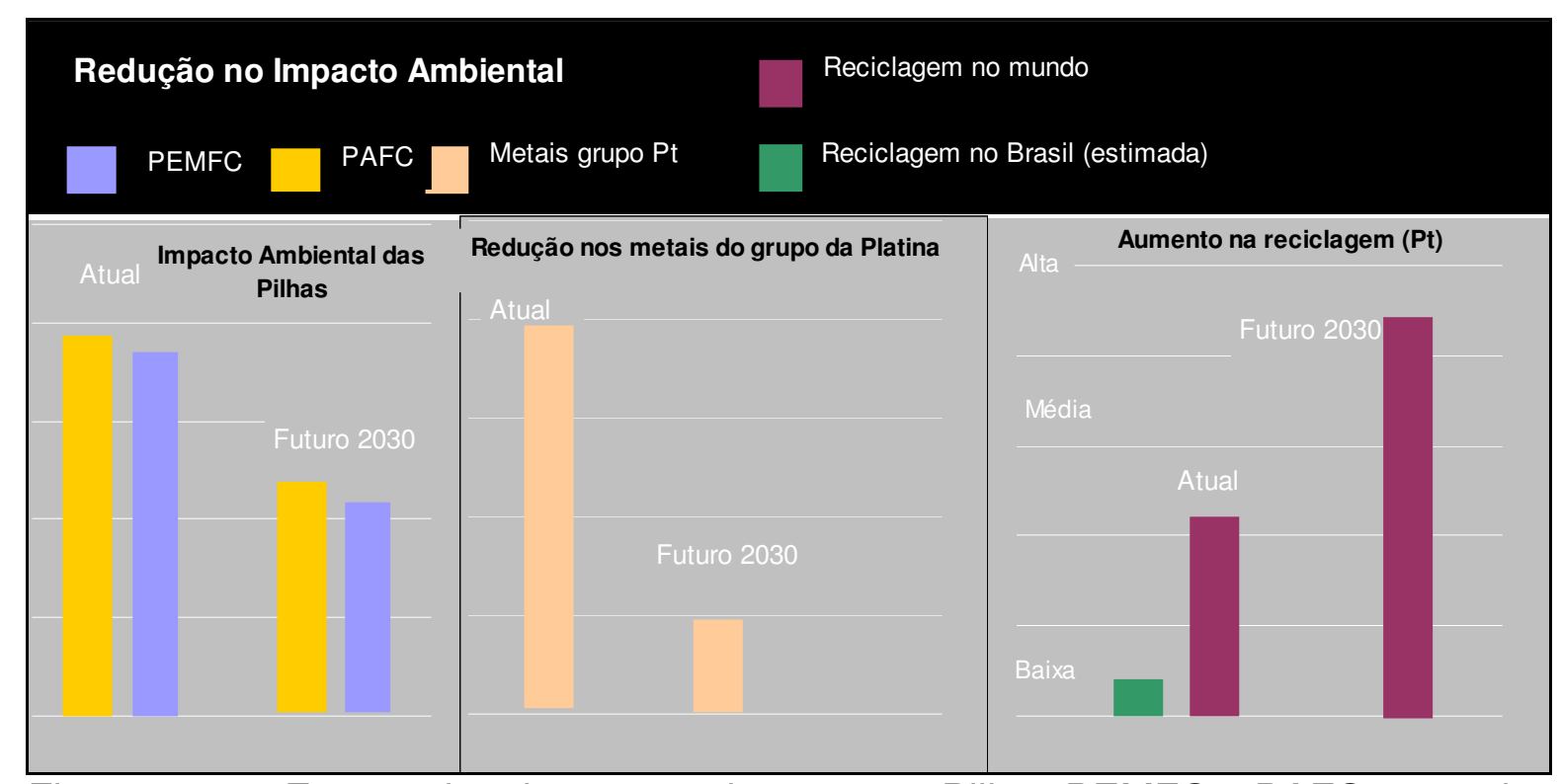

Figura 6-83 - Expectativa dos respondentes para Pilhas PEMFC e PAFC e metais

\subsubsection{O impacto ambiental das pilhas MCFC} do grupo da Platina.

A avaliação dos respondentes para a redução do impacto ambiental das pilhas MCFC, para um futuro de 20 anos, é de que ocorra uma redução entre "Redução média".

Já a consideração sobre a possibilidade de um novo tipo de projeto para este tipo de pilha, implicar na redução do impacto ambiental, os respondentes parece avaliar que a probabilidade de que isto ocorra é "Probabilidade média".

E quanto ao catalisador utilizado neste tipo de pilhas a expectativa dos respondentes é que continue sendo o mesmo, mas que diminua a quantidade utilizada devido à possibilidade de mistura com outros materiais.

Em termos de eficiência, a da MCFC é maior que a da PEMFC e da PAFC, atualmente, sobretudo considerando a possibilidade de recuperação do calor na saída da pilha (ver Figura 6-84). 


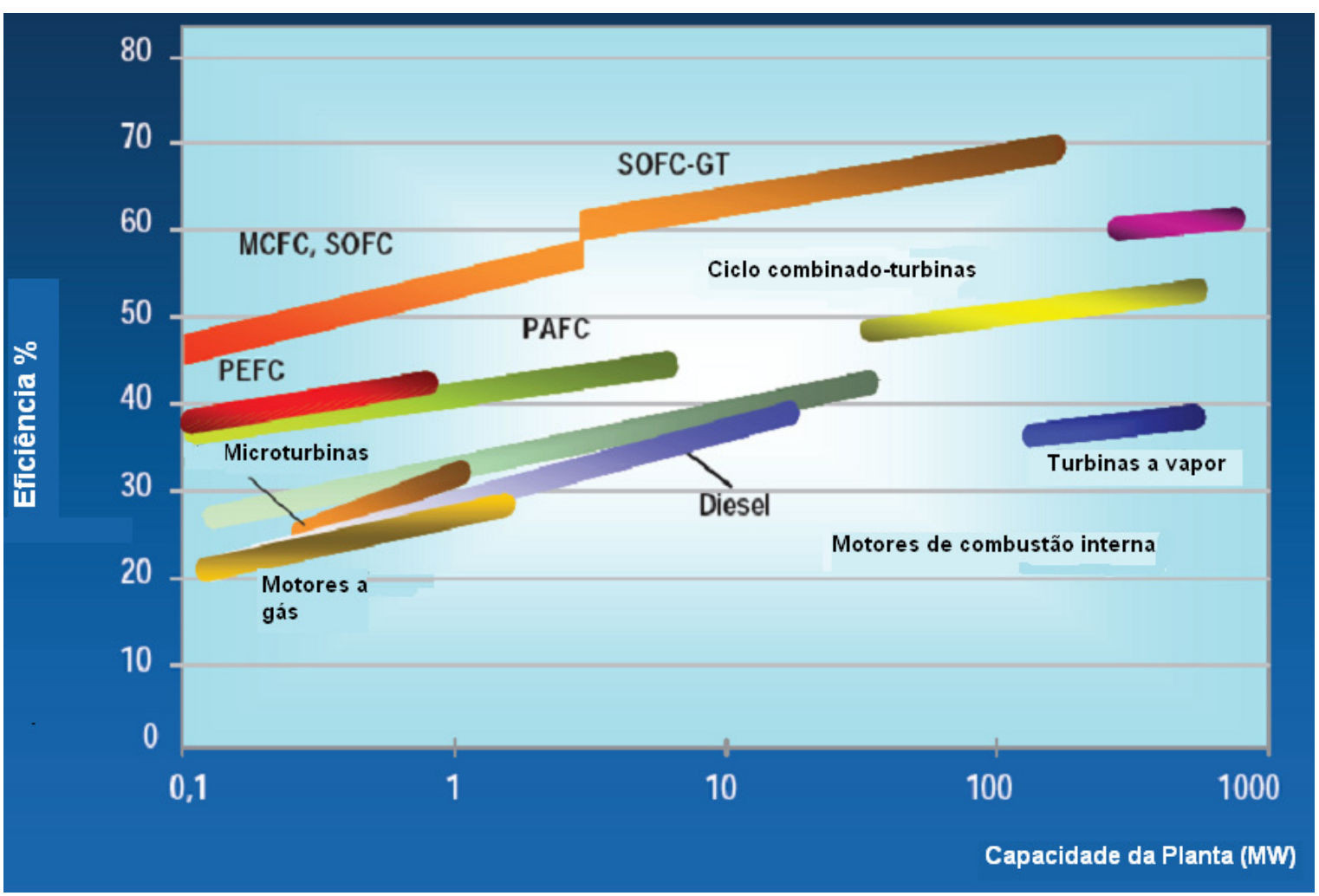

Figura 6-84 - Eficiência dos vários tipos de ciclos com pilhas PAFC, PEFC e MCFC.

\subsubsection{Combustível para as pilhas}

A primeira questão deste grupo referia-se à expectativa do impacto ambiental devido à produção local / "onboard" do hidrogênio. E os respondentes avaliaram que para o futuro ocorrerá uma "Redução Alta" no impacto ambiental deste tipo de produção e também para a produção distante do local.

Com referência à redução do impacto ambiental em razão do uso de novas matérias primas, os respondentes avaliaram que a expectativa é de "Redução Alta"-"Redução média”, a longo prazo. Já para o item b da questão que se referia ao uso de novos processos para a produção de hidrogênio, a expectativa dos respondentes é que este item seja responsável por uma "Redução alta".

A expectativa dos respondentes para a continuidade do uso dos processos de produção de hidrogênio está mostrada na Figura 6-85. 


\begin{tabular}{|c|c|c|c|c|c|c|}
\hline \multicolumn{7}{|c|}{ Overall Matrix Scorecard } \\
\hline & Question & $\begin{array}{l}\text { Very High } \\
\text { Reduction }\end{array}$ & $\begin{array}{c}\text { High } \\
\text { Reduction }\end{array}$ & $\begin{array}{l}\text { Medium } \\
\text { Reduction }\end{array}$ & $\begin{array}{l}\text { Low } \\
\text { Reduction }\end{array}$ & $\begin{array}{c}\text { No } \\
\text { Reduction }\end{array}$ \\
\hline 1. & Coal Gasification & & 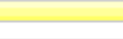 & 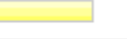 & & \\
\hline 2. & $\begin{array}{l}\text { Natural gas reforming } \\
\text { technology }\end{array}$ & $\square$ & 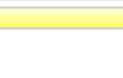 & 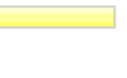 & & \\
\hline 3. & $\begin{array}{l}\text { Renewable Liquid Fuels } \\
\text { Reforming }\end{array}$ & $\square$ & 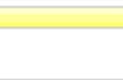 & +2 & & \\
\hline 4. & Thermal Dissociation & & & +2 & & \\
\hline 5. & Kvaerner Process & & & + & $\square$ & \\
\hline 6. & Plasmatron & & & 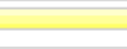 & $\square$ & \\
\hline 7. & Electrolytic Process & & & +2 & & \\
\hline 8. & Photolytic Processes & & & +2 & & \\
\hline 9. & Thermal Decomposition & & 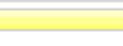 & 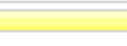 & & \\
\hline 10. & Gasification of Biomass & & & +2 & & \\
\hline 11. & Biological Process & & 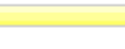 & +2 & $\square$ & \\
\hline \multicolumn{7}{|c|}{ Overall Matrix Scorecard } \\
\hline & Question & $\begin{array}{l}\text { Very High } \\
\text { Reduction }\end{array}$ & $\begin{array}{c}\text { High } \\
\text { Reduction }\end{array}$ & $\begin{array}{l}\text { Medium } \\
\text { Reduction }\end{array}$ & $\begin{array}{l}\text { Low } \\
\text { Reduction }\end{array}$ & $\begin{array}{c}\text { No } \\
\text { Reduction }\end{array}$ \\
\hline 1. & Coal Gasification & & 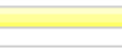 & & & \\
\hline 2. & $\begin{array}{l}\text { Natural gas reforming } \\
\text { technology }\end{array}$ & ए & 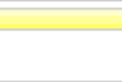 & 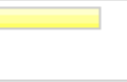 & & \\
\hline 3. & $\begin{array}{l}\text { Renewable Liquid Fuels } \\
\text { Reforming }\end{array}$ & & & 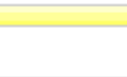 & & \\
\hline 4. & Thermal Dissociation & $\square$ & & $\square$ & & \\
\hline 5. & Kvaerner Process & $\square$ & & 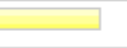 & & \\
\hline 6. & Plasmatron & $\square$ & & $\square$ & & \\
\hline 7. & Electrolytic Process & & & & $\square$ & \\
\hline 8. & Photolytic Processes & & & & & \\
\hline 9. & Thermal Decomposition & & & & & \\
\hline 10. & Gasification of Biomass & $\square$ & & & & \\
\hline 11. & Biological Process & & & & $\square$ & \\
\hline
\end{tabular}

Figura 6-85 - Expectativa de continuidade no uso dos processos de produção de $\mathrm{H} 2$ (na $1^{\mathrm{a}}$ rodada (superior) e $2^{\underline{a}}$ rodada (inferior) da pesquisa Delphi).

Em resumo os respondentes avaliaram em média, uma redução média para a gaseificação do carvão, indicando a preocupação com o processo poluente, apesar dos desenvolvimentos tecnológicos. Mas como o carvão é barato, mesmo com a preocupação ambiental e expectativa foi que a redução será média, o que implica ainda em grande impacto ambiental. Para os outros processos menos poluentes como eletrolítico se prevê uma baixa redução.

A expectativa dos respondentes para a questão do carvão e do gás natural parece divergir bastante, sobretudo considerando o continente. A Europa tende para uma expectativa de redução entre baixa e média para a gaseificação do carvão ao passo que a América do Norte+Central, América do Sul e Ásia e 
Oceania tendem entre redução alta e muito alta. Para a reforma do gás natural a divergência é bastante grande, exceto pelo grupo de respondentes da Ásia+Oceania que consideram que a redução será muito alta.Vide Figura 6-62 do item 6.6.1.18.

A expectativa de uso das matérias primas, a longo prazo, para produção de $\mathrm{H}_{2}$ está mostrada na Figura 6-86, para a primeira rodada (na parte superior da figura) e para a segunda rodada (na parte inferior da figura) da pesquisa Delphi. Também neste caso os respondentes possuem a visão de que, a longo prazo, o gás natural terá uma redução próxima à média. Os outros tipos de energia utilizada como matéria prima nos diferentes processos de produção de $\mathrm{H}_{2}$ são bem menos poluentes que o gás natural.

\begin{tabular}{|c|c|c|c|c|c|c|}
\hline \multicolumn{7}{|c|}{ Overall Matrix Scorecard } \\
\hline & Question & $\begin{array}{l}\text { Very High } \\
\text { Reduction }\end{array}$ & $\begin{array}{c}\text { High } \\
\text { Reduction }\end{array}$ & $\begin{array}{l}\text { Medium } \\
\text { Reduction }\end{array}$ & $\begin{array}{c}\text { Low } \\
\text { Reduction }\end{array}$ & $\begin{array}{c}\text { No } \\
\text { Reduction }\end{array}$ \\
\hline 1. & Hydrogen from PV & $\square$ & & 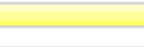 & & \\
\hline 2. & Hydrogen from Solar Thermal & & & 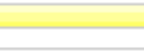 & $\square$ & \\
\hline 3. & Hydrogen from Wind & & & & & \\
\hline 4. & Hydrogen from hydropower & & & 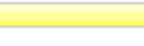 & $\square$ & \\
\hline 5. & Hydrogen from biomass & & & & & \\
\hline 6. & Hydrogen from Natural Gas & & & $\square$ & & \\
\hline \multicolumn{7}{|c|}{ Overall Matrix Scorecard } \\
\hline & Question & $\begin{array}{l}\text { Very High } \\
\text { Reduction }\end{array}$ & $\begin{array}{c}\text { High } \\
\text { Reduction }\end{array}$ & $\begin{array}{l}\text { Medium } \\
\text { Reduction }\end{array}$ & $\begin{array}{c}\text { Low } \\
\text { Reduction }\end{array}$ & $\begin{array}{c}\text { No } \\
\text { Reduction }\end{array}$ \\
\hline 1. & Hydrogen from PV & & & & $\square$ & \\
\hline 2. & Hydrogen from Solar Thermal & & & 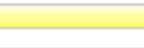 & & \\
\hline 3. & Hydrogen from Wind & & & & $\square$ & \\
\hline 4. & Hydrogen from hydropower & & & & $\square$ & \\
\hline 5. & Hydrogen from biomass & 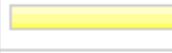 & 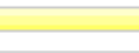 & 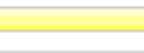 & $\square$ & \\
\hline 6. & Hydrogen from Natural Gas & 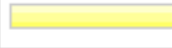 & & & & \\
\hline
\end{tabular}

Figura 6-86 - Expectativa de uso dos vários tipos de energia no processo de produção de $\mathrm{H} 2$ (na $1^{\underline{a}}$ rodada (superior) e $2^{\underline{a}}$ rodada (inferior) da pesquisa Delphi). 


\section{CONCLUSÕES}

Com base no cenário atual podemos concluir que a tecnologia das pilhas a combustível é emergente, visto que ainda devem ocorrer muitas etapas de desenvolvimento para que esta tecnologia possa ser considerada disponível em escala comercial.

O impacto ambiental da pilha a combustível não é nulo, como defendem muitos cientistas, e deve ser estudado para se obter uma avaliação clara do impacto ambiental real. O impacto da etapa de produção de hidrogênio parece ser o mais importante. Assim caso se utilize o hidrogênio proveniente da hidrólise da água poder-se-á ter uma menor liberação de gases responsáveis pelo aquecimento global. Mas deve-se também avaliar o impacto do uso do hidrogênio no ambiente, visto que este gás não é encontrado em quantidade na nossa atmosfera e poderá vir a ser um gás que indiretamente aumente, ainda que de forma branda, o aquecimento global.

Assim o impacto das pilhas no ambiente deve, em particular, avaliar o tipo de combustível a ser utilizado, ou seja, se é um combustível fóssil ou renovável. É aí que se localiza o grande responsável pelo impacto ambiental da pilha. O impacto referente à operação da pilha é realmente muito baixo quando não se utilizam combustível fosseis.

Considerando todo o ciclo da vida, a comparação entre os sistemas de turbinas a gás, operando em ciclo combinado ou em cogeração, as pilhas a combustível não oferecem uma clara vantagem, em termos de emissões de $\mathrm{CO}_{2}$, a não ser em caso de operação a cargas parciais, quando as turbinas têm sua eficiência muito diminuída.

Quanto à etapa de disposição final da pilha, parece ser a menos estudada visto que a tecnologia das pilhas a combustível ainda não está totalmente solidificada em relação aos materiais que serão realmente utilizados, quando a tecnologia tornar-se um processo de produção em larga escala. 0 material que mais causa preocupações parece ser a Platina, visto que é um metal precioso. 
Os resultados obtidos, através da análise de variância, mostram que não se faz necessária a pesagem das respostas de acordo com o grau de especialidade, setor de atuação, continente ou sexo, visto que as opiniões, em sua grande maioria, foram independentes destas características.

Os dados demonstram que ocorreu um aumento de consenso em parte dos itens do grupo G1, G2 e G4. Também é possível afirmar que na segunda rodada a média dos mais qualificados tendeu para a média global da primeira rodada entre 33 e $46 \%$ das questões, dependendo do grupo. E para o grupo dos respondentes menos qualificados ocorreu uma tendência da média da segunda rodada para a média global (1 ${ }^{a}$. Rodada) entre 15,38 e $45,45 \%$ das questões, dependendo do grupo.

Quanto à pesquisa efetuada a posição global sobre o impacto ambiental foi positiva, pois demonstrou que, para muitos especialistas, existe a expectativa de soluções para os problemas específicos, ou contornos que podem ser encontrados, que implicam em diminuição do impacto ambiental das pilhas a combustível.

Foi surpreendente que boa parte dos respondentes considerasse que os catalisadores baseados em metais do grupo PGM, possa ser substituído por outros tipos de metais que causem uma grande diminuição do impacto ambiental.

A expectativa dos respondentes remete à conclusão que as emissões, referentes à etapa de produção da pilha tipo PEM, serão reduzidas devido à opção dos respondentes pela substituição do catalisador (grupo da Platina) ou a diminuição da carga através da mistura com outros metais menos poluentes. A diminuição do impacto ambiental também será considerável com a previsão de que a reciclagem possa atingir entre $80-99 \%$, e a opção mais escolhida foi de reciclagem até $99 \%$.

Assim o cenário que se forma a partir das respostas é uma pilha tipo PEMFC que, a longo prazo apresenta as seguintes características:

- as pilhas PEMFC terão menor impacto ambiental (redução entre média e média alta);

- o projeto da PEMFC pode sofrer alterações (probabilidade entre média e média baixa) de modo que este novo projeto reduza o impacto ambiental;

- alguns dos itens utilizados nas pilhas podem ser substituídos por itens de menor impacto ambiental ou mesmo podem ser abolidos. 
Para as pilhas PAFC a expectativa a longo prazo é que a redução no impacto ambiental esteja entre redução baixa e redução média alta, denotando que o impacto ambiental será menos reduzido que no caso das pilhas PEMFC,. Provavelmente em razão do impacto ambiental atual das PAFC ser menor que o das PEMFC.

Foi aparente a preocupação ambiental dos europeus com a reciclagem através das respostas e previsão de grande evolução da reciclagem (até 99\% de recuperação). Esta preocupação foi muito menor nos asiáticos. Este fato pode ser devido não só à maior consciência ambiental dos europeus, mas devido à infraestrutura de reciclagem já implantada na Comunidade Européia. Mas deve ser lembrado também que o custo da Platina é alto e também é um dos motivos da preocupação com a reciclagem.

Para as pilhas de carbonato fundido (MCFC), a expectativa a longo prazo é que a redução no impacto ambiental seja redução média. E esta redução é levemente menor que no caso da PEMFC provavelmente porque a eficiência da MCFC já é maior que a da PEM e da PAFC, ou seja, os respondentes podem ter dificuldade em visualizar pontos no qual se possa diminuir o impacto ambiental das pilhas MCFC visto que ela já tem atualmente um menor impacto ambiental. $A$ possibilidade de um novo tipo de projeto implicar na redução do impacto ambiental é de Probabilidade Média. E sobre o catalisador utilizado os respondentes têm a expectativa que continue o mesmo e apenas se reduza a quantidade utilizada devido à possibilidade de mistura com outros materiais.

Com relação à produção de hidrogênio a celeuma entre a produção ser efetuada próxima ao local de consumo/"onboard" ou em local distante do consumo não teve uma preferência em termos de redução do impacto no futuro, pois os respondentes possuem a mesma expectativa de redução alta para o futuro. E também existe a expectativa de redução entre redução alta-redução média para os novos processos e novas matérias primas utilizadas na produção de hidrogênio.

É importante ressaltar que o objetivo da pesquisa Delphi realizada não é o de gerar previsões estatísticas exatas sobre os temas abordados, mas sim tendências futuras e "insights" que possam ser úteis para apoiar os tomadores de decisão a definir os rumos estratégicos de seus negócios. 
Wright et al. (2001) já dizia que a despeito das inúmeras polêmicas acadêmicas que cercam a metodologia Delphi, observamos que, se utilizada com criatividade e com cuidados, pode ser um instrumento de grande valia às atividades que buscam identificar oportunidades e tendências sobre o futuro.

A contribuição deste trabalho é a indicação de que devem ser efetuadas pesquisas direcionadas para novos catalisadores, que não sejam metais do grupo PGM, para pilhas PEMFC e PAFC.

Dessa forma, o objetivo desse trabalho, como já foi dito anteriormente, não foi o de esgotar o tema impacto ambiental das pilhas a combustível e as discussões sobre ele. $\mathrm{O}$ objetivo foi o de apresentar uma contribuição que tem se mostrado interessante para a aplicação de uma metodologia de pesquisa qualitativa, a técnica Delphi de previsão de tendências, suscitando dúvidas, críticas e lançando uma semente de discussão sobre o assunto.

Outro trabalho futuro que é previsto é a utilização de fontes de energia menos poluentes / renováveis para produção de hidrogênio. Este trabalho prevê, sobretudo para o caso do Brasil, a utilização da energia "fora de pico", proveniente das hidrelétricas, que hoje está disponível e sem uso. A utilização desta energia permitiria a produção de $\mathrm{H}_{2}$, o qual ficaria estocado para alimentar pilhas a combustível estacionárias, que no horário de pico, produziriam energia elétrica e a colocariam na rede. Esta solução permitiria que se produzisse energia sem a necessidade de construção de novas centrais elétricas e hidrelétricas, que também causam grande impacto ambiental na etapa da construção. 


\section{REFERÊNCIAS}

AMARA, R. and Salanik, G. Forecasting: from conjectural art toward science. Technological Forecasting and Social Change. v.3, n.3, p.415-426, 1972.

ANDERSON, T. W. and Finn, J. D. The New Statistical Analysis of Data, Springer, 1996.

ARGONNE National Laboratory Greet 2.7(2007) Disponível em: www.transportation.anl.gov/modeling simulation/GREET/ Acesso em 28/03/2009.

\begin{tabular}{llrr}
\multicolumn{1}{c}{ BRINKMAN, G. Economics and Environmental Effects of } & Hydrogen \\
Production $\quad$ Methods, & $2003 . \quad$ Disponível & em: \\
http://www.publicpolicy.umd.edu/Fetter/students/papers.htm & Acesso & em \\
\hline $18 / 05 / 2009$. & &
\end{tabular}

BROCKHAUS, W. L. and Mickelsen, J. F. An analysis of prior Delphi applications and some observations on its future applicability, Technological Forecasting and Social Change, v.10, p.103-110, 1977.

BROMBERT, L.; Crane, S. ; Rabinovich, A.; Kong, Y.; Cohn, D. R. ; Heywood, J.; Alexeev, N. and Samokhin, A. Hydrogen Generation from PLASMATRON reformers: a promising technology for NOx adsorber regeneration and other automotive applications. Diesel Engine Emission Reduction (DEER) Workshop, 2003 Newport RI, August 24-28, 2003

CARLBRING,P.; Brunt, S.; Bohman, S.; Austin, D.; Richards, J.; Ost, L. and Anderson, G. Internet vs. paper and pencil administration of questionnaires commonly used in panic/agoraphobia research, Computers in Human Behavior v. 23, 1421-1434, 2007.

CAMPBELL, V How RAND Invented the Postwar World. American Heritage - Invention \& Technology Magazine, p.50-59, v. 20, n.1, summer, 2004. Disponível em: http://www.rand.org/about/history/Rand.IT.Summer04.pdf Acesso em 16/03/2009.

CARDOSO, L. R. de A.; Abiko, A. K.; Haga, C. R.; Inouye, K. P.; Gonçalves, O. M. Prospecção de futuro e Método Delphi: uma aplicação para a cadeia produtiva da construção habitacional. Ambiente Construído, Porto Alegre, v. 5, n. 3, p. 63-78, jul./set. 2005.

CLINE, W.R. The Economics of Climate Change. Washington: Institute for International Economics, 1993.

CONTADINI, J.F.; Moore, R. M. Life cycle assessment of fuel cell. 
vehicles- A case study summary. Int. Journal of Life Cycle Assessment, v. 8, n. 3, p.179-180, 2003.

CONTADINI, M.R.S. Life cycle assessment of fuel cell vehicles ,Dealing with uncertainties. 2002a. Dissertação (PhD) - University of California, Davis, USA.

CONTADINI, J.F.; Moore, R. M. Life cycle assessment of fuel cell vehicles- A methodology Example of input data treatment for future technology. Int. Journal of Life Cycle Assessment, v. 7(online first), p. 1-12, 2002b.

COOPER, J; Lee, S.; Elter, J.; Boussu, J. and Boman, S. Life cycle design metrics for energy generation technologies: Method, data, and case study. J. of Power Sources. Available online 27 September 2008,

CORTINA, J. M. What is coefficient alpha? An examination of theory 3 and applications J. of Applied Psychology, v.78, n.1, p. 98-104, 1993.

CRONBACH, L. Coefficient alpha and the internal structure of tests. Psychometrika, 16, p. 297-334, 1951.

Citation Classics. Disponível em: http://www.garfield.library.upenn.edu/classics1978/A1978EQ39200002.pdf Acesso em 20/03/2009.

CUHLS, K. and Grupp, H. Alemanha: abordagens prospectivas nacionais. Parcerias Tecnológicas, Brasília, n. 10, p.75-104, março, 2001.

DERWENT, R. G. et al. Transient behavior of tropospheric ozone precursors in a floba 3-D CTM and their indirect greenhouse effects. Climate Change, v. 49, p. 463-487, 2001.

Disponível

EERE-Energy Efficiency and Renewable Energy. Fuel Cells. http://www.eere.energy.gov/hydrogenandfuelcells/fuelcells/fc types.html\#alkaline . Acesso em 15/05/2005 $\begin{array}{ccccc}\text { EXPO } 2005 \quad \text { AICHI JAPAN } & \text { Disponível } & \text { em: } \\ \text { http://www.expo2005.or.jp/en/technology/new energy } & \text { 03.html } & \text { Acesso } & \text { em }\end{array}$

EUROPEAN FERTILIZER MANUFACTURERS' ASSOCIATION Production of phosphoric acid. Best Available Techniques for Pollution Prevention and Control in the European Fertilizer Industry. Booklet no. 4 of 8 , 2000.

EUROFOUND - European Foundation for the Improvement of Living and Working Conditions Handbook of Knowledge Society Foresight, 2003. 
FACULTY OF ENGINEERING UNIVERSITY OF STRATHCLYDE Energy Systems and the Environment - PV-fuel cell energy system. Disponível em:

http://www.esru.strath.ac.uk/EandE/Web sites/9900/hybrid PV FC/environment.html Acesso em 14/05/2005.

FIATES, J. E. A. Geração de Riqueza por Meio de Ciência, Tecnologia e Inovação. Conferência Nacional de CTI, 2005. Disponível em: www.cgee.org.br/atividades/redirect.php?idProduto=2185 Acesso em 02/03/2009

FRIENDS OF EARTH New research shows global "footprint" of motoring as FOE puts the car on trial. 1996. Disponível em: http://www.foe.co.uk/pubsinfo/infoteam/pressrel/1996/19960606151456.html Acesso em 25/03/2005

Fuel Cell Demonstration Project Disponível em http://dnr.metrokc.gov/wtd/fuelcell/index.htm Acesso em 15/05/2005

GEORGE, R.; Hassmann, K. Fuel Cell Applications and TypesDevelopments and Potentials Power Journal. 2001.

GEORGHIU, L. The United Kingdom Technology Foresight Program. Futures, v.28, n. 4, pp. 359-377, 1996.

GETACHEW, A. Environmental system Analysis of waste management. 2001. Master Thesis - Royal Institute of Technology of Stockholm, Suécia.

GIOVINAZZO, R. A. Modelo de Aplicação da Metodologia Delphi pela Internet - Vantagens e Ressalvas Administração On Line Prática - Pesquisa Ensino, v. 2, n. 2, 2001.

GONÇALVES, A. Jornal O Estado de São Paulo, 215/01/2009, p10, São Paulo, Brasil.

GORDON, T. J., Helmer, O. Report on a long-range forecasting study. Santa Monica, California, The RAND Corporation, September 1964. (Relatório Interno P-2982)

GRAHAM, B.; Regehr, G.; Wright, J. G. Delphi as a method to establish consensus for diagnostic criteria. Journal of Clinical Epidemiology, v. 56, n.12, p. 1150-1156, 2003.Futures, v.28, n. 4, pp. 359-377, 1996.

GRIMES, C, A.; Varghese, O. K. and Ranjan, S. Light, water, hydrogen: the solar generation of hydrogen by water photoelectrolysis, Springer, 2007.

GROT, S. and Grot, W. Platinum Recycling Technology Development Department of Energy, DOE Hydrogen Program, Progress Report, 2008. Disponível em: http://www.hydrogen.energy.gov/pdfs/progress08/v f 2 grot.pdf Acesso em 04/03/2008. 
GUPTA, U. G., Clarke, R. E. Theory and Applications of the Delphi Technique: A Bibliography (1975-1994). Technological Forecasting and Social Change, n. 53, p. 185-211, 1996.

GUTTMAN, L. A basis for analyzing test-retest reliability. Psychometrika, 10 (4), 255-282, 1945.

A.R. Hakstian, T.E. Whalen, A K-sample significance test for independent alpha coefficients, Psychometrika 41 219-231, 1976.

HART, D., Anghel, A. T.; Huijsmans, J. and Vuille, F. A quasi-Delphi study on technological barriers to the uptake of hydrogen as a fuel for transport applications-Production, storage and fuel cell drivetrain considerations, J. Power Sources, 2009, doi:10.1016/j.jpowsour.2008.12.122

HUTCHINSON E.J.; Pearson, P.J. An evaluation of the environmental and health effects of vehicle exhaust catalysts in the UK. Environ. Health Perspect., v.112, n.2, p.132-41, 2004.

HALAL, W.E., Kull, M.D., and Leffmann, A.: Emerging Technologies. What's Ahead for 2001-2030? The Futurist, Nov.-Dec, 1997

HART;D.; Bauen, A.;Chase, A.;Howes, J. Liquid biofuels and hydrogen from renewable resources in the UK to 2050. UK Department for Transport, Sept. 2003. Disponível em: http://www.dti.gov.uk/energy/sepn/h2biofuelsassessment.shtml Acesso em 25/03/2005

HETLAND, J. and Karlsen, J. E. Prospectives for the Provision of Hydrogen in a European Context - a Selection of plausible Hydrogen Routes and Policy Recommendations. In: 15th world hydrogen energy conference, Yokohama, Japan, June/July 2004.

HUFFMAN, G. L.; Lee, C. C.; Rolander, S. and White, J. T. Energy Sources part B, v.1, p.67-74, 2006.

HUNGERBUHLER, K. Editorial, International Journal of LCA, v.4, n.1, p.1, January 1999.

INT-Instituto Nacional de Tecnologia - Prospecção Tecnológica: Metodologias e Experiências Nacionais e Internacionais, Projeto CTPetro Tendência Tecnológicas, Nota Técnica NT14, Jan. 2003

INTERNATIONAL ORGANIZATION FOR STANDARDIZATION Codes for the representation of names of countries and their subdivisions - Part 1: Country codes, 2006 (ISO-3166 -1:2006). A lista está disponível em: http://www.iso.org/iso/country codes/iso 3166 code lists/english country names and code elements.htm\#z Acesso em 20/04/2009. 
Policy Makers, vol. II, 2001.

JONES, P.D. and Mann, M.E. (2004), 'Climate over Past Millennia', Review of Geophysics, 42, RG2002, doi: 10.1029/2003RG000143.

KARAKOUSSIS, V.; Leach, M.; Van der Vorst, R.; Brandon, N. P. The environmental impact of manufacturing planar and tubular solid oxide fuel cells. J. of Power Sources v.101, p.10-26, 2003.

KARAKOUSSIS, V.; Leach, M.; Van der Vorst, R.; Hart, D.; Lane, J.; Pearson, P. and Kilner, J. Environmental emission of SOFC and SPFC System Manufacture and Disposal. Imperial College of Science, Technology and Medicine, 2000. (F/01/00164/REP). Disponível em: http://www.berr.gov.uk/files/file15216.pdf. Acesso em 20/03/2005.

KIRK-OTHMER - Kirk-Othmer Encyclopedia of Chemical Technology, Vol. 4, Fourth Edition, John Wiley \& Sons, New York, $1996 a$.

KIRK-OTHMER - Kirk-Othmer Encyclopedia of Chemical Technology, Vol. 20, Fourth Edition, John Wiley \& Sons, New York, 1996B.

KIKUCHI, R. Penetration of hydrogen-based energy system and its potential for causing global environmental change: Scoping risk analysis based on life cycle thinking Environmental Impact Assessment Review, n. 26, p. 206218, 2006.

KLUCHAREV, V..; Hytonen, K.; Rijpkema, M. and Fernández, G. Reinforcement Learning Signal Predicts Social Conformity Neuron, 61(1), p. 140151, Jan. 2009.

KONING, A. J. and Franses, P. H. Confidence Intervals for Cronbach's Coefficient Alpha - ERIM Report Series Research in Management ERS-2003-041-MKT, June 2003.

KRUSE,B.; Grinna,S.; Buch, C. Hydrogen. The Belona Foundation Noruega, 2002. (Report 6:2002).

LANDETA, J. Current validity of the Delphi method in social sciences Technological Forecasting \& Social Change v.73, p. 467-482, 2006.

LARSEN, H.; FEIDENHANS'L, R. and Petersen, L. S. Hydrogen and its competitors, Risø Energy Report n. 3, Risø National Laboratory, October 2004.

LEONTITSIS, A. Cronbach's Alpha Software. Mathworks - Matlab Central File, Jun. 2005. Disponível em: http://www.mathworks.com/matlabcentral/fileexchange/7829 Acesso em 18/03/2009.

LEONTITSIS, A. and Pagge, J. A simulation approach on Cronbach's alpha statistical significance Mathematics and Computers in Simulation, v. 73, 
n. 5, p. 336-340, Jan. 2007.

LILEWELLYN, J. The business of Climate Change - Challenges and Opportunities, Lemon Brothers, Feb.-2007.

LINSTONE, H. A., Turoff, M. (eds.) The Delphi Method: Techniques and Applications. Addison-Wesley Publishing Company, Massachusetts, 2002.

LIPINSKI, A. and Loveridge, D. How we forecast: Institute for the Future's study of the UK 1978-95. Futures, v. 14 n. 3, p.205-239, June, 1982.

LOVERIDGE, D. Foresight, Technology Assessment and Evaluation- Synergy or disjunction? Manchester, University of Manchester, Ideas in Progress - Paper Number 5, October 1996.

LOVERIDGE, D. Who is an expert? Manchester, University of Manchester, March 2001. (Discussion Paper Series Paper 22)

LOVERIDGE, D. Experts and foresight: Review and experience. Manchester, University of Manchester, June 2002. (Discussion Paper Series Paper 02-09)

LOVERIDGE, D. On Delphi questions. Manchester, University of Manchester, October 2002. (Discussion Paper Series Paper 31)

LUNGHI, P.; Bove, R.; Desideri, U. Life cycle assessment of fuel cells bases landfill gas energy conversion technologies. Journal of Power Sources, v.131, p.120-126, 2004.

LUNGHI, P.; Bove, R.; Desideri, U. Life cycle assessment of molten carbonate fuel cells system. Journal of Power Sources, v.137, p.239-247, 2004.

MAGRINI-BAIR, K. Czernik, S. French, R., Parent, Y. Ritland, M. and Chornet, E. Fluidizable Catalysts for Producing Hydrogen by Steam Reforming Biomass Pyrolysis Liquids In: Presentation to the 2002 Annual Hydrogen Review held May 6-8, 2002 in Golden, CO.

MANN, M.E. et al. 'Global Scale Temperatures Patterns and Climate Forcing over the Past Six Centuries', Nature, 392, p. 779-787, 1998

Mann, M.E et al. 'Northern Hemisphere Temperatures during the Past Millennium: Inferences, Uncertainties, and Limitations', Geophysical Research Letters, 26, p. 759-762, 1999.

MANN, M.E. et al. 'On Past Temperatures and Anomalous Late 20th Century Warmth', Eos, 84, pp. 419-420, 2003.

Martin, B.R. and Johnston, R. Technology Foresight for Wiring Up the National Innovation System: Experiences from Britain, Australia and New Zealand, Technological Forecasting and Social Change, Vol. 60, No. 1, 1999. 
MAXMIND - Continent List. Disponível em: http://www.maxmind.com/app/country continent Acesso em 20/04/2009.

MCINTYRE, S. and MCKITRICK, R. (2003), 'Corrections to the Mann et al. (1998) Proxy Data Base and Northern Hemispheric Average Temperature Series', Energy and Environment, 14, pp. 757-771.

MCINTYRE, S. and MCKITRICK, R. (2005a), 'The M\&M Critique of the MBH98 Northern Hemisphere Climate Index: Update and Implications', Energy and Environment, 16, pp. 69-100.

MCINTYRE, S. and MCKITRICK, R. (2005b), 'Hockey Sticks, Principal Components, and Spurious Significance', Geophysical Research Letters, 32, L03710

MEHTA, V. and COOPER, J. Review and analysis of PEM Fuel Cell design and manufacturing Journal of Power Sources, 114, p.32-53, 2003.

MILES, I. and Keenan, M. Practical Guide to regional Foresight in the United Kingdom. European Commission Directorate for Research K, Unit "Science and Technology Foresight". Disponível em: http://foretech.online.bg/docs/CGRF.pdf Acesso em 25/02/2008.

MOCK, P. and SCHMID, S. A. Fuel cells for automotive powertrains A techno-economic assessment Journal of Power Sources, 190, p.133-140, 2009.

MORENO, A. Hydrogen and fuel cells in CCS power plant. In: INTERNATIONAL SCHOOL OF GEOPHYSICS - $30^{\circ}$ Course $\mathrm{CO}_{2}$ Capture \& Storage, Erice, Nov. 2007.

NADAL, G. Life Cycle Air Emissions from Fuel Cells and Gas Turbines in Power Generation. Dissertação (Msc), London University, UK, 1997.

NASA - GISS Surface Temperature Analysis. Disponível em: http://data.giss.nasa.gov/gistemp/ Acesso em 26/11/2008

NASA - GISS Surface Temperature Analysis - Global Temperature Trends: $2005 \quad$ Summation, $2005 . \quad$ Disponível em: http://data.giss.nasa.gov/gistemp/2005/ . Acesso em 01/12/2008.

NASA - GISS Surface Temperature Analysis - 2007 Was Tied as Earth's Second-Warmest Year, $2007 . \quad$ Disponível em: http://www.giss.nasa.gov/research/news/20080116/ Acesso em 26/11/2008.

NATIONMASTER Encyclopedia - Disponível em: http://www.nationmaster.com/encyclopedia/Delphi\#Oracle Acesso em 16/03/2009.

ONISZK-POPLAWSKA, A.; Bonacina, M.; Joergensen, B. H; Velte, D. and Wehnert, T. EurEnDel - European Energy Delphi. In: ENER FORUM 5. 
TECHNOLOGICAL CHANGE, MARKET REFORM AND CLIMATE POLICIES. Bucharest, Romania, 16-17 October 2003.

OKOLI, C. and Pawlowski, S. D. The Delphi method as a research tool: an example design considerations and applications Information \& Management, v.42, p.15-19, 2004.

Phosphoric Acid - Livestock. Organic Materials Review Institute. Disponível em www.omri.org/Phosporic acid livestock.pdf Acesso em 14/05/2005.

PALM, T., Buch, C. Kruse, B.; Sauar, E. Green Heat and Power. Noruega: The Bellona Foundation, June 1999. (Report 3:1999).

PEHNT, M. Life Cycle Assessment of fuel cells and relevant fuel chains. In PROC. HYFORUM THE INTERNATIONAL HYDROGEN ENERGY FORUM $2000,11^{\text {th }}-15^{\text {th }}$ Sept., Munich.

PEHNT, M. Life-cycle assessment of fuel cell stacks production Int. Journal of Hydrogen Energy, v.26, p.91-101, 2001a.

PEHNT, M. Ganzheitliche Bilanzierung von Brennstoffzellenin der Energie- und Verkehrstechnik Dissertação apresentada na Universität Stuttgart, 2001b.

PEHNT, M. Assessing future energy and transport systems: The case of Fuel Cells-Part1: Methodological aspects Int. Journal of Life Cycle Assessment, v.8, n.5, p.283-289, 2003a.

PEHNT, M. Assessing future energy and transport systems: The case of Fuel Cells-Part2: Environmental Performance Int. Journal of Life Cycle Assessment, v.8, n.6, p. 365-378 (2003b).

PEHNT, M. Life cycle analysis of fuel cell system components. In: HUBERT, W. V.; Glasteiger, A.; Lamim, A.(Ed.) Handbook of Fuel Cells Fundamentals Technology and Applications, Chichester: John Wiley \& Sons, 2003c. v. 4. p.1293-1317.

PETIT, J.R. et al. (1999), 'Climate and Atmospheric History of the past 420,000 years from the Vostok Ice Core, Antarctica', Nature, 399, pp. 429-436.

Caroline.

POPOV, N. B. Molten Carbonate Fuel Cells. University of South http://www.che.sc.edu/faculty/popov/drbnp/WebSite/Research\%20-

\%20Molten\%20Carbonate\%20Fuell\%20Cell.html Acesso em 21/05/2005

PORTER, A. et al. Forecasting and management of technology. John Wiley, New York, 1991.

PORTER, A. et al. Technology futures analysis: Toward integration of 
the field and new methods. Technological Forecasting \& Social Change, v.71, n.3, p.287-303, 2004.

PRATER, M.; Ehhalt, D. et al. IPCC 2001 - Working Group I: The Scientific Basis, cap 4: Atmospheric Chemistry and Greenhouse Gases 2001. Disponível

em: http://www.grida.no/publications/other/ipcc tar/?src=/CLIMATE/IPCC TAR/WG1/1 27.htm Acesso em 21/05/2009.

RADE, I. Requirement and availability of scarce metals for fuel cell and battery vehicles. Thesis for the degree of doctor of philosophy - Chalmers University of Technology and Goterborg University Sweden, 2001.

RAUGEI, M.; Bargigli, S. and Ulgiati, S. A multi-criteria life cycle assessment of molten carbonate fuel cells (MCFC) - a comparison to natural gas turbines, International Journal of Hydrogen Energy, v.30, p.123-130 (2005).

RODER, A. Integration of Life-Cycle Assessment and Energy Planning Models for the Evaluation of Car Powertrains and Fuels. Dissertação (Doctor of Natural Sciences) - Swiss Federal Institute of Technology, 2001.

ROOIJETN, J. Van; Kleijn, R.; Keoleian, G. A. and Hemmes, K. A Life Cycle Assessment of the PureCellTM Stationary Fuel Cell System: Providing a Guide for Environmental Improvement Dissertação (Master of Sciences) Industrial Ecology, University of Michigan, 2006.

SGL_Carbon. Personal communication, cited in: PEHNT, M. Life-cycle assessment of fuel cell stacks Int. Journal of Hydrogen Energy, v.26, p.91-101, 2002.

SALANCIK, J. R.; Wenger, W. and Helfer, E. The construction of Delphi Event Statement Technological Forecasting and Social Change, v. 3, p.65-73, 1971.

SANT'ANA, P. H. Análise prospectiva de tecnologias de energia: validação e análise de uma consulta Delphi com especialistas no Brasil, 2005. Dissertação (Mestrado) - Universidade de Campinas (UNICAMP), Campinas.

SCHAEFFER, G. Jan FUEL CELLS FOR THE FUTURE -A contribution to technology forecasting from a technology dynamics perspective, 1998. Dissertação (Doutoramento) - Universidade de Twente, Holanda.

SCHULTZ, K.. Thermochemical production of Hydrogen from solar and nuclear energy. In: Presentation to the STANFORD GLOBAL CLIMATE AND ENERGY PROJECT WORKSHOP, April, 2003.

SHIN, T. Using Delphi for a Long-Range Technology Forecasting, 
and Assessing Directions of Future R\&D Activities The Korean Exercise Technological Forecasting and Social Change, v.58, p.125-154, 1998.

SHINNAR, R. The hydrogen economy, fuel cells and electric cars, Technology in Society, v.25, p.455-476, 2003.

SHINNAR, R. The mirage of $\mathrm{H}_{2}$ economy.

SOLI, C., Fission or fossil? A Comparative Hybrid life production Methods. Master Thesis to Norwegian University of Science and Technology, 2004.

SPATH, P. L. and Mann, M. K. Life Cycle Assessment of Hydrogen Production via Natural Gas Steam Reforming, National Renewable Energy Laboratory, Feb. 2001 (NREL/TTP-570-27637).

SPIEGEL, R. J. Platinum and fuel cells Transportation Research part D, v.9, p.357-371, 2004.

STATSOFT, Inc. Electronic Statistics Textbook, 2007, Tulsa, OK. Disponível em: http://www.statsoft.com/textbook/stathome.html Acesso em 16/03/2009.

TROMP, T. K. et al, Potential Environmental Impact of a Hydrogen Economy on the Stratosphere, Science, 300, p. 1740-1741, June 13, 2003).

UK DEPARTMENT FOR TRANSPORT. Platinum and Hydrogen for fuel cell vehicles, 2006.

UNIVERSITY OF STRATHCLYDE. Domestic PV/Fuel Cell Systems. Disponível em http:/www.esru.strath.ac.uk/EandE/Web sites/9900/hybrid PV FC/index.html Acesso em 14/05/2005.

UPADHYAYA, J.; Peters, R.W.; Fouad, H.F.; Ahluwalia, R. K.; Doss, E. D. and Das, T. Environmental Impact of Fuel Cell Technology for Electric Power Generation: An Overview and Case Studies. Cheric-Chemical Engineering Research Information Center, Korea, 2001.

UTC POWER. Tipos de pilhas. Disponível em: http://www.utcfuelcells.com Acesso em 14/05/2005.

UTC POWER. UTC Power Fuel Cells Heading Aloft Again on Space Shuttle, 2006.2 Disponível em: http://www.utcpower.com/fs/com/bin/fs com Page/0,11491,071,00.html Acesso em 21/06/2009.

UTGIKAR, V. and Thiesen, T. Life cycle assessment of high temperature electrolysis for hydrogen production via nuclear energy. Int. Journal of Hydrogen Energy, v.31, p.939-944, 2006. 
VAN ZOLINGEN, S. J. and Klaassen, C. A. Selection processes in a Delphi study about key qualifications in Senior Secondary Vocational Education Technological forecasting and Social Change, n. 70, p. 317-340, 2003.

VITORIA, Florbela, ALMEIDA, Leandro S. e PRIMI, Ricardo. Unidimensionalidade em testes psicológicos: conceito, estratégias e dificuldades na sua avaliação. Psic, jun. 2006, vol.7, n.1, p.01-07. ISSN 1676-7314.

ZACKIEWICZ, M.; Salles Filho, S. Technological Foresight: um instrumento para política científica e tecnológica. Parcerias estratégicas, v. 10, p. 144-161, 2001.

S.M. van Zyle, N. Heinz, D.G. Nel, On the distribution of the maximum likelihood estimator of Cronbach's alpha, Psychometrika 65 271-280, 2000.

WEBLER, T. et al. A Novel Approach to Reducing Uncertainty: The Group Delphi. Technological forecasting and Social Change, n. 39, p. 253-263, 1991.

WEIDEMA, B. P.; Frees, N. and Nielsen, A. M. Marginal Production Technologies for Life Cycle Inventories. Int. Journal of Life Cycle Assessment, v.4, p.48-56, 1999.

(data file). Disponível em: http://en.wikipedia.org/wiki/List of countries by continent (data file) Acesso em 20/04/2009. cycle assessment.

WORLD ENERGY COUNCIL Comparison of Energy Systems using life

WRIGHT, J. T.C. e Giovinazzo, R. A. WEBLER, T. et al. Delphi - Uma ferramenta de apoio ao planejamento prospectivo. Caderno de Pesquisas em Administração, v. 01, n. 12, p. 54-65, 2000.

WRIGHT, J.; BORJA REIS, C.; GIOVINAZZO, R. Prospecção Estratégica para 2003 com a Utilização do Método Delphi. In.: V SEMEAD Seminários em Administração, 27-28 jun. 2001. Anais. São Paulo. FEA-USP: Departamento de Administração e Programa de Pós Graduação. CD ROM V Semead, área de Política de negócios e Economia de empresas, p.1-13.

WURSTE , R. PEM Fuel Cells in Stationary and Mobile Applications infrastructural requirements, environmental benefits, efficiency advantages and economical implications. Published at the Electric and Lighting Industry Biennial, September 29th to October 4th 97, Buenos Aires. Hyweb-Hydrogen and fuel cell information system. 


\section{APÊNDICE A- Lista dos Tópicos a serem discutidos}

Grupo 1- Pilhas tipo PEM

1- Catalisadores

2-Membranas

3-Placas Bipolares

4-Outros Materiais

Grupo 2- Pilhas tipo PAFC

1- Catalisadores

2-Membranas

3-Placas Bipolares

4-Outros Materiais

Grupo 3- Pilhas tipo MCFC

1- Catalisadores

2-Membranas

3-Placas Bipolares

4-Outros Materiais

Grupo 4- Combustíveis utilizados nas pilhas

1-H2 obtido a partir da eletrólise da água

2- $\mathrm{H}_{2}$ obtido a partir da reforma de hidrocarbonetos

3- $\mathrm{H}_{2}$ obtido a partir da reforma de biomassa

4-Outros combustíveis, exceto $\mathrm{H} 2$ 


\section{APÊNDICE B- QUESTIONÁRIOS}

\section{B.1- Questionário da 1ª. Fase.}

\section{$4 \%$}

FORECAST OF THE ENVIRONMENTAL IMPACT, IN THE LONG-RANGE, OF THE FUEL CELLS OF LOW and MEDIUM TEMPERATURE APPLYING DELPHI METHOD

Dear Madam, Dear Sir:

You are invited to participate in our survey FORECAST OF THE ENVIRONMENTAL IMPACT, IN THE LONG-RANGE, OF THE STACKS (FUEL CELLS) OF LOW and MEDIUM TEMPERATURE APPLYING DELPHI METHOD and answer the Delphi.

This project is a fuel cell Delphi suwey, assessing technological developments, market trends and social visions for environmental impact of fuel cell in 2030

The results of the survey will be used to produce a long-range perspective on the Environmental impact of fuel cell in the future. Furthermore, they will serve as background information to define energy research policies and will be avaliable guideline for environmental impact.

In this survey, approximately 200 people will be asked to complete a survey with questions about forecast of environmental impact of fuel cell. It will take approximately 15 minutes to complete the questionnaire.

Your participation in this study is completely voluntary. There are no foreseeable risks associated with this project. However, if you feel uncomfortable answering any questions, you can withdraw from the survey at any point. It is very important for us to learn your opinions.

Your survey responses will be stricly confidential and data from this research will be reported only in the aggregate. Your information will be coded and will remain confidential.

If you have questions at any time about the survey or the procedures, you may contact Maria Alice Morato Ribeiro at 55-11-38169171 ext. 250 or by email at the address specified below.

Thank you very much for your time and support.

The survey was divided in 4 groups, subdivided in 4 subgroups. The groups are listed below.

Group 1 - PEM Fuel Cell.

Group 2 - Phosporic Acid Fuel Cell.

Group 3 - Molten Carbonate Fuel Cell.

Group 4 - Fuels used in the Fuel Cell 
1-Please mark the box that best describes your experience:

1. Academic research

2. Industrial research and development

3. Corporate strategy for research and

4. Technology

5. Marketing/business management

6. Production/operation

7. Consulting

8. Public agency/politics

The survey was divided in 4 groups, subdivided in 4 subgroups. The groups are listed below.

Group 1 - PEM Fuel Cell.

Group 2 - Phosphoric Acid Fuel Cell.

Group 3 - Molten Carbonate Fuel Cell.

Group 4 - Fuels used in the Fuel Cell-

Group 1 (PEM fuel cell)

2-In this question you assign your level of knowledge in PEM fuel cell:

1. EXPERT: you assign yourself if consider inside of the group of people that currently is dedicated to this topic with depth.

2. KNOWLEDGEABLE: you assign this classification in the following cases:a.If you are becoming an expert, but lacks some experience to dominate the topic.b.If you already was an expert in the topic has some years, but you consider at the moment little brought up to date in the topic.c.If you work in correlated area, but contribute regularly with subjects related to this topic.

3. FAMILIARIZED: you designate if you know the majority of the used arguments in the quarrels on the topic, you read about the subject, and has an opinion about it.

4. UNFAMILIAR

3-Group 1 (PEM fuel cell)Taking as base the current environmental impact of some items that compose a PEM fuel cell, what is your expectation of reduction concerned to environmental impact, in next 20 years?

\begin{tabular}{|c|c|c|c|c|c|}
\hline & $\begin{array}{c}\text { Very High } \\
\text { Reduction }\end{array}$ & $\begin{array}{c}\text { High } \\
\text { Medium } \\
\text { Reduction }\end{array}$ & $\begin{array}{c}\text { Medium } \\
\text { Reduction }\end{array}$ & $\begin{array}{c}\text { Medium } \\
\text { Low } \\
\text { Reduction }\end{array}$ & $\begin{array}{c}\text { No } \\
\text { Reduction }\end{array}$ \\
\hline Catalyst & $\square$ & $\square$ & $\square$ & $\square$ & $\square$ \\
\hline Bipolar plates & $\square$ & $\square$ & $\square$ & $\square$ & $\square$ \\
\hline Membrane & $\square$ & $\square$ & $\square$ & $\square$ & $\square$ \\
\hline $\begin{array}{c}\text { Other materials(Plastics, steel, } \\
\text { aluminum, phenolic resin, } \\
\text { carbon black, etc) }\end{array}$ & $\square$ & $\square$ & $\square$ & $\square$ & $\square$ \\
\hline
\end{tabular}


4-Considering the technological development and the discovery of new materials, what is your expectation for the substitution of the currently materials by new materials, with lesser environmental impact considering its use in fuel cell, for a future horizon of 20years?

\begin{tabular}{|c|c|c|c|c|c|}
\hline & $\begin{array}{c}\text { High } \\
\text { Probability }\end{array}$ & $\begin{array}{c}\text { High } \\
\text { Medium } \\
\text { Probability }\end{array}$ & $\begin{array}{c}\text { Medium } \\
\text { Probability }\end{array}$ & $\begin{array}{c}\text { Medium } \\
\text { Low } \\
\text { Probability }\end{array}$ & $\begin{array}{c}\text { Low } \\
\text { Probability }\end{array}$ \\
\hline Catalyst & $\square$ & $\square$ & $\square$ & $\square$ & $\square$ \\
\hline Membrane & $\square$ & $\square$ & $\square$ & $\square$ & $\square$ \\
\hline Bipolar Plates & $\square$ & $\square$ & $\square$ & $\square$ & $\square$ \\
\hline Other Materials & $\square$ & $\square$ & $\square$ & $\square$ & $\square$ \\
\hline
\end{tabular}

5-Group 1 (PEM fuel cell)Considering a future of 20 years and, considering also an evolution for another type of project, where the environmental impact would be reduced, what is your expectation for the abolition or substitution of this item?

\begin{tabular}{|c|c|c|c|c|c|}
\hline & $\begin{array}{c}\text { High } \\
\text { probability }\end{array}$ & $\begin{array}{c}\text { High } \\
\text { Medium } \\
\text { probability }\end{array}$ & $\begin{array}{c}\text { Medium } \\
\text { probability }\end{array}$ & $\begin{array}{c}\text { Medium } \\
\text { Low } \\
\text { probability }\end{array}$ & $\begin{array}{c}\text { Low } \\
\text { probability }\end{array}$ \\
\hline Catalyst & $\square$ & $\square$ & $\square$ & $\square$ & $\square$ \\
\hline Bipolar plates & $\square$ & $\square$ & $\square$ & $\square$ & $\square$ \\
\hline Membrane & $\square$ & $\square$ & $\square$ & $\square$ & $\square$ \\
\hline $\begin{array}{c}\text { Other materials(Plastics, steel, } \\
\text { aluminum, phenolic resin, } \\
\text { carbon black, etc) }\end{array}$ & $\square$ & $\square$ & $\square$ & $\square$ & $\square$ \\
\hline
\end{tabular}

6-Group 1 (PEM fuel cell) What is your expectation on the abolition/substitution of the PGMs - Platinum Metal Group's catalyst (PEM fuel cell), considering an evolution for another type project, considering a future of 20 years.

A. Substitution of the catalysts will occur

B. Substitution of the catalysts will not occur, but will be a big reduction in the $\mathrm{C}$ - concentration

C. Substitution of the catalysts will not occur and will be a small reduction in the concentration

D. Substitution of the catalysts will not occur but will be a reduction in the concentration through the mixture with other materials (with lesser environmental impact)

7-Group 2 (Phosphoric Acid Fuel Cell) In this question you assign your level of knowledge in Phosphoric Acid Fuel Cell: 
1. EXPERT: you assign yourself if consider inside of the group of people that currently is dedicated to this topic with depth.

2. KNOWLEDGEABLE: you assign this classification in the following cases:2a. If you are becoming an expert, but lacks some experience to dominate the topic.2b.If you already was an expert in the topic has some years, but you consider at the moment little brought up to date in the topic.2c.If you work in correlated area, but contribute regularly with subjects related to this topic.

3. FAMILIARIZED: you designate if you know the majority of the used arguments in the quarrels on the topic, you read about the subject, and has an opinion about it.

4. UNFAMILIAR

8-Group 2 (Phosphoric Acid Fuel Cell)Taking for base the current environmental impact of some item that compose a PAFC fuel cell, which is your expectation of reduction of environmental impact, for the horizon of 20 years?

\begin{tabular}{|c|c|c|c|c|c|}
\hline & $\begin{array}{c}\text { Very High } \\
\text { Reduction }\end{array}$ & $\begin{array}{c}\text { High } \\
\text { Reduction }\end{array}$ & $\begin{array}{c}\text { Medium } \\
\text { Reduction }\end{array}$ & $\begin{array}{c}\text { Low } \\
\text { Reduction }\end{array}$ & $\begin{array}{c}\text { No } \\
\text { Reduction }\end{array}$ \\
\hline Catalyst & $\square$ & $\square$ & $\square$ & $\square$ & $\square$ \\
\hline Bipolar plates & $\square$ & $\square$ & $\square$ & $\square$ & $\square$ \\
\hline Electrolyte matrix & $\square$ & $\square$ & $\square$ & $\square$ & $\square$ \\
\hline $\begin{array}{c}\text { Other materials(Plastics, steel, } \\
\text { aluminum, phenolic resin, } \\
\text { carbon black, etc) }\end{array}$ & $\square$ & $\square$ & $\square$ & $\square$ & $\square$ \\
\hline
\end{tabular}

9-Group 2 (Phosphoric Acid Fuel Cell)

What is your expectation on the abolition/substitution of the catalyst (PAFC fuel cell), considering an evolution for another type project, considering a future of 20 years.

A. Substitution of the catalysts will occur

B. Substitution of the catalysts will not occur, but will be a big reduction in the concentration

C. Substitution of the catalysts will not occur and will be a small reduction in the concentration

D. Substitution of the catalysts will not occur and will reduce the concentration through the mixture with other materials (with lesser environmental impact)

10-Group 2 (Phosphoric Acid Fuel Cell)Considering a future of 20 years and considering also an evolution for another type of project, where the environmental impact would be reduced, what is your expectation for the abolition or substitution of this item?

\begin{tabular}{|c|c|c|c|c|c|}
\hline & $\begin{array}{c}\text { High } \\
\text { probability }\end{array}$ & $\begin{array}{c}\text { High } \\
\text { Medium } \\
\text { probability }\end{array}$ & $\begin{array}{c}\text { Medium } \\
\text { probability }\end{array}$ & $\begin{array}{c}\text { Medium } \\
\text { Low } \\
\text { probability }\end{array}$ & $\begin{array}{c}\text { Low } \\
\text { probability }\end{array}$ \\
\hline Catalyst & $\square$ & $\square$ & $\square$ & $\square$ & $\square$ \\
\hline
\end{tabular}




\begin{tabular}{|c|c|c|c|c|c|}
\hline Bipolar plates & $\square$ & $\square$ & $\square$ & $\square$ & $\square$ \\
\hline Electrolyte matrix & $\square$ & $\square$ & $\square$ & $\square$ & $\square$ \\
\hline $\begin{array}{c}\text { Other materials(Plastics, steel, } \\
\text { aluminum, phenolic resin, } \\
\text { carbon black, etc) }\end{array}$ & $\square$ & $\square$ & $\square$ & $\square$ & $\square$ \\
\hline
\end{tabular}

11-Group 1 (PEM fuel cell) e Group 2 (Phosphoric Acid Fuel Cell)What is your forecast for performance of the catalyst (PGMs - Platinum Metal Group, considering a future of 20 years?

A. A very big evolution with reduction of metals of up to $1200 \%$.

B. A big evolution with reduction of metals of up to $700 \%$.

C. A medium evolution with reduction of metals of up to $400 \%$.

D. A small evolution with reduction of metals of up to $100 \%$.

12-Group 1 (PEM fuel cell) e Group 2 (Phosphoric Acid Fuel Cell) considering a future of 20 years, what is your expectation about the evolution in the current technology of recycling of catalyst (PGMs - Platinum Metal Group)?
A. A big evolution, with recovery of up to $99 \%$ of the catalyst
B. A medium evolution, with recovery of up to $80 \%$ of the catalyst
C. A small evolution, with recovery of up to $60 \%$ of the catalyst

13-Group 3 - Molten Carbonate Fuel Cell (MCFC)

In this question you assign your level of knowledge in MCFC fuel cell: *

1. EXPERT: you assign yourself if consider inside of the group of people that currently is dedicated to this topic with depth.

2. KNOWLEDGEABLE: you assign this classification in the following cases:2a. If you are becoming an expert, but lacks some experience to dominate the topic.2b.If you already was an expert in the topic has some years, but you consider at the moment little brought up to date in the topic.2c.If you work in correlated area, but contribute regularly with subjects related to this topic.

3. FAMILIARIZED: you designate if you know the majority of the used arguments in the quarrels on the topic, you read about the subject, and has an opinion about it.

4. UNFAMILIAR

14-Group 3 - Molten Carbonate Fuel Cell Taking for base the current environmental impact of the items that compose a MCFC fuel cell, what is your expectation about the reduction of environmental impact, considering a future of 20 years?

\begin{tabular}{|c|c|c|c|c|c|}
\hline & $\begin{array}{l}\text { Very High } \\
\text { Reduction }\end{array}$ & $\begin{array}{c}\text { High } \\
\text { Reduction }\end{array}$ & $\begin{array}{c}\text { Medium } \\
\text { Reduction }\end{array}$ & $\begin{array}{c}\text { Low } \\
\text { Reduction }\end{array}$ & $\begin{array}{c}\text { No } \\
\text { Reduction }\end{array}$ \\
\hline Catalyst & $\square$ & $\square$ & $\square$ & $\square$ & $\square$ \\
\hline Bipolar plates & $\square$ & $\square$ & $\square$ & $\square$ & $\square$ \\
\hline
\end{tabular}




\begin{tabular}{|c|c|c|c|c|c|}
\hline Electrolyte ceramic matrix & $\square$ & $\square$ & $\square$ & $\square$ & $\square$ \\
\hline $\begin{array}{c}\text { Other materials(Plastics, steel, } \\
\text { aluminum, phenolic resin, } \\
\text { carbon black, etc) }\end{array}$ & $\square$ & $\square$ & $\square$ & $\square$ & $\square$ \\
\hline
\end{tabular}

15-Group 3 - Molten Carbonate Fuel Cell

What is your expectation on the abolition/substitution of the catalyst (MCFC fuel cell), considering an evolution for another type project, considering a future of 20 years.

A. Substitution of the catalysts will occur

B. Substitution of the catalysts will not occur, but will be a big reduction in the concentration

C. Substitution of the catalysts will not occur and will be a small reduction in the concentration

D. Substitution of the catalysts will not occur but will be a reduction in the concentration through the mixture with other materials (with lesser environmental impact)

16-Group 3 - Molten Carbonate Fuel Cell Considering a future of 20 years and considering also an evolution for another type of project, where the environmental impact would be reduced, what is your expectation for the abolition or substitution of this item?

\begin{tabular}{|c|c|c|c|c|c|}
\hline & $\begin{array}{c}\text { High } \\
\text { probability }\end{array}$ & $\begin{array}{c}\text { High } \\
\text { Medium } \\
\text { probability }\end{array}$ & $\begin{array}{c}\text { Medium } \\
\text { probability }\end{array}$ & $\begin{array}{c}\text { Medium } \\
\text { Low } \\
\text { probability }\end{array}$ & $\begin{array}{c}\text { Low } \\
\text { probability }\end{array}$ \\
\hline Catalyst & $\square$ & $\square$ & $\square$ & $\square$ & $\square$ \\
\hline Bipolar plates & $\square$ & $\square$ & $\square$ & $\square$ & $\square$ \\
\hline Electrolyte ceramic matrix & $\square$ & $\square$ & $\square$ & $\square$ & $\square$ \\
\hline $\begin{array}{c}\text { Other materials(Plastics, steel, } \\
\text { aluminum, phenolic resin, } \\
\text { carbon black, etc) }\end{array}$ & $\square$ & $\square$ & $\square$ & $\square$ & $\square$ \\
\hline
\end{tabular}

\section{7-Group 4 - Fuels used in the Fuel Cell}

In this question you assign your level of knowledge about fuels used in the Fuel Cell:

1. EXPERT: you assign yourself if consider inside of the group of people that currently is dedicated to this topic with depth.

2. KNOWLEDGEABLE: you assign this classification in the following cases:2a.If you are becoming an expert, but lacks some experience to dominate the topic.2b.If you already was an expert in the topic has some years, but you consider at the moment little brought up to date in the topic.2c.If you work in correlated area, but contribute regularly with subjects related to this topic.

3. FAMILIARIZED: you designate if you know the majority of the used arguments in the quarrels on the topic, you read about the subject, and has an opinion about it.

4. UNFAMILIAR

18-Group 4 - Fuels used in the Fuel Cell in the stage of hydrogen production, for 
use as combustible in the fuel cells, which is your expectation for the environmental impact of this process for year 2030-2040?

\begin{tabular}{|c|c|c|c|c|c|}
\hline & $\begin{array}{c}\text { Very High } \\
\text { Reduction }\end{array}$ & $\begin{array}{c}\text { High } \\
\text { Reduction }\end{array}$ & $\begin{array}{c}\text { Medium } \\
\text { Reduction }\end{array}$ & $\begin{array}{c}\text { Low } \\
\text { Reduction }\end{array}$ & $\begin{array}{c}\text { No } \\
\text { Reduction }\end{array}$ \\
\hline $\begin{array}{c}\text { Hydrogen production onboard } \\
\text { or near the consumption place }\end{array}$ & $\square$ & $\square$ & $\square$ & $\square$ & $\square$ \\
\hline $\begin{array}{c}\text { Hydrogen production far away } \\
\text { of the consumption place }\end{array}$ & $\square$ & $\square$ & $\square$ & $\square$ & $\square$ \\
\hline
\end{tabular}

19-Group 4 - Fuels used in the Fuel Cell Considering the current environmental impact in the hydrogen production processes, what is your expectation about the reduction of environmental impact, due to the use of new raw materials and new process, considering a future of 20 years?

\begin{tabular}{|c|c|c|c|c|c|}
\hline & $\begin{array}{c}\text { Very High } \\
\text { Reduction }\end{array}$ & $\begin{array}{c}\text { High } \\
\text { Reduction }\end{array}$ & $\begin{array}{c}\text { Medium } \\
\text { Reduction }\end{array}$ & $\begin{array}{c}\text { Low } \\
\text { Reduction }\end{array}$ & $\begin{array}{c}\text { No } \\
\text { Reduction }\end{array}$ \\
\hline New raw materials & $\square$ & $\square$ & $\square$ & $\square$ & $\square$ \\
\hline New process & $\square$ & $\square$ & $\square$ & $\square$ & $\square$ \\
\hline
\end{tabular}

20-Group 4 - Fuels used in the Fuel Cell With relation to the current processes of hydrogen production, what is your expectation for the continuity of its use in the future of 20 years?

\begin{tabular}{|c|c|c|c|c|c|}
\hline & $\begin{array}{c}\text { Very High } \\
\text { Reduction }\end{array}$ & $\begin{array}{c}\text { High } \\
\text { Reduction }\end{array}$ & $\begin{array}{c}\text { Medium } \\
\text { Reduction }\end{array}$ & $\begin{array}{c}\text { Low } \\
\text { Reduction }\end{array}$ & $\begin{array}{c}\text { No } \\
\text { Reduction }\end{array}$ \\
\hline $\begin{array}{c}\text { Coatural gas reforming } \\
\text { technology }\end{array}$ & $\square$ & $\square$ & $\square$ & $\square$ & $\square$ \\
\hline $\begin{array}{c}\text { Renewable Liquid Fuels } \\
\text { Reforming }\end{array}$ & $\square$ & $\square$ & $\square$ & $\square$ & $\square$ \\
\hline Thermal Dissociation & $\square$ & $\square$ & $\square$ & $\square$ & $\square$ \\
\hline Kvaerner Process & $\square$ & $\square$ & $\square$ & $\square$ & $\square$ \\
\hline Plasmatron & $\square$ & $\square$ & $\square$ & $\square$ & $\square$ \\
\hline Electrolytic Process & $\square$ & $\square$ & $\square$ & $\square$ & $\square$ \\
\hline Photolytic Processes & $\square$ & $\square$ & $\square$ & $\square$ & $\square$ \\
\hline Thermal Decomposition & $\square$ & $\square$ & $\square$ & $\square$ & $\square$ \\
\hline Gasification of Biomass & $\square$ & $\square$ & $\square$ & $\square$ & $\square$ \\
\hline Biological Process & $\square$ & $\square$ & $\square$ & $\square$ & $\square$ \\
\hline
\end{tabular}

21-Group 4 - Fuels used in the Fuel Cell Considering the energy type used as raw material by production of hydrogen production processes, what is your expectation of use, considering a future of 20-30 years?

\begin{tabular}{|c|c|c|c|c|c|}
\hline & $\begin{array}{c}\text { Very High } \\
\text { Reduction }\end{array}$ & $\begin{array}{c}\text { High } \\
\text { Reduction }\end{array}$ & $\begin{array}{c}\text { Medium } \\
\text { Reduction }\end{array}$ & $\begin{array}{c}\text { Low } \\
\text { Reduction }\end{array}$ & $\begin{array}{c}\text { No } \\
\text { Reduction }\end{array}$ \\
\hline Hydrogen from PV & $\square$ & $\square$ & $\square$ & $\square$ & $\square$ \\
\hline Hydrogen from Solar Thermal & $\square$ & $\square$ & $\square$ & $\square$ & $\square$ \\
\hline Hydrogen from Wind & $\square$ & $\square$ & $\square$ & $\square$ & $\square$ \\
\hline
\end{tabular}




\begin{tabular}{|c|c|c|c|c|c|}
\hline Hydrogen from hydropower & $\square$ & $\square$ & $\square$ & $\square$ & $\square$ \\
\hline Hydrogen from biomass & $\square$ & $\square$ & $\square$ & $\square$ & $\square$ \\
\hline Hydrogen from Natural Gas & $\square$ & $\square$ & $\square$ & $\square$ & $\square$ \\
\hline
\end{tabular}

Full name:

Your Organization:

\section{Email:}

Comments on any of the questions or on the survey as a whole:

1. Environmental Impact of fuel cells 


\section{B.2- Questionário da 2ª. Fase.}

\section{$4 \%$}

\section{SECOND ROUND OF THE DELPHI SURVEY:FORECAST OF THE ENVIRONMENTAL IMPACT, IN THE LONG-RANGE, OF THE FUEL CELLS OF LOW and MEDIUM TEMPERATURE APPLYING DELPHI METHOD}

Dear Madam, Dear Sir:

We would like to askyou to participate in the SECOND ROUND of the survey led by Univesity of Säo Paulo and answer the Delphi questionnaire for which you have receives an invitation today.

You remember this project is a fuel cell Delphi survey, assessing technological developments, market trends and social visions for environmental impact of fuel cell for range 20-30 years. Your survey responses will be strictly confidential and data from this research will be reported only in the aggregate. Your information will be coded and will remain confidential.

Thank you for your participation in the University of Săo Paulo survey. Approximately 130 participants have answered in the first round and given us many very valuable comments. Some of the comments are included in the second questionnaire, but all comments will be reflected in the final data analysis following the completion of the survey.

This time we ask almost the same questions, but at the same time give you the opportunity to reflect on the results from the first round. If you strongly disagree with comments box. This contributes to the validation o the results from the survey.

The questionnaire will take appoximately 20 min to complete. In any case you should less time than it took you in the first round.

The results of the survey will be used to produce a long-range perspective on the Environmental impact of fuel cell in the future. Furthermore, they will serve as background information to define energy research policies and will be avaliable guideline for environmental impact.

We kindly ask you to complete this second questionnaire before 31 July 2008.

If you have questions at any time about the survey or the procedures, you may contact Maria Alice Morato Ribeiro at 55-11-31339483 or by email at the address specified below.

Thank you very much for your time and support.

Maria Alice Morato Ribeiro

University of Sấo Paulo 
Instituto de Pesquisas Energéticas e Nucleares

email:mmorato@usp.br

\section{SECOND ROUND}

\section{What is new in the second round?}

It is an integral part of the Delphi method to run the questionnaire with two or more rounds. Thus giving the participating experts - you - feedback on how their colleagues and peers access the issues in question, giving the chance to re-assess the statements of the questionnaire with this additional background information.

\section{New Statements}

Based on the numerous comments we received from you. We designed new statements.

Please be assured we do appreciate every single of your very constructive and detailed comments given in the first round! And although only very few led to new statements (as we tried hard to keep the size of the questionnaire reasonable) - all of them will be analysed in the upcoming evaluation steps, where they will be of great help for our work.

And now, click in CONTINUE to answer the question.

Tanks,

Maria Alice Morato Ribeiro 
1-Please mark the box that best describes your experience:

1. Academic research

2. Industrial research and development

3. Corporate strategy for research and

4. Technology

5. Marketing/business management

6. Production/operation

7. Consulting

8. Public agency/politics

1a-Please inform your age

1. $<31$

2. $31-40$

3. $41-50$

4. $51-60$

5. $61-70$

6. $>70$

The survey was divided in 4 groups, subdivided in 4 subgroups. The groups are listed below. Group 1 - PEM Fuel Cell. Group 2 - Phosphoric Acid Fuel Cell. Group 3 - Molten Carbonate Fuel Cell. Group 4 - Fuels used in the Fuel Cell3 - Group 1 (PEM fuel cell)-

This section contains 7 questions about PEM fuel cell

2-In this question you assign your level of knowledge in PEM fuel cell:

1. EXPERT: you assign yourself if consider inside of the group of people that currently is dedicated to this topic with depth.

2. KNOWLEDGEABLE: you assign this classification in the following cases:a.If you are becoming an expert, but lacks some experience to dominate the topic.b.If you already was an expert in the topic has some years, but you consider at the moment little brought up to date in the topic.c.If you work in correlated area, but contribute regularly with subjects related to this topic.

3. FAMILIARIZED: you designate if you know the majority of the used arguments in the quarrels on the topic, you read about the subject, and has an opinion about it.

4. UNFAMILIAR

3- Group 1 (PEM fuel cell)-The next graph shows the answers obtained for the first round. 


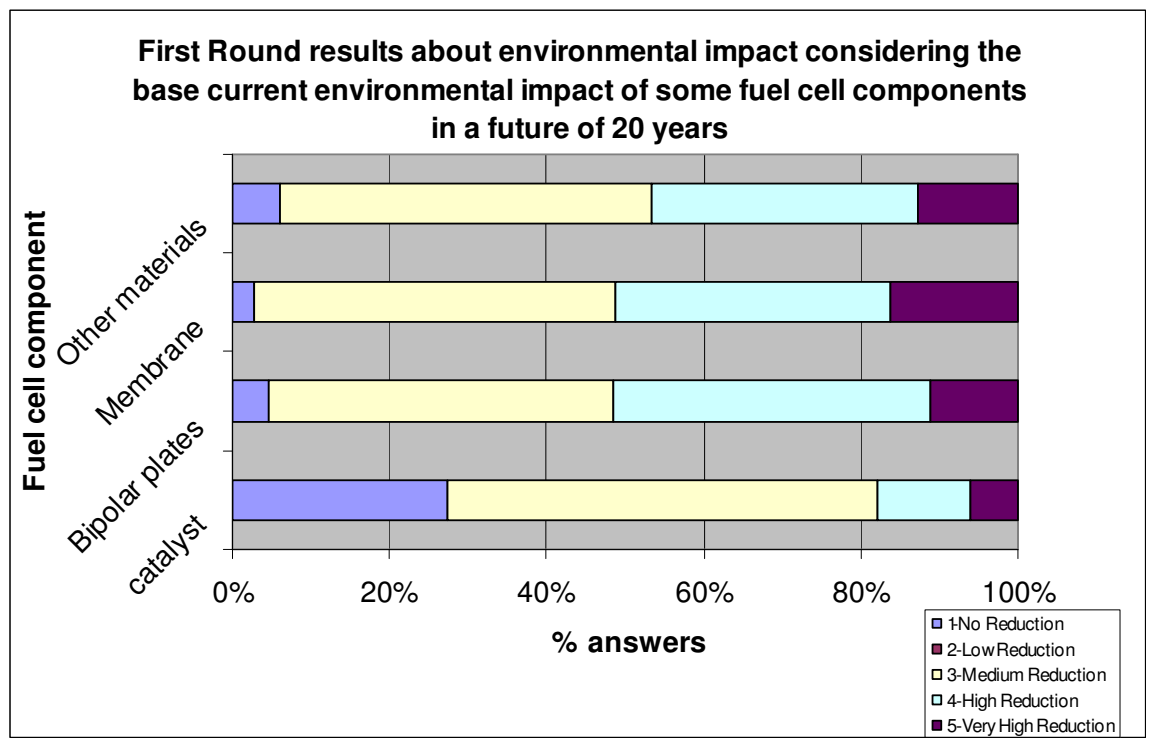

Please answer again the question: Taking as base the current environmental impact of some items that compose a PEM fuel cell, what is your expectation of reduction concerned to environmental impact, in next 20 years?

\begin{tabular}{|c|c|c|c|c|c|}
\hline & $\begin{array}{c}\text { Very High } \\
\text { Reduction }\end{array}$ & $\begin{array}{c}\text { High- } \\
\text { Medium } \\
\text { Reduction }\end{array}$ & $\begin{array}{c}\text { Medium } \\
\text { Reduction }\end{array}$ & $\begin{array}{c}\text { Medium- } \\
\text { Low } \\
\text { Reduction }\end{array}$ & $\begin{array}{c}\text { No } \\
\text { Reduction }\end{array}$ \\
\hline Catalyst & $\square$ & $\square$ & $\square$ & $\square$ & $\square$ \\
\hline Bipolar plates & $\square$ & $\square$ & $\square$ & $\square$ & $\square$ \\
\hline Membrane & $\square$ & $\square$ & $\square$ & $\square$ & $\square$ \\
\hline $\begin{array}{c}\text { Other materials(Plastics, } \\
\text { steel, aluminum, } \\
\text { phenolic resin, carbon } \\
\text { black, etc) }\end{array}$ & $\square$ & $\square$ & $\square$ & $\square$ & $\square$ \\
\hline
\end{tabular}

4- Group 1 (PEM fuel cell)-The next graph shows the answers obtained for the first round.

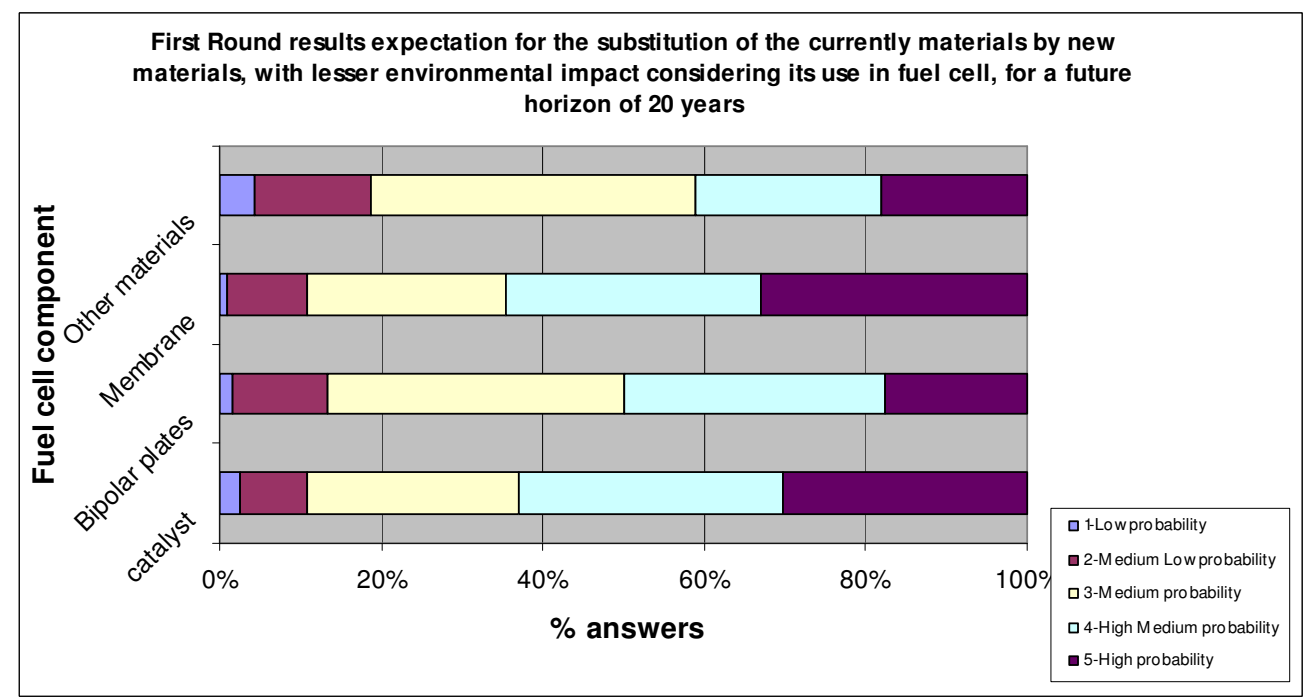


Considering the technological development and the discovery of new material, what is the expectation in the replacement of materials currently used by new ones, with lesser environmental impact considering their use in fuel cell, in next 20 years?

\begin{tabular}{|c|c|c|c|c|c|}
\hline & $\begin{array}{c}\text { High } \\
\text { probability }\end{array}$ & $\begin{array}{c}\text { High } \\
\text { Medium } \\
\text { probability }\end{array}$ & $\begin{array}{c}\text { Medium } \\
\text { probability }\end{array}$ & $\begin{array}{c}\text { Medium } \\
\text { Low } \\
\text { probability }\end{array}$ & $\begin{array}{c}\text { Low } \\
\text { probability }\end{array}$ \\
\hline Catalyst & $\square$ & $\square$ & $\square$ & $\square$ & $\square$ \\
\hline Bipolar plates & $\square$ & $\square$ & $\square$ & $\square$ & $\square$ \\
\hline $\begin{array}{c}\text { Othembrane } \\
\begin{array}{c}\text { Other materials(Plastics, } \\
\text { steel, aluminum, } \\
\text { phenolic resin, carbon } \\
\text { black, etc) }\end{array}\end{array} \quad \square$ & $\square$ & $\square$ & $\square$ & $\square$ \\
\hline
\end{tabular}

5- Group 1 (PEM fuel cell)-The next graph shows the answers obtained for the first round.

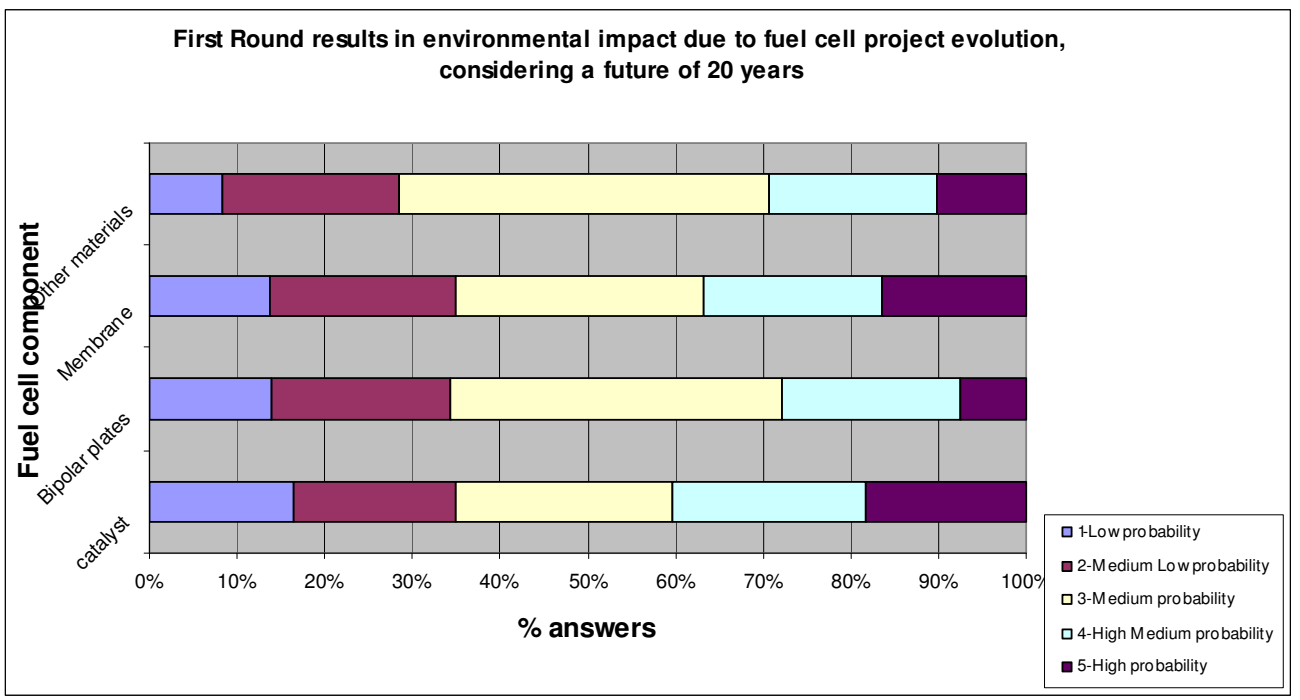

Considering next 20 years and, as well an evolution for another type of project, where the environmental impact would be reduced, what is your expectation for the revocation or replacement of this item?

\begin{tabular}{|c|c|c|c|c|c|}
\hline & $\begin{array}{c}\text { High } \\
\text { probability }\end{array}$ & $\begin{array}{c}\text { High } \\
\text { Medium } \\
\text { probability }\end{array}$ & $\begin{array}{c}\text { Medium } \\
\text { probability }\end{array}$ & $\begin{array}{c}\text { Medium } \\
\text { Low } \\
\text { probability }\end{array}$ & $\begin{array}{c}\text { Low } \\
\text { probability }\end{array}$ \\
\hline $\begin{array}{c}\text { Other materials(Plastics, } \\
\text { steel, aluminum, phenolic } \\
\text { resin, carbon black, etc) }\end{array}$ & $\square$ & $\square$ & $\square$ & $\square$ & $\square$ \\
\hline Membrane & $\square$ & $\square$ & $\square$ & $\square$ & $\square$ \\
\hline Bipolar plates & $\square$ & $\square$ & $\square$ & $\square$ & $\square$ \\
\hline Catalyst & $\square$ & $\square$ & $\square$ & $\square$ & $\square$ \\
\hline
\end{tabular}

6- Group 1 (PEM fuel cell)-What is your expectation on the abolition/substitution of 
the PGMs - Platinum Metal Group's catalyst (PEM fuel cell), considering an evolution for another type project, considering a future of 20 years.

The next table shows the first round results

\begin{tabular}{|l|l|}
\hline Catalysts replacement will occur & $49,07 \%$ \\
\hline $\begin{array}{l}\text { Catalysts replacement will not occur, but } \\
\text { there will be a great reduction in the } \\
\text { concentration }\end{array}$ & $17,59 \%$ | \\
\hline $\begin{array}{l}\text { Catalysts replacement will not occur and } \\
\text { will be a small reduction in the } \\
\text { concentration }\end{array}$ & $5,56 \%$ \\
\hline $\begin{array}{l}\text { Catalysts replacement will not occur and } \\
\text { there will be reduction in the } \\
\text { concentration from the mixture with other } \\
\text { materials(with lesser environmental } \\
\text { impact) }\end{array}$ & $27,78 \%$ \\
\hline
\end{tabular}

Please choose again the option in the question.
A. Catalyst replacement will occur
B. Catalyst replacement will not occur, but there will be a great reduction in the concentration
C. Catalyst replacement will not occur and there will be a small reduction in the concentration
D. Catalyst replacement will not occur but there will be a reduction in the concentration from the mixture with other materials (with lesser environmental impact)

\section{Group 2 (Phosphoric Acid Fuel Cell)}

7-In this question you assign your level of knowledge in Phosphoric Acid Fuel Cell:

1. EXPERT: you assign yourself if consider inside of the group of people that currently is dedicated to this topic with depth.

2. KNOWLEDGEABLE: you assign this classification in the following cases:2a. If you are becoming an expert, but lacks some experience to dominate the topic.2b.If you already was an expert in the topic has some years, but you consider at the moment little brought up to date in the topic.2c.If you work in correlated area, but contribute regularly with subjects related to this topic.

3. FAMILIARIZED: you designate if you know the majority of the used arguments in the quarrels on the topic, you read about the subject, and has an opinion about it.
4. UNFAMILIAR

8- Group 2 (Phosphoric Acid Fuel Cell)-The next graph shows first round results. Please, answer the question. 


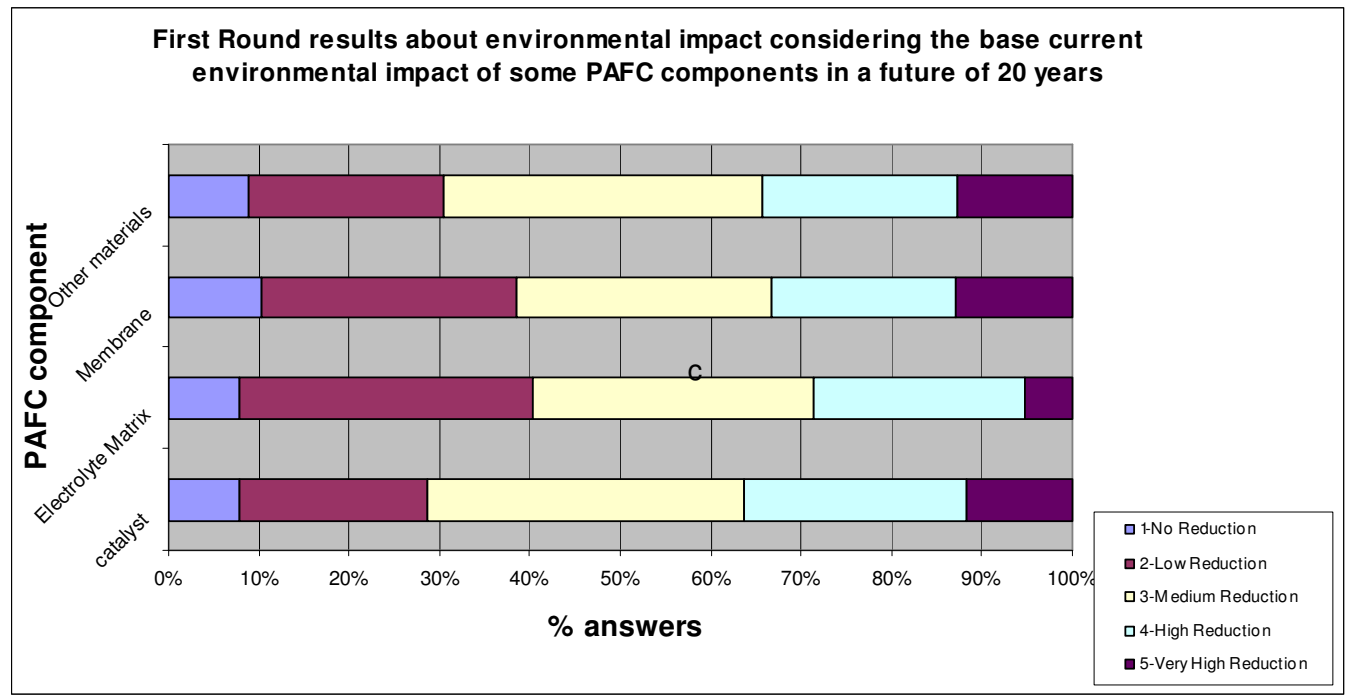

Taking as base the current environmental impact of some items that compose a PAFC fuel cell, what is your expectation of reduction in environmental impact in the next 20 years?

\begin{tabular}{|c|c|c|c|c|c|}
\hline & $\begin{array}{l}\text { Very High } \\
\text { Reduction }\end{array}$ & $\begin{array}{c}\text { High } \\
\text { Reduction }\end{array}$ & $\begin{array}{c}\text { Medium } \\
\text { Reduction }\end{array}$ & $\begin{array}{c}\text { Low } \\
\text { Reduction }\end{array}$ & $\begin{array}{c}\text { No } \\
\text { Reduction }\end{array}$ \\
\hline Catalyst & $\square$ & $\square$ & $\square$ & $\square$ & $\square$ \\
\hline Bipolar plates & $\square$ & $\square$ & $\square$ & $\square$ & $\square$ \\
\hline $\begin{array}{c}\text { Electrolyte matrix } \\
\text { alumaterials(Plastics, steel, } \\
\text { carbon, phenolic resin, } \\
\text { calack, etc) }\end{array}$ & $\square$ & $\square$ & $\square$ & $\square$ & $\square$ \\
\hline
\end{tabular}

Group 2 (Phosphoric Acid Fuel Cell)

9-What is your expectation revocation/replacement of the catalyst (PAFC fuel cell), as well an evolution for another project type, in the next 20 years. The next table shows first round results for the question.

\begin{tabular}{|l|l|}
\hline Catalysts replacement will occur & $40,26 \%$ \\
\hline $\begin{array}{l}\text { Catalysts replacement will not occur, but } \\
\text { there will be a great reduction in the } \\
\text { concentration }\end{array}$ & $16,88 \%$ \\
\hline $\begin{array}{l}\text { Catalysts replacement will not occur and } \\
\text { will be a small reduction in the } \\
\text { concentration }\end{array}$ & $14,29 \%$ । \\
\hline $\begin{array}{l}\text { Catalysts replacement will not occur and } \\
\text { there will be reduction in the } \\
\text { concentration from the mixture with other } \\
\text { materials(with lesser environmental } \\
\text { impact) }\end{array}$ & $28,57 \%$ \\
\hline
\end{tabular}


What is your prediction for the performance of the catalyst (PGMs - Platinum Metal Group, in the next 20 years?

Please choose one answer in the question below.

A. Catalyst replacement will occur

B. Catalyst replacement will not occur, but there will be a great reduction in the concentration

C. Catalyst replacement will not occur and will be a small reduction in the concentration

D. Catalyst replacement will not occur but there will be a reduction in the concentration from the mixture with other materials (with lesser environmental impact)

10- Group 2 (Phosphoric Acid Fuel Cell) - The figure below shows the first round results, for the next question.

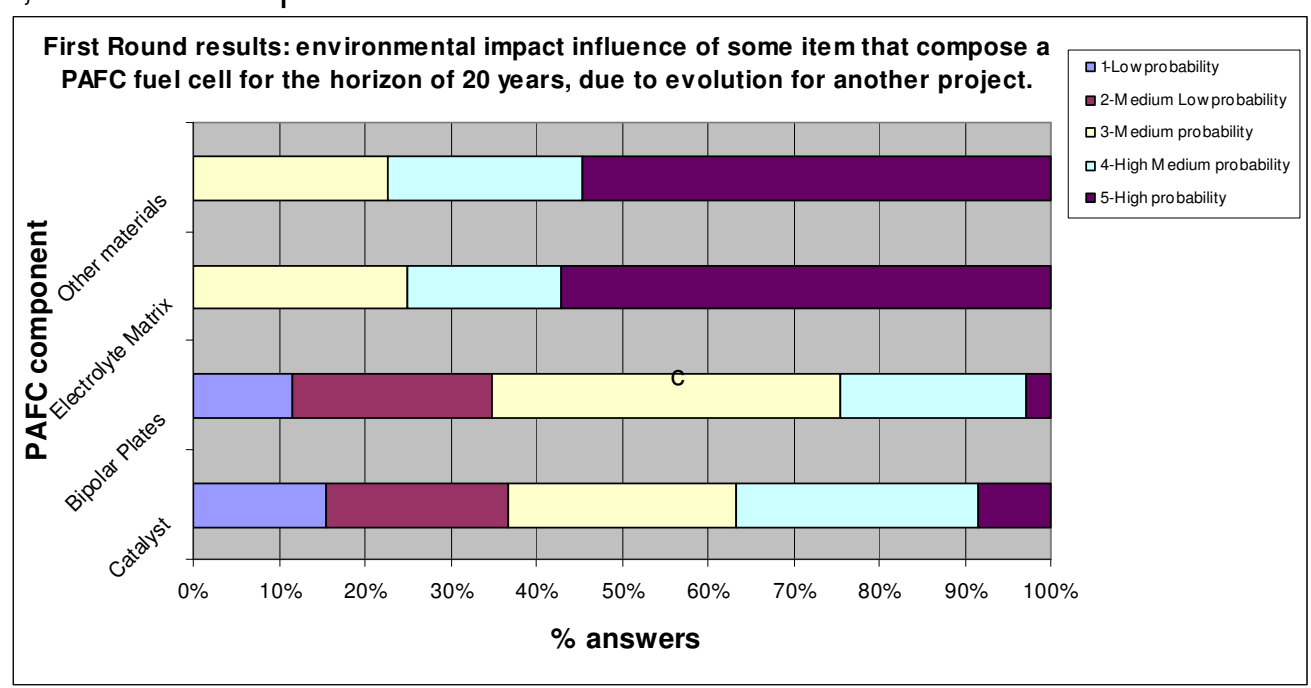

Considering next 20 years and, as well an evolution for another type of project, where the environmental impact would be reduced, what is your expectation for the revocation or replacement of this item?

\begin{tabular}{|c|c|c|c|c|c|}
\hline & $\begin{array}{c}\text { High } \\
\text { probability }\end{array}$ & $\begin{array}{c}\text { High } \\
\text { Medium } \\
\text { probability }\end{array}$ & $\begin{array}{c}\text { Medium } \\
\text { probability }\end{array}$ & $\begin{array}{c}\text { Medium } \\
\text { Low } \\
\text { probability }\end{array}$ & $\begin{array}{c}\text { Low } \\
\text { probability }\end{array}$ \\
\hline Catalyst & $\square$ & $\square$ & $\square$ & $\square$ & $\square$ \\
\hline Bipolar plates & $\square$ & $\square$ & $\square$ & $\square$ & $\square$ \\
\hline Electrolyte matrix & $\square$ & $\square$ & $\square$ & $\square$ & $\square$ \\
\hline $\begin{array}{c}\text { Other materials(Plastics, steel, } \\
\text { aluminum, phenolic resin, } \\
\text { carbon black, etc) }\end{array}$ & $\square$ & $\square$ & $\square$ & $\square$ & $\square$ \\
\hline
\end{tabular}

11 -Group 1 (PEM fuel cell) e Group 2 (Phosphoric Acid Fuel Cell) What is your prediction for the performance of the catalyst PGMs (Platinum Metal Group), in next 20 years?

The next table shows first round results for the question.

\begin{tabular}{|l|l|}
\hline $\begin{array}{l}\text { A very big evolution with metals } \\
\text { reduction up to } 1200 \%\end{array}$ & $10,71 \%$ \\
\hline A great evolution with metals reduction & $22,62 \%$ \\
\hline
\end{tabular}




\begin{tabular}{|l|l|}
\hline up to $700 \%$ & \\
\hline $\begin{array}{l}\text { A medium evolution with metals } \\
\text { reduction up to } 400 \% .\end{array}$ & $40,48 \%$ \\
\hline $\begin{array}{l}\text { A small evolution with metals reduction } \\
\text { up to } 100 \%\end{array}$ & $26,19 \%$ \\
\hline
\end{tabular}

Please answer again the same question: What is your prediction for the performance of the catalyst (PGMs - Platinum Metal Group, in the next 20 years?
A. A very high evolution with metals reduction up to $1200 \%$.
B. A great evolution with metals reduction up to $700 \%$.
C. A medium evolution with metals reduction up to $400 \%$.
D. A small evolution with metals reduction up to $100 \%$.

12 -Group 1 (PEM fuel cell) e Group 2 (Phosphoric Acid Fuel Cell)-The next table shows first round results for the question:

\begin{tabular}{|l|l|}
\hline $\begin{array}{l}\text { A great evolution, with catalyst recovery } \\
\text { of up to } 99 \%\end{array}$ & $38,37 \%$ \\
\hline $\begin{array}{l}\text { A medium evolution, with catalyst } \\
\text { recovery up to } 80 \%\end{array}$ & $41,86 \%$ \\
\hline $\begin{array}{l}\text { A small evolution, with catalyst recovery } \\
\text { up to } 60\end{array}$ & $19,77 \%$ \\
\hline
\end{tabular}

Please answer again the same question. Considering next 20 years, what is your expectation about the evolution in the current technology of catalyst recycling (PGMs - Platinum Metal Group)?
A. A great evolution, with catalyst recovery up to $99 \%$
B. A medium evolution, with catalyst recovery up to $80 \%$
C. A small evolution, with catalyst recovery up to $60 \%$

5-Group 3 - Molten Carbonate Fuel Cell (MCFC)

13-In this question you assign your level of knowledge in MCFC fuel cell: *

1. EXPERT: you assign yourself if consider inside of the group of people that currently is dedicated to this topic with depth.

2. KNOWLEDGEABLE: you assign this classification in the following cases:2a.If you are becoming an expert, but lacks some experience to dominate the topic.2b.If you already was an expert in the topic has some years, but you consider at the moment little brought up to date in the topic.2c.If you work in correlated area, but contribute regularly with subjects related to this topic.

3. FAMILIARIZED: you designate if you know the majority of the used arguments in the quarrels on the topic, you read about the subject, and has an opinion about it.

4. UNFAMILIAR

14- Group 3 - Molten Carbonate Fuel Cell The next figure presents first round results for the next question 


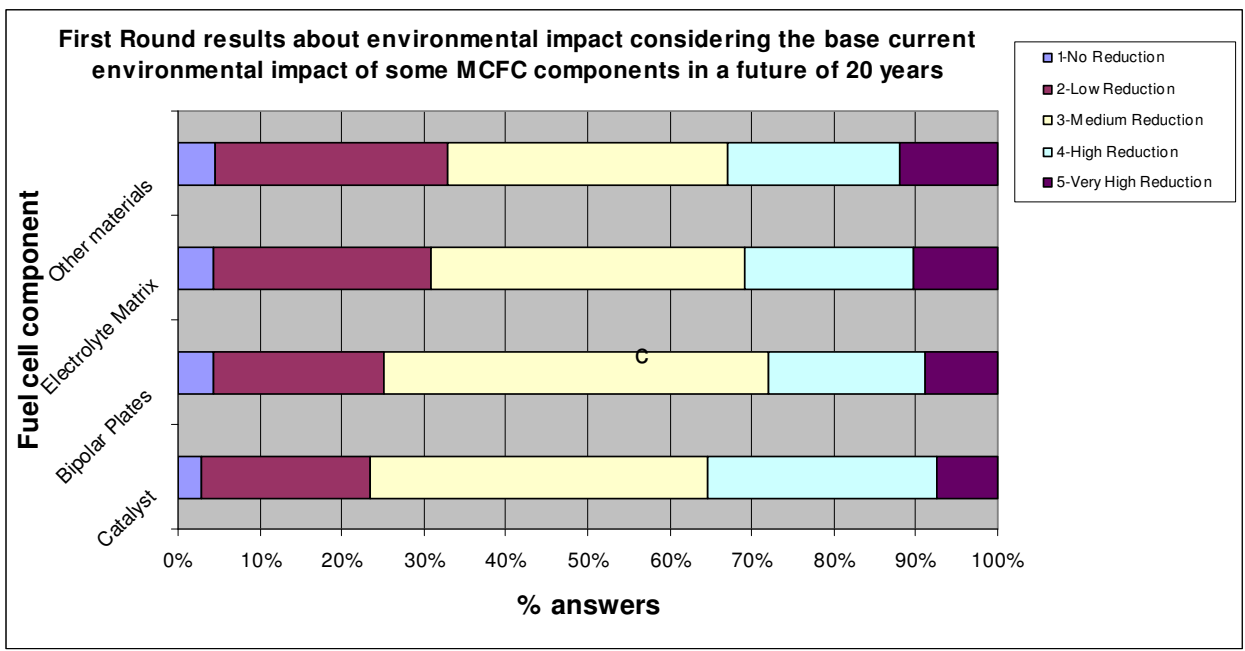

-Taking as base the current environmental impact of the items that compose a MCFC fuel cell, what is your expectation about the reduction of environmental impact, considering, in next 20 years?

\begin{tabular}{|c|c|c|c|c|c|}
\hline & $\begin{array}{c}\text { Very High } \\
\text { Reduction }\end{array}$ & $\begin{array}{c}\text { High } \\
\text { Reduction }\end{array}$ & $\begin{array}{c}\text { Medium } \\
\text { Reduction }\end{array}$ & $\begin{array}{c}\text { Low } \\
\text { Reduction }\end{array}$ & $\begin{array}{c}\text { No } \\
\text { Reduction }\end{array}$ \\
\hline Catalyst & $\square$ & $\square$ & $\square$ & $\square$ & $\square$ \\
\hline Bipolar plates & $\square$ & $\square$ & $\square$ & $\square$ & $\square$ \\
\hline Electrolyte ceramic matrix & $\square$ & $\square$ & $\square$ & $\square$ & $\square$ \\
\hline $\begin{array}{c}\text { Other materials(Plastics, steel, } \\
\text { aluminum, phenolic resin, } \\
\text { carbon black, etc) }\end{array}$ & $\square$ & $\square$ & $\square$ & $\square$ & $\square$ \\
\hline
\end{tabular}

\section{5- Group 3 - Molten Carbonate Fuel Cell}

The next table presents the first round results to the next question

\begin{tabular}{|l|l|}
\hline Catalysts replacement will occur & $31,88 \%$ \\
\hline $\begin{array}{l}\text { Catalysts replacement will not occur, but } \\
\text { there will be a great reduction in the } \\
\text { concentration }\end{array}$ & $14,99 \%$ \\
\hline $\begin{array}{l}\text { Catalysts replacement will not occur and } \\
\text { will be a small reduction in the } \\
\text { concentration }\end{array}$ & $20,29 \%$ | \\
\hline $\begin{array}{l}\text { Catalysts replacement will not occur and } \\
\text { there will be reduction in the } \\
\text { concentration from the mixture with other } \\
\text { materials(with lesser environmental } \\
\text { impact) }\end{array}$ & $33,33 \%$ \\
\hline
\end{tabular}

What is your expectation on the abolition/substitution of the catalyst (MCFC fuel cell), considering an evolution for another type project, considering a future of 20 years.
A. Catalysts replacement will occur
B. Catalysts replacement will not occur, but there will be a great reduction in the concentration
C. Catalysts replacement will not occur and there will be a small reduction in 
the concentration

D. Catalysts replacement will not occur and there will be reduction in the concentration from the mixture with other materials (with lesser environmental impact)

16 -Group 3 - Molten Carbonate Fuel Cell The next table presents first round results for next question

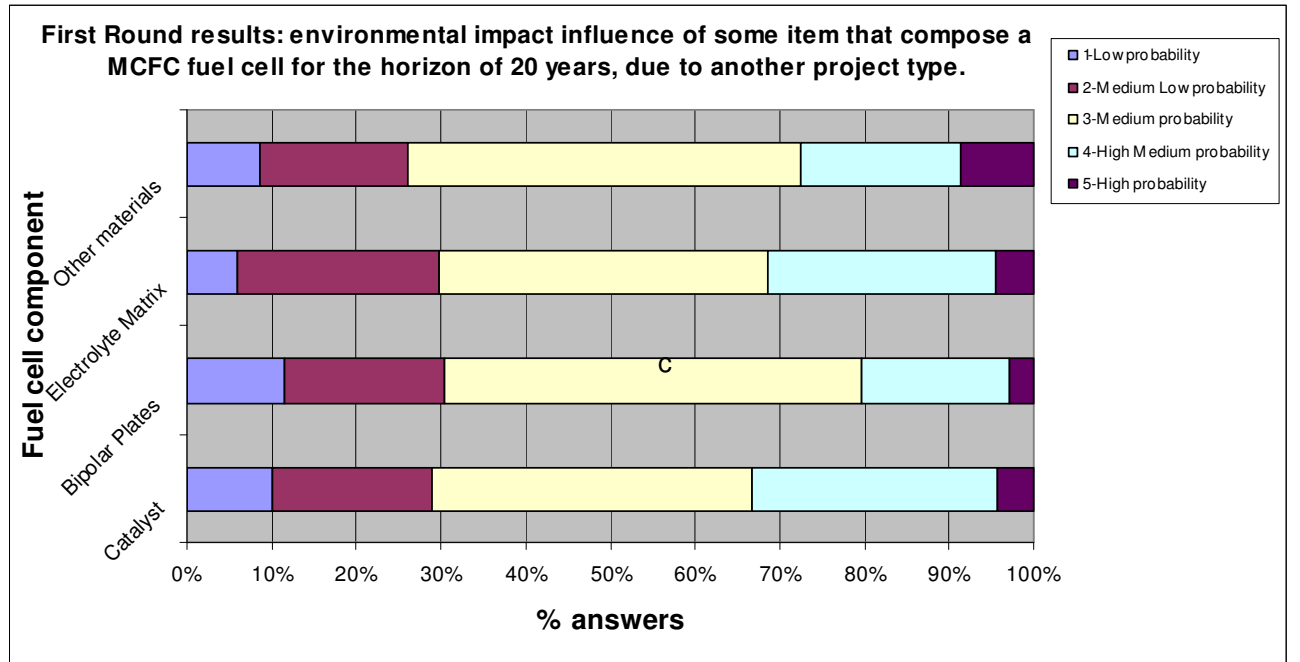

-Considering next 20 years and, as well as an evolution for another type of project, where the environmental impact would be reduced, what is your expectation for the revocation or replacement of this item?

\begin{tabular}{|c|c|c|c|c|c|}
\hline & $\begin{array}{c}\text { High } \\
\text { probability }\end{array}$ & $\begin{array}{c}\text { High } \\
\text { Medium } \\
\text { probability }\end{array}$ & $\begin{array}{c}\text { Medium } \\
\text { probability }\end{array}$ & $\begin{array}{c}\text { Medium } \\
\text { Low } \\
\text { probability }\end{array}$ & $\begin{array}{c}\text { Low } \\
\text { probability }\end{array}$ \\
\hline Catalyst & $\square$ & $\square$ & $\square$ & $\square$ & $\square$ \\
\hline Bipolar plates & $\square$ & $\square$ & $\square$ & $\square$ & $\square$ \\
\hline Electrolyte ceramic matrix & $\square$ & $\square$ & $\square$ & $\square$ & $\square$ \\
\hline $\begin{array}{c}\text { Other materials(Plastics, steel, } \\
\text { aluminum, phenolic resin, } \\
\text { carbon black, etc) }\end{array}$ & $\square$ & $\square$ & $\square$ & $\square$ & $\square$ \\
\hline
\end{tabular}

Group 4 - Fuels used in the Fuel Cell

17-In this question you assign your level of knowledge about fuels used in the Fuel Cell:

1. EXPERT: you assign yourself if consider inside of the group of people that currently is dedicated to this topic with depth.

2. KNOWLEDGEABLE: you assign this classification in the following cases:2a.If you are becoming an expert, but lacks some experience to dominate the topic.2b. If you already was an expert in the topic has some years, but you consider at the moment little brought up to date in the topic.2c. If you work in correlated area, but contribute regularly with subjects related to this topic.

3. FAMILIARIZED: you designate if you know the majority of the used arguments in the quarrels on the topic, you read about the subject, and has an opinion about it. 


\section{UNFAMILIAR}

18- Group 4 - Fuels used in the Fuel Cell:The next figure presents first round results to next question.

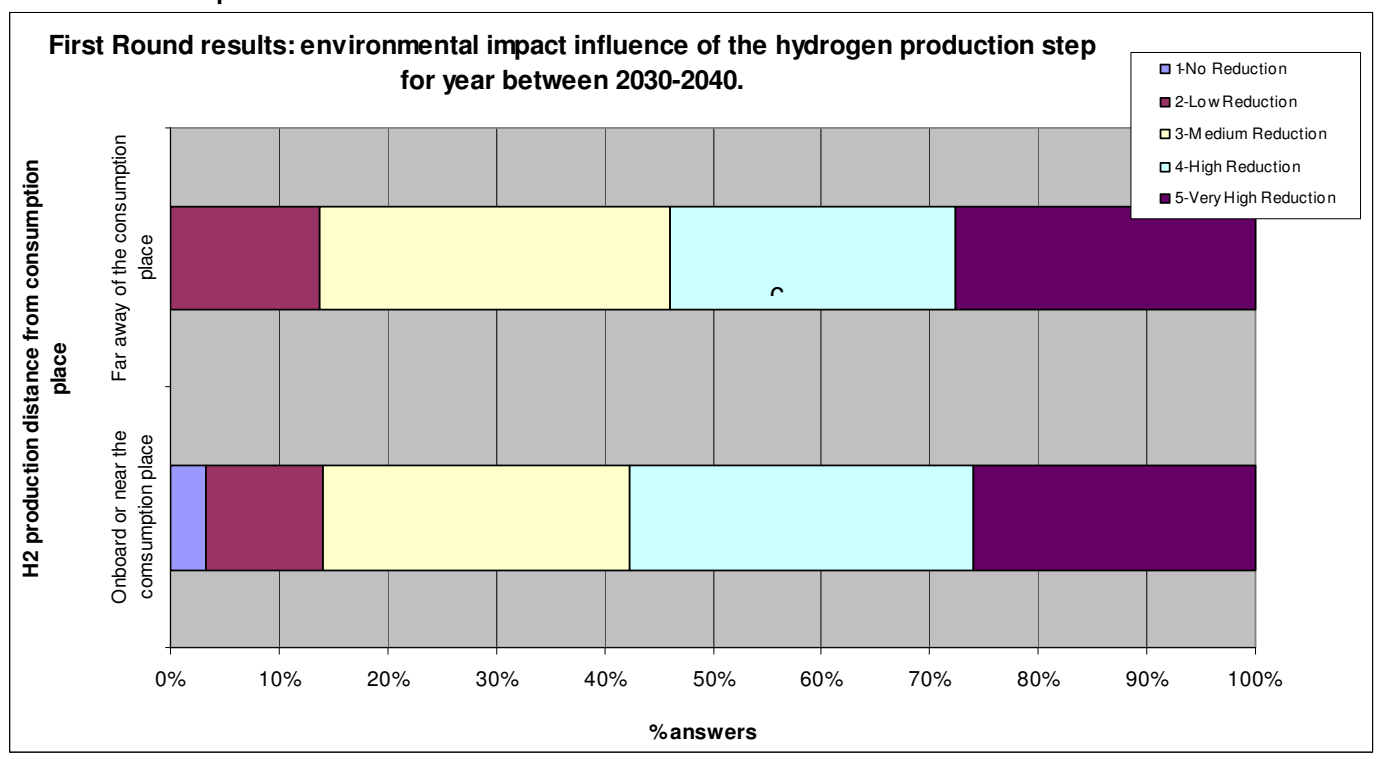

-At hydrogen production step, further used as combustible in the fuel cells, what is your expectation in the environmental impact from this process within 2030-2040 year?

\begin{tabular}{|c|c|c|c|c|c|}
\hline & $\begin{array}{c}\text { Very High } \\
\text { Reduction }\end{array}$ & $\begin{array}{c}\text { High } \\
\text { Reduction }\end{array}$ & $\begin{array}{c}\text { Medium } \\
\text { Reduction }\end{array}$ & $\begin{array}{c}\text { Low } \\
\text { Reduction }\end{array}$ & $\begin{array}{c}\text { No } \\
\text { Reduction }\end{array}$ \\
\hline $\begin{array}{c}\text { Hydrogen production onboard } \\
\text { or near the consumption place }\end{array}$ & $\square$ & $\square$ & $\square$ & $\square$ & $\square$ \\
\hline $\begin{array}{c}\text { Hydrogen production distant } \\
\text { from the consumption place }\end{array}$ & $\square$ & $\square$ & $\square$ & $\square$ & $\square$ \\
\hline
\end{tabular}

19- Group 4 - Fuels used in the Fuel Cell The figure below presents first round results for next question.

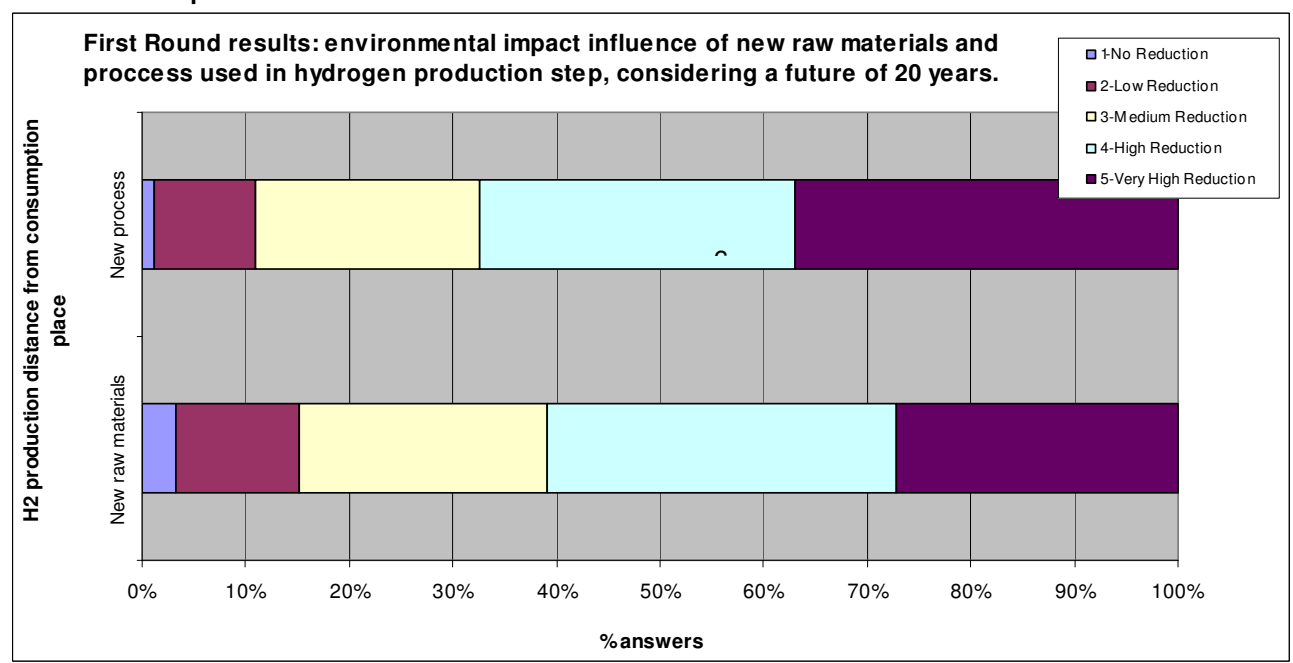

-Considering the current environmental impact in hydrogen production processes, what is your expectation on reduction in environmental impact, due to the use of new raw materials and new process, in next 20 years? 


\begin{tabular}{|c|c|c|c|c|c|}
\hline & $\begin{array}{c}\text { Very High } \\
\text { Reduction5 }\end{array}$ & $\begin{array}{c}\text { High } \\
\text { Reduction4 }\end{array}$ & $\begin{array}{c}\text { Medium } \\
\text { Reduction3 }\end{array}$ & $\begin{array}{c}\text { Low } \\
\text { Reduction2 }\end{array}$ & $\begin{array}{c}\text { No } \\
\text { Reduction1 }\end{array}$ \\
\hline New raw materials & $\square$ & $\square$ & $\square$ & $\square$ & $\square$ \\
\hline New process & $\square$ & $\square$ & $\square$ & $\square$ & $\square$ \\
\hline
\end{tabular}

20-Group 4 - Fuels used in the Fuel Cell: The next figure shows first round answers for the next question.

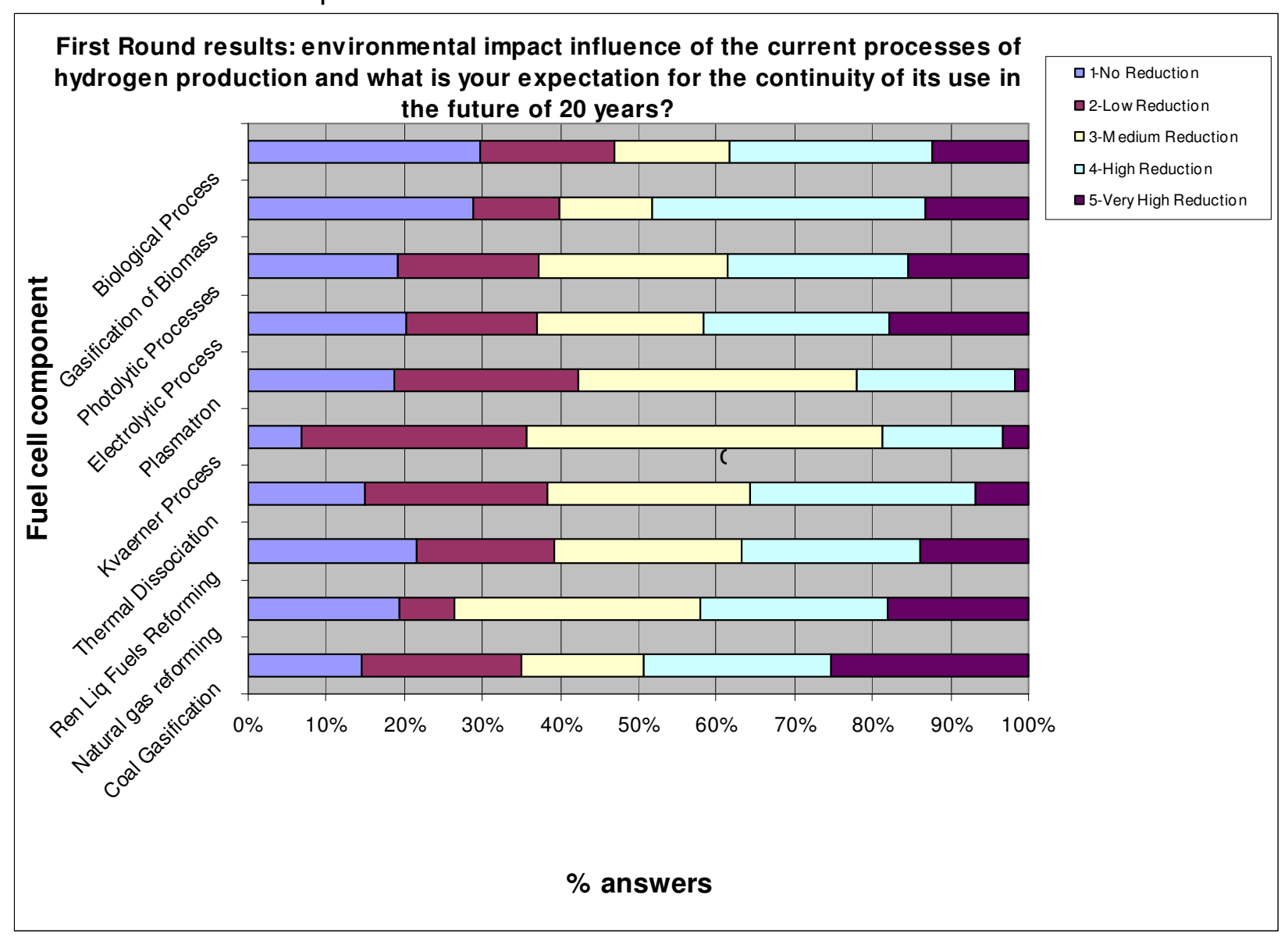

-In relation to the current processes of hydrogen production, what is your expectation for the continuity of its use in next 20 years?

\begin{tabular}{|c|c|c|c|c|c|}
\hline & $\begin{array}{c}\text { Very High } \\
\text { Reduction }\end{array}$ & $\begin{array}{c}\text { High } \\
\text { Reduction }\end{array}$ & $\begin{array}{c}\text { Medium } \\
\text { Reduction }\end{array}$ & $\begin{array}{c}\text { Low } \\
\text { Reduction }\end{array}$ & $\begin{array}{c}\text { No } \\
\text { Reduction }\end{array}$ \\
\hline Coal Gasification & $\square$ & $\square$ & $\square$ & $\square$ & $\square$ \\
\hline $\begin{array}{c}\text { Natural gas reforming } \\
\text { technology }\end{array}$ & $\square$ & $\square$ & $\square$ & $\square$ & $\square$ \\
\hline $\begin{array}{c}\text { Renewable Liquid Fuels } \\
\text { Reforming }\end{array}$ & $\square$ & $\square$ & $\square$ & $\square$ & $\square$ \\
\hline $\begin{array}{c}\text { Thermal Dissociation } \\
\text { Kvaerner Process }\end{array}$ & $\square$ & $\square$ & $\square$ & $\square$ & $\square$ \\
\hline Plasmatron & $\square$ & $\square$ & $\square$ & $\square$ & $\square$ \\
\hline Electrolytic Process & $\square$ & $\square$ & $\square$ & $\square$ & $\square$ \\
\hline Photolytic Processes & $\square$ & $\square$ & $\square$ & $\square$ & $\square$ \\
\hline Thermal Decomposition & $\square$ & $\square$ & $\square$ & $\square$ & $\square$ \\
\hline Gasification of Biomass & $\square$ & $\square$ & $\square$ & $\square$ & $\square$ \\
\hline
\end{tabular}




\section{Biological Process}

21- Group 4 - Fuels used in the Fuel Cell: The next figure presents first round answers for the next question:

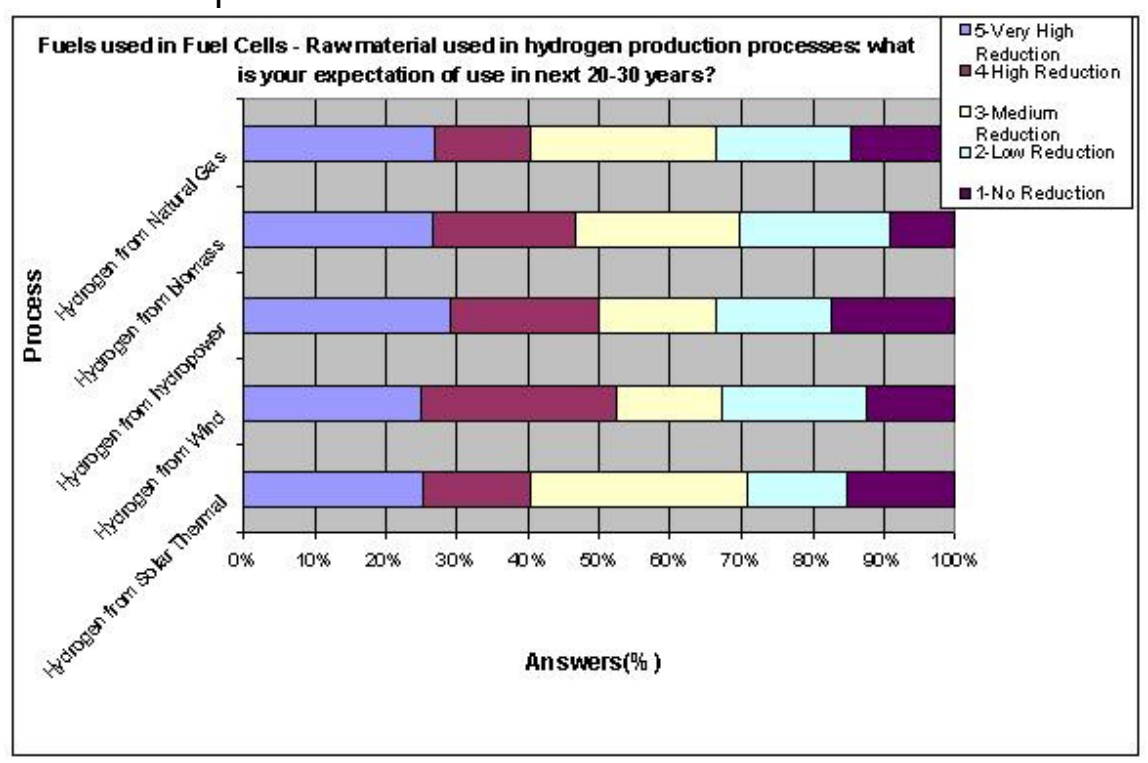

-Considering the energy type used as raw material in hydrogen production processes, what is your expectation of use, in next 20-30 years?

\begin{tabular}{|c|c|c|c|c|c|}
\hline & $\begin{array}{c}\text { Very High } \\
\text { Reduction5 }\end{array}$ & $\begin{array}{c}\text { High } \\
\text { Reduction }\end{array}$ & $\begin{array}{l}\text { Medium } \\
\text { Reduction3 }\end{array}$ & $\begin{array}{c}\text { Low } \\
\text { Reduction2 }\end{array}$ & $\begin{array}{c}\text { No } \\
\text { Reduction1 }\end{array}$ \\
\hline Hydrogen from PV & $\square$ & $\square$ & $\square$ & $\square$ & $\square$ \\
\hline $\begin{array}{c}\text { Hydrogen from Solar } \\
\text { Thermal }\end{array}$ & $\square$ & $\square$ & $\square$ & $\square$ & $\square$ \\
\hline Hydrogen from Wind & $\square$ & $\square$ & $\square$ & $\square$ & $\square$ \\
\hline $\begin{array}{l}\text { Hydrogen from } \\
\text { hydropower }\end{array}$ & $\square$ & $\square$ & $\square$ & $\square$ & $\square$ \\
\hline Hydrogen from biomass & $\square$ & $\square$ & $\square$ & $\square$ & $\square$ \\
\hline $\begin{array}{l}\text { Hydrogen from Natural } \\
\text { Gas }\end{array}$ & $\square$ & $\square$ & $\square$ & $\square$ & $\square$ \\
\hline
\end{tabular}

Full name:

Your Organization: 
Email:

Comments on any of the questions or on the survey as a whole: 


\section{A. ANEXO A - ANÁLISE ESTATÍSTICA DOS DADOS}

Este capítulo tem como objetivo revisar os principais conceitos de estatística básica e descrever o método da análise de variância, que será utilizado nesta dissertação para verificar se o nível de conhecimento (perito, conhecedor, familiarizado e não-familiarizado) e a categoria (academia, empresa ou governo) dos especialistas se comportaram de maneira diferenciada.

A revisão se inicia com conceitos básicos de estatística, pois através da descrição da inferência estatística básica, é possível explicar a análise de variância e entender como ela pôde servir como ferramenta de auxílio nas análises dos dados da primeira rodada da pesquisa Delphi em célula combustível. Esta revisão é baseada nas seguintes publicações Anderson e Finn (1996), StatSoft (2007), e Sant'ana (2005).

A proposta principal de uma análise estatística é avaliar os fatores que causam a variação num conjunto de medidas. Se as alturas de um número de crianças são registradas com precisão razoável, pode-se esperar que nem todas as alturas sejam iguais. Elas variam e esta variabilidade pode ser explicada pelo fato que as idades das crianças são diferentes, as alturas de suas mães e pais variam, suas dietas são diferentes, etc.. A tarefa de identificar as razões da variabilidade nos dados estatísticos é mais difícil pelo fato de que um grande número de fatores contaminantes pode estar presente.

A estatística denomina população ao conjunto de pessoas individuais ou objetos nos quais um investigador está interessado, num determinado estudo. Quando a população considerada é tal que possa ser listada fisicamente, então é denominada população finita.

Já a população hipotética compreende todos os objetos ou indivíduos identificados por uma lista de características comuns, tais como: idade, saúde, exposição real ou potencial a uma intervenção experimental, ou no caso de serem produzidos por um mesmo equipamento. Por exemplo, a preocupação no caso da vacina contra a poliomielite é prevenir a doença, em particular entre as crianças mais jovens, Estes grandes grupos constituem populações hipotéticas visto que 
por serem muito grandes não podem ser identificados ou listados.

A amostra é um subgrupo que é estudado, observado e medido. Os membros da amostra são denominados unidades de observação ou simplesmente observações. As observações podem ser objetos individuais ou pessoas ou podem ser grupos de pessoas tais como: famílias, cidades, universidades ou nações. Podem também ser eventos tais como: greves, guerras ou erupções vulcânicas. Denomina-se "dados" aos valores referentes aos registros de características particulares de cada unidade de observação,

A amostra pode refletir de forma tão precisa quanto possível, as características relevantes da população.

\section{A.1-Inferência Estatística}

Quando os dados amostrais são resumidos em tabelas ou índices numéricos a metodologia é denominada estatística descritiva. Quando os valores do resumo são usados para se efetuar generalizações sobre a população então a metodologia é denominada inferência estatística.

Inferência estatística é o processo pelo qual estatísticos tiram conclusões acerca da população usando informação de uma amostra e é utilizada para estimar as características de uma população baseada em dados de amostras da referida população. Este conceito de inferência é necessário para que se possa compreender a análise de variância, que será o método utilizado para as análises da primeira rodada da pesquisa Delphi em célula combustível.

\section{A.2-Teorema do Limite Central}

Um importante teorema em estatística é o teorema do limite central, que diz que se uma variável " $x$ " é composta de vários fatores determinantes, ou seja, se existem inúmeras variáveis que possam influir no seu valor (temperatura, gravidade, força, vento, umidade, genética, humor, por exemplo), a distribuição pode ser considerada como uma distribuição normal. A Figura A.-1 mostra que a distribuição das médias aproxima-se da normal quando aumenta o tamanho de amostras.

Algumas observações não possuem provas teóricas e só podem ser demonstradas empiricamente, através do método Monte-Carlo. Nestes experimentos, um grande número de amostras é gerado por meio de um 

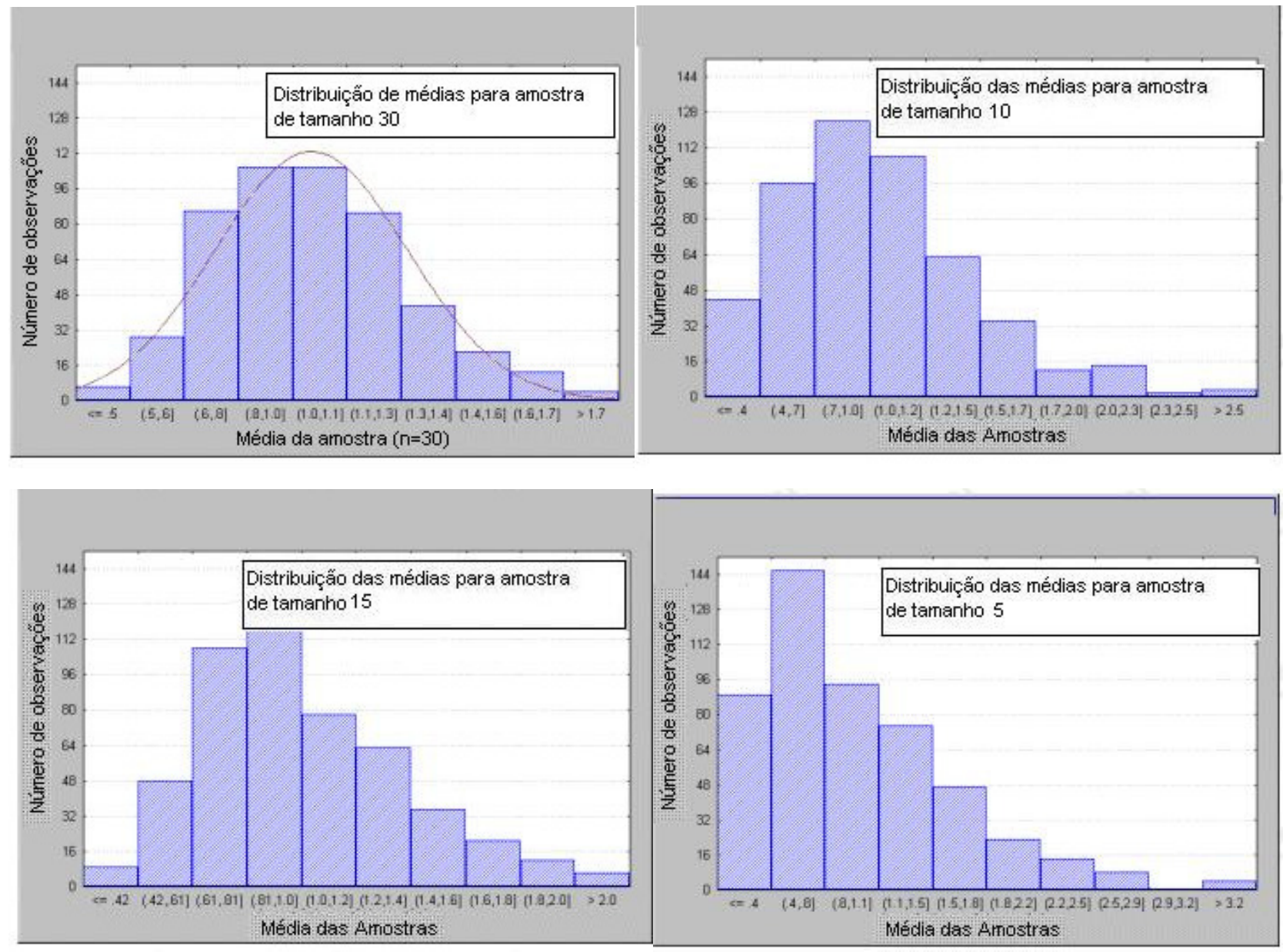

Figura A-1 - Gráfico mostrando que a distribuição de médias aproxima-se da normal quando aumenta o tamanho de amostras.

computador, conforme especificações previamente projetadas e os resultados de tais amostras são analisados usando uma variedade de testes. Desta forma podemos avaliar empiricamente o tipo e grandeza dos erros ou desvios a que estamos expostos, quando determinadas hipóteses teóricas dos testes que estão em uso não são cumpridas pelos nossos dados. Especificamente, o método de Monte-Carlo foi usado extensivamente, com testes baseados na distribuição normal para determinar como é a sensibilidade às violações da hipótese de distribuição normal das variáveis analisadas na população. A conclusão geral destes estudos é que as consequências dessas violações são menos graves do que se pensava anteriormente. Embora estas conclusões não devam desencorajar qualquer pessoa da preocupação em assumir a hipótese de distribuição normal, têm aumentado a popularidade global dos testes estatísticos dependentes da distribuição em todas as áreas de pesquisa. 


\section{A.3-Estimativa Pontual}

A estimativa pontual é a base do que será explicado a seguir. Considerando que uma variável cuja população finita tenha $N$ indivíduos e valores $\kappa y, y, \ldots ., y_{1}$. A variância desta população $\sigma_{2}$ desta variável é definida pela média aritmética de acordo com a fórmula:

$$
\mu=\sum \frac{y_{k}}{N}
$$

na qual $\mu=$ a média da população.

O resultado é ainda a média da população ou o "valor esperado" dos desvios quadrados de $\mu$. Dadas amostras de $n$ indivíduos com $x_{1}, x_{2}, \ldots, x_{N}$ observações, e como a média da população não é sabida,

$$
\bar{x}=\sum \frac{x_{k}}{n}
$$

na qual $\bar{x}=$ média aritmética das amostras

Então $\bar{x}$ é a estimativa pontual de $\mu$.

A média aritmética irá variar de amostra para amostra, mas a distribuição amostral de $x$ é centrada em torno de $\mu$; esta propriedade é chamada de imparcialidade, e é expressa como:

$$
E(\bar{x})=\mu
$$

Equação A-3

A variância da distribuição amostral de $\bar{x}$ é $\sigma_{\bar{x}}^{2}$, que é relacionada com a variância da população da qual ela foi retirada por:

$$
\sigma_{\overline{\mathrm{x}}}^{2}=\frac{\sigma^{2}}{\mathrm{n}}
$$

Equação A-4

O desvio padrão destra amostra, também chamado de erro padrão da média, vale: 


$$
\sigma_{\overline{\mathrm{x}}}=\frac{\sigma}{\sqrt{\mathrm{n}}} \quad \text { O erro padrão é uma medida de precisão, porque }
$$
quanto maior for a amostra, menor será o seu valor, ou seja, mais perto das características da população ele estará. Resumindo, quanto maior for a amostra, mais precisa será a estimativa de $\mu$, já que $\sigma_{\bar{x}}$ é o erro padrão da média.

A variância e do desvio padrão também podem ser estimados por meio de uma distribuição amostral de uma população.

Considerando de novo que uma variável cuja população finita tenha $N$ indivíduos e valores $y_{1}, y_{2}, \ldots ., y_{N}$. A variância desta população $\sigma^{2}$ destas, e como a média da população não é de graus de liberdade da amostra. Como pode ser notado, o erro padrão da média da amostra seria $\sigma_{\bar{x}}=\frac{\sigma}{\sqrt{n}}$ se $\sigma$ fosse uma informação disponível, mas senão ele pode ser estimado através da fórmula:

$$
\boldsymbol{s}_{\overline{\mathbf{x}}}=\frac{\boldsymbol{s}}{\sqrt{n}}, \quad \text { Equação A-6 }
$$

no qual $s_{x}$ é utilizado para indicar que a amostra é uma aproximação de $\sigma_{\bar{x}}$.

\section{A.4-Estimativa por meio de intervalos}

Normalmente a estimativa pontual não é exatamente correta, isto é, se alguém perguntar qual é a certeza de acerto de uma estimativa pontual, é necessária uma precisão para esta estimativa. Uma maneira de se fazer isto é através da estimativa por intervalos. Dois exemplos serão descritos para a estimativa de valores plausíveis para a média, o primeiro é quando o desvio padrão da população em questão é sabido, e o segundo quando desvio padrão não é sabido.

Supondo que o desvio padrão de uma população seja de $\sigma=12,6$ unidades, e que a distribuição em torno de $\mu$ seja aproximadamente normal e que valores muito acima ou muito abaixo da média não sejam desejados; uma amostra de 3 elementos tem uma distribuição cuja média é $\mu$, e de uma tabela de distribuição normal, é possível notar que a probabilidade da média da amostra $(\bar{x})$ estar a um erro padrão $\left(\sigma_{\bar{x}}=1\right)$ é de 0,6826 ; na mesma tabela é também 
possível notar que para uma probabilidade de 95\%, $z=1,96\left(z=\frac{\bar{x}-\mu}{\sigma / \sqrt{n}}\right)$. Nas unidades do exemplo, $\operatorname{Pr}(\bar{x}-14,3<\mu<\bar{x}+14,3)=0,95$; o valor de 14,3 advém de $1,96 \times 7,28$. Portanto, se uma amostra de $n$ elementos é retirada da população com desvio padrão $\sigma$, com 95\% nível de confiança a média da população está no intervalo. A Figura A-2 ilustra graficamente esta situação, em que tanto os extremos inferiores quanto os superiores não são desejados.

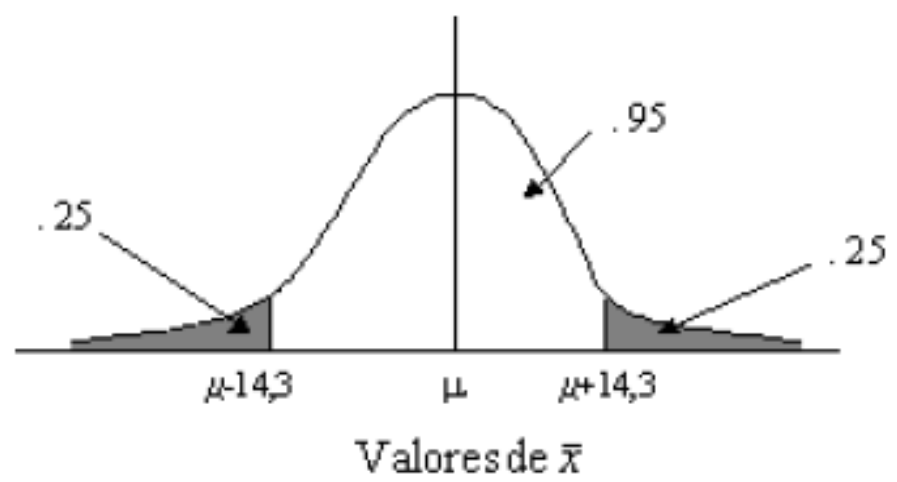

Figura A-2 - Distribuição amostral de $\bar{x}$

Suponha agora uma situação mais plausível cujo desvio padrão da população não é sabido: uma amostra de $n=10$ indivíduos cujas alturas sejam normalmente distribuídas, suponha que $x=172$ centímetros e que $s=7.3$ centímetros; considerando $95 \%$ de nível de confiança e que valores muito acima ou abaixo da média não sejam desejados. Conforme descrito no parágrafo anterior, $\operatorname{Pr}\left(\bar{x}-1,96 \frac{\sigma}{\sqrt{n}} ; \bar{x}+1,96 \frac{\sigma}{\sqrt{n}}\right)=0,95$. Se não é possível obtermos um valor correto para $\sigma$, substituímos por $s$, e chamamos a função de " $t$ " ao invés de " $z$ ", no qual:

$$
\left(t=\frac{\bar{x}-\mu}{s / \sqrt{n}}\right)
$$

esta é a conhecida função t-Student.

As condições para a função t-Student são as mesmas do teorema do limite central, de que a distribuição é aproximadamente normal. A distribuição 
depende da quantidade de informação sobre $\sigma^{2}$ que está contida em $s^{2}$, este é o número de graus de liberdade (o denominador vale $n-1$ ), ou seja, quanto maior a amostra, mais próxima a distribuição será de uma distribuição normal.

A Figura A-3 ilustra as distribuições normal (z) e t-Student com 1 e 5 graus de liberdade.

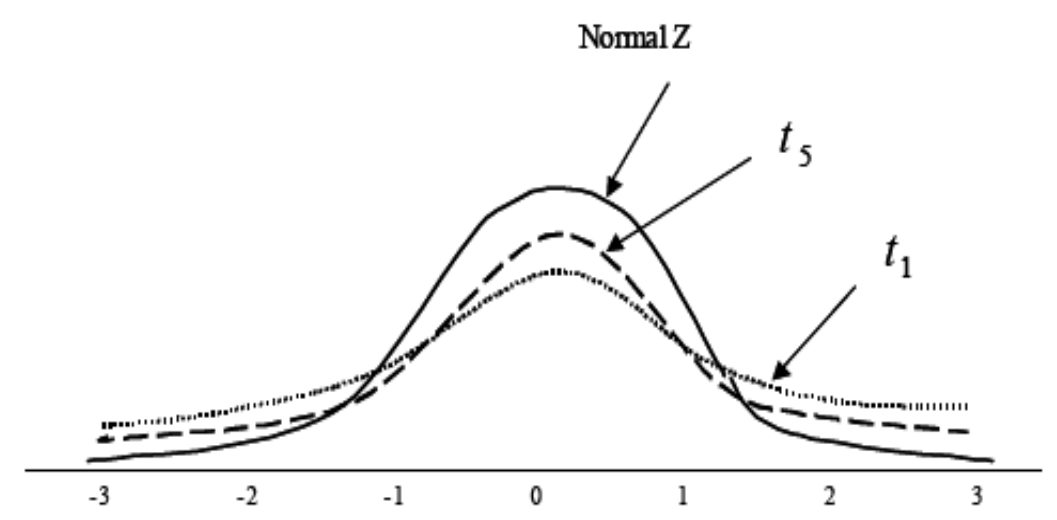

Figura A-3 - Distribuições de probabilidades de z, t1 e t2.

\section{A.5-Testes de Hipóteses}

Freqüentemente são requeridas respostas do tipo "sim" ou "não" sobre uma investigação estatística. O teste de hipóteses responde a estas perguntas com base no nível de confidência desejado e nas características da amostra da população a ser estudada. Apenas relembrando, o teorema do limite central diz que se uma variável $x$ é composta de vários componentes separados (fatores que influenciam no resultado), pode-se dizer que a distribuição desta população é aproximadamente normal.

No livro de Anderson e Finn (1996) encontram-se exemplos reais de uma consulta cuja pergunta a ser respondida era: Bebês de mães fumantes nascem abaixo do peso? A média da população de bebês considerada é de $\mu=$ 3.300 gramas e o desvio padrão de 516 gramas. A hipótese a ser testada é $H_{0} \geq 3.300$ gramas contra $H_{1}<3.300$ gramas. Se uma amostra de 100 bebês foi analisada, a distribuição da amostra da média será aproximadamente normal com um erro padrão. A hipótese foi testada com nível de confidencia de 10\% ( $\alpha=10 \%)$, e a Figura A-4 mostra a distribuição centrada em 3.300 gramas. $z(0.10)=1.28$, mas como estamos considerando apenas o limite inferior, $-z=-1.28$. Suponha agora que da amostra de 100 bebês retirada de diversos hospitais e em várias 
localizações de mães fumantes tenha a média $\bar{x}=3,207$ gramas. $O$ teste estatístico $\boldsymbol{z}=\frac{\overline{\boldsymbol{x}}-\mu}{\sigma_{\overline{\boldsymbol{x}}}}=\frac{(3207-3300)}{51.6}=1.80$, caindo na região além do nível de significância escolhido de $10 \%$. Portanto a hipótese $H_{0}$ é rejeitada em favor da conclusão de que bebês de mães fumantes nascem abaixo do peso médio. Se em algum caso o desvio padrão não for sabido, o uso da função t-Student é necessário, pois conforme visto anteriormente, esta distribuição depende da quantidade de informação sobre $\sigma^{2}$ que está contida em $s^{2}$.

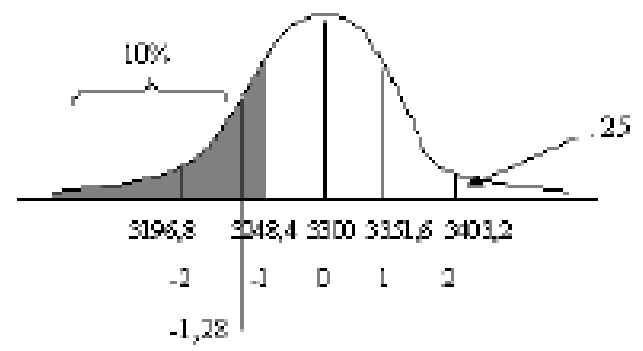

Figura A-4 - Distribuiçã̃o amostral da média com $\mu=3300 \mathrm{~g} \mathrm{e} \sigma=516 \mathrm{~g}$.

\section{A.6-Diferença entre populações}

A análise de variância verifica que a variabilidade de três ou mais populações diferem sobre algum aspecto, por isto é importante saber primeiro a diferença entre populações, para que possamos analisar a variabilidade de uma e de duas populações.

No livro de Anderson e Finn (1996) é apresentado um exemplo para ilustrar como funciona a comparação da média de duas amostras independentes quando o desvio padrão da população é sabido. Suponha que existam duas populações de estudantes, uma cuja criação e educação foram conduzidas pelo pai e pela mãe ( $x_{1}=22$ estudantes) e a outra somente pelo pai ou pela mãe ( $x_{2}=$ 7 alunos). Estes estudantes foram submetidos a testes e o desempenho foi comparado. As médias encontradas nos testes foram de $n_{1}=98,7$ e $n_{2}=91,7$ e 0 desvio padrão dos testes é sabido ser de $\sigma=12$. Com um nível de confidência de $\alpha$ $=10 \%$, existe diferença de desempenho nos testes? Para respondermos esta pergunta, basta achar $z=\frac{\bar{x}_{1}-\bar{x}_{2}}{\sqrt{\frac{\sigma^{2}}{n_{1}}+\frac{\sigma^{2}}{n_{2}}}}=\frac{98,7-91,7}{\sqrt{\frac{144}{22}+\frac{144}{7}}}=1,34$. Como para $\alpha=10 \%$, 
$z=1,28$, é possível afirmar que existam diferenças de desempenho entre os estudantes.

Quando os desvios padrões das duas amostras não são conhecidos, mas são tratados igualmente, a função t-Student entra em cena novamente, mas agora é necessário introduzir um novo conceito, que é a soma dos desvios quadrados. Assim como o exemplo anterior supõe-se que a distribuição é aproximadamente normal. Por exemplo, deseja-se saber se existe alguma diferença no desempenho de um curso numa universidade que tenha alunos da graduação e pós-graduação.

Por isto foi retirada uma amostra de 39 estudantes da graduação e 29 da pós-graduação; o desvio padrão das duas populações (estudantes de graduação fazendo o curso e estudantes de pós) não é sabido, mas serão tratados igualmente. Os dados extraídos das amostras podem ser vistos na tabela 1.

Tabela A-1 - Dados de desempenho das duas amostras de estudantes que fizeram o curso

\begin{tabular}{|l|l|}
\hline $\bar{x}_{1}=136,44$ & $\bar{x}_{2}=127,00$ \\
\hline$\sum\left(x_{1 i}-\bar{x}_{1}\right)^{2}=15.551$ & $\sum\left(x_{2 i}-\bar{x}_{2}\right)^{2}=13.388$ \\
\hline$s_{1}^{2}=409,2$ & $s_{2}^{2}=478,1$ \\
\hline$s_{1}=20,2$ & $s_{2}=21,9$ \\
\hline
\end{tabular}

A soma dos desvios quadrados das duas amostras é $S Q=15.551+13.388=28.939$. Dividindo este total pela soma dos graus de liberdade associados a eles $\left(n_{1}-1=38\right)+\left(n_{2}-1=28\right)=66$, obtemos $s_{p}^{2}=\frac{S Q}{g l_{1}+g l_{2}}=\frac{28.939}{66}=438,5$.

A função t-Student vale então $t=\frac{\bar{x}_{1}-\bar{x}_{2}}{\sqrt{\frac{s_{p}^{2}}{n_{1}}+\frac{s_{p}^{2}}{n_{2}}}}=\frac{136,44-127}{\sqrt{\frac{144}{22}+\frac{144}{7}}}=1,83$. Para um nível de significância de $\alpha=5 \%$, e considerando os dois extremos como parte da hipótese $H_{1}$, é possível notar que não existem evidências de que a população da graduação e da pós graduação tenham desempenhos diferentes, 
pois na tabela da função t-Student com 60 graus de liberdade, para $\alpha=5 \%$ vale 2.00, ou seja, para 66 este valor será ainda maior, distanciando ainda mais os $t=$ 1,83 encontrados.

\section{A.7-Análise de Variância}

Finalmente, após a introdução de todos os conceitos desenvolvidos ao longo do capítulo, é possível descrever com total compreensão a análise de variância, que será utilizada posteriormente para as análises da primeira rodada da consulta Delphi sobre impacto ambiental das pilhas combustíveis. A Análise de variância (ANOVA) são técnicas estatísticas que estudam a variabilidade de diferentes fontes, comparando-as para entender a importância relativa entre elas. Ela é também usada para fazer inferências sobre a população através dos testes de significância, incluindo a comparação das médias de duas ou mais populações.

ANOVA é a melhor forma de se examinar a associação entre uma variável categórica (grupos) e variáveis numéricas (medidas nas quais a média está baseada).

Suponha que queiramos comparar as médias de três populações sobre algumas variáveis dependentes. As médias são $\mu_{1}, \mu_{2}, \mu_{3}$ e a hipótese a ser testada é $H_{0}: \mu_{1}=\mu_{2}=\mu_{3}$. Se de alguma forma as médias forem diferentes, a hipótese é rejeitada. Isto quer dizer que se o teste estatístico refletir uma variação significante entre as amostras analisadas, como por exemplo exceder o ponto de significância correspondente, então a hipótese $H_{0}$ é rejeitada.

Quando apenas dois grupos são comparados, é óbvio que pelo simples conhecimento das médias dos dois grupos é possível saber qual deles tem uma média significantemente maior que o outro. Quando existem mais grupos, a rejeição de $H_{0}$ somente significa que ao menos uma população tem a média diferente das outras. É necessário realizar o teste de significância da ANOVA para determinar "qual" das médias da população é diferente das outras.

Para ilustrar este conceito suponhamos uma situação hipotética, em que um grupo de pesquisa queira saber se o nível de especialidade do respondente influencia nas respostas de uma pergunta ("Daqui a quantos anos conseguirá a viabilidade econômica necessária para produzir energia a partir da pilha a combustível, sem levar em conta os custos de transmissão?"). No exemplo 
serão considerados três níveis de especialidade e duas situações:

Situação 1

- Peritos, com média das respostas de 30 anos.

$\checkmark$ Conhecedores, com média das respostas de 28 anos.

- Familiarizados, com média das respostas de 32 anos.

Conforme a Figura A-5 pode ilustrar, a variabilidade dentro de cada grupo é tão grande que as pequenas diferenças na média dos valores dos grupos não justificam afirmar que o nível de especialidade dos respondentes influencie nas respostas.

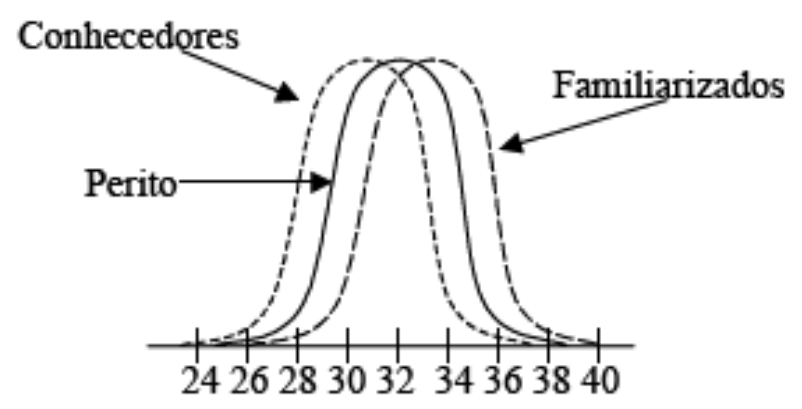

Figura A-5 - Variância não suficiente

Situação 2

- Peritos, com média das respostas de 30 anos.

- Conhecedores, com média das respostas de 24 anos.

- Familiarizados, com média de das respostas 36 anos.

A Figura A-6 mostra que a especialidade do respondente influencia nas respostas obtidas.

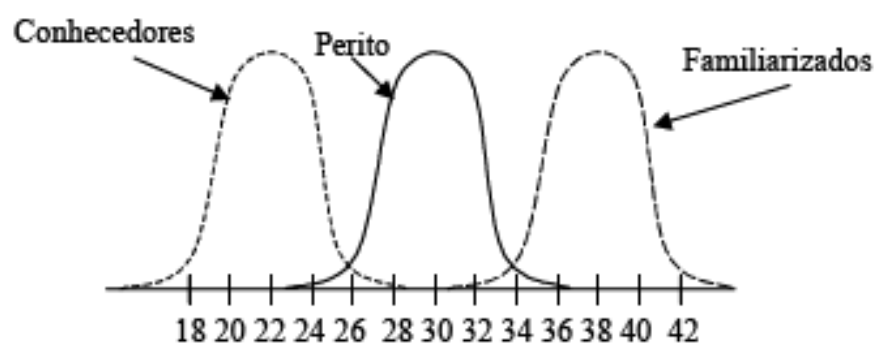

Figura A-6 - Variância suficiente

A análise de variância responde as questões de variabilidade comparando os valores entre os grupos e dentro deles.

A análise de variância indica se a as médias das populações são 
diferentes, comparando a variabilidade entre as médias das amostras com a variabilidade entre as observações individuais dentro dos grupos. A seguir cita-se um exemplo para facilitar o exemplo.

Suponha que alguém queira realizar uma ANOVA sobre uma pesquisa realizada com três grupos distintos. A Tabela A-2 ilustra esta situação.

Tabela A-2 - Situação hipotética para uma ANOVA.

\begin{tabular}{|c|c|c|c|}
\hline \multicolumn{4}{|c|}{ Qual a expectativa do impacto ambiental das pilhas } \\
\cline { 2 - 4 } & Peritos & Conhecedores & Familiarizados \\
\cline { 2 - 4 } & 1 & 1 & 1 \\
\cline { 2 - 4 } & 1 & 1 & 1 \\
\cline { 2 - 4 } & 2 & 1 & 1 \\
\cline { 2 - 4 } & 2 & 2 & 2 \\
\hline Soma & 3 & 2 & 2 \\
\hline Média das Amostras & 12 & 2 & 1.33 \\
\hline \multicolumn{2}{|c|}{ Total das amostras 27, média das 3 amostras: 1.61 } \\
\hline
\end{tabular}

\section{A.8-Variabilidade dentro dos grupos}

Primeiramente a variabilidade dentro dos grupos será computada. A medida da variabilidade entre as observações dentro dos grupos é chamada de média quadrada dentro dos grupos, $M Q_{D}$, ela é a variância de todos os valores, mas computados separadamente para cada uma das três amostras.

$$
M Q_{D}=\frac{S Q_{D}}{g l_{D}} \text {, no qual } S Q_{D} \text { é a soma dos desvios quadrados dentro }
$$

dos grupos e $g l_{D}$ é o número de graus de liberdade dos desvios dentro os grupos.

Com os dados da Tabela A-3; a soma é feita da soma de três amostras. Cada uma envolve 6 desvios quadrados, por isso cada uma tem (6$1=5)$, portanto $5+5+5=15$ graus de liberdade. Conforme os dados da Tabela $A-3$ temos que $S_{D}=4+3+1.334=8.334$. E a média quadrada dentro dos grupos é: $8.334 / / 15=1.80$. 
Tabela A-3 - Soma dos desvios quadrados dentro dos grupos.

\begin{tabular}{|c|c|c|c|}
\hline & Peritos & Conhecedores & Familiarizados \\
\hline & $(1-2)^{2}=1$ & $(1-1.5)^{2}=0.25$ & $(1-1.33)^{2}=0.109$ \\
\hline & $(1-2)^{2}=1$ & $(1-1.5)^{2}=0.25$ & $(1-1.33)^{2}=0.109$ \\
\hline & $(2-2)^{2}=0$ & $(1-1.5)^{2}=0.25$ & $(1-1.33)^{2}=0.109$ \\
\hline & $(2-2)^{2}=0$ & $(2-1.5)^{2}=0.25$ & $(1-1.33)^{2}=0.109$ \\
\hline & $(3-2)^{2}=1$ & $(2-1.5)^{2}=0.25$ & $(2-1.33)^{2}=0.449$ \\
\hline & $(3-2)^{2}=1$ & $(2-1.5)^{2}=0.25$ & $(2-1.33)^{2}=0.449$ \\
\hline Soma & 4 & 3 & 1.334 \\
\hline
\end{tabular}

\section{A.9-Variabilidade entre os grupos}

A medida da variabilidade das observações entre os grupos é chamada de média quadrada entre os grupos, $M Q_{E}$. Esta média é calculada das médias dos três subgrupos, 4, 9 e 5 (Vide tabela 2). A média quadrada entre grupos também tem uma soma de desvios quadrados no numerador e um número correspondente aos graus de liberdade no denominador. O numerador é chamado de soma dos quadrados entre os grupos, $S Q_{E}$, que é a soma dos desvios quadrados das médias dos subgrupos extraídos da média total. $O$ número de graus de liberdade entre os grupos $g l_{E}$ é o número dos desvios independentes resumidos em $S Q_{E}$.

A média total das observações vale "6", que é também é a média dos valores 4,9 e 5 (pois as amostras têm tamanhos iguais). A soma dos desvios quadrados das médias dos subgrupos extraídos da média total é $(4-6)^{2}=4,(9-6)^{2}$ $=9,(5-6)^{2}=1$. A soma portanto vale $4+9+5=14$. Esta soma não é a soma final, pois um ajuste final é necessário. Para colocar $S Q_{E}$ em escala comparável à $S Q_{D}$ (soma quadrada dentro dos grupos), é necessário multiplicar o valor 14 pelo número de observações em cada subgrupo, isto ocorre pois $S Q_{E}$ reflete a variabilidade entre as médias dos grupos ao passo que $S Q_{D}$ reflete a 
variabilidade entre as medidas individuais. Por isso ${ }^{S Q}{ }_{E}=6.14=84$.

A soma dos quadrados entre os grupos é compreendida de três desvios da média total, por isso o número dos graus de liberdade é e a média quadrada entre grupos $M Q_{E}$.

O teste estatístico para testar $H_{0}: \mu_{1}=\mu_{2}=\mu_{3}$ é chamado de razão "F", que é a razão de. Isto significa que a variabilidade entre grupos é bem maior que dentro eles. Entretanto, sabe-se que amostras diferentes nos dariam valores diferentes da taxa mesmo se as médias das três populações fossem iguais. Então ao valor de 22,50 é comparado com valores da distribuição- $F$ para ver se o teste estatístico das 3 amostras e 18 observações é grande o suficiente para rejeitar $H_{0}$

Os números de graus de liberdade valem $g l_{D}=15$ e $g l_{E}=2$. Se for usado um nível de significância de $1 \%$, o ponto de significância da tabela da distribuição- $F$ com 2 e 15 graus de liberdade vale 6,36. O valor de 22,50 é bem significante, por isso pode-se concluir que existam diferenças reais nas respostas da pesquisa se analisadas as diferentes classes sociais.

Conforme descrito anteriormente, a escolha da probabilidade " $p$ " é muito importante, pois ela é a probabilidade de erro tipo I ou II da análise.

O erro tipo I, conhecido também por $\alpha$, é o erro de se rejeitar a hipótese nula $\left(H_{0}\right)$ quando ela é correta; o erro tipo II, também conhecido por $\beta$, é o erro de se aceitar a hipótese nula $\left(H_{0}\right)$ quando ela é falsa. Portanto devemos ter muito cuidado com a escolha de $p$ ( $\alpha$ ou $\beta$ ), levando em conta os custos potenciais de um erro estatístico na magnitude do problema em questão. Posteriormente será descrito um exemplo de como esta escolha pode influenciar na decisão da rejeição de $H_{0}$.

\section{A.10-ANOVA em anotações algébricas}

A Tabela A-4 ilustra as notações utilizadas. A hipótese nula é $H_{0}: \mu_{1}=$ $\mu_{2}=\ldots=\mu_{k}$, que significa que as médias de $k$ (grupos) populações são iguais.

O número das amostras observadas em um grupo típico (grupo $g$ ) é denominado $n_{g}$, e o número total de observações de $n=n_{1}+n_{2} \ldots+n_{k}$. Cada observação tem dois subscritos, na qual o primeiro indica o grupo no qual a 
observação pertence e o segundo indica o número de observações dentro de cada grupo $\left(x_{g i}\right)$.

Tabela A-4 - Notações utilizadas para a ANOVA

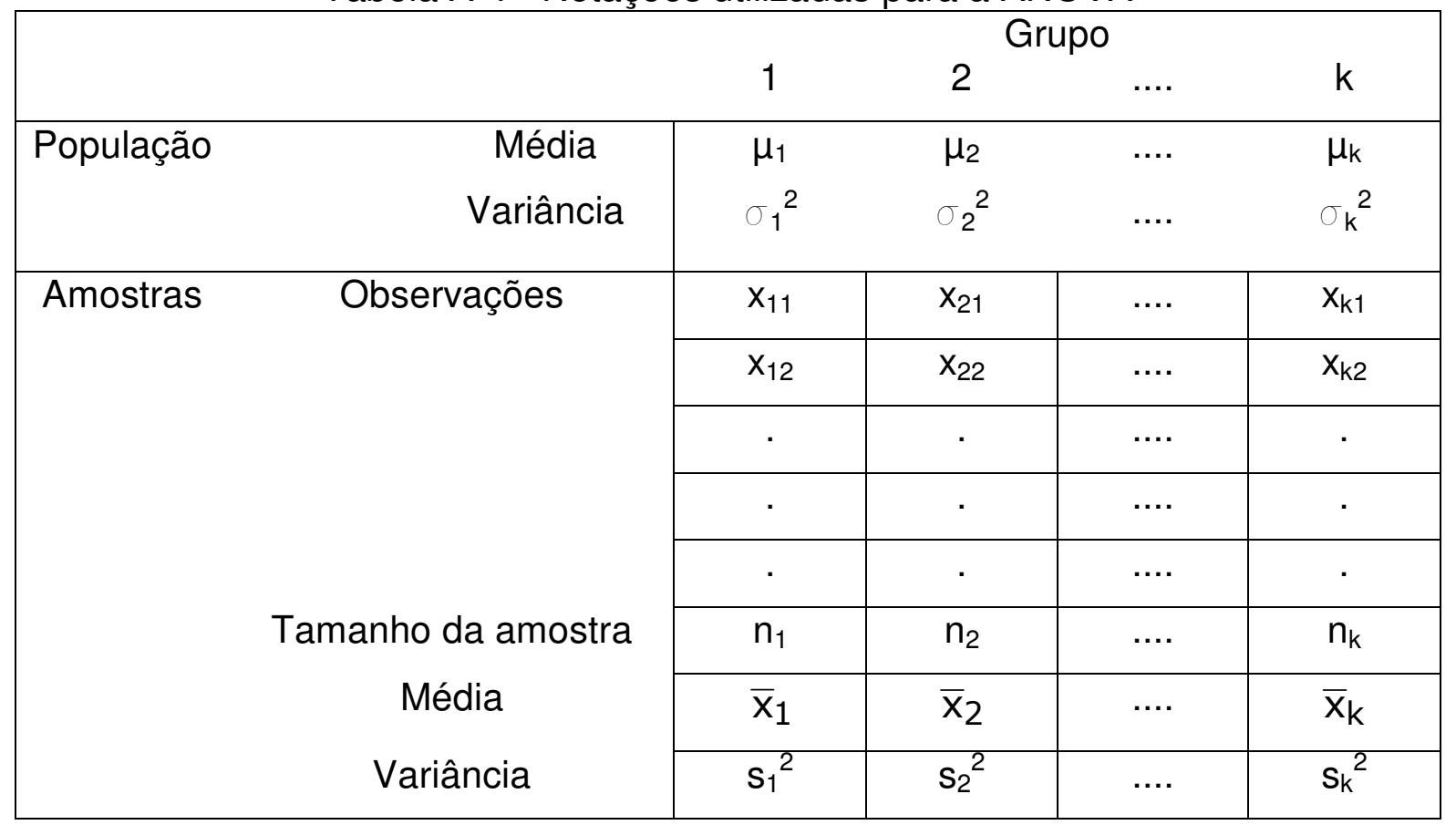

A média de um grupo típico (grupo $g$ ) é a soma das observações no grupo $g$ dividido pelo número de observações no grupo $g$. A média de todas as observações é $\bar{x}=\frac{\sum_{g} \sum_{i} x_{g i}}{n}$.

Para testar a hipótese $H_{0}$, a variabilidade entre a média dos grupos é comparada com a variabilidade entre as observações dentro dos grupos, que é a explicação do porque o valor observado sobre uma variável medida difere uma da outra, ou equivalentemente, porque os valores diferem da média total $\bar{x}$. Estas duas explicações podem ser juntadas em uma única expressão $\left(\bar{x}_{g i}-\bar{x}\right)=\left(\bar{x}_{g}-\bar{x}\right)+\left(\bar{x}_{g i}-\bar{x}_{g}\right)$. Esta expressão mostra que o desvio de valor da média total $\overline{\mathrm{X}}$ pode ser decomposto como uma soma de duas partes; o desvio da média dos grupos da média total e o desvio de uma observação da média do seu grupo. Estes são os elementos fundamentais dos conceitos "entre os grupos" e "dentro dos grupos", respectivamente. Elevando os termos ao quadrado, obtemos exatamente as somas quadradas que são essenciais para a 
análise de variância, na qual ${ }^{S Q_{T}}$ é a soma dos quadrados totais.

Tabela A-5 -Soma dos quadrados totais

\begin{tabular}{|c|c|}
\hline Grupo 1 & $\sum_{i}\left(\mathrm{x}_{1 \mathrm{i}}-\overline{\mathrm{x}}\right)^{2}=\mathrm{n}_{1}\left(\overline{\mathrm{x}}_{1}-\overline{\mathrm{x}}\right)^{2}+\Sigma_{\mathrm{i}}\left(\mathrm{x}_{1 \mathrm{i}}-\overline{\mathrm{x}}_{1}\right)$ \\
\hline Grupo 2 & $\Sigma_{\mathrm{i}}\left(\mathrm{x}_{2 \mathrm{i}}-\overline{\mathrm{x}}\right)^{2}=\mathrm{n}_{2}\left(\overline{\mathrm{x}}_{2}-\overline{\mathrm{x}}\right)^{2}+\Sigma_{\mathrm{i}}\left(\mathrm{x}_{2 \mathrm{i}}-\overline{\mathrm{x}}_{2}\right)$ \\
\hline$\cdots$ & $\cdots$ \\
\hline$\cdots$ & $\cdots$ \\
\hline Grupo k & $\sum_{\mathrm{i}}\left(\mathrm{x}_{\mathrm{ki}}-\overline{\mathrm{x}}\right)^{2}=\mathrm{n}_{\mathrm{k}}\left(\overline{\mathrm{x}}_{\mathrm{k}}-\overline{\mathrm{x}}\right)^{2}+\Sigma_{\mathrm{i}}\left(\mathrm{x}_{\mathrm{ki}}-\overline{\mathrm{x}}_{\mathrm{k}}\right)$ \\
\hline
\end{tabular}

Estes componentes mais os respectivos graus de liberdade $e$ distribuição- $F$ são geralmente resumidos em uma tabela.

Exemplo com tamanhos de amostra diferentes.

Suponha que uma pesquisa queira saber se o nível de escolaridade do respondente influi na resposta de uma determinada pergunta.

A média total de todas as observações vale: $\mathrm{x}_{\mathrm{gi}}=\frac{10,5+12+7,5+3}{3+4+3+2}=2,75$.

Tabela A-6 - Tabela de Análise de Variância

\begin{tabular}{|c|c|c|c|c|}
\hline $\begin{array}{l}\text { Fonte da } \\
\text { Variação }\end{array}$ & $\begin{array}{l}\text { Soma dos } \\
\text { Quadrados }\end{array}$ & $\begin{array}{l}\text { Graus de } \\
\text { Liberdade }\end{array}$ & $\begin{array}{c}\text { Médias } \\
\text { Quadradas }\end{array}$ & Razão F \\
\hline $\begin{array}{c}\text { Entre grupos } \\
\text { Dentro dos } \\
\text { grupos }\end{array}$ & $\begin{array}{l}S Q_{E} \\
S Q_{D}\end{array}$ & $\begin{array}{l}g l_{E} \\
g l_{D}\end{array}$ & $\begin{array}{l}M Q_{E}=S Q_{E} / g l_{E} \\
M Q_{D}=S Q_{D} / g l_{D}\end{array}$ & $\mathrm{~F}=\mathrm{MS}_{E} / \mathrm{MS}_{\mathrm{D}}$ \\
\hline TOTAL & $S Q_{t}$ & $\mathrm{Gl}_{\mathrm{t}}$ & & \\
\hline
\end{tabular}

As médias das amostras, 3,5; 3,0; 2,5 e 1,5 são diferentes umas das outras e decrescem sistematicamente conforme o nível de escolaridade decresce. $O$ teste de $H_{0}$, entretanto, irá determinar se as médias das amostras são suficientemente diferentes para que se possa concluir que existe uma diferença entre as médias das respectivas populações. Conforme visto anteriormente, , por isso $\mathrm{SQ}_{\mathrm{E}}=3 \times(3,5-2,75)^{2}+4(3-2,75)^{2}+2 \times(1,5-2,75)^{2}=5,25$ e, por isso 
$S Q_{D}=(3,5-3,5)^{2}+(4-3,5)^{2}+(3-3,5)^{2}+(3,5-3)^{2}+(3-3)^{2}+(2,5-3)^{2}+(3-2,5)^{2}+(2-2,5)^{2}=5,25$.

Tabela A-7 - Exemplo hipotético com diferentes tamanhos de amostras

\begin{tabular}{|c|c|c|c|c|}
\cline { 2 - 5 } \multicolumn{1}{c|}{} & \multicolumn{4}{|c|}{ Qual o tempo médio diário que você gasta com alguma leitura? } \\
\cline { 2 - 5 } & $\begin{array}{c}\text { Pós- } \\
\text { graduação } \\
\text { completa }\end{array}$ & $\begin{array}{c}\text { Superior } \\
\text { completo }\end{array}$ & $\begin{array}{c}2^{\circ} \text {. Grau } \\
\text { completo }\end{array}$ & $\begin{array}{c}1^{\circ} \text {. Grau } \\
\text { completo }\end{array}$ \\
\cline { 2 - 5 } & $\mathrm{x}_{11}=3.5$ & $\mathrm{x}_{21}=3.5$ & $\mathrm{x}_{31}=2.5$ & $\mathrm{x}_{41}=2.0$ \\
\cline { 2 - 5 } & $\mathrm{x}_{12}=4.0$ & $\mathrm{x}_{22}=3.0$ & $\mathrm{x}_{32}=3.0$ & $\mathrm{x}_{41}=1.0$ \\
\cline { 2 - 5 } & $\mathrm{x}_{13}=3.0$ & $\mathrm{x}_{23}=2.5$ & $\mathrm{x}_{33}=2.0$ & \\
\cline { 2 - 5 } & & $\mathrm{x}_{34}=3.0$ & & \\
\hline$\Sigma_{\mathrm{i}} \mathrm{x}_{\mathrm{g}}:$ & $\Sigma_{\mathrm{i}} \mathrm{x}_{1 \mathrm{i}}=10.5$ & $\sum_{\mathrm{i}} \mathrm{x}_{2 \mathrm{i}}=12.0$ & $\sum_{\mathrm{i}} \mathrm{x}_{3 \mathrm{i}}=7.5$ & $\sum_{\mathrm{i}} \mathrm{x}_{4 \mathrm{i}}=3.0$ \\
\hline $\mathrm{n}_{\mathrm{g}}$ & 3 & 4 & 3 & 2 \\
\hline$\overline{\mathrm{x}}_{\mathrm{g}}$ & 3.5 & 3 & 2.5 & 1.5 \\
\hline
\end{tabular}

Portanto a razão- $F$ : , sugerindo que exista uma diferença substancial na variação entre os grupos. Para decidir formalmente se $H_{0}$ é rejeitado ou não, a razão- $F$ é comparada ao valor da distribuição- $F$ com 3 e 8 graus de liberdade. Com um nível de significância de $5 \%$, o ponto de significância $F_{3,8}(0,05)=4,07$. 0 teste estatístico rejeita $H_{0}$, pois 7,00 $>4,07$. Com o nível de significância de $5 \%$, conclui-se que o nível de escolaridade do respondente influi nas horas de leituras diárias.

Se tivéssemos escolhido trabalhar com um nível de significância de $1 \%$, o ponto seria $F_{3,8}(0,01)=7,59$, e neste caso o teste estatístico $F=7,00$ não seria grande o suficiente para rejeitar $H_{0}$, por isso o nível de escolaridade não seria relacionado com as horas diárias de leitura.

Obviamente a escolha de a pode ter um efeito importante no resultado de uma análise estatística, na qual a é a probabilidade de ocorrência do erro tipo I, que é o erro de se rejeitar a hipótese nula $\left(H_{0}\right)$ quando ela é correta. Portanto, deve-se ter muito cuidado na escolha de $\alpha$, levando em conta os custos potenciais de um erro estatístico.

Resumindo, na ANOVA, o teste $F$ oferece a decisão sobre a diferença entre as médias. As Figuras A-7, 8 e 9 ilustram graficamente que quanto maior for 
o valor da razão-F, maior é sua significância estatística na rejeição da hipótese $H_{0}$

Como pode ser visto na figura A-7, cada amostra tem suas médias (linhas verticais) e medidas de dispersão $\left(\mathrm{MQ}_{\mathrm{D} 1}, \mathrm{MQ}_{\mathrm{D} 2}\right.$ e $\left.M \mathrm{MQ}_{\mathrm{D} 3}\right)$. Tomando as três amostras conjuntamente, existe então uma média geral dispersão geral (MQE).

Caso a dispersão $M Q_{D}$ (dentro dos grupos) seja mantida, mas as médias de cada amostra sejam mais distantes entre si, a dispersão $\left(\mathrm{MQ}_{\mathrm{E}}\right)$ aumentada (Figura A-8). Aplicando o teste $F=\frac{M Q_{E}}{M Q_{D}}$, verifica-se que o valor de F aumenta, aumentando a sua significância estatística.

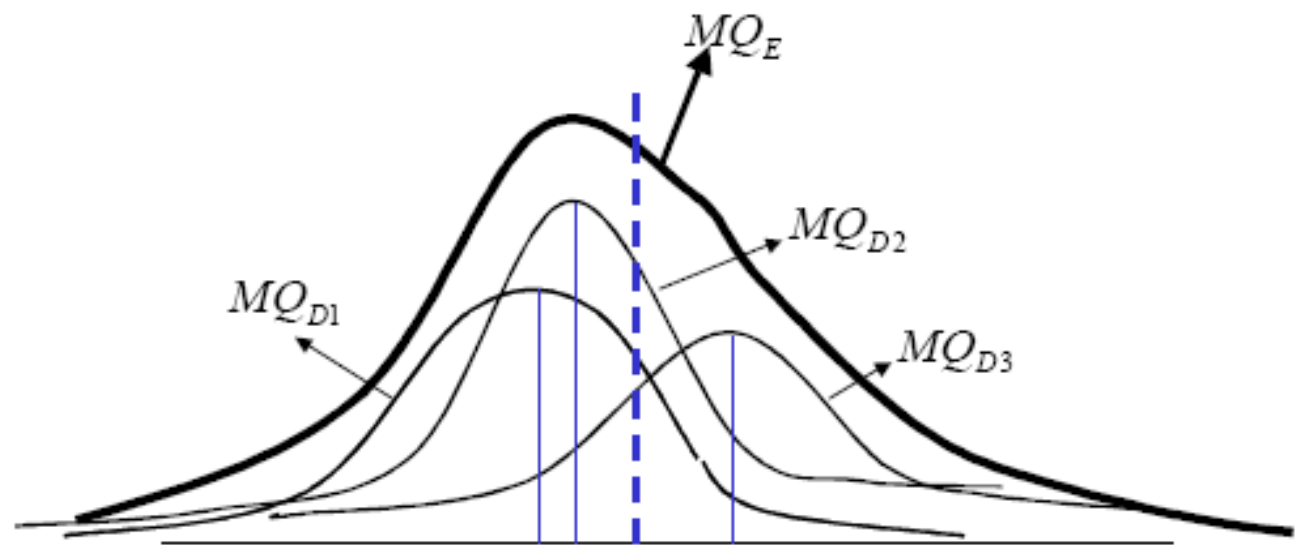

Figura A-7 - Gráfico de três distribuições hipotéticas

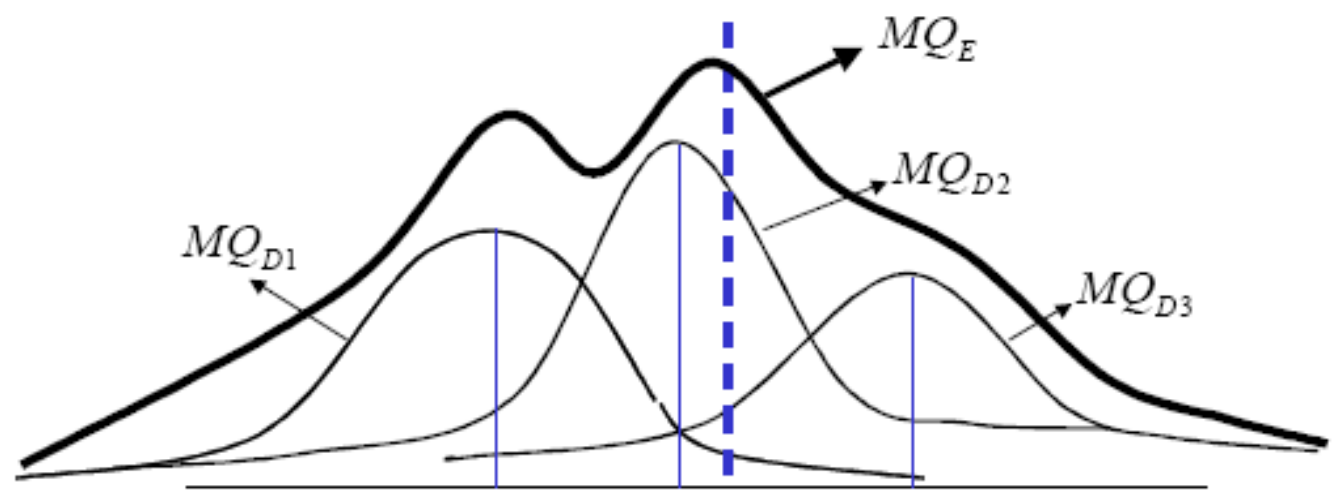

Figura A-8 - Aumento da razão-F em razão do aumento da diferença entre as médias , mantendo-se as dispersões constantes.

Mantendo agora as médias da Figura A-8, mas diminuindo a dispersão entre os grupos $\left(\mathrm{MQ}_{\mathrm{D}}\right)$, o que sofre maior redução no teste $F$ é o denominador, levando então a um aumento de $F$ (Figura A-9). 


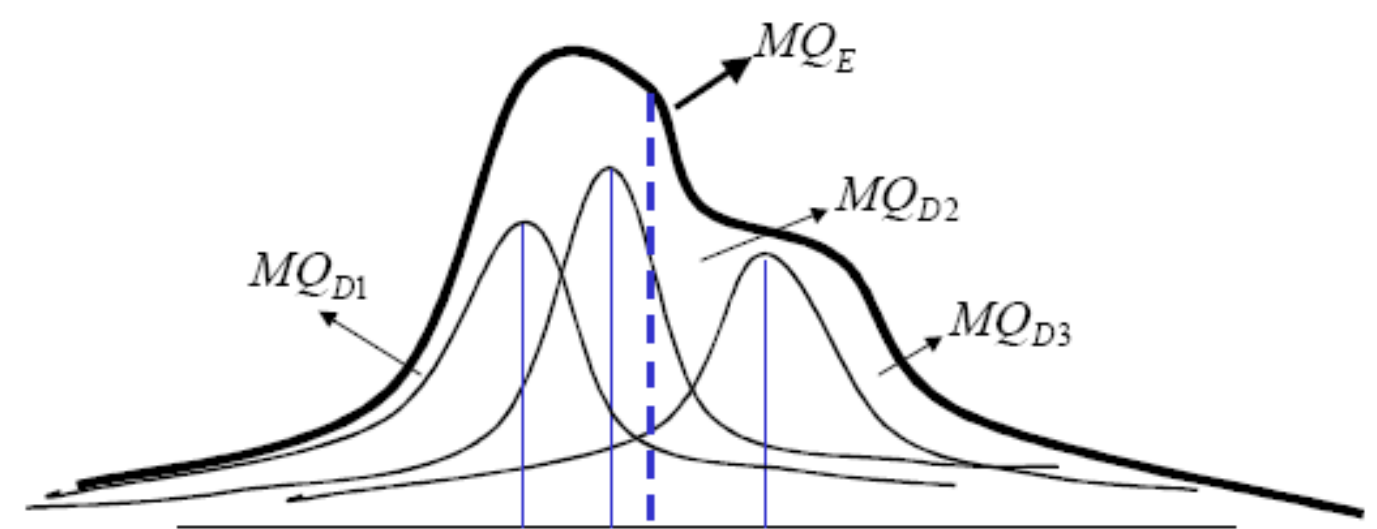

Figura A-9 - Aumento da razão-F em razão da diminuição da dispersão das amostras, mantendo-se as médias constantes.

\section{A.11- O alfa de Cronbach}

Os estudos empíricos de uma grande variedade de disciplinas aprovam o uso de questionários quantitativos, a fim de extrair informações a partir de uma amostra populacional. Muitos psicólogos aplicados, sociólogos e pesquisadores de mercado (citando somente alguns) inferem através da análise estatística análise das respostas (LEONTITSIS and Pagge 2007). Mas como se pode ter a certeza de que as respostas são confiáveis?

Nas estatísticas e pesquisas, a consistência interna é uma medida baseada na correlação entre os diferentes itens do mesmo teste (ou a mesma subescala em maior teste). Medem-se vários itens com a função de medir que a mesma construção geral produz pontuação semelhante. Por exemplo, se um inquirido manifestou concordância com as declarações "Eu gosto de andar de bicicletas" e "Adorei bicicletas no passado", e desacordo com a afirmação: "Eu odeio bicicletas", este seria indicativo de uma boa consistência interna do teste.

Cronbach (1951) quantificou esta confiabilidade, propondo um coeficiente (denominado de alfa de Cronbach, $\alpha$ ), que teoricamente varia entre 0 a 1. Se $\alpha$ estiver próximo de 0 , então as respostas quantificadas não são totalmente confiáveis, e se ele estiver perto de 1, as respostas são bastante confiáveis. Como regra geral, se $\alpha \geq 0,8$ em seguida, as respostas são consideradas confiáveis (CARLBRING et al., 2007).

O alfa de Cronbach's tem um uso importante como uma medida da confiabilidade de um instrumento psicométrico. Ele indica o grau em que um conjunto de itens de ensaio pode ser tratado como uma medida única variável 
latente. Ele foi denominado como alfa por Cronbach (1951), apesar de uma versão anterior ter sido a Kuder Fórmula-Richardson 20 (muitas vezes abreviado para KR-20), e Guttman (1945) desenvolveram o mesmo indicador como nome lambda-2.

Em Cronbach (1977), o próprio autor afirma estar certo de que o alfa de Cronbach's é citado sobretudo porque colocou um nome marcante em um coeficiente comum. Milhares de pesquisas relatam este coeficiente e alguns 0 rotulam de "alfa de Cronbach".

O alfa de Cronbach é um indicador de confiabilidade medido para a quantificação das respostas de questionários, a fim de concluir se as respostas que foram dadas de modo aleatório ou não.

$\mathrm{O}$ a de Cronbach's é definido, para uma amostra na qual foi medido um conjunto de $\mathrm{k}$ itens, como a média da correlação dos itens, ajustados para cima pela fórmula de previsão do $\mathrm{k}$ de Spearman-Brown. Ele está relacionado ao resultado da análise de variância dos dados do item em razão dos indivíduos na amostra e variância em razão dos itens. Quanto maior a proporção de variância por causa dos indivíduos, maior o a de Cronbach.

O inconveniente desta abordagem é que a nossa decisão em relação à confiabilidade é mais ou menos conduzida pela experiência e intuição dos pesquisadores. Portanto, se acharmos $\alpha=0,75$ devemos prosseguir considerando as respostas confiáveis ou não?

Muitos estatísticos (por exemplo, Cortina (1993), Hakstian Whalen (1976), van Zyle et al. (2000) , tentaram responder a questões deste tipo, através da introdução de testes estatísticos relativos $\alpha$. Infelizmente, todas as tentativas resultaram em outro teste estatístico. LEONTITSIS and Pagge (2007) propuseram que a simulação é capaz de dar uma estimativa única e precisa do significado estatístico de $\alpha$, sem consumir muito tempo computacional.

Seja $\mathrm{X}$ uma matriz $\mathrm{n} \times \mathrm{k}$ das respostas de um questionário. Cada linha de $\mathrm{X}$ representa um indivíduo e cada coluna uma pergunta. As respostas podem ser quantificadas em qualquer escala (por exemplo, $0-1,1-5,0-100$, etc.). $O$ coeficiente alfa de Cronbach é medido da seguinte forma: 


$$
\alpha=\frac{K}{K-1}\left[\frac{\sigma_{T}^{2}-\sum_{l=1}^{K} \sigma_{I}^{2}}{\sigma_{T}^{2}}\right]
$$

Na qual $\sigma^{2}$ ié a variância de cada coluna de $X, \sigma^{2}$ T é a variância da soma de cada linha de $X, k$ deve ser superior a 1 , a fim de que o denominador seja de zero e $n$ deve ser superior a 1 , a fim de não ter denominador zero no cálculo da $\sigma^{2}{ }_{\mathrm{i}}$ e os $\sigma^{2} \mathrm{~T}$.

Sobre a equação acima, k é um parâmetro de correção. Se houver coerência na respostas quantificadas então $\sigma^{2}{ }_{\mathrm{T}}$ será relativamente grande, o que levar $\alpha$ a tender para 1. Caso contrário, respostas aleatórias levarão $\sigma^{2}{ }_{\mathrm{T}}$ a ser comparável com a soma das variâncias individuais $\left(\sigma^{2}{ }_{i}\right)$, que, por sua vez, levará $\alpha$ a tender para 0 .

A idéia por trás do método proposto por Leontitsis e Pagge (2007) é simular as respostas de modo aleatório. Para isso, aleatoriamente misturou-se os valores de cada coluna de $\mathrm{X}$, a fim de ver qual seria o resultado em $\alpha$ se as respostas fossem dadas em uma forma aleatória. Quando se simula o processo muitas vezes (por exemplo, 1000), então teremos a distribuição de a para respostas aleatórias. Intuitivamente, pode-se dizer que é altamente improvável que essa distribuição seja normal ou de qualquer outro tipo conhecido (por exemplo, t, gama, F, etc.) Por isso o teste sugerido deve ser realizado numa forma não-paramétrica.

É o suficiente para encontrar o valor máximo ordenado de $95 \%$ e verificar se a medida de a nos nossos dados originais é maior ou menor que este valor crítico. Se for maior, é estatisticamente significativa em nível de $5 \%$, caso contrário, não é significativo neste nível. Da mesma forma, podemos definir outros níveis de significância estatística (por exemplo, 10\%, 1\%, 0,5\%, etc.).

A idéia da abordagem de Leontitsis e Page (2007) é simples e direta além de poder ser realizada até mesmo por um não-especialista. Não contém grandes exigências, tanto de poder computacional como de tempo. (Os cálculos demoraram cerca de 1,25 s para cada exemplo.) Não se assumiu distribuição normal ou qualquer hipótese sobre as propriedades estatísticas relativas à amostra e às perguntas do questionário que deve ser feito.

A principal vantagem do método proposto por Leontitsis e Pagge (2007) é que ele pode ser robusto sobre os valores que faltam, o que 
freqüentemente ocorre na prática. Outra vantagem fundamental é que ele pode lidar com casos em que a média das questões é previamente conhecida. Se o investigador tiver conhecimento prévio da variância de uma questão então ele / ela deve ajustar a média em conformidade para alcançar a variância desejada.

A desvantagem deste método é que o poder do teste proposto não pode ser medido. A simulação oferece a vantagem da construção da distribuição da hipótese nula com precisão arbitrária, mas não há como simular questionários com os dados sendo dado um resultado prévio de $\alpha$.

Leontitsis (2005) criou uma função Matlab que calcula o alfa de Cronbach de uma matriz de respostas. Também Nagel (2006) criou uma função Matlab para calcular o $\alpha$ de Cronbach.

Cortina (1993) relata que o a de Cronbach, tal como qualquer outro coeficiente estatístico, deve ser utilizado com cautela. O Coeficiente alfa é útil para estimar a confiabilidade em um caso especial: quando é de interesse a variância específica de um item, em um teste unidimensional. Se um teste tem uma grande $\alpha$, então se pode concluir que uma grande parte da variância no teste é atribuível a fatores gerais e de grupo. Por exemplo, considere um teste padronizado como uma prova da graduação. $O$ fator geral para esse teste pode ser a leitura, componente que está presente em todos os itens. O grupo fatores pode ser verbal, quantitativa e analítica. Qualquer variância adicional é específica do item. Esta variância específica do item é denominada de singularidade do item, e essa é a singularidade que é avaliada com coeficiente alfa. Novamente, esta informação é importante porque normalmente pode-se interpretar de forma geral e em grupo os fatores, mas não a variância específica dos itens. O problema com a interpretação ocorre quando grandes valores de alfa são avaliados como o teste sendo unidimensional.

Uma solução para esses problemas estatísticos é usar uma das muitas técnicas analíticas disponíveis para se certificar de que não existem grandes desvios da unidimensionalidade. Por exemplo, o primeiro passo para o estabelecimento unidimensionalidade está em realizar uma análise dos componentes principais de um conjunto de itens. Se esta análise sugerir a existência de apenas um fator, então alfa pode ser utilizado para concluir que o conjunto de itens é unidimensional. A análise dos principais componentes por si só não fornece provas suficientes para concluir que um conjunto de itens é 
unidimensional, pois este tipo de análise, por exemplo, pode produzir apenas um fator, mesmo se os itens têm correlações. 10 com os outros. Em essência, o que isto significa é que o alfa pode ser usado como uma medida de confirmação unidimensionalidade ou como uma medida da força de uma dimensão, uma vez a existência de um fator único pode ser determinada. E como sempre o número de fatores deve ser considerado. 